
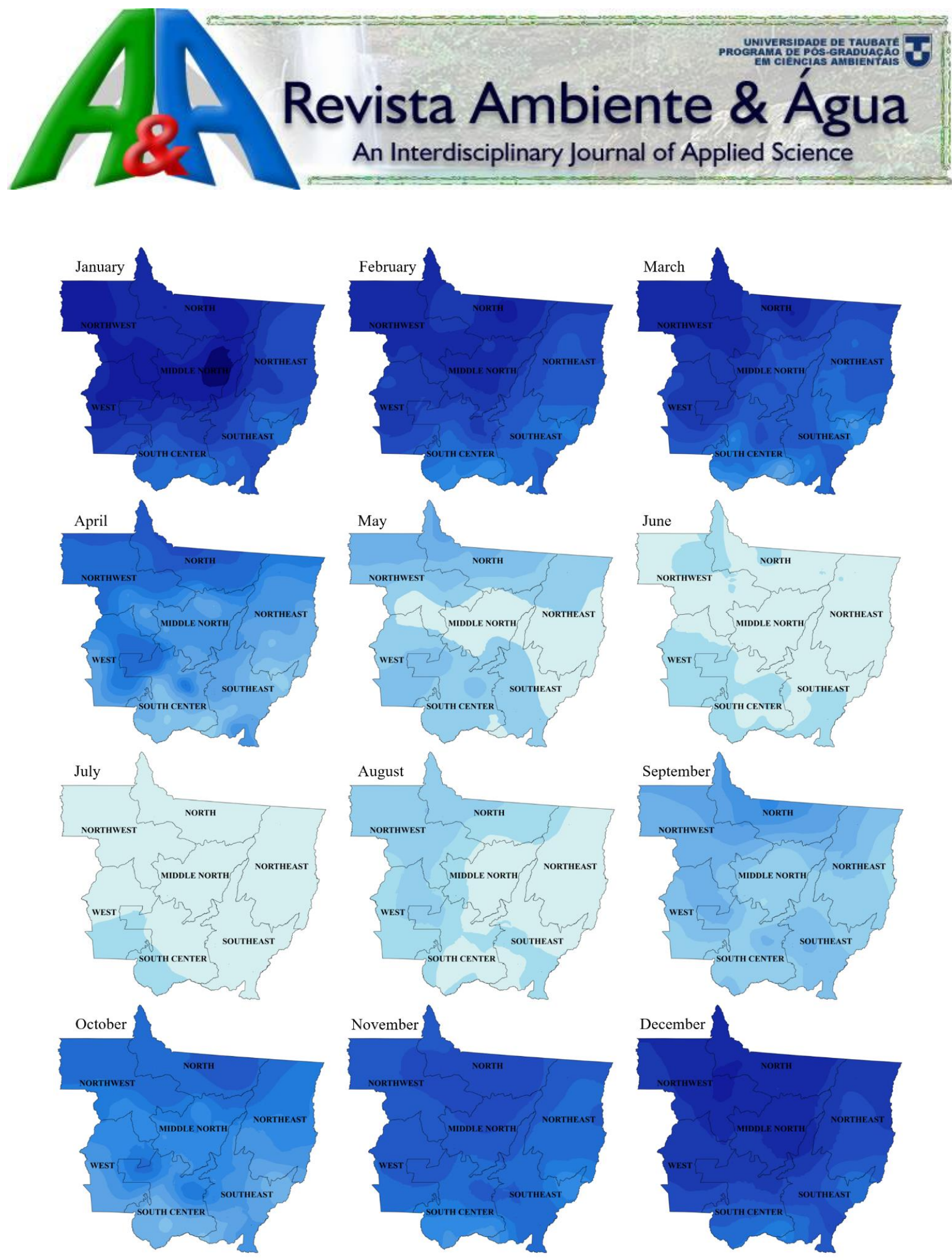

$\begin{array}{llllll}0 & 100 & 200 & 300 & 400 & 500\end{array}$

$\begin{array}{llllll}600 & 700 & 800 & 900 & 1100 & 1300\end{array}$

$1500 \quad 1700 \quad 1900 \quad 2100 \quad 2300$

ISSN $=$ 1980-993X (Online)

http://www.ambi-agua.net

$4^{\text {th }}$ Edition of Revista Ambiente \& Água - An Interdisciplinary Journal of Applied Science, Taubaté, V. 13, N. 6, p. 1-14 Nov/Dec. 2018. (doi:10.4136/ambi-agua.v13.n6) 


\section{EDITORIAL BOARD}

\section{Editors}

Getulio Teixeira Batista (Emeritus Editor) Universidade de Taubaté - UNITAU, BR

Nelson Wellausen Dias (Editor-in-Chief), Fundação Instituto Brasileiro de Geografia e Estatística - IBGE, BR

Ana Aparecida da Silva Almeida

Marcelo dos Santos Targa

Andrea Giuseppe Capodaglio

Arianna Callegari

Antonio Teixeira de Matos

Apostol Tiberiu

Claudia M. dos S. Cordovil

Dar Roberts

Giordano Urbini

Gustaf Olsson

Hélio Nobile Diniz

Ignacio Morell Evangelista

János Fehér

Julio Cesar Pascale Palhares

Luis Antonio Merino

Maria Cristina Collivignarelli

Massimo Raboni

Petr Hlavínek

Richarde Marques da Silva

Stefan Stanko

Teresa Maria Reyna

Yosio Edemir Shimabukuro

Zhongliang Liu Beijing

Text Editor

Reference Editor

Peer-Reviewing Process

System Analyst

Secretary and Communication

\section{Associate Editors}

Universidade de Taubaté (UNITAU), BR

Universidade de Taubaté (UNITAU), BR

\section{Editorial Commission}

University of Pavia, ITALY

Università degli Studi di Pavia, ITALY

Universidade Federal de Viçosa (UFV), BR

University Politechnica of Bucharest, Romênia

Centro de estudos de Engenharia Rural (CEER), Lisboa, Portugal

University of California, Santa Barbara, United States

University of Insubria, Varese, Italy

Lund University, Lund, Sweden

Inst. Geológico, Sec. do Meio Amb. do Est. de SP (IG/SMA), BR

University Jaume I- Pesticides and Water Research Institute, Spain

Debrecen University, Hungary

Embrapa Pecuária Sudeste, CPPSE, São Carlos, SP, BR

Institute of Regional Medicine, National University of the Northeast, Corrientes, Argentina

University of Pavia, Depart. of Civil Engineering and Architecture, Italy

LIUC - University "Cattaneo", School of Industrial Engineering, Italy

Brno University of Technology República Tcheca

Universidade Federal da Paraíba (UFPB), BR

Slovak Technical University in Bratislava Slovak, Eslováquia

Universidad Nacional de Córdoba, Argentina

Instituto Nacional de Pesquisas Espaciais (INPE), BR

University of Technology, China

Theodore D`Alessio, FL, USA, Maria Cristina Bean, FL, USA

Liliane Castro, Bibliotecária - CRB/8-6748, Taubaté, BR

Marcelo Siqueira Targa, UNITAU, BR

Tiago dos Santos Agostinho, UNITAU, BR

Luciana Gomes de Oliveira, UNITAU, BR

\section{Library catalog entry by Liliane Castro CRB/8-6748}

Revista Ambiente \& Água - An Interdisciplinary Journal of Applied Science / Instituto de Pesquisas Ambientais em Bacias Hidrográficas. Taubaté. v. 13, n.6 (2006) - Taubaté: IPABHi, 2018.

Quadrimestral (2006 - 2013), Trimestral (2014 - 2016), Bimestral (2017), Publicação Contínua a partir de Janeiro de 2018.

Resumo em português e inglês.

ISSN 1980-993X

1. Ciências ambientais. 2. Recursos hídricos. I. Instituto de Pesquisas Ambientais em Bacias Hidrográficas.

CDD - 333.705

CDU - (03)556.18 


\section{TABLE OF CONTENTS}

\section{COVER:}

These maps show the variation of $E I_{30}$ index that was computed as the product of total kinetic rainfall energy $(E C)$ and maximum 30-min precipitation intensity $\left(I_{30}\right)$ in Mato Grosso State, Brazil. During the first and second $E_{30}$ periods (October-November and December-March, respectively) many agricultural activities occur in the State. The most critical period is October to February when activities such as tilling, sowing, and harvesting are concentrated. The third period (April-September) is the least critical because the majority of the soils are covered by the crop canopy.

Source: RAIMO, L. A. D. L. D. et al. Spatio-temporal variability of erosivity in Mato Grosso, Brazil.

Rev. Ambient. Água, Taubaté, vol. 13 n. 6, p. 1-14, 2018. doi:10.4136/ambi-agua.2276

\section{ARTICLES}

Electron Spin Resonance (ESR) in detection of aquatic pollution through host-parasite relationship

01 doi:10.4136/ambi-agua.2085

Lucas Aparecido Rosa Leite; Angela Kinoshita; Oswaldo Baffa; Rodney Kozlowiski de Azevedo;

Vanessa Doro Abdallah

Hydrological modeling of an experimental basin in the semiarid region of the Brazilian State of Pernambuco

$\mathbf{0 2}$ doi:10.4136/ambi-agua.2204

Adriana Guedes Magalhães; Abelardo Antônio de Assunção Montenegro;

Carolyne Wanessa Lins de Andrade; Suzana Maria Gico Lima Montenegro; Robertson Valério de Paiva Fontes Júnior

Drinking water quality in schools of the Santarém region, Amazon, Brazil, and health implications for school children

03 doi:10.4136/ambi-agua.2218

Marina Smidt Celere Meschede; Bernardino Ribeiro Figueiredo; Renato Igor da silva Alves; Susana Inés Segura-Muñoz

A coupled model of hydrodynamics circulation and water quality applied to the Rio Verde reservoir, Brazil

04 doi:10.4136/ambi-agua.2244

Cynara de Lourdes da Nobrega Cunha; Gabriela Pacheco Corrêa; Paulo Cesar Colonna Rosman

Analysis of toxicity from the effluent generated in a furniture industry spray booth using the species Lactuca sativa and Allium cepa

05 doi:10.4136/ambi-agua.2246

Isabela Bruna de Tavares Machado Bolonhesi; Deize Dias Lopes

Growth and special structures production of Nostoc paludosum (Nostocaceae, Cyanobacteria) under nutrient starvation and different light intensities

06

doi:10.4136/ambi-agua.2191

Rafael Barty Dextro; Fellipe Henrique Martins Moutinho; Cristina Souza Freire Nordi

Peroxidase from green zucchini (Cucurbita pepo L.) immobilized on natural polymers removes phenolic compounds from water samples

07

doi:10.4136/ambi-agua.2226

Thâmara Machado e Silva; Aline Rodrigues dos Santos; Samantha Salomão Caramori

Quality of the water fluoridation and municipal-level indicators in a Brazilian metropolitan region

Lorrayne Belotti; Paulo Frazão; Carolina Dutra Degli Esposti; Jaime Aparecido Cury;

Edson Theodoro dos Santos Neto; Karina Tonini dos Santos Pacheco 
Spatio-temporal variability of erosivity in Mato Grosso, Brazil

doi:10.4136/ambi-agua.2276

09 Luis Augusto Di Loreto Di Raimo; Ricardo Santos Silva Amorim; Eduardo Guimarães Couto;

Rodolfo Luiz Bezerra Nóbrega; Gilmar Nunes Torres; Edwaldo Dias Bocuti;

Cristiana Oliveira Silva Almeida; Rafael Vinicius Rodrigues

\section{Silver nanoparticles impregnated with polyamide-66 to disinfect drinking water}

10

doi:10.4136/ambi-agua.1947

Luciano André Deitos Koslowski; André Lourenço Nogueira; Silvana Licodiedoff;

Adrieny Taliny Comper; Marilena Valadares Folgueras

Sensitivity analysis of the Soil and Water Assessment Tools (SWAT) model in streamflow modeling in a rural river basin

11

doi:10.4136/ambi-agua.2221

Luana Lavagnoli Moreira; Dimaghi Schwamback; Daniel Rigo

Analysis and modeling of water quality as a contribution to the preliminary framework proposal for the Una River (Pernambuco/Brazil)

Simone Rosa da Silva; Marcos Antonio Barbosa da Silva Junior; Eduardo Elvino Sales de Lima

Comparison of different slow-release nutrient composites produced to stimulate microorganisms

13

doi:10.4136/ambi-agua.2259

Everton Amazonas Reis; Emelay Pereira Bispo; Maria Helena Miguez Rocha Leão;

Selma Gomes Ferreira Leite

Variabilidade espacial do estoque de carbono e atributos físicos do solo em terra preta arqueológica sob pastagem

Marcelo Dayron Rodrigues Soares; Milton César Costa Campos; José Maurício da Cunha; Zigomar Menezes de Souza; Ivanildo Amorim de Oliveira; Renato Eleotério de Aquino;

Bruno Campos Mantovanelli; Ludimila Souza Oliveira 


Ambiente \& Água - An Interdisciplinary Journal of Applied Science
ISSN 1980-993X - doi:10.4136/1980-993X
www.ambi-agua.net
E-mail: ambi.agua@gmail.com

\title{
Reviewers of Volume 13, 2018 of Revista Ambiente \& Água
}

\section{Scientific Reviewers}

\author{
doi:10.4136/ambi-agua.2200 \\ Nelson Wellausen Dias \\ Editor of Revista Ambiente \& Água \\ E-mail: ambi.agua@gmail.com
}

The following list (Table 1) includes the names and affiliations of all reviewers that evaluated submissions processed for Volume 13, 2018 of Revista Ambiente \& Água. Including manuscripts that were accepted and published in one of the six annual issues and also manuscripts submitted and rejected up to October 10, 2018. It may therefore include the names of reviewers that completed their evaluations between September, 2017 and October, 2018.

We are deeply indebted to all of them that voluntarily and anonymously spent their precious time to support the journal, and contributed immensely to the quality of the published articles. We gratefully acknowledge their professional work and outstanding product.

Table 1. Ad Hoc Peer Reviewers that evaluated submissions for the 2018 editions of Revista Ambiente \& Água, Volume 13, n. 1, 2, 3, 4, 5, and 6, 2018.

Abdelhakim Jilali

Abdolmajid Gholizadeh

Abiola Toyin Ajay

Ada Scudelari

Adam Price

Adedeji Adebukola Adelodun

Adeel Mahmood

Adeildo Cabral da Silva

Adilson Pinheiro

Adriana Filgueira Leite

Adriana Maria Lotito

Adriano Valentim Diotto
Ministry of Energy, Mines and Sustainable Development, Rabat, Morocco

Shahid Sadoughi University of Medical Sciences and Health Services, Yazd, Iran

Adekunle Ajasin University, Akungba, Ondo, Nigeria

Universidade Federal do Rio Grande do Norte (UFRN), Natal, RN, Brazil

University of Aberdeen, Aberdeen, United Kingdom

Federal University of Technology Akure, Akura, Ondo, Nigeria

COMSATS Institute of Information Technology (CUI), Islamabad, Islamabad Capital Territory, Pakistan

Instituto Federal de Educação, Ciência e Tecnologia do Ceará (IFCE), Fortaleza, CE, Brazil

Universidade Regional de Blumenau (FURB), Blumenau, SC, Brazil

Universidade Federal Fluminense (UFF), Niterói, RJ, Brazil

Apulian Regional Agency for Environmental Protection (ARPA - Puglia), Italy

Universidade Federal de Lavras (UFLA), Lavras, MG, Brazil 
Adriano Weidner Cacciatori Marenzi

Agenor Tavares Jácome Júnior

Agnes Barbério

Agnieszka Makosza

Ahmed A. M. Al-Ogaidi

Ahmed Tawfik

Akram Javed

Alba Arana

Alberto Adriano Cavalheiro

Alexandre Kemenes

Alfonso Exposito

Ali Olad

Aline Falck

Alisson Carraro Borges

Álvaro José Back

Ambrogina Albergamo

Aminuddin $\mathrm{Ab}$ Ghani

Ana Cristina Mielli

Ana-Maria Stanescu

Ana-Marija Domijan

Anderson Schwingel Ribeiro

Andreia Patricia Andrade

Andrés Vargas Luna

Andrew Dean

Angelica Tarpanelli

Anjali Pal

Anne Watelet

Annibal Duarte Pereira Neto

Antônia Neves

Antonio Ganga
Universidade do Vale do Itajaí (UNIVALI), Itajaí, SC, Brazil

Associação Caruaruense de Ensino Superior (ASCES), Caruaru, PE, Brazil

Universidade de Taubaté (UNITAU), Taubaté, SP, Brazil

West Pomeranian University of Technology, Szczecin, Poland

University of Mosul, Mosul, Iraq

Egypt-Japan University of Science \& Technology, Alexandria, Alexandria, Egypt

Aligarh Muslim University (AMU), Aligarh, Uttar Pradesh, India

Universidade do Oeste Paulista (Unoeste), Presidente Prudente, SP, Brazil

Universidade Estadual de Mato Grosso do Sul (UEMS), Dourados, MS, Brazil

Empresa Brasileira de Pesquisa Agropecuária (EMBRAPA), Unidade de Execucao de Pesquisa e Desenvolvimento de Parnaiba, Parnaíba, Brazil

Universidad of Sevilla, Sevilla, Andalucía, Spain

University of Tabriz, Tabriz, East Azerbaijan, Iran

George Mason University, Fairfax, Virginia, United States

Universidade Federal de Viçosa (UFV), Viçosa, MG, Brazil

Empresa de Pesquisa Agropecuária e Extensão Rural de Santa Catarina (EPAGRI), Florianópolis, SC, Brazil

Università degli Studi di Messina (UniME), Locri, Sicilia, Italy

Universiti Sains Malaysia (USM), Nibong Tebal, Malaysia

Universidade de São Paulo (USP), São Paulo, SP, Brazil

National Research and Development Institute for Soil Science, Agrochemistry and Environmental Protection, Bucharest, Romania

School of Medicine - University of Zagreb, Zagreb, Croatia

Universidade Federal de Pelotas (UFPel), Pelotas, RS, Brazil

Universidade do Estado de Santa Catarina (UDESC), Lages, SC, Brazil

Pontificia Universidad Javeriana, Distrito Capital, Bogota, Colombia Manchester Metropolitan University, Manchester, United Kingdom

Research Institute for Geo-Hydrological Protection, National Research Council (IRPI-CNR), Perugia, Italy

Indian Institute Of Technology Kanpur (IIT Kanpur), Kanpur, Uttar Pradesh, India

Laurentian University, Sudbury, Ontario, Canada

Universidade Federal Fluminense (UFF), Niterói, RJ, Brazil

Universidade Federal do Ceará (UFC), Fortaleza, CE, Brazil

Università degli Studi di Sassari (UNISS), Nuoro, Sardegna, Italy 
Antonio Giuliano

Antonio Teixeira Matos

Artemi Cerdà

Ashutosh Kumar

Attila W. Kovacs

Basak Kilic Taseli

Benjamin Leonardo Alves White

Bo Li

Bruno Lemos Batista

Camila Mioto

Camila Gonçalves Athanásio

Carla Sirtori

Carlos Alexandre Borges Garcia

Carlos Asensio

Carlos Graeff-Teixeira

Carme Sans

Carolina Peña-Alonso

Cassia Farias

Catariny Cabral Aleman

Caterina Faggio

Celestina Pedras

Célia Leite Sant'Anna

Celso Souza Catelani

Cesario Cambaza

Cézar Henrique Barra Rocha

Chen Zhang

Choon Weng Lee

Claudia Ribeiro

Cristiano Christofaro Matosinhos

Cristiano Ragagnin de Menezes
Agenzia nazionale per le nuove tecnologie, l'energia e lo sviluppo economico sostenibile (ENEA), Rome, Italy

Universidade Federal de Minas Gerais (UFMG), Belo Horizonte, MG, Brazil

Universitat de València (UV), Valencia, Valencia, Italy

All India Institute Of Medical Sciences (AIIMS), Delhi, Delhi, India

Hungarian Academy of Sciences, Tihany, Hungary

Giresun University, Giresun, Turkey

Universidade Federal de Sergipe (UFS), Aracaju, SE, Brazil

Beijing Normal University, Haidian District, Beijing, China

Universidade Federal do ABC (UFABC), Santo André, SP, Brazil

Universidade Federal de Mato Grosso (UFMT), Rondonópolis, MT, Brazil

University of Birmingham, Birmingham, United Kingdom

Universidade Federal do Rio Grande do Sul (UFRGS), Porto Alegre, RS, Brazil

Universidade Federal de Sergipe (UFS), São Cristóvão, SE, Brazil

University of Almeria (UAL), Almería, Andalucía, Spain

Pontifícia Universidade Católica do Rio Grande do Sul (PUCRS), Porto Alegre, RS, Brazil

University of Barcelona (UB), Barcelona, Cataluña, Spain

Instituto de Oceanografía y Cambio Global (IOCAG), Telde, Spain

Universidade do Estado do Rio de Janeiro (UERJ), Rio de Janeiro, RJ, Brazil

Universidade Federal de Viçosa (UFV), Viçosa, MG, Brazil

Università degli Studi di Messina (UniME), Locri, Sicilia, Italy

Universidade do Algarve (UALg), Faro, Portugal

Instituto de Botanica (IBt), São Paulo, SP, Brazil

Universidade de Taubaté (UNITAU), Taubaté, SP, Brazil

Wageningen University (WUR), Wageningen, Netherlands

Universidade Federal de Juiz de Fora (UFJF), Juiz de Fora, MG, Brazil

Tianjin University, Tianjin, China

University of Malaya (UM), Kuala Lumpur, Malaysia

Cooperativa De Ensino Superior Politécnico Universitário (CESPU), Gandra, Portugal

Universidade Federal dos Vales do Jequitinhonha e Mucuri (UFVJM), Diamantina, MG, Brazil

Universidade Federal de Santa Maria (UFSM), Santa Maria, RS, Brazil 
Daniele Maia Bila

Dao Nguyen Khoi

Dawei Wang

Deanroy Mbabazi

Denice Schultz Vicentini

Diogo Couto

Domenico Casarano

Edlic Sathiamurthy

Edris Bazrafshan

Edson Nour

Eduardo Beraldo Morais

Eduardo Leite Kruger

Elaine Regina Lopes Tiburtius

Eleonora Deschamps

Elisangela Düsman

Elpidio Inacio Fernandes Filho

Elsa Mesquita

Elzbieta Zebek

Endler Marcel Borges d

Enrico Davoli

Enzo Laurenti

Eric Deleersnijder

Evangelin Ramani Sujatha

Everaldo Venâncio

Eyob Tesfamariam

Fabio Moraes Costa

Fabio Taioli
Universidade do Estado do Rio de Janeiro (UERJ), Rio de Janeiro, RJ, Brazil

Ho Chi Minh City University of Technology, Ho Chi Minh City, Viet Nam

Virginia Commonwealth University (VCU), Richmond, United States

Texas A\&M University, College Station, United States

Universidade Federal de Santa Catarina (UFSC), Florianópolis, SC, Brazil

Universidade de São Paulo (USP), São Paulo, SP, Brazil

Istituto di Ricerca per la Protezione Idrogeologica (IRPI), Bari, Italy

Universiti Malaysia Terengganu (UMT), Kuala Nerus, Terengganu, Malaysia

Tehran University of Medical Sciences (TUMS), Torbat Heydaryieh, Tehran, Iran

Universidade Estadual de Campinas (UNICAMP), Campinas, SP, Brazil

Universidade Federal de Mato Grosso (UFMT), Cuiabá, MT, Brazil

Universidade Tecnológica Federal do Paraná (UTFPR), Curitiba, PR, Brazil

Universidade Estadual de Ponta Grossa (UEPG), Ponta Grossa, PR, Brazil

Universidade FUMEC, Belo Horizonte, MG, Brazil

Universidade Federal do Paraná (UFPR), Francisco Beltrão, PR, Brazil

Universidade Federal de Viçosa (UFV), Viçosa, MG, Brazil

Laboratório Nacional de Engenharia Civil (LNEC), Lisboa, Portugal

Uniwersytet Warmińsko-Mazurski w Olsztynie (UWM), Olsztyn, Poland

Fundação Universidade Regional de Blumenau (FURB), Blumenau, SC, Brazil

Istituto di ricerche farmacologiche "Mario Negri" (IRCCS), Milano, Italy

Università di Torino (UniTo), Aosta, Piemonte, Italy

Université catholique de Louvain (UCLouvain), Louvain-la-Neuve, Belgium, France

Shanmugha Arts, Science, Technology \& Research Academy (SASTRA), Thanjavur, Tamil Nadu, India

Universidade Federal do ABC (UFABC), Santo André, SP, Brazil

University of Pretoria, Pretoria, South Africa

Universidade Federal do Rio de Janeiro (UFRJ), Rio de Janeiro, RJ, Brazil

Universidade de São Paulo (USP), São Paulo, SP, Brazil 
Fabrício Dalmas

Fatih Matyar

Felipe Correa Dos Santos

Fernando Ferrari Putti

Fernando Mainardi Fan

Fernando Ramos Martins

Francesco Cioffi

Francisco Vanies da Silva Sá

Frederico Yuri Hanay

Fuat Özyonar

Gabriel Constantino Blain

Gabriel Minea

Gerardino D`Errico

Getulio Rincon

Giordano Urbini

Gopal Krishan

Gordana Subakov

Guilherme Castioni

Guillermo Donoso

Günter Gunkel

Gustavo Mockaitis

Gustavo Rafael Mazzaron Barcelos

Hassan Fathizad

Hayet Djelal

Hazzeman Haris

Helena Cotler Avalos

Helenita Corrêa Ely

Heloisa Teixeira Firmo

Hongjie Xie
Universidade Guarulhos (UNG), São Paulo, SP, Brazil

Çukurova University, Adana, Turkey

Universidade Federal de Santa Maria (UFSM), Santa Maria, RS, Brazil

Universidade Estadual Paulista Julio de Mesquita Filho (UNESP), Tupã, SP, Brazil

Universidade Federal do Rio Grande do Sul (UFRGS), Porto Alegre, RS, Brazil

Universidade Federal de São Paulo (UNIFESP), Diadema, SP, Brazil

Università di Roma "La Sapienza", Rome, Italy

Universidade Federal Rural do Semi-Árido (UFERSA), Mossoró, RN, Brazil

Universidade Federal de São Carlos (UFSCar), São Carlos, SP, Brazil

Sivas Cumhuriyet Üniversitesi, Sivas, Turkey

Instituto Agronômico de Campinas (IAC), Brazil

University of Bucharest, București, Romania

Università degli Studi di Napoli Federico II (UNINA), Nápoles, Italy

Universidade Federal do Maranhão (UFMA), Pinheiro, MA, Brazil

University of Insubria, Varese, Italy

National Institute of Hydrology (NIH), Roorkee, India

Faculty of Biology, Beograd, Serbia

Universidade Estadual de Campinas (UNICAMP), Campinas, SP, Brazil

Pontificia Universidad Católica de Chile, Santiago, Chile

Technical University of Berlin (TU-Berlin), Berlin, Germany

Universidade Estadual de Campinas (UNICAMP), Campinas, SP, Brazil

Universidade Federal de São Paulo (UNIFESP), Santos, SP, Brazil

Yazd University, Yazd, Safaeih, Iran

Ecole Metiers L'environnement (EME), Bruz, France

Universiti Sains Malaysia (USM), Penang, Malaysia

Universidad Nacional Autónoma de México (UNAM), Ciudad Universitaria, Mexico

Pontificia Universidade Católica do Rio Grande do Sul (PUCRS), Porto Alegre, RS, Brazil

Universidade Federal do Rio de Janeiro (UFRJ), Rio de Janeiro, RJ, Brazil

International Food Policy Research Institute (IFPRI), Washington, United States 
Hongjun Lin

Imran Ali

Ion Sandu

Iran Lima Neto

Ivone Cristina Vaz-Moreira

Jaime L. da M. Oliveira

Jalil Jaafari

Jean Ricardo Simões Vitule

Jian Feng Ma

Jing Liu

Joana Darc Freire de Medeiros

João Bassin

Joel Dias da Silva

John McCartney

Jonas Teixeira Nery

Jonathan I Katz

José Francisco Berredo

Josias do Espírito Santo Coringa

Josué Alberton

Julia Silva

Julian Moreno Chan

Julio Cesar Pascale Palhares

Julio Cesar Raposo de Almeida Jun Wang

K. Ravikumar

Keith Warriner

Konstantinos Gudulas

Krzysztof Tadyszak
Chinese Academy Of Agricultural Sciences, People's Republic of China

Jamia Millia Islamia, Delhi, India

Romanian Inventors Forum (FIR), Iasi, Romania

Universidade Federal do Ceará (UFC), Fortaleza, CE, Brazil

Catholic University of Portugal (UCP), Porto, Portugal

Escola Nacional de Saude Publica Sergio Arouca (FIOCRUZ), Rio de Janeiro, RJ, Brazil

Tehran University of Medical Sciences (TUMS), Torbat Heydaryieh, Tehran, Iran

Universidade Federal do Paraná (UFPR), Curitiba, PR, Brazil

Okayama University, Okayama, Chugoku, Japan

Purdue University, Hammond, Indiana, United States

Universidade Federal do Rio Grande do Norte (UFRN), Natal, RN, Brazil

Universidade Federal do Rio de Janeiro (UFRJ), Rio de Janeiro, RJ, Brazil

Fundação Universidade Regional de Blumenau (FURB), Blumenau, SC, Brazil

University of California San Diego, La Jolla, United States

Universidade Estadual Paulista Júlio de Mesquita Filho (UNESP), Ourinhos, SP, Brazil

Washington University, Saint Louis, Missouri, United States

Museu Paraense Emilio Goeldi, Belem, Brazil

Instituto Federal do Mato Grosso (IFMT), Cuiabá, MT, Brazil

Centro Universitário Barriga Verde (Unibave), Orleans, SC, Brazil

Universidade Federal de Minas Gerais (UFMG), Montes Claros, MG, Brazil

Institute for Commercial Forestry Research (ICFR), Epworth, Pietermaritzburg, South Africa

Empresa Brasileira de Pesquisa Agropecuária (EMBRAPA), Embrapa Pecuária Sudeste, São Carlos, SP, Brazil

Universidade de Taubaté (UNITAU), Taubaté, SP, Brazil

Chinese Academy of Sciences (CAS), Xicheng District, Beijing, China

Environmental Resources Research Centre, Thiruvananthapuram, Thiruvananthapuram, India

University of Guelph, Guelph, Canada

Technological Education Institute of Western Macedonia, Kozani, Greece

Adam Mickiewicz University (UAM), Poznan, Greater Poland, Poland 
Laetitia Adelard

Lara Gabrielle Garcia

Larisa S. Seregina

Laurel Schaider

Laurence Maurice

Leah Bremer

Leandro de Godoy

Leila Thaise Santana de Oliveira Santos

Leonardo Peres

Leticia Belén Escudero

Lidia Sas-Paszt

Long $\mathrm{Yu}$

Luana Pampuch

Lucas Machado Pontes

Ludgero Cardoso Galli Vieira

Luis Hamilton Pospissil Garbossa

Luiza Teixeira

M. Jerold

M. Naushad

Mahmoud Abouseoud

Marat Gafurov

Marcelo Araujo

Marcelo Guerra Santos

Marcelo Rodrigues Bessa

Márcia Carvalho

Marcio Ricardo Salla

Marcos Furlan

Marcus Cruz

Marcus Vinicius de Liz

Maria Cristina Cangussu

Maria del Pilar Díaz
University of La Réunion, Le Tampon, Réunion

Universidade de São Paulo (USP), São Paulo, SP, Brazil

Karlsruhe Institute of Technology (KIT), Karlsruhe, Germany

Silent Spring Institute, Newton, United States

Institut de recherche pour le développement (IRD), Marseille, France

University of Hawaii, Honolulu, United States

Universidade Estadual Paulista Julio de Mesquita Filho (UNESP), Botucatu, SP, Brazil

Universidade Estadual de Feira de Santana (UEFS), Feira de Santana, Brazil

Universidade Federal do Rio de Janeiro (UFRJ), Rio de Janeiro, RJ, Brazil

Universidad Nacional de Cuyo (UNCUYO), Mendoza, Argentina

Instytut Ogrodnictwa, Skierniewice, Poland

Monash University, Guangzhou, China

Universidade Estadual Paulista Julio de Mesquita Filho (UNESP), São José dos Campos, SP, Brazil

Universidade Federal de Lavras (UFLA), Lavras, MG, Brazil

Universidade de Brasília (UnB), Brasília, DF, Brasil

Empresa de Pesquisa Agropecuária e Extensão Rural de Santa Catarina (EPAGRI), Florianópolis, SC, Brazil

Universidade Federal do Pará (UFPA), Belém, PA, Brazil

National Institute of Technology Calicut (NITC), Kattangal, Kerala, India

King Saud University, Riyadh, Arábia Saudita

Université Dr Yahia Fares de Médéa, Médéa, Algeria

Kazan Federal University, Kazan, Russian Federation

Fundação Oswaldo Cruz (FIOCRUZ), Rio de Janeiro, RJ, Brazil

Universidade do Estado do Rio de Janeiro (UERJ), Rio de Janeiro, RJ, Brazil

Universidade Tecnológica Federal do Paraná (UTFPR), Curitiba, PR, Brazil

Embrapa Arroz e Feijão, Santo Antônio de Goiás, GO, Brazil

Universidade Federal de Uberlândia (UFU), Uberlândia, MG, Brazil

Universidade de Taubaté (UNITAU), Taubaté,SP, Brazil

Embrapa Tabuleiros Costeiros, Aracaju, SE, Brazil

Universidade Tecnológica Federal do Paraná (UTFPR), Curitiba, PR, Brazil

Universidade Federal da Bahia (UFBA), Salvador, BA, Brazil

Universidad Nacional de Córdoba, Córdoba, Argentina 
Maria do Carmo Martins Sobral

Maria Helena Nadais

Maria Olimpia de Oliveira Rezende

Maria Renata Rocha Pereira

Marian Brestic

Marianna Gilli

Mariko Ueno

Marilisa Gabardo

Marina Prisciandaro

Marisol Vega

Mark A. Borchardt

Marta Vivar

Martin Johannes Enk

Mary Lynam

Massimo Raboni

Masud Yunesian

Mauro Iberite

Mehmet Sait

Michal Bodzek

Michelle Fernanda Brugnera

Miguel Redon-Santafe

Milton Franklin Benial Amirtham

Mirian Fernanda Rodrigues

Mirtha Latsague

Mohamed S. Hellal

Muhammad Hassan

Murat Eyvaz

Narendra Kumar Meena

Nélia Henriques Callado

Newton Silva Lima

Nívea Adriana Dias Pons

Okwudiri A. Anyiam
Universidade Técnica de Berlin (TU BERLIN) Berlin, Germany

University of Aveiro (UA), Aveiro, Portugal

Universidade de São Paulo (USP), São Paulo, SP, Brazil

Faculdade de Tecnologia de São Paulo (FATEC), São Paulo, SP, Brazil

Slovak University of Agriculture, Nitra, Slovakia

Universitá Degli Studi della Tuscia (UNITUS), Ferrara, Italy

Universidade de Taubaté (UNITAU), Taubaté,SP, Brazil

Universidade Positivo (UP), Curitiba, PR, Brazil

Università degli Studi dell'Aquila, Avezzano, Abruzzo, Italy

Universidad de Valladolid (UVa), Valladolid, Spain

University of California, Davis, United States

Universidad de Jaén, Jaén, Andalucía, Spain

Instituto Evandro Chagas (IEC), Ananindeua, PA, Brazil

University of Michigan (UM), Ann Arbor, Michigan, United States

LIUC - University "Cattaneo", School of Industrial Engineering, Castellanza (VA), Italy

Tehran University of Medical Sciences (TUMS), Torbat Heydaryieh, Tehran, Iran

Università di Roma "La Sapienza", Rome, Italy

Ondokuz Mayis University, Samsun, Turkey

Polish Academy of Sciences (PAN), Washington, United States

Universidade Federal de Mato Grosso (UFMT), Cuiabá, MT, Brazil

Università di Roma "La Sapienza", Rome, Italy

Nadar Mahajana Sangam S. Vellaichamy Nadar College, Madurai, Tamil Nadu, India

Universidade Federal de Santa Maria (UFSM), Santa Maria, RS, Brazil

Temuco Catholic University, Temuco, IX Región, Chile

National Research Center (NRC), Boulder, United States

National University of Sciences and Technology, Islamabad, Pakistan

Gebze Technical University (GIT), Kocaeli, Turkey

Wadia Institute of Himalayan Geology, Dehradun, Uttarakhand, India

Universidade Federal de Alagoas (UFAL), Maceió, AL, Brazil

Centro Universitário Luterano de Manaus (CEULM/ULBRA), Manaus, AM, Brazil

Universidade Federal de Itajubá (UNIFEI), Itajubá, MG, Brazil

University of Nigeria - Nsukka, Enugu, Nigeria 
Olatunde Dahunsi

Olga Heredia

Oluwatoyin Osekita

Orville P. Grey

P. Jigisha

Pankaj Bhatt

Panos Panagos

Patricia de Falco

Paul Chambonniere

Paulo Cesar de Jesus

Paulo Fortes Neto

Paulo Moutinho

Pawel Pohl

Pedro Roberto Jacobi

Piero Sirini

Rabin Bhattarai

Raffaella Pomi

Raniere Barbosa de Lira

Raphael Ligeiro

Razmah Ghazali

Renato Dantas Alencar

Renato Fernandes

Renato Igor da silva Alves

Ricardo José de Paula Souza e Guimarães

Ricardo Luis Radis Steinmetz

Rita Cassia Silva Von Randow

Robert Home

Roberta Bettinetti

Ronald F. Bond

Ronaldo Borges Barthem

Ronaldo Teixeira Pelegrini
Landmark University, Omu-Aran, Nigeria

Universidad de Buenos Aires, Avellaneda, Buenos Aires, Argentina

Adekunle Ajasin University (AAUA), Akungba-Akoko, Nigeria

University of the West Indies (UWI), Mona, Kingston, Jamaica

Sardar Vallabhbhai Natl Inst Technol, Surat, India

Govind Ballabh Pant University Of Agriculture \& Technology, Pantnagar, Uttarakhand, India

European Soil Data Centre (ESDAC), Ispra, Italy

Universidade Federal de São Carlos (UFSCar), São Carlos, SP, Brazil

Massey University, Palmerston North, New Zealand

Universidade Regional de Blumenau (FURB), Blumenau, SC, Brazil

Universidade de Taubaté (UNITAU), Taubaté,SP, Brazil

Instituto Nacional de Pesquisas da Amazônia (IPAM), Brasília, DF, Brazil

Wroclaw University of Science and Technology (WUT), Wroclaw, Poland

Universidade de Sao Paulo (USP), São Paulo, SP, Brazil

Università degli Studi di Firenze (UniFI), Florence, Italy

University of Illinois at Urbana-Champaign College of Education, Champaign, United States

Universita degli Studi di Roma La Sapienza, Roma, Italy

Cooperativa de Assessoria de Serviços (COOPERVIDA), Mossoró, RN, Brazil

Universidade Federal do Pará (UFPA), Belém, PA, Brazil

Malaysian Palm Oil Board (MPOB), Kajang, Malaysia

Instituto Federal do Rio Grande do Norte (IFRN), Mossoró, RN, Brazil

Universidade Regional do Cariri (URCA), Crato, CE, Brazil

Universidade de São Paulo (USP), Ribeirão Preto, SP, Brazil

Instituto Evandro Chagas (IEC), Ananindeua, PA, Brazil

Empresa Brasileira de Pesquisa Agropecuaria, Concórdia, Brazil

Instituto Nacional de Pesquisas Espaciais (INPE), São José dos Campos, SP, Brazil

Research Institute of Organic Agriculture (FiBL), Frick, Switzerland

University of Insubria, Como, Italy

University of California, Davis, United States

Museu Paraense Emílio Goeldi (MPEG), Belém, PA, Braszil

Universidade Federal de São Carlos (UFSCAR), São Carlos, SP, Brazil 
Roselene Maria Schneider

Rossi Silva

Rudy Gargano

Sait Cemil Sofuoglu

Salvatore Grimaldi

Sandra Stets

Santiago Garcia Lopez

Sarfaraz Ahmed Mahesar

Sarva Mangala Praveena

Satya Prakash

Saurav Kumar

Selma Regina Aranha Ribeiro

Selma Unlu

Sérgio Augusto Rodrigues

Shi-Peng Sun

Silvia Helena Zanirato

Simone Andrea Pozza

Sohair I. Abou-Elela

Sueli Van der Sand

Suzana C. Wrublack

Suzete Gomes

Ta Yeong Wu

Tala Navab-Daneshmand

Tarun Adak

Tassio Franchi

Tatiana Rodriguez Chaparro

Tawfik A. Saleh

Teppei Imaizumi

Teresa Maria Reyna

Thieres George Freire Da Silva
Universidade Federal de Mato Grosso (UFMT), Sinop, MT, Brazil

Universidade Federal de Lavras (UFLA), Lavras, MG, Brazil

Universita degli Studi di Cassino e del Lazio Meridionale, Cassino, Italy

Izmir Yuksek Teknoloji Enstitusu, Urla, Turkey

Universitá Degli Studi della Tuscia (UNITUS), Lazio, Italy

Universidade Estadual do Paraná (UNESPAR), União da Vitória, PR, Brazil

Universidad de Cadiz Facultad de Ciencias del Mar y Ambientales, Puerto Real, Spain

University of Sindh, Jamshoro, Pakistan

Universiti Putra Malaysia (UPM), Serdang, Malaysia

The City University of New York (CUNY), New York, United States

Central Institute of Fisheries Technology (ICAR CIFT), Kerala, India

Universidade Estadual de Ponta Grossa (UEPG), Ponta Grossa, PR, Brazil

İstanbul University, Istanbul, Turkey

Universidade Estadual Paulista Julio de Mesquita Filho (UNESP), Botucatu, SP, Brazil

Nanjing Tech University, Nanjing, Jiangsu, China

Universidade de São Paulo (USP), São Paulo, SP, Brazil

Universidade Estadual de Campinas (UNICAMP), Limeira, SP, Brazil

National Research Center (NRC), Boulder, United States

Universidade Federal do Rio Grande do Sul (UFRGS), Porto Alegre, RS, Brazil

Universidade Estadual do Oeste do Paraná (UNIOESTE), Cascavel, PR, Brazil

Fundação Oswaldo Cruz (FIOCRUZ), Rio de Janeiro, RJ, Brazil

Monash University, Subang Jaya, Selangor, Malaysia

Oregon State University (OSU), Corvallis, Oregon, United States

Indian Council of Agricultural Research (ICAR), Lucknow, India

Escola de Comando e Estado-Maior do Exercito (Eceme), Rio de Janeiro, RJ, Brazil

Universidad Militar Nueva Granada (UMNG), Bogota, Colombia

King Fahd University of Petroleum \& Minerals, (KFUPM), Dhahran, Saudi Arabia

Gifu University, Gifu, Japan

Universidad Nacional de Córdoba, Córdoba, Argentina

Universidade Federal Rural de Pernambuco (UFRPE), Recife, BA, Brazil 
Todd Swannack

Valerija Vujčić

Vasili Simeonov

Veronique Ruban

Vesela Yancheva

Vhahangwele Masindia

Vicent Chaplot

Victor Orlando Magaña

Vilis Dubrovskis

Vito Ferro

Wei Lun Ang

Wei-Chi Li

Wellington Akira Iwamoto

Wellington Betencurte da Silva

William Burgos

Wouter Buytaert

Xuesong Zhang

Yanfeng Zhang

Yang Peng

Yoshiaki Tsuzuki

Yvonilde Dantas Pinto Medeiros

Zakaria Al-Qodah

Zhaoqin Li
Texas State University, San Marcos, Texas, United States

University of Zagreb (UNIZG), Zagreb, Croatia

Sofia University "St. Kl. Ohridski", Sofia, Bulgaria

French institute of science and technology for transport, spatial planning, development and networks (IFSTTAR), Bouguenais, France

Medical University of Plovdiv, Plovdiv, Bulgaria

Council for Scientific and Industrial Research (CSIR), Pretoria, South Africa

Institute of Research for Development (IRD), Paris, France

Universidad Nacional Autónoma de México (UNAM), Ciudad Universitaria, Mexico

Latvia University of Life Sciences and Technologies, Jelgava, Latvia Università degli Studi di Palermo, Agrigento, Sicilia, Italy

Universiti Kebangsaan Malaysia (UKM), Selangor, Malaysia

National Central University, Zhongli District, Taoyuan City, Taiwan

Universidade Federal de Uberlândia (UFU), Uberlândia, MG, Brazil

Universidade Federal do Espírito Santo (UFES), Vitória, ES, Brazil

Pennsylvania State University, University Park, Pennsylvania, United States

Imperial College London, London, United Kingdom

Joint Global Change Research Institute, College Park, United States

Joint Global Change Research Institute, College Park, United States

North China Electric Power University, Changping District, Beijing, China

Water Qual Management Bur, Mangere East, New Zealand

Universidade Federal da Bahia (UFBA), Salvador, BA, Brazil

Al-Balqa`Applied University, Amman, Jordan

University of Saskatchewan, Saskatoon, Saskatchewan, Canada

Note: 1) Some of these reviewers evaluated more than one manuscript;

2) This list includes reviewers that evaluated submissions that were not accepted for publication, in addition to the ones published in 2018 .

As seen in Table 2, 174 reviewers are from international institution. This is an indication that the journal is gaining international acceptance and inclusion.

Table 2. Number and type of institutions of reviewers that contributed to Volume 13 of 2018.

\begin{tabular}{|c|c|c|c|c|c|c|}
\hline \multicolumn{5}{|c|}{ From Brazil } & \multicolumn{2}{|l|}{ From abroad } \\
\hline $\begin{array}{c}\text { Federal } \\
\text { Universities }\end{array}$ & $\begin{array}{c}\text { State } \\
\text { Universities }\end{array}$ & $\begin{array}{l}\text { State/Federal } \\
\text { Institutions }\end{array}$ & $\begin{array}{c}\text { National } \\
\text { private } \\
\text { Universities }\end{array}$ & $\begin{array}{l}\text { Municipal } \\
\text { Universities }\end{array}$ & $\begin{array}{l}\text { Reviewers from } \\
\text { international Institutions }\end{array}$ & Total \\
\hline 58 & 28 & 20 & 15 & 8 & 174 & 303 \\
\hline
\end{tabular}




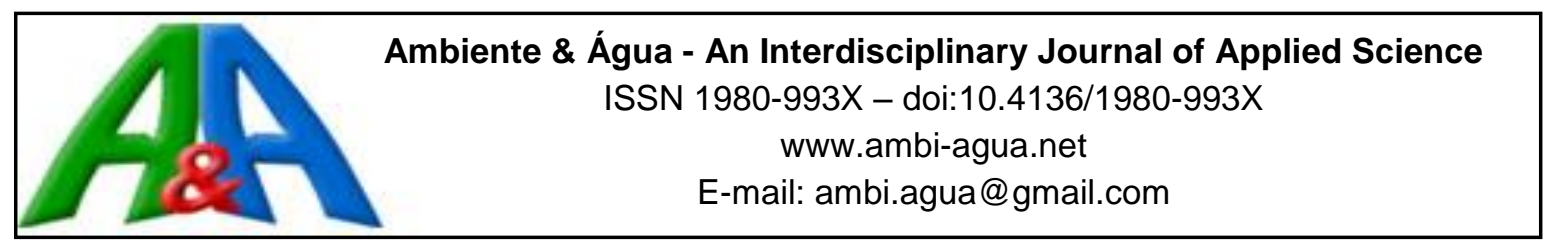

\title{
Electron Spin Resonance (ESR) in detection of aquatic pollution through host-parasite relationship
}

\author{
ARTICLES doi:10.4136/ambi-agua.2085
}

Received: 20 Mar. 2017; Accepted: 09 Sep. 2018

\author{
Lucas Aparecido Rosa Leite'; Angela Kinoshita'; Oswaldo Baffa²; \\ Rodney Kozlowiski de Azevedo ${ }^{1}$; Vanessa Doro Abdallah ${ }^{1 *}$ \\ ${ }^{1}$ Universidade do Sagrado Coração (USC), Bauru, SP, Brasil \\ Programa de Mestrado em Ciência e Tecnologia Ambiental. \\ E-mail: lucas.leite@aedu.com, angelamitie@gmail.com, azevedork@gmail.com, \\ vanessaabdallahusc@gmail.com \\ ${ }^{2}$ Universidade de São Paulo (USP), Ribeirão Preto, SP, Brasil \\ Faculdade de Filosofia, Ciências e Letras de Ribeirão Preto (FFCLRP). \\ Departamento de Física (DF). E-mail: baffa@usp.br \\ *Corresponding author
}

\begin{abstract}
Aquatic environmental pollution due to negative human activities remains a major problem. Bioindicators that primarily describe the total concentration of the respective pollutant are very useful tools to aid in the chemical analysis of water in order to obtain knowledge about the levels of pollutants in the environment. This study therefore used Electron Spin Resonance Spectroscopy (ESR) to detect the presence of transition metals (copper, iron and manganese) and possible radicals present in samples of Neoechinorhynchus curemai and its host tissues Prochilodus lineatus, as well in water and sediment of the Batalha River, at the same sample site where fish were collected. Spectral analysis of samples showed the presence of three metals $\left(\mathrm{Cu}^{2+}, \mathrm{Fe}^{3+}\right.$ and $\left.\mathrm{Mn}^{2+}\right)$, in addition to nitric oxide (NO) and humic acid (HA). Quantification of the elements in the samples was possible only for $\mathrm{Cu}$ detected in the spectrum of parasites, which was equivalent to $2 \mathrm{ppm}$. ESR proved to be efficient in the detection of transition-metal ions $\left(\mathrm{Cu}^{2+}, \mathrm{Fe}^{3+}\right.$ and $\left.\mathrm{Mn}^{2+}\right)$, in addition to $\mathrm{NO}$ and $\mathrm{HA}$. However, the low concentration values of these compounds in P. lineatus tissues (liver, muscle and intestine) and in the water and sediment samples collected did not allow their quantification, as they were below the limit of detection. It can be concluded that $N$. curemai had the capacity to accumulate these ions, especially copper.
\end{abstract}

Keywords: environmental monitoring, free radicals, Neoechinorhynchus curemai, Prochilodus lineatus, transition metals.

\section{Ressonância do Spin Eletrônico (ESR) na detecção de poluição aquática através da relação parasito-hospedeiro}

\section{RESUMO}

A poluição de ambientes aquáticos em decorrência de atividades antrópicas negativas permanece sendo um grande problema. Para se obter conhecimento acerca dos níveis biológicos de poluentes disponíveis no meio, os bioindicadores tornam-se uma ferramenta muito útil no 
auxílio das análises químicas da água que primariamente descrevem a total concentração do respectivo poluente. Nesse contexto, o objetivo desse trabalho foi o de empregar a técnica de Espectroscopia de Ressonância do Spin Eletrônico (ESR) para detectar a presença de poluentes, diretamente em espécimes de Neoechinorhynchus curemai e nos tecidos do seu hospedeiro Prochilodus lineatus, assim também como na água e sedimento do rio Batalha, no mesmo ponto onde os peixes foram coletados. A análise do espectro das amostras identificou a presença de três metais $\left(\mathrm{Cu}^{2+}, \mathrm{Fe}^{3+}\right.$ e $\left.\mathrm{Mn}^{2+}\right)$, além do óxido nítrico (NO) e do ácido húmico (AH). A quantificação dos elementos nas amostras só foi possível para o $\mathrm{Cu}$, detectado no espectro dos parasitos, que foi de $2 \mathrm{ppm}$. A ESR se mostrou eficiente na detecção de íons metálicos de transição $\left(\mathrm{Cu}^{2+}, \mathrm{Fe}^{3+}\right.$ e $\left.\mathrm{Mn}^{2+}\right)$, além do $\mathrm{NO}$ e do $\mathrm{AH}$. Entretanto, a baixa concentração desses compostos nos tecidos (fígado, músculo e intestino) de $P$. lineatus. não possibilitaram sua quantificação, já que as concentrações dos mesmos estão abaixo do limite de detecção do aparelho. É possível concluir que $N$. curemai teve a capacidade de acumular esses íons, especialmente cobre.

Palavras-chave: metais de transição, monitoramento ambiental, Neoechinorhynchus curemai, Prochilodus lineatus, radicais livres.

\section{INTRODUCTION}

Pollution of aquatic ecosystems as a result of anthropogenic activities remains a major problem in these environments, causing disastrous effects on the health of living organisms and becoming subject of many discussions (Khan and Thulin, 1991; Sures, 2008). In freshwater ecosystems, both organic and inorganic pollution (especially metals) are global issues and deserve attention since they directly and indirectly affect organisms, causing them irreparable damage (Wen et al., 2017; Schmeller et al., 2018; Väänänen et al., 2018).

Bioindicators that primarily describe the total concentration of a respective pollutant are very useful tools in the chemical analyses of water in order to obtain knowledge about levels of pollutants in the environment. Recent studies have shown that, in addition to already established indicators, certain parasites and their hosts can be used as biomonitoring tools, since the pollution also effects their health and, consequently, their occurrence and distribution. Another important point to consider is that, just like pollutants, parasites affect the health of organisms, and some of these organisms' responses to pollutants and parasites are very similar (Lafferty, 2008; Lafferty and Kuris, 2005; Sures, 2008; Thielen et al., 2004).

Studies evaluating the role of parasites as accumulators and pollution indicators have been carried out for decades, using a vast host-parasite combination (Sures et al., 1999; 2017) where fish are the most frequently used hosts (Vidal-Martínez and Wunderlich, 2017). In addition, the high potential of parasites for metal accumulation (especially heavy metals) and their high effectiveness in assessing aquatic pollution compared to free-living organisms (such as mussels, for example) has been clearly demonstrated (Sures et al., 1997; 1999;).

Different fish endoparasites have been suggested for use in the detection of pollution in aquatic environments. Among them, acanthocephalans are highlighted as presenting a high capacity for heavy metal accumulation (Vidal-Martínez et al., 2009; Nachev et al., 2013). Laboratory studies have shown that fish parasitized by acanthocephalans have lower levels of heavy metal contamination in their tissues when compared to non-parasitized specimens. However, the results of the analyses are difficult to predict, and there is a need for further studies in this field to contextualize information already obtained in different types of environments with different levels of degradation (Thielen et al., 2004; Sures, 2008).

Usually bioaccumulation studies in the host-parasite relationship are made using inductively coupled plasma mass spectrometry (ICP-MS) (Brázová et al., 2012; 2015; Leite et 
al., 2017; Nachev et al., 2010; 2013; Thielen et al., 2004) or Atomic absorption spectrometry (AAS) (Baruš et al., 2001; Bayoumy et al., 2015; Baruš et al., 2007; Dural et al., 2011; Morsy et al., 2012). Eletron Spin Resonance (ESR) is a spectroscopy designed to detect non-zero electronic spin systems, such as free radicals and some transition metals. In biological systems, it can be used to detect the presence of some ions, including copper, manganese and iron, directly in tissues without biochemical manipulations, thus reducing the risk of structural disturbances. This makes the technique a powerful tool in research involving biological and environmental systems (Wertz and Bolton, 2012).

ESR has already been used to detect pollutants (both organic and inorganic) in several systems. In aquatic ecosystems, ESR has been used to detect Reactive Oxygen Species (ROS) in amphibians (D'Errico et al., 2018) and to detect and quantify $\mathrm{Mn}^{2+}$ in fish otoliths (Di Beneditto and Franco, 2018). In both cases the technique proved to be efficient, and could be used to aid other spectrometric techniques. In the host-parasite system, however, there are still no published studies where ESR was used. In this context, the objective of this study was to use the ESR technique to detect transition metals (copper, iron and manganese) and possible radicals present in parasites and host tissues (muscle, liver and intestine).

\section{MATERIAL AND METHODS}

\subsection{STUDY AREA}

This study was conducted in a stretch of the Batalha River, the Tietê-Batalha River Basin, located in the municipality of Reginópolis, State of São Paulo (21'53'17' S and 49¹3'31' W). It is an area with severe anthropic influences and predominantly lotic characteristics. Limnologic and structure variables of the stretch are plotted in Table 1.

The river area in this stretch, even though surrounded by native riparian forest for most of its extension, is used predominantly for agricultural and livestock purposes, with emphasis on cattle raising, sugar cane, corn and eucalyptus plantations, increasing the amount of organic matter and leachate pollutants. In addition, the municipality does not treat sewage, and so sewage is thrown in natura into a tributary of the river (São Paulo, 2010; Santos and Heubel, 2008; Sistema Nacional De Informações Sobre Saneamento, 2016).

Table 1. Mean values of physicochemical parameters: $\mathrm{pH}$, temperature, dissolved oxygen (DO) and conductivity (CD); and structural parameters: width of the stretch, and width of the permanent preservation area (APP) surrounding the sampling point, located in the municipality of Reginópolis.

\begin{tabular}{lc}
\hline Parameter & Value \pm SD \\
\hline $\mathrm{pH}$ & $7.7 \pm 0.3$ \\
Temperature $\left({ }^{\circ} \mathrm{C}\right)$ & $26.5 \pm 1.5$ \\
$\mathrm{DO}(\mathrm{mg} / \mathrm{L})$ & $4.9 \pm 1.6$ \\
$\mathrm{CD}(\mu \mathrm{S} / \mathrm{cm})$ & $68 \pm 14.7$ \\
Width $(\mathrm{m})$ & $13.2 \pm 1.7$ \\
APP width $(\mathrm{m})$ & $83.1 \pm 7.9$ \\
\hline
\end{tabular}

\subsection{SAMPLING AND PROCESSING OF PARASITES AND HOSTS}

Thirty-nine specimens of Prochilodus lineatus (Valenciennes, 1837) (Characiformes: Prochilodontidae) were collected between May 2015 and May 2016 on the Batalha River. Fish were necropsied in the laboratory, and the internal organs were analyzed separately using a 
stereomicroscope to collect parasites. In this study, only fish specimens that showed positive results for Neoechinorhynchus curemai Noronha, 1973 (Acanthocephala: Neoechinorhynchidae) parasitism were used, totaling 19 P. lineatus specimens analyzed.

After collection, the parasites were placed in a recepticle containing distilled water and then washed with a vortex mixer. Subsequently, they were placed in glass flasks and frozen at $-20^{\circ} \mathrm{C}$ until the ESR analysis. Samples of muscle, liver and intestine were also taken from hosts. The washing and storage of the tissue samples followed the same methodology used for parasites.

\subsection{WATER AND SEDIMENT SAMPLING}

Water and sediment samples were collected from the Batalha River at the same point of the fish collection. The sampling followed the procedures recommended by Gomes and Filizola (2006) for sediment and Pires et al. (2006) for water. The samples were stored in $20 \mathrm{~mL}$ plastic tubes and frozen at $-20^{\circ} \mathrm{C}$ until ESR analysis.

\subsection{ESR ANALYSIS}

Samples of parasites and host tissues were externally cleaned with ultrapure water (Milli Q) and then dehydrated in absolute alcohol by immersion for 10 minutes. These materials and sediment were then oven-dried at $40^{\circ} \mathrm{C}$ (Table 2). After drying, the samples were carefully crushed with agate mortar and pestle for homogenization under low impact, in order to avoid induction of other radicals by mechanical action. Subsequently, an aliquot of each sample was transferred to an ESR quartz tube, with a $3 \mathrm{~mm}$ internal diameter. The mass used to record the spectrum was determined (Table 2). The water sample was placed in a capillary tube and sealed prior to insertion in the quartz tube. The tube containing the sample was inserted into a quartz dewar for freezing with liquid nitrogen for spectrum recording $(77 \mathrm{~K})$.

A JEOL Band-X spectrometer was used to record the spectra, some of them with a scan width of $500 \mathrm{mT}$ and others with $80 \mathrm{mT}$, centered on the g 2 spectral region. Some spectra were recorded simultaneously with a $\mathrm{Mn}^{2+}$ standard, present in the spectrometer, that consists of $\mathrm{MgO}$ crystal doped with $\mathrm{Mn}^{2+}$. A $0.5 \mathrm{mM}$ solution of $\mathrm{CuSO}_{4}$ complexed with $\mathrm{C}_{3} \mathrm{H}_{7} \mathrm{NO}_{2}$ was used for the quantification of copper $\left(\mathrm{Cu}^{2+}\right)$ present in the sample. The spectra of the parasite and the copper solution were acquired under the same spectrometer conditions of microwave power, modulation and gain. Copper can be complexed with several compounds producing different spectral symmetries. Alanine was used as a ligand due to the same symmetry of the complex found in the parasites samples. The volume of the standard solution used was $20 \mu \mathrm{L}$.

Table 2. Mass values (mg) of parasites, host tissues and sediment samples before and after drying, and the amount used in ESR analysis.

\begin{tabular}{lccccc}
\hline Mass & Parasite & Intestine & Liver & Muscle & Sediment \\
\hline Wet & $102 \mathrm{mg}$ & $189.5 \mathrm{mg}$ & $690 \mathrm{mg}$ & $674.4 \mathrm{mg}$ & -- \\
Dry & $17.1 \mathrm{mg}$ & $20.21 \mathrm{mg}$ & $77.44 \mathrm{mg}$ & $114 \mathrm{mg}$ & -- \\
ESR & $5.68 \mathrm{mg}$ & $6.08 \mathrm{mg}$ & $24.45 \mathrm{mg}$ & $5.8 \mathrm{mg}$ & $77.6 \mathrm{mg}$ \\
\hline
\end{tabular}

\section{RESULTS AND DISCUSSION}

The specimens of $P$. lineatus showed mean standard length and weight of $27.44 \pm 6.37 \mathrm{~cm}$ and $568.38 \pm 318.14 \mathrm{~g}$, respectively. The specimens of $N$. curemai were all adults and had mean abundance of $2.83 \pm 0.12$ parasites per fish and mean intensity of $5.52 \pm 0.13$ parasites.

The analysis of the parasite samples' spectrum in the $500 \mathrm{mT}$ scan was performed under two conditions: only parasite, and parasite with $\mathrm{Mn}^{2+}$ as a secondary standard. The analysis of 
the obtained signals showed that there is no $\mathrm{Mn}^{2+}$ in the parasite samples (Figure 1A). In the spectrum of the central region $\mathrm{g} \sim 2$ it was possible to notice characteristic lines of copper (Figure 1B). To confirm the presence of $\mathrm{Cu}^{2+}$ in the sample, spectral simulation of the $\mathrm{Cu}^{2+}$ present in the parasites was carried out using Simfonia-Bruker software. Through the simulation, it was possible to observe the agreement between the simulated $\mathrm{Cu}^{2+}$ signal and the radical present in the parasites. Double integration of the $\mathrm{Cu}^{2+}$ simulated signal was compared to element pattern spectrum. The $\mathrm{Cu}^{2+}$ mass of the total mass of the parasite was obtained from the atomic mass of the ion $(63.6 \mathrm{~g})$, resulting in a concentration of $2 \mathrm{ppm}$ of $\mathrm{Cu}^{2+}$ in the parasites (Figure $1 \mathrm{C}$ ).
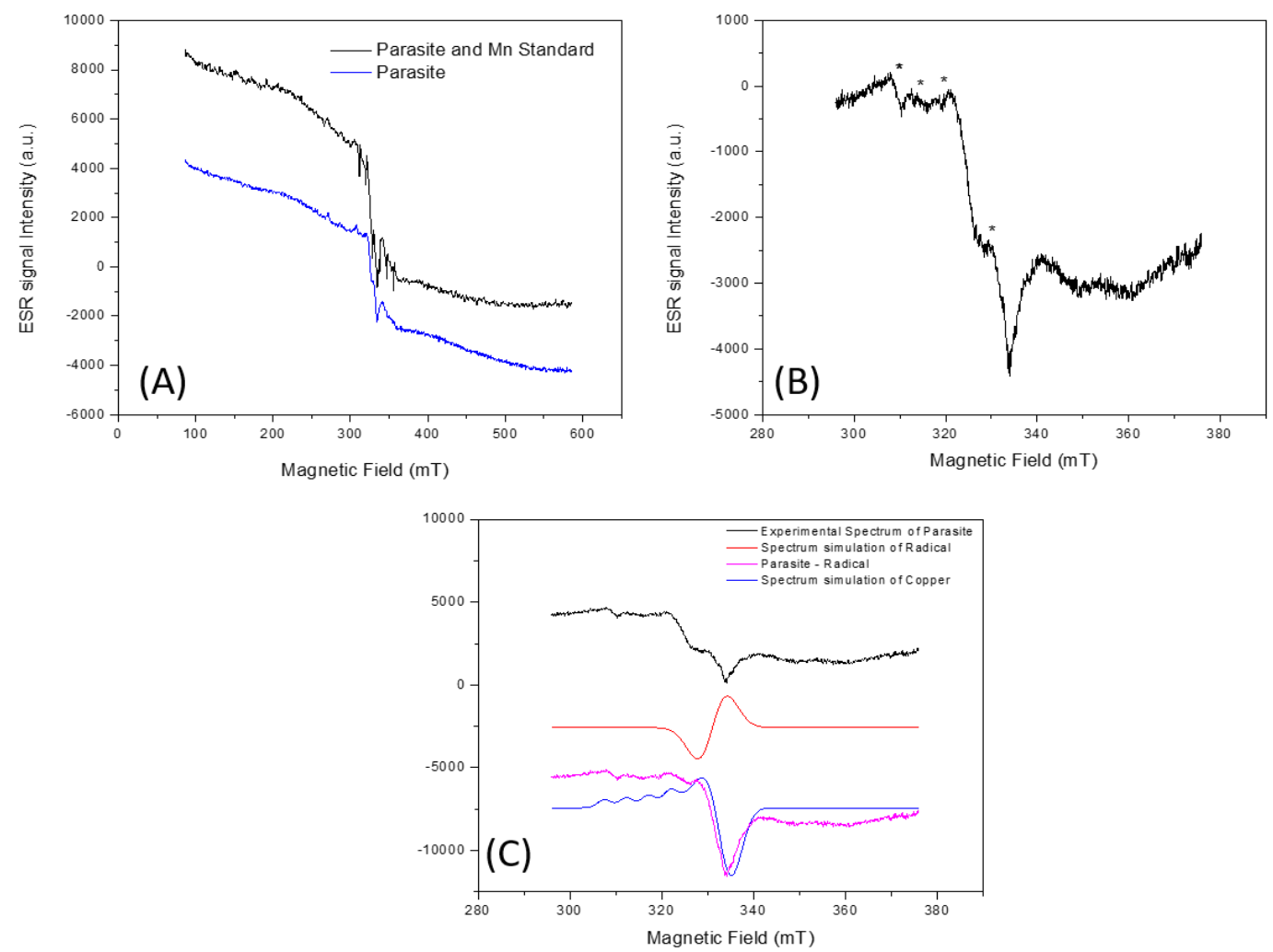

Figure 1. ESR spectrum of Neoechinorhynchus curemai specimens with and without the simultaneous register of manganese (A), centered on the $\mathrm{g} \sim 2$ region, where the signals indicated by asterisks represent the lines belonging to the copper $(B)\left(g_{\perp}: 2.0032 \pm 0.0001\right.$; $\left.\mathrm{g}_{/ /:}: 2.1160 \pm 0.0001 ; \mathrm{A}_{\perp}: 1.1 \pm 0.1 \mathrm{mT} ; \mathrm{A}_{/ /:} 4.8 \pm 0.1 \mathrm{mT}\right)$ and spectral simulation of the radical (g-factor: $2.0084 \pm 0.0001$ ) (C). Acquisition parameters are: Center Field $336 \mathrm{mT}$, Modulation Frequency $100 \mathrm{kHz}$, Modulation amplitude $0.1 \mathrm{mT}$, gain 2000, microwave frequency 9131.4 MHz, Microwave Power $5 \mathrm{~mW}$. In (A) sweep width 500mT and (B) 80 $\mathrm{mT}$.

The liver sample spectrum was recorded with 500mT scanning width. The spectrum was dominated by iron, as shown in the simulation (Figure 2A). In the $\mathrm{g} 22$ region of the spectrum it was possible to identify other radicals. By performing a more detailed recording of the spectrum in the $\mathrm{g} \sim 2$ region it was possible to observe a structure of lines. The spectrum was recorded with the manganese pattern for investigation, where very weak signals of this ion in this region can be noted (Figure 2B), indicating a small concentration of $\mathrm{Mn}^{2+}$ in the tissue. A more detailed scan at the g 2 region showed that the lines' structure in the central region corresponds to nitric oxide (NO), bound to $\mathrm{Fe}^{3+}$, leading to the three-line structure observed. Figure $2 \mathrm{C}$ shows the spectrum of the liver sample and the simulation of the NO radical spectrum. 

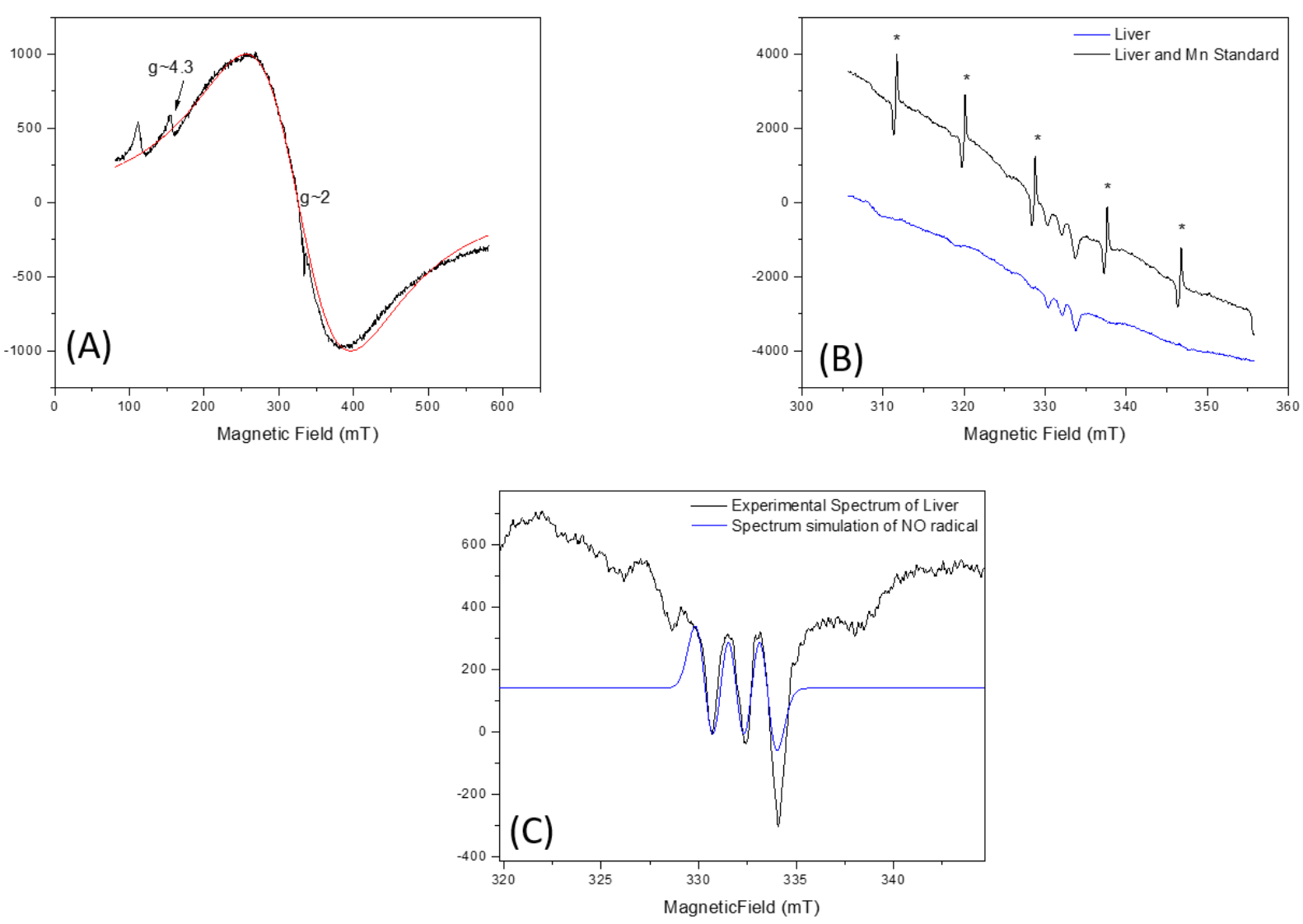

Figure 2. ESR spectrum in the $500 \mathrm{mT}$ scan of the fish liver samples and iron spectral simulation in red (A) (g-factor $=2.0453 \pm 0.0001)$. The spectrum centered on the $\mathrm{g} 2$ region with and without the manganese $(*)$ pattern (B). Spectrum of the sample also centered on the $\mathrm{g} \sim 2$ region and the simulation of the NO (g-factor $=2.0040 \pm 0.0001, \mathrm{~A}=1.82 \pm 0.01 \mathrm{mT}$ ) present in the sample $(\mathrm{C})$. Acquisition parameters are: Center Field $330 \mathrm{mT}$, Modulation Frequency $100 \mathrm{kHz}$, Modulation amplitude $0.1 \mathrm{mT}$, gain 300, microwave frequency $9133.4 \mathrm{MHz}$, Microwave Power $5 \mathrm{~mW}$. In (A) sweep width 500mT and (B) $100 \mathrm{mT}$.

In the spectrum of fish intestine samples, it was possible to notice the presence of $\mathrm{Fe}^{3+}$ and $\mathrm{Mn}^{2+}$ (Figure 3A). The spectrum was recorded with $\mathrm{Mn}^{2+}$ standard to confirm the presence of this element in the sample (Figure 3B). Incorporation of manganese ions in different matrices have been studied with multifrequency ESR, and this can give more information about the complex formed; but these techniques are not easily found, and these studies have corroborated the experiments done at X band (Murzakhanov et al., 2017).

In the fish muscle spectrum, it was also possible to notice the presence of the $\mathrm{Fe}^{3+}$ element and $\mathrm{Mn}^{2+}$ traces (Figure 4), suggesting that this element, although present in the sample, was in low concentration. 

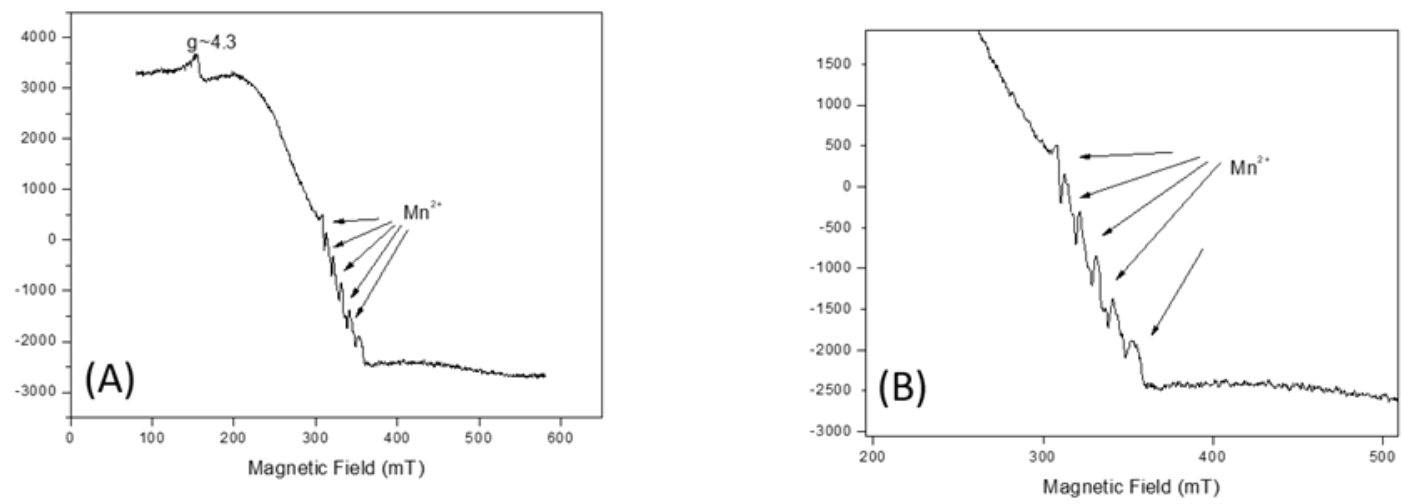

Figure 3. ESR spectrum of the fish intestine samples centered in the $g \sim 2$ region where the presence of iron is noted, with a peak at g 4.3 and manganese, as indicated (A). Spectrum in the $\mathrm{Mn}^{2+}$ region, recorded with manganese standard, for confirmation (B). Acquisition parameters are: Center Field $330 \mathrm{mT}$, Modulation Frequency $100 \mathrm{kHz}$, Modulation amplitude $0.1 \mathrm{mT}$, gain 300, microwave frequency $9133.4 \mathrm{MHz}$, Microwave Power $5 \mathrm{~mW}$, sweep width $500 \mathrm{mT}$.

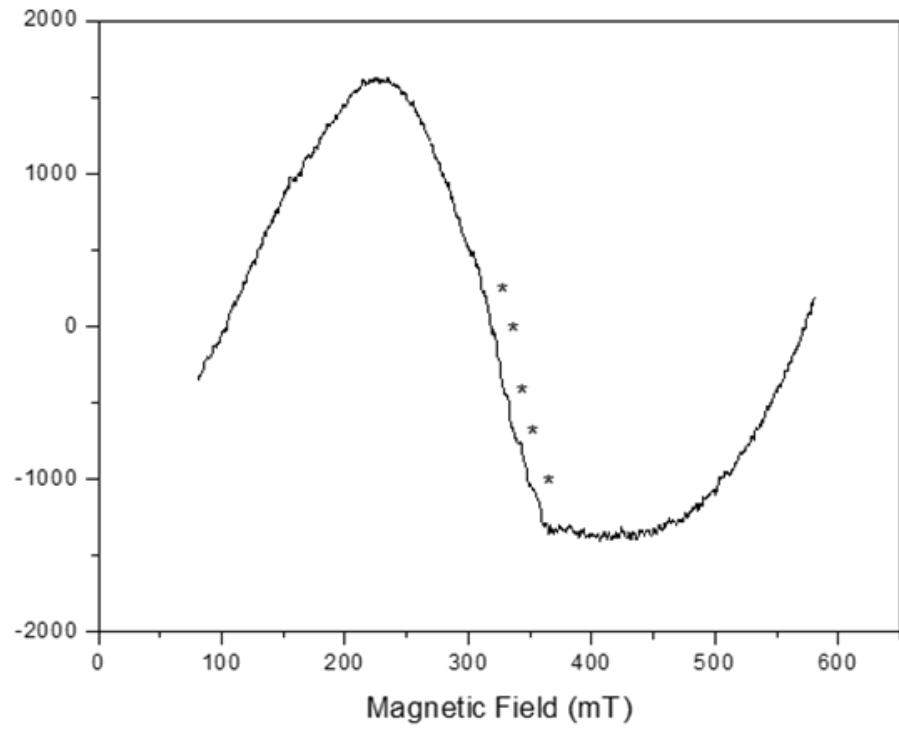

Figure 4. ESR spectrum of the fish muscle samples, where the presence of iron is observed and traces suggesting the presence of manganese $(*)$. Acquisition parameters are: Center Field $330 \mathrm{mT}$, Modulation Frequency $100 \mathrm{kHz}$, Modulation amplitude $0.1 \mathrm{mT}$, gain 300 , microwave frequency $9133.4 \mathrm{MHz}$, Microwave Power $5 \mathrm{~mW}$, sweep width $500 \mathrm{mT}$.

In the spectrum of the sediment samples analyzed, the presence of $\mathrm{Fe}^{3+}$ and $\mathrm{Mn}^{2+}$ can be observed. In addition to these elements, another central radical was recorded in the $\mathrm{g} \sim 2$ region, attributed to humic acid (AH) (Figure 5B). In the water sample, the spectrum showed only the presence of $\mathrm{Fe}^{3+}$ (Figure 5A).

Low concentrations of elements considered essential, that is, those necessary for the development of organisms and that occur naturally in the environment (Merian et al., 2004), are expected in acanthocephalans fish parasites, which are more susceptible to accumulate high concentrations of toxic elements (Nachev et al., 2013). Although copper is considered essential and is involved in several metabolic processes of living organisms (Momčilović, 2004), it is a heavy metal and at higher concentrations can bring potential risks to the health of animals, including humans (Papagiannis et al., 2004). The impacts of copper on the aquatic environment

\section{IPABH}

Rev. Ambient. Água vol. 13 n. 6, e2085 - Taubaté 2018 
depend on water physico-chemical characteristics, such as alkalinity, hardness and $\mathrm{pH}$ (Carvalho and Fernandes, 2006). Generally, concentrations of this element in water are lower than those found in fish and parasites (Porto and Ethur, 2009; Brázová et al., 2012), and the maximum concentration of copper allowed for Class 2 waters, such as the Batalha River, is $0.009 \mathrm{mg} / \mathrm{L}$ (Conama, 2005). In this case, as the element was not detected in fish-tissue spectrums nor in the water or sediment collected from the river, it was assumed that the concentrations are below the ESR detection limit.
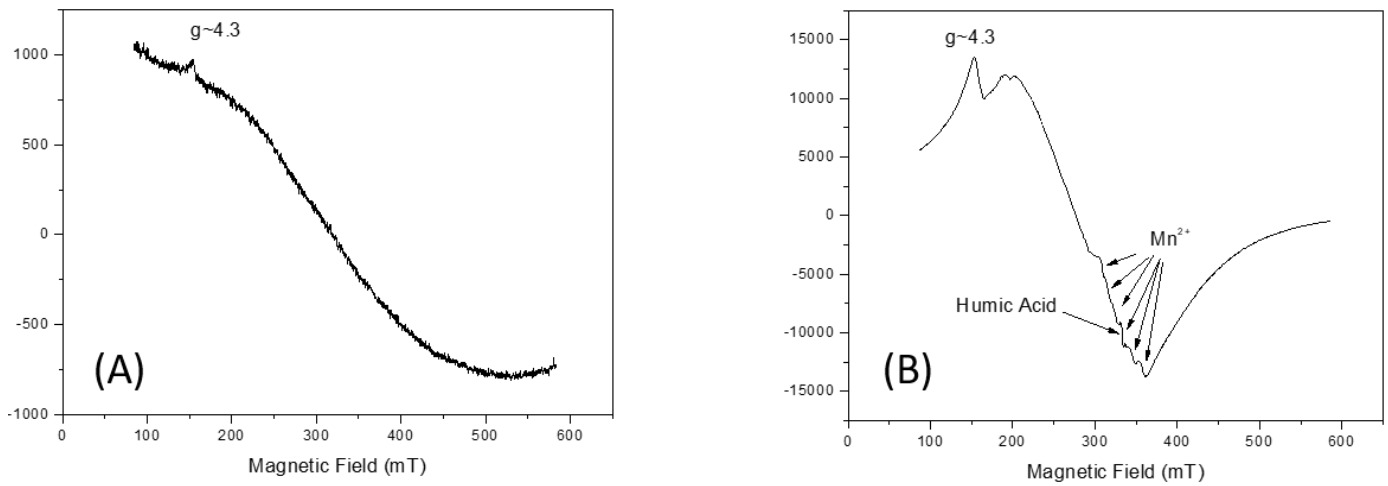

Figure 5. ESR spectrum of the water sample, where the presence of iron $(\mathrm{A})$ is noted. The ESR spectrum of sediment sample shows the presence of iron, traces of manganese, as indicated, and the presence of humic acid in the $\mathrm{g} 2$ region $(\mathrm{g}$-factor $=1.9976 \pm 0.0001$ ) (B). Acquisition parameters are: Center Field $330 \mathrm{mT}$, Modulation Frequency $100 \mathrm{kHz}$, Modulation amplitude $0.1 \mathrm{mT}$, gain 300, microwave frequency $9133.4 \mathrm{MHz}$, Microwave Power $5 \mathrm{~mW}$, sweep width 500mT.

The presence of iron and manganese ions in the spectrum of the tissues (liver, muscle and intestine) of $P$. lineatus and also in the samples of water and sediment of the Batalha River was already expected due to the high natural occurrence of these elements, which are the two most abundant metals in the environment (Förstner and Wittmann, 1983). Both elements in water and sediment are considered essential for both flora and fauna (Howe et al., 2004; Schümann and Elsenhans, 2004). Iron in fish acts mainly in oxidation-reduction and oxygen-transport processes, occurring as a component of the respiratory pigment (heme), as hemoglobin and myoglobin, as well as the heme enzymes (peroxidase, catalase and cytochromes) being absorbed from the water through the gills (Lim et al., 2001). Manganese plays a key role in the metabolism of amino acids, lipids, proteins and carbohydrates, besides being involved in functions of the immune system, blood glucose regulation, reproduction and also in defense mechanisms against free radicals (Keen et al., 1999).

In aquatic vertebrates, iron excess can cause several effects such as breathing problems, reduced growth, feeding difficulties, high mortality and histopathological changes in liver cells (Bury et al., 2003; Lim et al., 2001), in addition to the production of oxygen free radicals, which may be toxic to cells (Bury et al., 2003). Negative effects of excess Mn on fish include anemia, leukocytosis, disruption of sodium balance, impaired calcium absorption and impacts on metabolism (Agrawal and Srivastava, 1980; Barnhoorn et al., 1999; Gonzalez et al., 1990; Nath and Kumar, 1987; Reader et al., 1988).

The presence of NO detected in the spectrum of fish liver samples may also be associated with $\mathrm{Fe}^{3+}$ domain in the spectrum of the same tissue, since the molecule exerts its physiological functions through the binding with $\mathrm{Fe}^{3+}$ present in heme (Denninger and Marletta, 1999). In fish, NO has important roles in cardiovascular homeostasis, neurotransmission, immune defenses, vasodilation, muscle performance and embryonic development (Eddy, 2005; Jensen, 2009; Moncada and Higgs, 2006; Rudnick et al., 2004), and may be potentially toxic depending 
on tissue concentration or clearance (Hansen and Jensen, 2010). In addition, NO production may be directly associated with hypoxias situations, where the increase in NO causes fish and other aquatic organisms to become more resistant to situations of low oxygen availability in water (Jensen, 2009; McNeill and Perry, 2006). Hansen and Jensen (2010), evaluating the production of NO in goldenfish (Carassius auratus Linnaeus, 1758), observed that in situations of severe hypoxia, NO production by fish was increased as well as its resistance capacity, since the vasodilatation caused by NO increased the oxygen delivery rate in the organs. Thus, it is possible to verify that presence of NO in the tissues of $P$. lineatus can be an indicative of the lack of oxygen in the water, which in the study site of the Batalha River is around $4.9 \mathrm{mg} / \mathrm{L}$, below the established limit by CONAMA for Class 2 waters (Conama, 2005). However, it would be necessary to quantify $\mathrm{NO}$ in the samples in order to obtain safer and more accurate results. Another factor that should be considered is the fact that NO production is also directly associated with production of nitrosamines, which are potentially carcinogenic organic compounds (Al Bulushi et al., 2009). In humans, the highest rate of exposure to this compound occurs through food, which includes water and fish (Dutra et al., 2007).

Humic acids (HA), derived from humic substances (HS), which are part of organic matter, belong to the class of natural products most abundant in the biosphere, being precursors of fossil fuels. They are the most-studied fraction of HS, since they can contain voids of different sizes in their molecular structures, and can accommodate a wide range of pollutants (Mangrich and Vugman, 1988). HA act as binders for the complexation of ions, mainly $\mathrm{Mn}^{2+}, \mathrm{Fe}^{3+}$ and $\mathrm{Cu}^{2+}$, where the formation and transport of these complexes, and their deposition, can be important mechanisms in the accumulation of metals in the sedimentary deposits (Saab, 1999). It is known that in HA the content of certain ions, such as $\mathrm{Fe}^{3+}$, in concentrate domain sites increases with decreases in the degree of environmental pollution (Silva, 2001). However, the mere presence of HA in the sediment spectrum cannot be considered an indicator of pollution, and a more robust analysis of its structure is necessary to establish relationships with environmental impacts such as forest-pasture conversion (Araújo et al., 2011) or pollution by heavy metals, pesticides and other substances of anthropogenic origin (Toscano, 1999).

\section{CONCLUSION}

In this study, the Electron Spin Resonance technique proved to be efficient in detecting transition metals (manganese, iron and copper) and nitric oxide and humic acid. However, low concentration values of these compounds in $P$. lineatus tissues (liver, muscle and intestine) and in water and sediment samples collected did not allow their quantification, as the concentration of metals in the tissues is at a level below the limit of detection. It can be concluded that $N$. curemai had the capacity to accumulate these ions, especially copper.

\section{ACKNOWLEDGMENTS}

We thank the Fundação de Amparo à Pesquisa do Estado de São Paulo (FAPESP) (process $n^{\circ}$ 2014/12682-0 and 07/06720-4) and the Coordenação de Aperfeiçoamento de Pessoal de Nível Superior - Brasil (CAPES) - Finance Code 001, for the financial support.

\section{REFERENCES}

AGRAWAL, S. J.; SRIVASTAVA, A. K. Haematological responses in a fresh water fish to experimental manganese poisoning. Toxicology, v. 17, p. 97-100, 1980. https://doi.org/10.1016/0300-483X(80)90031-1 
AL BULUSHI, I.; POOLE, S.; DEETH, H. C.; DYKES, G. A. Biogenic Amines in Fish: Roles in Intoxication, Spoilage, and Nitrosamine Formation - A Review. Critical Reviews in

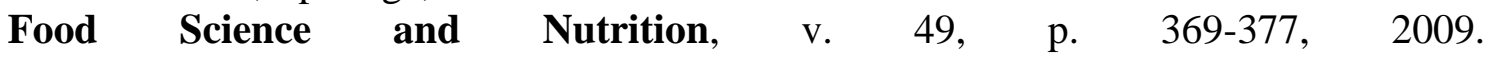
https://doi.org/10.1080/10408390802067514

ARAÚJO, E.; KER, J. C.; MENDONÇA, E. S.; SILVA, I. R; OLIVEIRA, E. K. Impacto da conversão floresta-pastagem nos estoques na dinâmica do carbono e substâncias húmicas do solo no bioma Amazônico. Acta Amazônica, v. 41, n. 1, p. 103-114, 2011.

BARNHOORN, I.; VAN VUREN, J. H. J.; PREEZ, H. H. Sublethal effects of manganese on the carbohydrate metabolism of Oreochromis mossambicus after acute and chronic exposure. African Zoology, v. 34, p. 102-107, 1999.

BARUŠ, V.; TENORA, F.; KRÁCMAR, S.; PROKES, M. Cadmium and lead concentrations in Contracaecum rudolphii (Nematoda) and its host, the cormorant Phalacrocorax carbo (Aves). Folia Parasitologica, v. 48, p. 77-78, 2001.

BARUŠ, V.; JARKOVSKÝ, J.; PROKEŠ, M. Philometra ovata (Nematoda: Philometroidea): a potential sentinel species of heavy metal accumulation. Parasitology Researh, v. 100, p. 929-933, 2007. https://doi.org/10.1007/s00436-006-0384-8

BAYOUMY, E. M.; ABOU-EL-DOBAL, S. K. A.; HASSANAIN, M. A. Assessment of Heavy Metal Pollution and Fish Parasites as Biological Indicators at Arabian Gulf off Dammam Coast, Saudi Arabia. International Journal of Zoological Research, v. 11, n. 5, p. 198206, 2015. http://dx.doi.org/10.3923/ijzr.2015.198.206

BRÁZOVÁ, T.; TORRES, J.; EIRA, C.; HANZELOVÁ, V.; MIKLISOVÁ, D.; ŠALAMÚN, P. Perch and Its Parasites as Heavy Metal Biomonitors in a Freshwater Environment: The Case Study of the Ružín Water Reservoir, Slovakia. Sensors, v. 12, p. 3068-3081, 2012. https://doi.org/10.3390/s120303068

BRÁZOVÁ, T.; HANZELOVÁ, V.; MIKLISOVÁ, D.; ŠALAMÚN, P.; VIDAL-MARTÍNEZ, V. M. Host-parasite relationships as determinants of heavy metal concentrations in perch (Perca fluviatilis) and its intestinal parasite infection. Ecotoxicology and $\begin{array}{llllll}\text { Environmental Safe, } & \text { n. } 122, \quad \text { p. } & \text { 551-556, } & \end{array}$ https://doi.org/10.1016/j.ecoenv.2015.09.032

BURY, N. R.; WALKER, P. A.; GLOVER, C. N. Nutritive metal uptake by teleost fish. Journal of Experimental Biology, v. 206, p. 11-23, 2003. https://dx.doi.org/10.1242/jeb.00068

CARVALHO, C. S.; FERNANDES, M. N. Effect of temperature on copper toxicity and hematological responses in the neotropical fish Prochilodus scrofa at low and high $\mathrm{pH}$. $\begin{array}{lllll}\text { Aquaculture, } & \text { v. } & 251, & \text { p. } & 109-117,\end{array}$ https://doi.org/10.1016/j.aquaculture.2005.05.018

CONSELHO NACIONAL DO MEIO AMBIENTE - CONAMA. Resolução nº 357, de 17 de março de 2005. Dispõe sobre a classificação dos corpos de água e diretrizes ambientais para o seu enquadramento, bem como estabelece as condições e padrões de lançamento de efluentes, e dá outras providências. Diário Oficial [da] União, n. 53, p. 58-63, 18 mar. 2015.

DENNINGER, J. W.; MARLETTA, M. A. Guanylate cyclase and the NO/cGMP signaling pathway. Biochimica and Biophysica Acta (BBA) - Bioenergetics, n. 1411, p. 334350, 1999. https://doi.org/10.1016/S0005-2728(99)00024-9 
D’ERRICO, G.; VITIELLO, G.; TOMMASO, G.; ABDEL-GAWAD, F. K.; BRUNDO, M. V.; FERRANTE, M. et al. Electron Spin Resonance (ESR) for the study of Reactive Oxygen Species (ROS) on the isolated frog skin (Pelophylax bergeri): A non-invasive method for environmental monitoring. Environmental Research, v. 165, p. 11-18, 2018. https://doi.org/10.1016/j.envres.2018.03.044

DI BENETITTO, A. P. M. D.; FRANCO, R. W. A. $\mathrm{Mn}^{2+}$ concentrations in coastal fish otoliths: understanding environmental and biological influences from EPR. Journal of Biological Physics, 2018. https://doi.org/10.1007/s10867-018-9502-y

DURAL, M.; GENC, E.; SANGUN, M. K.; GÜNER, O. Accumulation of some heavy metals in Hysterothylacium aduncum (Nematoda) and its host sea bream, Sparus aurata (Sparidae) from North-Eastern Mediterranean Sea (Iskenderun Bay). Environmental Monitoring and Assessment, v. 174, p. 147-155, 2011. https://doi.org/10.1007/s10661010-1445-0

DUTRA, C. B.; RATH, S.; REYES, F. G. Nitrosaminas voláteis em alimentos. Alimentos e Nutrição, v.18, p. 111-120, 2007.

EDDY, F. B. Role of nitric oxide in larval and juvenile fish. Comparative Biochemistry and Physiology Part A: Molecular \& Interative Physiology, v. 142, p. 221-230, 2005. https://doi.org/10.1016/j.cbpb.2005.05.038

FÖRStner, U.; WITMAnN, G. T. W. Metal Pollution in Aquatic Environment. 2. ed. Berlin: Spinger-Verlag, 1983. 485 p.

GOMES, M. A. F.; FILIZOLA, H. F. Amostragem de sedimento para análise de metais pesados. In: FILIZOLA, H. F.; GOMES, M. A. F.; SOUZA, M. D. (Eds.). Manual de procedimentos de coleta de amostras em áreas agrícolas para análise da qualidade ambiental: solo, água e sedimentos. Jaguariúna: Embrapa Meio Ambiente, 2006. p. 119124.

GONZALEZ, R. J.; GRIPPO, R. S.; DUNSON, W. A. The disruption of sodium balance inbrook charr, Salvelinus fontinalis (Mitchell), by manganese and iron. Journal of Fish Biology, v. 37, p. 765-774, 1990. https://doi.org/10.1111/j.1095-8649.1990.tb02540.x

HANSEN, M. N.; JENSEN, F. B. Nitric oxide metabolites in goldfish under normoxic and hypoxic conditions. Journal of Experimental Biology, v. 213, p. 3593-3602, 2010. Htttps://dx.doi.org/10.1242/jeb.048140

HOWE, P.; MALCOLM, H.; DOBSON, S. Manganese and its compounds: Environmental aspects. Geneva: World Health Organization, 2004, 63 p.

JENSEN, F. B. The role of nitrite in nitric oxide homeostasis: a comparative perspective. Biochimica et Biophysica. Acta (BBA) - Bionergetics, v. 1787, p. 841-848, 2009. https://doi.org/10.1016/j.bbabio.2009.02.010

KEEN, C. L.; ENSUNSA, J. L.; WATSON, M. H.; BALY, D. L.; DONOVAN, S. M.; MONACO, M. H. et al. Nutritional aspects of manganese from experimental studies. Neurotoxicology, v. 20, p. 213-223, 1999.

KHAN, R. A.; THULIN, J. Influence of pollution on parasites of aquatic animals. Advances in Parasitology, v. 30, p. 201-238, 1991. https://doi.org/10.1016/S0065-308X(08)60309-7

LAFFERTY, K. D. Ecosystem consequences of fish parasites. Journal of Fish Biology, n. 73, p. 2083-2093, 2008. https://doi.org/10.1111/j.1095-8649.2008.02059.x 
LAFFERTY, K. D.; KURIS, A. M. Parasitism and environmental disturbances. In: THOMAS, F.; RENAUD, F. L.; GUÉGAN, J. (Org.). Parasitism and Ecosystems. Oxford: Oxford University Press., 2005. p. 113-123.

LEITE, L. A. R.; PEDRO, N. H. O. P.; AZEVEDO, R. K.; KINOSHITA, A.; GENNARI, R. F.; WATANABE, S. et al. Contracaecum sp. parasitizing Acestrorhynchus lacustris as a bioindicator for metal pollution in the Batalha River, southeast Brazil. Science of the $\begin{array}{llllll}\text { Total Environment, } & \text { v. } & \text { 5. } & \text { 836, }\end{array}$ https://doi.org/10.1016/j.scitotenv.2016.09.132

LIM, C.; KLEUSIUS, P. H.; SHOEMAKER, C. A. Dietary Iron and Fish Health. In: LIM, C.; WEBSTER, C. D. Nutrition and Fish Health. New York: Food Products Press, 2001. p. 216-226.

MANGRICH, A. S.; VUGMAN, N. V. Bonding Parameters of Vanadyl ion in humic acid from the Jucu river estuarine Region, Brazil. Science of the Total Environment, v. 75, p. 235 241, 1988. https://doi.org/10.1016/0048-9697(88)90036-8

MCNEILL, B.; PERRY, S. F. The interactive effects of hypoxia and nitric oxide on catecholamine secretion in rainbow trout (Oncorhynchus mykiss). Journal of Experimental Biology, v. 209, p. 4214-4223, 2006. https://dx.doi.org/10.1242/jeb.02519

MERIAN, E.; ANKE, M.; IHNAT, M.; STOEPPLER, M. (Eds.). Elements and their compounds in the environment: occurrence, analysis and biological relevance. 2. ed. Weinheim: WILEY-VCH Verlag GmbH \& Co. KGaA, 2004. 1806 p.

MOMČILOVIĆ, B. The Copper Group. In: MERIAN, E.; ANKE, M.; IHNAT, M.; STOEPPLER, M. (Eds.). Elements and their compounds in the environment: occurrence, analysis and biological relevance. 2. ed. Weinheim: WILEY-VCH Verlag GmbH \& Co. KGaA, 2004. p. 731-750.

MONCADA, S.; HIGGS, E. A. The Discovery of nitric oxide and its role in vascular biology. British Journal of Pharmacology, n. 147, p. S193-S201, 2006. https://doi.org/10.1038/sj.bjp.0706458

MORSY, K.; MORSY, K.; BASHTAR, A. R.; ABDEL-GHAFFAR, F.; MEHLHORN, H.; QURAISHY, S. A. et al. First record of anisakid juveniles (Nematoda) in the European seabass Dicentrarchus labrax (family: Moronidae), and their role as bio-indicators of heavy metal pollution. Parasitology Research, v. 110, p. 1131-1138, 2012. https://doi.org/10.1007/s00436-011-2600-4

MURZAKHANOV, F.; MAMIN, G.; VOLOSHIN, A.; KLIMASHINA, E.; PUTLYAEV, V.; DORONIN, V. et al. Conventional electron paramagnetic resonance of $\mathrm{Mn}^{2+}$ in synthetic hydroxyapatite at different concentrations of the doped manganese. IOP Conference Series: Earth and Environmental Science, v. 155, p. 1-5, 2017. https://dx.doi.org/10.1088/1755-1315/155/1/012006

NACHEV, M.; ZIMMERMANN, S.; RIGAUD, T; SURES, B. Is metal accumulation in Pomphorhynchus laevis dependent on parasite sex or infrapopulation size? Parasitology, v. 137, 1239-1248, 2010. https://doi.org/10.1017/S0031182010000065

NACHEV, M.; SCHERTZINGER, G.; SURES, B. Comparison of the metal accumulation capacity between the acanthocephalan Pomphorhynchus laevis and larvae nematodes of the genus Eustrongylides sp. infecting barbell (Barbus barbus). Parasites \& Vectors, v. 6, n. 21, p. 1-8, 2013. https://doi.org/10.1186/1756-3305-6-21 
NATH, K; KUMAR, N. Toxicity of manganese and its impact on some aspects of Carbohydrate metabolism of a freshwater teleost, Colisa fasciatus. Science of the Total Environment, v. 67, p. 257-262, 1987. https://doi.org/10.1016/0048-9697(87)90216-6

PAPAGIANNIS, I.; KAGALOU, I.; LEONARDOS, J. PETRIDIS, D.; KALFAKAKOU, V. Copper and zinc in four freshwater fish species from Lake Pamvotis (Greece). $\begin{array}{llllll}\text { Environment International, } & \text { v. } 3004 .\end{array}$ https://doi.org/10.1016/j.envint.2003.08.002

PIRES, A. M. M.; SOUZA, M. D.; LIGO, M. A. V. Amostragem de água para análise de nitrato e de metais pesados. In: FILIZOLA, H. F.; GOMES, M. A. F.; SOUZA, M. D. (Eds.). Manual de Procedimentos de Coleta de Amostras em Áreas Agrícolas para Análise da Qualidade Ambiental: Solo, Água e Sedimentos. Jaguariúna: Embrapa Meio Ambiente, 2006. p. 103-106.

PORTO, L. C. S.; ETHUR, E. M. Elementos traço na água e em vísceras de peixes da Bacia Hidrográfica Butuí-Icamaquã, Rio Grande do Sul, Brasil. Ciência Rural, v. 39, n. 9, p. 2512-2518, 2009.

READER, J. P.; DALZIEL, T. R. K.; MORRIS, R. Groth, mineral uptake and skeletal calcium deposition in brown trout, Salmo trutta L., yolk-sac fry exposed to aluminium and manganese in soft acid water. Journal of Fish Biology, v. 32, p. 607-624, 1988. https://doi.org/10.1111/j.1095-8649.1988.tb05399.x

RUDNICK, J.; PÜTTMANN, B.; TESCH, P. A.; ALKNER, B.; SCHOSER, B. G.; SALANOVA, M. et al. Differential expression of nitric oxide synthases (NOS 1-3) in human skeletal muscle following exercise countermeasure during 12 weeks. FASEB J., v. 18, p. 1228-1230, 2004. https://doi.org/10.1096/fj.03-0792fje

SAAB, S. C. Caracterização da matéria orgânica em gleissolos por espectroscopias de EPR, RMN, IV e UV-Visível. 1999. Tese (Doutorado em Ciências) - Universidade de São Paulo, São Carlos, 1999.

SANTOS, F. S.; HEUBEL, M. T. C. D. Composição da comunidade ictiológica e biometria taxológica na lagoa de captação de água do DAE no rio Batalha (Bauru-SP). Salusvita, v. 27, n. 1, p. 29-44, 2008.

SÃO PAULO (Estado). Comitê da bacia hidrográfica do Tietê Batalha: fundamentos para implantação da cobrança pelo uso dos recursos hídricos. 2010. Disponível em: https://goo.gl/F4ienM. Acesso em: 23 set. 2016.

SCHMELLER, D. S.; LOYAU, A.; BAO, K.; BRACK, W.; CHATZINOTAS, A.; VLEESCHOUWER, F. et al. People, pollution and pathogens - Global change impacts in mountain freshwater ecosystems. Science of the Total Environment, v. 622-623, p. 756-763, 2018. https://doi.org/10.1016/j.scitotenv.2017.12.006

SCHÜMANN, K.; ELSENHANS, B. The Iron Group. In: MERIAN, E.; ANKE, M.; IHNAT, M.; STOEPPLER, M. (Eds.). Elements and their compounds in the environment: occurrence, analysis and biological relevance. 2. ed. Weinheim: WILEY-VCH Verlag GmbH \& Co. KGaA, 2004. p. 811-824.

SILVA, L. Estruturas químicas dos ácidos húmicos de sedimento de mangue e o nível de poluição ambiental. 2001. Dissertação (Mestrado em Química) - Universidade Federal do Paraná, Curitiba, 2001. 
SISTEMA NACIONAL DE INFORMAÇÕES SOBRE SANEAMENTO. Série histórica: informações sobre água e esgoto dos municípios brasileiros. 2016. Disponível em: http://app.cidades.gov.br/serieHistorica/\#. Acesso em: 23 set. 2016.

SURES, B. Environmental Parasitology: Interactions between parasites and pollutants in the aquatic environment. Parasite, v. 15, p. 434-438, 2008. https://doi.org/10.1051/parasite/2008153434

SURES, B.; NACHEV, M.; SELBACH, C.; MARCOGLIESE, D. J. Parasites responses to pollution: what we know and where we go in 'Environmental Parasitology'. Parasites \& Vectors, v. 10, p. 1-19, 2017. https://doi.org/10.1186/s13071-017-2001-3

SURES, B.; SIDALL, R.; TARASCHEWSKI, H. Parasites as accumulation indicators of heavy metal pollution. Parasitology Today, v. 15, p. 16-21, 1999. https://doi.org/10.1016/S0169-4758(98)01358-1

SURES, B.; TARACHEWSKI, H.; RYDLO, M. Intestinal fish parasites as heavy metal bioindicators: a comparison between Acanthocephalus lucii (Palaeacanthocephala) and the Zebra Mussel, Dreissena polymorpha. Bulletin of Environmental Contamination and Toxicology, v. 59, p. 14-21, 1997. https://doi.org/10.1007/s001289900437

THIELEN, F.; ZIMMERMAN, S.; BASKA, F.; TARASCHEWSKI, H.; SURES, B. The intestinal parasite Pomphorhynchus laevis (Acanthocephala) from barbel as a bioindicator for metal pollution in the Danube River near Budapest, Hungary. $\begin{array}{llllll}\text { Environmental Pollution, } & \text { v. 121, p. 421-429, }\end{array}$ https://doi.org/10.1016/j.envpol.2003.11.011

TOSCANO, I. A. S. Influência das substâncias húmicas aquáticas na determinação de atrazina por imunoensaio (elisa). 1999. Tese (Doutorado em Química) - Universidade Estadual Paulista "Júlio de Mesquita Filho", Araraquara, 1999.

VÄÄNÄNEN, K.; LEPPÄNEN, M. T.; CHEN, X.; AKKANEN, J. Metal bioavailability in ecological risk assessment of freshwater ecosystems: From science to environmental management. Ecotoxicology and Environmental Safety, v. 147, p. 430-446, 2018. https://doi.org/10.1016/j.ecoenv.2017.08.064

VIDAL-MARTÍNEZ, V. M.; PECH, D.; SURES, B.; PURUCKER, S. T.; POULIN, R. Can parasites really reveal environmental impact? Trends in Parasitology, v. 26, n. 1, p. 4451, 2009. https://doi.org/10.1016/j.pt.2009.11.001

VIDAL-MARTÍNEZ, V. M.; WUNDERLICH, A. C. Parasites as bioindicators of environmental degradation in Latin America: a meta-analysis. Journal of $\begin{array}{lllllll}\text { Helminthology, } & \text { v. } & 91, \quad \text { n. } & 2, & \text { p. } & 165-173,\end{array}$ https://doi.org/10.1017/S0022149X16000432

WEN, Y.; SCHOUPS, G.; van de GIESEN, N. Organic pollution of rivers: Combined threats of urbanization, livestock farming and global climate change. Scientific Reports, v. 7, p. 43289, 2017. https://doi.org/10.1038/srep43289

WERTZ, J.; BOLTON, J. R. Electron spin resonance: elementary theory and practical applications. New York: Springer Science \& Business Media, 2012. 498 p. 


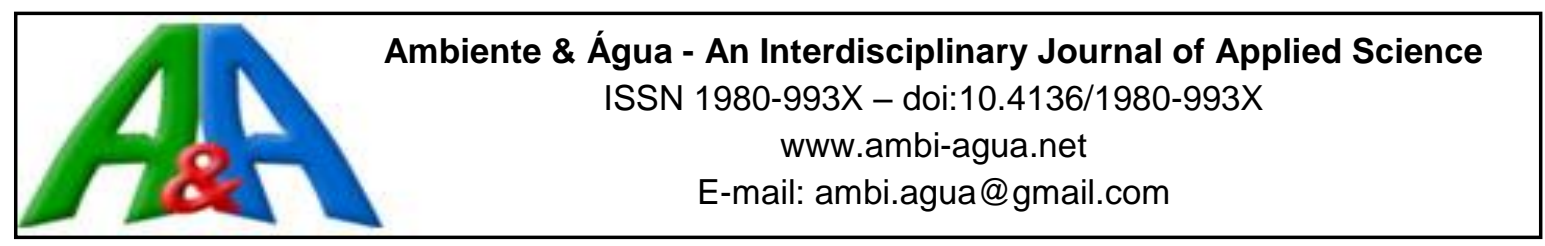

\title{
Hydrological modeling of an experimental basin in the semiarid region of the Brazilian State of Pernambuco
}

\author{
ARTICLES doi:10.4136/ambi-agua.2204
}

Received: 26 Oct. 2017; Accepted: 23 Sep. 2018

\author{
Adriana Guedes Magalhães ${ }^{1 *}$; Abelardo Antônio de Assunção Montenegro" ${ }^{1}$; \\ Carolyne Wanessa Lins de Andrade²; Suzana Maria Gico Lima Montenegro ${ }^{3}$; \\ Robertson Valério de Paiva Fontes Júnior ${ }^{1}$ \\ ${ }^{1}$ Universidade Federal Rural de Pernambuco (UFRPE), Recife, PE, Brasil \\ Departamento de Engenharia Agrícola (DEAGRI).E-mail: agmguedes@gmail.com, \\ abelardo.montenegro@yahoo.com.br,rr_fontes@hotmail.com \\ ${ }^{2}$ Universidade Federal Rural de Pernambuco (UFRPE), Recife, PE, Brasil \\ Unidade Acadêmica de Serra Talhada (UAST). E-mail: carolynelins200@gmail.com \\ ${ }^{3}$ Universidade Federal de Pernambuco (UFPE), Recife, PE, Brasil \\ Departamento de Engenharia Civil (DECIVIL).E-mail: suzanam.ufpe@gmail.com \\ *Corresponding author
}

\begin{abstract}
Hydrological simulation models have proven to be an important tool for managing and planning water resources, enabling the assessment of the impacts of rainfall on surface runoff and soil moisture. This work therefore aimed to apply the SWAT model for the analysis of hydrological processes in the Experimental Basin of the Jatobá Stream, in the semiarid region of the State of Pernambuco, Brazil, considering the calibration and validation of the model from streamflow and soil moisture data. Moreover, the study investigated hydrological effectiveness in a recovery scenario in areas of higher topographic elevation of the arborescent Caatinga and the behavior of the hydrological components under an agricultural expansion scenario. Events which occured between 2009 and 2010 were used to calibrate and validate streamflow and soil moisture data. The calibration and validation of streamflow exhibited efficiency coefficients (NSE) of 0.58 and 0.42 , respectively, and 0.53 and 0.46 for soil moisture. The adjustment of the parameters was considered adequate for representing streamflow recession periods. It was also verified that the alternative process of calibration and validation with soil moisture reduced uncertainty. Regeneration of the vegetative cover over $21 \%$ of the hilltop areas of arborescent Caatinga led to a significant increase in percolation (42\%) and a decrease of $34 \%$ in soil moisture (due to water consumption by plants), thus contributing to the recovery of headwaters, increasing resilience to water scarcity. On the other hand, the $38 \%$ expansion of agriculture caused an increase of $11 \%$ in surface runoff and, consequently, an increase of $10 \%$ in soil moisture.
\end{abstract}

Keywords: Caatinga, hydrological models, multiple datasets, SWAT model. 


\section{Modelagem hidrológica em bacia experimental do semiárido Pernambucano}

\section{RESUMO}

A simulação de processos hidrológicos apresenta-se como importante ferramenta de gestão e planejamento dos recursos hídricos, possibilitando avaliação dos impactos da precipitação sobre a geração de escoamento superficial e umedecimento do solo. O objetivo do presente trabalho foi aplicar o modelo hidrológico SWAT para análise de processos hidrológicos na Bacia Experimental do Riacho Jatobá, no semiárido de Pernambuco, considerando a calibração e a validação do modelo a partir de dados de vazão e de umidade do solo. Além disso, o estudo buscou investigar a efetividade hidrológica em um cenário de recomposição de Caatinga arbórea em áreas de maior elevação topográfica na bacia experimental, e o comportamento dos componentes hidrológicos em um cenário de expansão agrícola. Para a calibração e validação da vazão e umidade do solo utilizaram-se eventos ocorridos entre 2009 e 2010 . A calibração e a validação com a vazão apresentaram coeficientes de eficiência NSE de 0,58 e 0,42, respectivamente, e para a umidade do solo de 0,53 e 0,46, respectivamente. Os ajustes dos parâmetros foram adequados para representar os períodos de recessão do escoamento. Verificou-se que o processo alternativo de calibração e validação por meio da umidade do solo possibilitou a redução nas incertezas. Cenários de recomposição da cobertura vegetal de $21 \%$ na área de Caatinga arbórea nos topos de morro produziram significativo aumento de $42 \%$ na percolação e diminuição de $34 \%$ na umidade do solo (devido ao consumo de água pelas plantas), contribuindo assim para a recuperação das nascentes e aumentando a resiliência frente a cenários de escassez hídrica. Por outro lado, o cenário de expansão agrícola de $38 \%$, provocou aumento de $11 \%$ no escoamento superficial e, consequentemente, um aumento de $10 \%$ na umidade do solo.

Palavras-chave: Caatinga, modelos hidrológicos, múltiplos conjuntos de dados, modelo SWAT.

\section{INTRODUCTION}

The Caatinga, a typical vegetation of the Brazilian semiarid region, is comprised of woody, herbaceous, cactaceous and bromeliaceous species that exhibit under the adverse climatic and hydrological conditions of the region. In the semiarid region, the Caatinga vegetation is subjected to an intense process of degradation, due to deforestation and the burning of natural vegetation to allow for the planting of cash crops and pastures. According to Blainski et al. (2017), changes in plant cover without planning and without proper management of natural resources can have negative effects on the ecosystem and water availability. The substitution or removal of natural vegetation affects hydrological processes and budgets, causing lower water retention during droughts and increasing overland flow during rainy seasons. The increase in surface runoff may present problems such as soil nutrient losses and the production of sediment, leading to the sedimentation of reservoirs and rivers. Bales (2015), Ilstedt et al. (2016) and Şen (2015) verified that the positive water vegetation nexus is indirect, as increases in vegetative cover, although producing higher evapotranspiration, may at the same time increase infiltration, and therefore possibly enlarge subsurface water storage, particularly at the vadose zone. Such a hypothesis, however, requires proper analysis, as it depends on multiple variables, changing across scales.

Several studies have used hydrological models, such as the Soil and Water Assessment Tool (SWAT), to evaluate the hydrological impact of changes in vegetation cover in watersheds. The SWAT model combines climatic, topographic, edaphic, and land use factors 
to evaluate the variation of the hydrological conditions of the watersheds, identifying the vulnerabilities related to water quantity and quality in the basin. According to Britto et al. (2014), the results from the combination of these factors can be applied effectively in the development of watersheds management plans.

The SWAT model has been listed as a keyword in $12 \%$ of published international articles from 2009 to 2013 (Li et al., 2014). In Brazil, between 1999 and 2015, the model was used in more than 100 studies published in Brazilian and international journals (Bressiani et al., 2015). The applications of the SWAT model include studies of the streamflow calculation (Brighenti et al., 2016; Melo Neto et al., 2014; Aragão et al., 2013; Andrade et al., 2013), transport of sediments and pollutants (Silva and Medeiros, 2014; Veiga, 2014; Galharte et al., 2014), and in the quantification of impacts resulting from changes in land use on hydrological and sedimentological dynamics (Aragão et al., 2013; Blainski et al., 2011; Rodrigues et al., 2015; Silva et al., 2015; 2018). Santos (2015) analyzed sediment production and its spatial distribution with the SWAT model in the Tapacurá River Basin $\left(472 \mathrm{~km}^{2}\right)$, State of Pernambuco. Brighenti et al. (2016) verified that the SWAT model was representative in the simulations of streamflow data in wet and dry periods in the Negrinho River Basin $\left(200 \mathrm{~km}^{2}\right)$ in Santa Catarina. Silva and Medeiros (2014) analyzed the spatial and temporal variability of surface runoff and sediment production using the SWAT model in the São João do Cariri Experimental Basin (BESJC), with an area of $13.5 \mathrm{~km}^{2}$. The results presented adequate efficiency in the analysis of sediment yield and streamflow, with Pearson's Linear Correlation Coefficients of 0.84 and 0.88, and Nash-Sutcliffe Coefficients of 0.03 and 0.77, respectively.

Finger et al. (2015) pointed out that calibration and validation with multiple data sets increases the overall performance of hydrological models. Applying SWAT to a semiarid catchment in Australia, Kundu et al. (2017) endorsed the value of remotely sensed surface soil moisture in conjunction with flow data for improving model calibration using SWAT, despite the low correlation between satellite outputs and in situ observations. Previously, adopting the Dicasm model for the Alto Ipanema catchment (which encompasses the Jatobá Basin adopted in this study), Montenegro and Ragab (2010) analyzed the impact of land-use changes on water availability, using jointly flow and in situ soil moisture data, and verified the relevance of multiple data sets to achieve a more rigorous model simulation.

The Jatobá River Experimental Basin (BERJ) is located in the semiarid region of Pernambuco, where rainfall is extremely irregular and water courses are intermittent. Due to its characteristics, the Network of Hydrology of the Semiarid Region (REHISA) has been monitoring and conducting different studies around the basin area. The years 2009 and 2010 presented high precipitation in the region, with flow generation in the Alto Ipanema Basin (Silva Junior et al., 2011), in which the BERJ is inserted. In the last six years, the Alto Ipanema Basin (a tributary of the São Francisco River) had very little rainfall, which significantly reduced surface runoff generation.

Several studies have been carried out with reference to soil moisture in the BERJ (Santos et al., 2011; Silva et al., 2015; Silva Junior et al., 2016), addressing the performance of soil conservation techniques. At plot scale, Silva et al. (2015) simulated soil water dynamics in the BERJ. In the Alto Ipanema Basin, Montenegro and Ragab (2010) studied temporal variations of runoff and soil moisture in the basin, considering different scenarios of land use in climate. However, it should be noted that there is still a lack of studies addressing soil moisture dynamics under different land-use scenarios in the Brazilian semiarid basins, particularly at an experimental catchment scale.

Thus, the use of the SWAT model under land-use changes, together with the climatic diversity of biomes and water availability of the semiarid region of the Brazilian Northeast, provide relevant information for future studies that address the impact of vegetal cover changes on the water resources in similar watersheds. 
This work therefore aims to apply the SWAT model for the analysis of hydrological processes in the Experimental Basin of the Jatobá Stream, in the semiarid region of State of Pernambuco, Brazil, considering the joint calibration and validation for both in situ streamflow and soil moisture data. Moreover, the study investigates the hydrological effectiveness in a reforestation scenario of the arborescent Caatinga in areas of higher topographic elevation, and the behavior of the hydrological components under an agricultural expansion scenario.

\section{MATERIAL AND METHODS}

\subsection{Study Domain}

The Experimental Basin of the Jatobá Stream (BERJ) is $13.50 \mathrm{~km}^{2}$, with a perimeter of 16 $\mathrm{km}$, located between the coordinates of $8^{\circ} 34^{\prime} 17^{\prime \prime}$ and $8^{\circ} 18^{\prime} 11^{\prime \prime}$ South Latitude and $37^{\circ} 1^{\prime} 35^{\prime \prime}$ and $36^{\circ} 47^{\prime} 20^{\prime \prime}$ West Longitude (Melo and Montenegro, 2015). The basin is located in the municipality of Pesqueira and is inserted in the Representative Basin of the Alto Ipanema River, in the semiarid region of Pernambuco, and represents one of the sub-basins investigated by the Network of Hydrology of the Semiarid Region (REHISA).

The Alto Ipanema River Basin is a sub-basin in the upstream part of the Ipanema River, an affluent of the Low São Francisco River Basin (Figure 1). The prevailing climate in the region is characterized as extremely hot semiarid steppe Type, according to the Köppen classification, with a mean annual rainfall of $600 \mathrm{~mm}$ and an average temperature of $23{ }^{\circ} \mathrm{C}$, and potential evapotranspiration of approximately 2,000 $\mathrm{mm}$ a year (Melo and Montenegro, 2015). Furthermore, the vegetation is predominantly hyperxerophytic Caatinga (Montenegro and Montenegro, 2006).

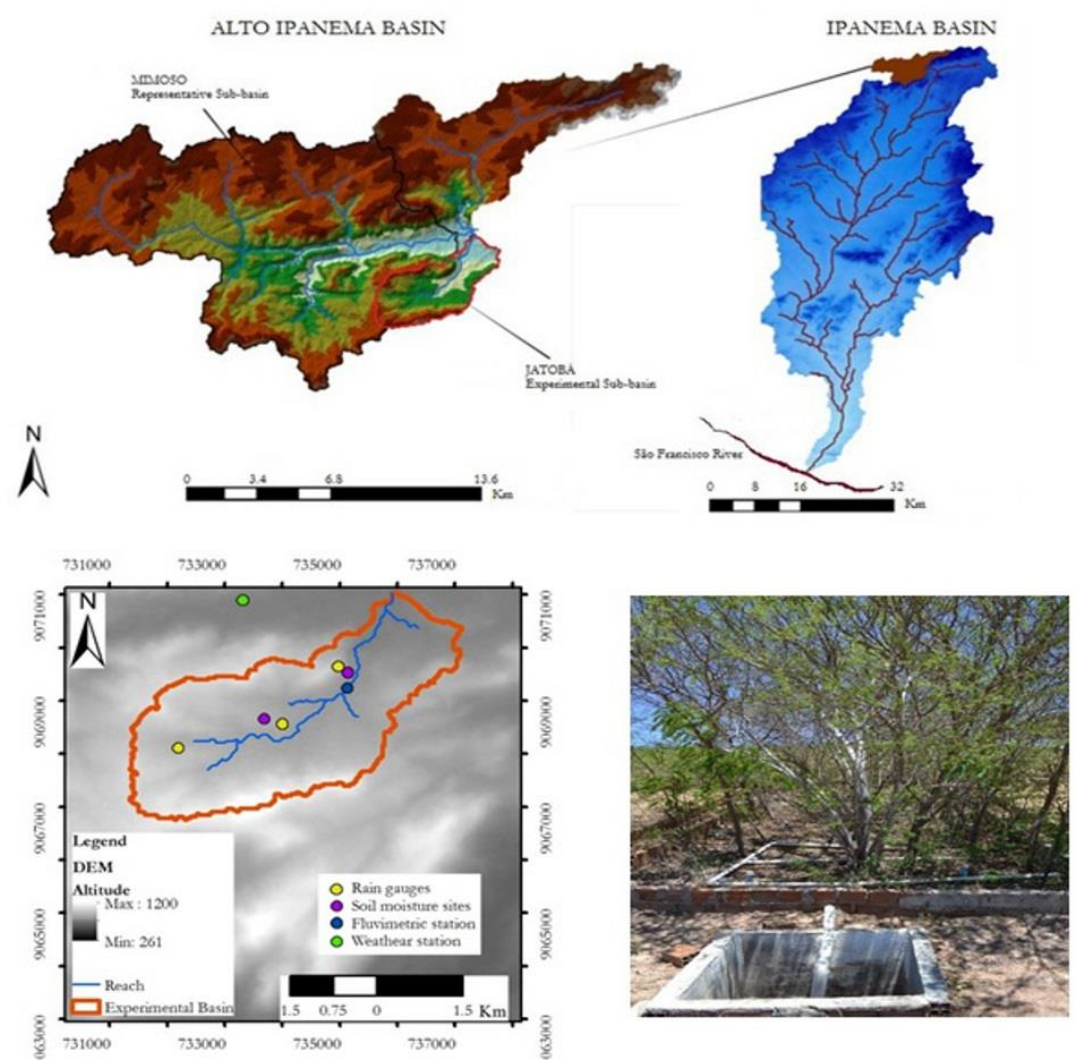

Figure 1. Location of the Jatobá Stream Experimental Basin, Alto Ipanema River Basin, inserted in the Ipanema Basin in Pesqueira $\mathrm{PE}$, digital elevation model, location of rain gauges, weather station, and fluviometric station, and soil moisture measurement sites. 


\subsection{SWAT Model}

SWAT is a hydro-sedimentological model which simulates different hydrological processes, estimating streamflow, sediment movement and nutrient cycling. The model requires specific data of climate, temperature, soil properties, topography and vegetation. The model is based on the water balance equation (Equation 1) in order to simulate the hydrologic cycle as well as to estimate surface runoff using the Curve Number method (CN) (Equation 2) (Neitsch et al., 2005).

$$
\mathrm{SW}_{\mathrm{t}}=\mathrm{SW}_{0}+\sum_{\mathrm{i}=1}^{\mathrm{t}}\left(\mathrm{R}_{\text {day }}-\mathrm{Q}_{\text {surf }}-\mathrm{E}_{\mathrm{a}}-\mathrm{w}_{\text {seep }}-\mathrm{Q}_{\mathrm{gw}}\right)
$$

Where: $S w_{t}$ is the final water content $(\mathrm{mm}) ; S W_{0}$ is the initial water content $(\mathrm{mm}) ; t$ is the time (days); $R_{\text {day }}$ is the amount of precipitation on day $i(\mathrm{~mm}) ; Q_{\text {surf }}$ is the amount of surface runoff on day $i(\mathrm{~mm}) ; \mathrm{E}_{\mathrm{a}}$ is the amount of evapotranspiration on day $i(\mathrm{~mm}) ; w_{\text {seep }}$ is the amount of percolation on day $i(\mathrm{~mm})$, and $Q_{g w}$ is the amount of bypass exiting the soil profile bottom on day $i(\mathrm{~mm})$.

$$
Q_{\text {surf }}=\frac{\left(\mathrm{R}_{\text {day }}-\mathrm{I}_{\mathrm{a}}\right)^{2}}{\left(\mathrm{R}_{\text {day }}-\mathrm{I}_{\mathrm{a}}+S\right)}
$$

Where: $I_{a}$ is the initial abstractions which includes surface storage, interception and infiltration prior to runoff $(\mathrm{mm})$, and $S$ is the retention parameter $(\mathrm{mm})$.

For hydrological modelling using SWAT, the river basin was divided into sub-basins, each being divided into hydrologic response units (HRUs), characterized by the combinations of land use and management, soil types and slope (Aragão et al., 2013).

\subsection{Inputs and Instrumentation}

The delimitation of the sub-basins of the Experimental Basin of the Jatobá Stream was carried out using the ArcSWAT extension based on the image from the Shuttle Radar Topography Mission (SRTM), with a spatial resolution of $30 \mathrm{~m}$, obtained from the website of the Brazilian Institute of Space Research (INPE) (Figure 1). Meteorological information such as maximum and minimum temperature $\left({ }^{\circ} \mathrm{C}\right)$, solar radiation $\left(\mathrm{MJ} \mathrm{m}^{-2}\right)$, relative humidity $(\%)$ and wind speed $\left(\mathrm{m} \mathrm{s}^{-1}\right)$ were registered at an automatic agrometeorological station (Model GRWS100 - Campbell Scientific $($ ), inserted in the Alto Ipanema River Basin. The precipitation data used in the study were obtained from three automatic rain gauges located in the Experimental Basin. For measuring soil moisture, experimental sites of $198 \mathrm{~m}^{2}$ were used with four different soil covers, one with natural Caatinga Vegetation, two plots with general agriculture and one with bare soil, with effective dimensions of $4.5 \mathrm{~m} \mathrm{x} 11 \mathrm{~m}$, in a total area of $49.5 \mathrm{~m}^{2}$ each (Figure 1). Five Time Domain Reflectometry (TDR) sensors were installed at soil depths of $20 \mathrm{~cm}$ at each layer, with hourly measurements. These measurements of soil moisture were extrapolated for the sub-basin in which the layer is inserted.

The period defined for the study of the hydrological behavior of the sub-basins ranged from 2009 to 2010, with simulations from rain gauge measurements and moisture measurement sites.

The land-use map was drawn based on images from the RapidEye satellite from April 2013, from the REHIDRO project (Lima et al., 2014). Land use was divided into six different classifications (Figure 2A): Agriculture, Gallery Forest, arborescent closed Caatinga, arborescent-shrubby closed Caatinga, arborescent-open Caatinga and Bams (Silva Junior et al., 2011). The soil-types map was based on soil mapping carried out by EMBRAPA-Soils, from information provided by the Agroecological Zoning of Pernambuco (ZAPE) (EMBRAPA, 2000), identifying three predominant soil types: red-yellow Clay soil, Litolic Neosoil and Regolitic Neosoil (Figure 2D).

\section{IPABH}




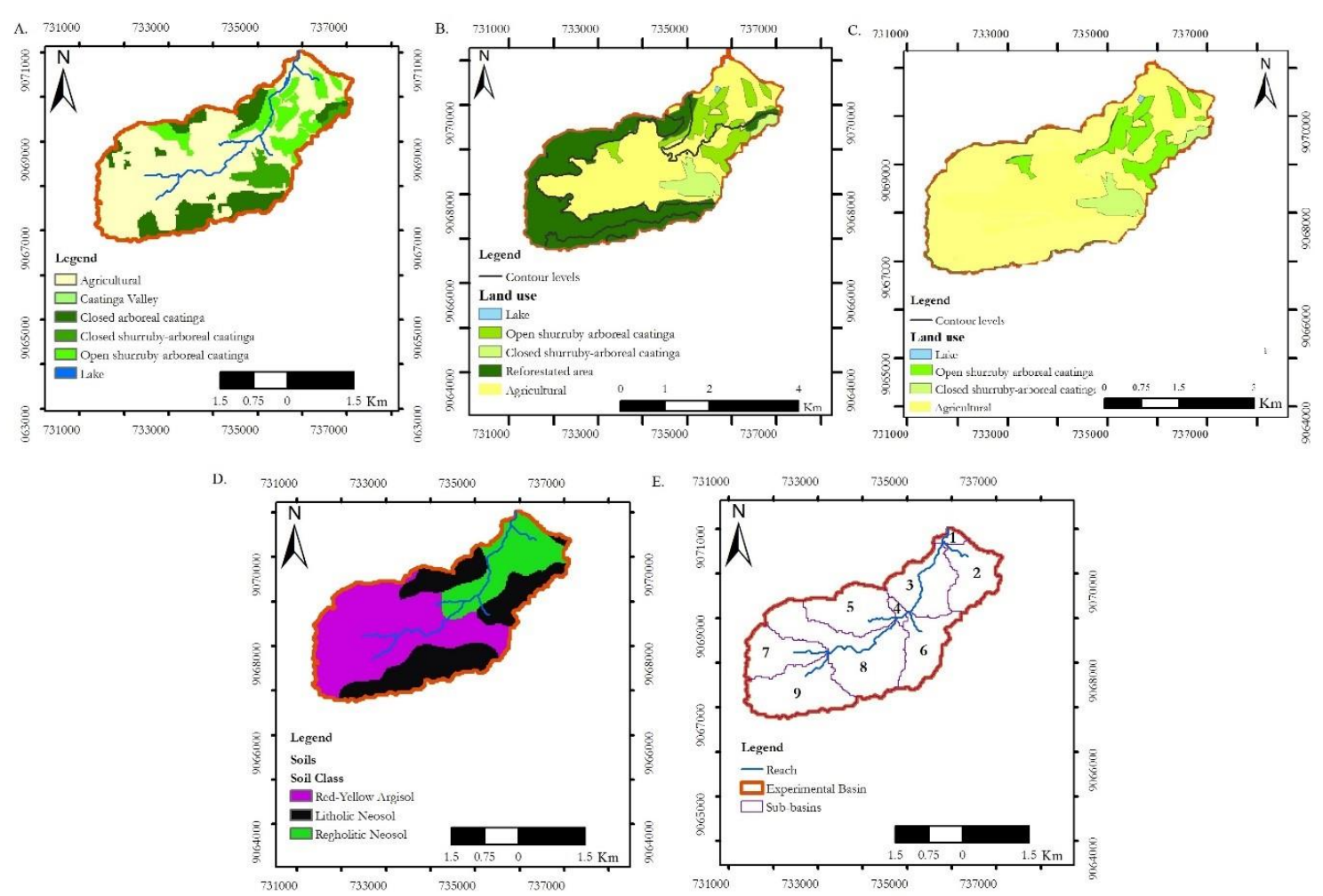

Figure 2. Current land use map (A), Scenario 1: Reforestation Soil map (B), Scenario 2: Agricultural expansion map (C), soil map (D) and delineating of sub-basin in SWAT model for the Jatobá Stream Basin, Pesqueira-PE (E).

In order to improve the performance of the SWAT model, before initiating the calibration and validation processes, some parameters were modified in relation to the default values of the model; such modifications are presented in Table 1. The modified values were based on previously published works that involved the Caatinga vegetation, for example the work developed by Silva (2014).

Table 1. Adjustment of key parameters for the BERJ in the SWAT model before beginning the calibration and validation procedures.

\begin{tabular}{|c|c|c|c|c|}
\hline $\mathrm{N}^{\mathrm{o}}$ & Parameter & Description & Default value & Adjusted value \\
\hline 1 & LAI_INIT & Initial leaf area index (range from 0 to 8 ) & 0 & 2 \\
\hline 2 & BIO_INIT & $\begin{array}{l}\text { Initial dry weight biomass }\left(\mathrm{kg} \mathrm{ha}^{-1}\right) \\
\text { (range from } 0 \text { to } 1000)\end{array}$ & 0 & 1000 \\
\hline 3 & PHU_PLT & $\begin{array}{l}\text { Total number of heat units or growing } \\
\text { degree days needed to bring plant to } \\
\text { maturity (range from } 0 \text { to } 3500 \text { ) }\end{array}$ & 0 & 2500 \\
\hline 4 & ESCO.hru and. bsn & $\begin{array}{l}\text { Soil evaporation compensation factor } \\
\text { (range from } 0 \text { to } 1 \text { ) }\end{array}$ & 0.95 & 0.6 \\
\hline
\end{tabular}

The SWAT model offers three options for estimating the potential evapotranspiration (ET0) component: the Penman-Monteith-FAO, Hargreaves \& Samani and Priestley-Taylor methods. The standard method of the model is the Penman-Monteith-FAO, which requires meteorological variables such as solar radiation, temperature, relative humidity and wind speed to estimate ET0 (Neitsch et al., 2005). In the present work, the Hargreaves \& Samani method was used, as it requires a smaller amount of data (only radiation and temperature), and because it fits very well in semiarid regions, as already verified for the Jatobá Basin. 


\subsection{Calibration and Validation}

Evaluation of the most sensitive parameters is considered a crucial step, which precedes the calibration and validation process of the given model (Arnold et al., 2012). The sensitivity analysis of the parameters was performed previously by Fontes Júnior (2016) using SWATCUP software, an independent software developed for uncertainty and sensitivity analysis, calibration and validation processes, using SWAT simulations (Abbaspour et al., 2007). The method used in SWATCUP was SUFI-2 (Sequential Uncertainty Fitting). This method is based on a Bayesian structure and determines uncertainties by sequential adjustment. Some studies report that the SUFI-2 method is an adequate technique for analyzing the uncertainty of modeling results (Khoi and Thom, 2015; Uniyal et al., 2015).

The sensitivity study was based on the analysis of parameters and input variables of the model, to observe those that, when altered, exert a significant influence on the results. We selected 19 parameters related to the processes of flow, evapotranspiration, percolation, recharge, infiltration, among others, for a first analysis. The parameters sensitivity was determined through the application of a multiple regression system, in which the parameters generated by the Latin Hypercubic Sampling are related to the objective function values. The t-test was used to identify the relative significance of each parameter, and the higher the value (in absolute terms) the parameter has, the more sensitive it will be. The p-value determines the significance of the sensitivity, and values close to zero indicate the most significant parameters (Abbaspour et al., 2015).

The model calibration was carried out manually using the ArcSWAT, using the manual calibration helper function. For the analysis of streamflow data, daily events were used, measured at the flow control cross-section, with a Soilinst ${ }^{\circledR}$ pressure transducer. For the calibration, events that had occurred in the period from 6/11/2009 to 8/27/2009 were used, with the period from 4/1/2010 to 5/31/2010 being adopted for the model validation. For the analysis of soil moisture, the observation period ranging from 4/4/2009 to 5/7/2009 was used for the calibration, while the period from 2/4/2010 to 3/27/2010 was adopted for the validation. The parameters used in calibration for streamflow and soil moisture with the SWAT model in the BERJ are presented in Table 2.

Table 2. Parameters used in calibration for streamflow and soil moisture with SWAT model in the Jatobá Basin, Pesqueira-PE.

\begin{tabular}{ccclc}
\hline $\mathrm{N}^{\mathrm{o}}$ & $\begin{array}{c}\text { Ranking } \\
\text { (Fontes Júnior, 2016) }\end{array}$ & Parameter & Description & Calibrated value \\
\hline 1 & $3^{\circ}$ & CN2 & $\begin{array}{l}\text { Curve number, moisture } \\
\text { condition II } \\
\text { Base flow recession constant, } \\
\text { days } \\
\text { Depth of water in shallow } \\
\text { aquifer required for return } \\
\text { flow, mm }\end{array}$ & 73.7 \\
3 & $2^{\circ}$ & ALPHA_BF & 700 \\
\hline
\end{tabular}

For evaluating the model precision, observed and simulated hydrographs were used, as well as the coefficient of determination $\left(\mathrm{R}^{2}\right)$ and the Nash-Sutcliffe efficiency coefficient (NSE) (Brighenti et al., 2016; Melo Neto et al., 2014; Aragão et al., 2013). The $\mathrm{R}^{2}$ coefficient indicates the proportion of variance in the data observed captured by the model, while the NSE coefficient depends on the variance of the data simulated and the data observed. The results of the model are considered more representative as the values of $\mathrm{R}^{2}$ and NSE are closer to 1 . The NashSutcliffe coefficients (NSE) (Nash and Sutcliffe, 1970) in this work were classified according to Santhi et al. (2001); adapted by Bracmort et al. (2006), which considered the performance of 
the SWAT model, both in the calibration and in the validation, as being satisfactory when the NSE was above 0.5 .

\subsection{Land use change scenarios}

The basin in study (BERJ) exhibits degradation of the native vegetation, with the presence of secondary vegetation, and is susceptible to soil erosion (Santos et al., 2010), and efforts have been made to support reforestation programs, funded by the São Francisco Basin Committee (CBHSF, 2016). Thus, for this study, two scenarios were proposed: a scenario considered optimistic (reforestation) and another scenario considered pessimistic (agricultural expansion). For the first scenario, a reforestation with native vegetation (arborescent closed Caatinga) at high elevations of the BERJ was adopted (Figure 2B). Such scenario is a recommendation of the Management Plan of the São Francisco River Basin, for the semiarid region (CBHSF, 2016). The reforested area replaced $100 \%$ of the Gallery Forest present in the basin, as well as $8.33 \%$ of the arborescent open Caatinga and $46 \%$ of the total agricultural area. In total, arborescent open Caatinga vegetation was added to $21 \%$ of the entire area of reforestation. In the second scenario, the entire area considered reforested in the first scenario $(37.7 \%)$ was replaced by agriculture, simulating a possible agricultural expansion along the basin.

\section{RESULTS AND DISCUSSION}

\subsection{Sub-basins and Hydrologic Response Units (HRUs)}

Based on the results of the digital elevation model, 29 sub-basins were formed in the Experimental Basin. These hydrological areas were established considering drainage flow, boundaries of the river basin, the drainage basin and the sub-basins with their mouths.

The information generated in the maps of soil types, slope and land use provided the necessary data to delimit the Hydrologic Response Units (HRUs), with 104 HRUs being generated in this study. Veiga (2014) working in the Córrego Samambaia River Basin, in the Brazilian State of Goiânia, with an area of $31 \mathrm{~km}^{2}$ subdivided the basin into 15 sub-basins, creating 315 Hydrological Response Units. Castro (2013) when simulating the Experimental Basin of the High-Jardim River in the Federal District, with approximately $105 \mathrm{~km}^{2}$, established 6 sub-basins with 628 HRUs for the application of the SWAT model.

\subsection{Sensitivity analysis}

Figure 3 presents the results of the sensitivity analysis of the variable streamflow in the study area. The five parameters considered most sensitive for the BERJ were: CN2.mgt, ALPHA_BF.gw, CH_K2.rte, CH_N2.rte and SOL_K.sol. These parameters refer to surface runoff, base flow, hydraulic conductivity and water storage capacity in the soil surface. Lelis et al. (2012) observed that the parameter CN2.mgt was the most sensitive for two sub-basins in the São Bartolomeu Stream watershed in Southeastern Brazil. Topography, land use, basin delineation and rainfall period are considered the main factors related to the sensitivity of the parameters studied (Schmalz and Fohrer, 2009). The work carried out by Maneta et al. (2008) highlighted some of the parameters considered most-sensitive, such as hydraulic conductivity and the soil infiltration rate, which influence water movement from the surface to the subsurface layers. According to the authors, information regarding soil moisture and water levels in monitoring wells improved the calibration and reduced uncertainties related to the simulations.

\subsection{Calibration and validation analysis for streamflow and soil moisture}

The analysis of the simulated hydrograph, compared against the observed time series, allows the assessment of model performance and the temporal dynamics of the selected variable. Figure 4A presents the streamflow calibration hydrograph in 2009. The SWAT 
adjustments were adequate in the recession period, both in terms of calibration and validation, demonstrating that the model is well adjusted for low flow periods. The value of NSE for the streamflow calibration was 0.58 , with $\mathrm{R}^{2}$ being equal to 0.69 . The results were classified as "satisfactory" according to the NSE classification presented by Bracmort et al. (2006). The model adequately presented the peak runoff rate taken place on June 27, 2009, with precipitation of $10.9 \mathrm{~mm}$ and the previous five-day rainfall of $0.99 \mathrm{~mm}$, which generated an average observed surface runoff of $2.78 \mathrm{~m}^{3} / \mathrm{s}$ and an average simulated surface runoff of $2.02 \mathrm{~m}^{3} / \mathrm{s}$.

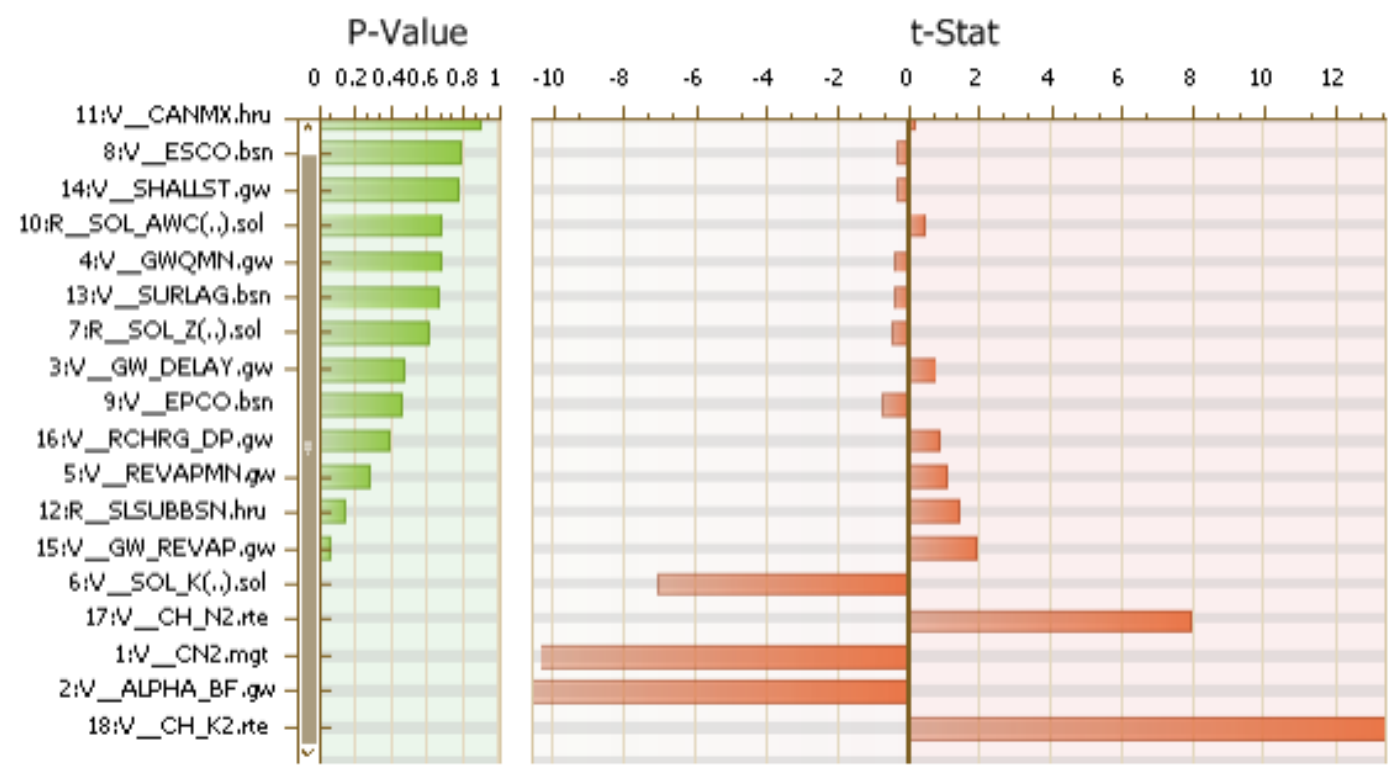

Figure 3. Sensitivity analysis performed by SWAT-CUP for streamflow daily observations.

Source: Fontes Júnior, 2016.
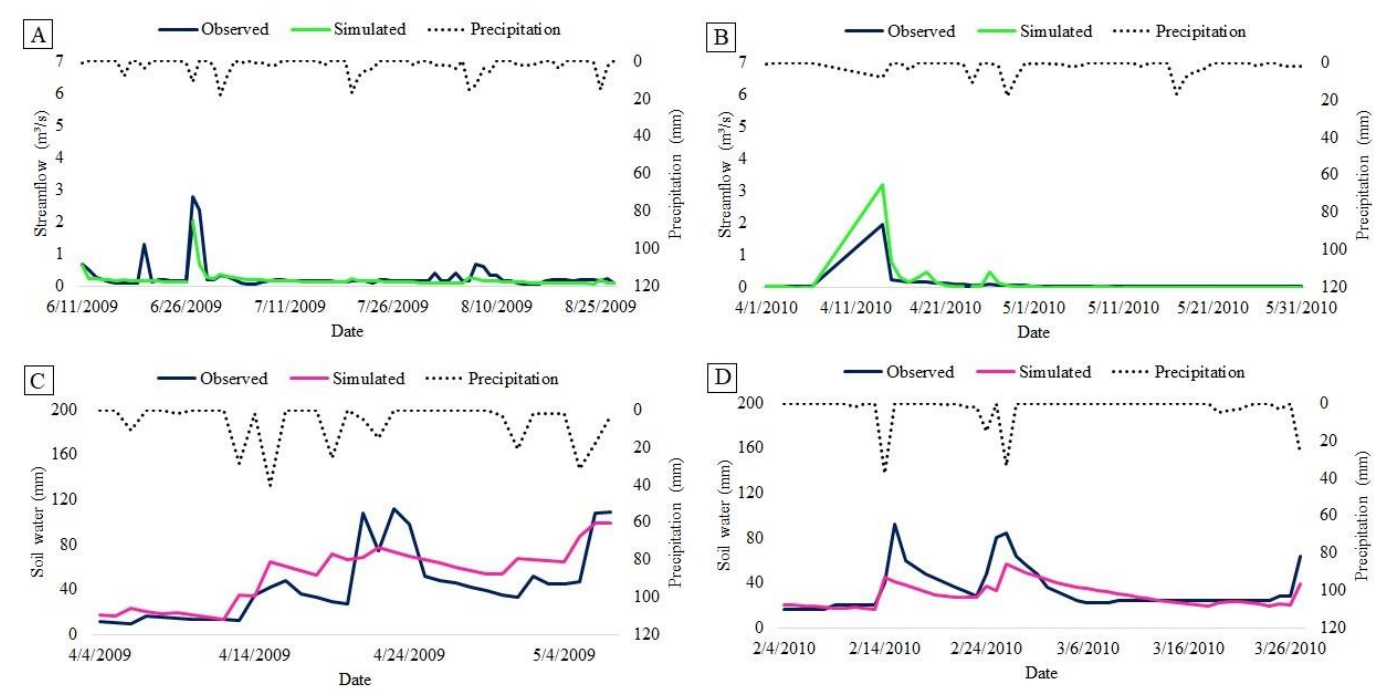

Figure 4. Calibration (A) and validation (B) of the streamflow and calibration (C) and validation (D) of the soil moisture in sub-basin located in soil moisture monitoring sites in Jatobá Stream Experimental Basin, Pesqueira-PE.

The results of the model validation for the year of 2010 are presented in Figure 4B. The model overestimated the mean value observed, with an average surface runoff of $0.79 \mathrm{~m}^{3} / \mathrm{s}$, with $3.21 \mathrm{~m}^{3} / \mathrm{s}$ for the simulated value, for a precipitation of $56.3 \mathrm{~mm}$. Nevertheless, the

\section{IPABH}


validation NSE coefficient was 0.42 . In average terms, the value observed for the streamflow in the validation period was $0.08 \mathrm{~m}^{3} / \mathrm{s}$, while the value simulated by the SWAT was very close to that observed, being equal to $0.12 \mathrm{~m}^{3} / \mathrm{s}$. Consequently, the $\mathrm{R}^{2}$ value was very good, being equal to 0.97 . The $\mathrm{R}^{2}$ for the validation period was higher than for the calibration, indicating no severe discrepancy between the simulated and observed hydrographs.

The NSE coefficients found comported with the ones obtained by Andrade et al. (2013), who applied the SWAT hydrological model in the Jaguara Stream watershed in the southern part of the Brazilian state of Minas Gerais, exhibiting NSE coefficients of 0.66 and 0.87 for calibration and validation, respectively. Studies carried out in the headwater watershed of the Mantiqueira Mountains, applying the SWAT model, produced a NSE coefficient for calibration of 0.81 and of 0.79 for validation (Pinto, 2011).

Viola et al. (2009) applied the hydrological model in the Aiuruoca River Basin, obtaining NSE coefficients of 0.87 and 0.92 for the calibration and validation phases, respectively. Satisfactory results were also found by Viola et al. (2012) when applying hydrological modeling in a sub-basin of the Araguaia River, in the Brazilian State of Tocantins, with NSE coefficients of 0.74 and 0.75 for the calibration and validation stages, respectively.

Dantas et al. (2015) simulated streamflow and estimated sediment movement in the Taperoá River Basin, using the SWAT model. The results showed that the model presented a satisfactory result for the calibration stage, though not in the validation phase. In the study, a reduction of surface runoff in the basin could be verified, as a consequence of an increase in temperature, alterations of vegetative cover and the insertion of small- and medium-scale reservoirs.

In most recent studies involving the SWAT model, different alternative variables have been adopted for the calibration and validation of the model. These data include evapotranspiration (Miranda, 2017; Bressiani et al., 2015; Maneta et al., 2008), soil moisture (Maneta et al., 2008), potentiometric levels (Fontes Júnior, 2016) and leaf-area index (Miranda, 2017). Soil moisture is considered a parameter of great importance, associated with the movement processes in the soil. The understanding of this variable contributes to adopting adequate agricultural and irrigation management processes, and vegetation parametrization.

Maneta et al. (2008) studied the application of a hydrological model in an experimental basin in a semiarid region of Spain. The study pointed out the importance of evapotranspiration and soil moisture in the simulation of small-scale perennial semiarid watersheds. According to the authors, the application of models in river basins inserted in a semiarid region is considered challenging given the characteristics of such a region, in which irregular rainfall or heavy rain during short periods of time may lead to a discontinuous and perennial streamflow, with consequent local saturated layers and non-saturated areas.

The summary of the statistical results of calibration and validation of the SWAT model with streamflow and soil moisture data are presented in Table 3. Figure 4C presents the soil moisture calibration hydrograph in 2009, and Figure 4D illustrates the validation hydrograph in 2010. The NSE coefficients in the soil moisture calibration stage were 0.53 , with $\mathrm{R}^{2}$ being equal to 0.63 . The validation NSE and $\mathrm{R}^{2}$ coefficients were lower $\left(\mathrm{NSE}=0.46\right.$ and $\mathrm{R}^{2}=0.55$ ) than the calibration coefficients, similar to the NSE coefficients estimated for streamflow. The results found are thus classified as "satisfactory" for the calibration stage, according to the NSE classification presented by Bracmort et al. (2006). Montenegro and Ragab (2010) carried out a comparison between the soil moisture data simulated by the model with the soil moisture measurements observed. The authors estimated a determination coefficient of 0.70 between the simulated values and the observed data. The values and general trends of soil moisture were properly simulated by the DiCaSM model. 
Table 3. Summary statistics of calibration and validation for streamflow and soil moisture in daily time step with SWAT model in the Jatobá Basin, Pesqueira-PE.

\begin{tabular}{lcc}
\hline Statistics & Streamflow & Soil moisture \\
\hline \multicolumn{3}{c}{ Calibration } \\
\hline $\mathrm{R}^{2}$ & 0.69 & 0.63 \\
$\mathrm{NS}$ & 0.58 & 0.53 \\
\hline \multicolumn{3}{c}{ Validation } \\
\hline $\mathrm{R}^{2}$ & 0.97 & 0.55 \\
$\mathrm{NS}$ & 0.42 & 0.46 \\
\hline
\end{tabular}

\subsection{Hydrological processes under land-use change scenarios}

Table 4 shows the results of the water balance for current-use, reforestation and agricultural-expansion scenarios. The results reveal the magnitude of the impact of land use changes on water resources. When we observe the results of the reforestation scenario in relation to the current-use scenario, it is verified that the increased native forest provided a decrease in surface runoff of about $51 \%$ in the BERJ, corresponding to $13.2 \mathrm{~mm}_{\text {year }}{ }^{-1}$. This decrease in surface runoff can be explained by the ability of forests to intercept precipitation, reducing the water loss through runoff. This higher plant density also allows, through interception, more water infiltrated into the soil, with increased percolation and aquiferrecharge processes. In the present study, the increase of water percolation to the shallow aquifer was approximately 11 times greater in the reforestation scenario. In Brazil and in the world, several studies have been developed with the objective of verifying the effects of the land-use changes on the surface runoff dynamics in watersheds (Aragão et al., 2013; Blainski et al., 2011; Rodrigues et al., 2015; Silva et al., 2015; 2018). Blainski et al. (2011) applied the SWAT model to the Araranguá River Basin to evaluate the influence of agricultural activities on the basin's water availability. They considered different scenarios: i) current use, with predominance of rhiziculture in agricultural areas; ii) replacement of agriculture by reforestation; and iii) removal of vegetative cover from agricultural areas. The authors verified that the average flow rate was higher in the bare soil scenario, and this increase was attributed to the reduction of water infiltration into the soil and the increase in surface runoff.

Table 4. Water balance components for current use, reforestation and agricultural expansion scenarios in the Jatobá Basin.

\begin{tabular}{lccc}
\hline Variables of water balance & Current land use & $\begin{array}{c}\text { Scenario 1 } \\
\text { Reforestation }\end{array}$ & $\begin{array}{c}\text { Scenario 2 } \\
\text { Agricultural expansion }\end{array}$ \\
\hline Precipitation & 654.3 & 654.3 & 654.3 \\
Surface runoff & 25.99 & 12.8 & 28.81 \\
Percolation & 42 & 59 & 42 \\
Soil water & 200.72 & 131.01 & 221.64 \\
Base flow & 56.34 & 63.09 & 56.19 \\
Potential evapotranspiration & 1763.90 & 1763.90 & 1763.90 \\
Actual Evapotranspiration & 588.2 & 592.10 & 587.50 \\
Total sediment loading & $21.02 \mathrm{t} / \mathrm{ha}$ & $6.74 \mathrm{t} / \mathrm{ha}$ & $28.10 \mathrm{t} / \mathrm{ha}$ \\
\hline
\end{tabular}

Rodrigues et al. (2015) used the SWAT to analyze the outflow in the Pará River Basin, in Minas Gerais, Brazil, and to evaluate the impact caused by changes in land use on the basin's water availability. They considered two scenarios: original vegetation and current use. 
According to the authors, there was an increase of about $10 \%$ in the flow due to changes in soil use, basically contemplating the suppression of the original vegetation for grassland implantation in $38 \%$ of the basin. It is a fact that the forests attenuate the direct runoff and might increase evapotranspiration.

Another point worth mentioning regards soil loss: the reforestation scenario provided a reduction of the total sediment load generated, compared to the current use scenario. This lower sediment rate can be explained by the superior quantity of native vegetation, which is able to intercept the rainfall, reducing the impact of the raindrops that fall directly to the soil, which would cause the particles to detach and move, as erosion. According to Silva et al. (2015), reclaimed forest areas decrease streamflow and sediment movement, intensifying the importance of the preservation of native vegetation areas. Silva et al. (2018) evaluated the erosion process with simulated rainfall in different cover crops (beans, corn, bare land and Caatinga) in the semiarid region of Paraiba. In the evaluation, the soil covers with Caatinga showed less erosion and surface runoff when compared with the other treatments. According to the authors, the shape of the vegetative cover, the leaf area and the stem structure are determining factors for canopy water storage, influencing soil conservation and the hydrological responses in the semiarid environment. Aragão et al. (2013) identified that native vegetation and regenerated areas make it possible to reduce rainfall impacts on the soil, avoiding degradation and surface runoff, decreasing the sediment loading around the basin. These results reinforce even more the importance of the preservation of the nascent areas of the BERJ, and in regions where water security is highly vulnerable, as is the case in many Brazilian semiarid basins.

In this study, the average value of evapotranspiration was higher for the reforestation scenario $(592.1 \mathrm{~mm})$ when compared to the current-use scenario $(588.2 \mathrm{~mm})$. This fact can be explained by the higher density of vegetative cover in the recomposition scenario. According to Tucci and Clarke (1997) and Bruijnzeel (1996), the greatest amount of solar radiation absorption and consequently, the greatest energy available for evapotranspiration comes from forests, and in this way the direct evaporation of intercepted water tends to be higher. In turn, the suppression of vegetative cover results in a decrease in evapotranspiration, since less radiation absorption occurs and less capacity to remove water from the soil and to intercept precipitation. This leads to a decrease in vertical water flow and an increase in horizontal flow (Viola, 2008).

When we observe the results of the agricultural-expansion scenario in relation to the current-use scenario, it is verified that the increase in agricultural land provided an increase in surface runoff of approximately $11 \%$ in the BERJ, corresponding to $28.8 \mathrm{~mm}_{\text {year }}{ }^{-1}$. On the other hand, there was a decrease in the percolation process for the shallow aquifer of approximately $32 \%$, being only $0.48 \mathrm{~mm}$. When observing the evapotranspiration, it is noticed that there was a decrease in the scenario of agricultural expansion compared to the current use of $0.12 \%$. These changes are in line with the same principles discussed earlier for the reforestation scenario. This is because these agricultural areas, in the current condition, are occupied by vegetation. It was verified that the increase of agricultural areas resulted in a greater surface runoff, a lower percolation of water in the soil and a lower evapotranspiration.

The amplitude and dispersion of data on simulated streamflow and soil moisture in scenarios of reforestation, agricultural expansion and current use in the Jatobá Basin are shown in Figure 5. From the obtained results by the SWAT model, it is possible to verify that between the scenarios, there was an increase of the average values of evapotranspiration in the reforestation scenario, due to the greater area of vegetative cover that provides greater evapotranspiration. Mean values and amplitudes of streamflow were increasing over the scenarios, being smaller in the condition of reforestation, then increasing in the current use, and 
finally, the greatest generation of streamflow occurred in the condition of agricultural expansion.
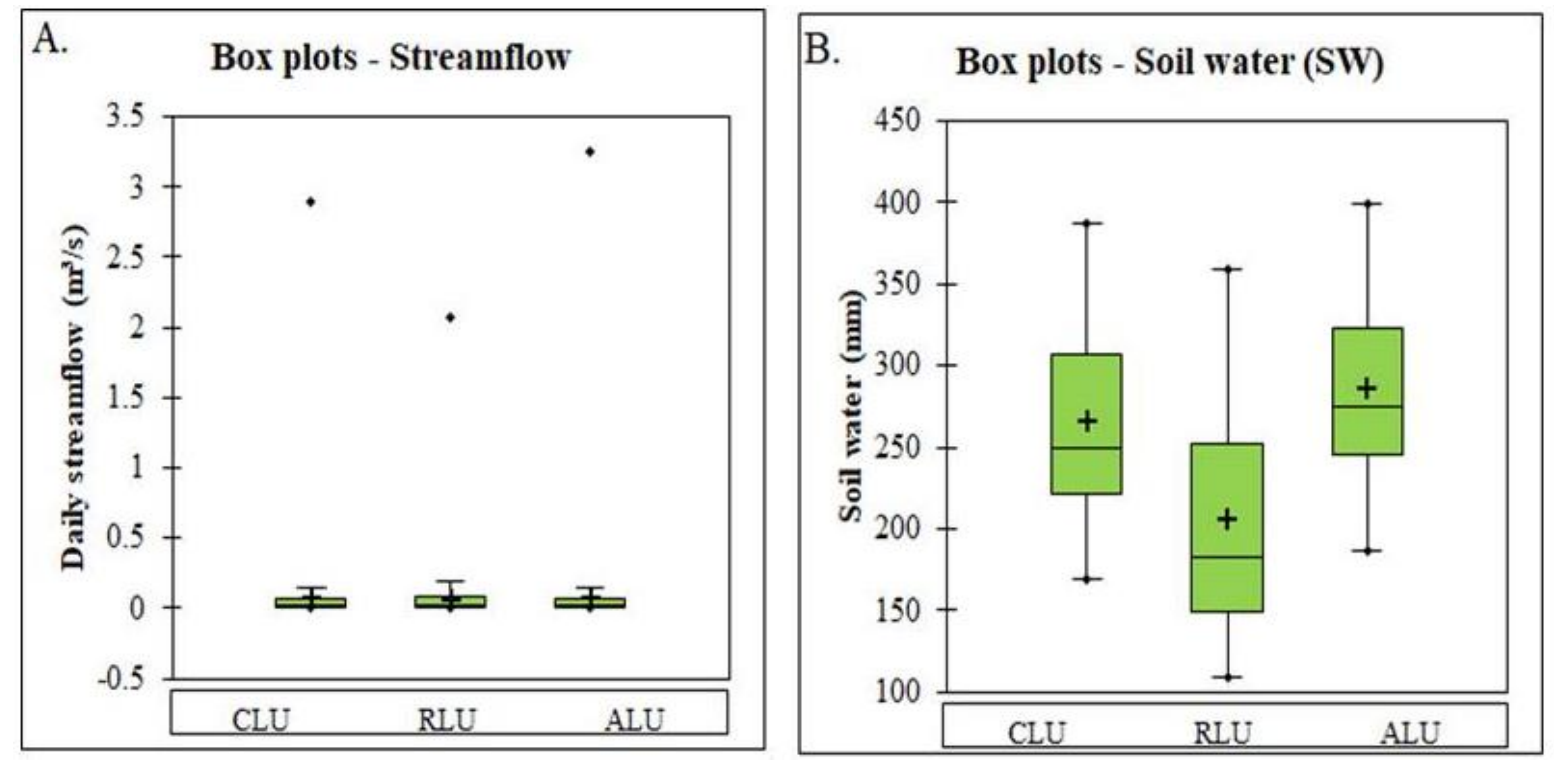

Figure 5. Box plots for streamflow and soil moisture in daily time step in the Jatobá Basin, PesqueiraPE.

In the Alto Ipanema Basin, Montenegro and Ragab (2010) verified that converting 7\% of Caatinga to agriculture area increased streamflow by 3\%. According to Munoz-Villers and Mcdonnell, 2013; and Yan et al., 2013, the change in land use is one of the main causes of surface runoff changes in a watershed, due to changes in precipitation interception, evapotranspiration and soil hydraulic conductivity. Within this context, knowledge of the effects of land use change on water dynamics in watersheds is of great importance in order to assist decision making within the scope of water resource management (Kuhnle et al., 1996).

Figure 6A presents the time series for soil moisture depths for the three scenarios analyzed, highlighting that a well-defined pattern of variation is similar for all series (Figure 6B). Figure 6C exhibits the time series for percolation $(\mathrm{mm})$ for the three scenarios and Figure 6D presents the scatter plot of the two modified scenarios as a function of the current land use. Differences of soil moistures between the current and reforested scenarios tends to increase for lower values of soil moisture. It can be verified that the impact of reforestation (decreasing soil moisture) is higher than that produced by the conversion of the current scenario to agriculture, the latter producing slightly higher soil moisture depths. When verifying percolation from the vadose zone, reforestation tends to increase such flux, as shown both in the time series (Figures 6A and 6B) and in the scatter plot in Figure 6D. 

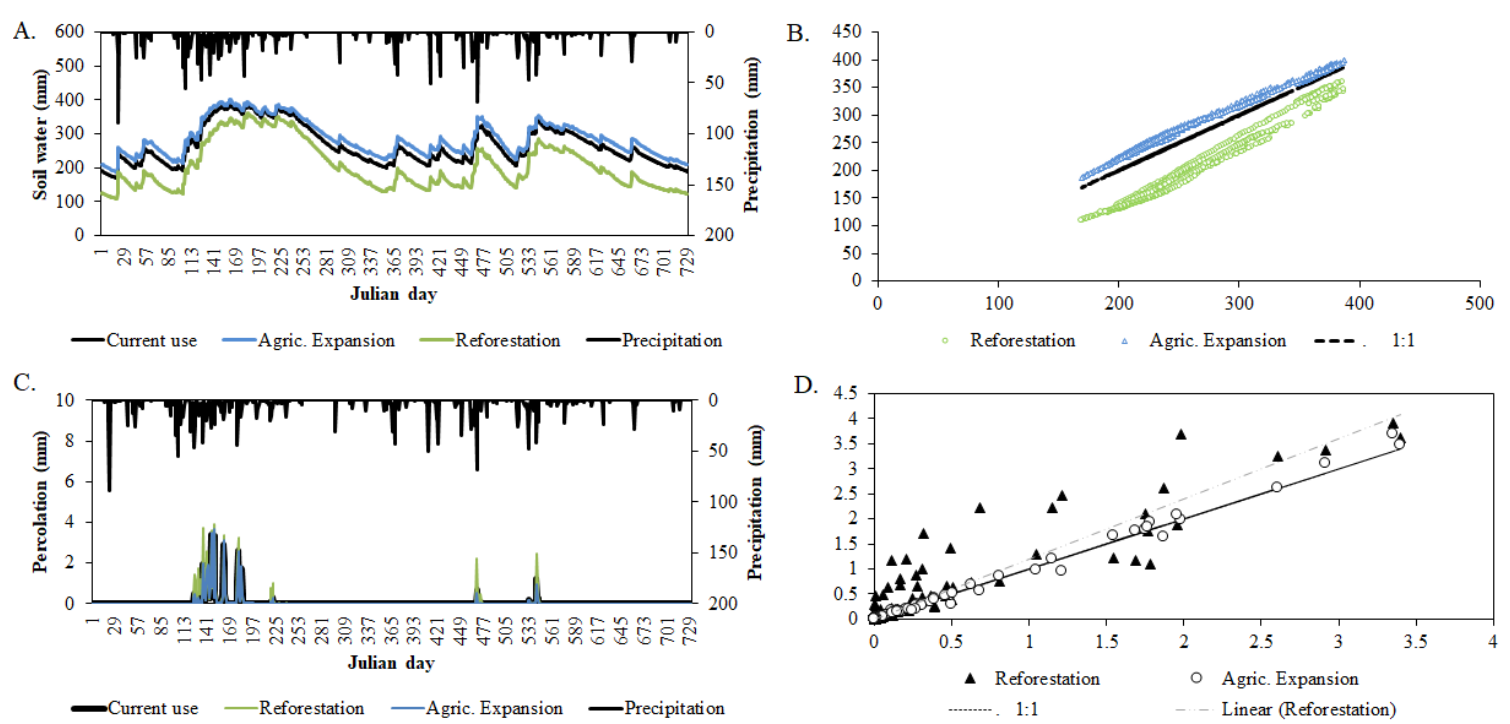

Figure 6. (A) Time series for soil moisture for the three scenarios analyzed; (B) pattern of variation for the series; (C) time series for percolation $(\mathrm{mm})$ for the three scenarios; and (D) scatter plot of the two modified scenario as function of the current land use.

\section{CONCLUSIONS}

The parameters most sensitive to the SWAT model were related to surface runoff, baseflow and hydraulic conductivity. The alternative process of calibration and validation in terms of both flow and soil moisture presented satisfactory results according to the NSE coefficients obtained, contributing to a more realistic simulation. Scenarios of regeneration of the vegetation cover of $21 \%$ of the area of arborescent Caatinga on hilltops led to significant changes on soil moisture and streamflow, thus contributing to the recovery of headwaters, increasing the base flow and the resilience to scenarios of water scarcity. On the other hand, the scenario of agricultural expansion caused an increase in surface runoff and, consequently, a decrease in the soil water storage.

\section{ACKNOWLEDGEMENTS}

This work was supported in part by the Foundation for Science and Technology of Pernambuco State (FACEPE) (Grants APQ 0300-5.03/17, APQ 0913-5.03/15 and Doctoral scholarship), the National Council for Scientific and Technological Development (CNPq) (Grants no. 446254/2015 (Super Project)) and the Brazilian Innovation Agency (FINEP) (Grant REHIDRO no. 1830/ 2010). This study was also financed in part by the Coordination for the Improvement of Higher Education and Personnel (CAPES) - Finance Code 001 (PVE024/2013 project (Grant no. 23038007733/2013-76). We are also grateful for all important comments from the anonymous reviewers, which contributed to a significant upgrade of the manuscript.

\section{REFERENCES}

ABBASPOUR, K. C.; ROUHOLAHNEJAD, E.; VAGHEFI, S.; SRINIVASAN, R.; YANG, H.; KLOVE, B. A continental-scale hydrology and water quality model for Europe: Calibration and uncertainty of a high-resolution large-scale SWAT model. Journal of Hydrology, v. 524, p. 733-752, 2015. https://doi.org/10.1016/j.jhydrol.2015.03.027 
ABBASPOUR, K. C.; YANG, J.; MAXIMOV, I.; SIBER, R.; BOGNER, K.; MIELEITNER, $\mathrm{J}$. et al. Modelling hydrology and water quality in the pre-alpine/alpine Thur watershed using SWAT. Journal of Hydrology, v. 333, p. 413-430, 2007. https://doi.org/10.1016/j.jhydrol.2006.09.014

ANDRADE, M. A.; MELLO, C. R.; BESKOW, S. Simulação hidrológica em uma bacia hidrográfica representativa dos latossolos na região Alto Rio Grande, MG. Revista Brasileira de Engenharia Agrícola e Ambiental, v. 17, n. 1, p. 69-76, 2013. http://dx.doi.org/10.1590/S1415-43662013000100010

ARAGÃO, R.; CRUZ, M. A. S.; AMORIM, J. R. A.; MENDONÇA, L. C.; FIGUEIREDO, E. E.; SRINIVASAN, V. S. Análise de sensibilidade dos parâmetros do modelo SWAT e simulação dos processos hidrossedimentológicos em uma bacia no agreste nordestino. Revista Brasileira de Ciência do Solo, v. 37, p. 1091-1102, 2013. http://dx.doi.org/10.1590/S0100-06832013000400026

ARNOLD, J. G.; KINITY, J. R.; SRINIVASAN, R.; WILLIAMS, J. R.; HANEY, E. B.; NEITSCH, S. L. Input/Output Documentation Version 2012. Temple: Black and Research Center: Texas Water Resources Institute, 2012.

BALES, R. C. Hydrology, floods and droughts - Overview. Reference Module in Earth Systems and Environmental Sciences. In: NORTH, G. R.; PYLE, J.; ZHANG, F. (Eds.). Encyclopedia of Atmospheric Sciences. $2^{\text {nd }}$. Cambridge: Academic Press, 2015. p. 180184.

BLAINSKI, E.; SILVEIRA, F. A.; CONCEIÇÃO, G.; GARBOSSA, L. H. P.; VIANNA, L. F. Simulação de cenários de uso do solo na bacia hidrográfica do rio Araranguá utilizando a técnica da modelagem hidrológica. Agropecuária Catarinense, v. 24, n. 1, p. 65-70, 2011.

BLAINSKI, E.; PORRAS, E. A. A.; GARBOSSA, L. H. P.; PINHEIRO, A. Simulation of land use scenarios in the Camboriú River Basin using the SWAT model. Revista Brasileira de Recursos Hídricos, v. 22 e. 33, 2017. http://dx.doi.org/10.1590/23180331.011716110

BRACMORT, K. S.; ARABI, M.; FRANKENBERGER, J. R.; ENGEL, B. A.; ARNOLD, J. G. Modeling long-term water quality impact of structural BMPS. American Society of Agricultural and Biological Engineers, v. 49, n. 2, p. 367-384, 2006.

BRESSIANI, D. A.; GASSMAN, P. W.; FERNANDES, J. G.; GARBOSSA, L.; SRINIVASAN, R.; BONUMA, N. B. et al. A review of Soil and Water Assessment Tool (SWAT) applications in Brazil: challenges and prospects. International Journal of Agricultural and Biological Engineering, v. 8, n. 3 p. 1-27, 2015. https://doi.org/doi./0.3965/j.ijabe.20150803.1765

BRIGHENTI, T. M.; BONUMÁ, N. B.; CHAFFE, P. L. B. Calibração hierárquica do modelo Swat em uma bacia hidrográfica Catarinense. Revista Brasileira de Recursos Hídricos, v. 21, n. 1, p. 53-64, 2016. http://dx.doi.org/10.21168/rbrh.v21n1.p53-64

BRITTO, F. B.; MENEZES NETO, E. L.; NETTO, A. O. A.; REGO, N. A. C. Sustentabilidade hídrica da Sub-bacia do Rio Sangradouro, Sergipe. Revista Brasileira de Geografia Física, v. 7, n. 1, p. 155-164, 2014. 
BRUIJNZEEL, L. A. Predicting the hydrological impacts of land cover transformation in the humid tropics: the need for integrated research. In: GASH, J. H. C.; NOBRE, C. A.; ROBERTS, J. M.; VICTORIA, R. L. Amazonian deforestation and climate. Chichester: J Wiley, 1996. p. 15-55.

CASTRO, K. B. Avaliação do modelo SWAT na simulação da vazão em bacia agrícola do cerrado intensamente monitorada. 2013. $122 \mathrm{f}$. Dissertation (Master in Geoprocessing and Environmental Analysis) - Institute of Applied Geosciences, University of Brasília, Brasília, 2013.

COMITÊ DA BACIA HIDROGRÁFICA DO RIO SÃO FRANCISCO - CBHSF. Plano de Recursos Hídricos da Bacia Hidrográfica do Rio São Francisco, PRH-SF 2016-2025. Lisboa: Nemus, 2016. 74p.

DANTAS, J. C.; SILVA, M. A.; SILVA, R. M.; VIANNA, P. C. G. Simulação vazão-erosão usando o modelo SWAT para uma grande bacia da região semiárida da Paraíba. Geociências, v. 34, n. 4, p. 816-827, 2015.

EMPRESA BRASILEIRA DE PESQUISA AGROPECUÁRIA - EMBRAPA. Levantamento de reconhecimento de baixa e média intensidade dos solos do estado de Pernambuco. Recife, 2000.

FINGER, D.; VIS, M.; HUSS, M.; SEIBERT, J. The value of multiple data set calibration versus model complexity for improving the performance of hydrological models in mountain catchments. Water Resources Research, v. 51, p. 1939-1958, 2015. https://doi.org/10.1002/2014WR015712

FONTES JÚNIOR, R. V. P. Experimentação e modelagem hidrológica aplicada à bacia do Alto Ipanema - PE. 2016. 160f. Thesis (PhD in Agricultural Engineering) - Federal Rural University of Pernambuco, Recife, 2016.

GALHARTE, C. A.; VILLELA, J. M.; CRESTANA, S. Estimativa da produção de sedimentos em função da mudança de uso e cobertura do solo. Revista Brasileira de Engenharia Agrícola e Ambiental, v. 18, n. 2, p. 194-201, 2014. http://dx.doi.org/10.1590/S141543662014000200010

ILSTEDT, U.; BARGUÉS TOBELLA, A.; BAZIÉ, H. R.; BAYALA, J.; VERBEETEN, E.; NYBERG, G. et al. Intermediate tree cover can maximize groundwater recharge in the seasonally dry tropics. Scientific Reports, v. 6, n. 21930, p. 1-12, 2016. http://dx.doi.org/10.1038/srep21930

KHOI, D. N.; THOM, V. T. Parameter uncertainty analysis for simulating streamflow in river catchment of Vietnam. Global ecology and conservation, v. 4, p. 538-548, 2015. https://doi.org/10.1016/j.gecco.2015.10.007

KUHNLE, R. A.; BINGER, R. L.; FOSTER, G. R.; GRISSINGER, E. H. Effect of land use changes on sediment transport. Water Resources Research, v. 32, n. 3, p. 189-3196, 1996. https://doi.org/10.1029/96WR02104

KUNDU, D.; VERVOOT, R. W.; van OGTROP, F. F. The value of remotely sensed surface soil moisture for model calibration using SWAT. Hydrological Processes, v. 31, p. 2764-2780, 2017. https://doi.org/10.1002/hyp.11219 
LELIS, T. A.; CALIJURI, M. L.; SANTIAGO, A. F.; LIMA, D. C.; ROCHA, E. O. Análise de Sensibilidade e Calibração do Modelo Swat Aplicado em Bacia Hidrográfica da Região Sudeste do Brasil. Revista Brasileira de Ciência do Solo, v. 36, p. 623-634, 2012. http://dx.doi.org/10.1590/S0100-06832012000200031

LI, S.; ZHUANG, Y.; ZHANG, L.; DU, Y.; LIU, H. Worldwide performance and trends in nonpoint source pollution modeling research from 1994 to 2013: A review based on bibliometrics. Journal of Soil and Water Conservation, v. 69, p. 121-126, 2014. https://doi.10.2489/jswc.69.4.121A

LIMA, J. E. F. W.; MONTENEGRO, S. M. G. L.; MONTENEGRO, A. A. A.; KOIDE, S. Comparative hydrology: relationships among physical characteristics, hydrological behavior, and results of the SWAT model in different regions of Brazil. Revista Brasileira de Geografia Física, v. 7, n. 6, p. 1187-1195, 2014.

MANETA, M.; SCHANABEL, S.; JETTEN, V. Continuous spatially distributed simulation of surface and subsurface hydrological processes in a small semi-arid catchment. Hydrological Processes, v. 22, p. 2196-2214, 2008. https://doi.org/10.1002/hyp.6817

MELO, R. O.; MONTENEGRO, A. A. A. Dinâmica temporal da umidade do solo em uma bacia hidrográfica no semiárido Pernambucano. Revista Brasileira de Recursos Hídricos, v. 20, n. 2, p. 430-441, 2015. https://doi.10.21168/rbrh.v20n2.p430-441

MELO NETO, J. O.; SILVA, A. M.; MELlO, C. R.; MÉLlO JÚNIOR, A. V. Simulação hidrológica escalar com o Modelo SWAT. Revista Brasileira de Recursos Hídricos, v. 19, n. 1, p. 177-188, 2014. https://doi.10.21168/rbrh.v19n1.p 177-188

MIRANDA, R. Q. Avaliação integrada da variação espacial e temporal do balanço hídrico na Caatinga utilizando o modelo hidrológico SWAT. 2017. $122 \mathrm{f}$. Thesis (PhD in Development and Environment) - Federal University of Pernambuco, Recife, 2017.

MONTENEGRO, A. A. A.; RAGAB, R. Hydrological response of a Brazilian semi-arid catchment to different land use and climate change scenarios: a modelling study. Hydrological Processes, v. 24, p. 2705-2723, 2010. https://doi.org/10.1002/hyp.7825

MONTENEGRO, A. A. A.; MONTENEGRO, S. M. G. L. Variabilidade espacial de classes de textura, salinidade e condutividade hidráulica de solos em planície aluvial. Revista Brasileira de Engenharia Agrícola e Ambiental, v. 10, n. 1, p. 30-37, 2006. http://dx.doi.org/10.1590/s1415-43662006000100005

MUNOZ-VILLERS, L. E.; MCDONNELL, J. J. Land use change effects on runoff generation in a humid tropical montane cloud forest region. Hydrological Earth System Science, v. 17, p. 3543-3560, 2013. https://doi.org/10.5194/hess-17-3543-2013

NASH, J. E.; SUTCLIFFE, J. V. River flow forecasting through conceptual models Part I - A discussion of principles. Journal of Hydrology, v. 10, p. 282-290, 1970. https://doi.org/10.1016/0022-1694(70)90255-6

NEITSCH, S. L.; ARNOLD, J. G.; KINIRY, J. R.; WILlIAMS, J. R. Soil and water assessment tool - Theoretical documentation version 2005. Temple: Black and Research Center: Texas Agricultural Experiment Station, 2005. Available: http://hdl.handle.net/1969.1/149194. Access: Apr. 2017. 
PINTO, D. B. F. Aplicação do modelo SWAT (Soil and Water Assessment Tool) na simulação hidrossedimentológica em bacia hidrográfica da Serra da Mantiqueira, MG. 2011. 225f. Thesis (PhD in Agricultural Engineering) - Federal Rural University of Lavras, Lavras, 2011.

RODRIGUES, E. L.; ELMIRO, M. A. T.; BRAGA, F. A.; JACOBI, C. M.; ROSSI, R. D. Impact of changes in land use in the flow of the Pará River Basin, MG. Revista Brasileira de Engenharia Agrícola e Ambiental, v. 19, n. 1, p. 70-76, 2015. http://dx.doi.org/10.1590/1807-1929/agriambi.v19n1p70-76

SANTHI, C.; ARNOLD, J. G.; WILLIAMS, J. R.; DUGAS, W. A.; SRINIVASAN, R.; HAUCK, L. M. Validation of the SWAT model on a large river basin with point and nonpoint sources. Journal of the American Water Resources Association, v. 37, n. 5, p. 1169-1188, 2001. https://doi.org/10.1111/j.1752-1688.2001.tb03630.x

SANTOS, J. Y. G. Análise espaço-temporal de processos hidrossedimentológicos na Bacia do Rio Tapacurá (Pernambuco, Brasil). 2015. 205f. Thesis (PhD in Civil Engineering of the Center of Technology and Geosciences), Federal University of Pernambuco, Recife, 2015.

SANTOS, T. E. M.; MONTENEGRO, A. A. A.; SILVA, D. D. Umidade do solo no semiárido pernambucano usando-se reflectometria no domínio do tempo (TDR). Revista Brasileira de Engenharia Agrícola e Ambiental, v. 15, n. 7, p. 670-679, 2011. http://dx.doi.org/10.1590/S1415-43662011000700004

SANTOS, T. E. M.; SILVA, D. D.; MONTENEGRO, A. A. A. Temporal variability of soil water content under different surface conditions in the semiarid region of the Pernambuco state. Revista Brasileira de Ciência do Solo, v. 34, n. 5, p. 1733-1741, 2010. http://dx.doi.org/10.1590/S0100-06832010000500025

SCHMALZ, B.; FOHRER, N. Comparing model sensitivities of different landscapes using the eco hydrological SWAT model. Advances in Geosciences, v. 21, p. 91-98, 2009. https://doi.org/10.5194/adgeo-21-91-2009

ŞEN, Z. Water Science Basic Information. Practical and Applied Hydrogeology, v. 1, p. 141, 2015. https://doi.org/10.1016/B978-0-12-800075-5.00001-7

SILVA, G. J. F. Estimativa de indicadores biofísicos para avaliação do processo de desertificação no município de São João do Cariri - PB. 2014. 127f. Dissertation (Master in Geography) - Federal University of Paraiba, João Pessoa, 2014.

SILVA, R. M. E.; MEDEIROS, I. C. Análise hidrossedimentológica em ambiente SIG usando o modelo SWAT. GeoFocus (Artículos), v. 14, p. 211-231, 2014.

SILVA, R. M.; SANTOS, C. A. G.; SANTOS, J. Y. G. Evaluation and modeling of runoff and sediment yield for different land covers under simulated rain in a semiarid region of Brazil. International Journal of Sediment Research, v. 33, n. 2, p. 117-125, 2018. https://doi.org/10.1016/j.ijsrc.2017.04.005

SILVA JUNIOR, V. P.; MONTENEGRO, A. A. A.; MELO, R. O. Temporal stability of soil moisture in an experimental watershed in the Pernambuco semiarid region. Revista Brasileira de Engenharia Agrícola e Ambiental, v. 20, n. 10, p. 880-885, 2016. http://dx.doi.org/10.1590/1807-1929/agriambi.v20n10p880-885 
SILVA JUNIOR, V. P.; MONTENEGRO, A. A. A.; SILVA, T. P.; GUERRA, S. M.; SANTOS, E. S. Produção de água e sedimentos em bacia representativa do semiárido pernambucano. Revista Brasileira de Engenharia Agrícola e Ambiental, v. 15, n. 10, p. 1073-1081, 2011.

SILVA, J. R. L.; MONTENEGRO, A. A. A.; MONTEIRO, A. L. N.; SILVA JUNIOR, V. P. Modelagem da dinâmica de umidade do solo em diferentes condições de cobertura no semiárido pernambucano. Revista Brasileira de Ciências Agrárias, v. 10, n. 2, p. 293 303, 2015. http://dx.doi.10.5039/agraria.v10i2a4219

TUCCI, C. E. M.; CLARKE, R. T. Impacto das mudanças de cobertura vegetal no escoamento: Revisão. Revista Brasileira de Recursos Hídricos, v. 2, p. 135-152, 1997. http://dx.doi.10.21168/rbrh.v2n1.p135-152

UNIYAL, B.; JHA, M. K.; VERMA, A. K. Parameter identification and uncertainty analysis for simulating streamflow in a River Basin of Eastern India. Hydrological Processes, v. 29, n.17 p. 3744-3766, 2015. https://doi.org/10.1002/hyp.10446

VEIGA, A. M. Calibração do modelo hidrossedimentológicos SWAT na bacia hidrográfica do córrego samambaia, Goiânia - GO. 2014. 132f. Dissertation (Master's degree in Environmental Engineering) - Federal University of Goiás, Goiânia, 2014.

VIOLA, M. R. Simulação hidrológica na região Alto Rio Grande a montante do reservatório de Camargos/CEMIG. 2008. 120f. Dissertation (Master in Water and Soil Engineering) - Federal University of Lavras, Lavras, 2008.

VIOLA, M. R.; MELlO, C. R.; ACERBI JUNIOR, F. W.; SILVA, A.M. Modelagem hidrológica na bacia hidrográfica do Rio Aiuruoca, MG. Revista Brasileira de Engenharia Agrícola e Ambiental, v. 13, n. 5, p. 581-590, 2009.

VIOLA, M. R.; MELLO, C. R.; GIONGO, M.; BESKOW, S.; SANTOS, A. F. Modelagem Hidrológica em uma Sub-bacia Hidrográfica do Baixo Rio Araguaia, TO. Journal of Biotechnology and Biodiversity, v. 3, n. 3, p. 38-47, 2012.

YAN, B.; FANG, N. F.; ZHANG, P. C.; SHI, Z. H. Impacts of land use change on watershed streamflow and sediment yield: an assessment using hydrologic modelling and partial least squares regression. Journal of Hydrology, v. 484, p. 26-37, 2013. https://doi.org/10.1016/j.jhydrol.2013.01.008 


Ambiente \& Água - An Interdisciplinary Journal of Applied Science
ISSN 1980-993X - doi:10.4136/1980-993X
www.ambi-agua.net
E-mail: ambi.agua@gmail.com

\title{
Drinking water quality in schools of the Santarém region, Amazon, Brazil, and health implications for school children
}

\author{
ARTICLES doi:10.4136/ambi-agua.2218
}

Received: 29 Nov. 2017; Accepted: 23 Sep. 2018

\author{
Marina Smidt Celere Meschede ${ }^{1 *}$; Bernardino Ribeiro Figueiredo² \\ Renato Igor da silva Alves³; Susana Inés Segura-Muñoz ${ }^{3}$ \\ ${ }^{1}$ Universidade Federal do Oeste do Pará (UFOPA), Santarém, PA, Brasil \\ Instituto de Saúde Coletiva (ISCO). E-mail: marcelere@ yahoo.com.br \\ ${ }^{2}$ Universidade Estadual de Campinas (UNICAMP), Campinas, SP, Brasil \\ Instituto de Geociências (IG). E-mail: berna@ige.unicamp.br \\ ${ }^{3}$ Universidade de São Paulo (USP), Ribeirão Preto, SP, Brasil \\ Escola de Enfermagem de Ribeirão Preto (EERP). \\ Departamento de Enfermagem Materno-Infantil e Saúde Pública (DEMISP). \\ E-mail: renatobio_usp@yahoo.com.br, susis@eerp.usp.br \\ *Corresponding author
}

\begin{abstract}
The quality of drinking water and its health implications for school children were examined at schools in the Santarém region, Amazon, Brazil. In this region, the population is fully supplied by groundwater from the voluminous Alter do Chão aquifer. Drinking water samples from three schools in Santarem city and from one school at the rural Mojuí dos Campos town were subjected to microbiological and physicochemical compositional analyses. The health risk of human exposure to chemical compounds through water intake was also evaluated. The results indicated that most water samples were contaminated with total coliform and with E. coli, which could cause serious intestinal disorders for school children. Drinking water was acidic and most of the chemical element concentrations were within Brazilian water potability recommended levels. One exception was the high aluminium content in schools from Santarem served by shallower wells, suggesting that further epidemiological studies are necessary and the monitoring of exposed school children should not be discarded. Elevated nitrate concentrations were also noted in schools from Santarém with shallower wells, indicating lack of sanitation and the importance of periodic monitoring of drinking water to prevent adverse health effects. Quantification of human health risk indicated a hazard in schools served by shallower wells, with aluminium as the main pollutant, followed by nitrate. The results showed that most drinking water quality parameters are in accordance with Brazilian legislation. However, microbiological contamination, water acidity, aluminium and nitrate concentrations must be taken into consideration for local governments in order to prevent related diseases among school children.
\end{abstract}

Keywords: Amazon, drinking water, groundwater, health, pollution. 


\section{Qualidade da água de consumo em escolas na região de Santarém, Amazônia, Brasil e implicações para saúde dos escolares}

\section{RESUMO}

Qualidade da água de consumo e implicações em saúde de escolares foram avaliadas em escolas na região de Santarém, Pará, Amazônia. Nessa região, a população é abastecida totalmente por água subterrânea do volumoso aquífero Alter do Chão. Amostras de água de consumo de três escolas na cidade de Santarém e uma escola no município rural de Mojuí dos Campos foram submetidas a análises microbiológicas e de composição físico química. O risco à saúde por meio da exposição a contaminantes químicos pela ingestão da água, também, foi avaliado. Os resultados indicaram que a maior parte das amostras estiveram contaminadas por coliformes totais e E.coli, o que poderá ocasionar distúrbios intestinais importantes nos escolares. A água é ácida e as concentrações dos elementos químicos estão de acordo com os níveis recomendados pela legislação brasileira. Uma exceção foi observada para o alumínio, que apresentou concentrações superiores ao recomendado na água das escolas de Santarém com poços mais rasos, sugerindo que novos estudos epidemiológicos devam ser realizados e o monitoramento de crianças expostas não deverá ser descartado. Concentrações elevadas de nitrato também foram encontradas na água das escolas de Santarém com poços mais rasos, indicando deficiências sanitárias e a importância do seu monitoramento visando evitar efeitos em saúde. A avaliação quantitativa de risco em saúde evidenciou perigo somente nas escolas com poços mais rasos, sendo que o principal contribuinte foi o alumínio, seguido do nitrato. Os resultados mostram que a maioria dos parâmetros de qualidade da água das escolas estão de acordo com os limites recomendados pela legislação brasileira, entretanto, a contaminação microbiológica, a acidez e as concentrações elevadas de alumínio e nitrato na água devem ser consideradas prioridades visando a prevenção de doenças relacionadas com consumo de água pelos escolares.

Palavras-chave: água de consumo, água subterrânea, Amazônia, saúde, poluição.

\section{INTRODUCTION}

Water is essential to sustain life, and a satisfactory water supply must be available to the human population. According to the World Health Organization (WHO), in 2017, access to safe drinking water can result in tangible benefits to health (WHO, 2017). Safety of the water supply is key to public health, especially for children, who generally require greater protection. School children can spend five to eight hours a day in public elementary schools in Brazil. In this sense, it is essential that this communal space presents favourable environmental conditions to ensure good health practices and quality of life for children.

Adequate quality of drinking water is a human right (WHO, 2017). Unfortunately, the supply of safe drinking water has been compromised by the absence of adequate sanitary infrastructure in some regions of developing countries like Brazil, where this vital resource is vulnerable to pollution. In the case of groundwater supply, over the past 20 years it has become increasingly apparent that groundwater sources are being contaminated by hazardous microbiological agents and chemicals derived from a variety of social, economic and urban activities; therefore groundwater protection has become essential for governmental agencies (Palamuleni and Akoth, 2015; Llopis-González et al., 2014).

Groundwater is an important source of drinking water and often requires little or no treatment. Nevertheless, diseases caused by contaminated groundwater consumption are reported from countries at all levels of economic development (WHO, 2006). In general, 
groundwater has good microbiological quality, but may become rapidly polluted if protective actions are not implemented and well maintained. Some studies highlight microbiological contamination due to the proximity of septic tanks to artesian wells in countries with precarious basic sanitation infrastructure (Dahunsi et al., 2014; Mendes et al., 2017). Fecal-derived pathogens are the principal concerns in setting health-based targets for microbial safety and diarrhea is the most common disease in school children that is associated with water contaminated by pathogens through the fecal-oral route (WHO, 2006). The control of the microbial quality of drinking water should be the first priority in all countries, given the immediate and potentially devastating consequences of waterborne infectious disease.

The health concerns associated with chemical constituents of drinking water differ from those associated with microbial contamination and arise primarily from the ability of chemicals to cause adverse health effects after prolonged periods of exposure, as evidenced by Kim et al. (2016). There are many inorganic and organic compounds that naturally occur in groundwater which may originate from the rocks and soil percolated by the water. However, chemicals from anthropogenic sources (i.e., urban or agricultural activities) can reach groundwater from diverse sources arising from the use and disposal of materials and products containing toxic elements in high concentrations, such as trace elements and nitrates (WHO, 2017).

Assessing groundwater quality and the risk for human health has become an important task in public health concerns. Studies of the quality of drinking water collected by wells have been developed worldwide, and are of great importance (Majumdar and Gupta, 2000; Nalbantcilar and Pinarkara, 2016; Lapworth et al., 2018). In the Santarém region, there is a lack of research involving groundwater quality and health. Some studies (Azevedo, 2006; Aguiar et al., 2014) have been carried out investigating surface water quality in the Amazon region and, in general, the implications for ecosystems, such as the effects on fish development and other living aquatic organisms. For these reasons, in this study we investigated the quality of drinking groundwater in four schools in the Amazon region, three located in an urban area, Santarém city, and one in a rural area, Mojuí dos Campos, during two seasons (dry and rainy). We compared the results with reference values from Brazilian legislation Ordinance 2914 (Brasil, 2011), which provides the standards for drinking water in Brazil based on the guidelines of the WHO. The health risk for children associated with ingestion of chemical compounds through drinking water was also quantified in schools, following the United States Environmental Protection Agency (USEPA) guidelines (USEPA, 1989; 1996).

\section{MATERIALS AND METHODS}

\subsection{Study area}

The study area is located in the Santarém region, in the west of Pará State, in the Brazilian Amazon. The region of Santarém includes the urbanized city of Santarém and the rural Mojuí dos Campos town, $30 \mathrm{~km}$ southeast of Santarém city (Figure 1). This region has a seasonal climate with two distinct periods (i) dry season (July to November) and (ii) rainy season (December to May), with June considered a transition month (Gomes et al., 2016). The climate in the Santarém region is tropical humid, and is classified as Am3 in the Köppen climate classification system (Köppen, 1936). In the last two years, according to the Brazilian National Institute of Meteorology (INMET), 95\% of recorded values of temperature were in the range of $32.7^{\circ} \mathrm{C}-22.5^{\circ} \mathrm{C}$ in the dry season and $31.2^{\circ} \mathrm{C}-22.3^{\circ} \mathrm{C}$ in the rainy season. In 2016 , the total precipitation and average relative humidity in the dry season were $371.5 \mathrm{~mm}$ and $84.6 \%$, and in the rainy season these were $986.0 \mathrm{~mm}$ and $87.4 \%$, respectively (INMET, 2017). 


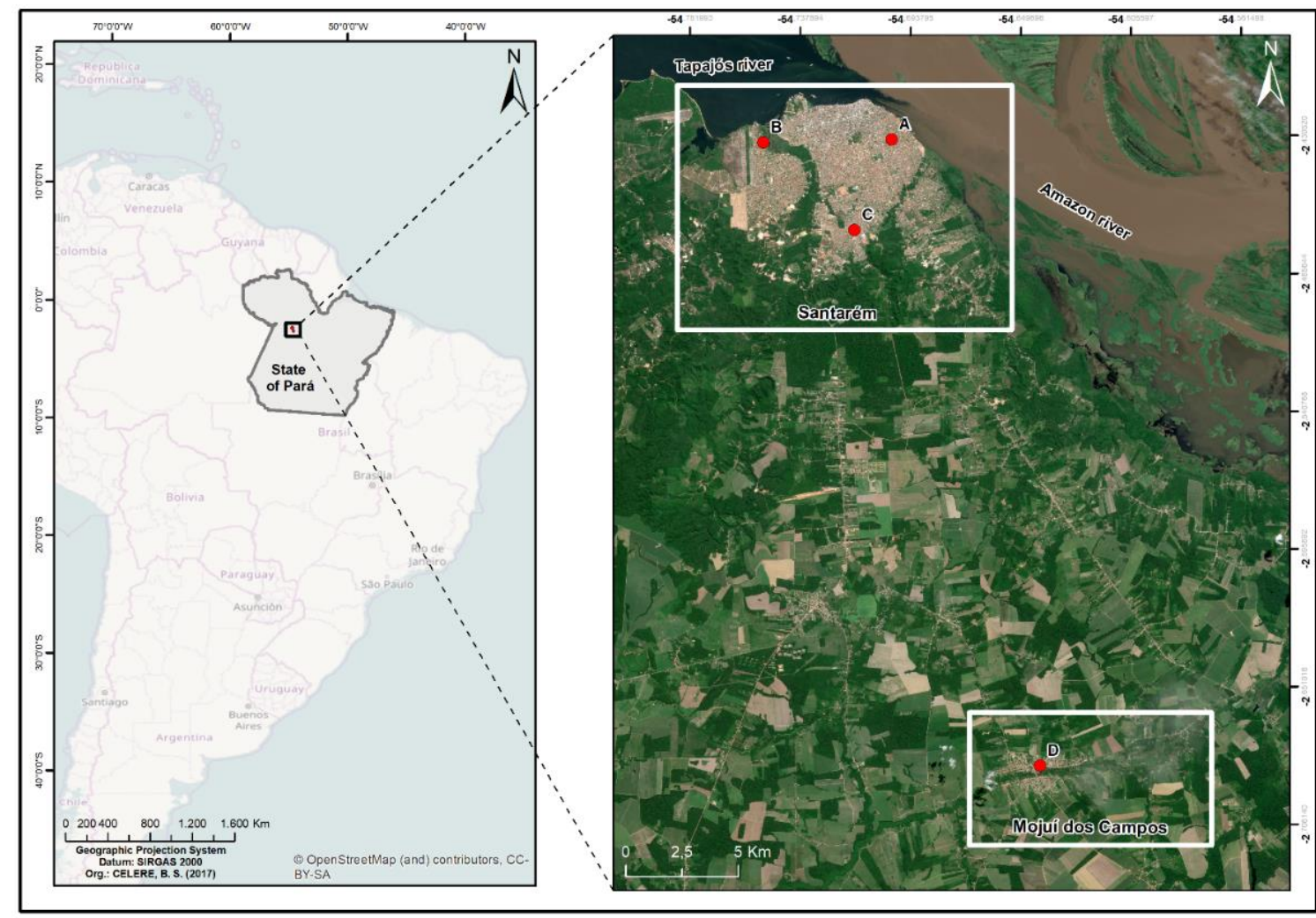

Figure 1. Location map of the State of Pará and Santarém region indicating the Schools A, B and C in Santarém and the Sschool D at Mojuí dos Campos, State of Pará, Amazon, Brazil.

The city of Santarém had an estimated 294.447 inhabitants in 2016 according to the Brazilian Institute of Geography and Statistics (IBGE, 2016), and is the second most important urban region in the State of Pará, with economic activity based on local commerce, and it is located at the intersection of the Tapajos and Amazonas Rivers (Figure 1). These two rivers are important routes for regional transport; however, surface water is not used for human consumption. The Sanitation Company of Pará (COSANPA) and the Municipality of Santarém distribute drinking water in Santarém. COSANPA takes advantage of its own deep-water wells (> $250 \mathrm{~m}$ ) that intercept the Alter do Chão aquifer and distributes water to $61 \%$ of the population; of these, $49 \%$ receive chlorinated water, whereas $12 \%$ of the population is not served by treated and disinfected water (COSANPA, 2013). The voluminous Alter do Chão aquifer is the major groundwater supply for most of the State of Pará (Tancredi, 1996). The Municipality of Santarém captures drinking water from shallower wells at 18 to $30 \mathrm{~m}$ deep. Households and other areas that are not served by either of these two water systems use groundwater from private shallow wells. According to the Sanitation Ranking published by the Trata Brazil Institute (2016), Santarém is among the ten municipalities in Brazil with the poorest drinking water treatment system.

The town of Mojuí dos Campos has 15.548 inhabitants (IBGE, 2016), and the main economic activity is the agricultural cultivation of soybeans, corn and black pepper. Agriculture plays a key role in supporting the rural population of the area. At Mojuí dos Campos, there is an important main water microsystem which captures water for human consumption from the Alter do Chão aquifer at a depth of $202 \mathrm{~m}$ without treatment and water disinfection.

\subsection{Overview of schools and water sampling}

A total of 36 drinking groundwater samples were collected at three elementary schools in Santarém (denominated in this study as Schools A, B and C) and at one school at Mojuí dos 
Campos (denominated in this study as School D) (Figure 1). An overview of the characteristics of these schools is shown in Table 1. The water at the schools is used for food preparation, washing of household utensils, in the toilets and as drinking water by school children and employees. The supply of drinking water after its underground capture is provided by tanks (water tanks) with a capacity of up to $1.500 \mathrm{~L}$, which are located inside the schools and made of polyethylene and fitted with a lid. Water was sampled from a drinking fountain over a period of three months (one sampling day in February, March and April) in the rainy season and in another three months (one sampling day in September, October and November) in the dry season, between 2015 and 2017. Immediately preceding water sampling the drinking fountains were cleaned with $70 \%$ alcohol and then tapped and allowed to drain for one to two minutes, following specifications established by the Brazilian Ministry of Health - National Health Foundation of Brazil (FUNASA, 2006). The volumes of the collected samples were $100 \mathrm{~mL}$ for the bacteriological analyses, $1 \mathrm{~L}$ for the parasitological analyses, $200 \mathrm{~mL}$ for the physicochemical parameters, and $100 \mathrm{~mL}$ for chemical analyses. After collection, the samples were conserved in a cold thermal box $\left(4^{\circ} \mathrm{C}\right)$ until the analyses were conducted.

Table 1. Overview of schools in Santarém (A, B and C) and in Mojuí dos Campos (D) in the western region of the State of Pará, Amazon, Brazil.

\begin{tabular}{|c|c|c|c|c|}
\hline Characteristics & School A & School B & School C & School D \\
\hline Location & Santarém city & Santarém city & Santarém city & Mojuí dos Campos \\
\hline $\begin{array}{l}\text { Number of } \\
\text { students in } \\
2017\end{array}$ & 823 & 306 & 1069 & 376 \\
\hline $\begin{array}{l}\text { Drinking water } \\
\text { source }\end{array}$ & $\begin{array}{c}\text { Groundwater } \\
\text { (30 m deep) - private } \\
\text { well }\end{array}$ & $\begin{array}{l}\text { Groundwater } \\
\text { (200 m deep) - } \\
\text { COSANPA }\end{array}$ & $\begin{array}{l}\text { Groundwater } \\
\text { (18 m deep) } \\
\text { - private well }\end{array}$ & $\begin{array}{l}\text { Groundwater } \\
\text { (202 m deep) municipal } \\
\text { microsystem }\end{array}$ \\
\hline $\begin{array}{l}\text { Water storage } \\
\text { after } \\
\text { underground } \\
\text { collection }\end{array}$ & Water tank & Water tank & Water tank & Water tank \\
\hline $\begin{array}{l}\text { Sewage } \\
\text { treatment }\end{array}$ & Septic tank & Septic tank & Septic tank & Septic tank \\
\hline $\begin{array}{l}\text { Distance of } \\
\text { septic tank of } \\
\text { school to } \\
\text { groundwater } \\
\text { well }\end{array}$ & Approximately $15 \mathrm{~m}$ & More than $50 \mathrm{~m}$ & $\begin{array}{l}\text { Approximately } \\
15 \mathrm{~m}\end{array}$ & More than $50 \mathrm{~m}$ \\
\hline
\end{tabular}

\subsection{Water analyses}

The drinking water samples from the schools were analysed for microbiological characteristics (total coliform, E.coli, heterotrophic bacteria and parasites), physicochemical parameters $(\mathrm{pH}$, turbidity, conductivity and alkalinity) and chemical composition (anions and trace elements).

The microbiological analyses for total coliforms, E. coli and heterotrophic bacteria were carried out using a vacuum pump and the method of membrane filters following standard methods of FUNASA (2006), which consists of filtration of $100 \mathrm{ml}$ of the water sample through a sterile membrane with $47 \mathrm{~mm}$ in diameter and a porosity of $0.45 \mu \mathrm{m}$. The membranes were then placed in Petri plates with a Rapid HiColiform Agar (Himedia ${ }^{\circledR}$ ) culture media for growth of total coliforms and E.coli. Petri plates were incubated at $35^{\circ} \mathrm{C}$ for $24 \pm 2$ hours in order to count Colony Forming Units (CFU) of total coliforms; after incubation, the colonies that grew 
with blue-greenish coloration were considered as total coliforms. The Petri plates were incubated at $44^{\circ} \mathrm{C}$ for $24 \pm 2$ hours for $E$. coli counting and after incubation, the Petri plates were exposed to ultraviolet light $(366 \mathrm{~nm}, 6 \mathrm{~W})$ at a distance of 6 to $8 \mathrm{~cm}$ in a dark environment. A positive result was considered for E.coli when colonies in the fluorescent staining were detected. For the reading of heterotrophic bacteria, the result was considered positive when there was CFU present on the membrane after the pre-established conditions of incubation. Heterotrophic bacteria Petri plates were incubated for $35^{\circ} \mathrm{C}$ for $48 \pm 3$ hours with de media Plate Count Agar (Himedia ${ }^{\circledR}$ ) for counting the colonies. The counting of heterotrophic bacteria includes the entire group of microorganisms that is capable of growing in a nutrient-rich solid medium agar.

Parasitological analysis was performed using the spontaneous sedimentation method, for a determination of eggs, cysts and larvae of helminths and protozoa. For this analysis, $1 \mathrm{~L}$ of the water sample was arranged in a sedimentation chalice, where it remained for a period of 24 hours. Afterwards, $1 \mathrm{ml}$ of the sediment material was deposited on a slide and stained with a drop of lugol solution (Neves, 2005; Ferreira et al., 2008; Julião, 2011). The material was then analysed under an optical microscope NIKON Model E200.

The $\mathrm{pH}$ of the water was measured by the potentiometric method using a portable $\mathrm{pH}$ meter, Model HI 991003 (Hanna ${ }^{\circledR}$ ), at a temperature of $25-30^{\circ} \mathrm{C}$, and water turbidity and conductivity were measured with the same equipment. Alkalinity was determined by titration measuring the amount of sulphuric acid used, and the calculation indicated the amount of carbonate and bicarbonate ions involved in the reaction expressed as mg.L of $\mathrm{CaCO}_{3}$ (Brazil, 2006).

Samples intended for chemical composition analyses were filtered through a $0.2 \mu \mathrm{m}$ syringe filter and kept cooled $\left(4^{\circ} \mathrm{C}\right)$ until analysis. Additionally, samples intended for traceelement analysis by Inductively Coupled Plasma Mass Spectrometer (ICP-MS) were preserved with two drops of concentrated $\mathrm{HNO}_{3}$ at a $\mathrm{pH}$ of less than 2 .

The anion contents in water were analysed by Ion Chromatography in a Thermo Scientific Dionex ICS-5000 spectrophotometer. All the samples were analysed for fluoride $\left(\mathrm{F}^{-}\right)$, chloride $\left(\mathrm{Cl}^{-}\right)$, nitrite $\left(\mathrm{N}^{-} \mathrm{NO}_{2}{ }^{-}\right)$, nitrate $\left(\mathrm{N}-\mathrm{NO}_{3}{ }^{-}\right)$, sulphate $\left(\mathrm{SO}_{4}{ }^{2-}\right)$, bromide $\left(\mathrm{Br}^{-}\right)$and phosphate $\left(\mathrm{PO}_{4}{ }^{3-}\right)$. For the anions, the following components were used: an IonPaC AS19 Capillary Column $(0.4 \times 250 \mathrm{~mm})$ in combination with the AG19 Guard Column $(0.4$ x $50 \mathrm{~mm})$, Anion Capillary Electrolytic Suppressor (ACES ${ }^{\mathrm{TM}}$ 300) and Eluent Generator Cartridges for the generation of potassium hydroxide $\left(\mathrm{KOH}^{-}\right)$with concentrations between 2 and $50 \mathrm{mmol} \mathrm{L} \mathrm{L}^{-1}$. The runs lasted $30 \mathrm{~min}$ with a flow of $0.010 \mathrm{~mL} \mathrm{~min}^{-1}$ with the following concentrations' slope: 0-10 min (2-10 mmol L-1 $)$; 10-20 min (10-45 mmol L-1) and 21.1-30 min (2-2 $\left.\mathrm{mmol} \mathrm{L}^{-1}\right)$. For cations, the components were as follows: IonPac CS12A Capillary Column (2 x $250 \mathrm{~mm})$ in combination with the CG12A Guard Column (2 x $50 \mathrm{~mm})$, Cations Capillary Electrolytic Suppressor (CCES ${ }^{\mathrm{TM}}$ 300) and Eluent Generator Cartridges (EGC) for the generation of methanesulfonic acid (MSA) at a concentration of $20 \mathrm{mmol} \mathrm{L}^{-1}$ and a flow $0.25 \mathrm{~mL} \mathrm{~min}^{-1}$ throughout the 17 minutes of the run. For both determinations, the injection was made by the Automatic Sampling System (Dionex AS-AP) with a high-performance conductivity detector. Data were analyzed with the Chromeleon 6.8 software. For the equipment calibration, analytical curves were constructed for each of the ionic species, obtaining seven concentration points (in triplicate) for each curve at the following concentrations: $0.2 ; 0.4 ; 0.6 ; 0.8 ; 1.0 ; 2.0$ and $3.0 \mathrm{mg}$ $\mathrm{L}^{-1}$. The detection limits in $\mathrm{mg} \mathrm{L}^{-1}$ were estimated to be 0.001 for $\mathrm{F}^{-} ; 0.015$ for $\mathrm{Cl}^{-}$and $\mathrm{PO}_{4}{ }^{3-} ; 0.005$ for $\mathrm{NO}_{2}{ }^{-}$and $\mathrm{Br}^{-} ; 0.003$ for $\mathrm{NO}_{3}{ }^{-}$and 0.010 for $\mathrm{SO}_{4}{ }^{2-}$.

The concentrations of the 57 trace elements were determined in all water samples by ICPMS equipped with collision cell technology (CCT) (Xseries II Thermo Scientific), but only 16 elements were quantified in this study: aluminium (Al); arsenic (As), boron (B), barium (Ba), 
calcium $(\mathrm{Ca})$, cadmium $(\mathrm{Cd})$, chromium $(\mathrm{Cr})$, copper $(\mathrm{Cu})$, iron $(\mathrm{Fe})$, potassium $(\mathrm{K})$, magnesium $(\mathrm{Mg})$, manganese $(\mathrm{Mn})$, sodium $(\mathrm{Na})$, nickel $(\mathrm{Ni})$, lead $(\mathrm{Pb})$ and zinc $(\mathrm{Zn})$. For quality control, all analyses were performed in triplicate and quality control of the measurements was carried out by the analysis of the reference material: River Water Reference Material for Trace Metals (SLRS-5). The detection limits in $\mathrm{ng} \mathrm{mL}^{-1}$ were estimated to be 0.4 for $\mathrm{Al}, 0.005$ for As, 1.2 for B, 0.009 for $\mathrm{Ba}, 9.3$ for $\mathrm{Ca}, 0.004$ for $\mathrm{Cd}, 0.01$ for $\mathrm{Cr}, 0.05$ for $\mathrm{Cu}$, 29 for $\mathrm{Fe}, 47$ for K, 0.2 for $\mathrm{Mg}, 0.03$ for $\mathrm{Mn}, 2$ for $\mathrm{Na}, 0.04$ for Ni, 0.002 for $\mathrm{Pb}$ and 0.1 for $\mathrm{Zn}$.

\subsection{Data analysis}

Element concentrations were examined by descriptive statistics and compared with the maximum values recommended by Brazilian Ordinance 2914 that provides guidelines for controlling and monitoring the quality of drinking water for human consumption in Brazil (Brazil, 2011).

USEPA guidelines were used to quantify risk for human health considering the exposure through ingestion of groundwater in the schools (USEPA 1989; 1996). Human health risk assessment has become a widely applied methodology to quantify the risks derived from exposure to environmental pollutants (Turdi and Yang, 2016). The health risks include noncarcinogenic and carcinogenic agents in drinking water for school children.

The non-carcinogenic risks were assessed by estimating the Hazard Quotient (HQ) and Hazard Index (HI) for each school during six months. The HQ was calculated as the quotient between the environmental Daily Exposure (DE) dose and the Reference Dose (RfD), which was obtained from the Integrated Risk Information System (IRIS) in mg.Kg.day (USEPA, 2014). The non-carcinogenic risk was calculated for chemicals that had their reference doses established by IRIS using the following Equation 1:

$D E=C * C o * E F * E D / B w * A T$

In the equation, $\mathrm{DE}$ is the daily exposure doses through oral intake ( $\mathrm{mg} \mathrm{Kg}-\mathrm{day}^{-1}$ ); $\mathrm{C}$ is the chemical concentration in water $\left(\mathrm{mg} \mathrm{L}^{-1}\right)$; Co is the volume of drinking water consumed by the children in one day (L); EF is exposure frequency in days; ED is the exposure duration in years; $\mathrm{Bw}$ is the average body weight in $\mathrm{kg}$ and $\mathrm{AT}$ is averaging time in days. Adopted values and description of the different parameters are shown in Table 2.

The Hazard Quotient (HQ) values were obtained for a number of elements (Al; As; Ba; B; $\mathrm{Cd} ; \mathrm{Cr} ; \mathrm{Cu} ; \mathrm{Mn} ; \mathrm{Ni} ; \mathrm{Zn}$ ) and for nitrate by the ratio between $\mathrm{DE}$ and their respective reference doses from IRIS (RfD). When the ratio exceeds the unit, it is characterized as a danger to human health, with the possibility of non-cancerous effects of human exposure to substances. Subsequently, the Hazard Index, defined as the total risk, was obtained by summing the HQ of each element. Values of the Hazard Index (HI) under unity are considered as safe.

\subsection{Ethical aspects}

The Research Ethics Committee of the State University of Pará (UEPA) approved this study in September 2015 with the register number 1.318.594. 
Table 2. Input data for calculating the non-carcinogenic risk for school children from drinking water in schools in Santarém (A, B and C) and in Mojuí dos Campos (D) in the Santarém region, Amazon, Brazil.

\begin{tabular}{|c|c|c|c|}
\hline Parameters & Values adopted & Unit & Reference data \\
\hline $\begin{array}{l}\text { Mean concentration of chemical } \\
\text { in drinking water }(C)\end{array}$ & Results of present study & $\mathrm{mg} \mathrm{L}^{-1}$ & Present study \\
\hline $\begin{array}{l}\text { Daily water consumption by } \\
\text { children }(\mathrm{Co})\end{array}$ & 1.26 & L day & USEPA (1996) \\
\hline Exposure frequency (EF) & 275 & days & USEPA (1996) \\
\hline Exposure duration (ED) & 06 & years & USEPA (1996) \\
\hline Body weight children (Bw) & 15 & $\mathrm{~kg}$ & USEPA (1996) \\
\hline $\begin{array}{l}\text { Averaging time for non- } \\
\text { carcinogenic exposure (ATnc) }\end{array}$ & ED x 275 (1650 days) & days & USEPA (1989) \\
\hline Reference Doses (RfD) from IRIS & $\begin{array}{c}\mathrm{Al}=0.018 \\
\mathrm{As}=0.0003 \\
\mathrm{Ba} \text { and } \mathrm{B}=0.2 \\
\mathrm{Cd}=0.0005 \\
\mathrm{Cr}=0.003 \\
\mathrm{Cu}=0.04 \\
\mathrm{Mn}=0.14 \\
\mathrm{Ni}=0.02 \\
\mathrm{Zn}=0.3 \\
\mathrm{~N} \text { - nitrate }=1.6\end{array}$ & mg kg day & USEPA (2014) \\
\hline
\end{tabular}

\section{RESULTS AND DISCUSSION}

\subsection{Microbiological contamination}

Table 3 shows the results of microbiological analyses of 36 water samples from schools corresponding to dry and rainy seasons and indicates the growth of Colony Forming Units (CFU) per $100 \mathrm{ml}$ water. The results showed the presence of heterotrophic bacteria in all samples whereas total coliforms were detected in 28 samples and E. coli in 16 samples. Cysts and parasites in water samples were not found. The concentrations of heterotrophic bacteria agree with Brazilian Ordinance 2914 (Brasil, 2011). The highest values were found in School A during the rainy season (240 to $1144 \mathrm{CFU} / 100 \mathrm{~mL}$ ) and in School C during the dry season (396 to $1694 \mathrm{CFU} / 100 \mathrm{~mL}$ ). These heterotrophic bacteria have no effects on human health, but are a good indicator of the quality of water (i.e., the lower the concentration of heterotrophic bacteria in drinking water the better its quality) (Brasil, 2011).

Detection of total coliforms in schools was accentuated during the rainy season with 17 positive samples compared to 11 samples in the dry season. Values of CFU varied widely between schools. The schools with shallower wells are more susceptible to the infiltration of soil contaminants that may increase during rainy periods. Some explanations can be raised for the growth of total coliforms in water samples. The proximity between wells and the septic tanks and the shallower depth of the wells in Schools A and C may favour the presence of coliforms and the higher value of CFU/100 mL. Septic tanks should be constructed in the lowest part of the area and at a minimum horizontal distance of approximately $16 \mathrm{~m}$ from the wells (USEPA, 2002). However, this criteria is not always followed at schools with shallower wells. Another explanation is the inadequate maintenance of water tanks in schools. The maintenance of these reservoirs in schools often does not follow a cleaning routine. 
Table 3. Microbiological analyses of drinking water samples from Schools A, B and C in Santarém and D in Mojuí dos Campos during the dry and rainy seasons, Santarém region, Amazon, Brazil, and the reference values from Brazilian Ordinance 2914.

\begin{tabular}{|c|c|c|c|c|c|c|c|c|c|}
\hline \multirow{2}{*}{$\begin{array}{l}\text { Microbiological } \\
\text { Parameters }\end{array}$} & \multicolumn{2}{|c|}{ School A } & \multicolumn{2}{|c|}{ School B } & \multicolumn{2}{|c|}{ School C } & \multicolumn{2}{|c|}{ School D } & \multirow[t]{2}{*}{$\begin{array}{l}\text { Reference value } \\
\text { Ordinance } 2914\end{array}$} \\
\hline & $\begin{array}{c}\text { Samples with } \\
\text { microbial } \\
\text { growth }\end{array}$ & $\begin{array}{l}\text { CFU/ } \\
100 \mathrm{~mL}\end{array}$ & $\begin{array}{l}\text { Samples } \\
\text { with } \\
\text { microbial } \\
\text { growth }\end{array}$ & $\begin{array}{c}\text { CFU/ } \\
100 \mathrm{~mL}\end{array}$ & $\begin{array}{l}\text { Samples with } \\
\text { microbial } \\
\text { growth }\end{array}$ & $\begin{array}{c}\text { CFU/ } \\
100 \mathrm{~mL}\end{array}$ & $\begin{array}{l}\text { Samples with } \\
\text { microbial } \\
\text { growth }\end{array}$ & $\begin{array}{c}\text { CFU/ } \\
100 \mathrm{~mL}\end{array}$ & \\
\hline Dry season & $n=6$ & & $n=3$ & & $n=6$ & & $n=3$ & & \\
\hline Heterotrophic bacteria & All samples & $73-724$ & All samples & $220-484$ & All samples & $396-1694$ & All samples & $132-643$ & $\begin{array}{c}<50.000 \\
\mathrm{CFU} / 100 \mathrm{~mL}\end{array}$ \\
\hline Total coliform & 3 samples & $04-512$ & 3 samples & $01-06$ & 2 samples & $02-146$ & 3 samples & $01-14$ & Absence \\
\hline E. coli & Absence & -- & 2 samples & 01- 02 & Absence & -- & 3 samples & $01-02$ & Absence \\
\hline Parasites & Absence & -- & Absence & -- & Absence & -- & Absence & -- & Absence \\
\hline Rainy season & $n=6$ & & $n=$ & & $n=6$ & & $n=3$ & & \\
\hline Heterotrophic bacteria & All samples & $240-1144$ & All samples & $18-360$ & All samples & $17-189$ & All samples & $51-308$ & $\begin{array}{c}<50.000 \\
\mathrm{CFU} / 100 \mathrm{~mL}\end{array}$ \\
\hline Total coliform & 6 samples & $02-348$ & 2 samples & $300-973$ & 3 samples & $04-280$ & 6 samples & 01- 69 & Absence \\
\hline E. coli & 4 samples & $02-07$ & 1 sample & 15 & 2 samples & $01-163$ & 4 samples & $02-33$ & Absence \\
\hline Parasites & Absence & -- & Absence & -- & Absence & -- & Absence & -- & Absence \\
\hline
\end{tabular}


The number of samples with E. coli was also higher during the rainy season, with 11 positive samples but just 5 during the dry period. The presence of E.coli in water samples from schools is in disagreement with the Brazilian standards for potability as delineated in the Decree 2914 (Brasil, 2011). E. coli is an excellent indicator of fecal contamination in water because it is a microorganism belonging to the intestinal microbiota of mammals and birds (Hunter, 2003). The origin of E.coli in water samples may be the same as that of the total coliforms, due to the proximity of the shallow well to the septic tank and the lack of adequate maintenance of the water tanks. The presence of these microorganisms in water suggests contact with fecal material and highlights the possibility that other fecal microorganisms could be present in the water (i.e., Cryptosporidium and hepatitis virus), indicating that the water is inadequate for human consumption and could cause health risks to school children, such as diarrhea, hepatitis and other gastric intestinal disturbances. More detailed research on this region also is recommended, since most studies in the Amazon region have been conducted to evaluate the presence of total coliforms and E.coli in surface waters such as rivers and streams (Aguiar et al., 2014; Azevedo, 2006).

\subsection{Physical chemical parameters and chemical composition of drinking water}

The mean, minimum and maximum values of some physicochemical parameters in water from schools are presented in Table 4. Drinking water at temperatures between $25-30^{\circ} \mathrm{C}$ was acidic with $\mathrm{pH}$ ranging from 4.2 to 5.2 at Schools $\mathrm{A}, \mathrm{B}$ and $\mathrm{C}$ and 4.7 to 5.0 at School D. The values found for $\mathrm{pH}$ in all schools are below the recommended minimum of 6.0. The low $\mathrm{pH}$ of local groundwater may result from natural processes, such as partial solubilisation of siliciclastic rocks (e.g., sandstone of the Alter do Chão formation). Alternative processes like pyrite oxidation or acid rain, commonly found in industrial areas (Edmunds and Smedley, 1996), are unlikely to occur in the region. Other studies have detected low groundwater $\mathrm{pH}$ (around 4.5 - 5.0) as a common feature in different places in the Amazon (Medeiros et al., 2016; Mendes et al., 2017).

The health effects of acidic water intake remain unclear. The WHO (2003) reported about skin and mucous irritation after exposure to acid water, but some gastric and intestinal disturbances are likely to occur. The acid drinking water may contribute to adverse health effects, since many minerals are soluble in acid water, thus releasing some toxic trace metals such as $\mathrm{Al}, \mathrm{Cd}$ and $\mathrm{Pb}$ (Edmunds and Smedley, 1996). The solubility of $\mathrm{Al}$ is strongly $\mathrm{pH}-$ dependent and significant environmental concentrations could be found below $\mathrm{pH} 5.5$, where increasing concentrations are related to the solubility of microcrystalline gibbsite (Bache, 1986).

Water turbidity was very low for all samples and yielded no great variations between the schools. Potable water normally registers turbidity up to 5.0 NTU (Brasil, 2011).

The highest water conductivity found in Schoolss A and C, with shallower wells, suggests a greater susceptibility to water contamination. There are no recommended values for conductivity in Brazilian legislation. Natural waters, in general, according the Environmental Company of the State of São Paulo (CETESB), show conductivity of 10 to $100 \mu \mathrm{S} \mathrm{cm}$ and the values increase in more-polluted waters when solid particles are added to water (CETESB, 2009). Tancredi (1996) showed conductivity ranging from 11 to $28 \mu \mathrm{S} \mathrm{cm}$ in groundwater from Santarém. These figures are similar to those found in School D and lower than those found in Schoolss A and C.

The alkalinity of water presented a wide variation among schools in the range of 3 to $40 \mathrm{mg} \mathrm{L}^{-1}$ of $\mathrm{CaCO}_{3}$. There is no recommendation for water alkalinity in Ordinance 2914; however, in general, water for human consumption should not exceed $120 \mathrm{mg} / \mathrm{L}$ of $\mathrm{CaCO}_{3}$. Below this limit, alkalinity has no sanitary significance, although at higher levels it can cause an unpleasant taste for consumers (CETESB, 2009). 
Table 4. Mean, Minimum (Min) and Maximum (Max) of some physicochemical parameters in drinking water from Schools A, B and C in Santarém and D in Mojuí dos Campos.

\begin{tabular}{|c|c|c|c|c|c|c|c|c|c|c|c|c|}
\hline \multirow{2}{*}{ Parameters } & \multicolumn{3}{|c|}{ School A } & \multicolumn{3}{|c|}{ School B } & \multicolumn{3}{|c|}{ School C } & \multicolumn{3}{|c|}{ School D } \\
\hline & Mean & Min & Max & Mean & Min & $\operatorname{Max}$ & Mean & Min & $\operatorname{Max}$ & Mean & Min & $\operatorname{Max}$ \\
\hline \multicolumn{13}{|c|}{ Dry season } \\
\hline pH & 4.2 & 3.8 & 4.8 & 4.6 & 4.3 & 5.0 & 4.5 & 4.0 & 5.0 & 5.0 & 4.3 & 5.8 \\
\hline Turbidity (NTU) & 0.2 & 0.1 & 0.5 & 0.5 & 0.4 & 0.6 & 0.1 & 0.1 & 0.2 & 0.6 & 0.2 & 1.5 \\
\hline $\begin{array}{l}\text { Conductivity } \\
(\mu \mathrm{S} \mathrm{cm})\end{array}$ & 99 & 88 & 131 & 57 & 32 & 81 & 67 & 22 & 126 & 27 & 16 & 59 \\
\hline $\begin{array}{l}\text { Alkalinity } \\
\left(\mathrm{mg} \mathrm{L}^{-1} \text { of } \mathrm{CaCO}_{3}\right)\end{array}$ & 13 & 10 & 18 & 06 & 04 & 10 & 04 & 03 & 07 & 13 & 07 & 20 \\
\hline
\end{tabular}

\begin{tabular}{lllllllllllll}
\hline \multicolumn{10}{c}{ Rainy season } \\
\hline $\mathrm{pH}$ & 4.3 & 4.1 & 4.8 & 5.2 & 4.6 & 6.0 & 4.6 & 4.0 & 5.4 & 4.7 & 4.4 & 4.9 \\
Turbidity (NTU) & 0.2 & 0.1 & 0.6 & 0.7 & 0.2 & 1.7 & 0.1 & 0.1 & 0.2 & 0.3 & 0.1 & 0.7 \\
$\begin{array}{l}\text { Conductivity } \\
(/ \mathrm{S} \mathrm{cm})\end{array}$ & 144 & 118 & 166 & 48 & 23 & 95 & 91 & 78 & 104 & 18 & 14 & 26 \\
$\begin{array}{l}\text { Alkalinity } \\
\left(\mathrm{mg} \mathrm{L}^{-1} \text { of } \mathrm{CaCO}_{3}\right)\end{array}$ & 08 & 03 & 11 & 30 & 15 & 40 & 24 & 13 & 35 & 11 & 10 & 12 \\
\hline
\end{tabular}

The mean, minimum and maximum concentrations of the most abundant anions in groundwater and the maximum value allowed by Brazilian Ordinance 2914 are shown in Table 5. Concentrations of $\mathrm{N}_{-} \mathrm{NO}_{2}{ }^{-}, \mathrm{PO}_{4}{ }^{3-}$ and $\mathrm{Br}^{-}$were below detection limits in all samples and were not registered in Table 5; the mean concentrations of $\mathrm{F}^{-}$were very low as well, but were included in the table. All anion concentrations were below the maximum limits of Ordinance 2914.

Table 5. Mean, Minimum (Min) and Maximum (Max) values of anions $\left(\mathrm{mg} \mathrm{L}^{-1}\right)$ in water samples from Schools A, B and C in Santarém and D in Mojuí dos Campos and the reference values $\left(\mathrm{mg} \mathrm{L}^{-1}\right)$ from Brazilian ordinance 2914.

\begin{tabular}{|c|c|c|c|c|c|c|c|c|c|c|c|c|}
\hline \multicolumn{3}{|c|}{ School A } & \multicolumn{3}{|c|}{ School B } & \multicolumn{3}{|c|}{ School C } & \multicolumn{3}{|c|}{ School D } & \multirow[t]{2}{*}{$\begin{array}{c}\text { Maximum limits } \\
\text { Ordinance } 2914\end{array}$} \\
\hline Mean & Min & Max & Mean & Min & Max & Mean & Min & $\operatorname{Max}$ & Mean & Min & $\operatorname{Max}$ & \\
\hline \multicolumn{13}{|c|}{ Dry season } \\
\hline 0.02 & 0.02 & 0.04 & LD & LD & LD & LD & LD & LD & 0.01 & 0.01 & 0.03 & 1.5 \\
\hline 11.2 & 11.1 & 11.4 & 1.8 & 1.7 & 2.2 & 4.0 & 1.3 & 9.2 & 2.0 & 2.0 & 2.0 & 250 \\
\hline 5.8 & 5.7 & 6.0 & 0.5 & 0.2 & 0.8 & 1.9 & 0.06 & 5.6 & 0.1 & 0.09 & 0.1 & 10 \\
\hline 6.8 & 6.7 & 7.2 & 0.3 & 0.1 & 0.6 & 0.2 & 0.1 & 0.4 & 0.75 & 0.7 & 0.8 & 250 \\
\hline \multicolumn{13}{|c|}{ Rainy season } \\
\hline 0.02 & 0.02 & 0.03 & LD & LD & LD & 0.03 & 0.03 & 0.05 & 0.01 & 0.01 & 0.04 & 1.5 \\
\hline 14.2 & 12.5 & 15.1 & 2.5 & 1.5 & 4.4 & 9.1 & 7.4 & 12.6 & 2.3 & 2.3 & 2.3 & 250 \\
\hline 8.0 & 7.1 & 8.7 & 0.3 & 0.04 & 0.8 & 5.4 & 4.3 & 7.4 & 0.1 & 0.1 & 0.2 & 10 \\
\hline 8.6 & 7.6 & 9.5 & 0.8 & 0.1 & 2.0 & 0.5 & 0.4 & 0.51 & 0.6 & 0.6 & 0.6 & 250 \\
\hline
\end{tabular}

$\mathrm{LD}=$ below detection limit.

The anion $\mathrm{Cl}^{-}$presented the greatest anion concentration in drinking water at all schools, in the range of 1.3 to $15.1 \mathrm{mg} \mathrm{L}^{-1}$, and $\mathrm{SO}_{4}{ }^{2-}$ yielded concentrations well below the recommended maximum. These findings are consistent with those reported by Tancredi (1996). $\mathrm{Cl}^{-}$and $\mathrm{SO}_{4}{ }^{2-}$ are widely distributed in the environment, including in waters, and no healthbased guideline value is proposed for chloride in drinking water (Tancredi, 1996).

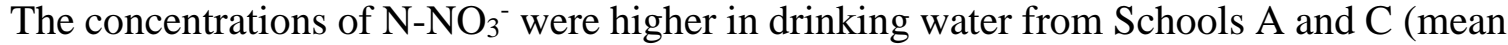
values 1.9 and $8.0 \mathrm{mg} \mathrm{L}^{-1}$ ) than at Schools $\mathrm{B}$ and $\mathrm{D}$ (mean values between 0.1 and $0.5 \mathrm{mg} \mathrm{L}^{-1}$ ) 
with deeper wells, and the highest concentrations were found in the rainy season. Contamination by $\mathrm{N}_{-} \mathrm{NO}_{3}{ }^{-}$in groundwater is possible due to deficient sanitation systems, based on increasing use of septic tanks in areas of high population density (Vanier et al., 2010). The proximity (less than $16 \mathrm{~m}$ ) between the wells and the septic tanks in Schools A and C may explain this finding. In the Santarém region, Tancredi (1996) found low values for $\mathrm{N}^{-\mathrm{NO}_{3}}{ }^{-}$up to $3.32 \mathrm{mg} \mathrm{L}^{-1}$ in groundwater. These values are greater than our results for drinking water from deep wells (Schools B and D) and lower than those found from shallow wells (Schools A and C). Medeiros et al. (2016) found high concentrations of $\mathrm{N}^{-\mathrm{NO}_{3}}{ }^{-}$in shallow wells $(7.7-61.35$ $\mathrm{mg} \mathrm{L}^{-1}$ ) in riparian communities that were exposed to domestic and industrial pollutants elsewhere in the Amazon region.

The toxicity of $\mathrm{N}^{-\mathrm{NO}_{3}}{ }^{-}$is mainly attributable to its reduction to nitrite in the human body and the major biological effect of nitrite is its involvement in the oxidation of normal Haemoglobin $(\mathrm{Hb})$ to methaHb (haematological disturbance), which is unable to transport oxygen to tissues (WHO, 2011). The $\mathrm{Hb}$ of infants is more susceptible to conversion to metHb and the reduced oxygen transport becomes clinically manifest; the condition, called "methemoglobinemia", causes cyanosis. In addition, nitrite was shown to react with nitrosatable compounds in the human stomach to form N-nitroso compounds, which have been demonstrated to be carcinogenic in tested animal species, although some of the most readily formed compounds, such as N-nitrosoproline, are not carcinogenic in humans (WHO, 2011).

Mean concentrations of trace elements as well as maximum and minimum contents in drinking water from the schools are shown in Table 6.

The concentrations of cations in the samples of Schools $\mathrm{A}$ and $\mathrm{C}$ were, in descending order, $\mathrm{Na}>\mathrm{Ca}>\mathrm{K}>\mathrm{Mg}>\mathrm{Al}$; and in the samples of Schools $\mathrm{B}$ and $\mathrm{D}$ the order was $\mathrm{Na}>\mathrm{K}>\mathrm{Ca}>\mathrm{Mg}>$ Al. Cations are commonly found in compounds in acceptable concentrations in the chemical constitution of natural waters (Edmunds and Smedley, 1996), and these elements are essential for human health, since they play important roles in cellular metabolism and physiology (Bowman et al., 2003). Water is an important source of these elements, and Ordinance 2914 does not set recommended maximum limits for $\mathrm{Ca}, \mathrm{K}$ and $\mathrm{Mg}$, but only for $\mathrm{Na}$ and $\mathrm{Al}$. The acceptable limit of $\mathrm{Na}$ in water is based on the taste it can confer, since water with high concentrations of $\mathrm{Na}$ becomes brackish and is not recommended for human consumption. The $\mathrm{Na}$ levels in the water samples are acceptable and at higher concentrations in Schools A and C. Similarly, concentrations of $\mathrm{Ca}, \mathrm{K}, \mathrm{Mg}$ and $\mathrm{Al}$ were higher in shallower well samples. The concentrations of these chemical compounds, with the exception of $\mathrm{Al}$, in schools with deep wells (B and D) were very similar to those found by Tancredi in 1996. The results suggest that the shallow wells of the schools were more susceptible to contamination by these elements and it is recommended to conduct periodic monitoring of the quality of drinking water in these schools.

The concentrations of trace elements are below the maximum limits recommended by the Ordinance 2914, except for Al at Schools A (414-672 $\mathrm{ng} \mathrm{ml}^{-1}$ ) and C (71-1370 $\mathrm{ng} \mathrm{ml}^{-1}$ ). The concentration of $\mathrm{Al}$ exceeded the recommended concentrations in all samples of School $\mathrm{A}$ and in four samples (out of the six analysed) of School C. The rather high concentration of $\mathrm{Al}$ in water samples from Schools A and C could be associated with natural process, i.e., interaction between water and rocks in the upper portion of the Alter do Chão geologic formation; moreover, when the $\mathrm{pH}$ value of the water is below 5.5, the chances of solubilization of $\mathrm{Al}$ in water increases substantially (Bache, 1986). Soils rich in organic matter and acids (pH below 5.5) also favor Al mobility and solubility, especially in areas with acidic rainfall and mining (Bache, 1986). 
Table 6. Mean, Minimum (Min) and Maximum (Max) concentrations of trace elements (ng $\mathrm{ml}^{-1}$ ) in drinking water from Schools $\mathrm{A}$, B, C and $\mathrm{D}$ in the Santarém region, State of Pará, Amazon and the maximum value allowed (ng ml-1) by Brazilian Ordinance 2914.

\begin{tabular}{|c|c|c|c|c|c|c|c|c|c|c|c|c|c|}
\hline \multirow{2}{*}{$\begin{array}{c}\text { Trace } \\
\text { elements }\end{array}$} & \multicolumn{3}{|c|}{ School A } & \multicolumn{3}{|c|}{ School B } & \multicolumn{3}{|c|}{ School C } & \multicolumn{3}{|c|}{ School D } & \multirow{2}{*}{$\begin{array}{l}\text { Maximum value Brazilian } \\
\text { Ordinance } 2914\end{array}$} \\
\hline & Mean & Min & Max & Mean & Min & Max & Mean & Min & Max & Mean & Min & Max & \\
\hline \multicolumn{14}{|c|}{ Dry season } \\
\hline $\mathrm{Al}$ & 429 & 414 & 429 & 92 & 32 & 184 & 510 & 71 & 1370 & 39 & 37 & 41 & 200 \\
\hline As & 0.04 & 0.02 & 0.06 & 0.008 & 0.008 & 0.02 & 0.01 & 0.01 & 0.04 & 0.01 & 0.01 & 0.02 & 10 \\
\hline B & 8.4 & 7.5 & 9.3 & LD & LD & LD & LD & LD & LD & LD & LD & LD & -- \\
\hline $\mathrm{Ba}$ & 6.6 & 6.1 & 7.4 & 33.8 & 31.8 & 36.2 & 21.4 & 13.6 & 26.0 & 19.1 & 18.5 & 19.4 & 700 \\
\hline $\mathrm{Ca}$ & 4271 & 4080 & 4387 & 234 & 158 & 383 & 1231 & 885 & 1691 & 130 & 121 & 153 & -- \\
\hline $\mathrm{Cd}$ & 0.004 & 0.002 & 0.007 & 0.01 & 0.01 & 0.02 & 0.007 & 0.004 & 0.01 & 0.02 & 0.02 & 0.01 & 5.0 \\
\hline $\mathrm{Cr}$ & 0.02 & 0.02 & 0.04 & 0.05 & 0.04 & 0.07 & 0.14 & 0.04 & 0.3 & 0.04 & 0.03 & 0.05 & 50 \\
\hline $\mathrm{Cu}$ & 6.1 & 4.8 & 7.6 & 32.2 & 24.6 & 58.0 & 1.9 & 1.5 & 2.2 & 9.3 & 2.8 & 27.1 & 2000 \\
\hline $\mathrm{Fe}$ & $L D$ & $L D$ & $L D$ & 8.3 & 6.2 & 11.5 & 9.6 & 8.0 & 12.0 & $L D$ & $L D$ & $L D$ & 300 \\
\hline $\mathrm{K}$ & 2177 & 2139 & 2217 & 1386 & 1333 & 1476 & 955 & 530 & 1778 & 144 & 138 & 152 & -- \\
\hline $\mathrm{Mg}$ & 593 & 585 & 612 & 172 & 150 & 207 & 564 & 469 & 679 & 116 & 115 & 119 & -- \\
\hline $\mathrm{Mn}$ & 10.8 & 10.5 & 11.0 & 5.5 & 5.0 & 6.4 & 7.9 & 6.2 & 11.2 & 4.2 & 4.01 & 4.2 & 100 \\
\hline $\mathrm{Na}$ & 1034 & 10440 & 10055 & 1225 & 860 & 1832 & 3733 & 970 & 9257 & 853 & 832 & 870 & 200000 \\
\hline $\mathrm{Ni}$ & 0.1 & 0.07 & 0.16 & 0.62 & 0.3 & 1.1 & 0.38 & 0.37 & 0.40 & LD & LD & LD & 70 \\
\hline $\mathrm{Pb}$ & 2.9 & 0.4 & 10 & 2.8 & 1.6 & 1.8 & 0.9 & 0.2 & 2.2 & 0.38 & 0.17 & 1.08 & 10 \\
\hline $\mathrm{Zn}$ & 11.3 & 9.68 & 16.89 & 50.5 & 18.4 & 93.7 & 4.3 & 3.2 & 5.7 & 11.1 & 6.9 & 23.3 & 5000 \\
\hline \multicolumn{14}{|c|}{ Rainy season } \\
\hline $\mathrm{Al}$ & 625.3 & 586 & 672 & 53.4 & 36.0 & 83.0 & 1045 & 868 & 1353 & 43 & 37 & 54 & 200 \\
\hline As & 0.07 & 0.05 & 0.1 & 0.01 & 0.01 & 0.02 & 0.1 & 0.06 & 0.2 & 0.02 & 0.02 & 0.05 & 10 \\
\hline B & 6.8 & 6.4 & 7.3 & 2.3 & 1.7 & 2.6 & 3.4 & 2.6 & 3.8 & $L D$ & $L D$ & $L D$ & -- \\
\hline $\mathrm{Ba}$ & 6.6 & 6.1 & 7.1 & 35.4 & 32.7 & 39.7 & 11.0 & 9.2 & 13.7 & 19.3 & 17.9 & 20.2 & 700 \\
\hline $\mathrm{Ca}$ & 5675 & 5395 & 6109 & 337 & 163 & 613 & 1579 & 1223 & 2240 & 156 & 146 & 178 & -- \\
\hline $\mathrm{Cd}$ & 0.013 & 0.008 & 0.01 & 0.02 & 0.01 & 0.03 & 0.03 & 0.01 & 0.04 & 0.006 & 0.003 & 0.006 & 5.0 \\
\hline $\mathrm{Cr}$ & 0.06 & 0.06 & 0.08 & 0.06 & 0.05 & 0.08 & 0.11 & 0.10 & 0.12 & 0.03 & 0.03 & 0.04 & 50 \\
\hline $\mathrm{Cu}$ & 6.9 & 6.02 & 7.8 & 67.4 & 23.8 & 137 & 5.0 & 2.1 & 10.1 & 9.3 & 4.27 & 14.8 & 2000 \\
\hline $\mathrm{Fe}$ & $L D$ & $L D$ & $L D$ & 5.0 & 4.1 & 6.3 & 4.2 & 2.5 & 6.9 & LD & LD & LD & 300 \\
\hline $\mathrm{K}$ & 2661 & 2585 & 2840 & 1530 & 1378 & 1458 & 1503 & 1190 & 1977 & 168 & 162 & 185 & -- \\
\hline $\mathrm{Mg}$ & 771 & 744 & 811 & 202 & 153 & 289 & 437 & 375 & 561 & 140 & 134 & 144 & -- \\
\hline $\mathrm{Mn}$ & 11.4 & 10.5 & 11.9 & 6.3 & 5.1 & 8.0 & 9.4 & 8.1 & 11.6 & 4.5 & 4.4 & 4.6 & 100 \\
\hline $\mathrm{Na}$ & 13087 & 12649 & 13817 & 1760 & 905 & 3456 & 8337 & 6400 & 11760 & 944 & 916 & 981 & 200000 \\
\hline $\mathrm{Ni}$ & 0.3 & 0.2 & 0.3 & 1.1 & 0.9 & 2.0 & 0.2 & 0.2 & 0.3 & 0.1 & 0.1 & 0.1 & 70 \\
\hline $\mathrm{Pb}$ & 0.74 & 0.55 & 1.1 & 5.4 & 1.8 & 9.5 & 5.9 & 3.2 & 9.6 & 0.3 & 0.29 & 0.34 & 10 \\
\hline $\mathrm{Zn}$ & 11.9 & 10.6 & 14.8 & 110 & 42.6 & 222 & 3.7 & 3.3 & 4.1 & 9.5 & 7.2 & 11.8 & 5000 \\
\hline
\end{tabular}

$\mathrm{LD}=$ below detection limit. 
According to the Agency for Toxic Substances and Disease Registry (ATSDR), neurological effects and Alzheimer's disease have been associated with oral exposure to Al, (ATSDR, 2008). Although there is evidence for this association, as proposed over 40 years ago, it is still controversial. Studies indicated a weak association between elevated intake doses of $\mathrm{Al}$ and increasing risk of neurological dysfunction and Alzheimer's disease (Walton, 2014). Alzheimer's disease is a human form of chronic Al neurotoxicity (Walton, 2014). However, according to ATSDR (2008), the absorption of Al is low through the human intestinal system, generally in the range of $0.1-0.4 \%$, and therefore oral exposure should be not be harmful. In children, the effects may be higher, especially in individuals with pathologies associated with the renal system. In these cases, bone damage may also occur, since excess Al may limit phosphate absorption, which is necessary for bone maintenance and is an important concern in growing children (ATSDR, 2008).

\subsection{Human health risk assessment}

Human health risk assessment associated with the ingestion of groundwater is important due to the increased demand for drinking water from the Alter do Chão aquifer in the Santarém region, and disorganized growth and lack of sound sanitary measures in the region could affect groundwater quality. With the values obtained from the environmental Daily Exposure and Reference Dose, we estimated the non-carcinogenic risks through the HQ and HI for each school during six months. Input values of exposure were assumed, aiming to quantify and indicate the contaminants as a priority for health in drinking water (Castilhos et al., 2014).

Table 7 shows the Hazard Quotient (HQ) for a number of metals and nitrate exposure through water consumption for children in schools and their respective Hazard Index (HI) (sum of the HQs). The non-carcinogenic risk associated with water intake in schools had a HI $>1$ for Schools A (2.84) and C (3.62). The drinking water in Schools B (0.48) and D (0.21) was considered safe according to the methodology adopted and does not show a risk for children. Aluminium presented HQ> 1 in Schools A and C and was the chemical compound that most contributed to the HI with $86.2 \%$ and $94.6 \%$, respectively. The second chemical element with the greatest contribution to the HI in Schools A and C was nitrate with $12.7 \%$ and $4.9 \%$, respectively. The values found for the non-carcinogenic daily exposure (DE) values for $\mathrm{As}, \mathrm{Cd}$ and $\mathrm{Cr}$ were less than $3.9 \times 10^{-6} \mathrm{mg} \mathrm{kg}$ day in schools due to the very low concentration of these elements in drinking water. Consequently, non-carcinogenic and carcinogenic risks were considered to be absent for these elements in the present study.

The methodology of health risk assessment has been used mainly due to exposure by contaminants from surface waters (USEPA, 1989; 1996), whereas groundwater is less frequently considered. In the Santarém region, to date, no reports of this type of methodology applied to chemical contaminants have been published. Castilhos et al. (2014) assessed the potential health risk to exposure groundwater for $\mathrm{Ni}, \mathrm{Hg}, \mathrm{Zn}, \mathrm{B}$ and $\mathrm{Ba}$ in 12 groundwater wells in urban area of the city Capitão Gervásio (Piauí State, northeast of Brazil), and found a noncarcinogenic risk $\mathrm{HQ}>1$ for $\mathrm{Ni}$. The presence of $\mathrm{Ni}$ in regional geology may have favoured the occurrence of hydrogeochemical anomalies or contamination from the soil in inadequate well constructions. Turdi and Yang (2016) assessed exposure to chemical contaminants through groundwater wells in four agricultural and pasture regions of China for children and adults and found more severe (carcinogenic and non-carcinogenic) risks for children. The authors found that non-carcinogenic risk was primarily associated with $\mathrm{Zn}$ and the carcinogenic risk was due to $\mathrm{Cr}$, As and $\mathrm{Cd}$. The hazard ratio was higher in agricultural areas, especially because of the high concentrations of As and $\mathrm{Cr}$ in the sampled wells.

The methodology mentioned above deals with the generation of numerical indices of critical areas and should be prioritized in public health and environmental control programs. The current results showed that groundwater of the most superficial layers of the Alter do Chão 
aquifer might be a matter of concern for local governments, especially for $\mathrm{Al}$ and nitrate contents.

Table 7. Hazard Quotient (HQ) due to oral exposure (ingestion) of some trace elements and nitrate in water in schools and the respective Hazard Index (HI).

\begin{tabular}{lcccc}
\hline & HQ School A & HQ School B & HQ School C & HQ School D \\
\hline $\mathrm{Al}$ & 2.45 & 0.33 & 3.40 & 0.19 \\
$\mathrm{~B}$ & 0.003 & 0.0004 & 0.0009 & 0.0003 \\
$\mathrm{Ba}$ & 0.002 & 0.010 & 0.007 & 0.008 \\
$\mathrm{Cu}$ & 0.013 & 0.10 & 0.007 & 0.01 \\
$\mathrm{Mn}$ & 0.006 & 0.003 & 0.005 & 0.002 \\
$\mathrm{Ni}$ & 0.0008 & 0.003 & 0.001 & 0.0004 \\
$\mathrm{Zn}$ & 0.006 & 0.02 & 0.001 & 0.002 \\
$\mathrm{~N}-\mathrm{Nitrato}$ & 0.36 & 0.02 & 0.20 & 0.005 \\
\hline HI & 2.84 & 0.48 & 3.62 & 0.21 \\
\hline
\end{tabular}

\section{CONCLUSIONS}

These results for drinking water quality from schools in Santarém and Mojuí dos Campos, Brazilian Amazon, allow us to make a series of conclusions and recommendations about how the quality of the water in this region should be managed.

The bacterial contamination (total coliforms and E. coli), especially during the rainy season of water samples from urban Schools (A and C), with shallower wells, show inconsistencies with the Brazilian Ordinance 2914 and expose school children to risks such as acute diarrheal diseases. Furthermore, the detection of E.coli in water samples from all schools indicates fecal contamination, suggesting that new microorganisms should be investigated such as hepatitis A virus and Cryptosporidium. The lack of maintenance and correct sealing of water tanks is a probable explanation for bacterial contamination in some water samples from wells of different depths in these schools. These results suggest that, to avoid these implications, schools should use chlorine-diluting pumps in their water supply systems, as well as establish a cleaning routine for the water tanks based on recommendations of the Brazilian Sanitary Surveillance Agency (ANVISA).

Determination of physicochemical parameters indicates that the water consumed in schools is acidic and confirmed results found in other studies in the Amazon region. The acid water may induce gastric and intestinal dysfunctions for school children, and favour the solubility of other toxic substances at the water source and along the course of groundwater. The chemical analyses showed low concentrations for most chemicals at levels below the recommended values in the Brazilian legislation. However, aluminium concentrations in water yielded values up to 5 times higher than the reference values of Ordinance 2914 in samples from schools with shallower wells in Santarém (Schools A and C). The prolonged exposure to high concentrations of aluminium in water may lead to some neurological implications, and in this case, the results of this study are preliminary, and it is suggested that future epidemiological studies are necessary in schools in the Santarém region, especially those with shallow wells. These future studies will serve to expand this debate and promote future interventions in the field of public and environmental health in this region. The acidic $\mathrm{pH}$ of the drinking waters and the presence of aluminium is probably related to natural processes of interaction between rock and water from the shallower layers of the aquifer system Alter do Chão. Nitrate concentrations in water yielded higher values in shallower well samples, up to 62 times higher than water from samples from deeper wells, and the presence of nitrate indicates a deficiency in sanitation that may lead to adverse implications for children's health, such as infant 
methemoglobinemia.

The evaluation of the health risk for children in schools, assessed through the ingestion of water, showed a non-carcinogenic risk only for schools with shallower wells located in Santarém. At these schools, the chemical compound that most contributed to risk was aluminium, followed by nitrate. In schools with deeper wells, the value of the hazard index remained below 1, evidencing the absence of risk for the evaluated elements. These results are preliminary for schools from the Santarém region, and they represent an important contribution to a necessary debate for future interventions in the field of public and environmental health in this region.

The current research shows unprecedented results related to the quality of groundwater from the Alter do Chão aquifer and its relation to human health in the region of Santarém. We emphasize the importance of implementation of control actions and monitoring of water quality, especially at localities where groundwater is collected from shallower wells that put the health of the population that use these waters at risk.

\section{ACKNOWLEDGEMENTS}

The research was supported by the Federal University of West Pará (UFOPA) and by the National Council of Technological and Scientific Development (CNPq) - Grant number 305119/2015-0. The assistance provided by Maria Aparecida Vendemiatto and Margareth Sugano from Geochemical Laboratory at the Institute of Geosciences of UNICAMP were fundamental in the construction of this work. The support provide by Gustavo Meschede (Laboratory LabVida) and Cátia Gonçalves, post-doctoral student, in water analysis were essential in the execution of this study. Thanks are also due to Jozinei Ferreira Lopes for the collaboration in the field work.

\section{REFERENCES}

AGENCY FOR TOXIC SUBSTANCES AND DISEASE REGISTRY - ATSDR. Toxicological profile for Aluminium. Atlanta: US department of health and human services, 2008.

AGUIAR, C. P. O.; PELEJA, J. R. P.; SOUSA, K. N. S. Qualidade da água em microbacias hidrográficas com agricultura nos municípios de Santarém e Belterra, Pará. Revista Árvore, v. 38, p. 983-992, 2014.

AZEVEDO, R. P. Uso da água subterrânea em sistema de abastecimento público de comunidades na várzea da Amazônia central. Acta Amazônica, v. 3, p. 313-320, 2006.

BACHE, B. W. Aluminium mobilisation in soils and waters. Journal of the Geological Society, v. 143, p.699-706, 1986.

BOWMAN, C. A.; BOBROWSKY, P. T.; SELINUS, O. Medical geology new relevance in the earth sciences. Episodes, Journal of International Geosciences, 2003.

BRASIL. Ministério da Saúde. Portaria N. 2.914, de 12 de Dezembro de 2011. Dispõe sobre os procedimentos de controle e vigilância da água para consumo e seu padrão de potabilidade. Diário Oficial [da] União, Brasília, DF, 14 de dezembro de 2011.

CASTILHOS, Z.; CESAR, R.; SIERPE, R.; FLORENCIO, J.; ARAUJO, P. Avaliação de risco à saúde humana associada ao consumo de águas subterrâneas contaminadas em Capitão Gervásio de Oliveira, Estado do Piauí. Geochimica Brasiliensis, v. 1, p. 13-22, 2014. http://dx.doi.org/10.21715/gb.v28i1.397 
COMPANHIA DE SANEAMENTO DO PARÁ- COSANPA. Companhia de Saneamento do Pará: Histórico. 2013. Disponível em http://www.cosanpa.pa.gov.br. Acesso em: 20 de Agosto de 2017.

EDMUNDS, W. M.; SMEDLEY, P. L. Groundwater geochemistry and health: an overview.

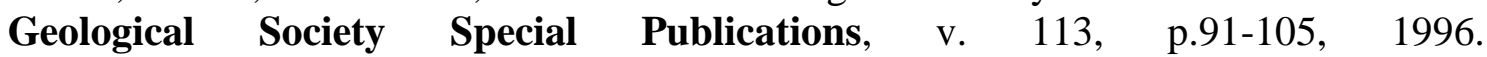
https://doi.org/10.1144/GSL.SP.1996.113.01.08

COMPANHIA AMBIENTAL DO ESTADO DE SÃO PAULO - CETESB. Qualidade das águas interiores no estado de São Paulo. 2009. Disponível em http://cetesb.sp.gov.br/aguas-interiores/wpcontent/uploads/sites/32/2013/11/variaveis.pdf. Acesso em: 20 setembro de 2017.

DAHUNSI, S. O.; OWAMAH, H. I.; AYANDIRAN, T. A.; ORANUSI, S. U. Drinking water quality and public health of selected towns in South Western Nigeria. Water Quality Exposure and Health, v. 6, p. 143-153, 2014. https://doi.org/10.1007/s12403-014-0118-6

FERREIRA, M. D.; ABREU, K. A.; FERREIRA, P. C.; ALVES, R. I. S; MUÑOZ, S. I. S. Parasites and prevalent bacteria in Monte Alegre Stream, located at the área of influence of the sanitary landfill of Ribeirão Preto. O mundo da saúde, v. 32, n. 3, p. 287-293, 2008 .

FUNDAÇÃO NACIONAL DE SAÚDE - FUNASA (Brasil). Manual prático de análise de água. Brasília, 2006. 147 p.

GOMES A. C. S.; COSTA, G. B.; VALE, R. S.; SANTANA, R. A. S.; BATALHA, S. S. A.; SILVA, J. T. et al. Micrometeorological index and children hospitalizations for respiratory diseases in Santarém Western Pará. Ciência e Natura, v. 38, p. 01-06, 2016.

HUNTER, P. R. Drinking water and diarrheal disease due to Escherichia coli. Journal of Water and Health, v. 1, n. 2, p. 65- 72, 2003. https://doi.org/10.2166/wh.2003.0008

INSTITUTO DE GeOgRAFIA E ESTATÍSTICA - IBGE. Population estimate of Pará State. 2016. Disponível em: http://cod.ibge.gov.br/2IAY2. Acesso em: 15 de julho de 2017.

INSTITUTO NACIONAL DE METEOROLOGIA - INMET. Dados da Rede do INMET. Banco de Dados Meteorológicos para Ensino e Pesquisa. Dados históricos - estação meteorológica de Santarém, dados mensais 2015-2016. Disponível em: http://www.inmet.gov.br/portal/index.php?r=bdmep/bdmep. Acesso: 20 March 2017.

JULIÃO, F. C. Avaliação das condições microbiológicas e físico químicas da água de reservatório domiciliar e predial: importância da qualidade dessa água no contexto da saúde pública. 2011. 157p. Tese (Doutorado). Escola de Enfermagem de Ribeirão Preto, Universidade de São Paulo, Ribeirão Preto, 2011.

KIM, K. N.; LEE, M. R.; CHOI, Y. H.; LEE, B. E.; HONG Y. C. Associations of blood cadmium levels with depression and lower handgrip strength in a community-dwelling elderly population: a repeated-measures panel study. The journals of gerontology. Series A, Biological sciences and medical sciences, v. 71, n. 11, p. 1525-1530, 2016. https://doi.org/10.1093/gerona/glw119

KÖPPEN, W. Das geographische System der Klimate. In: HANN, J. Von. Handbuch der Klimatologie. Berlin: Verlag von Gebrüder Borntraeger, 1936. p. 1-11. 
LAPWORTH, D. J.; DAS, P.; SHAW, A.; MURKHERJEE, A.; CIVIL, W.; PETERSEN, J. O. et al. Deep urban groundwater vulnerability in India revealed through the use of emerging organic contaminants and residence time tracers. Environmental Pollution, v. 240, p. 938-949, 2018. https://doi.org/10.1016/j.envpol.2018.04.053

LLOPIS-GONZÁLEZ, A.; SÁNCHEZ A. L.; REQUENA, P. M.; SUÁREZ-VARELA, M. M. Assessment of the Microbiological quality of groundwater in three regions of the Valencian Community (Spain). International Journal of Environmental Research and $\begin{array}{llllll}\text { Public Health, } & \text { v. 11, n. } & \text { p, }\end{array}$ http://dx.doi.org/10.3390/ijerph110505527

MAJUMDAR, D.; GUPTA, N. Nitrate pollution of groundwater and associated human health disorders. Indian Journal of Environmental Health, v. 42, n. 1, p. 28-39, 2000.

MEDEIROS, A. C.; LIMA, M. O.; GUIMARAES, R. M. Avaliação da qualidade da água de consumo por comunidades ribeirinhas em áreas de exposição a poluentes urbanos e industriais nos municípios de Abaetetuba e Barcarena no estado do Pará, Brasil. Ciência e saúde coletiva, v. 21, p. 695-708, 2016. https://doi.org/10.1590/141381232015213.26572015

MENDES, A.; GALVÃO, P.; SOUSA, J.; SILVA, I.; CARNEIRO, R. N. Relations of the groundwater quality and disorderly occupation in na Amazon low-income neighbourhood developed over a former dump area, Santarém-PA, Brazil. Environment, Development and Sustainability, p.1-16, 2017. https://doi.org/10.1007/s10668-017-0040-8

NALBANTCILAR, M. T.; PINARKARA, S. Y. Public health risk assessment of groundwater contamination in Batman, Turkey. Journal of Water and Health, v. 14, n. 4, p. 650-661, 2016.

NEVES, D. P. Human Parasitology. São Paulo: Atheneu, 2005. 501 p.

PALAMULENI, L.; AKOTH, M. Physico-Chemical and Microbial Analysis of Selected Borehole Water in Mahikeng, South Africa. International Journal of Environmental Research and Public Health, v. 12, n. 8, p .8619-8630, 2015. https://doi.org/10.3390/ijerph120808619

TANCREDI, F. N. S. Groundwater Resources of Santarém Fundamentals for use and protection. 1996. [PhD thesis]. Belém, PA: Universidade Federal do Pará, Belém, 1996.

TRATA BRASIL INSTITUTO. Organização da Sociedade Civil de Interesse Público. Ranking do Saneamento 2016. Disponível em http://www.tratabrasil.org.br/ranking-dosaneamento-4. Acesso em: 20 de novembro de 2017.

TURDI, M.; YANG, L. Trace Elements Contamination and Human Health Risk Assessment in Drinking Water from the Agricultural and Pastoral Areas of Bay County, Xinjiang, China. International Journal of Environmental Research and Public Health, v. 13, n.10, p. 938, 2016. http://dx.doi.org/10.3390/ijerph13100938

UNITED STATES. Environmental Protection Agency - USEPA. Office of Water. Risk Assessment Guidance for Superfund. vol I: Human Health Evaluation Manual. Washington, D.C, 1989.

UNITED STATES. Environmental Protection Agency - USEPA. Office of Water. Quantitative Uncertainty Analysis of Superfund Residential Risk Pathway Models for Soil and Groundwater: White Paper. OakRidge: Office of Health and Environmental Assessment, 1996. 
UNITED STATES. Environmental Protection Agency - USEPA. Office of Water. Integrated Risk Information System - IRIS. 2014. Disponível em: http://www.epa.gov.br/iris. Acesso em 20 de november de 2017.

UNITED STATES. Environmental Protection Agency - USEPA. Office of Water. Drinking Water from Household Wells. 2002. Disponível em: https://www.epa.gov/privatewells/drinking-water-household-wells. Acesso em: 25 Agosto de 2017.

WALTON, J. R. Chronic Aluminum Intake Causes Alzheimer's Disease: Applying Sir Austin Bradford Hill's Causality Criteria. Journal of Alzheimer's Disease, v. 40, p. 765-838, 2014. http://dx.doi.org/10.3233/JAD-132204

WORLD HEALTH ORGANIZATION - WHO. pH in Drinking-water. 2003. Disponível em: http://www.who.int/water_sanitation_health/dwq/chemicals/ph_revised_2007_clean_ve rsion.pdf. Acesso: 20 March 2017.

WORLD HEALTH ORGANIZATION - WHO. Protecting Groundwater for Health Managing the Quality of Drinking-water Sources. London: IWA Publishing, 2006.

WORLD HEALTH ORGANIZATION - WHO. Nitrate and nitrite in drinking-water. 2011. Disponível em: http://www.who.int/water_sanitation_health/dwq/chemicals/nitratenitrite2ndadd.pdf. Acesso: 21 August 2017.

WORLD HEALTH ORGANIZATION - WHO. Guidelines for Drinking-water quality: fourth edition incorporating the first addendum. 4rd ed. Geneva, 2017. 


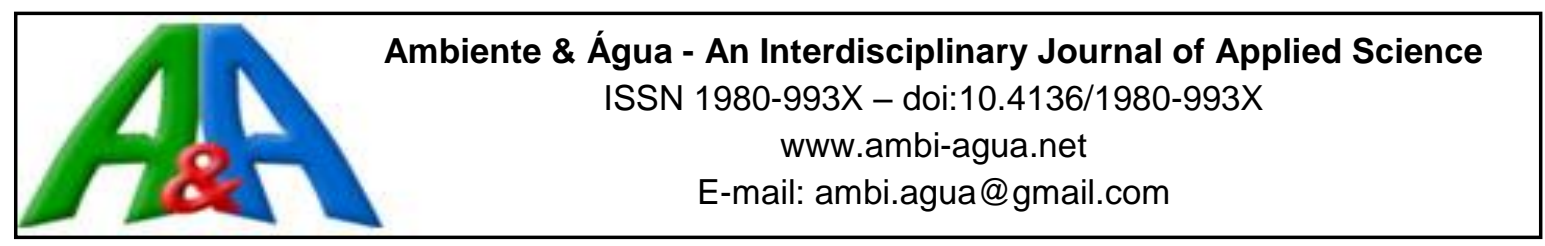

\title{
A coupled model of hydrodynamics circulation and water quality applied to the Rio Verde reservoir, Brazil
}

\author{
ARTICLES doi:10.4136/ambi-agua.2244
}

Received: 20 Feb. 2018; Accepted: 05 Oct. 2018

\section{Cynara de Lourdes da Nobrega Cunha ${ }^{1 *}$; Gabriela Pacheco Corrêa ${ }^{1}$; Paulo Cesar Colonna Rosman ${ }^{2}$}

\author{
${ }^{1}$ Universidade Federal do Paraná (UFPR), Curitiba, PR, Brasil \\ Programa de Pós-Graduação em Engenharia Ambiental (PPGEA). \\ Departamento de Engenharia Ambiental (DEA).E-mail: cynara@ufpr.br, gabrielapaco@yahoo.com.br \\ ${ }^{2}$ Universidade Federal do Rio de Janeiro (UFRRJ), Rio de Janeiro, RJ, Brasil \\ Programa de Engenharia Costeira e Oceanográfica (COPPE). E-mail: pccrosman@ufrj.br \\ *Corresponding author
}

\begin{abstract}
This work applied the coupled horizontal two-dimensional hydrodynamic circulation model (2DH) and the vertically integrated water quality model for non-conservative and passive scalars to the Rio Verde reservoir in the state of Paraná, Brazil, to simulate flow, temperature and water quality parameters. The water quality model uses the same spatial grid applied for the hydrodynamics model. Flow velocities and turbulence coefficients previously defined in the hydrodynamics model can be used directly in the water quality model. Modeling results were compared to field data for a period of 308 days, from February $27^{\text {th }} 2010$ and December $31^{\text {th }}$ 2010. Field data included water and air temperature, wind, relative humidity, radiation, discharges and concentration values of some substances in the tributaries of the reservoir. The results indicated that hydrodynamic circulation and, consequently, horizontal transport, are strongly dependent on the wind. Inflows/outflows generated a localized circulation. The results for the temperature and dissolved oxygen concentration were compared with field measures and a satisfactory consistency was achieved. Despite the errors associated with boundary conditions, the models demonstrated their potential to adequately simulate the data set collected from the reservoir.
\end{abstract}

Keywords: hydrodynamic circulation, Rio Verde reservoir, water quality models.

\section{Acoplamento entre modelos de circulação de hidrodinâmica e de qualidade da água aplicado ao reservatório do Rio Verde, Brasil}

\section{RESUMO}

No presente trabalho, os modelos de circulação hidrodinâmico bidimensional horizontal (2DH) e de qualidade da água integrados na direção vertical, para escalares não conservativos e passivos, são resolvidos de forma acoplada e aplicados ao reservatório de Rio Verde, localizado no estado do Paraná, Brasil, para simular a circulação e parâmetros qualidade da água no reservatório de Rio Verde. O modelo de qualidade da água utiliza a mesma grade espacial aplicada ao modelo hidrodinâmico. As velocidades e os coeficientes de relacionados à turbulência, previamente definidos no modelo hidrodinâmico, podem ser utilizados diretamente 
no modelo de qualidade da água. Os resultados de modelagem foram comparados com dados de campo para um período de 308 dias, de 27 de fevereiro de 2010 a 31 de dezembro de 2010. Dados de campo incluem temperatura da água e do ar, vento, umidade relativa, radiação, vazões e valores de concentração de algumas substâncias nos afluentes do reservatório de Rio Verde. Os resultados mostram que a circulação hidrodinâmica e, consequentemente, o transporte horizontal, são fortemente dependentes do vento. As vazões afluentes/efluentes geram uma circulação localizada, restrita as regiões próximas às embocaduras. Os resultados de temperatura e da concentração de oxigênio dissolvido obtidos pelo modelo foram comparados com dados medidos, mostrando uma concordância satisfatória. Apesar dos erros associados às condições de contorno, os modelos demonstraram seu potencial para simular adequadamente o conjunto de dados coletados do reservatório.

Palavras-chave: circulação hidrodinâmica, modelos de qualidade da água, reservatório do Rio Verde.

\section{INTRODUCTION}

Reservoirs are complex environments which create interdependent relationships between their tributaries (rivers and streams that contribute for reservoir discharge) and the watershed environmental conditions, which are strongly influenced by water resources uses. By reducing rivers' velocities with dams, lentic environments can be created which can in turn drastically alter the original conditions of the rivers with greater flow (lotic environments). In this context, the importance of limnological studies aiming at understanding the transport and mixing mechanisms of substances in lentic environments is emphasized.

Quantitative water quality modeling is a major challenge of these studies, due to the need for interdisciplinary approaches that involve advective-diffusive mechanisms and physical, chemical and biological processes in substance transportation. As a consequence, the development of mathematical models to quantify these processes has been the subject of intense research in the last decades. System complexity should be taken into account during the modeling process, ensuring that it has the capacity to model the environmental behavior and evaluate its several effects. Numerical models have been used as a scientific and managerial tool for analyzing temporal-spatial distributions of non-conservative water quality parameters. Among many works, the following deserve to be mentioned: Deus et al. (2013) show the application of the CE-QUAL-W2 model in the Tucurui reservoir in Brazil for different pisciculture scenarios. Using the same model, Kuo et al. (2006) simulated water quality changes at temperate and sub-tropical reservoirs in Taiwan. Liu et al. (2008) published a study describing a 2-D coupled model of hydrodynamics and water quality applied to Yuqiao reservoir in China, developed to compute the hydrodynamic field and the variations of total phosphorus and total nitrogen.

The Rio Verde reservoir is located in the Metropolitan Region of Curitiba (RMC), in the state of Paraná, Brazil. Based on collected data included in the work by Carneiro et al. (2014), one can notice that the Rio Verde reservoir presented a moderately degraded environment. In 2005, an algae bloom of Cylindrospermopsis reciborskii was recorded, reaching 96,489 cells.mL ${ }^{-1}$. The Rio Verde reservoir has a dynamic system of stratification characterized by a reasonable stratification in the summer and a mixed water column in the winter. Due to the shallow depths, it is expected that the currents flowing can be well represented by depthaveraged variables.

Therefore, the purpose of this study was to use the hydrodynamic and water quality models of the SisBAHIA ${ }^{\circledR}$, in coupled form, to simulate flow, temperature and water quality parameters in the Rio Verde reservoir. The advantage of coupling the two models, as developed in the current work, appears in the determination of the flow velocities and turbulence coefficients, 
which is done previously in the hydrodynamic model, and can be used directly in the water quality model. For this reason, the size of the system to be solved and, consequently, the computational effort, are reduced when compared to other schemes.

The SisBAHIA ${ }^{\circledR}$ (in Portuguese, Sistema Base de Hidrodinâmica Ambiental) is the Hydrodynamic Environmental System developed by the Coastal and Oceanographic Engineering Department, Oceanic Engineering Program, Federal University of Rio de Janeiro (COPPE/UFRJ). In the present work, only the water quality model of SisBAHIA ${ }^{\circledR}$ is shown. Further information about the hydrodynamic model of SisBaHiA ${ }^{\circledR}$ can be obtained through: www.sisbahia.coppe.ufrj.br.

\section{MATERIALS AND METHODS}

The water quality model of $\mathrm{SisBaHiA}^{\circledR}$ (MQA) is an Eulerian advective-diffusive transport model vertically integrated for non-conservative scales; in other words, the variability of substances concentrations is a result of physical, chemical and biological processes.

In the discretization of time and space, the SisBaHiA ${ }^{\circledR}$ adopts the finite difference method and the finite element method, respectively. The MQA uses the same spatial grid applied for the hydrodynamics model and different time-step lengths can be employed in analyses. Flow velocities and turbulence coefficients, previously defined in the hydrodynamics model, can be used directly in the water quality model. The advective mechanism is related to flow velocities and can be estimated through hydrodynamic models, which represent an important previous procedure for water quality models' input data. The time step of the two-dimensional hydrodynamic model was 30s with an average Courant number of 4.0. The time step of the MQA was 60s.

The MQA is able to simulate the oxygen, nitrogen and phosphorus cycles, as well as temperature and salinity parameters due to their strong influence in kinetic processes (Sellers, 1965). Overall, 11 water quality parameters can be evaluated, namely: Salinity, Temperature, Dissolved Oxygen (DO), Biochemical Oxygen Demand (BOD), Organic Nitrogen, Ammonia Nitrogen, Nitrate Nitrogen, Chlorophyll_a, Herbivore Zooplankton, Organic Phosphorus and Inorganic Phosphorus. The MQA uses an Eulerian approach by the finite element mesh, previously defined in the hydrodynamic model. With this condition it is possible to share the same flow velocity components, wind velocity and geometric characteristics. The spatial discretization employs, mainly, squared biquadratic finite elements (Rosman, 2016).

\subsection{Mathematical model}

In the MQA, the mass-balance equation for a non-conservative substance is applied considering depth-integrated Cartesian System $(x, y)$ aligning in the east, north and vertical directions for three transport mechanisms: the advective term, the diffusive term, and the kinetic processes. The mass-balance equation is expressed by Equation 1, as defined by Sheng and Villaret (1989):

$\frac{\partial C_{m}}{\partial t}+U_{i} \frac{\partial C_{m}}{\partial x_{i}}=\frac{1}{H} \frac{\partial}{\partial x_{j}}\left(H\left[D_{i j} \delta_{j k}+\frac{\Lambda_{k}^{2}}{12}\left|\frac{\partial U_{j}}{\partial x_{k}}\right|\right] \frac{\partial C_{m}}{\partial x_{k}}\right)+\sum R_{m}$

In Equation $1, C_{m}$ is the concentration of $\mathrm{m}$ substance $\left(\mathrm{mg} \mathrm{L}^{-1}\right) ; t$ is the time $(\mathrm{s}) ; U_{i}$ represents the depth-averaged components of the horizontal velocity ( $\mathrm{U}$ and $\mathrm{V})\left(\mathrm{m} \mathrm{s}^{-1}\right) ; H$ is the water depth (m); $D_{i j}$ is the turbulent viscosity coefficient of mass $\left(\mathrm{m}^{2} \mathrm{~s}^{-1}\right) ; \delta_{j k}$ is the Kronecker delta; $\Lambda_{k}$ represents the widths of the spatial and temporal Gaussian filters; and $R_{m}$ represents the kinetic processes of substance production and consumption. In Equation $1, i, j=1,2$ and $k$ $=1,2,3$, with $k=3$ corresponding to time $t$. The following interpretation is valid for the index coefficient $C_{m}: C_{1}=$ ammonia nitrogen $\left(\mathrm{mg} \mathrm{N} \mathrm{L} \mathrm{L}^{-1}\right), C_{2}=$ nitrate nitrogen $\left(\mathrm{mg} \mathrm{N} \mathrm{L}^{-1}\right)$, 
$C_{3}=$ inorganic phosphorus $\left(\mathrm{mg} \quad \mathrm{P} \mathrm{L}^{-1}\right), \quad C_{4}=$ Herbivore Zooplankton $\left(\begin{array}{lll}m g & \mathrm{~L}^{-1}\end{array}\right)$, $C_{5}=$ biochemical oxygen demand $\left(\mathrm{mg} \mathrm{O}_{2} \mathrm{~L}^{-1}\right), C_{6}=$ dissolved oxygen $\left(\mathrm{mg} \mathrm{O} \mathrm{O}_{2} \mathrm{~L}^{-1}\right)$, $C_{7}=\operatorname{organic}$ nitrogen $\left(\mathrm{mg} \mathrm{N} \mathrm{L}^{-1}\right), C_{8}=$ organic phosphorus $\left(\mathrm{mg} \mathrm{P} \mathrm{L}^{-1}\right), C_{9}=$ Chlorophyll_a $(\mu \mathrm{g}$ $\left.\mathrm{L}^{-1}\right), C_{T}=$ temperature $\left({ }^{0} \mathrm{C}\right)$ and $C_{S}=$ salinity (psu).

The MQA is coupled with the $\mathrm{SisBaHiA}{ }^{\circledR}$ hydrodynamic model to provide the advective and diffusive terms in the mass-balance equation. The kinetic processes in MQA were obtained according to the Equations 2, 3, 4, 5, 6, 7, 8, 9 and 10 below (Sheng et al., 1996).

$\mathrm{C}_{1}$ : Ammonia nitrogen

$\Sigma R_{1}=r_{n a} k_{r a}\left(1-f_{o n}\right) C_{9}+\frac{r_{n a}}{r_{c a}} k_{r z}\left(1-f_{o n}\right) C_{4}+r_{n a} k_{e a}\left(1-f_{o n}\right) C_{9}+\left(\frac{r_{n a}}{r_{c a}}\right) k_{e z}\left(1-f_{o n}\right) C_{4}-$ $\frac{C_{1}}{\left(k_{a m}+C_{1}\right)} r_{n a} f_{u N} k_{g} C_{9}+k_{71} C_{7}-k_{12} C_{1}$

$\mathrm{C}_{2}$ : Nitrate nitrogen

$\Sigma R_{2}=k_{12} C_{1}-k_{2 D} C_{2}-\left(1-\frac{C_{1}}{\left(k_{\mathrm{am}}+C_{1}\right)}\right) r_{\mathrm{na}} f_{u N} k_{g} C_{9}$

$\mathrm{C}_{3}$ : Inorganic phosphorus

$\Sigma R_{3}=r_{p a} k_{r a}\left(1-f_{o p}\right) C_{9}+\left(\frac{r_{p a}}{r_{c a}}\right) k_{r z}\left(1-f_{o p}\right) C_{4}+r_{p a} k_{e a}\left(1-f_{o p}\right) C_{9}+\left(\frac{r_{p a}}{r_{c a}}\right) k_{e z}\left(1-f_{o p}\right) C_{4}-$ $r_{p a} f_{u P} k_{g} C_{9}+k_{83} C_{8}-\frac{v_{f r}}{H} C$

$\mathrm{C}_{4}$ : Herbivore zooplankton

$\Sigma R_{4}=r_{\mathrm{ca}} E_{z} k_{\mathrm{gz}} C_{9} C_{4}-k_{\mathrm{rz}} C_{4}-k_{e z} C_{4}-k_{g z c} C_{4}$

$\mathrm{C}_{5}$ : BOD - Biochemical oxygen demand

$\Sigma R_{5}=-k_{D} C_{5}-\frac{v_{s 3}\left(1-f_{D 5}\right)}{H} C_{5}+r_{o c} r_{c a}\left(1-E_{Z}\right) k_{g z} C_{9}+r_{\mathrm{oc}} r_{\mathrm{ca}} k_{e a} C_{9}+r_{o c} k_{e z} C_{4}$

$\mathrm{C}_{6}$ : DO - Dissolved oxygen

$\Sigma R_{6}=k_{a}\left(O_{s}-C_{6}\right)-k_{D} C_{5}-r_{o n} k_{12} C_{1}+r_{\mathrm{oc}} r_{\mathrm{ca}} k_{g} C_{9}-r_{o c} r_{c a} k_{r a} C_{9}-r_{o c} k_{r z} C_{4}-\frac{S O D}{H}$

$\mathrm{C}_{7}$ : Organic nitrogen

$\Sigma R_{7}=-k_{71} C_{7}-\frac{v_{s 3}\left(1-f_{7}\right)}{H} C_{7}+r_{n a}\left(1-E_{z}\right) k_{g z} C_{9} C_{4}+r_{n a} k_{r a} f_{o n} C_{9}+\left(\frac{r_{n a}}{r_{c a}}\right) k_{r z} f_{o n} C_{4}+$ $r_{n a} k_{e a} f_{o n} C_{9}+\left(\frac{r_{n a}}{r_{c a}}\right) k_{e z} f_{o n} C_{4}$

$\mathrm{C}_{8}$ : Organic phosphorus

$\Sigma R_{8}=r_{p a} K_{r a} f_{o p} C_{9}+\left(\frac{r_{p a}}{r_{c a}}\right) K_{r z} f_{o p} C_{4}+r_{p a} K_{e a} f_{o p} C_{9}+\left(\frac{r_{p a}}{r_{c a}}\right) K_{e z} f_{o p} C_{4}+r_{p a}\left(1-E_{z}\right) K_{g z} C_{9} C_{4}-$
$K_{83} C_{8}-\frac{v_{s 3}\left(1-f_{D 8}\right)}{H} C_{8}$

C9: Chlorophyll_a

$\Sigma R_{9}=k_{g} C_{9}-k_{r a} C_{9}-k_{e a} C_{9}-k_{g z} C_{9}-\frac{v_{s}}{H} C_{9}$ 
The coefficients used in the model are given in Table 1. In the MQA two different types of horizontal boundaries are considered: land boundaries and open boundaries. The land boundaries, in general, represent the water body margins and points with inflows or outflows, such as rivers, streams, surface water abstraction points, among others. The open boundaries represent the water domain limits of the study area. The prescription of normal fluxes in this model is associated with land boundaries. Along open boundaries, it is usual to neglect the diffusive fluxes; the model computes the mass balance equation with no diffusive terms.

The numerical implementation of the two models, hydrodynamic and water quality, are not discussed here; the interested reader is referred to Rosman (2016) for additional information concerning the hydrodynamic model. The numerical model developed for the advective and diffusive transport is described in detail by Cunha et al. (2002).

Table 1. Parameters employed in the water quality model and values adopted in the Rio Verde reservoir analysis.

\begin{tabular}{|c|c|}
\hline$k_{g}$ - Phytoplankton growth rate $\left(\mathrm{d}^{-1}\right)$ & 2.0 \\
\hline$k_{s N}-$ Half-Saturation Constant for Nitrogen $\left(\mu \mathrm{gN} \mathrm{L}^{-1}\right)$ & 25.0 \\
\hline$k_{s P}$ - Half-Saturation Constant for Phosphorus $\left(\mu \mathrm{gP} \mathrm{L}^{-1}\right)$ & 20.0 \\
\hline$I_{S}$ - Optimal light level $\left(\mathrm{ly} \mathrm{d}^{-1}\right)$ & 250.0 \\
\hline$k_{s a}$ - Half saturation constant for predation of zooplankton on algae $\left(\mu \mathrm{gChla} \mathrm{\textrm {L } ^ { - 1 } )}\right.$ & 15.0 \\
\hline$k_{g z}-$ Grazing rate $\left(\mathrm{m}^{3} \mathrm{gC}^{-1} \mathrm{~d}^{-1}\right)$ & 1.0 \\
\hline$k_{r a}$-Phytoplankton losses due to respiration and excretion $\left(\mathrm{d}^{-1}\right)$ & 0.05 \\
\hline$k_{r z}-$ Zooplankton losses due to respiration and excretion $\left(\mathrm{d}^{-1}\right)$ & 0.01 \\
\hline$E_{r}$ - Efficiency predation of zooplankton on algae & 0.6 \\
\hline$k_{g z c}-$ Predation losses rate $\left(\mathrm{d}^{-1}\right)$ & 0.01 \\
\hline$f_{0 n}$ - Fraction of death and respiration of phytoplankton recycled to organic nitrogen & 0.5 \\
\hline$K_{a m}$ - Half-saturation constant for preference of Ammonia Nitrogen $\left(\mu \mathrm{gN} \mathrm{L}^{-1}\right)$ & 50.0 \\
\hline$r_{o c}$ - Oxygen amount consumed in the decomposition of one gram of organic carbon $\left(\mathrm{gO} \mathrm{gC}^{-1}\right)$ & 2.67 \\
\hline$r_{p a}-$ Ratio of Phosphorus to chlorophyll in the phytoplankton $\left(\mathrm{gP} \mathrm{gChla}^{-1}\right)$ & 1.0 \\
\hline$r_{n a}-$ Ratio of Nitrogen to chlorophyll in the phytoplankton $\left(\mathrm{gN} \mathrm{gChla}^{-1}\right)$ & 7.2 \\
\hline$r_{c a}-$ Ratio carbon/chlorophyll in phytoplankton cells $\left(\mathrm{gC} \mathrm{gChla}^{-1}\right)$ & 50.0 \\
\hline$f_{D 5}-$ BOD fraction dissolved in the water column & 0.5 \\
\hline$f_{D 7}-$ Fraction of dissolved organic nitrogen in the water column & 1.0 \\
\hline$f_{D 8}$ - Fraction of dissolved organic phosphorus in the water column & 0.85 \\
\hline$f_{o p}$ - Fraction of dead and respired of phytoplankton in phosphorus cycle & 0.5 \\
\hline$k_{12}-$ Nitrification coefficient $\left(\mathrm{d}^{-1}\right)$ & 0.1 \\
\hline$k_{2 D}$ - Denitrification coefficient $\left(\mathrm{d}^{-1}\right)$ & 0.1 \\
\hline$k_{71}-$ Organic nitrogen mineralization coefficient $\left(\mathrm{d}^{-1}\right)$ & 0.03 \\
\hline$k_{83}-$ Organic phosphorus mineralization rate $\left(\mathrm{d}^{-1}\right)$ & 0.03 \\
\hline$k_{a}-$ Reaeration coefficient $\left(\mathrm{d}^{-1}\right)$ & 1.38 \\
\hline$k_{D}$ - Deoxygenation coefficient $\left(\mathrm{d}^{-1}\right)$ & 0.2 \\
\hline$k_{D B O}-$ Half saturation constant for oxidation of $\mathrm{BOD}\left(\mathrm{mgO}_{2} \mathrm{~L}^{-1}\right)$ & 0.5 \\
\hline$k_{n i t}$ - Half-saturation constant for DO limitation in the nitrification process $\left(\mathrm{mgO}_{2} \mathrm{~L}^{-1}\right)$ & 0.5 \\
\hline$k_{n o 3}$ - Half-saturation constant for DO limitation in the denitrification process $\left(\mathrm{mgO}_{2} \mathrm{~L}^{-1}\right)$ & 0.1 \\
\hline$k_{e a}-$ Phytoplankton mortality rate $\left(\mathrm{d}^{-1}\right)$ & 0.1 \\
\hline$k_{e z}-$ Zooplankton mortality rate $\left(\mathrm{d}^{-1}\right)$ & 0.005 \\
\hline$S O D$ - Sediment oxygen demand $\left(\mathrm{gO}_{2} \mathrm{~m}^{-2} \mathrm{~d}^{-1}\right)$ & 1.0 \\
\hline$v_{s 3}-$ Organic matter settling velocity $\left(\mathrm{m} \mathrm{d}^{-1}\right)$ & 1.0 \\
\hline$v_{s 4}-$ Phytoplankton settling velocity $\left(\mathrm{m} \mathrm{d}^{-1}\right)$ & 0.05 \\
\hline$v_{f r}$ - Inorganic sediment settling velocity $\left(\mathrm{m} \mathrm{d}^{-1}\right)$ & 0.02 \\
\hline
\end{tabular}




\subsection{Description of the Rio Verde Reservoir}

The Rio Verde reservoir is located in the Metropolitan Region of Curitiba (RMC) and inserted in the Rio Verde watershed, which has a total area of $242 \mathrm{~km}^{2}$. The reservoir has a plan area of $5.971 \mathrm{Km}^{2}$, an average volume of $25.6 \mathrm{hm}^{3}$, an average water depth about $5.6 \mathrm{~m}$ and receives the water contribution of 14 sub-watersheds. The Rio Verde reservoir is oriented in a Northeast (NE)-Southwest (SW) direction, with a length of approximately 7,500 m and a maximum width of $1,300 \mathrm{~m}$. The ratio between the depth and width of the reservoir is about 1:230 and between the depth and length is about 1:1330; these features suggest a predominance of horizontal velocities.

Figure 1 shows the bathymetry data and also the water quality and discharge points used for measurement. The main tributary of the reservoir is the Verde River (F4), accounting for about $70 \%$ of the total discharge flow; the other 13 smaller tributaries contribute with low flow levels. Figure 2 shows the daily discharge of each tributary from March 2010 to December 2010, estimated by the SWAT model (Soil and Water Assessment Tool). In relation to outflows, two points can be set: one close to the dam, which represents a REPAR (President Getúlio Vargas Refinery) license, with value of $0.83 \mathrm{~m}^{3} / \mathrm{s}$; and another at the spillway, which represents difference between the sum of inflows and outflows (Carneiro et al., 2014).

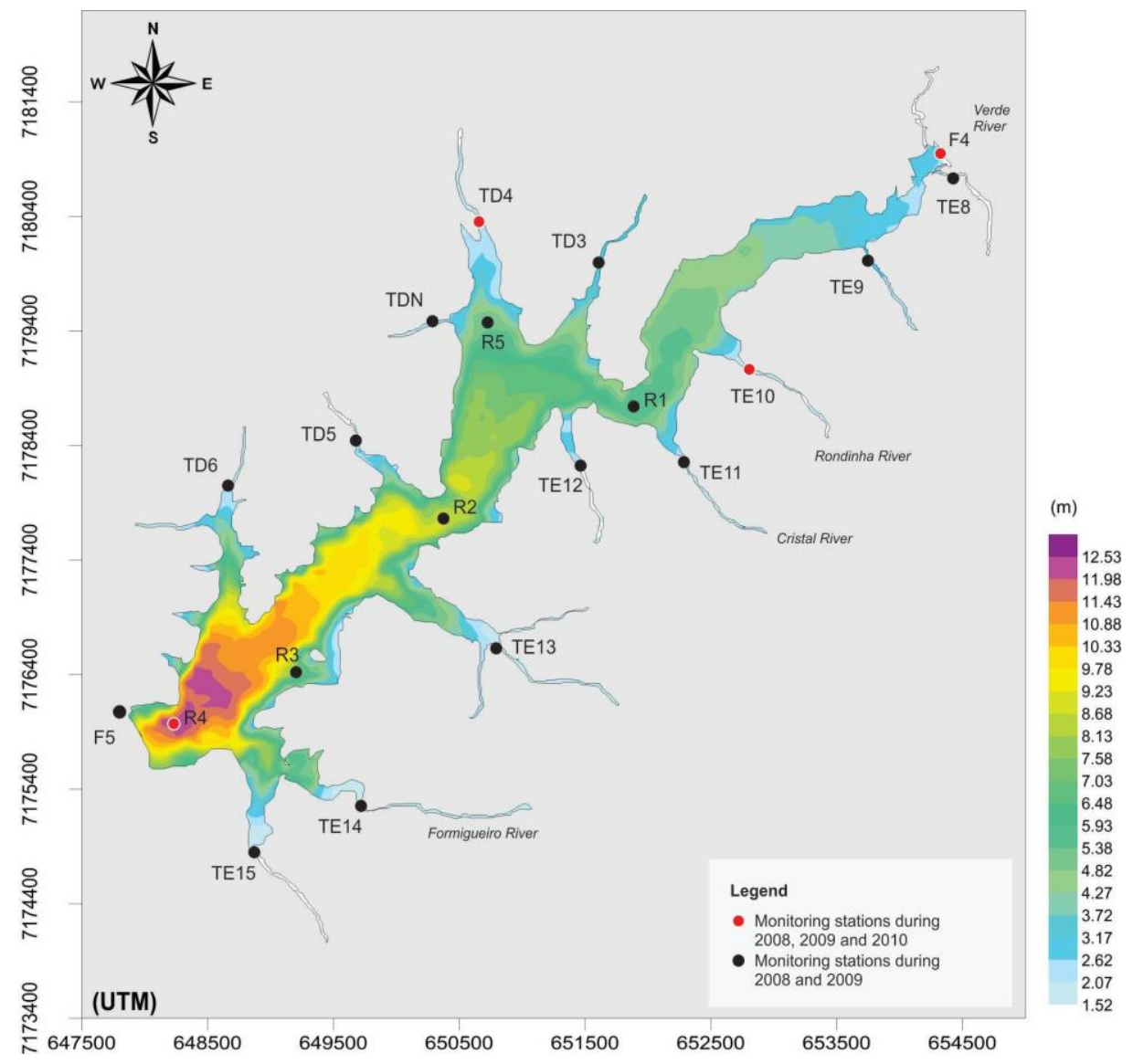

Figure 1. Map of Rio Verde reservoir bathymetry, water quality measure points and discharge measure points during 2010.

Meteorological data were obtained from a station installed near the dam (Latitude $25^{\circ} 31^{\prime} 36,83^{\prime \prime} \mathrm{S}$ and Longitude 49 $31^{\prime} 39,07^{\prime \prime} \mathrm{W}$ ). This station provided wind direction, wind velocity, air temperature, solar radiation, relative humidity and precipitation from March 2010 to December 2010. The daily maxima values of solar radiation showed a gradual decrease from March to July, reaching $457 \mathrm{~W} \mathrm{~m}^{-2}$ in May (Figure 2); from August to December the values 
increased, reaching $851 \mathrm{~W} \mathrm{~m}^{-2}$ in November. In Figure 2, the air temperatures data show a variability related to seasons, with minimum moving average of $12.6^{\circ} \mathrm{C}$ in August and maximum moving average of $20.7^{\circ} \mathrm{C}$ in April. With respect to the relative humidity, Figure 2 shows a small moving average variation over 2010 , with values between $74.1 \%$ and $88.2 \%$.

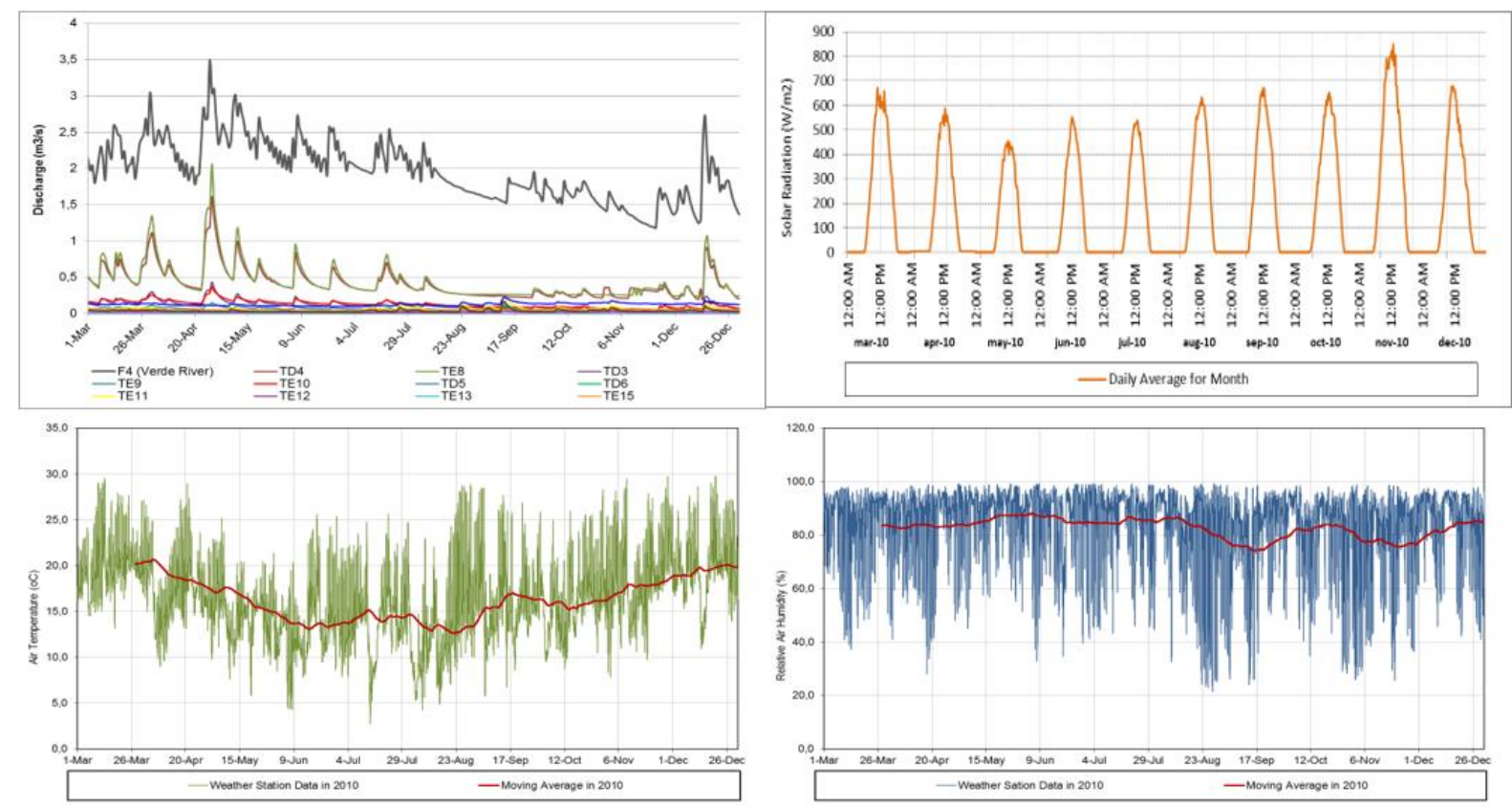

Figure 2. Tributaries daily discharge $\left(\mathrm{m}^{3} \mathrm{~s}^{-1}\right)$, daily average of solar radiation $\left(\mathrm{W} \mathrm{m}^{-2}\right)$, air temperature and relative humidity measured at the meteorological station of the Rio Verde reservoir from March 2010 to December 2010. The continuous line represents the moving average for 30 days.

Carneiro et al. (2014) show that only the Verde River (F4) and two tributaries (TE10 and TD4) account for $90 \%$ of the pollutant load that arrives at the Rio Verde reservoir. Figure 3 shows the concentration values of eight parameters in three tributaries (F4, TE10 and TD4) from March 2010 to December 2010: water temperature, ammonia, nitrate, organic nitrogen, organic phosphorus, inorganic phosphorus, DO and BOD.

The Rio Verde reservoir presents a dynamic system of stratification characterized by a reasonable stratification in the summer and a mixed water column in the winter. Figure 4 shows the temperature profiles measured at R1 and R4 stations (see Figure 1) from March 2010 to December 2010. At the R4 station between April and September, the water column shows no stratification and can be considered well mixed; from October the water column begins to stratify with the increasing air temperature, reaching largest gradients in December. The station $\mathrm{R} 1$ is located in the shallow portion of the reservoir, and it is not possible to observe any stratification phenomena there.

With respect to the wind characteristics, the measured data between March and December 2010 demonstrate a predominance of NE direction, which coincides with the alignment of the reservoir axis. The wind flow represents the major influential variable for hydrodynamic circulation and mass transport in this reservoir. In two areas the hydrodynamic flow and mass transport are dominated by inflows and outflows: one near the dam, where the main water intake and the spillway are located; and the other near the Verde River, the main tributary. Outside these areas, circulation and transport are determined by the wind. 


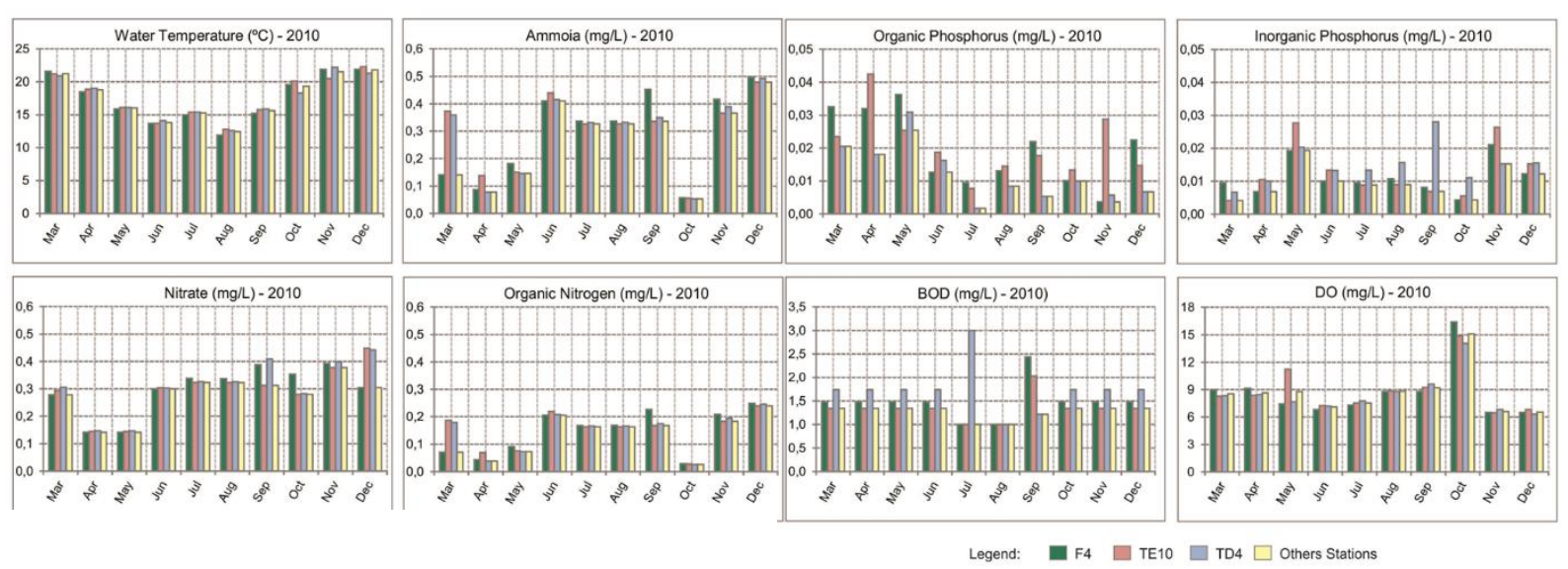

Figure 3. Concentrations values of some substances in the tributaries of the Rio Verde reservoir.

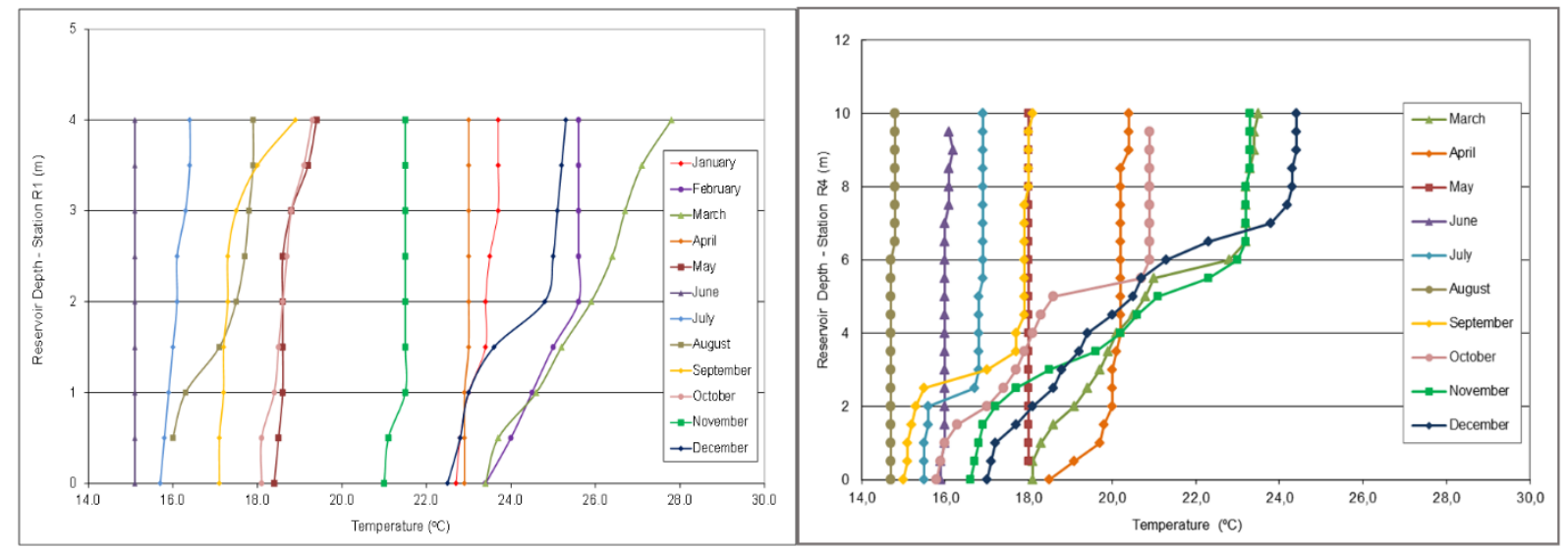

Figure 4. Temperature profiles at station R1 (left) and R4 (right) during 2010.

\section{RESULTS AND DISCUSSION}

Two-dimensional hydrodynamic models of Rio Verde reservoir were developed using SisBaHiA ${ }^{\circledR}$. The spatial discretization in the horizontal $x-y$ plane was carried out through subparametric Lagrangian quadrilateral finite elements with 9 nodes. In a sub-parametric element, the geometry of the element is linear and is defined only by the vertices. However, the variables are quadratic, and in addition to the values at the vertices, the middle values at each side are also needed and, in the case of quadrilaterals, a node at the center of the element is also necessary.

The mesh consists of 507 elements and 2402 nodes. The simulation was performed for a period of 308 days, from February $27^{\text {th }} 2010$ to December $31^{\text {th }}$, 2010, with a 60s time step. These dates were chosen due to available measurements of water quality parameters, made at four locations in the reservoir, which enabled the calibration process in MQA evaluation.

In the numerical model, wind conditions are considered unsteady and spatially homogeneous; the input data used in the model were the time series of wind speeds and directions measured at the meteorological station in the reservoir. At the open boundaries domain, the elevations were imposed; at the land boundary, except for the nodes corresponding to the rivers, all nodes were considered impermeable with null tangential and normal velocity components imposed.

The bottom friction coefficient can be written in terms of the Chezy coefficient, which depends on the amplitude of the equivalent bottom roughness. The amplitude of the equivalent bottom roughness, $\varepsilon$, was defined according to the bottom sediment characterization and 
distribution (Rosman, 2016). Silty-clay sediments are predominant in the reservoir $(\varepsilon \approx 0.015 \mathrm{~m})$ and in regions with large amount of submerged trees, bottom roughness amplitude values were increased (with values around $0.130 \mathrm{~m}$ ).

Figure 5 shows the hydrodynamic model results for two situations: in June $26^{\text {th }}$, 2010, with an average wind speed of $1,81 \mathrm{~m} \mathrm{~s}^{-1}$, an average wind direction of $73^{\circ}$, and a main river discharge of $2,24 \mathrm{~m}^{3} / \mathrm{s}$; and in October $18^{\text {th }}, 2010$, with an average wind speed of $4,84 \mathrm{~m} \mathrm{~s}^{-1}$, an average wind direction of $22^{\circ}$, and a main river discharge of $1,63 \mathrm{~m}^{3} \mathrm{~s}^{-1}$. The velocity fields show a strong relationship with the local wind pattern through the presence of a clockwise vortex formed in the region near the dam, which intensifies depending on the wind pattern. On June $26^{\text {th }}, 2010$, there was a northeasterly wind at an average of $1.81 \mathrm{~m} \mathrm{~s}^{-1}$. The currents follow the wind direction, forming a large clockwise vortex in the region near the dam. In the regions near the spillway and the Verde river, there is an intensification of the currents due to local effects of inflows/outflows. On October $18^{\text {th }}, 2010$, the wind speed is stronger, at an average of $4.84 \mathrm{~m} \mathrm{~s}^{-1}$. Under these conditions, two vortices were formed: a large vortex, clockwise in the central region of the reservoir, and a smaller one, also clockwise. There was an intensification of the currents in the region near the Verde river, caused by the flooding observed during this period. Taking into account these patterns, it can be stated that the hydrodynamic circulation, and consequently the horizontal transport, is strongly dependent on the wind and that inflows/outflows generate a localized circulation.
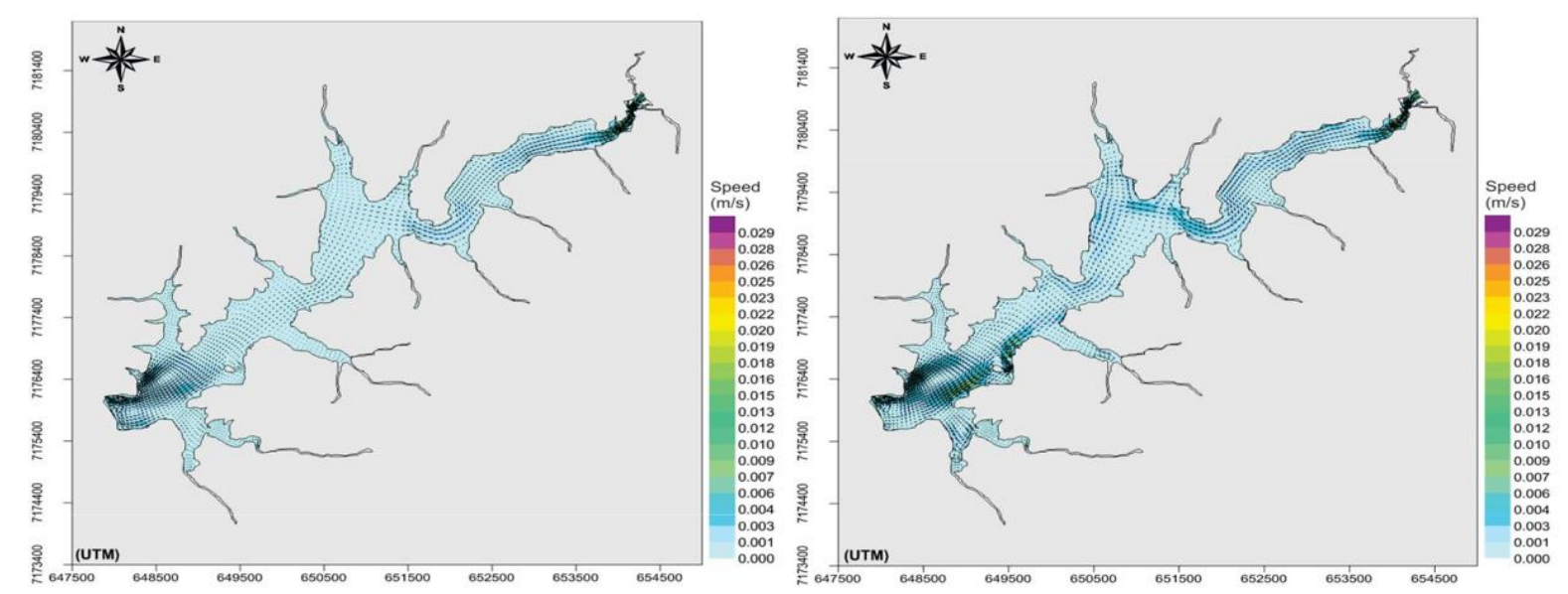

Figure 5. Velocity fields obtained with $\mathrm{SisBaHi}^{\circledR}$ from June $26^{\text {th }}$, 2010. Velocity fields obtained with $\mathrm{SisBaHiA}{ }^{\circledR}$ from October $18^{\text {th }}, 2010$.

From March 2010 to December 2010, data related to Temperature and DO were collected. The measurements were made at R4 station in reservoir, see Figure 1; the measurements were obtained at a several positions along the water depth. The analyses were performed for the same dates as that of the hydrodynamic simulation, between February $27^{\text {th }} 2010$ and December $31^{\text {th }}$, 2010. This article shows just the results for the Temperature and DO, which have measured data for comparison.

The turbulent diffusion coefficient used from the water quality model are: $D_{x x}\left(\mathrm{~m}^{2} \mathrm{~s}^{-1}\right)=$ 2.0, $D_{y y}\left(\mathrm{~m}^{2} \mathrm{~s}^{-1}\right)=0.5$, with a $60 \mathrm{~s}$ time step. Table 1 lists the model coefficients and constants employed in the numerical simulation. The values of the parameters and constants are welldefined in the literature and were used in the application considering that there are no available studies for water quality modeling in Rio Verde reservoir. This is the main difficulty in performing the analysis proposed in this article. The field data are not sufficient for a complete calibration, and some adjustments were carried out manually to obtain numerical results close to the measured data, within a specified variation limit; some adjustments proved to be necessary, mainly in the reaeration and deoxygenation coefficients. In order to quantify the 
accuracy of fit, correlation coefficient $\mathrm{R}^{2}$ of the regression line between the model results and the field data at $\mathrm{R} 4$ station was computed. The best calibration required a $\mathrm{R}^{2}$ value as close to 1.0 as possible.

The initial concentrations are: Salinity $=0.0 \mathrm{psu}$, Temperature $=21.08^{\circ} \mathrm{C}$; Organic Nitrogen $=0.30 \mathrm{mg} \mathrm{N} \mathrm{L}^{-1} ;$ Ammoniac Nitrogen $=0.157 \mathrm{mg} \mathrm{N} \mathrm{L}^{-1} ;$ Nitrate Nitrogen $=0.038 \mathrm{mg}$ $\mathrm{N} \mathrm{L}^{-1}$; Biochemical Oxygen Demand $=1.50 \mathrm{mg} \mathrm{O}_{2} \mathrm{~L}^{-1}$; Dissolved Oxygen $=5.80 \mathrm{mg} \mathrm{O}_{2} \mathrm{~L}^{-1}$; Chlorophyll-a $=12.80 \mu \mathrm{g} \mathrm{L}^{-1}$; Zooplankton $=0.0 \mathrm{mg} \mathrm{L}^{-1}$; Organic Phosphorus $=0.0189 \mathrm{mg} \mathrm{P}$ $\mathrm{L}^{-1}$; Inorganic Phosphorus $=0.0039 \mathrm{mg} \mathrm{P} \mathrm{L}^{-1}$. Such parameters represent the measurement made at the R4 monitoring point in the reservoir, see Figure 1, on March, $16^{\text {th }}, 2010$.

The temperature is used as the calibration parameter for variables related to advective and diffusive transport. The long-term temperature data simulated with $\mathrm{SisBaHiA}^{\circledR}$ were compared with average values of vertical profiles, measured at R4 station from March 2010 to December 2010. The model reproduces the average temperature variation and, according to Figure 6 , it is possible to state that variable boundary conditions are adequately reproduced. The R4 is not under the direct influence of the rivers; consequently, there is a better agreement between the results. Figure 6 shows the DO concentrations measured at the R4 station and computed numerically by SisBAHIA ${ }^{\circledR}$. The differences between these results showed that SisBAHIA ${ }^{\circledR}$ can predict adequately the variations of DO in the process of oxidation of organic matter present in the reservoir. The average relative errors between the model results and the field data at R4 station are: 0.095 for temperature and 0.406 for DO. Figure 6 also depicts the regression line; the correlation coefficient values $\left(\mathrm{R}^{2}\right)$ were 0.8973 for the temperature, and 0.4575 for the DO. This indicated good agreement between simulated and field data for the temperature. However, DO concentrations do not indicate a good fit. For a better calibration of the model, a larger temporal series would be necessary.

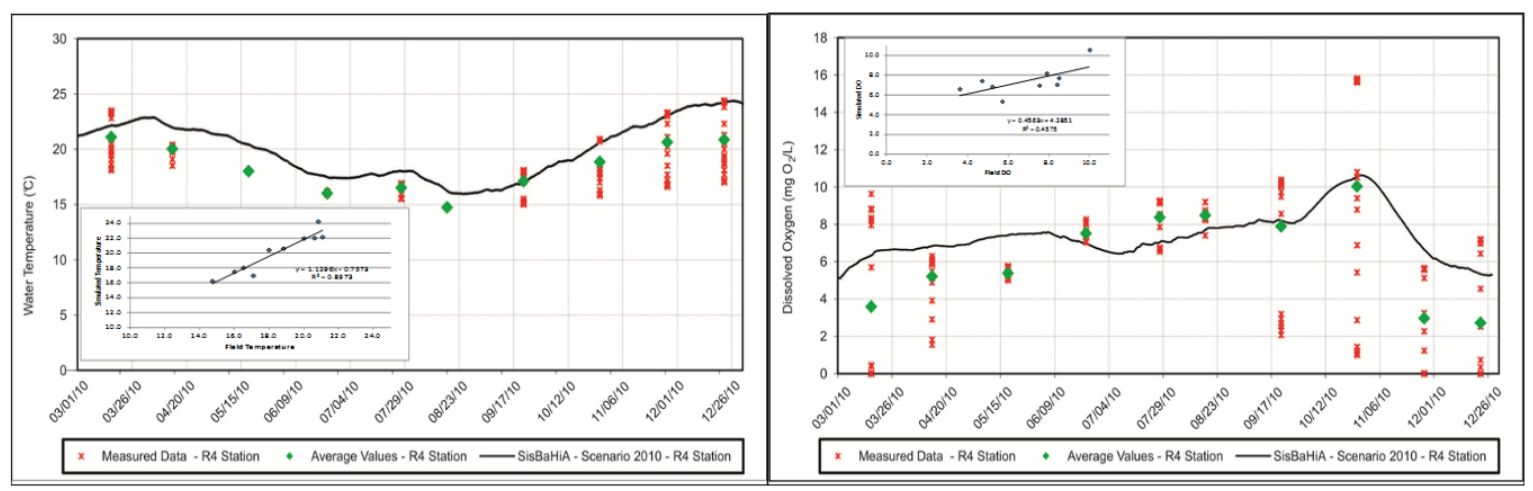

Figure 6. Temperature and DO concentration measured at the R4 station and computed numerically by $\operatorname{SisBAHIA}{ }^{\circledR}$.

\section{CONCLUSIONS}

The results presented in this paper show that the environmental modeling of the Rio Verde reservoir is appropriate and can be used quantitatively to study the phenomenon of eutrophication. Whereas the advective and diffusive transport is independent from the parameter modeled, the correct definition of the chemical, physical and biological processes involved in each water quality parameter, made it possible to characterize the distribution of these parameters in the Rio Verde reservoir. Based on the results of the hydrodynamic model, it was possible to note the significant influence of the wind in the hydrodynamic circulation. Thus, the importance of the proper use of wind data when modeling reservoirs becomes clear. Inflows/outflows generate impacts in circulation only in their immediate surroundings and do not contribute to the circulation of the reservoir as a whole. The results for the temperature and 
dissolved oxygen concentration were compared with field measures and a satisfactory consistency was achieved.

\section{REFERENCES}

CARNEIRO, C.; ANDREOLI, C. V.; CUNHA, C. L. N.; GOBBI, E. F. Reservoir Eutrophication: Preventive Management An Introduction to Eutrophication and the Studies. London: IWA Publishing, 2014. 478p.

CUNHA, C. L. N.; MONTEIRO, T. C.; ROSMAN, P. C. C. Two-Dimensional Modelling of Scalars Transport. Revista Brasileira de Recursos Hídricos, v. 7, p. 63-79, 2002.

DEUS, R.; BRITO, D.; MATEUS, M.; KENOV, I.; FORNARO, A.; NEVES, R. et al. Impact evaluation of a pisciculture in the Tucuruí reservoir (Pará, Brazil) using a twodimensional water quality model. Journal of Hydrology, v. 487, p. 1-12, 2013. https://doi.org/10.1016/j.jhydrol.2013.01.022

KUO, J.; LUNG, W.; YANG, C.; LIU, W.; YANG, M.; TANG, T. Eutrophication modelling of reservoirs in Taiwan. Environmental Modelling \& Software, v. 21, p 829-844, 2006. https://doi.org/10.1016/j.envsoft.2005.03.006

LIU, X.; PENG,W.; HE, G.; LIU, J.; WANG, Y. A Coupled Model of Hydrodynamics and Water Quality for Yuqiao Reservoir in Haihe River Basin. Journal of Hydrodynamics, v. 20, p. 574-582, 2008. https://doi.org/10.1016/S1001-6058(08)60097-9

ROSMAN, P. C. C. Referência Técnica do SISBAHIA - SISTEMA BASE DE HIDRODINÂMICA AMBIENTAL. Programa COPPE: Engenharia Oceânica, Área de Engenharia Costeira e Oceanográfica. Rio de Janeiro: UFRJ, 2016.

SELLERS, W. D. Physical Climatology. Chicago: The University of Chicago Press, 1965.

SHENG, Y. P.; YASSUDA, E. A.; YANG, C. Modeling the effect of reduced nitrogen loading on water quality. In: SPAULDING, M. L.; CHENG, R. T. Estuarine and Coastal modeling. New York: American Society of Civil Engineers, 1996.

SHENG, Y. P.; VILLARET, C. Modeling the effect of suspended sediment stratification on bottom exchange processes. Journal of Geophysical Research, v. 94, p.1429-1444, 1989. https://doi.org/10.1029/JC094iC10p14429 


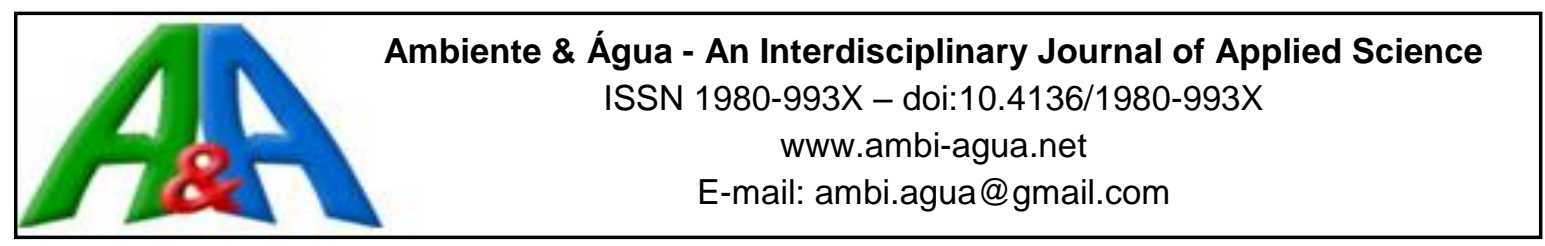

\title{
Analysis of toxicity from the effluent generated in a furniture industry spray booth using the species Lactuca sativa and Allium cepa
}

\author{
ARTICLES doi:10.4136/ambi-agua.2246
}

Received: 21 Feb. 2018; Accepted: 05 Oct. 2018

\author{
Isabela Bruna de Tavares Machado Bolonhesi ${ }^{1,2 *}$; Deize Dias Lopes ${ }^{2}$ \\ ${ }^{1}$ Universidade Tecnológica Federal do Paraná (UTFPR), Londrina, PR, Brasil \\ Departamento de Engenharia Ambiental. E-mail: ibtmachado@gmail.com \\ ${ }^{2}$ Universidade Estadual de Londrina (UEL), Londrina, PR, Brasil \\ Centro de Tecnologia e Urbanismo (CTU). Departamento de Engenharia Civil. \\ E-mail: ibtmachado@gmail.com,deize@uel.br \\ *Corresponding author
}

\begin{abstract}
This study evaluated the toxicity of effluent generated in a furniture industry spray booth, before and after treatment in a system composed of an anaerobic sequencing batch (ASBR) followed by an aerobic sequencing batch reactor (SBR). The toxicity tests were carried out with raw (with and without dilutions) and treated effluent to evaluate the toxic potential using Allium cepa and Lactuca sativa as bioindicators. The toxicity tests, using Allium cepa and Lactuca sativa, indicated that the anaerobic-aerobic treatment performed was efficient to reduce the toxicity of the paint booth effluent. The raw effluent, undiluted and diluted (at 1:10;1:8 and 1:6 dilutions), showed toxic effect on the root growth of Allium cepa, as it inhibited root growth by $100 \%$. In the tests with Lactuca sativa seeds, there was partial inhibition, between $44 \%$ and $63 \%$, for 1:10 and 1:8 dilutions, but for the 1: 6 dilution and without dilution of effluent the inhibition was $100 \%$. The treated effluent, in an ASBR followed by an SBR, presented a small percentage of inhibition for tests with Allium cepa (13\%) and Lactuca sativa seeds (4\%). The effluent treated by the anaerobic system followed by aerobic presented low toxicity without generating lethal or sub-lethal effects to the test organisms, which indicates the efficiency of the treatment process.
\end{abstract}

Keywords: Bioassay, formaldehyde, wastewater.

\section{Análise da toxicidade do efluente de cabine de pintura de indústria moveleira por meio das espécies Lactuca sativa e Allium cepa}

\section{RESUMO}

Este estudo avaliou a toxicidade do efluente gerado na cabine de pintura da indústria moveleira, antes e após o tratamento, em um sistema composto por um reator anaeróbio em bateladas (ASBR) seguido de um reator aeróbico em batelada sequencial (SBR). Os testes de toxicidade foram realizados com efluente bruto (sem e com diluição) e tratado para avaliação do potencial tóxico utilizando como bioindicador Allium cepa e Lactuca sativa. Os testes de toxicidade, utilizando Allium cepa e Lactuca sativa, indicaram que o tratamento aeróbioanaeróbico realizado foi eficiente para reduzir a toxicidade do efluente da cabine de pintura. $\mathrm{O}$ efluente bruto, não diluído e diluído (diluições de 1:10; 1: 8 e diluição 1: 6), apresentou efeito 
tóxico no crescimento radicular de Allium cepa, pois inibiu o crescimento radicular em $100 \%$. Nos testes com sementes de Lactuca sativa, houve inibição parcial, entre $44 \%$ e $63 \%$, para diluições de 1:10 e 1: 8, mas para a diluição de 1: 6 e sem diluição do efluente a inibição foi de 100\%. O efluente tratado, em ASBR seguido de SBR, apresentou pequena porcentagem de inibição para testes com sementes de Allium cepa (13\%) e Lactuca sativa (4\%). O efluente tratado pelo sistema anaeróbio seguido de aeróbio apresentou baixa toxicidade sem gerar efeitos letais ou subletais aos organismos testados, o que indica a eficiência do processo de tratamento realizado.

Palavras-chave: águas residuárias, bioensaio, formaldeído.

\section{INTRODUCTION}

The wastewater produced in spray booths of the furniture industry change according to the type of the production. The most-used products in the final finishing step, besides dyes, were varnishes and thinner (solvent). Paints and varnishes contain urea-formaldehyde resins, so formaldehyde is one of the organic compounds in higher concentrations (up to $400 \mathrm{mg} . \mathrm{L}^{-1}$ ) in this type of wastewater, and this compound can be toxic to humans and animals (Lu e Hegemann, 1998).

However, formaldehyde can be biodegradable in concentrations lower than $100 \mathrm{mg}$ HCHO. L ${ }^{-1}$ (Pereira and Zaiat, 2009). In higher concentrations, it causes the inhibition of the microorganisms, and consequently reduces the capacity of organic matter removal in the treatment process. In this case, it might be necessary to dilute the effluent to avoid inhibition of the process (Lu and Hegemann, 1998).

The toxicity of a compound, such as formaldehyde, can be analyzed by means of a toxicity test. According to Kapanen and Itävaara (2001), toxicity tests are classified by time of exposure (acute or chronic), the effect mode (death, growth or reproduction) or the effect response (lethal and sub-lethal). The acute and subacute exposure tests differ from the chronic because they evaluate the effects upon an organism during a short time, unlike the chronic test, which is based on a longer exposure. Subacute toxicity tests, known as low-duration tests, are developed with a focus on quantitative assessments, such as the effects on the growth of organisms tested. (Kapanen and Itävaara, 2001).

Plants have been shown to be useful when used as bioindicators to monitor the presence of toxic compounds in rivers and lakes. Allium cepa (onion) has been used in ecotoxicological tests to evaluate several compounds (Düsman et al., 2014).

Düsman et al. (2014) analyzed the cytotoxic potential of the surface water of the Quatorze River in Francisco Beltrão, Paraná, Brazil by means of tests with the roots of Allium cepa. Besides root growth, the authors verified possible alterations in meristematic cells of the plant. The authors affirmed that among the advantages of using the test with Allium cepa, it is worth noticing that it is a low-cost, easy-to-handle test with no prior preparation required.

According to Fiskesjö (1985), the National Water Research Institute recommends the use of lettuce seeds (Lactuca sativa) in toxicity tests in effluents, soils or sediments, due to its rapid grow and the fact that little energy is required to germinate it. The advantages of the usage of theses vegetables are their low-cost, easy-cultivation, availability during the whole year and the possibility of using them both in acute and chronic toxicity tests, in laboratory and field conditions (Fiskesjö, 1985).

This study evaluated the toxicity of the effluent generated in a spray booth of the furniture industry, before and after treatment in a system composed of an anaerobic sequencing batch (ASBR) followed by an aerobic reactor operated under an SBR mode. The toxicity tests were carried out with raw (without and with dilutions) and treated effluent for evaluating the toxic 
potential using as bioindicators Allium cepa and Lactuca sativa.

\section{MATERIALS AND METHODS}

\subsection{Experimental apparatus and procedures}

For the biological treatment of the furniture industry spray booth effluent, a bench-scale system was used (Figure 1), composed of an anaerobic sequencing batch reactor (ASBR) followed by an aerobic reactor operated under an SBR mode. The ASBR was constructed of Polyvinyl chloride, with an internal diameter of $10 \mathrm{~cm}$ and height of $33.5 \mathrm{~cm}$ with total volume of $2.5 \mathrm{~L}$ and working volume of $2.0 \mathrm{~L}$. The aerobic SBR was a glass vessel with a total volume of $2 \mathrm{~L}$ and useful volume of $1.1 \mathrm{~L}$. Continuous aeration was performed by means of an aquarium aerator with porous stone at the end of the hose connected to the system.

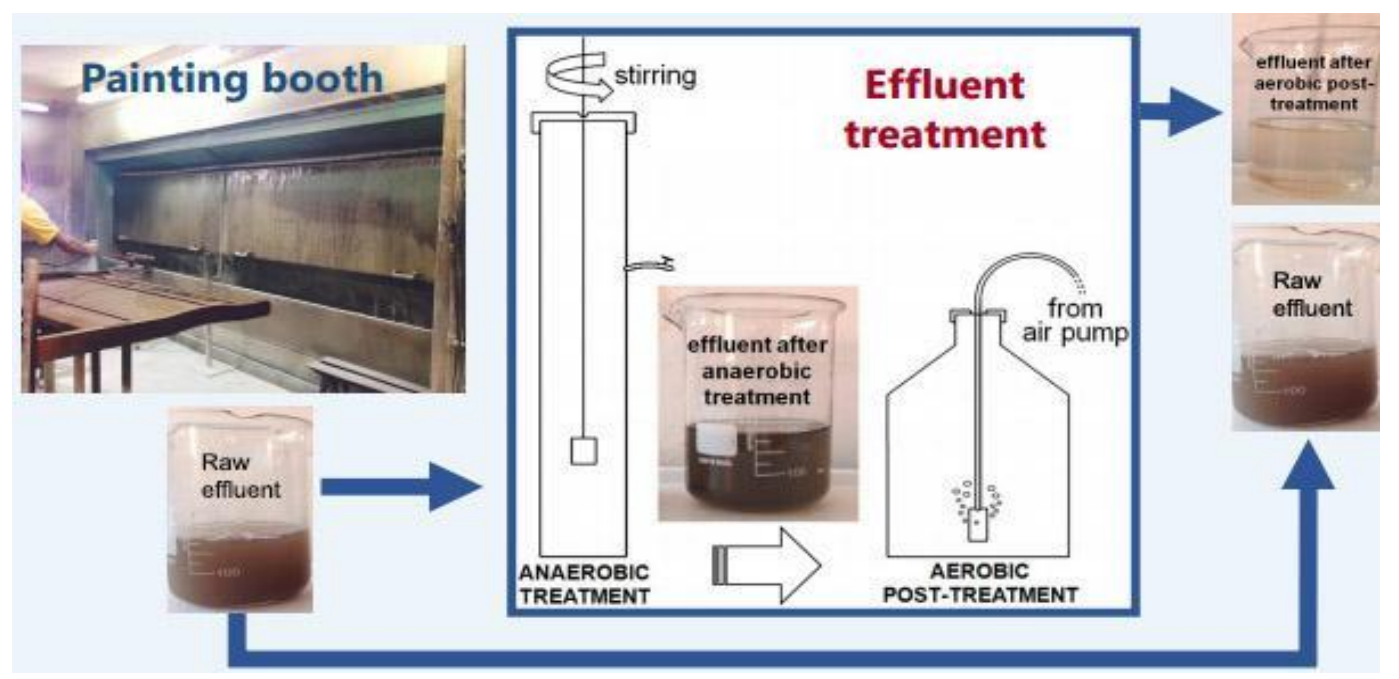

Figure 1. Schematic diagram of the experimental system.

Sludge of an upflow anaerobic sludge blanket reactor from the Sewage Treatment Plant ETE Norte / Sanepar -Londrina-PR was used as inoculum for the start-up of an ASBR. The

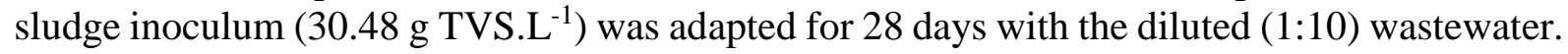
For the start-up of the SBR the seed sludge was obtained from the aeration $300 \mathrm{~mL}$ of treated sewage in a structured-bed reactor, in bench-scale with intermittent aeration. The $300 \mathrm{~mL}$ were mixed with $800 \mathrm{~mL}$ of effluent from the ASBR and kept in aeration for adaptation. The biomass adaptation occurred within 1 week and was monitored by COD $\left(\mathrm{mg} \mathrm{O}_{2}\right.$. $\left.\mathrm{L}^{-1}\right)$.

The hydraulic detention time (HDT) of operation was 4 days for the ASBR and 2 days for the SBR. The ASBR was fed with raw effluent and the SBR was fed with the effluent coming out of the ASBR. The main characteristics of the raw effluent were COD of $10550 \mathrm{mg} \mathrm{O}_{2} \cdot \mathrm{L}^{-1}$ and formaldehyde of $400 \mathrm{mg}$ HCHO.L $\mathrm{L}^{-1}$.

The ASBR-SBR system was operated in three distinct phases according to the concentrations of influent COD, so it was necessary to dilute the wastewater to feed the ASBR. Dilutions to obtain the desired COD concentrations were performed with tap water. The operating conditions of the ASBR-SBR system were, according to COD concentration: Phase 1 - 1:10 dilution ratio $\left(700 \pm 70 \mathrm{mgO}_{2} . \mathrm{L}^{-1}\right.$ and $\left.34 \pm 5 \mathrm{mg} \mathrm{HCHO} . \mathrm{L}^{-1}\right)$; Phase 2 - 1: 8 dilution ratio $\left(1856 \pm 200 \mathrm{mg} \mathrm{O}_{2} . \mathrm{L}^{-1}\right.$ and $157 \pm 7 \mathrm{mg} \mathrm{HCHO}$. L-1); Phase $3-1: 6$ dilution ratio (3960 $\pm 100 \mathrm{mg} \mathrm{O} \mathrm{O}_{2} \mathrm{~L}^{-1}$ and $\left.232 \pm 10 \mathrm{mg} \mathrm{HCHO} . \mathrm{L}^{-1}\right)$. There was no adaptation period between the different phases.

The SBR was fed with $600 \mathrm{~mL}$ of the ASBR effluent every 48 hours. To coincide with the 4-day HDT of the ASBR, the remaining $600 \mathrm{~mL}$ of the ASBR effluent - once $1.2 \mathrm{~L}$ of the ASBR 
was withdrawn - were kept in a refrigerator programmed to reach room temperature for each new feed after $48 \mathrm{~h}$

The concentrations of COD were determined (potassium dichromate oxidation methodCOD 5220 -D) according to APHA (2005). Formaldehyde was determined by the colorimetric method according to Bailey and Rankin (1971).

\subsection{Toxicity tests using Allium cepa}

The toxicity tests were performed with samples of the undiluted and diluted raw effluent (dilutions with distilled water - 1:10;1:8 and 1:6) and with samples of the treated effluent of Phase 2. The treated effluent from Phase 2 was used because it was the phase that presented better stability of operation of the ASBR-SBR system.

The tests were conducted as described by Fiskesjö (1985) with modifications. The onion bulbs were bought commercially in the supermarket and kept in a place free of moisture and protected from light. The surface peels were removed and the onions were placed in flasks (small vessels) with the root portion immersed in $50 \mathrm{~mL}$ of mineral water for hydration for 48 hours. After this period, those that showed root growth were selected, excluding those that did not show any growth. The roots were then carefully cut so that they were not more than $5 \mathrm{~mm}$.

The bulbs were placed into vials, with their root portions exposed to $50 \mathrm{~mL}$ of the raw effluent with and without dilution and the treated effluent from the ASBR system followed by the SBR. The characteristics of the samples tested are shown in Table 1.

Table 1. Concentrations of organic matter and formaldehyde in the samples tested.

\begin{tabular}{|c|c|c|c|}
\hline \multirow{2}{*}{ Samples tested } & \multirow{2}{*}{ Dilution } & \multicolumn{2}{|c|}{ Characteristics of the samples tested } \\
\hline & & $\operatorname{COD}\left(\mathrm{mg} \mathrm{O}_{2} \cdot \mathrm{L}^{-1}\right)$ & $\mathrm{HCHO}\left(\mathrm{mg} \mathrm{L}^{-1}\right)$ \\
\hline \multirow{4}{*}{ Raw Effluent } & $1: 10$ & 700 & 36 \\
\hline & $1: 8$ & 1960 & 157 \\
\hline & $1: 6$ & 4060 & 235 \\
\hline & Without dilution & 10550 & 400 \\
\hline Treated Effluent from Phase 2 & Without dilution & $<25$ & 0.8 \\
\hline
\end{tabular}

The test had as negative control onions exposed only to mineral water. After seven days of exposure at a temperature of $25^{\circ} \mathrm{C}$ and in the absence of light, root growth was observed. The tests were performed with six replicates for each sample and each set of tests was repeated three times.

The tests were performed to analyze the subacute toxicity, checking at the end of the procedure the length of the highest root of each onion, performing the measurement with ruler. The root growth of the Allium cepa in the control condition was used as a parameter, and from that parameter root growth inhibition ratios (ICR) exposed to treated effluent and untreated effluent were developed, using Equation 1, according to the methodology proposed by Palácio et al. (2012):

$$
\% I C R=\frac{N R C A}{N R C C} * 100
$$

Being:

$I C R$ : Root growth inhibition;

$N R C A$ : Number of grown roots in the samples;

$N R C C$ : Number of grown roots in the control. 


\subsection{Toxicity test used in Lactuca sativa seeds}

The test was performed following the methodology described by Sobrero and Ronco (2004) and Palácio et al. (2013) with some adaptations. Lactuca sativa (mimosa lettuce) seeds with the germination percentage of $98 \%$ were used.

The used samples followed the conditions presented in Table 1, as used in the tests with Allium cepa. Mineral water was used as a negative control. Petri dishes $9 \mathrm{~cm}$ in diameter were prepared with filter paper, where twenty seeds of lettuce moistened with the samples were prepared previously and deposited. The tests were carried out in triplicate.

The plates were packed in plastic bags to avoid the loss of humidity and taken to the bacteriological oven with a temperature of $20^{\circ} \mathrm{C} \pm 2$, in the dark, for a period of 120 hours. After the incubation period, the number of germinated seeds was counted and the roots and the radicle lengths were measured. The percentage of relative germination for each dilution was calculated using Equation 2.

$$
\% G R=\frac{N S G A}{N S G C} * 100
$$

Being:

$\% G R$ : The relative germination percentage;

NSGA: Number of germination seeds in samples;

$N S G C$ : Number of germinations seeds in control.

Percentages of relative roots growth inhibition (\%ICRRz) were calculated by the medium values for each sample, using Equation 3.

$$
\% \operatorname{ICRRz}=\frac{M C R z C-M C R z A}{M C R z C} * 100
$$

Being:

$M C R z C$ : Root growth average in control;

$M C R z A$ : Root growth average in samples;

\section{RESULTS AND DISCUSSION}

The anaerobic treatment followed by aerobic (ASBR-SBR) provided a $98 \%$ efficiency in the removal of COD for Phases 1 and 2 (dilutions: 1:10 and 1:8). As shown in Table 1, the treated effluent from Phase 2 had organic matter content lower than $25 \mathrm{mg} \mathrm{O}_{2} \cdot \mathrm{L}^{-1}$ (COD) and formaldehyde less than $0.8 \mathrm{mg} \mathrm{HCHO.L^{-1 }}$.

It should be noted that for Phase 3 (dilution of 1:6), the ASBR presented instability with less organic matter and formaldehyde removal (efficiency of $75 \%$ and $64 \%$, respectively) compared to Phases 1 and 2. This must have been due to the inhibition of the action of microorganisms caused by the high concentration of formaldehyde (Pereira and Zaiat, 2009). However, the polishing in the aerobic reactor (SBR) was efficient in the removal of the organic matter (COD) and formaldehyde with a final concentration lower than $50 \mathrm{mg} \mathrm{O}_{2}$. $\mathrm{L}^{-1}$ and $50.9 \mathrm{mg} \mathrm{HCHO}$. $\mathrm{L}^{-1}$.

\subsection{Tests with Allium cepa}

The tests found that the toxicity of the raw effluent and its dilutions had sub-lethal effects, and caused root-growth inhibition, especially for the raw effluent without dilution. It was observed that in the raw effluent, with and without dilution, there was no root growth, and the

\section{IPABH}

Rev. Ambient. Água vol. 13 n. 6, e2246 - Taubaté 2018 
roots had sizes smaller than $5 \mathrm{~mm}$, as shown in Figure 2. The results showed the toxicity of raw effluent (without dilution) in all tested dilutions. Further, the results found that the raw effluent without dilution had lethal effects (inhibiting germination) that deteriorated the roots and left them with sizes smaller than $5 \mathrm{~mm}$ (Figure $2(\mathrm{~d})$ ).

The treated effluent tests showed growth of the Allium cepa root similar to the root growth of the control samples kept in contact with only mineral water (Figure 2 (e) (f) (g)).

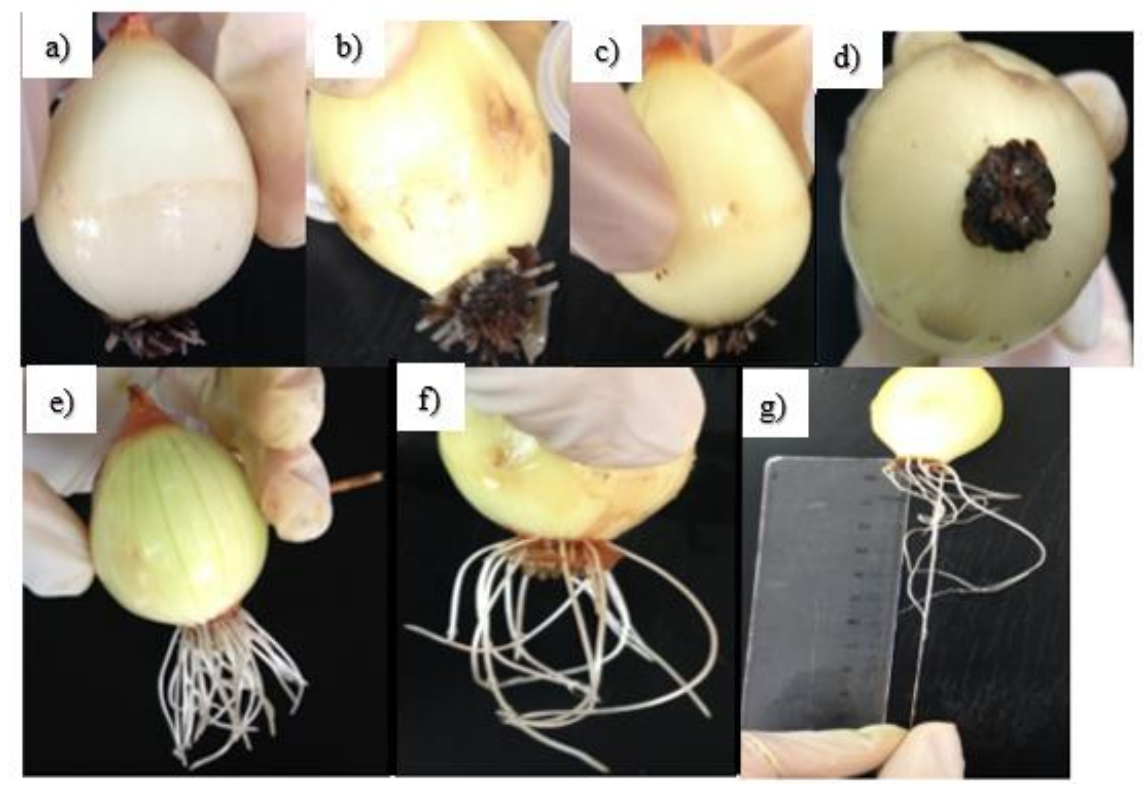

Figure 2. Image of the Allium cepa root grown after the incubation to the toxicity test with the raw effluent for dilutions of a) $1: 10$; b) $1: 8$; c) $1: 6$; and d) without dilution; e) control; f) treated effluent; g) measurement of the bulb root growth immersed in treated effluent.

In Table 2, the medium values of the length of the roots are presented for the samples tested and the mentioned inhibition, in relation to the observed growth in the control. An inhibition of $100 \%$ was verified for the raw effluent and for all its tested dilutions. For the treated effluent, there was root growth under conditions similar to the control bulbs, with maximum inhibition of $13 \%$.

Table 2. Root length (cm) and growth inhibition (\%) after 7 days.

\begin{tabular}{lccc}
\hline Samples tested & Dilution & Root length $(\mathrm{cm})$ & Growth inhibition - ICR (\%) \\
\hline Control & & $9.1 \pm 2.3$ & - \\
\hline \multirow{4}{*}{ Raw Effluent } & $1: 10$ & 0 & 100 \\
& $1: 8$ & 0 & 100 \\
& $1: 6$ & 0 & 100 \\
& without dilution & 0 & 100 \\
\hline \multirow{2}{*}{ Treat effluent } & without dilution & $8.3 \pm 2.5$ & 13.4 \\
\hline
\end{tabular}

Fiskesjö (1985) observed that root growth was inversely proportional to concentrations of determined toxic compounds and heavy metals, such as mercury, copper, zinc and cadmium present in industry effluent. Santos et al. (2010) evaluated formaldehyde toxicity by means of biotests with Allium cepa and, besides growth inhibition, the tests indicated the appearance of micronuclei in bulbs exposed to toxic components caused by mutagenicity. 
Butler et al (2011) observed toxicity reduction in tests with Allium cepa of metallurgical industry effluent after biological treatment. According to the authors, the toxicity reduction occurred due to the removal of metals and of other toxic substances in the effluent treatment process. In this study, despite of the different dilutions tested for the raw effluent, all toxicity tests with Allium cepa indicate $100 \%$ growth inhibition while the treated effluent inhibition was only $13.4 \%$.

\subsection{Tests with Lactuca sativa}

The tests with Lactuca sativa were performed with the same samples of the effluent used for the Allium cepa test. The soaked seeds in the treated effluent had germination potential in all the prepared samples and had root growth similar to the that obtained in the controls. The germination potential and root growth obtained after 4 days in the tested samples can be observed in Figure 3. The relative germination index and the root growth inhibition index are presented in Table 3.
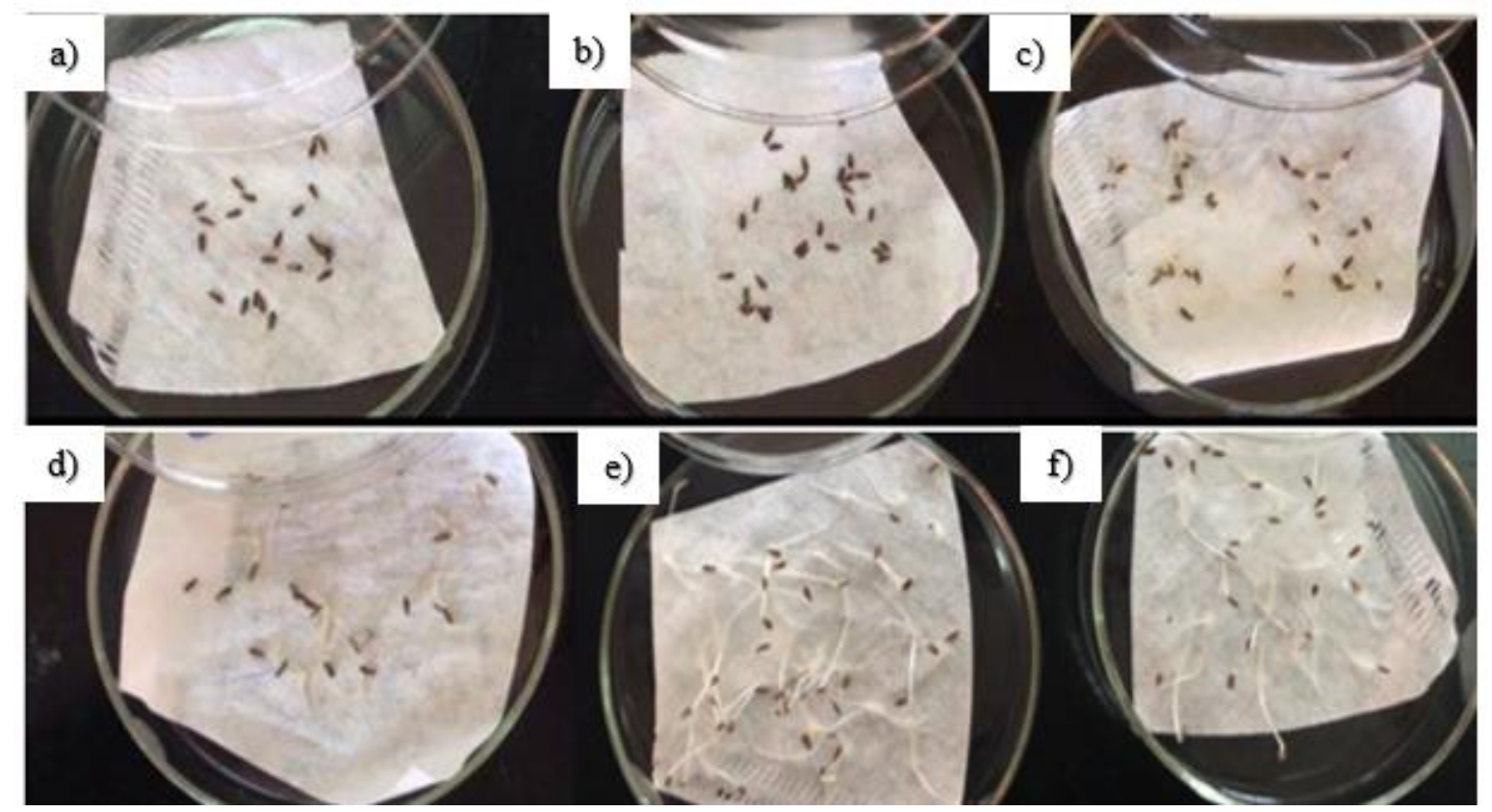

Figure 3. Petri Dishes contain Lactuca sativa seeds soaked in the raw effluent a) without dilution and with dilutions of b) 1:6; c) 1:8; d) 1:10; e) treated effluent; f) control, after 120 hours.

Table 3. Relative Germination (RG) and Root Growth Inhibition (ICRRz) for the raw effluent without dilution and for tested dilutions $(1: 10 ; 1: 8 ; 1: 6)$ and for the treated effluent.

\begin{tabular}{cccc}
\hline Samples tested & Dilution & RG $(\%)$ & ICRRz (\%) \\
\hline \multirow{3}{*}{ Raw effluent } & $1: 10$ & 79 & 44 \\
& $1: 8$ & 22 & 63 \\
& $1: 6$ & 0 & 100 \\
& without dilution & 0 & 100 \\
\hline Treat effluent & without dilution & 100 & 4 \\
\hline
\end{tabular}

Considering that values of ICCR below $80 \%$ indicate a root-growth inhibition effect (Young et al., 2012), it was verified that the raw effluent without dilution and with a dilution of 1:6 showed lethal toxicity to the lettuce seeds, with $100 \%$ inhibition of relative germination. However, for dilutions of 1:8 and 1:10 the toxic effect was less aggressive, classified as sub- 
lethal, making the seeds' germination and root growth possible. For a dilution of 1:8, only one of the triplicates showed germination and root growth for 12 of 60 seeds, while for a dilution of 1:10 potential germination and root growth was found in the all of the triplicates.

There was not germination in tests of raw effluent without dilution and for the dilution of 1:6, probably due to the presence of toxic components, such as formaldehyde. Palácio et al. (2012) obtained 100\% inhibition of the potential germination of Lactuca sativa seeds for the textile industry, with a decrease of the inhibition percentage for the same diluted effluent.

Borba et al. (2008), in a test with Lactuca sativa, identified a reduction of $50 \%$ in the toxicity of furniture industry effluent after the treatment of the effluent by the photo-fenton method. According to the authors, the reduction was due to the removal of organic toxic compounds, such as formaldehyde.

The test with Lactuca sativa showed less resistance of the lettuce seeds to the toxic effect of the effluent when compared to the test performed with Allium cepa. However, both tests showed a low toxicity potential of the treated effluent.

Duffeck et al. (2017) analyzed toxicity of the same effluent used in the present research: raw without dilution and diluted (1:6, 1:8, 1:10), and treated, using the Fish Embryo Toxicity test (FET) in Danio rerio (zebrafish). The authors verified that the raw effluent, even diluted, was toxic to Danio rerio embryos, causing high lethality as early as the first 24 hours of exposure. However, the treated effluent did not cause lethality, nor any sublethal alteration, indicating a decrease of the toxic load after the biological treatment, as was verified in the tests with Allium cepa e Lactuca sativa in this study.

\section{CONCLUSIONS}

Toxicity tests using Allium cepa and Lactuca sativa indicated that the anaerobic followed by aerobic treatment performed was efficient to reduce the toxicity of furniture industry wastewater. The raw effluent without dilution and diluted $(1: 10,1: 8,1: 6)$ showed a toxic effect on the root growth of Allium cepa, since it inhibited root growth by $100 \%$. The raw effluent without dilution and for the dilution of 1:6 inhibited the germination of Lactuca sativa seeds (100\% inhibition); however, there was a partial inhibition, between $44 \%$ and $63 \%$, for dilutions of 1:10 and 1:8 of the raw effluent. The effluent treated by the anaerobic-aerobic process (ASBR-SBR) presented a small percentage of inhibition for tests with Allium cepa and Lactuca sativa seeds (13\% and $4 \%$, respectively).

\section{REFERENCES}

\section{AMERICAN PUBLIC HEALTH ASSOCIATION. Standard Methods for The Examination} of Water and Wastewater. 21 ed. Washington, 2005.

BAILEY, B. W.; RANKIN, J. M. New spectrophotometric method for determination of formaldehyde. Analytical Chemistry, v. 43, n. 6, p. 782 - 84, 1971. https://dx.doi.org/10.1021/ac60301a050

BORBA, F. H.; SOTTORIVA, P. R. S.; MÓDENES, A. N. Tratamento do efluente madeireiro por processo foto-Fenton. Estudos tecnológicos, v. 4, n. 1, p. 12-20, 2008.

BUTLER, B. A.; SMITH, M. E.; REISMAN, D. J.; LAZORCHAK, J. M. Metal removal efficiency and ecotoxicological assessment of field-scale passive treatment biochemical reactors. Environmental Toxicology and Chemistry, v. 30, p. 385-392, 2011. http://dx.doi.org/10.1002/etc.397 
DÜSMAN, E.; LUZZA, M.; SAVEGNAGO, L.; LAUXEN, D.; VICENTINI, V. E. P.; TONAIL, I. B. et al. Allium cepa as bioindicator to measure cytotoxicity of surface water of the Quatorze River, located in Franscisco Beltrão, Paraná, Brazil. Environmental Monintoring and Assessment, v. 186, p. 1793-1800, 2014. https://dx.doi.org/10.1007/s10661-013-3493-8

DUFFECK, C. E.; BOLONHESI-MACHADO, I. B. T.; LOPES, D. D.; MELETTI, P. C. Toxicity of the furniture painting booth effluent to zebrafish (Danio rerio) embryo before and after biological treatment. In: SETAC LATIN AMERICA, 12., 2017, Santos. Proceedings... Santos: Universidade Santa Cecilia, 2017.

FISKESJÖ, G. The Allium test as a standard in environmental monitoring. Hereditas, v. 102, p. 99-112, 1985. https://doi.org/10.1111/j.1601-5223.1985.tb00471.x

LU, Z.; HEGEMANN, W. Anaerobic toxicity and biodegradation of formaldehyde in batch cultures. Water Research, v. 32, n. 1, p. 209 -215, 1998. https://doi.org/10.1016/S00431354(97)00181-4

KAPANEN, A.; ITÄVAARA, M. Ecotoxicity tests for compost applications. Ecotoxicology and Environmental Safety, v. 49, p. 1-16, 2001. https://doi.org/10.1006/eesa.2000.1927

PALÁCIO, S. M.; NOGUEIRA, D. A.; MANENTI, D. R.; MÓDENES, A. N.; ESPINOZAQUIÑONES, F. R.; BORBA, F. H. Estudo da toxicidade de efluente têxtil tratado por foto-fenton artificial utilizando as espécies Lactuca Sativa e Artemia Salina. Engevista, v. 14; n. 12; p. 127-134, 2012. https://dx.doi.org/10.22409/engevista.v14i2.382

PALÁCIO, M. S.; CUNHA, B. M.; ESPINOZA-QUINONES, R. F.; NOGUEIRA, A. D. Toxicidade de metais em soluções aquosas: um bioensaio para a sala de aula. Química Nova na Escola, v. 35, n. 2, p. 79-83, 2013.

PEREIRA, N. S.; ZAIAT, M. Degradation on formaldehyde in anaerobic sequencing batch biofilm reactor (ASBBR). Journal of Hazardous Materials, v.163, p. 777-782, 2009. https://doi.org/10.1016/j.jhazmat.2008.07.028

SANTOS, L. R. A.; AQUINO, F. S.; CARVALHO, F. C.; VIEIRA, A. L.; GONTIJO, J. S. E. Characterization and biological treatability of liquid effluents generated in paint booths of a furniture industry. Sanitary and Environmental Engineering, v. 15, 2010.

SOBRERO, M. S.; RONCO, A. Ensayo de toxicidad aguda con semillas de lechuga. In: CASTILLO MORALES, G. (Ed.). Ensayos Toxicológicos y Métodos de Evaluación de calidad de Aguas: estandarización, intercalibración, resultados y aplicaciones. México: IMTA, 2004.

YOUNG, B. J.; RIERA, N. I.; BEILY, M. E.; BRES P. A.; CRESPO, D. C.; RONCO, A. E. Toxicity of the effluent from anaerobic bioreactor treating cereal residues on Lactuca sativa. Ecotoxicology and Environmental Safety, v. 76, p. 182-186, 2012. https://doi.org/10.1016/j.ecoenv.2011.09.019 


\begin{tabular}{|} 
Ambiente \& Água - An Interdisciplinary Journal of Applied Science \\
ISSN 1980-993X - doi:10.4136/1980-993X \\
www.ambi-agua.net \\
E-mail: ambi.agua@gmail.com
\end{tabular}

\title{
Growth and special structures production of Nostoc paludosum (Nostocaceae, Cyanobacteria) under nutrient starvation and different light intensities
}

\author{
ARTICLES doi:10.4136/ambi-agua.2191 \\ Received: 02 Oct. 2017; Accepted: 12 Oct. 2018
Rafael Barty Dextro ${ }^{*}$; Fellipe Henrique Martins Moutinho²; Cristina Souza Freire Nordi ${ }^{2}$

\begin{abstract}
${ }^{1}$ Universidade Federal de São Carlos (UFSCar), São Carlos, SP, Brasil Departamento de Botânica (DB). E-mail: rafaelbarty@yahoo.com.br

${ }^{2}$ Universidade Federal de São Paulo (UNIFESP), São Paulo, SP, Brasil Departamento de Ecologia (DE).E-mail: fhm.moutinho@gmail.com, cris_nordi@hotmail.com

*Corresponding author
\end{abstract}

\begin{abstract}
The effects of the absence of nitrogen and phosphorus on AA media and three different light intensities (100\% Light, $60.0 \pm 2.7 \mu \mathrm{mol} \mathrm{m}^{-2} \mathrm{~s}^{-1}, 50 \%$ Light, $30.0 \pm 2.7 \mu \mathrm{mol} \mathrm{m}^{-2} \mathrm{~s}^{-1}$, and $13.5 \%$ Light, $8.1 \pm 2.7 \mu \mathrm{mol} \mathrm{m}^{-2} \mathrm{~s}^{-1}$ ) on cell production and synthesis of heterocytes and akinetes were determined in a strain of Nostoc paludosum. In the experiment concerning the absence of nutrients, significant variations were observed between the control group and the groups with absence of nutrients, especially in cell numbers and in synthesis of heterocytes and akinetes. The absence of nitrogen boosted the formation of heterocytes and the absence of phosphorus produced the most akinetes. As for the different light conditions, the growth curves determined for each treatment showed that cell synthesis is slightly affected by the reduction of illuminance. The different light intensities are capable of reducing the maximum growth rates of Nostoc paludosum, with $13.5 \%$ light restriction being the most effective on limiting the cell growth rate and inducing the formation of akinetes. The synthesis of heterocyte does not seem directly correlated to light intensity, being better explained by nutritional factors. The data found contributes to the understanding of some of the factors involving growth and synthesis of special structures in Nostoc paludosum.
\end{abstract}

Keywords: Limnology, microbiology, nostocales.

\section{Crescimento e produção de estruturas especiais em Nostoc palusodum (Nostocaceae, Cyanobacteria) sob limitação nutricional e diferentes intensidades luminosas}

\section{RESUMO}

O efeito da ausência de nitrogênio e fósforo em meio AA e de três diferentes intensidades luminosas (100\% Luz, $60.0 \pm 2.7 \mu \mathrm{mol} \mathrm{m}^{-2} \mathrm{~s}^{-1}, 50 \% \mathrm{Luz}, 30.0 \pm 2.7 \mu \mathrm{mol} \mathrm{m} \mathrm{m}^{-2} \mathrm{~s}^{-1}$, e $13.5 \% \mathrm{Luz}$, $\left.8.1 \pm 2.7 \mu \mathrm{mol} \mathrm{m} \mathrm{m}^{-2} \mathrm{~s}^{-1}\right)$ sobre a quantidade de células e síntese de heterócitos e acinetos foi determinada em uma cepa de Nostoc paludosum. No experimento de limitação nutricional, 
variações significantes foram observadas entre o grupo controle e os grupos com ausência de um nutriente, especialmente em relação ao número de células e na síntese de heterócitos e acinetos. A ausência de nitrogênio induziu a formação de heterócitos e a falta de fósforo produziu a maior quantidade de acinetos. Para as diferentes condições luminosas, as curvas de crescimento de cada tratamento mostraram que a síntese celular é afetada pela redução de luminosidade. As diferentes intensidades de luz são capazes de alterar a taxa máxima de crescimento de Nostoc paludosum, sendo o grupo de $13.5 \%$ de luz o mais afetado e no qual há maior formação de acinetos. A síntese de heterócitos não parece ter relação direta com a intensidade luminosa, sendo melhor explicada pelos fatores nutricionais. Os resultados obtidos contribuem para a compreensão de fatores envolvendo o crescimento e a síntese de estruturas especiais em Nostoc paludosum.

Palavras-chave: limnologia, microbiologia, nostocales.

\section{INTRODUCTION}

Cyanobacteria are frequently a dominant group of primary producers in freshwaters, especially reservoirs, lakes and waters retained by dams. In Brazil, these water bodies are generally shallow and with a long residence time, generating advantageous conditions for the development and dominance of cyanobacteria (Sant'Anna et al., 2007). It is well known that these water bodies can be directly affected by human activities, reaching a eutrophic state in which there is an increase of nutrient concentrations, especially phosphorus and nitrogen.

Some cyanobacteria, such as the genera Dolichospermum, Anabaena and Nostoc, possess morphological plasticity in the vegetative cells that form the trichomes, a reflection of differential gene expression (Lyra et al., 2001), allowing them to alter cellular structures in order to form akinetes and heterocytes, which are highly specific cells.

Akinetes are specialized cells, generated from vegetative cells, which have thickened cell walls and can store large amounts of reserve substances (Braune, 1980). The akinetes play an important role in cyanobacterial reproduction, also acting as a resistant cell that can remain dormant in the sediment when environmental conditions are unfavorable.

Heterocytes are also specialized cells present in some filamentous cyanobacteria that give them the capacity to fix atmospheric nitrogen under light. They are different from the other vegetative cells because of their thick cell walls, pores in each of their extremities and different cytoplasm organization (Haselkorn et al., 1993). Through these pores, selective exchanges of materials occur with neighboring cells.

The alteration of the nutrient composition in the growth media has been explored by several studies, using different species of organisms. In Healey and Hendzel (1979), five species of freshwater algae are submitted to various degrees of nitrogen $(\mathrm{N})$ and phosphorus $(\mathrm{P})$ limitation. Their analyses was focused on metabolic activity, with little to no evaluation of the algae's morphologies.

The evaluation of the effects of the removal of specific nutrients is also commonly found in the literature. One of the most-studied nutrients is nitrogen, since its removal causes great alterations in growth patterns and can induce the formation of special structures in some species of cyanobacteria (Healey and Hendzel, 1979; Haselkorn et al., 1993; Nalewajko and Murphy, 2001 and Zapomělová et al., 2008b). Other focus nutrients studied include zinc, phosphorus and copper due their physiological and environmental significance.

Light intensity is a very important factor in microorganisms' cultivation. Each species normally presents a range of optimal illuminance associated with their photosynthetic apparatus. An excess or reduction of light can severely alter cell morphology and the cyanobacteria's growth pattern (Tonk et al., 2005). 
Because of the occurrence of blooms associated with the production of toxins and unpleasant taste and odor in freshwater, studies of cyanobacteria control and monitoring in reservoirs, which provide drinkable water for millions of people in major cities, can prevent serious environment and public health problems. A detailed understanding of the production of akinetes and heterocytes is crucially important for the future control of these cyanobacteria populations in natural environments. There are many researchers evaluating how these structures are produced and the factors involved in their synthesis, especially the aspects that trigger their formation. The majority of the recent studies are done using the Dolichospermum, Anabaena and Cylindrospermopsis genera (Zapomělová et al., 2008a; 2008b), which are more abundant and dominant in natural environments. Nevertheless, studies using other cyanobacteria as models are just as important to provide a wider spectrum of how akinetes and heterocytes are linked with these organisms' biology.

Apart from its ecological role as a member of the phytoplankton, the species Nostoc paludosum Kützing ex Bornet and Flahault 1888 is currently being used or shows potential to be used in various applications: antibiotic production, phycobiliprotein-pigment extraction, fatty acid production and agricultural use in root nodules (Temina et al., 2007; Pankratova et al., 2008). However, there has been little research concerning its biology and none evaluating its reaction to different growth conditions. The main purpose of this study was to monitor the morphological changes that occur in trichomes by quantifying vegetative cells, akinetes and heterocytes of Nostoc paludosum during different phases of growth in laboratory-controlled conditions.

\section{MATERIALS AND METHODS}

The inoculum of Noctoc paludosum used in these experiments was provided by Dr. Armando Augusto Henriques Vieira from the algae bank of the Botany Department of UFSCAR/ São Carlos Campus (strain 145). This particular strain was collected from the Monjolinho pond, from a preserved cerrado area in the city of São Carlos. In the natural habitat, this strain presented an epiphytic habit, which is characteristic for the genus Nostoc. All the samples were maintained in AA medium (Allen and Arnon, 1955) and in controlled temperature conditions $\left(25 \pm 1^{\circ} \mathrm{C}\right)$ and light/dark cycle $(12 \mathrm{~h}: 12 \mathrm{~h})$ in a greenhouse (ElectroLab $®$, Model EL202/4) with maximum internal luminous intensity of $175 \mu \mathrm{mol} \mathrm{m}^{-2} \mathrm{~s}^{-1}$ produced by white fluorescent lights.

\subsection{General methodology}

All cultures were grown in an axenic state and in Mariotte's bottles because their inferior exit makes it easier for samples to be taken. All the manipulation done to the culture bottles was done in a laminar flow chamber. The inoculums were allowed to grow for 5 days in AA medium prior to the experiments. An equal sample for all groups was taken and transferred to the Mariotte's bottles for each experimental group and their replicates, totaling 3 bottles for each experimental condition. The total duration of the experiment was 30 days, with sampling being done daily until day 10; afterwards, it was done every other day until the end of the experiment. The samples taken contained the same volume $(3 \mathrm{~mL})$, and lugol $(1 \%)$ was used to fix them as soon as they were removed.

\subsection{Morphological Evaluation}

The morphology of the cells, the cell number and the production of akinetes and heterocytes in each sample were analyzed and counted daily using a Labomed 400x optical microscope. The number of cells, heterocytes and akinetes were observed in a Sedwick-Rafter counting chamber using the score from 50 squares in horizontal and vertical transects. The following confidence interval Equation 1 was applied after 50 squares were counted:

\section{IPABH}

Rev. Ambient. Água vol. 13 n. 6, e2191 - Taubaté 2018 
$A=t_{n} \sqrt{\frac{X \cdot(N-n)}{(N \cdot n)}}$

Being:

A - count error;

$\mathrm{X}$ - total cell number found divided by number of squares counted;

$\mathrm{t}$ - t-test (n-1), using 0.05 as significance level;

$\mathrm{N}$ - total squares on the Sedwick-Rafter chamber $(\mathrm{N}=1000)$;

$\mathrm{n}$ - number of squares counted.

After each application of the test, the number of cells was only accepted if it produced a count error of $25 \%$ or less. When the error passed this limit, 10 additional squares were counted and the equation was reapplied until the results were within desired maximum error. After the counting was done for all the samples, an average of each group resulted in a final number of average cell production, average heterocytes and average akinetes per day. This data was used to produce the growth curves and the special structures synthesis graphs.

Measurements were also performed for each experimental group on days 5, 10 and 20. A hundred vegetative cells, heterocytes and akinetes were measured for each bottle each day. The measured cells were selected randomly and they could not belong to the same trichome. An ANOVA test (Excel 2013) was used to determine the statistical significance of the size variation observed between treatments. During the measurements, the positioning of the heterocytes and akinetes along the trichome was recorded.

\subsection{Absence of Nitrogen and Phosphorus Experiment}

Modified AA medium was used in two different formulations: the first without nitrogen source (ammonium metavanadate) and the other without phosphorus (lacking potassium phosphate). A third treatment was used as a control, containing the original AA medium, and all of these treatments were done with triplicates. The nutrient-absent media had their $\mathrm{pH}$ corrected to a value similar to that of the regular AA medium used in the control group (approximately 6.85). All treatments were exposed to the same light intensity of approximately $120.0 \pm 0.9 \mu \mathrm{mol} \mathrm{m} \mathrm{m}^{-2} \mathrm{~s}^{-1}$, measured inside the bottles with culture media. To ensure that no bottle was favored, their positions were daily switched inside the greenhouse. The experiment duration was 29 days, with daily samples taken as explained in the General Methodology section. The initial inoculum for each treatment was kept the same, at approximately $1.00 \times 10^{5}$ cells per $\mathrm{mL}^{-1}$. The data gathered permitted the construction of growth curves and the bar graphs representing the production of the specialized cells (akinetes and heterocytes) using Igor Pro 6.3 software. The number of cells per day was obtained by calculating the average value between all three replicates of each treatment. Standard deviation of each day was also calculated. The maximum specific growth rates per day $\left(\mu_{\max } /\right.$ day $)$ were calculated by linear fitting of $\ln$ values of growth curve in $\log$ phase and were used to determine the duplication time during log phase. Apart from cell number and akinete/heterocyte productions, the shape, size and position of cells and specialized cells was also evaluated, as was trichome fragmentation and number of heterocytes per trichome.

\subsection{Light Experiment}

The three light conditions evaluated were: total light intensity $(100 \%$ light $=60.0 \pm$ $\left.2.7 \mu \mathrm{mol} \mathrm{m} \mathrm{m}^{-2} \mathrm{~s}^{-1}\right)$; partial light intensity $\left(50 \%\right.$ light $=30.0 \pm 2.7 \mu \mathrm{mol} \mathrm{m}^{-2} \mathrm{~s}^{-1}$, obtained with the effect of covering the Mariotte's bottle with black tulle fabric); and restricted light intensity 
$\left(13.5 \%\right.$ light $=8.1 \pm 2.7 \mu \mathrm{mol} \mathrm{m} \mathrm{m}^{-2} \mathrm{~s}^{-1}$, obtained with the effect of covering the Mariotte's bottle with black TNT fabric). All of these treatments were done with triplicates. The light measurements were done with a manual and portable light meter and these light intensities were determined inside the bottles with culture media. To ensure that no bottle was favored, their positions were daily switched inside the greenhouse. All conditions were maintained in AA medium, with the total light intensity treatment used as a control. The experiment duration was 30 days, with daily samples taken as explained in the General Methodology section. The initial inoculum for each treatment was kept the same, at approximately $2.50 \times 10^{6}$ cells per $\mathrm{mL}^{-1}$. The data gathered permitted the construction of growth curves and the bar graphs representing the production of the specialized cells (akinetes and heterocytes) using Igor Pro 6.3 software. The number of cells per day was obtained by calculating the average value between all three replicates of each treatment. The standard deviation for each day was also calculated. The maximum specific growth rates per day $\left(\mu_{\max } /\right.$ day) were calculated by linear fitting of $\ln$ values of the growth curve in the log phase and were used to determine the duplication time during the log phase. Apart from the cell number and akinete/heterocyte production, the shape, size and position of cells and specialized cells was also evaluated, as was trichome fragmentation and the number of heterocytes per trichome.

\section{RESULTS AND DISCUSSION}

\subsection{Absence of Nitrogen and Phosphorus Experiment}

Growth curves using the average number of total cells counted for each treatment were produced for the first experiment (Figure 1). A growth curve displaying only the log and stationary phases was obtained for the control group, whereas the nitrogen-absent and phosphorus-absent groups displayed a different pattern, with a slight drop after the stationary phase.

The control group showed a considerably larger number of cells when compared to the other two groups, which produced an average of 100 times less cells than the control. As for the maximum specific growth rate of each treatment, the control showed the highest value when compared to the other treatments $\left(\mu_{\max }=0.814\right.$ day $^{-1}$ for the control, $\mu_{\max }=0.598$ day $^{-1}$ for nitrogen-absent and $\mu_{\max }=0.592$ day $^{-1}$ for phosphorus-absent). The control group duplication time was 5 hours ( $299 \pm 12$ minutes), much lower than the duplication time exhibited in the nitrogen-absent group (14 hours or $842 \pm 7$ minutes) and in the phosphorus-absent group (13 hours or $785 \pm 11$ minutes).

Although the heterocyte synthesis followed a similar pattern in the nutrient-absent groups, the quantities were significantly higher in the nitrogen-absent group throughout the experiment (Figure 2A). The control group presented the smallest values for heterocytes per cell among all groups and during throughout the experiment. The synthesis of heterocytes in the nutrientabsent groups peaked during the log phase, in the beginning of the experiment, then increased continuously after the eighth day of experiment, with the highest value observed at the end of the experiment (at day 20).

The presence of akinetes was only considerably noticeable at the end of the experiment (Figure 2B), with the highest frequency occurring in the phosphorus-starved group on the last day of the experiment $\left(0.0361\right.$ akinete per cell or 16,360 akinetes $\left.\mathrm{mL}^{-1}\right)$. 


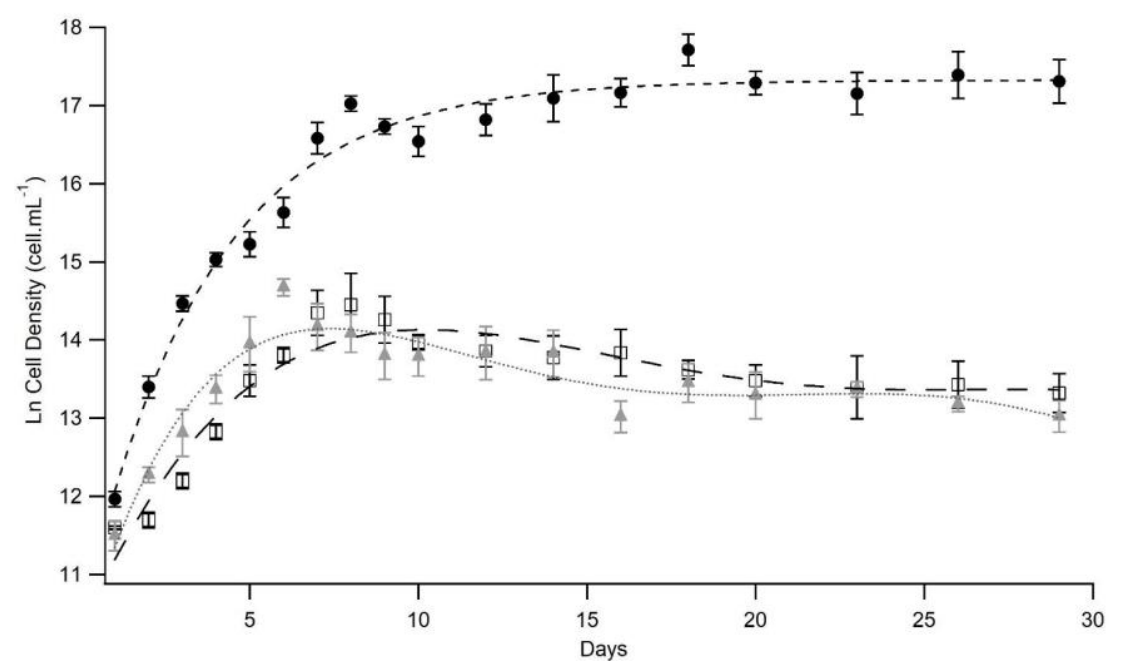

Figure 1. Comparison among the growth performance of Nostoc paludosum in the control group (•), nitrogen-absent group ( $\square$ ) and phosphorus-absent group $(\rightarrow)$ with respective trend lines and standard deviation.
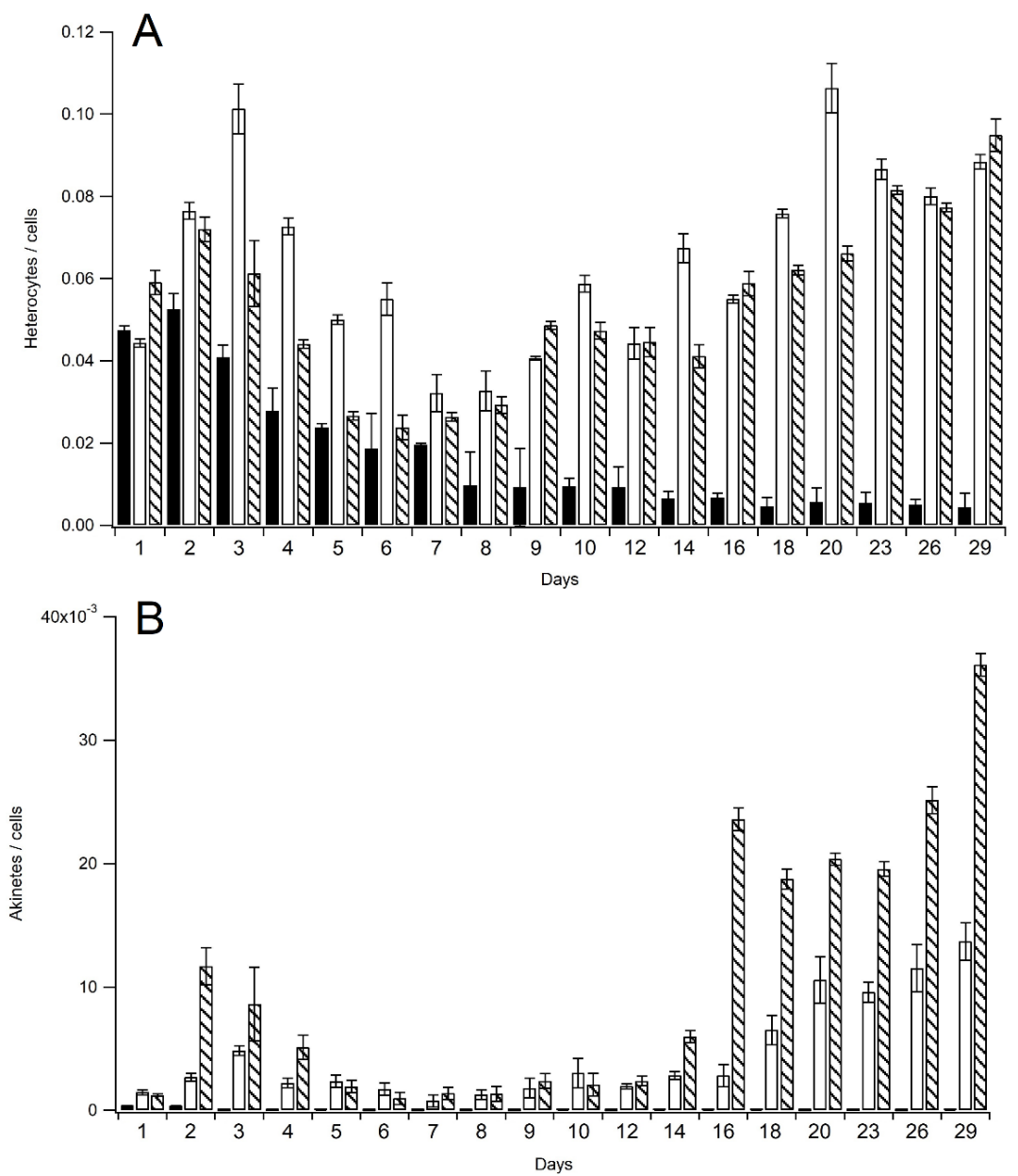

Figure 2. Average heterocyte (A) and akinete (B) production per cell of Nostoc paludosum grown in the control group ( $\mathbf{\square})$, nitrogen-absent group ( $\square$ ), and phosphorus-absent group $(\mathbb{\Xi})$, with respective standard deviation. 
As for the variation in size of vegetative cells, heterocytes and akinetes, statistically significant differences were observed between the control, nitrogen-absent and phosphorusabsent groups (Table 1). The largest and the smallest vegetative cells on all days measured were in the control group and in the phosphorus-absent group, respectively. The bigger heterocytes were found in the nitrogen-absent group, while the data for akinetes showed no statistical difference. A severe fragmentation of the trichomes was observed in the phosphorus- and nitrogen-absent groups, especially after the log phase. Differences in morphology and position of the heterocytes on the trichomes were present significantly in the nitrogen-absent group, with double and triple heterocytes occurring in between vegetative cells and terminal heterocytes at the end of some trichomes. Similarly, variations in size and position of akinetes were seen more prominently in the phosphorus-absent group.

Table 1. Mean size $(\mu \mathrm{m})$ with standard deviation (s.d.) of vegetative cells $(\mathrm{V})$, heterocytes $(\mathrm{H})$ and akinetes $(\mathrm{A})$ on days 5, 10 and 20 of the experiment for each of the three experimental groups.

\begin{tabular}{lcccc}
\hline \multirow{2}{*}{ Groups } & & Day 5 & Day 10 & Day 20 \\
\cline { 3 - 5 } & & Mean \pm s.d. & Mean \pm s.d. & Mean \pm s.d. \\
\hline \multirow{3}{*}{ Control } & V & $3.66 \pm 0.56^{* *}$ & $3.69 \pm 0.67 * *$ & $3.45 \pm 0.64 * *$ \\
& H & $4.69 \pm 0.71^{* *}$ & $4.64 \pm 0.75^{* *}$ & $4.19 \pm 0.95^{* *}$ \\
& A & $-*$ & $5.85 \pm 1.14$ & $5.32 \pm 0.33$ \\
\hline \multirow{3}{*}{ Nitrogen Absence } & V & $3.55 \pm 0.84^{* *}$ & $3.06 \pm 0.62^{* *}$ & $2.89 \pm 0.59 * *$ \\
& H & $4.96 \pm 0.83^{* *}$ & $5.09 \pm 1.03^{* *}$ & $4.42 \pm 0.79^{* *}$ \\
& A & $-*$ & $5.06 \pm 0.78$ & $5.02 \pm 0.45$ \\
\hline \multirow{3}{*}{ Phosphorus Absence } & V & $3.12 \pm 0.61 * *$ & $2.49 \pm 0.48^{* *}$ & $2.22 \pm 0.32^{* *}$ \\
& H & $4.35 \pm 1.14^{* *}$ & $3.70 \pm 0.60^{* *}$ & $3.54 \pm 0.85^{* *}$ \\
& A & $-*$ & $5.74 \pm 1.04$ & $5.26 \pm 1.11$ \\
\hline
\end{tabular}

$*(-)$ indicates no data; $* *$ Differences observed are statistically significant (ANOVA test $\mathrm{p}<0.05)$.

\subsection{Nitrogen and Phosphorus starvation effects on cell growth}

According to the growth curves, in the conditions without nutrients there was an initial growth, but at a reduced pace (smaller $\mu_{\max }$ and a duplication time almost three times longer) and with an inferior maximum cell number achieved along the growth curve when compared to the control culture. This rapid initial growth observed in all treatments can be explained by the capability of these cyanobacteria of storing phosphate as polyphosphate bodies (Lee, 2008), demonstrating that this nutrient was consumed to provide energy for the first growth event. This same strategy has already been described in the literature as a major survival factor of the genus Anabaena in low-phosphorus environments (Nalewajko and Murphy, 2001; Zapomělová et al., 2008a) and also for the Cylindrospermopsis genus (Willis et al., 2015). It seems that this reserve was consumed in the initial days of the experiment, resulting in the lowest cell production, smaller cell size and an early stationary phase in the groups with nutrient deficiencies. The maximum specific growth rates and the duplication time obtained show that for the first seven days of the experiment (the exponential phase) the nitrogen- and the phosphorus-absent populations increased much less than the control group, for which cell density at the seventh day was almost four times bigger than the other groups. The occurrence of cell division and growth in the nutrient-absent treatments proves the nutrient storage capability of the Nostoc paludosum, but their reduced rate (with a reduction of $30 \%$ in the $\mu_{\max }$ of the nutrient-absent treatments and an increment of almost 3 times at their duplication time during the log phase) in comparison to the control provides evidence as to the importance of both nutrients' presence in 
order to support the optimum growth of this cyanobacteria.

During the daily sampling of the phosphorus-absent group, tangling and fragmentation of the trichomes was observed, which was similarly seen with the nitrogen-absent group. Zapomělová et al. (2008a) discussed that phosphorus deficiency can reduce the size of the vegetative cells, generating morphospecies of Anabaena circinalis and Anabaena crassa (currently as Dolichospermum circinalis and D. crassum). There were alterations seen in trichome length, showing that the reduction of nutrients can induce fragmentation especially during the log phase, in which growth is dependent on a large number of different nutrients in the culture medium (Nalewajko and Murphy, 2001).

The growth in the nitrogen-absent group occurred at a lower rate than the control group and almost at the same rate as the phosphorus group, showing that the nutrient-starvation conditions are indeed a negative growing state when compared to normal conditions (control). Similar results were obtained in studies evaluating other species of cyanobacteria in which the absence of phosphorus caused irregular cell-membrane formation and reduced overall cell division (Chevalier et al., 2000).

\subsection{Nitrogen and Phosphorus starvation effects on heterocytes and akinetes synthesis}

As for the synthesis of heterocytes, it is noticeable that this structure was produced in all treatments, in different intensities and mainly in the stationary phase of growing, as normally happens due the decrease of nutrients in the culture. The lower rates of heterocyte per cell were recorded in the control group, which support the idea that the synthesis of this structure is related to stressful nutritional conditions (Willis et al., 2015, Guo et al., 2016). It is discussed by many researchers that nitrogen limitation is the main factor that starts the formation of heterocytes in cyanobacteria (Adams and Carr, 1981; Haselkorn et al., 1993 and Zapomělová et al., 2008b) and, while this fact was observed in this study, we add the information that the stress caused by the absence of phosphorus in the medium can also trigger the synthesis of special structures in Nostoc paludosum.

The more evident differences in morphology, size and position of the heterocytes on the trichomes were present in the nitrogen-absent group, where the heterocytes were significantly larger than those found on the other treatments. Apparently, these differences are related to the amount of nutrient dissolved in the medium, as analyzed in laboratory conditions by Zapomělová et al. (2008b), in which a great variation of the heterocyte's positions are shown. The relationship observed in this study between the absence of phosphorus and heterocyte synthesis differs from the data of Zapomělová et al. (2008b), in which it is described that this nutrient has little influence on heterocyte production.

The position of the heterocytes in the trichome was the most remarkable trace found in this study, with terminal and intercalary heterocytes being found in all treatments. The nitrogenabsent group also displayed rarer positions, such as double- and triple heterocytes and heterocytes next to akinetes. In the literature, these variations of position are related to stressful growth conditions such as the absence of vital nutrients developed in our study or also high light intensity combined with nitrogen starvation, shown in studies using Anabaena cylindrica (Adams and Carr, 1981), another species of the Nostocales order. Muro-Pastor and Hess (2012) argue that the differentiation of heterocytes is a delicate and precise intracellular process that requires optimal regulation and cell communication to properly occur. Stressful environmental conditions, such as the one created by our experiments (lack of nutrients) can cause negative effects on intracellular communication and on regulatory pathways, leading to abnormal heterocyte positioning on the trichome.

The akinete synthesis is strongly related to late phases of the growing curve, associated with the deficiency of nutrients characteristic of these stages in batch cultures. The phosphorusabsent treatment showed the higher production of akinetes. It was also in this group that most 
variations of position and morphology of akinetes were observed. Zapomělová et al. (2008b) discuss in their study that akinete production in the genus Anabaena varies with the nutritional state of the medium, altering the dimensions and form of this structure. Light seems to also play a crucial role in the synthesis of akinetes, as examined in the different light intensities experiment of this study. The significantly high values of akinetes observed in the final days of the experiment in the phosphorus-absent group clearly show the importance of this nutrient in maintaining a healthy cellular state. Therefore, the general observations regarding the effects of nutrient starvation on growth, synthesis and abnormal positioning of heterocytes and akinetes on Nostoc paludosum provide significant information about this cyanobacteria's biology.

\subsection{Light Experiment}

The growth curves show that all treatments produced similar growth trend lines, with the $100 \%$ light culture producing the higher quantities of cells, followed by the $50 \%$ light group (Figure 3). The log phase was short, followed by a stationary phase with high cell density and, after the tenth day, cell numbers decreased continuously for all treatments. A death phase was observed at the end of the experiment for all groups. The average cell number decreased with the light intensity. As for the maximum specific growth rate of each treatment, the total light treatment showed the highest value when compared to the other treatments $\left(\mu_{\max }=1.515\right.$ day $^{-1}$ for $100 \%$ light, $\mu_{\max }=0.874$ day $^{-1}$ for $50 \%$ light and $\mu_{\max }=0.689$ day $^{-1}$ for $13.5 \%$ light). All experimental treatments presented similar duplication times of approximately 4 hours $(201 \pm$ 4 minutes for $100 \%$ light, $204 \pm 9$ minutes for the $50 \%$ light and $238 \pm 14$ minutes for the $13.5 \%$ light).

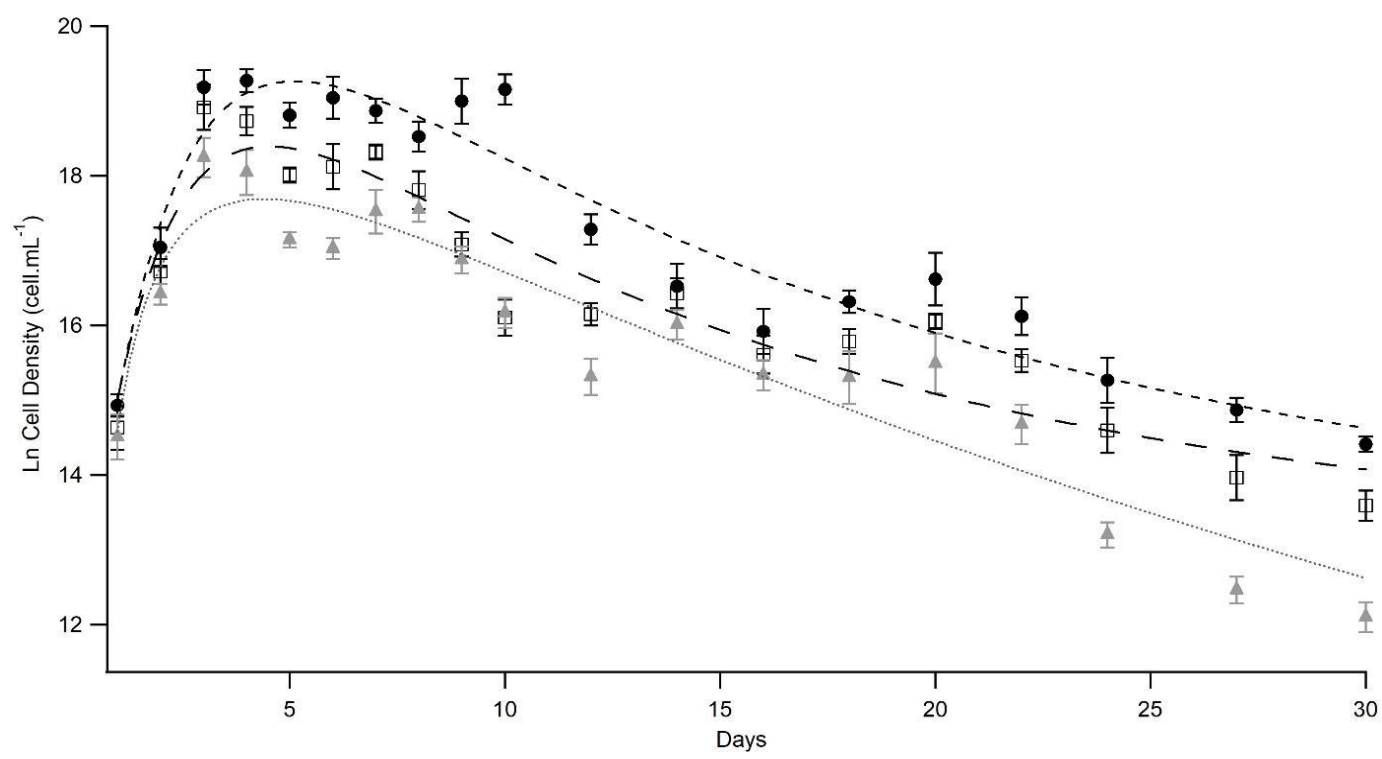

Figure 3. Comparison of the growth performance of Nostoc paludosum in the $100 \%$ / total light group $(\bullet), 50 \%$ / partial light group $(\square)$ and $13.5 \%$ / restricted light group $(\triangle)$, with respective trend lines and standard deviation.

The average heterocyte frequency per cell (Figure 4A) shows that all treatments produced small amounts of this structure during most of the experiment's duration. Only on the $24^{\text {th }}$ day and beyond was a considerable amount of heterocytes per cell registered for the severely restricted light group (13.5\%). This trend was also observed at the 50\% light group in the two final sampling points of the experiment.

The presence of akinetes (Figure 4B) only occurred significantly at the end of the experiment and only in the severely restricted light intensity (13.5\% light) group. The highest synthesis of akinetes happened on the $30^{\text {th }}$ day ( 0.08 akinete per cell or 14360 akinetes $\left.\mathrm{mL}^{-1}\right)$.

\section{IPABH}

Rev. Ambient. Água vol. 13 n. 6, e2191 - Taubaté 2018 

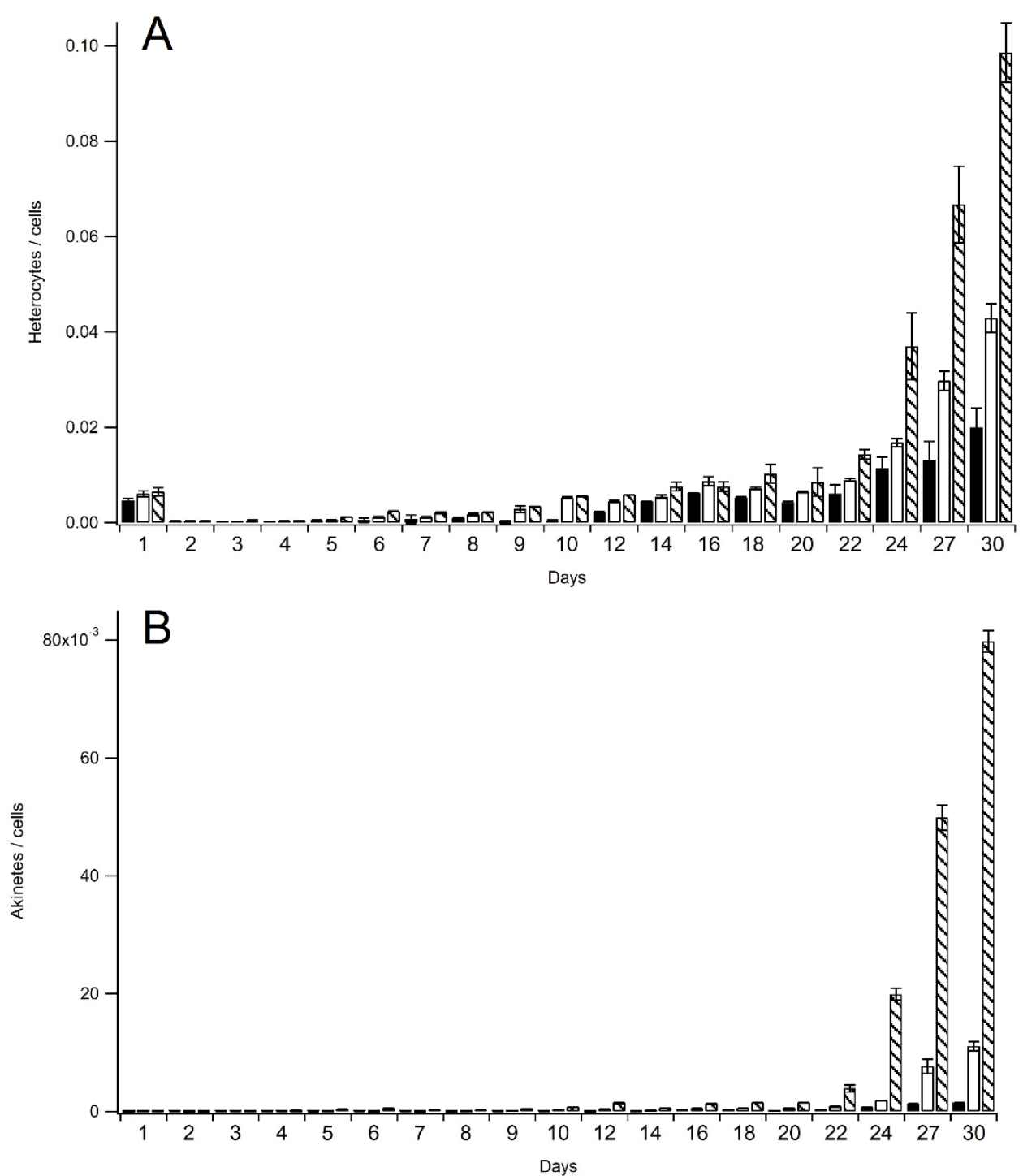

Figure 4. Average heterocyte (A) and akinete (B) production per cell of Nostoc

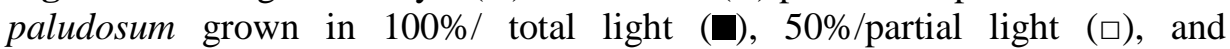
$13.5 \% /$ restricted light $(\mathbf{\nabla})$, with respective standard deviation.

Variation in the size of vegetative cells, heterocytes and akinetes was observed for each light treatment (Table 2). The only statistically significant result obtained was for the akinetes' size, with the largest occurring in the 13.5\%/restricted-light group. Vegetative cells and heterocytes data were not statistically different. Considerable fragmentation of the trichomes was observed in the restricted-light intensity (13.5\% of the total light) group, especially after the fifth day of the experiment. Differences in the morphology and position of the heterocytes on the trichomes were not observed; however, variations in the size and position of akinetes were noticed in the restricted-light group.

\subsection{Effects of light intensity on cell growth}

The higher light-restriction treatments had a slightly smaller initial yield when compared to the $100 \%$ light group during the exponential phase. When directly compared to the total light group, the $13.5 \%$ light treatment had a fourfold mean reduction in cell production, indicating a direct correlation between light intensity, cell division and, consequently, photosynthesis. It helps to explain how the cyanobacteria are capable of colonizing most of the photic zone. Even with severe light-intensity reduction, which resembles a deeper depth in the natural 
environment, the Nostoc paludosum was capable of surviving and producing high cell density. Other species of the Nostoc genera were observed to form a non-characteristic morphotype under severe luminosity reduction conditions (Lazaroff and Vishniac, 1961), returning to regular cell morphology when exposed to light again. The main hypotheses for the formation of morphotypes is that the presence of light is responsible for the synthesis of light-dependent morphogenic substances that induce normal growth and morphology. In our work. In our work, there were no significant morphologic alterations observed in any of the treatments, probably due the short duration of the experiments.

Table 2. Mean size $(\mu \mathrm{m})$ with standard deviation (s.d.) of vegetative cells $(\mathrm{V})$, heterocytes $(\mathrm{H})$ and akinetes $(\mathrm{A})$ on days 5,10 and 20 of the experiment for each of the three experimental groups.

\begin{tabular}{lcccc}
\hline \multirow{2}{*}{ Groups } & & Day 5 & Day 10 & Day 20 \\
\cline { 2 - 5 } & & Mean \pm s.d. & Mean \pm s.d. & Mean \pm s.d. \\
\hline \multirow{3}{*}{ 100\% Light } & V & $3.55 \pm 0.84$ & $3.36 \pm 0.62$ & $3.18 \pm 0.32$ \\
& H & $4.96 \pm 0.83$ & $5.09 \pm 1.03$ & $4.42 \pm 0.79$ \\
& A & $-*$ & $5.05 \pm 0.78^{* *}$ & $5.08 \pm 0.45^{* *}$ \\
\hline \multirow{3}{*}{ 50\% Light } & V & $3.24 \pm 0.61$ & $3.09 \pm 0.48$ & $2.98 \pm 0.32$ \\
& H & $4.35 \pm 1.14$ & $4.70 \pm 0.60$ & $4.34 \pm 0.85$ \\
& A & $-*$ & $5.69 \pm 1.04^{* *}$ & $5.76 \pm 1.11^{* *}$ \\
\hline \multirow{3}{*}{$13.5 \%$ Light } & V & $3.34 \pm 0.81$ & $2.89 \pm 0.36$ & $2.75 \pm 0.44$ \\
& H & $4.48 \pm 0.77$ & $4.81 \pm 0.83$ & $4.42 \pm 0.70$ \\
& A & $5.47 \pm 0.57$ & $6.24 \pm 0.89^{* *}$ & $6.39 \pm 1.01 * *$ \\
\hline
\end{tabular}

*(-) indicates no data; **Differences observed are statistically significant (ANOVA test $\mathrm{p}<0.05$ ).

Other research using Nostoc flagelliforme showed that increased light intensity (up to $200 \mu \mathrm{mol} \mathrm{m} \mathrm{m}^{-2} \mathrm{~s}^{-1}$ ) combined with the addition of $\mathrm{CO}_{2}$ enhances the yield of cell production by several times without major cell damage caused by high-light conditions (Gao and $\mathrm{Yu}, 2000$ ). However, there are other cases when reduced light intensity serves as a stimulus to growth. A comparison between the Planktothrix and Dolichospermum genus (cited as Oscillatoria and Anabaena) has showed that under 6 hours of light exposure (a short period) and low light intensity, the Planktothrix genus is benefited, growing faster and producing more cells than the Dolichospermum (Foy et al., 1976). The Dolichospermum genus is considered a dominant cyanobacteria in natural environments, which would make sense for it to be adapted to growth better under higher light intensities in order to outgrow other competitors on the phytoplankton. The Nostoc genus is not a dominant or common representative of the phytoplankton in most aquatic ecosystems, but in extreme habitats such as the polar regions or temperate climates this genus might represent a significant portion of the phytoplankton community (Vincent, 2000; Pócs, 2009). It has been shown that this genus benefits from periods of long, low-intensity light exposure, such as the ones found in colder environments. For the light cycle used in our experiment (12:12), the light intensity tested proved to be lower than necessary for optimum growth of the control group.

However, a great decline in cell density is noticeable in our experiment after the tenth day in all experimental groups. Differently from our control group of the previous experiment, this culture did not maintain its cell density for the rest of the experiment. One explanation is the self-shading effect suffered by the culture after its great density after the exponential phase, which could have greatly affected the photosynthetic capacity of the cells (Kaplan-Levy et al., 2010). Nonetheless, this effect may only partially explain this steep drop. Our decision to 
maintain the control group under the light intensity of $60.0 \pm 2.7 \mu \mathrm{mol} \mathrm{m} \mathrm{m}^{-2} \mathrm{~s}^{-1}$ may have caused some extent of stress or may have proven to be less light than the Nostoc paludosum really requires to grow ideally, as observed in the control group of the nutrient-absent experiment, which was exposed to $120 \mu \mathrm{mol} \mathrm{m} \mathrm{m}^{-2} \mathrm{~s}^{-1}$. The decision to reduce the maximum light intensity for the control group between experiments was based on many studies in the literature that claim that optimal light intensity for several Nostocales species varies from 50 to $75 \mu \mathrm{mol} \mathrm{m} \mathrm{m}^{-2} \mathrm{~s}^{-1}$ (Saker and Neilan, 2001, Moore et al., 2005; Dyble et al., 2006). Another factor that may explain the observation of the decline in cell density in all groups was the value of inoculum used in this experiment (which was 250 times larger than the inoculum of the nutrient deficiency experiment). The much larger population of cells demanded a great amount of nutrients to maintain itself, which may have become a restricting factor after the tenth day. This is supported by the fact that the cell density of the all treatments in the light experiment were higher than the density observed in the control group of the previous experiment $\left(\mu_{\max }\right.$ obtained for the $100 \%$ and 50\% light groups were higher than the maximum growth rate observed for the control group of the previous experiment, while the duplication time was similar). However, after the tenth day, the overpopulated groups in the light experiment show a continuous decline in cell numbers, whereas the control of the nutrient-absent experiment maintain the average cell number until the end of the 30-day period.

Nonetheless, the data gathered in both experiments show that Nostoc paludosum is able to grow efficiently in an interval of light intensity between 120 to less than $60 \mu \mathrm{mol} \mathrm{m} \mathrm{m}^{-2} \mathrm{~s}^{-1}$, which demonstrates its adaptability to different environmental conditions.

\subsection{Effects of light intensity on heterocyte and akinete synthesis}

According to the akinete data obtained in this study, light intensity and its effects on the ability of the cell to realize photosynthesis are the main triggers to induce the formation of akinetes. It is already known that light is essential to akinete germination. In a study of Braune (1980), irradiations of $20 \mathrm{~W} \mathrm{~m}^{-2}$ for 30-70 hours were capable of inducing germination of akinetes of Anabaena variabilis. Since light is the determinant factor to activate this structure, the lack of light is probably associated with its formation. Our results showed that under more than $85 \%$ light reduction, a culture of Nostoc paludosum produces 50 times more akinetes than when it is cultivated in a condition with no light limitations, underlining the vital role of this structure in the maintenance of this species' survival.

It is also interesting to highlight that we registered the formation of akinetes in all groups towards the end of the experiment. However, the akinetes found in the 100\% light group were significantly smaller than those found in the light-restricted treatments. An explanation for the production of akinetes in all treatments may be drawn if we consider the culture self-shading effect (Kaplan-Levy et al., 2010). The group without light restriction presented the highest cell density, which means that many of this culture's cells were probably being shaded by other cells in the Mariotte bottle, receiving less than the ideal amount of light. These shaded cells probably formed the akinetes we found on the $100 \%$ light group, enhancing our understanding that light is crucial for akinete formation.

Nonetheless, other significant akinete formation factors in cyanobacteria have already been described in the literature. The reduction of the temperature has induced the formation of akinetes in Dolichospermum spiroides and D. crassum (Li et al., 2008). The same study has also suggested that the formation of heterocytes in a large quantity also induces the production of resistance cells. Another study that evaluated the effects of temperature and light intensity in Nostoc flagelliforme has found that an increase in temperature $\left(25\right.$ to $\left.45^{\circ} \mathrm{C}\right)$ favors cell growth, whereas a reduction in light intensity diminishes the cell division rate and the synthesis of polysaccharides, essential substances to the cells' survival (Bi and $\mathrm{Hu}, 2004$ ). All of these effects are probably related to the reduction of the photosynthetic rate, which could also explain 
the results obtained for our $13.5 \%$ light treatment concerning cell numbers and expression of akinetes, demonstrating the significance of this structure for the species' survival.

Since all light treatments produced heterocytes in a similar amount and pattern during most of the experiment's duration, it can be concluded that the light intensities used in this experiment $\left(60.0,30.0\right.$ and $\left.8.1 \mu \mathrm{mol} \mathrm{m}^{-2} \mathrm{~s}^{-1}\right)$ demonstrate that light is not the main factor driving heterocyte differentiation. In the nutrient-starvation experiment, all groups were submitted to the same light intensity $\left(120.0 \mu \mathrm{mol} \mathrm{m} \mathrm{m}^{-1}\right)$ and the amount of heterocytes produced and their positions in the trichome were different between treatments, supporting the idea that the synthesis of heterocytes can be better explained by the nutritional condition of the environment. The heterocytes observed at the end of the experiment may indicate the beginning of a nutritional stress at the culture media after supporting a great cell density for more than 20 days.

Light limitation not only affects the photosynthetic capacity of the cell, but it also alters the cyanobacteria's ability to fixate nitrogen through the heterocyte. The sporulation (name given to the process of differentiation of a vegetative cell into an akinete) is related to the reduction of the activity on the heterocytes. In our analysis of the heterocyte synthesis, there was no direct relation between light restriction and production of this structure, with it being better explained in the nitrogen and phosphorus starvation experiment. However, the light limitation could have indirectly altered the functionality of the heterocytes and their capability to properly fixate nitrogen since the reduction of light creates a stressful condition to the overall photosynthetic metabolism of the cell (Zapomělová et al., 2008b). Consequently, by affecting the heterocytes, the light restriction also triggered the sporulation of the akinetes found in our experiments.

The connection between akinetes and heterocytes also seems to be related to genetic mechanisms and development factors along the life cycle of the cyanobacteria. According to Leganés et al. (1994), the hetR and hetP genes of Nostoc ellipsosporum are directly responsible for the formation of special structures. When het $R$ is blocked, there is no production of heterocytes or akinetes; however, a mutation that silences the hetP gene inhibits the synthesis of heterocytes, with the regular occurrence of akinetes. Only further morphologic and genetic studies can truly clarify the relation between these two special structures.

\section{CONCLUSIONS}

Our results showed that the nutritional deficiencies of nitrogen and phosphorus and the variation in light intensities are capable of altering the regular growth dynamics of Nostoc paludosum, with the nitrogen and phosphorus limitations and the severe light restriction of $13.5 \%$ being the most effective in reducing cell-growth rates. The absence of nutrients in the culture medium and the limitation of light reaching the cyanobacteria cells are capable of altering the morphology of vegetative cells, with an increase in fragmentation, also affecting the special structures, akinetes and heterocytes. The most evident variations in the heterocytes was observed in the nitrogen-absent group, while a similar trend happened for the akinetes in the phosphorus-absent group and in the severely restricted-light treatment, with both data being supported by other studies in the literature. Particularly for the heterocytes synthesis, we observed that illuminance did not seem to play a direct role in its formation and position on the trichome, but it is probably associated with its functionality, with nutrient concentration, specially nitrogen, as the key aspect that explains heterocyte production. That is why the restriction of this essential nutrient increased this structure's synthesis, a fact that help us understand the strategies used by heterocytous cyanobacteria to survive in extremely limiting environments, particularly related to nitrogen deficiency.

The data generated in this research broadens the understanding of some factors involved in the general growth and synthesis of heterocytes and akinetes in Nostoc paludosum, a species 
that has had few studies published about its basic biology. Our study will therefore aid future research that can further the knowledge regarding this species of cyanobacteria or the study of its applications in bioengineering.

\section{ACKNOWLEDGEMENTS}

This study was financially supported by the Research Foundation of the State of Sao Paulo, FAPESP (processs number 2010/ 50738-8) and the National Council of Technological and Scientific Development, CNPq (project number 800408/ 2011-0), both being Brazilian public organizations.

\section{REFERENCES}

ADAMS, D. G.; CARR, N. G. Heterocyte differentiation and cell division in the cyanobacterium Anabaena cylindrical: effect of high light intensity. Journal of Cell Science, v. 49, n. 1, p. 341-352, 1981.

ALLEN, M. B.; ARNON, D. I. Studies on Nitrogen-Fixing Blue-Green Algae. I. Growth and Nitrogen Fixation by Anabaena Cylindrica. Plant Physiology, v. 30, n. 4, p. 366-372, 1955 .

BI, Y. H.; HU, Z. Y. Influence of temperature, nutrients and light intensity on the growth of Nostoc flagelliforme. The Chinese Journal of Process Engineering, v. 4, n. 3, p. 249254, 2004.

BRAUNE, W. Structural aspects of akinete germination in the cyanobacterium Anabaena variabilis. Archives of Microbiology, v. 126, n. 3, p. 257-261, 1980. https://doi.org/10.1007/BF00409929

CHEVALIER, P.; PROULX, D.; LESSARD, P.; VINCENT, W. F.; DE LA NOÜE, J. Nitrogen and phosphorus removal by high latitude mat-forming cyanobacteria for potential use in tertiary wastewater treatment. Journal of Applied Phycology, v. 12, n. 2, p. 105-112, 2000. https://doi.org/10.1023/A:1008168128654

DYBLE, J.; TESTER, P. A.; LITAKER, R. W. Effects of light intensity on cylindrospermopsin production in the cyanobacterial HAB species Cylindrospermopsis raciborskii. African Journal of Marine Science, v. 28, n. 2, p. 309-312, 2006. https://doi.org/10.2989/18142320609504168

FOY, R. H.; GIBSON, C. E.; SMITH, R. V. The influence of daylength, light intensity and temperature on the growth rates of planktonic blue-green algae. British Phycological Journal, v. 11, n. 2, p. 151-163, 1976. https://doi.org/10.1080/00071617600650181

GAO, K.; YU, A. Influence of $\mathrm{CO} 2$, light and watering on growth of Nostoc flagelliforme. Journal of Applied Phycology, v. 12, n. 2, p. 185-189, 2000. https://doi.org/10.1023/A:1008123203409

GUO, L. L.; LIAO, J. Z.; SHEN, J. Y.; SHEN, Q. G. Effects of Bensulfuron-Methyl on cell morphology of A. azotica. Feb-Fresenius Environmental Bulletin, v. 2016, p. 3981, 2016.

HASELKORN, R.; LIANG, J. H.; SCAPPINO, L.; BUIKEMA, W. J. Heterocyte differentiation and nitrogen fixation in the cyanobacteria Anabaena. In: NEWTON, W. E. (Ed.). New Horizons in Nitrogen Fixation. Germany: Kluwer Academic Publishers, 1993. p. 417- 422. 
HEALEY, F. P.; HENDZEL, L. L. Indicators of phosphorus and nitrogen deficiency in five algae in culture. Journal of the Fisheries Board of Canada, v. 36, n. 11, p. 1364 -1369, 1979. https://doi.org/10.1139/f79-195

KAPLAN-LEVY, R. N.; HADAS, O.; SUMMERS, M.; RUCKER, J.; SUKENIK, A. Akinetes: dormant cells of cyanobacteria. In: CERDÀ, J. (Ed.). Dormancy and resistance in harsh environments. Germany: Springer, 2010. p. 5-27.

LAZAROFF, N.; VISHNIAC, W. The effect of light on the developmental cycle of Nostoc muscorum, a filamentous blue-green alga. Journal of General Microbiology, v. 25, n. 3, p. 365-374, 1961. https://dx.doi.org/10.1099/00221287-25-3-365

LEE, R. E. Phycology. Cambridge: Cambridge University Press, 2008. 560 p.

LEGANÉS, F.; FERNANDEZ-PIÑAS, F.; WOLK, C. P. Two mutations that block heterocytes differentiation have different effects on akinete differentiation in Nostoc ellipsosporum. Molecular Microbiology, v. 12, n. 4, p. 679-684, 1994. https://doi.org/10.1111/j.13652958.1994.tb01055.x

LI, R.; WATANABE, M.; WATANABE, M. M. Akinete formation in planktonic Anabaena spp. (Cyanobacteria) by treatment with low temperature. Journal of Phycology, v. 33, n. 4, p. 576-584, 2008. https://doi.org/10.1111/j.0022-3646.1997.00576.x

LYRA, C.; SUOMALAINEN, M.; GUGGER, C.; VEZIE, P.; SUNDMAN, L. et al. Molecular characterization of planktic cyanobacteria of Anabaena, Aphanizomenon, Microcystis and Planktothrix genera. International Journal of Systematic and Evolutionary Microbiology, v. 51, n. 2, p. 513-526, 2001. https://dx.doi.org/10.1099/00207713-51-2513

MOORE, D.; O’DONOHUE, M. A. R. K.; GARNETT, C.; CRITCHLEY, C.; SHAW, G. Factors affecting akinete differentiation in Cylindrospermopsis raciborskii (Nostocales, Cyanobacteria). Freshwater Biology, v. 50, n. 2, p. 345-352, 2005. https://doi.org/10.1111/j.1365-2427.2004.01324.x

MURO-PASTOR, A. M.; HESS, W. R. Heterocyst differentiation: from single mutants to global approaches. Trends in Microbiology, v. 20, n. 11, p. 548-557, 2012. https://doi.org/10.1016/j.tim.2012.07.005

NALEWAJKO, C.; MURPHY, T. P. Effects of temperature and availability of nitrogen and phosphorus on the abundance of Anabaena and Microcystis in Lake Biwa, Japan: an experimental approach. Limnology, v. 1, n. 1, p. 45-48, 2001. https://doi.org/10.1007/s102010170015

PANKRATOVA, E. M.; TREFILOVA, L. V.; ZYABLYKH, R. Y.; USTYUZHANIN, I. A. Cyanobacterium Nostoc paludosum Kütz as a basis for creation of agriculturally useful microbial associations by the example of bacteria of the genus. Microbiology, v. 77, n. 2, p. 228-234, 2008. https://doi.org/10.1134/S0026261708020173

PÓCS, T. Cyanobacterial crust types, as strategies for survival in extreme habitats. Acta $\begin{array}{llllllll}\text { Botanica Hungarica, } & \text { v. 51, } & \text { n. } 1, & \text { p. 147-178, }\end{array}$ https://doi.org/10.1556/ABot.51.2009.1-2.16

SAKER, M. L.; NEILAN, B. A. Varied diazotrophies, morphologies and toxicities of genetically similar isolates of Cylindrospermopsis raciborskii (Nostocales, Cyanophyceae) from northern Australia. Applied and Environmental Microbiology, v. 67, n. 4, p. 1839-1845, 2001. http://dx.doi.org/10.1128/AEM.67.4.1839-1845.2001 
SANT'ANNA, C. L.; MELCHER, S. S.; CARVALHO, M. C.; GELMEGO, M. P.; AZEVEDO, M. T. de P. Planktic Cyanobacteria from upper Tietê basin reservoirs, SP, Brazil. Brazilian Journal of Botanic, v. 30, p. 1-17, 2007. http://dx.doi.org/10.1590/S010084042007000100002

TEMINA, M.; REZANKOVA, H.; REZANKA, T.; DEMBITSKY, V. M. Diversity of the fatty acids of the Nostoc species and their statistical analysis. Microbiological Research, v. 162, n. 4, p. 308-321, 2007. https://doi.org/10.1016/j.micres.2006.01.010

TONK, L.; VISSER, P. M.; CHRISTIANSEN, G.; DITTMANN, E.; SNELDER, E. O. F. M.; WIEDNER, C. et al. The microcystin composition of the cyanobacterium Planktothrix agardhii changes toward a more toxic variant with increasing light intensity. Applied and Environmental Microbiology, v. 9, n. 71, p. 5177-5181, 2005. http://dx.doi.org/10.1128/AEM.71.9.5177-5181.2005

VINCENT, W. F. Cyanobacterial dominance in the Polar Regions. In: POTTS, M. (Ed.). The ecology of cyanobacteria. Netherlands: Springer, 2000. p. 321-340.

WILLIS, A.; ADAMS, M. P.; CHUANG, A. W.; ORR, P. T.; O’BRIEN, K. R.; BURFORD, M. A. Constitutive toxin production under various nitrogen and phosphorus regimes of three ecotypes of Cylindrospermopsis raciborskii (Woloszynska) Seenayya et Subba Raju). Harmful algae, v. 47, p. 27-34, 2015.

ZAPOMĚLOVÁ, E.; HISEM, D.; ŘEHÁKOVÁ, K; HROUZEK, P.; JEZBEROVÁ, J.; KOMÁRKOVÁ, J. et al. Experimental comparison of phenotypical plasticity and growth demands of two strains from the Anabaena circinalis/ A. crassa complex (cyanobacteria). Journal of Plankton Research, v. 30, n. 11, p. 1257-1269, 2008. https://doi.org/10.1093/plankt/fbn081

ZAPOMĚlOVÁ, E.; HROUZEK, P.; ŘEHÁKOVÁ, K.; ŠABACKÁ, M.; STIBAL, M.; CAISOVÁ, L. et al. Morphological Variability in Selected Heterocysteous Cyanobacterial Strains as a Response to Varied Temperature, Light Intensity and Medium Composition. Folia Microbiology, v. 4, n. 53, p. 333-341, 2008. https://doi.org/10.1007/s12223-008-0052-8 


Ambiente \& Água - An Interdisciplinary Journal of Applied Science
ISSN 1980-993X - doi:10.4136/1980-993X
www.ambi-agua.net
E-mail: ambi.agua@gmail.com

\title{
Peroxidase from green zucchini (Cucurbita pepo $L$.) immobilized on natural polymers removes phenolic compounds from water samples
}

\author{
ARTICLES doi:10.4136/ambi-agua.2226
}

Received: 27 Dec. 2017; Accepted: 10 Oct. 2018

\author{
Thâmara Machado e Silva; Aline Rodrigues dos Santos; Samantha Salomão Caramori* \\ Universidade Estadual de Goiás (UEG), Anápolis, GO, Brasil \\ Câmpus Anápolis de Ciências Exatas e Tecnológicas (CCET). \\ Laboratório de Biotecnologia. E-mail:thamaramachado.silva@gmail.com, \\ alinerodriguesdossantos3@gmail.com, sscaramori@gmail.com \\ *Corresponding author
}

\begin{abstract}
Phenolic compounds occur in effluents from a wide variety of industrial operations, and they present toxicity and generate environmental problems. The treatment of these wastes via enzyme immobilization indicates that peroxidase (E.C.1.11.1.7) is the enzyme with the widest application. In the same process, biodegradable polymers have generated significant interest from research and industrial communities. Here we applied biopolymers from sugarcane bagasse (SB) and Cerrado cashew-tree polysaccharide (PEJU-GO) as supports for peroxidase immobilization from crude green zucchini extract via physical adsorption and covalent bonding. In addition, we used these systems in the removal of phenols from industrial effluents. Electron microscopy showed a fibrous surface for SB and a microporous material for PEJUGO, characteristics that facilitate the immobilization. The infrared of both materials elucidated characteristic bands of sugars. For operational stability after 30 days of storage, the immobilized peroxidase retained 69 and 50\% activity for SB and PEJU-GO, respectively. The systems were able to remove up to $79 \%$ of phenolics from industrial wastes. Therefore, the biopolymers from sugarcane bagasse and cashew-tree polysaccharide are promising sources for biotechnology, especially when used for peroxidase immobilization. This will support enzymatic activity in laboratory practice, with homogeneous behavior in different $\mathrm{pH}$ conditions, at low cost, biodegradable, non-toxic and extracted in a sustainable way.
\end{abstract}

Keywords: biopolymers, effluents, water treatment.

\section{Peroxidase de abobrinha verde (Cucurbita pepo L.) imobilizada em polímeros naturais remove compostos fenólicos de amostras de água}

\section{RESUMO}

Os compostos fenólicos ocorrem em efluentes de uma grande variedade de processos industriais e apresentam toxicidade e geram problemas ambientais. $\mathrm{O}$ tratamento desses resíduos via imobilização de enzimas indica que a peroxidase (EC 1.11.1.7) é a enzima mais utilizada. Nos mesmos processos, polímeros biodegradáveis têm gerado grande interesse para a comunidade científica e industrial. Neste trabalho os biopolímeros de bagaço de cana-deaçúcar (BC) e o polissacarídeo de caju arbóreo do Cerrado (PEJU-GO) foram utilizados como suportes para imobilização de peroxidase de extrato bruto de abobrinha verde via adsorção

This is an Open Access article distributed under the terms of the Creative Commons Attribution License, which permits unrestricted use, distribution, and reproduction in any medium, provided the original work is properly cited. 
física e ligação covalente. Além disso, usamos esses sistemas para a remoção de fenóis de efluentes industriais. A microscopia eletrônica mostrou que BC possui uma superfície fibrosa e que PEJU-GO apresentou-se como material microporoso, características que facilitam processos de imobilização. Os espectros de infravermelho de ambos materiais elucidaram bandas características de açúcares. Para a estabilidade operacional após 30 dias de armazenamento a peroxidase imobilizada reteve 69 e 50\% de atividade para BC e PEJU-GO, respectivamente. Os sistemas foram capazes de remover até $79 \%$ de compostos fenólicos de efluentes industriais. Assim sendo, os biopolímeros de bagaço de cana-de-açúcar e do polissacarídeo de caju arbóreo do Cerrado são fontes promissoras para a biotecnologia, especialmente para a imobilização de peroxidase. Isto irá proporcionar a imobilização enzimática na prática laboratorial, com comportamento estável em diferentes condições de $\mathrm{pH}$, a custo baixo, sendo um material biodegradável, não-tóxico e extraído de forma sustentável.

Palavras-chave: biopolímeros, efluentes, tratamento de água.

\section{INTRODUCTION}

The volume of chemical pollutants is on the rise, especially textile dyes, which are stable and resistant to primary treatment methods. Since water reservoirs are affected by these and other pollutants, new remediation strategies have been developed (Choong and Focatiis, 2016).

In recent years, environmentally friendly technologies have been gradually implemented to minimize the negative impacts of industrial development on the environment, the economy and society (Darko et al., 2017). Among those products are biodegradable polymers, which have generated significant interest in research and industrial communities. The degradation of these materials, linked to their renewable sources, promotes a reduced accumulation of waste and less environmental stress, and they are more easily degraded throughout industrial processing (Choong and Focatiis, 2016).

In this regard, lignocellulosic materials in the form of plant biomass, such as sugarcane bagasse (Saccharum officinarum, L.) (SB), are the most abundant organic carbon complexes, mainly composed of cellulose, hemicellulose and lignin, used on a large scale in ethanol bioconversion. These materials have a high carbohydrate content, low lignin content, easy use, low cost of harvesting, transport and storage (Gouveia et al., 2009). The polysaccharide of Cerrado-arboreal cashew (Anacardium othonianum Rizz.) (PEJU-GO) is biocompatible, biodegradable and easy to obtain, and it presents a physicochemical structure in line with properties that allow technological applications (Silva et al., 2017). Moreover, due to their colloidal properties, this material and other polysaccharides have been used as thickeners, gelling agents, emulsifiers, stabilizers, binders (Bhushette and Annapure, 2017) and biodegradable polymers (Akthar and Ding, 2017).

Phenolic compounds occur in waste outflows from a wide variety of industrial operations. Almost all are toxic (Liu et al., 2002), and some are known to be carcinogenic in humans; they are incorporated in the food chain and generate important environmental problems. Some methods for phenolic removal involve the use of microorganisms, activated charcoal or chemical oxidation. However, the methods often have disadvantages, such as low efficiency, high cost or the fact that they may generate even more toxic products than the original targets.

An alternative to treat phenolic wastewater is the use of the enzyme peroxidase (E.C.1.11.1.7). Horseradish peroxidase (HRP) has been successfully used to eliminate phenol from aqueous solutions and is by far the most-researched enzyme (Kalaiarasan and Palvannan, 2013). However, due to the cost of purification, many efforts have been made to find alternative sources of this enzyme, mainly in plants. The green zucchini (Cucurbita pepo L.) has been presented as a promising source of peroxidase when compared to other fruit and vegetables, 
such as peach (Prunus pérsica, L.), manioc (Manihot utilíssima, L.) and artichokes (Cynara scolymus L.) (Vieira et al., 2003), for example. In this work, the hypothesis is that sugarcane bagasse (S. officinarum, L.) and the Cerrado-arboreal cashew polysaccharide (A. othonianum Rizz.) are capable of immobilizing peroxidase (POX) extracted from green zucchini (Cucurbita реро, L) to remove phenol from industrial effluents, in order to reduce their concentration in these environments.

\section{MATERIALS AND METHODS}

We purchased the samples of green zucchini (Cucurbita pepo, L.) and sugarcane bagasse (Saccharum officinarum, L.) in local stores in Anápolis, Goiás, Brazil, during January 2016. The gums of Cerrado-arboreal cashew (Anacardium othonianum Rizz.) were collected in the arboretum of the School of Agronomy, Federal University of Goiás, Brazil (16 $35^{\circ} 59.1^{\prime \prime}$ S, 49 $16^{\prime} 47.1^{\prime \prime}$ W) in February 2016.

The reagents ethyl alcohol P.A., pyrogallol, 35\% hydrogen peroxide, sodium phosphate monobasic, sodium meta-periodate, nitrophenol, phenol, bromophenol, catechol and FolinCiocalteu reagent were obtained from Sigma-Aldrich (USA).

\subsection{Obtaining the Green Zucchini Extract and Peroxidase Activity}

The Cucurbita pepo L. plant samples were cut, crushed in $0.1 \mathrm{~mol} \mathrm{~L}^{-1}$ monobasic sodium acetate solutions ( $\mathrm{pH} 4 ; 4.5 ; 5), 0.1 \mathrm{~mol} \mathrm{~L}^{-1}$ sodium phosphate monobasic ( $\mathrm{pH} 6 ; 6.5 ; 7 ; 7.5$ ) and $0.1 \mathrm{~mol} \mathrm{~L}^{-1}$ sodium borate $(\mathrm{pH} 8)$ in the proportion of $1: 1(\mathrm{p} / \mathrm{v})$, then filtered for use. The peroxidase activity in the green zucchini (GZP) was determined in a Kasuaki UV/VIS UV/VIS spectrophotometer Model IL-592 (Japan), using pyrogallol in $0.1 \mathrm{~mol} \mathrm{~L}^{-1}$ sodium phosphate, $\mathrm{pH}$ 6.0. Absorbance (at $420 \mathrm{~nm}$ ) was measured after 1 min of reaction. We considered the enzyme unit (U) as the amount of peroxidase capable of increasing 0.1 absorbance / min of reaction under the assay conditions. To choose the best $\mathrm{pH}$ extract, we tested the data using analysis a posteriori (Tukey test), considering $\mathrm{p}<0.05$.

\subsection{Characterization of Sugarcane Bagasse and Cerrado-Arboreal Cashew}

The characterization of the polysaccharide from Cerrado-arboreal cashew (PEJU-GO) was performed according to Silva et al. (2017). To obtain PEJU-GO and SB treated with sodium periodate (PEJUp-GO and SBp, respectively), $0.05 \mathrm{~g}$ of support stirred for $30 \mathrm{~min}$ at $26^{\circ} \mathrm{C}$ with $2.0 \mathrm{~mL}$ of $0.1 \mathrm{~mol} \mathrm{~L}^{-1}$ sodium periodate solution and $10 \mathrm{~mL}$ of $0.1 \mathrm{~mol} \mathrm{~L}^{-1}$ sodium phosphate buffer $\mathrm{pH}$ 7.0. PEJU-GO was precipitated with absolute ethanol for $24 \mathrm{~h}$. After discarding the supernatant, both PEJUp-GO and SBp were dried at room temperature and the powder kept in amber flasks at $4^{\circ} \mathrm{C}$ for use.

The morphological analysis of the polymers (PEJU-GO, PEJU-GO, SB and SBp) was performed by scanning electron microscopy (Shimadzu, model SSx 550, Japan), with magnification from 50 to 1000. The polymers (PEJU-GO, PEJUp -GO, SB and SBp) were analyzed in infrared spectrometry with $\mathrm{KBr}$ pellets (Bomn FT-IR model MB100, USA) and the scanning performed in the range of 4000 to $500 \mathrm{~cm}^{-1}$. We compared the spectra to characterize the chemical groups present in the samples, according to the literature.

We evaluated the thermal stability of PEJU-GO, PEJU-GO, SB and SBp by thermogravimetric analysis. The samples were subjected to heating ramps of $25^{\circ} \mathrm{C}$ at $500^{\circ} \mathrm{C}$, at a rate of $10^{\circ} \mathrm{C} \mathrm{min}^{-1}$, using DTG-60H (Shimadzu, China).

\subsection{Tests of Immobilization of Peroxidase from Crude Extract of Green Zucchini}

The immobilization of GZP was performed in PEJU-GO and SB by physical adsorption and covalent binding using sodium periodate, and the supports were identified as PEJUp-GO and $\mathrm{SBp}$, respectively. 
The tests for the best retention of enzyme activity at different concentrations of enzyme and support, immobilization $\mathrm{pH}$, storage and reuse days were conducted using $1000 \mu \mathrm{L}$ GZP (270 U) in $10 \mathrm{mg}$ PEJU-GO, $20 \mathrm{mg}$ PEJUp-GO, $2.5 \mathrm{mg}$ of SB and $15 \mathrm{mg}$ SBp under gentle agitation (720 rpm) for $2 \mathrm{~h}$ at $4^{\circ} \mathrm{C}$.

For the method of physical adsorption, the immobilization in PEJU-GO used $1000 \mu \mathrm{L}$ of the crude GZP extract ( $270 \mathrm{U}$ ) (obtained by milling the plant samples in $0.1 \mathrm{~mol} \mathrm{~L}^{-1}$ sodium phosphate buffer solution and $\mathrm{pH} 7.0$ ), allowed to react with $10 \mathrm{mg}$ of the support under gentle agitation $(720 \mathrm{rpm})$ for $2 \mathrm{~h}$ at $4^{\circ} \mathrm{C}$. A control group was made using only $0.1 \mathrm{~mol} \mathrm{~L}^{-1}$ sodium phosphate buffer solution $\mathrm{pH} 7.0$ and the support, without adding enzyme. The PEJU-GO-GZP complex was precipitated with ice-cold absolute ethanol, centrifuged and assayed for immobilized enzymatic activity. The same procedure was performed for immobilization by physical adsorption in SB, including the control group. $1000 \mu \mathrm{L}$ of crude GZP extract (270 U) were allowed to react with $2.5 \mathrm{mg} \mathrm{SB}$ under gentle stirring $(720 \mathrm{rpm})$ for $2 \mathrm{~h}$ at $4^{\circ} \mathrm{C}$.

For the immobilization tests by covalent bonding, the supports were activated with sodium periodate as described in 2.2. After the activated substrates, $1000 \mu \mathrm{L}$ of the crude GZP extract $(270 \mathrm{U})$ were allowed to react with $20 \mathrm{mg}$ PEJU-GO under gentle agitation $(720 \mathrm{rpm})$ for $2 \mathrm{~h}$ at $4{ }^{\circ} \mathrm{C}$. A control group was made using only sodium phosphate buffer solution, $0.1 \mathrm{~mol} \mathrm{~L}^{-1} \mathrm{pH}$ 7.0, and support. Then, the PEJUp-GO-GZP complex was precipitated with ice-cold absolute ethanol, centrifuged and assayed for immobilized enzymatic activity. The same procedure was performed for immobilization in SBp, including the control group. $1000 \mu \mathrm{L}$ of crude GZP extract $(270 \mathrm{U})$ were allowed to react with $15 \mathrm{mg}$ of SB under gentle agitation $(720 \mathrm{rpm})$ for $2 \mathrm{~h}$ at $4^{\circ} \mathrm{C}$.

The enzyme activity test consisted of adding to the immobilized GZP complex $1.4 \mathrm{~mL}$ of $0.1 \mathrm{~mol} \mathrm{~L}{ }^{-1}$ sodium phosphate buffer, $\mathrm{pH} 6.0,0.5 \mathrm{~mL}$ of $0.05 \mathrm{~mol} \mathrm{~L}^{-1}$ hydrogen peroxide and $1.0 \mathrm{ml}$ of $0.07 \mathrm{~mol} \mathrm{~L}^{-1}$ pyrogallol. After $1 \mathrm{~min}$ of reaction the reading was performed according to Item 2.1 .

\subsection{Potential use of free and immobilized peroxidase for degradation of phenolic compounds}

The tests with phenolic compounds and industrial effluents (WTS and Textiles) were carried out based on the methodology of Ramalho et al. (2016). The effluent samples were collected at the Waste Treatment Station (WTS) of the Agribusiness District of Anápolis (DAIA) $\left(16^{\circ} 30^{\prime} \mathrm{S}\right.$ and $\left.49^{\circ} 00^{\prime} \mathrm{W}\right)$ and at a textile corporation, Cia Hering of São Luís dos Montes Belos, Goiás (16 $52^{\prime} \mathrm{S}$ and $\left.50^{\circ} 32^{\prime} \mathrm{W}\right)$. The organic load contained in the raw sewage, according to the Department of the Environment of the DAIA, is $3.750 \mathrm{~kg}$ BOD.day ${ }^{-1}$.

We incubated the free GZP and the PEJU-GO-GZP, PEJUp-GO-GZP, SB-GZP and SBpGZP complexes with pyrogallol, catechol, phenol, bromophenol, and nitrophenol (1.0 $\mathrm{mol} \mathrm{L}^{-1}$, initial concentration). We performed the same procedure replacing the phenolic compounds with the crude effluent (WTS at $0.1 \mathrm{~mol} \mathrm{~L}^{-1}$ and Textiles at $0.2 \mathrm{~mol} \mathrm{~L}^{-1}$ ). We then evaluated the capacity of immobilized complexes to remove phenols from the effluent samples using timedependent kinetics ranging from $10 \mathrm{~min}$ to $420 \mathrm{~min}$. The residual phenol concentration was monitored as in Ramalho et al. (2016). We used the immobilized complexes obtained through physical adsorption, since they presented better immobilization conditions.

\section{RESULTS AND DISCUSSION}

Figure 1 shows the enzymatic activities at different extraction $\mathrm{pH}$. The optimum $\mathrm{pH}$ for peroxidases of crude extracts varies according to the inherent characteristics of the enzyme itself, the composition of plant isoenzymes in the crude extract and the choice of substrate (Ramalho et al., 2016). The differences in the mean values among the treatment groups are not 
great enough to exclude the possibility that the difference is due to random sampling variability; there is not a statistically significant difference $(p=0.824>0.05)$. We chose the maximum mean value (44.1U), obtained when $0.1 \mathrm{~mol} \mathrm{~L}^{-1}$ sodium phosphate buffer, $\mathrm{pH} 7.0$ was used to define the extraction $\mathrm{pH}$ for the subsequent tests.

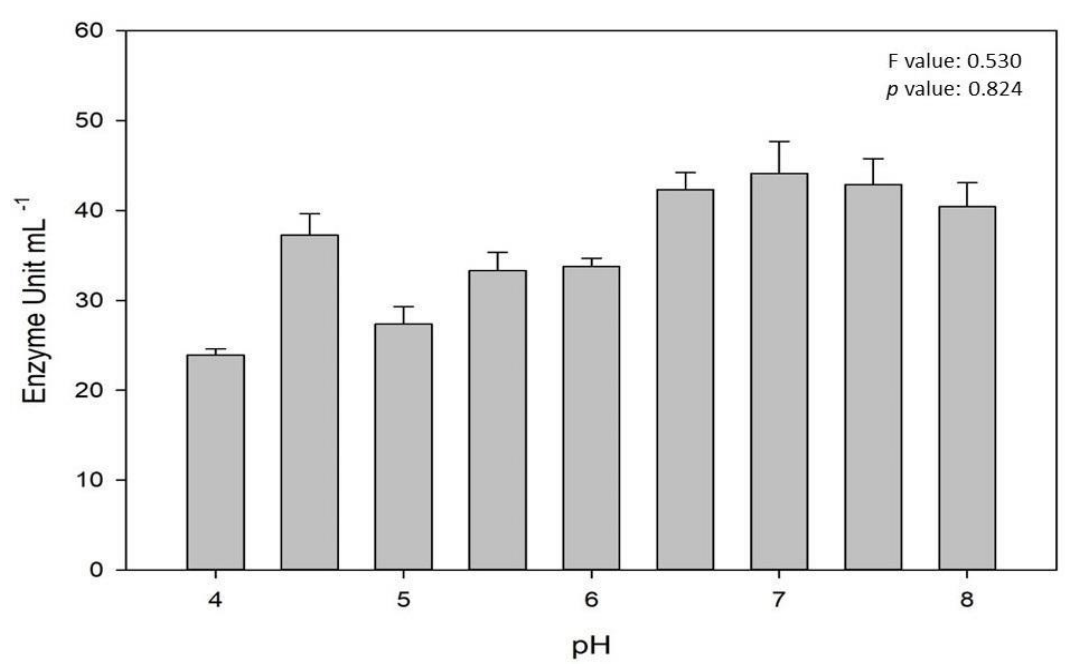

Figure 1. Activity of green zucchini peroxidase (Cucurbita pepo, L.) in different extraction $\mathrm{pH}$ values. The extracts were obtained from monobasic sodium acetate $0.1 \mathrm{~mol} \mathrm{~L}^{-1}(\mathrm{pH} 4 ; 4.5 ; 5), 0.1 \mathrm{~mol} \mathrm{~L}^{-1}$ sodium phosphate monobasic $(\mathrm{pH} 6 ; 6.5 ; 7 ; 7.5)$ and $0.1 \mathrm{~mol} \mathrm{~L}^{-1}$ sodium borate $(\mathrm{pH} 8)$ at the proportion of $1: 1(\mathrm{p} / \mathrm{v})$.

Source: Prepared by the author.

\subsection{Characterization of Sugarcane Bagasse and Cerrado-Arboreal Cashew}

Figure 2 shows the morphological aspects obtained by scanning electron microscopy of SB (2A), SB-p (2B), PEJU-GO (2C) and PEJUp-GO (2D), respectively.
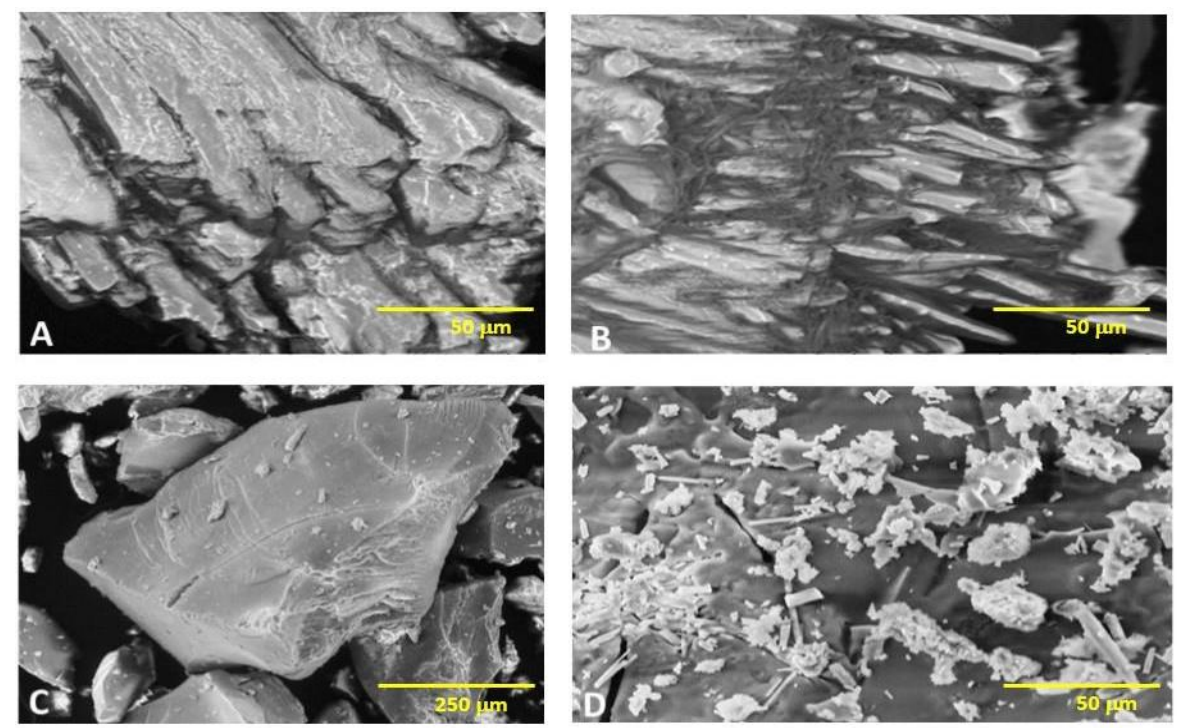

Figure 2. Electron micrograph of crude sugarcane bagasse (Saccharum officinarum, L.) (A), sugarcane bagasse treated with sodium periodate (B), crude Cerrado-arboreal polysaccharide (Anacardium othonianum Rizz.) (C) and Cerrado-arboreal polysaccharide treated with sodium periodate (D) at 1000x and 1500x, respectively.

Source: Prepared by the author. 
Figure 2A shows a fibrous aspect with bundles of microfibrils as also demonstrated by Kristiansen et al. (2010). The SBp (Figure 2B) presented a rupture of these microfibrils, characteristic of the treatment of sodium periodate in sugars. The PEJU-GO (Figure 2C) had a porous, irregular and crystalline surface, with an extensive and amorphous mass, reliefs and depressions. This can favor the application of this material in biotechnological processes, such as enzyme immobilization, because it allows adhesion to and stability of the immobilized complex. In the present study, PEJUp-GO had characteristic aspects for the sodium periodatetreated polysaccharides: irregular fragments, amorphous and dispersed mass (Kristiansen et al., 2010).

Infrared spectra of SB and SBp (Figure 3A) showed characteristic bands of lignocellulosic fibers. The strongest peaks occurred at 3428 and $1048 \mathrm{~cm}^{-1}$, characterizing stretches of $\mathrm{OH}$ and $\mathrm{COH}$ groups, respectively. There was the appearance of bands between 2918 and $2850 \mathrm{~cm}^{-1}$, characteristic of the hemicellulose spectrum. The sugarcane bagasse treated with sodium periodate (Figure 3A) showed bands close to 1740 and $880 \mathrm{~cm}^{-1}$, with a strong peak at $1728 \mathrm{~cm}^{-1}$, as observed in carbonyl groups (Calvini et al., 2006). In addition, when the oxidation degree was higher, the bands in cellulose periodate appeared near to 1740 and $880 \mathrm{~cm}^{-1}$ (Calvini et al., 2006). For the PEJU-GO (Figure 3B), we found polysaccharide bands, such as at 3000 to $2840 \mathrm{~cm}^{-1}$ (OH stretch). The bands present in the range of 1870 to $1540 \mathrm{~cm}^{-1}$ are related to the presence of $\mathrm{C}=\mathrm{O}$ groups (Kristiansen et al., 2010). For PEJU-GO (Figure 3B) there were absorptions between 1600 and $1500 \mathrm{~cm}^{-1}$ corresponding to amide Group I $(\mathrm{C}=\mathrm{O})$ and $\mathrm{N}-\mathrm{H}$ amine bond vibrations, respectively. The spectrum showed high intensity absorption at $1736 \mathrm{~cm}^{-1}(\mathrm{C}=\mathrm{O})$, indicating the oxidation of PEJUp-GO. The approximate absorbance of $1740 \mathrm{~cm}^{-1}$ is characteristic of carbonyl groups, whereas the $880 \mathrm{~cm}^{-1}$ range is generally attributed to the formation of hemiacetal bonds between the aldehyde groups and neighboring hydroxyl groups (Calvini et al., 2006).
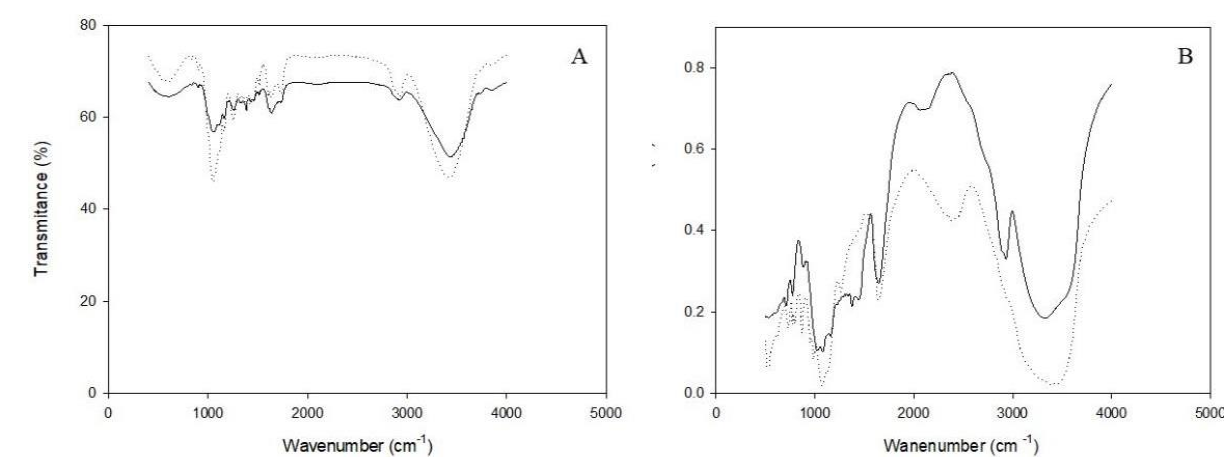

Figure 3. Infrared spectra of crude sugarcane bagasse (Saccharum officinarum, L.) and treated with sodium periodate (A) and polysaccharide from Cerrado-arboreal cashew (Anacardium othonianum Rizz.), crude and treated with sodium periodate (B), respectively. The full rows represent both sugarcane bagasse and crude polysaccharide. The dashed lines represent the two polymers treated with sodium periodate. Samples were analyzed with $\mathrm{KBr}$ pellets (Bomn FT-IR model MB100, USA) and scanned in the range of 500 to $4000 \mathrm{~cm}^{-1}$.

Source: Prepared by the author.

The evaluation of the thermal stability of the polymers is in Figure 4. For the SB (Figure $4 \mathrm{~A}$, full line) decomposition occurs at two peaks: $338^{\circ} \mathrm{C}$ and $480^{\circ} \mathrm{C}$. For SBp (Figure $4 \mathrm{~A}$, dashed line) decomposition occurred at $334^{\circ} \mathrm{C}$ and $450^{\circ} \mathrm{C}$ due to exposure of the sugars after treatment with sodium periodate, because of the chemical modification on the fibers. 

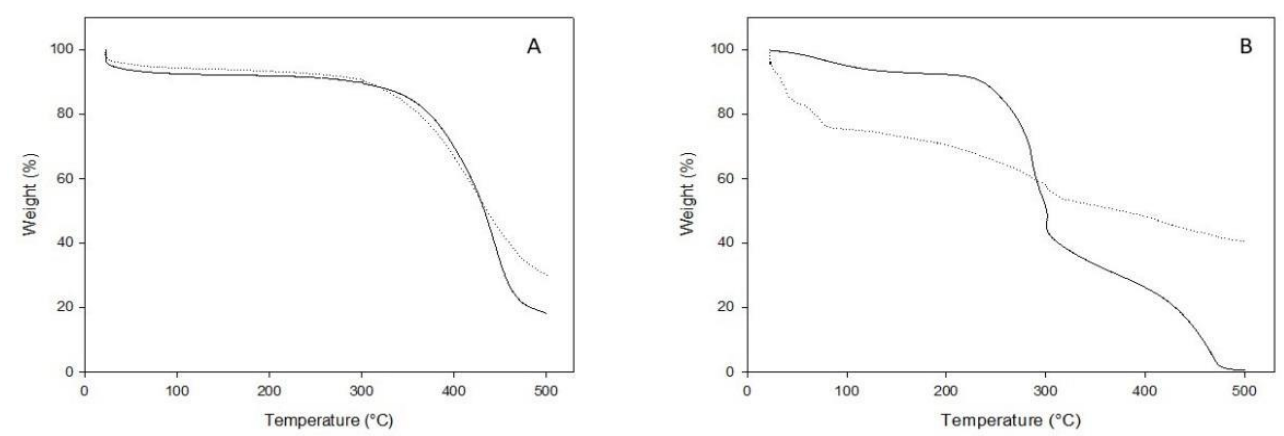

Figure 4. Thermogravimetry of Saccharum officinarum, L. crude and treated with sodium periodate (A) and Cerrado-arboreal cashew polysaccharide (Anacardium othonianum Rizz.), crude and treated with sodium periodate (B), respectively. The full rows represent the sugarcane bagasse and the crude cashew polysaccharide. The dotted lines represent the polymers treated with sodium periodate. Samples were heated at $25^{\circ} \mathrm{C}$ to $500^{\circ} \mathrm{C}$ at the rate of $10^{\circ} \mathrm{C} \mathrm{min}{ }^{-1}$ using DTG-60H (Shimadzu, China).

Source: Prepared by the author.

The thermal decomposition of PEJU-GO found by Silva et al. (2017) (Figure 4B, full line) was at 280 and $300^{\circ} \mathrm{C}$ (first stage) and between 300 and $490^{\circ} \mathrm{C}$ (second stage). For PEJUp-GO (Figure $4 \mathrm{~B}$, dashed line) the decomposition occurs between $50^{\circ} \mathrm{C}$ and $100^{\circ} \mathrm{C}$ (maximum at $80^{\circ} \mathrm{C}$ ). This finding is in accordance with the characteristic of sugar chain disruption caused by sodium periodate, starting decomposition of the carbon skeleton earlier than the crude polysaccharide. The second peak was observed between 320 and $500^{\circ} \mathrm{C}$ (maximum at $500^{\circ} \mathrm{C}$ ), probably due to the depolymerization of $\mathrm{CO}$ and $\mathrm{CH}_{4}$ bonds. Degradation of the sodium periodate-treated polysaccharide occurs initially at mild temperatures, since oxidation may decrease the interactions (electrostatic forces, hydrogen bonds and van der Waals forces) among the biopolymers. Both polymers behave in a stable manner along a temperature gradient, which, for an industrial application, guarantees the stability of the support and the effective and stable conduction of the process at high temperatures.

\subsection{Immobilization of Peroxidase from Green Zucchini Crude Extract}

The activity of GZP used for the immobilization reactions via physical adsorption (in SB and PEJU-GO) and covalent binding (in SBp and PEJUp-GO) was $270 \mathrm{U}$. The best immobilization conditions for sugarcane bagasse and Cerrado-arboreal polysaccharide are in Table 1.

The physical, chemical and morphological modifications on the supports, by the application of additives (in this case sodium periodate), produce immobilized biocatalysts with greater catalytic efficiency due to the minimization of the diffusion effects of substrates and products during reaction, besides the improvement of the operational stability in several processes (Niu et al., 2013). In this aspect, both SB and PEJU-GO were more efficient via physical adsorption than in covalent binding, since all systems demonstrated versatility and stability in the two immobilization tested routes.

For the GZP-SB and GZP-SBp complexes, the physical adsorption method allowed the retention of $100 \%$ of the enzymatic activity, followed by $75 \%$ by covalent binding, respectively. This yield is remarkable due to the structure presented through electron microscopy and the infrared spectrum, showing functional groups capable of allowing the union of the enzyme with the support, through electrostatic attractions established between the opposing charges that are present both on the surface of the support (for the cane bagasse, fibrous and with relief) and the enzyme. In the case of physical adsorption, the enzymes are bound to the matrix through electrostatic and hydrophobic interactions (Silva et al., 2017). 
Table 1. Optimal conditions for immobilized GZP in sugarcane bagasse (Saccharum officinarum, L.) and in Cerrado-arboreal cashew polysaccharide (Anacardium othonianum Rizz.) via physical adsorption and covalent binding.

\begin{tabular}{|c|c|c|c|c|}
\hline \multirow[t]{2}{*}{ Parameters } & \multicolumn{2}{|c|}{ Sugarcane bagasse } & \multicolumn{2}{|c|}{ Cerrado cashew polysaccharide } \\
\hline & Adsorption & Covalent binding & Adsorption & Covalent binding \\
\hline & SB & SBp & PEJU-GO & PEJUp-GO \\
\hline $\begin{array}{l}\text { Offered support } \\
\qquad(\mathrm{mg})\end{array}$ & 2.5 & 15 & 10 & 20 \\
\hline $\begin{array}{l}\text { Offered GZP } \\
(\mu \mathrm{L})\end{array}$ & 1000 & 1000 & 1000 & 1000 \\
\hline $\begin{array}{c}\text { Immobilization } \\
\mathrm{pH}\end{array}$ & $5.0 ; 7.0$ & $5.0 ; 7.0$ & 7 & $5.0 ; 7.0$ \\
\hline $\begin{array}{c}\text { Immobilization } \\
\text { time (h) }\end{array}$ & $2 \mathrm{~h}$ & $1 \mathrm{~h}$ & $2 \mathrm{~h}$ & $2 \mathrm{~h}$ \\
\hline Repeated use & $\begin{array}{l}8 \text { cycles, } 28 \% \\
\text { remaining enzyme } \\
\text { activity }\end{array}$ & $\begin{array}{l}8 \text { cycles, } 47 \% \\
\text { remaining enzyme } \\
\text { activity }\end{array}$ & $\begin{array}{c}7 \text { cycles, } 28 \% \\
\text { remaining enzyme } \\
\text { activity }\end{array}$ & $\begin{array}{l}8 \text { cycles, } 21 \% \mathrm{~d} \\
\text { remaining enzyme } \\
\text { activity }\end{array}$ \\
\hline Shelf life (days) & $\begin{array}{c}30 \text { days, } 69 \% \\
\text { remaining enzyme } \\
\text { activity }\end{array}$ & $\begin{array}{c}30 \text { days, } 77 \% \\
\text { remaining enzyme } \\
\text { activity }\end{array}$ & $\begin{array}{c}30 \text { days, } 50 \% \\
\text { remaining enzyme } \\
\text { activity }\end{array}$ & $\begin{array}{c}30 \text { days, } 60 \% \\
\text { remaining enzyme } \\
\text { activity }\end{array}$ \\
\hline
\end{tabular}

The repeated use for GZP-SBp ( 8 cycles, $28 \%$ of remaining enzyme activity) and GZPSBp ( 8 cycles, $47 \%$ of remaining enzymatic activity) indicates that those biodegradable systems are promising materials for biotechnological applications. The physical nature of the support, such as morphology, size and distribution of the beams in the structure (Figure 2A), provides an increase in immobilization efficiency caused by mass transfer between the immobilized liquid and enzyme medium (Niu et al., 2013).

The $\mathrm{pH}$ monitoring in industrial processes (feedstuffs, pharmaceuticals, water treatment and effluents) is essential for their effectiveness. The application of the GZP-SB and GZP-SBp complexes (Table 1) in industrial processes makes it possible to perform at different $\mathrm{pH}$ ranges.

After analyzing the stability of GZP-SB and GZP-SBp complexes for 30 days, we observed the maintenance of the peroxidase activity at 69 and 77\%, respectively (Table 1). The ability of SB to retain active enzymes was also identified by Ahirwar et al. (2017), using cellulase immobilized assays via covalent attachment to polystyrene pellets (77\% activity after 35 days of storage). This reinforces the understanding that SB is a promising support for enzyme immobilization with the differential of biodegradability in the environment. Under the same storage conditions, the peroxidase activity in the GZP-PEJU and GZP-PEJUp complexes remained at 50\% at the end of that period (Table 1). Niu et al. (2013) found a similar result for the same conditions in fibrous membranes. The authors suggest that the polysaccharides play fundamental roles in enzymatic stability through electrostatic, dipole-ionic or hydrophobic interactions. This is due to the chemical interactions and functional groups that are present in the support.

GZP immobilization studies in the PEJU-GO and PEJUp-GO complexes presented 100\% and $85 \%$ immobilization yield, respectively. In this context, the solubility in water presented by PEJU-GO makes this material an attractive support for enzyme immobilization, since its recovery can easily be achieved by simple precipitation with polar organic solvents, such as ethanol. This yield is justifiable due to the structure presented by electron microscopy (Figure 2C), in which the enzyme binds to the support through electrostatic attractions established between the opposing charges, both on the surface of the support (for PEJU-GO, porous and with reliefs) and on the enzyme. In addition, the total adsorption capacity of the final product is predicted as a function of the texture and chemistry of the polymer (Kristiansen et al., 2010). 
The influence of $\mathrm{pH}$ in this process is determinant and is shown in Table 1. Studies by Liu et al. (2002) reported the stabilization of the enzymatic activity of HRP in the presence of polysaccharides (such as dextran and sodium alginate), resulting in the retention of HRP activity when there are changes in $\mathrm{pH}$ and temperature. The use of polysaccharides as additives may increase catalytic efficiency by forming a protective layer at the active site of the enzyme to restrain the attack of free phenoxy radicals formed in the catalytic cycle (Kalaiarasan and Palvannan, 2013). Since PEJU-GO is able to retain HRP activity in both acidic (66\% enzymatic activity at $\mathrm{pH} 5)$ and neutral (65\% enzymatic activity at $\mathrm{pH} 7)$ conditions, this behavior allows its application in different reaction media.

Table 1 also shows the operational stability of the immobilized complexes, allowing up to seven reaction cycles with retention of $21 \%$ of the enzymatic activity. These data demonstrate the potential of support-immobilized peroxidase systems in commercial applications such as low-cost waste treatment.

\subsection{Potential use of free and immobilized POX from green zucchini crude extract (Cucurbita pepo $\mathrm{L}$.) for the degradation of phenolic compounds}

In the phenol removal tests, the immobilized enzymes were effective in the treatment of any phenolic compounds (Figure 5). The GZP-SB removed $79 \%$ of phenol from the WTS (after $120 \mathrm{~min}$ ), $19 \%$ of pyrogallol after $10 \mathrm{~min}$ and more than $90 \%$ of the textile effluent after 400 min of reaction. The GZP-PEJU complex was able to remove $59 \%$ of pyrogallol and $48 \%$ of bromophenol after $10 \mathrm{~min}$ of reaction. For the textile effluent, GZP-PEJU presented 76\% removal efficiency in $180 \mathrm{~min}$ of reaction and $93 \%$ for the industrial effluent in $420 \mathrm{~min}$ of reaction.

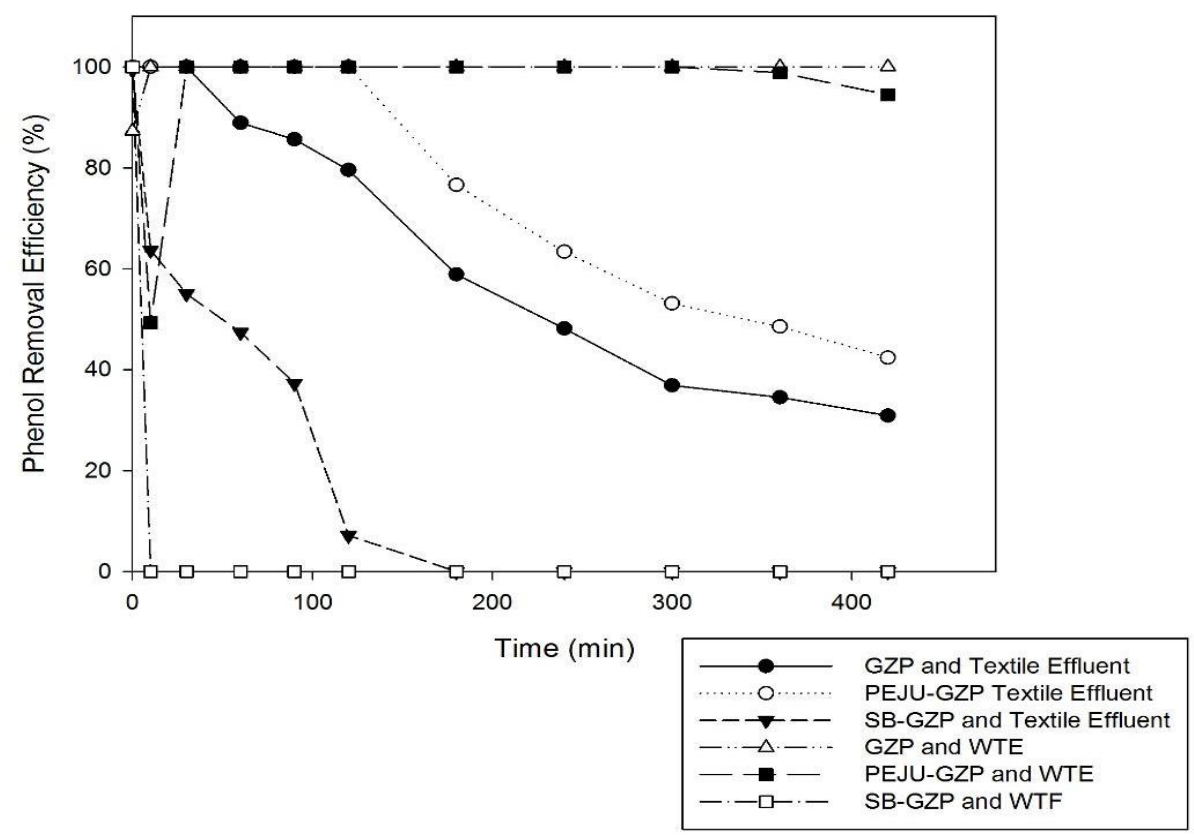

Figure 5. Phenol efficiency removal of green zucchini peroxidase (Cucurbita pepo, L.) and immobilized complexes in the effluent samples. Data were expressed in percentages. Circles represent the treatment on the textile effluent (a closed circle is free GZP and an open circle is the PEJU-GZP treatment). Downward-pointing triangles are SB-GZP treatments on textile effluent. Open triangles show the GZP capacity to treat effluent from WTS. Squares represent WTS effluent treatment by PEJU-GZP (closed) and by SBGZP (open).

Source: Prepared by the author. 
The immobilized complexes removed phenolic compounds and presented similar or superior performance in relation to the free enzyme. This can be explained by the inactivation and / or inhibition of the free enzyme caused by interactions between phenoxyl radicals or phenolic polymers produced during catalysis (Vineh et al., 2018).

Industrial effluents were degraded by all enzymatic forms. However, if we consider the time incubation period, the GZP immobilized form was more stable and continually removed phenols from complex mixtures over time. This is in agreement with Tatsumi et al. (1996), which used HRP immobilized on cellulose via oxidation through periodate and removed more than $80 \%$ phenol from aqueous solutions using continuous reactors. Figure 5 also demonstrates that the maximum reaction time for the phenol removal by the immobilized complexes was up to $30 \mathrm{~min}$. The free enzyme needed $90 \mathrm{~min}$ to achieve the maximum of phenol removal capacity.

The GZP complexes immobilized in PEJU-GO and SB are effective for the removal of phenols, with better performance (in the majority of the treatments) in the treatment with the free enzyme, after 10 min of reaction. Both materials (Enzyme and Support) are biodegradable and extracted in a sustainable manner, thus reducing the negative impact of chemical analyses on the environment and analytical laboratories.

\section{CONCLUSIONS}

This survey offers new alternatives for enzyme immobilization techniques using sources from crude extracts in a biodegradable carrier. The crude extract of green zucchini (Cucurbita pepo L.) showed a high content of peroxidase activity in different $\mathrm{pH}$ ranges, which makes this material a promising source for application in enzymatic technology. In addition, both sugarcane bagasse and arboreal cashew polysaccharide are sources of biotechnological application, especially as low-cost supports for peroxidase immobilization by physical adsorption and covalent binding. The enzymatic activity occurs in different reaction media, with a biodegradable and non-toxic material that is extracted in a sustainable way. In addition to these applications, the removal of phenolic compounds by the immobilized enzyme system showed high efficiency when using physical adsorption immobilization. This set of advantages reduces the negative impact of chemical waste on the environment and provides new analytical laboratory practices. The immobilized systems could be effectively operable and reliable and considered as a techno-economical and eco-friendly-oriented process for a large-scale application.

\section{ACKNOWLEDGEMENTS}

The authors are grateful to the Technological and Innovation Regional Centre, to the employees of DAIA Waste Treatment and to Alessandro de Paula Cardoso (engineer, Hering Company) for providing the effluent samples. They also thank the Coordination for the Improvement of Higher Level Personnel (CAPES), the PROBIP/UEG program and the National Scientific and Technological Council $(C N P q)$ for providing fellowship support.

\section{REFERENCES}

AHIRWAR, R.; SHARMA, J. G.; NAHAR, P.; KUMAR, S. Immobilization studies of cellulase on three engineered polymer surfaces. Biocatalysis and Agricultural Biotechnology, v. 11, p. 248-251, 2017. http://dx.doi.org/10.1016/j.bcab.2017.07.014

AKHTAR, M.; DING, R. Covalently cross-linked proteins \& polysaccharides: Formation, characterisation and potential applications. Current Opinion in Colloid \& Interface Science, v. 28, p. 31-36, 2017. https://doi.org/10.1016/j.cocis.2017.01.002 
BHUSHETTE, P. R.; ANNAPURE, U. S. Comparative study of Acacia nilotica exudate gum and Acacia Gum. International Journal of Biological Macromolecules, v. 102, p. 266271, 2017. http://dx.doi.org/10.1016/j.ijbiomac.2017.03.178

CALVINI, P.; GORASSINI, A.; LUCIANO, G.; FRANCESCHI, E. FTIR and WAXS analysis of periodate oxycellulose: Evidence for a cluster mechanism of oxidation. Vibrational Spectroscopy, v. 40, p. 177-183, 2006. https://doi.org/10.1016/j.vibspec.2005.08.004

CHOONG, G. Y. H.; FOCATTIS, D. S. A. A method for the determination and correction of the effect of thermal degradation on the viscoelastic properties of degradable polymers. Polymer Degradation and Stability, v. 130, p. 182-188, 2016. https://doi.org/10.1016/j.polymdegradstab.2016.06.018

DARKO, A.; CHAN, A. P. C.; OWUSU-MANU, D. G.; AMEYAW, E. E. Drivers for implementing green building technologies: An international survey of experts. Journal $\begin{array}{llllll}\text { of Cleaner Production, v. 145, p. 386-394, } 2017 . & \end{array}$ https://doi.org/10.1016/j.jclepro.2017.01.043

GOUVEIA, E. R.; NASCIMENTO, R. T.; SOUTO-MAIOR, A. M.; ROCHA, G. J. M. Validação de metodologia para caracterização química de bagaço de cana-de-açúcar. Química Nova, v. 32, n. 6, p. 1500-1503, 2009.

KALAIARASAN, E.; PALVANNAN, T. Removal of phenols from acidic environment by horseradish peroxidase (HRP): Aqueous thermostabilization of HRP by polysaccharide additives. Journal of the Taiwan Institute of Chemical Engineers, v. 11, p. 51-64, 2013. https://doi.org/10.1016/j.jtice.2013.07.003

KRISTIANSEN, K. A.; POTTHAST, A.; CHRISTENSEN, B. E. Periodate oxidation of polysaccharides for modification of chemical and physical properties. Carbohydrate Research, v. 345, p. 1264-1271, 2010. https://doi.org/10.1016/j.carres.2010.02.011

LIU, J. Z.; SONG, H. Y.; WENG, L. P.; JI, L. N. Increased thermostability and phenol removal efficiency by chemical modified horseradish peroxidase. Journal of Molecular Catalysis B: Enzymatic, v. 18, p. 225-232, 2002. https://doi.org/10.1016/S13811177(02)00100-5

NIU, J.; XU, J.; DAI, Y.; XU, J.; GUO, H.; SUN, K, LIU, R. Immobilization of horseradish peroxidase by electrospun fibrous membranes for adsorption and degradation of pentachlorophenol in water. Journal of Hazardous Materials, v. 246-247, p. 119-125, 2013. https://doi.org/10.1016/j.jhazmat.2012.12.023

RAMALHO, R. P. R. S.; SCALIZE, P. S.; CARAMORI, S. S. Peroxidase of Brazilian Cerrado grass as an alternative for agro industrial waste treatment. Revista Ambiente \& Água, v. 11, n. 1, p. 50-59, 2016. http://dx.doi.org/10.4136/ambi-agua.1735

SILVA T. M.; SOUZA, E. R. B., de PAUlA, J. A. M.; CARAMORI, S. S. Chemical characterization and biotechnological application of cashew tree polysaccharide of Brazilian Cerrado (Anacardium othonianum Rizz.), Anarcadiaceae. Revista Fronteiras: Journal of Social, Technological and Environmental Science, v. 6, n. 3, p. 230-246, 2017. http://dx.doi.org/10.21664/2238-8869.2017v6i3.p230-246

TATSUMI, K.; WADA, S.; ICHIKAWA, H. Removal of chlorophenols from wastewater by immobilized horseradish peroxidase. Biotechnology Bioengineering, v. 51; p. 126-30, 1996. https://doi.org/10.1002/(SICI)1097-0290(19960705)51:1\%3C126::AIDBIT15\%3E3.0.CO;2-O 
VIEIRA, I. C.; LUPETTI, K. O.; FATIBELLO-FILHO, O. Determination of paracetamol in pharmaceutical products using a carbon paste biosensor modified with crude extract of zucchini (Cucurbita pepo). Química Nova, v. 26, n. 1, p. 39-43, 2003. http://dx.doi.org/10.1590/S0100-40422003000100009

VINEH, M. B.; SABOURY, A. A.; POOSTCHI, A. A.; RASHID, A. M.; PARIVA, K. Stability and activity improvement of horseradish peroxidase by covalent immobilization on functionalized reduced graphene oxide and biodegradation of high phenol concentration. Journal of Biological Macromolecules, v. 106, p. 1314-1322, 2018. https://doi.org/10.1016/j.ijbiomac.2017.08.133 


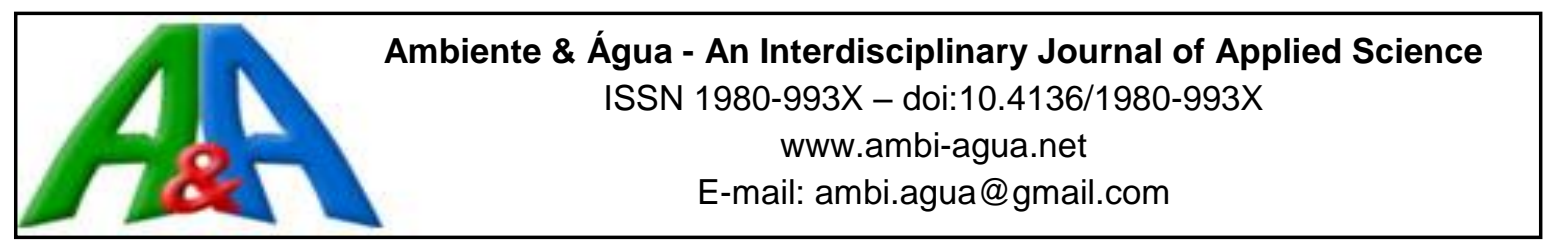

\title{
Quality of the water fluoridation and municipal-level indicators in a Brazilian metropolitan region
}

\author{
ARTICLES doi:10.4136/ambi-agua.2270
}

Received: 20 Apr. 2018; Accepted: 05 Oct. 2018

\section{Lorrayne Belotti $^{1 *}$; Paulo Frazão ${ }^{1}$; Carolina Dutra Degli Esposti²; Jaime Aparecido Cury ${ }^{3}$; Edson Theodoro dos Santos Neto²; Karina Tonini dos Santos Pacheco ${ }^{2}$}

\author{
${ }^{1}$ Faculdade de Saúde Pública da Universidade de São Paulo (FSP-USP), São Paulo, SP, Brasil \\ Departamento de Política, Gestão e Saúde. E-mail: lorraynebelotti@usp.br, pafrazao@usp.br \\ ${ }^{2}$ Universidade Federal do Espírito Santo (UFES), Vitória, ES, Brasil \\ Departamento de Medicina Social (DMS). E-mail: carolinaesposti@gmail.com, \\ edsontheodoro@uol.com.br, kktonini@yahoo.com.br \\ ${ }^{3}$ Faculdade de Odontologia de Piracicaba (FOP/UNICAMP), Piracicaba, SP, Brasil \\ Departamento de Ciências Fisiológicas (DCF). E-mail: jcury@unicamp.br \\ "Corresponding author
}

\begin{abstract}
This study explored the relationship between water fluoridation quality and development indicators at municipal level. In addition, fluoride concentrations found were classified based on two criteria for interpreting the samples. A cross-sectional ecological exploratory study was carried out including all municipalities of the metropolitan region of Great Vitória, ES, Brazil. From May to October 2016, 648 samples of water were collected covering water treatment plants responsible for more than $80 \%$ of the population of each municipality. The fluoride concentration of each sample was determined using ion-specific electrode and the results were classified according to the federal act and the criterion proposed by the Collaborating Center of the Brazilian Ministry of Health for Oral Health Surveillance. The outcome was the rate of values included in the optimal concentration interval and the independent variables were municipal-level indicators related to demographics, economics, sanitation, health conditions and human development characteristics. The Spearman test and Kappa statistic were used in the analysis. The percentage of samples presenting optimal fluoride concentration ranged from 68.1 to $81.4 \%$, considering the two criteria used. The Kappa statistic between the criteria was 0.671 (p-value $=0.001)$. Human development, average coverage of supervised toothbrushing, and total population showed a strong positive correlation with the quality of fluoridation while infant mortality and tooth-extraction/dental procedures ratio showed a strong negative correlation. The plausibility of observed correlations encourages further investigations of potential causes.
\end{abstract}

Keywords: development indicators, fluoride, vigilance in health, water analysis, water fluoridation. 


\section{Qualidade da fluoretação da água e indicadores de nível municipal em uma região metropolitana Brasileira}

\section{RESUMO}

O objetivo do estudo foi analisar a relação entre a qualidade da fluoretação da água e indicadores de desenvolvimento em nível municipal. Além disso, a concentração de fluoreto foi classificada de acordo com dois critérios para interpretação das amostras. Foi realizado um estudo exploratório ecológico transversal nos municípios que compõem a Região Metropolitana da Grande Vitória, ES, Brasil. Foram coletadas 648 amostras de água tratada em Estações de Tratamento de Água que abastecem mais de $80 \%$ da população de cada município, durante o período de maio a outubro de 2016. A concentração de fluoreto de cada amostra foi determinada através do método do eletrodo específico e os resultados foram categorizados de acordo com a legislação brasileira e o critério proposto pelo Centro Colaborador do Ministério da Saúde em Vigilância da Saúde Bucal. A variável dependente foi a taxa de valores incluídos no intervalo de concentração ideal e as variáveis independentes foram indicadores de nível municipal relacionados às características demográficas, econômicas, saneamento, condições de saúde e desenvolvimento humano. Correlação de Spearman e estatística Kappa foram utilizadas nas análises. O percentual de amostras que apresentou níveis ótimos de fluoreto variou entre 68,1 e $81,4 \%$ de acordo com os diferentes critérios. O valor da estatística Kappa entre os critérios foi 0,671 ( $\mathrm{p}<0,001)$. O nível de desenvolvimento humano, a média de escovação supervisionada e a população total exibiram forte correlação positiva com a qualidade da fluoretação, enquanto, a taxa de mortalidade infantil e a proporção de exodontias apresentaram correlação forte e negativa. A plausibilidade das correlações observadas pode encorajar novas investigações sobre possíveis relações causais.

Palavras-chave: análise da água, indicadores de desenvolvimento, flúor, fluoretação da água, vigilância em saúde.

\section{INTRODUCTION}

Fluoridation of public water supply is considered one of the ten most important public health measures of the 20th century (CDC, 1999). In addition to reducing tooth-decay rates (rates of cavities), its low cost compared to the high social benefit reduces social inequality in the access to fluoride and can benefit all strata of the population according to the reach of the network of public utilities' water supply (Kumar, 2008).

Data from British Fluoridation Society showed that water fluoridation had reached about 370 million people worldwide around 2012. Among the ten most populous countries, United States and Brazil have the greatest coverages (Rugg-Gunn and Do, 2012; Frazão and Narvai, 2017). However, there are important within-country differences regarding access to water fluoridation. Generally, the residents in the least-developed least-populated areas do not have access to water fluoridation or the fluoride amount in drinking water is unknown (Gabardo et al., 2008; Peres et al., 2004).

Experts advocate the need for the implementation of control and monitoring systems to ensure the quality and effectiveness of the water fluoridation as a public policy (Narvai, 2000; Pelletier, 2004; Yarmolinky et al., 2009; Esposti and Frazão, 2015). Systematic assessment revealed a potential discontinuity characterized by concentration values not complying with the legislation and being below the level prescribed to prevent tooth decay, reinforcing the warnings of several researchers regarding the need to expand water fluoridation monitoring systems. While not exposed to the risk of dental fluorosis, the population would be deprived of the maximum benefit provided by an adequate level of fluoride in water (Venturini et al., 2016). 
Except for a study that found increasing rates of fluoridation standard compliance according to the scale of the supply systems and the values of the HDI (Daré et al., 2009), information on the relationship between the quality level of fluoridation and municipal-level indicators related to sanitation, health, economic and income inequality variables is scarce.

Considering the dissimilarity showed in the scientific literature regarding the interpretation of data on fluoride concentration (Venturini et al., 2016) and the interest in the qualification of fluoridation systems, Brazilian experts have reached a technical consensus (CECOL, 2011) to classify public water supplies according to fluoride contents. Few studies have compared this new criterion with the conventional one (Brasil, 1976), assessing the differences among the results. Kuhnen et al. (2017) and Peixoto et al. (2012) interpreted the results of water samples using both criteria and observed substantial differences between them.

This study explored the relationship between water fluoridation quality and development indicators at the municipal level. In addition, fluoride concentrations were classified based on two classification criteria for interpreting the samples.

\section{MATERIALS AND METHODS}

A cross-sectional ecological exploratory study was carried out comprising all municipalities of the Metropolitan Region of Great Vitória (RMGV), Espírito Santo (ES). The RMGV-ES includes $49 \%$ of the population of the state (Incaper, 2016). It is comprised of seven municipalities: Cariacica, Guarapari, Fundão, Serra, Viana, Vila Velha and Vitória. There are important socioeconomic and demographic differences among them (Table 1). In 2010, the urbanization rate of the RMGV-ES amounted to $98.3 \%$. The water supply reaches a significant share of the population (98.1\%). The value of the Human Development Index (HDI) is high (0.772) and the region ranks eighth among the 20 Brazilian metropolitan regions (PNUD, 2010).

Treated water was collected throughout six consecutive months, from May to October 2016. The quality of fluoridated water was assessed based on optimal fluoride concentration values observed in the distribution network for obtaining the preventive effect, assuming that these values represent the main critical point of a complex chain of events regarding the stages of water supply, from catchment to consumer.

\subsection{Setting the location of sampling points}

The sampling points were established by taking into account the water-treatment plants (ETS) and treated-water reservoirs (RAT) as reference units (RU) in compliance with the Sampling Guide for Surveillance of Fluoride Concentration in Public Water Supply provided by the Collaborating Center of the Brazilian Ministry of Health for Oral Health Surveillance (www.cecol.fsp.usp.br). The selected ETS were the ones supplying 80\% of the population of each municipality. In one municipality where $77 \%$ of the population had access to treated water, all ETS were included in the survey (Frazão and Narvai, 2017).

In municipalities where there was no ETS, the RAT supplied by the selected ETS became the RU for sampling. Therefore, 18 UR were selected for the region as a whole, six samples were collected by UR, three at their nearest point and three at the most distant reach from the ETS or RAT. In all, 108 water samples were collected at different points per month, totalling 648 samples at the end of the six months of sampling. The selected points cover $91.4 \%$ of the total population of the RMGV-ES (Table 1).

To facilitate access to the site and avoid sample losses, sampling points were defined primarily in public places and commercial establishments, such as schools, health units, town squares, supermarkets and bakeries. Therefore, private buildings or residences were not included in the sampling universe.

\section{IPABH}

Rev. Ambient. Água vol. 13 n. 6, e2270 - Taubaté 2018 
Table 1. Distribution of water samples and the municipal variables that make up the RMGV-ES.

\begin{tabular}{lcccccccc}
\hline Description & Cariacica & Fundão & Guarapari & Serra & Viana & $\begin{array}{c}\text { Vila } \\
\text { Velha }\end{array}$ & Vitória & Total \\
\hline $\begin{array}{l}\text { Reference Units } \\
\text { (UR) }\end{array}$ & 1 & 2 & 1 & 1 & 4 & 4 & 5 & 18 \\
\hline $\begin{array}{l}\text { Sampling Points } \\
\text { per Month }\end{array}$ & 6 & 12 & 6 & 6 & 24 & 24 & 30 & 108 \\
\hline $\begin{array}{l}\text { Number of } \\
\text { Samples }\end{array}$ & 36 & 72 & 36 & 36 & 144 & 144 & 180 & 648 \\
\hline $\begin{array}{l}\text { Population } \\
\begin{array}{l}\text { Coverage } \\
\text { by UR }\end{array}\end{array}$ & $80 \%$ & $88 \%$ & $92 \%$ & $98 \%$ & $77 \%$ & $86 \%$ & $100 \%$ & $91.4 \%$ \\
\hline
\end{tabular}

\begin{tabular}{|c|c|c|c|c|c|c|c|c|}
\hline \multicolumn{9}{|c|}{ Variables } \\
\hline Total Population & 381,802 & 19,985 & 119,802 & 485,376 & 74,499 & 472,762 & 355,875 & $1,910,101$ \\
\hline $\begin{array}{l}\text { GDP per capita } \\
\text { (in thousand of } \\
\text { Brazilian Real*) }\end{array}$ & 18,371 & 24,183 & 15,389 & 33,039 & 20,217 & 21,914 & 64,002 & - \\
\hline HDI & 0.718 & 0.718 & 0.731 & 0.739 & 0.686 & 0.800 & 0.845 & - \\
\hline Gini Index & 0.473 & 0.500 & 0.592 & 0.491 & 0.450 & 0.568 & 0.612 & - \\
\hline $\begin{array}{l}\text { Rate of } \\
\text { households with } \\
\text { running water }\end{array}$ & $99.3 \%$ & $95.0 \%$ & $97.3 \%$ & $99.1 \%$ & $96.1 \%$ & $99.5 \%$ & $99.9 \%$ & - \\
\hline $\begin{array}{l}\text { Infant Mortality } \\
\text { Rate }\end{array}$ & 13.20 & 13.60 & 14.40 & 13.20 & 15.60 & 10.90 & 11.40 & - \\
\hline $\begin{array}{l}\text { Hospitalization } \\
\text { for diarrhea } \\
(\text { rate / 10,000) }\end{array}$ & 4.00 & 4.00 & 6.70 & 3.10 & 3.90 & 4.90 & 4.50 & - \\
\hline $\begin{array}{l}\text { Tooth- } \\
\text { extraction/dental } \\
\text { procedures ratio }\end{array}$ & 7.10 & 8,24 & 6,81 & 4,80 & 6,38 & 5,32 & 4,16 & \\
\hline $\begin{array}{l}\text { Access to } \\
\text { innovative oral } \\
\text { primary health } \\
\text { care }\end{array}$ & $35.8 \%$ & $85.1 \%$ & $57.7 \%$ & $50.8 \%$ & $62.9 \%$ & $31.1 \%$ & $70.7 \%$ & - \\
\hline $\begin{array}{l}\text { Monthly } \\
\text { Average } \\
\text { coverage } \\
\text { supervised } \\
\text { toothbrushing }\end{array}$ & $1.79 \%$ & $0.44 \%$ & $1.41 \%$ & $2.54 \%$ & $0.33 \%$ & $2.46 \%$ & $5.96 \%$ & - \\
\hline
\end{tabular}

Note: *The official currency of Brazil. GDP: Gross Domestic Product, HDI: Human Development Index.

\subsection{Sampling and Analysis of the Fluoride Content}

The adopted technical procedures complied with the Protocol of Water Sampling and Analysis provided by the Collaborating Center of the Brazilian Ministry of Health for Oral Health Surveillance (www.cecol.fsp.usp.br). The water samples were collected using $10 \mathrm{~mL}$ polyethylene bottles identified with labels indicating the point of the collection, the date of the collection and the name of the collector. Samples were collected once a month, on working 
days, at previously set points. At the end of each week of collection, samples were sent for analysis to the Biochemistry Laboratory from Piracicaba Dentistry School - University of Campinas, São Paulo, Brazil (FOP-UNICAMP).

The content of fluoride in the water samples was determined in duplicate, using an ion specific electrode, coupled to the potentiometer, due to its practicability and sensitivity. This electrode was previously calibrated with standard solutions containing $0.1,0.2,0.4,0.8,1.6$ or $3.2 \mathrm{mg}$ fluoride. Only calibration curves with a maximum variation of $5 \%$ were accepted. The reliability of the results were checked with a new reading of $10 \%$ of the samples (Frazão \& Narvai, 2017).

\subsection{Classification of the Samples}

Considering that the average annual maximum daily temperatures ranged from $28^{\circ} \mathrm{C}$ to $32^{\circ} \mathrm{C}$ (Incaper, 2016), the fluoride content of the samples were classified according to two interpretation criteria described below.

Criterion I: according to federal act (Brasil, 1976), the samples were classified as suitable for content between $0.6 \mathrm{mg} \mathrm{F} / \mathrm{L}$ and $0.8 \mathrm{mg} \mathrm{F} / \mathrm{L}$, inadequate low when $<0.6 \mathrm{mg} \mathrm{F} / \mathrm{L}$ and inadequate high when $>0.8 \mathrm{mg} \mathrm{F} / \mathrm{L}$. The optimum fluoride content for the region is set to be $0.7 \mathrm{mg} \mathrm{F} / \mathrm{L}$, with a minimum limit of $0.6 \mathrm{mg} \mathrm{F} / \mathrm{L}$ and a maximum limit of $0.8 \mathrm{mg} \mathrm{F} / \mathrm{L}$ (variation of $0.1 \mathrm{mg} \mathrm{F} / \mathrm{L}$ ).

Criterion II: in compliance with the technical consensus document (CECOL, 2011), the samples were classified into six categories according to the prevention of dental caries and the inherent risk of dental fluorosis. The categories are: benefit and negligible risk ( 0.00 to $0.44 \mathrm{mg}$ $\mathrm{F} / \mathrm{L})$; minimal benefit and low risk ( 0.45 to $0.54 \mathrm{mg} \mathrm{F} / \mathrm{L})$; maximum benefit and low risk $(0.55$ to $0.84 \mathrm{mg} \mathrm{F} / \mathrm{L})$; maximum benefit and moderate risk (0.85 to $1.14 \mathrm{mg} \mathrm{F} / \mathrm{L})$; questionable benefit and high risk (1.15 to $1.44 \mathrm{mg} \mathrm{F} / \mathrm{L})$; and damage and very high risk (>1.45 $\mathrm{mg} \mathrm{F} / \mathrm{L}$ ).

\subsection{Quality Level of Fluoridation}

The quality level of fluoridation was set by the percentage of samples included in the interval of optimal concentration values to obtain the preventive effect as per each criterion of interpretation shown below. Similarly to Pelletier (2004), it was assumed that 80 percent or more of samples within optimal values constituted high quality for water fluoridation supply (Equation 1 and 2).

$$
\begin{aligned}
& Q L_{\text {Criterion I }}=\frac{\text { No.of samples }\left(0.6 \leq T_{\text {fluoride }} \leq 0.8\right)}{\text { Total number of samples }(n)} \times 100 \\
& Q L_{\text {Criterion II }}=\frac{\text { No.of samples }\left(0.55 \leq T_{\text {fluoride }} \leq 0.84\right)}{\text { Total number of samples }(n)} \times 100
\end{aligned}
$$

\subsection{Characteristics of the Municipal Development}

Demographic, economic, sanitation, health conditions, human development, income inequality and oral health care indicators obtained from official sources (PNUD, 2010; Brasil, 2016; IBGE, 2015) were used in order to explore possible relationships with the quality level of fluoridation, as described below:

- demographic: data of the total population of each municipality estimated for the year 2015 were used, assuming that more populous municipalities would gather conditions and resources that would be reflected in higher quality levels of fluoridation.

- economic: the gross domestic product (GDP) per capita was used, considering that municipalities with higher economic output would have more resources and, consequently, better quality levels of fluoridation.

- health indicators: we used data on deaths of children under one year of age per thousand live births in the year 2010 and hospitalizations for diarrhea per 10 thousand inhabitants in the 
period from 2010 to 2015, since both indicators reflect municipal-level health conditions, assuming that poorer conditions would be related to low quality levels of fluoridation.

- human development: the HDI was used, assuming that municipalities with the worst indicators of education, longevity and income would also have low quality levels of fluoridation.

- income inequality: the Gini index (which ranges from 0 to 1) was used for the year 2010, considering that higher values of inequality in income distribution would be associated with municipalities with low investment in public policies, reflecting lower levels of fluoridation.

- sanitation: percentage of households with running water in 2010, considering that lower rates of access to treated water would correlate with worse quality levels of fluoridation.

- oral health care: access rate to innovative oral primary health care provided by dental health teams in the Health Family Strategy (WHO, 2008), ratio of the extractions of permanent teeth in relation to the total number of individual dental procedures that were performed, monthly average coverage of supervised toothbrushing related to 2015 . These indicators were used assuming that better indicators of oral health care would correlate with better levels of water fluoridation quality.

\subsection{Statistical Analysis}

Absolute and relative frequencies were calculated according to both sample classification criteria. The quality level of community water fluoridation was measured and Spearman's nonparametric test was used to analyze the correlation between the outcome and the characteristics of the municipalities according to Criterion II. Correlation values were classified as strong for 0.5 or higher, moderate for values ranging from 0.3 to 0.5 , and weak for values between 0.1 and 0.244 (Cohen, 1988). Interpretation criteria of fluoride content in water were compared using Kappa statistics. The similarity levels were assessed according to the categories proposed by Landis and Koch (1977). In order to make it possible to compare the values recommended by the legislation with the ones proposed by CECOL, they were sorted out into three categories: negligible benefit / minimum risk; maximum benefit / low risk; and maximum benefit / moderate to very high risk. The level of significance adopted for rejection of the null hypothesis was 5\%. Statistical Package for the Social Sciences (SPSS), Version 20.0 was used.

\section{RESULTS AND DISCUSSION}

A total of 646 samples were analyzed from May to October 2016, because two samples were lost during the analysis process. Table 2 shows that $68.1 \%$ of the samples showed adequate fluoride content in the water according to the Criterion I classification. The percentage of adequate samples according to the Criterion II was $81.4 \%$; therefore, with maximum benefit against tooth decay and low risk of fluorosis. However, the rate of adequate samples decreased considerably in July, $24.1 \%$ and $41.7 \%$, respectively for Criteria I and II.

Table 3 illustrates the rates of optimal fluoride levels by municipality throughout the six months of sampling. The differences were remarkable according to the used criterion. As shown in the last column, only the municipality of Serra showed a high level of quality in both criteria. Vitoria and Cariacica would present nonconformity if only Criterion I were adopted. The lowest rates were observed in the city of Viana, according to both criteria (46.5\% according to Criterion I and $66 \%$ according to Criterion II). In all municipalities, the month of July showed disproportions in the concentration of fluoride. The municipality of Cariacica did not show any optimal value in both criteria in that month. In spite of the observed differences between the criteria, the Kappa statistic was 0.671 , showing substantial agreement (p-value $<0,001$ ).

This exploratory study showed that the proportion of optimal fluoride levels in the RMGVES was higher with regard to Criterion II than Criterion I. Although a high-quality standard was 
observed, when one analyzes each municipality, some irregularities stood out. It is worth noting that all the samples of the municipality of Cariacica in July were inadequate according to both criteria.

Table 2. Classification of samples according to fluoride concentration values (mg F / L) (Criterion I and II) in the RMGV-ES.

\begin{tabular}{|c|c|c|c|c|c|c|c|c|c|c|c|c|c|c|}
\hline \multirow{2}{*}{$\frac{\text { Criteria }}{\text { I-Legislation }}$} & \multicolumn{2}{|c|}{ May } & \multicolumn{2}{|c|}{ June } & \multicolumn{2}{|c|}{ July } & \multicolumn{2}{|c|}{ August } & \multicolumn{2}{|c|}{ September* } & \multicolumn{2}{|c|}{ October } & \multicolumn{2}{|c|}{ Total } \\
\hline & $\mathrm{N}$ & $\%$ & $\mathrm{~N}$ & $\%$ & $\mathrm{~N}$ & $\%$ & $\mathrm{~N}$ & $\%$ & $\mathrm{~N}$ & $\%$ & $\mathrm{~N}$ & $\%$ & $\mathrm{~N}$ & $\%$ \\
\hline $\begin{array}{l}\text { Inadequate low } \\
(<0,599)\end{array}$ & 11 & 10.2 & 20 & 18.5 & 82 & 75.9 & 10 & 9.3 & 13 & 12.3 & 25 & 23.1 & 161 & 24.9 \\
\hline $\begin{array}{l}\text { Adequate } \\
(0.6 \text { a } 0.8)\end{array}$ & 80 & 74.1 & 83 & 76.8 & 26 & 24.1 & 83 & 76.9 & 87 & 82.1 & 81 & 75.0 & 440 & 68.1 \\
\hline $\begin{array}{l}\text { Inadequate high } \\
(>0.801)\end{array}$ & 17 & 15.7 & 5 & 4.6 & 0 & 0 & 15 & 13.9 & 6 & 5.7 & 2 & 1.9 & 45 & 7.0 \\
\hline Total & 108 & 100 & 108 & 100 & 108 & 100 & 108 & 100 & 106 & 100 & 108 & 100 & 646 & 100 \\
\hline II- Cecol & $\mathrm{N}$ & $\%$ & $\mathrm{~N}$ & $\%$ & $\mathrm{~N}$ & $\%$ & $\mathrm{~N}$ & $\%$ & $\mathrm{~N}$ & $\%$ & $\mathrm{~N}$ & $\%$ & $\mathrm{~N}$ & $\%$ \\
\hline Benefit/ Risk & & & & & & & & & & & & & & \\
\hline $\begin{array}{l}\text { Negligible/ } \\
\text { Negligible } \\
(0.00 \text { a } 0.44)\end{array}$ & 2 & 1.8 & 3 & 2.8 & 9 & 8.3 & 4 & 3.7 & 4 & 3.8 & 1 & 0.9 & 23 & 3.6 \\
\hline $\begin{array}{l}\text { Minimum/ } \\
\text { low } \\
(0.45 \text { a } 0.54)\end{array}$ & 0 & 0.0 & 7 & 6.5 & 54 & 50.0 & 3 & 2.8 & 6 & 5.7 & 9 & 8.3 & 79 & 12.2 \\
\hline $\begin{array}{l}\text { Maximum/ } \\
\text { low } \\
(0.55 \text { a } 0.84)\end{array}$ & 97 & 89.8 & 96 & 88.9 & 45 & 41.7 & 98 & 90.7 & 93 & 87.7 & 97 & 89.8 & 526 & 81.4 \\
\hline $\begin{array}{l}\text { Maximum / } \\
\text { Moderate } \\
(0.85 \text { a } 1.14)\end{array}$ & 5 & 4.6 & 2 & 1.8 & 0 & 0.0 & 3 & 2.8 & 3 & 2.8 & 1 & 0.9 & 14 & 2.2 \\
\hline $\begin{array}{l}\text { Questionable/High } \\
\text { (1.15 a } 1.44)\end{array}$ & 0 & 0.0 & 0 & 0.0 & 0 & 0.0 & 0 & 0.0 & 0 & 0.0 & 0 & 0.0 & 0 & 0.6 \\
\hline $\begin{array}{l}\text { Damage/ Very } \\
\text { High ( } 1.45 \text { or } \\
\text { higher) }\end{array}$ & 0 & 0.0 & 0 & 0.0 & 0 & 0.0 & 0 & 0.0 & 0 & 0.0 & 0 & 0.0 & 0 & 0.0 \\
\hline Total & 108 & 100 & 108 & 100 & 108 & 100 & 108 & 100 & 106 & 100 & 108 & 100 & 646 & 100 \\
\hline
\end{tabular}

*Two samples were lost during the analysis process.

Despite the discrepancies of the results in some municipalities in the month of July, there was a satisfactory recovery of the quality levels of fluoridation in the following months. This may show that monitoring has, indeed, fulfilled its role through enforcement actions and adoption of measures to guarantee access to high quality of treated and fluoridated water (Stancari et al., 2014). However, a study conducted in municipalities in Brazil with more than 50,000 inhabitants evidenced the need to formulate strategies for monitoring fluoridation in the country, because only $53.0 \%$ of fluoridated municipalities conducted monitoring based on external control data (Frazão and Narvai, 2017). 
Table 3. Percentage of optimal concentration values according to the month and the municipalities of the RMGV-ES, as per Criterion I and II.

\begin{tabular}{lcccccccccccccc}
\hline Municipality & \multicolumn{2}{c}{ May } & \multicolumn{2}{c}{ June } & \multicolumn{2}{c}{ July } & \multicolumn{2}{c}{ August } & \multicolumn{2}{c}{ September* } & October & \multicolumn{2}{c}{ Total } \\
\hline Criterion I & $\mathrm{N}$ & $\%$ & $\mathrm{~N}$ & $\%$ & $\mathrm{~N}$ & $\%$ & $\mathrm{~N}$ & $\%$ & $\mathrm{~N}$ & $\%$ & $\mathrm{~N}$ & $\%$ & $\mathrm{~N}$ & $\%$ \\
\hline Viana & 9 & 37.5 & 12 & 50.0 & 3 & 12.5 & 13 & 54.2 & 12 & 50.0 & 18 & 75.0 & 67 & 46.5 \\
Vitória & 27 & 90.0 & 26 & 86.7 & 7 & 23.3 & 26 & 86.7 & 29 & 100.0 & 19 & 63.3 & 134 & 74.9 \\
Cariacica & 6 & 100.0 & 6 & 100.0 & 0 & 0.0 & 4 & 66.7 & 3 & 50.0 & 6 & 100.0 & 25 & 69.4 \\
Serra & 5 & 83.3 & 6 & 100.0 & 5 & 83.3 & 6 & 100.0 & 6 & 100.0 & 4 & 66.7 & 32 & 88.9 \\
Fundão & 8 & 66.7 & 8 & 66.7 & 8 & 66.7 & 8 & 66.7 & 9 & 75.0 & 8 & 66.7 & 49 & 68.1 \\
Guarapari & 5 & 83.3 & 4 & 66.7 & 0 & 0.0 & 6 & 100.0 & 6 & 100.0 & 3 & 50.0 & 24 & 66.7 \\
Vila Velha & 20 & 83.3 & 21 & 87.5 & 3 & 12.5 & 20 & 83.3 & 22 & 95.7 & 23 & 95.8 & 109 & 76.2 \\
\hline Criterion II & $\mathrm{N}$ & $\%$ & $\mathrm{~N}$ & $\%$ & $\mathrm{~N}$ & $\%$ & $\mathrm{~N}$ & $\%$ & $\mathrm{~N}$ & $\%$ & $\mathrm{~N}$ & $\%$ & $\mathrm{~N}$ & $\%$ \\
\hline Viana & 20 & 83.3 & 13 & 54.2 & 6 & 25.0 & 20 & 83.3 & 13 & 54.2 & 23 & 95.8 & 95 & 66.0 \\
Vitória & 29 & 96.7 & 29 & 96.7 & 16 & 53.3 & 29 & 96.7 & 29 & 100.0 & 30 & 100.0 & 162 & 90.5 \\
Cariacica & 6 & 100.0 & 6 & 100.0 & 0 & 0.0 & 6 & 100.0 & 6 & 100.0 & 6 & 100.0 & 30 & 83.3 \\
Serra & 5 & 83.3 & 6 & 100.0 & 6 & 100.0 & 6 & 100.0 & 6 & 100.0 & 4 & 66.7 & 33 & 91.7 \\
Fundão & 10 & 83.3 & 12 & 100.0 & 8 & 66.7 & 8 & 66.7 & 10 & 83.3 & 8 & 66.7 & 56 & 77.8 \\
Guarapari & 5 & 83.3 & 6 & 100.0 & 4 & 66.7 & 6 & 100.0 & 6 & 100.0 & 3 & 50.0 & 30 & 83.3 \\
Vila Velha & 22 & 91.7 & 24 & 100.0 & 5 & 20.8 & 23 & 95.8 & 23 & 100.0 & 23 & 95.8 & 120 & 83.9 \\
\hline
\end{tabular}

*Two water samples were lost during the analysis process.

Note: Criterion I - Range values from 0.6 to $0.8 \mathrm{mg}$ F/L Criterion II - Range values from 0.55 to $0.84 \mathrm{mg} \mathrm{F} / \mathrm{L}$.

The differences related to the rates of optimal fluoride levels observed between the criteria may be associated to some points. First, the legislation criterion enacted in 1975 uses only one decimal place for interpretation of the results, unlike the CECOL criterion that uses at least two decimal places. The interpretation of the fluoride values through criterion that considers two or more decimal places is compatible with the advanced and the greater precision of the measurement methods currently employed. Consequently, a greater number of samples are included in the category of maximum preventive benefit, without implying an undesirable increase in the interval corresponding to the expected level of quality. A second point refers to the classification categories. Criterion II adopts six categories based on the current scientific evidence that water fluoridation can be considered a protective and risky factor simultaneously.

Regarding the parameters for assessing the benefits of fluoride content in water for human consumption, the Ordinance of the Ministry of Health (Brazil) No. 2914 from 2011 refers to the standards included in Administrative Rule MS No. 635 of 1975 (Brasil, 1976). This normative device is outdated and needs to be revised (Frazão et al., 2011). In addition, because it presents a dichotomous classification, experts have noted that it is an undesirable interpretative reduction (Venturini et al., 2016), and have emphasized that it does not consider the balance between benefits and risks to health (Frazão et al., 2011). Although most of the studies (75\%) used the dichotomous (adequate/inadequate) classification criterion, it is acknowledged that these narrow down the options for interpretation and attribution of meaning to the characteristics of the samples (Cecol, 2011; Bergamo et al., 2015).

In addition, fluoride concentrations between 1.0 and $1.7 \mathrm{mg} \mathrm{F} / \mathrm{L}$ would be tolerated for Criterion I at mean temperatures lower than those observed in the metropolitan region under study. These values are recognized as very high according to current scientific evidence. The CECOL criterion recommends the maximum concentration of $0.94 \mathrm{mg} \mathrm{F} / \mathrm{L}$ for mean temperatures below $26.3^{\circ}$, corresponding to the combination of maximum benefit against tooth decay and low risk of fluorosis.

It is important to note that, regarding the compliance rate, a substantial similarity was observed between both criteria. Because the classification takes into account both benefits and risks to health, the main advantage of the CECOL criterion is to redistribute the values of the 
samples that would be otherwise considered inadequate, to the categories indicating zero and minimum preventive benefit to dental health and moderate and high risk to fluorosis, situations that require different measures and arrangements from the environmental surveillance point of view.

In the metropolitan region throughout the period under study, the nonconformities were more frequent with respect to benefit reduction than with respect to an increase in risk, a result similar to that observed in the municipality of Jaguaribara, in the state of Ceará, whose temperature was similar to the metropolitan area of the present investigation (Peixoto et al., 2012). In Lages, Santa Catarina state, where the climate was cooler and the average annual value of the maximum daily temperatures ranged between $21.5^{\circ} \mathrm{C}$ and $26.3^{\circ} \mathrm{C}$, a study found a lower compliance rate according to the CECOL criterion and the nonconformities were more frequent (45\% of the samples) with respect to risk (Kuhnen et al., 2017).

As shown in the Table 4, the variables Gini index, GDP per capita, access to innovative oral primary healthcare, percentage of the households with running water and rate of hospitalization for diarrhea per 10 thousand inhabitants did not show statistically significant correlation values with the rates of optimal fluoride levels based on Criterion II. Values of strong positive correlation were found between the outcome and the following indicators: municipal HDI $(\mathrm{r}=0.864$; $\mathrm{p}$-value $=0.012)$, average supervised brushing $(\mathrm{r}=0.955, \mathrm{p}$-value $=$ $0.001)$ and the total population $(\mathrm{r}=0.829 ; \mathrm{p}$-value $=0.021)$. The infant mortality rate $(\mathrm{r}=-$ $0.736, \mathrm{p}$-value $=0.059)$ and the tooth extraction/dental procedures ratio $(\mathrm{r}=-0.764, \mathrm{p}$-value $=$ 0.046) showed strong and negative correlation.

The findings show that the quality level of the community water fluoridation may mirror local municipal factors. The values in the municipalities increase as values of HDI and population size increase. A study also found a relationship between the highest percentages of compliance with the fluoridation standard in larger scale systems and municipalities with higher HDI (Daré et al., 2009).

Table 4. Spearman's correlation between the quality level of community water fluoridation according to Criterion II and the municipal-level indicators.

\begin{tabular}{lccc}
\hline Variables & Correlation coefficient & $p$-value & Correlation \\
\hline Total Population & 0.829 & 0.021 & Strong \\
GDP per capita & 0.559 & 0.192 & Not significant \\
HDI & 0.864 & 0.012 & Strong \\
Gini Index & 0.468 & 0.289 & Not significant \\
$\begin{array}{l}\text { Rate of households with } \\
\text { running water }\end{array}$ & 0.721 & 0.068 & Not significant \\
$\begin{array}{l}\text { Infant Mortality Rate } \\
\text { Hospitalization for diarrhea }\end{array}$ & -0.736 & 0.059 & Strong \\
$\begin{array}{l}\text { per 10000 inhabitants } \\
\text { Tooth-extraction/dental }\end{array}$ & 0.036 & 0.938 & Not significant \\
$\begin{array}{l}\text { procedures ratio } \\
\text { Access to innovative oral }\end{array}$ & -0.764 & 0.046 & Strong \\
$\begin{array}{l}\text { Monthy health care } \\
\text { supervised toothbrushing }\end{array}$ & -0.360 & 0.427 & Not significant \\
\hline Note: GDP: Gross Domerage of & 0.955 & 0.001 & Strong \\
\hline
\end{tabular}

Note: GDP: Gross Domestic Product according to the official currency of Brazil; HDI: Human Development Index.

The association of the HDI with aspects such as the availability of public utilities water supply and the oral health conditions of the population is recognized (Ardenghi et al., 2013). In Brazil, populations living in cities with the worst socioeconomic conditions are the ones that do not benefit from water fluoridation as a public health measure (Gabardo et al., 2008). Also, 
the adoption of such preventive measure is delayed in cities with worse socioeconomic and demographic indicators, such as HDI, Gini index and GDP per capita (Peres et al., 2004). Municipalities with the worst HDI offer dental services with mutilating characteristics, which is probably related to difficult access to services and poor oral health conditions in those places (Fernandes and Peres, 2005; Fischer et al., 2010).

The highest quality levels in the municipalities with the largest populations may be related to the better municipal conditions of structure, organization and human resources in the water quality control program. In a study conducted in the US state of Illinois, less populated areas reported higher rates of nonconformity in the maintenance of adequate levels of fluoride in water (Kuthy et al., 1985).

Queiroz et al. (2012) also pointed out that small municipalities have difficulties in developing any corrective action based on the results of the analyses of water monitoring reports. In smaller municipalities, the lack of specialized manpower and the lack of training for the professionals that operate water treatment plants, and the lack of inspection structure and experience in controlling the fluoridation process are possible causes for difficulties in maintaining the appropriate concentrations of fluoride in public utilities' water supplies (Stancari et al., 2014).

The relationship between the municipal health indicators and the quality standard of fluoridation may reflect the fragility of the organization of services provided to the population, both in terms of health care and basic sanitation. The improvement of basic sanitation has a high impact on infant mortality. In this study, municipalities with higher infant mortality rates, an indicator that expresses the level of health of a population (Nascimento et al., 2014), showed the lowest rates of water fluoridation quality.

Among the indicators of oral healthcare, the monthly average coverage of supervised toothbrushing correlated positively with the quality of fluoridation. Both measures, fluoridation and supervised toothbrushing, are priorities of the national oral health policy (Brasil, 2004) and are essential for improving oral health conditions; they should be incorporated with other community health measures. Therefore, when absent or incipient, they may represent the ineffectiveness of local oral health policy regarding the provision of public policies aimed at the prevention of dental caries. It was also observed that the higher the tooth-extraction/dental procedures ratio, the lower the quality level of fluoridation. This negative correlation may mirror how structured local dental services are. Municipalities that have a well-structured dental practice associated with an adequate offer of scheduled consultations to the population tend to have a lower rate of exodontia (Celeste et al., 2011). Besides access to dental treatment, other factors also interfere with the rate of exodontia, such as socioeconomic conditions and level of education (Rihs et al., 2007; Pearson et al., 2001).

It is thus important to consider that the maintenance of high quality levels of water fluoridation could guarantee the benefits of such public health measures for the economically disadvantaged and contribute to reduce the socioeconomic bias in the prevalence of dental caries (Antunes and Narvai, 2010; Narvai et al., 2014).

The study's potential limitations include its cross-sectional design, number of municipalities analyzed, differences between population coverage by UR and rate of households with running water in Viana. In addition, based on a more comprehensive perspective, one could argue that the quality of water fluoridation is a construct that is not limited to optimum levels of fluoride concentration involving, among other aspects, the quality of the fluoridating substance, the level of qualification of the system's operators and the accuracy of the equipment used. However, it is one of the first studies exploring the relationships between the quality level of community water fluoridation and municipal-level indicators. 


\section{CONCLUSIONS}

RMGV-ES showed a high-quality level of fluoridation according to both criteria. The CECOL criterion presented some advantages compared to the criterion based on the current legislation. The municipalities showed important differences regarding the adequacy of fluoride levels that should be the focus of attention by the control and surveillance authorities.

Whereas the demographic, human development, and monthly average coverage of supervised toothbrushing indicators correlated positively with the quality level of public policy, indicators of infant mortality and tooth-extraction/dental procedures ratio correlated negatively.

Finally, the findings reinforced the relevance of water fluoridation surveillance for assuring the effectiveness and safety of the public policy and the plausibility of observed correlations may encourage further investigations on potential causal factors.

\section{ACKNOWLEDGEMENTS}

To the Foundation for Research Support in Espirito Santo (FAPES) for the financing of the project, obtained in FAPES no. 007/2014 UNIVERSAL - Integrated Research Project. Process number 28598.422.19193.18062015. The second author is researcher from CNPq (Grant 303681/2016-0).

\section{REFERENCES}

ANTUNES, J. L. F.; NARVAI, P. C. Políticas de saúde bucal no Brasil e seu impacto sobre as desigualdades em saúde. Revista de Saúde Pública, v. 44, n. 2, p. 360-365, 2010. http://dx.doi.org/10.1590/S0034-89102010005000002

ARDENGHI, T. M.; PIOVESAN, C.; ANTUNES, J. L. F. Desigualdades na prevalência de cárie dentária não tratada em crianças pré-escolares no Brasil. Revista de Saúde Pública, v. 47, n. 3, p. 129-137, 2013. http://dx.doi.org/10.1590/S0034-8910.2013047004352

BERGAMO, E. T. P.; BARBANA, M.; TERADA, R. S. S.; CURY, J. A.; FUJIMAKI, M. Fluoride concentrations in the water of Maringá, Brazil, considering the benefit/risk balance of caries and fluorosis. Brazilian Oral Research, v. 29, n. 1, p. 1-6, 2015. http://dx.doi.org/10.1590/1807-3107BOR-2015.vol29.0047

BRASIL. Ministério da Saúde. Secretaria de Atenção à Saúde. Departamento de Atenção Básica. Coordenação Nacional de Saúde Bucal. Diretrizes da Política Nacional de Saúde Bucal. Brasília, DF, 2004.

BRASIL. Ministério da Saúde. Banco de dados do Sistema Único de Saúde-DATASUS. Disponível em: http://www.datasus.gov.br. Acesso em: 10 nov. 2016.

BRASIL. Ministério da Saúde. Portaria no 635/ BSB, de 25 de dezembro de 1975. Aprova as normas e padrões sobre a fluoretação da água dos sistemas públicos de abastecimento destinada ao consumo humano. Diário Oficial da União, Brasília, DF, 30 jan. 1976.

CELESTE, R. K.; VITAL, J. F.; JUNGER, W. L.; REICHENHEIM, M. E. Séries de procedimentos odontológicos realizadas nos serviços públicos brasileiros, 1994-2000. Ciência \& Saúde Coletiva, v. 16, n. 11, p. 4523-4532, 2011.

CENTERS FOR DISEASE CONTROL AND PREVENTION - CDC. Achievements in public health, 1900-1999: fluoridation of drinking water to prevent dental caries. MMWR Morbidity and Mortality Weekly Report, v. 48, p. 933-940, 1999. 
CENTRO COLABORADOR DO MINISTÉRIO DA SAÚDE EM VIGILÂNCIA DA SAÚDE BUCAL - CECOL/USP. Documento de consenso técnico: classificação de águas de abastecimento público segundo o teor de flúor. In: SEMINÁRIO VIGILÂNCIA DA FLUORETAÇÃ̃O DE ÁGUAS, 2011, São Paulo. Arquivos... São Paulo: Faculdade de Saúde Pública, Universidade de São Paulo, 2011.

COHEN, J. Statistical power analysis for the behavioral sciences. Hillsdale: Lawrence Erlbaum Associates, 1988.

DARÉ, F.; DALL'AGLIO SOBRINHO, M.; LIBÂNIO, M. Avaliação do processo de fluoretação nos sistemas de abastecimento de água da região de Araçatuba, São Paulo. Engenharia Sanitária e Ambiental, v. 14, n. 2, p. 173-182, 2009. http://dx.doi.org/10.1590/S1413-41522009000200005

ESPOSTI, C. D. D.; FRAZÃO, P. O relevante papel da vigilância para assegurar a efetividade da fluoretação da água de abastecimento público. Revista Brasileira de Pesquisa em Saúde, v. 17, n. 2, p. 4-6, 2015. https://doi.org/10.21722/rbps.v17i2.13180

FERNANDES, L. S.; PERES, M. A. Associação entre atenção básica em saúde bucal e indicadores socioeconômicos municipais. Revista de Saúde Pública, v. 39, n. 6, p. 930 936, 2005. http://dx.doi.org/10.1590/S0034-89102005000600010

FISCHER, T. K.; PERES, K. G.; KUPEK, E.; PERES, M. A. Indicadores de atenção básica em saúde bucal: associação com as condições socioeconômicas, provisão de serviços, fluoretação de águas e a estratégia de saúde da família no Sul do Brasil. Revista

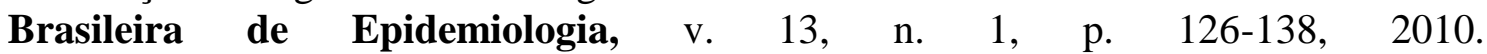
http://dx.doi.org/10.1590/S1415-790X2010000100012

FRAZÃO, P.; NARVAI, P. C. Fluoretação da água em cidades brasileiras na primeira década do século XXI. Revista de Saúde Pública, v. 51, n. 47, p. 1-11, 2017. https://doi.org/10.1590/S1518-8787.2017051006372

FRAZÃO, P.; NARVAI, P. C. Cobertura e vigilância da fluoretação da água no Brasil: municípios com mais de 50 mil habitantes. São Paulo: Faculdade de Saúde Pública da USP, 202p. 2017. https://doi.org/10.11606/9788588848252

FRAZÃO, P.; PERES, M. A.; CURY, J. A. Drinking water quality and fluoride concentration. Revista de Saúde Pública, v. 45, n. 5, p. 964-973, 2011. http://dx.doi.org/10.1590/S0034-89102011005000046

GABARDO, M. C. L.; SILVA, W. J.; OLANDOSKI, M.; MOYSÉS, S. T.; MOYSÉS, S. J. Inequalities in public water supply Fluoridation in Brazil: an ecological study. BMC Oral Health, v. 8, n. 9, p. 1-7, 2008. https://doi.org/10.1186/1472-6831-8-9

INSTITUTO BRASILEIRO DE GEOGRAFIA E ESTATÍSTICA - IBGE. Estimativas da população residente para os municípios e para as Unidades da Federação brasileiros com data de referência em $\mathbf{1}^{\mathbf{0}}$ de julho de 2015. Rio de Janeiro, 2015.

INSTITUTO CAPIXABA DE PESQUISA, ASSISTÊNCIA TÉCNICA E EXTENSÃO RURAL - INCAPER. Análise climática do trimestre janeiro a março de 2016. Boletim Climatológico Trimestral do Espírito Santo, v. 2, n. 5, 2016.

KUHNEN, M.; GAMBA, B.; NARVAI, P.C.; TOASSI, R. F. C. Qualidade da água tratada: avaliação dos teores de flúor em 10 anos de heterocontrole no município de Lages, Santa

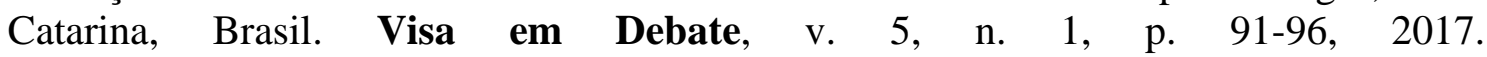
http://dx.doi.org/10.22239/2317-269x.00833 
KUMAR, J. V. Is water fluoridation still necessary? Advances in Dental Research, v. 20, n. 1, p. 8-12, 2008. http://dx.doi.org/10.1177/154407370802000103

KUTHY, R. A.; NALEWAY, C.; DURKEE, J. Factors associated with maintenance of proper water fluoride levels. Journal of American Dental Association, v. 110, n. 4, p. 511-513, 1985.

LANDIS, J. R.; KOCH, G. G. The measurement of observer agreement for categorical data. Biometrics, v. 33, n. 1, p.159-174, 1977. http://dx.doi.org/10.2307/2529310

NARVAI, P. C. Cárie dentária e flúor: uma relação do século XX. Ciência \& saúde coletiva, v. 5, n. 2, p. 381-392, 2000. http://dx.doi.org/10.1590/S1413-81232000000200011

NARVAI, P. C.; FRIAS, A. C. F.; FRATUCCI, M. V. B.; ANTUNES, J. L. F.; FRAZÃO, P. Fluoretação da água em capitais brasileiras no início do século XXI: a efetividade em questão. Saúde em Debate, v. 38, n. 102, p. 562-571, 2014. http://dx.doi.org/10.5935/0103-1104.20140052

NASCIMENTO, S. G.; OLIVEIRA, C. M.; SPOSITO, V.; FERREIRA, D. K. S.; BONFIM, C. V. Mortalidade infantil por causas evitáveis em uma cidade do Nordeste do Brasil. Revista Brasileira de Enfermagem, v. 67, n. 2, p. 208-212, 2014. http://dx.doi.org/10.1590/S0104-12902012000200019

PEARSON, N.; CROUCHER, R.; MARCENES, W.; O'FARRELL, M. Prevalence of Oral Lesions Among a Sample of Bangladeshi Medical Users Aged 40 Years and over Living in Tower Hamlets, UK. International Dental Journal, v. 51, n. 1, p. 30-34, 2001. http://dx.doi.org/10.1002/j.1875-595X.2001.tb00814.x

PEIXOTO, D.F.; ALENCAR, K.P.; PEIXOTO, R.F.; SOUSA, C.F.M.; SAMPAIO, F.C.; FORTE, F.D.S. Heterocontrole da fluoretação da água de abastecimento público do município de Jaguaribara, Ceará, Brasil. Revista Brasileira em Promoção da Saúde, v.25, n.3, p.271-277, 2012. http://dx.doi.org/10.5020/2255

PELLETIER, A.R. Maintenance of optimal fluoride levels in public water systems. Journal of Public Health Dentistry, v. 64, n.4, p.237-239, 2004. http://dx.doi.org/10.1111/j.17527325.2004.tb02759.x

PERES, M.A.; FERNANDES, L.S.; PERES, K.G. Inequality of water in Southern Brazil - the inverse equity hypothesis revisited. Social Science \& Medicine, v. 58, n. 6, p. 11811189, 2004. https://doi.org/10.1016/S0277-9536(03)00289-2

PROGRAMA DAS NAÇÕES UNIDAS PARA O DESENVOLVIMENTO - PNUD. Atlas do Desenvolvimento humano no Brasil. Brasília: Programa das Nações Unidas para o Desenvolvimento, 2010. Disponível em: http://www.atlasbrasil.org.br/2013/ Acesso em: 10 set. 2016.

QUEIROZ, A. C. L.; CARDOSO, L. S. M.; SILVA, S. C. F.; HELLER, L.; CAIRNCROSS, S. Programa Nacional de Vigilância em Saúde Ambiental Relacionada à Qualidade da Água para Consumo Humano (VIGIAGUA): lacunas entre a formulação do programa e sua implantação na instância municipal. Saúde e Sociedade, v. 21, n. 2, p. 465-478, 2012. http://dx.doi.org/10.1590/S0104-12902012000200019

RIHS, L. B.; SOUZA, M. L. R.; CYPRIANO, S. Cárie Dentária em Adultos em Locais com e sem Água Fluoretadada Região de Campinas, São Paulo. Revista da Faculdade de Odontologia de Porto Alegre, v. 48, n. 1, p. 69-72, 2007. 
RUGG-GUNN, A. J.; DO, L. Effectiveness of water fluoridation in caries prevention. Community Dentistry and Oral Epidemiology, v. 40, n. 2, p. 55-64, 2012. https://doi.org/10.1111/j.1600-0528.2012.00721.x

STANCARI, R. C. A.; DIAS JÚNIOR, F. L.; FREDDI, F. G. Avaliação do processo de fluoretação da água de abastecimento público nos municípios pertencentes ao Grupo de Vigilância Sanitária XV-Bauru, no período de 2002 a 2011. Epidemiologia e Serviços de Saúde, v. 23, n. 2, p. 239-248, 2014. http://dx.doi.org/10.5123/S167949742014000200005

VENTURINI, C. Q.; NARVAI, P. C.; MANFREDINI, M. A.; FRAZÃO, P. Vigilância e monitoramento de fluoretos em águas de abastecimento público: uma revisão sistemática. Revista Ambiente \& Água, v. 11, n. 4, p. 972-988, 2016. http://dx.doi.org/10.4136/ambi-agua.1929

YARMOLINKY, J.; RATNAPALAN, S.; KENNY, D. J. Variation in urban and rural water fluoride levels in Ontario. Journal of Canadian Dental Association, v. 75, n. 10, p. 707, 2009.

WORLD HEALTH ORGANIZATION - WHO. Brazil's health system reaches out to the poor. Bulletin of the World Health Organization, v. 86, n. 4, p. 241-230, 2008. http://www.who.int/bulletin/volumes/86/4/08-030408/en/ 
Supplementary Table. Agreement between classfication Criterion I and II of fluoride concentration values in public utilities' water supply.

\begin{tabular}{|c|c|c|c|c|c|c|c|c|c|}
\hline & & \multicolumn{3}{|c|}{ Criterion I } & \multirow[b]{2}{*}{ Total } & \multirow[b]{2}{*}{ Simple Percentage } & \multirow[b]{2}{*}{ Kappa } & \multirow[b]{2}{*}{ IC95\% } & \multirow[b]{2}{*}{ p-value Kappa } \\
\hline & & Inadequate Low & Adequate & Inadequate High & & & & & \\
\hline \multirow{4}{*}{ Criterion II } & $\begin{array}{l}\text { Negligible Benefit/ } \\
\text { Minimum Risk }\end{array}$ & 102 & 0 & 0 & 102 & \multirow{4}{*}{$86.69 \%$} & \multirow{4}{*}{0.671} & \multirow{4}{*}{0.61 to 0.73} & \multirow{4}{*}{$<0.001$} \\
\hline & $\begin{array}{l}\text { Maximum Benefit / } \\
\text { Low risk }\end{array}$ & 59 & 440 & 27 & 526 & & & & \\
\hline & $\begin{array}{l}\text { Maximum Benefit / } \\
\text { Moderate to Very } \\
\text { High Risk }\end{array}$ & 0 & 0 & 18 & 18 & & & & \\
\hline & Total & 161 & 440 & 45 & 646 & & & & \\
\hline
\end{tabular}

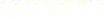




\begin{tabular}{|c} 
Ambiente \& Água - An Interdisciplinary Journal of Applied Science \\
ISSN 1980-993X - doi:10.4136/1980-993X \\
www.ambi-agua.net \\
E-mail: ambi.agua@gmail.com
\end{tabular}

\title{
Spatio-temporal variability of erosivity in Mato Grosso, Brazil
}

\author{
ARTICLES doi:10.4136/ambi-agua.2276 \\ Received: 02 May 2018; Accepted: 09 Sep. 2018 \\ Luis Augusto Di Loreto Di Raimo ${ }^{1 *}$; Ricardo Santos Silva Amorim ${ }^{1}$; \\ Eduardo Guimarães Couto'; Rodolfo Luiz Bezerra Nóbrega ${ }^{2}$; \\ Gilmar Nunes Torres ${ }^{1}$; Edwaldo Dias Bocuti'; \\ Cristiana Oliveira Silva Almeida ${ }^{3}$; \\ Rafael Vinicius Rodrigues ${ }^{4}$ \\ ${ }^{1}$ Universidade Federal de Mato Grosso (UFMT), Cuiabá, MT, Brasil \\ Faculdade de Agronomia e Zootecnia (FAAZ). Programa de Pós-Graduação em Agricultura Tropical (PPGAT). \\ E-mail: luis.diloreto@hotmail.com,rsamorim.ufmt@gmail.com, egcouto@gmail.com, \\ gilmaragro@gmail.com, ed.bocuti@hotmail.com \\ ${ }^{2}$ University of Reading, Reading, United Kingdom \\ Department of Geography and Environmental Sciences. E-mail: r.nobrega@ reading.ac.uk \\ ${ }^{3}$ Instituto Nacional de Colonização e Reforma Agrária (Incra), Brasília, DF, Brasil \\ E-mail: kika.df@gmail.com \\ ${ }^{4}$ Universidade Federal de Mato Grosso (UFMT), Cuiabá, MT, Brasil \\ Faculdade de Arquitetura, Engenharia e Tecnologia (FAET). E-mail: rafael.vinicius@live.com \\ *Corresponding author
}

\begin{abstract}
The impact of rainfall on surfaces lacking vegetal cover can dissociate soil particles, thereby initiating the erosion process. This is known as rainfall erosivity and is expressed by the $\mathrm{R}$ factor in the Universal Soil Loss Equation. Agricultural areas often show seasonally erosion susceptibility throughout the year due to oscillations of the soil exposure rate and the vegetation change. Considering that approximately 30 million ha of the Mato Grosso State in Brazil is used for agriculture, this study aimed to predict and map the spatial and temporal variability of its territory. We evaluated the monthly $\left(E I_{30}\right)$ and annual $(\mathrm{R})$ erosivity for 158 rain gauge stations and spatialized the values of $E I_{30}$ and $R$ by the Kriging method. It was observed that $\mathrm{R}$ values ranked as very high in the north, and high and medium-high in the south of Mato Grosso state. The mean value is $8835 \mathrm{MJ} \mathrm{mm} \mathrm{ha}^{-1} \mathrm{~h}^{-1}$ year $^{-1}$, considered high. Ninety-one percent of the annual erosivity was concentrated in the period between October and April, corresponding to the rainy season. The highest $\mathrm{R}$ factor values were found in the macro-regions of the northwest, north, west and medium-north of Mato Grosso State.
\end{abstract}

Keywords: erosion, geostatistics, GIS, soil conservation, USLE.

\section{Variabilidade espacial e temporal da erosividade em Mato Grosso, Brasil}

\section{RESUMO}

O impacto da chuva com a superfície de solos descobertos pode causar a desagregação de partículas e iniciar processos erosivos. Esta capacidade da chuva causar erosão em solos sem cobertura é chamada de erosividade e é expressa como R na Equação Universal de Perda de 
Solo. Áreas utilizadas com agricultura apresentam grau de susceptibilidade variável ao longo do ano, devido as oscilações nas taxas de exposição do solo e mudança da vegetação. Considerando que aproximadamente 30 milhões de hectares de Mato Grosso, no Brasil, são utilizados com agricultura, objetivou-se com o presente estudo estimar e mapear a variabilidade espacial e temporal da erosividade em seu território. Primeiramente, foram estimados valores de erosividade mensal $\left(\mathrm{EI}_{30}\right)$ e anual $(\mathrm{R})$ para 158 estações que, posteriormente, foram espacializados pelo método de krigagem. Observou-se que no estado de Mato Grosso predominam valores muito altos de $\mathrm{R}$ ao norte e altos e médio-altos ao sul. $\mathrm{O}$ valor médio de $\mathrm{R}$ é igual à $8835 \mathrm{MJ} \mathrm{mm} \mathrm{ha} \mathrm{h}^{-1} \mathrm{~h}^{-1} \mathrm{ano}^{-1}$, considerado alto. Noventa e um porcento do $\mathrm{R}$ se concentra no período entre os meses de outubro e abril, correspondente a estação chuvosa. Os maiores valores de $\mathrm{R}$ foram observados nas macrorregiões noroeste, norte, oeste e médio norte do estado de Mato Grosso.

Palavras-chave: erosão, conservação do solo, geoestatística, SIG, USLE.

\section{INTRODUCTION}

Erosivity determines the ability of rainfall to cause erosion in an unprotected soil, and it is represented in the Universal Soil Loss Equation (USLE) by the R factor (Wischmeier and Smith, 1978). This factor represents the cumulated monthly values of EI30 index, which can be computed as the product of total kinetic rainfall energy (EC) and maximum 30-min precipitation intensity (I30), both obtained by using pluviographic data. Due to the necessity of pluviographic data, which is scarce in Brazil, the determination of $E I_{30}$ values by the standard method was considered difficult or unfeasible in many regions for a long time. Many studies addressed this gap by obtaining $E I_{30}$ values from regression equations that use the rainfall coefficient $(R c)$ as an independent variable, which is based purely on pluviometric data (Almeida et al., 2012; Aquino et al., 2012; Oliveira et al., 2012). Certainly, the standard method is the most recommended to obtain erosivity, due to the higher temporal resolution of the pluviographic data. However, in regions with scarcity of pluviographic data, such as Mato Grosso State, one alternative that remains is the use of estimation of erosivity values by regression equations. For some areas of Mato Grosso State, Almeida et al. (2011), Almeida et al. (2012) and Di Raimo et al. (2018) obtained high correlations between erosivity, determined by the standard method, and values of $R c$, indicating the high reliability of the estimates.

It is observed that after the simplification of the procedure of obtaining $\mathrm{R}$ values several studies were developed in Brazil to identify the spatiotemporal distribution of erosivity in different regions of the country (Silva et al., 2010a; Oliveira et al., 2012; Aquino et al., 2012; Viola et al., 2014; Machado et al., 2014; Waltrick et al., 2015; Almeida and Casaroli, 2016). These studies with a low density of pluviographic stations were only possible due to the implementation of regression equations in pluviometric stations of locations with correlated $R c$ coefficients, as performed by Oliveira et al. (2012), Waltrick et al. (2015) and Almeida and Casaroli (2016). However, although Mato Grosso State has extensive agricultural activities concentrated between October and March, when $85 \%$ of the annual precipitation occurs (Marcuzzo et al., 2011a; 2011b), no research has yet provided the spatial variation of $\mathrm{R}$ and spatiotemporal variation of $E I_{30}$ in this region.

Preliminary studies about erosivity in the Mato Grosso were done by Almeida et al. (2011), Almeida et al. (2012) and Di Raimo et al. (2018), who developed equations to estimate $E I_{30}$ values for several sites in Mato Grosso. Nevertheless, this punctual information contributes little to regional planning of tillage practices and soil conservation, given that rainfall, $E I_{30}$ and $R$ values have high spatial and temporal variability. Silva (2004), Oliveira et al. (2013) and Trindade et al. (2016) mapped $\mathrm{R}$ values for the entire Brazilian territory. However, as 
demonstrated by Trindade et al. (2016), more specific and detailed studies on smaller areas, such as State-level, are crucial to identifying accurate erosivity information.

Understanding of the spatial and temporal variability of erosivity in Mato Grosso would enable identification of critical areas and periods, in which the rainfall has a comparatively stronger erosive action. Such information is crucial in the planning of tillage practices and soil conservation because the vegetal cover rate of explored areas in Mato Grosso State change throughout the year, especially those cultivated with soybean, corn and cotton. Thus, this study aimed to estimate the rainfall erosivity and its spatial and temporal variability in the entire state of Mato Grosso.

\section{MATERIAL AND METHODS}

The pluviometric data used to undertake this study were obtained from the Hydrological Information System of the National Water Agency (ANA, 2017). In our study, 148 pluviometric stations with a minimum of 10 years of continuous data were selected (Figure 1).

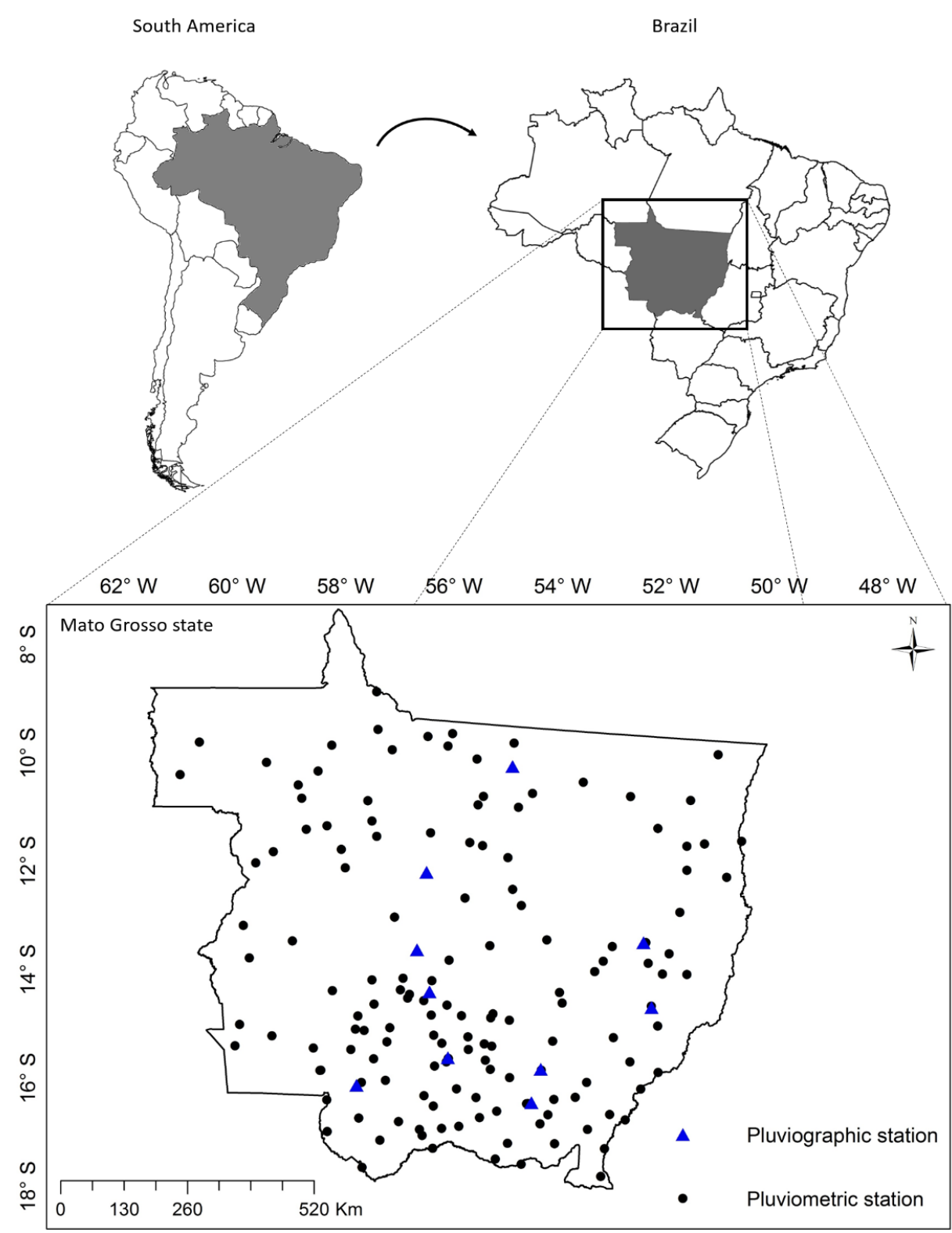

Figure 1. Distribution of the 148 pluviometric stations and the 10 pluviographic stations used. 
For the calculation of the $E I_{30}$ coefficient, equations developed by Almeida (2009) were used. These equations allowed the estimation of the $E I_{30}$ value from the rainfall coefficient $(R c)$ for 10 pluviographic stations in Mato Grosso State (Table 1, Figure 1). The R values were computed from the sum of the monthly values of the $E I_{30}$ coefficient. The $R c$ was derived from Equation 1 (Renard and Freimund, 1994), where $p$ is the average monthly precipitation (mm), and $P$ is the average annual precipitation $(\mathrm{mm})$.

$$
R c=\frac{p^{2}}{P}
$$

Table 1. Regression equations used to estimate monthly erosivity $\left(E I_{30}\right)$ index from the rainfall coefficient $(R c)$ of the respective stations and municipalities of Mato Grosso State (Almeida 2009).

\begin{tabular}{lccc}
\hline Station & County & Equation & $\mathbf{R}^{\mathbf{2}}$ \\
\hline Cáceres & Cáceres & $E I_{30}=135.43\left(R c^{0.538}\right)$ & 0.78 \\
Canarana & Canarana & $E I_{30}=121.18\left(R c^{0.622}\right)$ & 0.87 \\
Cuiabá & Cuiabá & $E I_{30}=244.47\left(R c^{0.508}\right)$ & 0.67 \\
Diamantino & Diamantino & $E I_{30}=51.46\left(R c^{0.883}\right)$ & 0.96 \\
Gleba Celeste & Diamantino & $E I_{30}=171.29\left(R c^{0.605}\right)$ & 0.84 \\
Matupá & Guarantã do Norte & $E I_{30}=115.72\left(R c^{0.746}\right)$ & 0.99 \\
Nova Xavantina & Nova Xavantina & $E I_{30}=96.36\left(R c^{0.517}\right)$ & 0.95 \\
Poxoréu & Poxoréu & $E I_{30}=156.38\left(R c^{0.552}\right)$ & 0.60 \\
Rondonópolis & Rondonópolis & $E I_{30}=167.16\left(R c^{0.567}\right)$ & 0.77 \\
São José do Rio Claro & São José do Rio Claro & $E I_{30}=126.76\left(R c^{0.464}\right)$ & 0.72 \\
\hline
\end{tabular}

To estimate the $E I_{30}$ values, one equation in Table 1 was selected for each of the 148 pluviometric stations. The criteria used to select the equations were adapted from Oliveira et al. (2012). We correlated rainfall characteristics (mean daily precipitation, mean monthly precipitation, mean annual precipitation, precipitated monthly volume, mean monthly Rc and cumulative monthly $\mathrm{Rc}$ ) of the 10 available pluviographic stations with the same rainfall characteristics of the 148 pluviometric stations. The different locations were considered similar when the linear correlation value was equal to or greater than 0.95 . When more than one pluviometric station had a correlation equal or greater than 0.95 with one of the pluviographic stations, the closest among them was considered. Although the standard method for determining erosivity is that proposed by Wischmeier and Smith (1978), regions with scarce rainfall information can be mapped using regression equations to estimate erosivity, as observed in Silva et al. (2010a), Oliveira et al. (2012), Aquino et al. (2012), Viola et al. (2014), Machado et al. (2014), Waltrick et al. (2015) and Almeida and Casaroli (2016).

After defining the equations and the $R c$ values, their respective $E I_{30}$ and $\mathrm{R}$ values were estimated. The spatial variability characterization of the $E I_{30}$ and $\mathrm{R}$ values was conducted using geostatistical techniques. To choose a semivariogram model most appropriate for each situation, the following parameters were analyzed: nugget effect $\left(C_{0}\right)$, sill $\left(C_{0}+C_{1}\right)$, determination coefficient $\left(\mathrm{R}^{2} \mathrm{~s}\right)$, spatial dependence degree (SDD) and range.

SDD was calculated using Equation 2 and classified, according to Cambardella et al. (1994), into three categories: $\leq 25 \%$ as strong spatial dependence; $25 \% \leq$ SDD $\leq 75 \%$ as moderate spatial dependence; and $\geq 75 \%$ as weak spatial dependence. To evaluate the performance of the models in the cross-validation, their respective determination coefficient $\left(\mathrm{R}^{2} \mathrm{cv}\right)$ was analyzed.

$S D D=\frac{C_{0}}{C_{0}+C_{1}} \times 100$ 
After the adjustment of the semivariogram models and the spatial dependence evaluation, the spatial variability of the $E I_{30}$ and R factor was mapped for Mato Grosso State by the ordinary Kriging technique (Behera et al., 2018). Such technique was used because it is more reliable than the other methods (Meul and Meirvenne, 2003), including for specialization of erosivity (Mello et al., 2015), and because this is the best predictor to obtain values at unsampled locations and in conditions with sparse and random sampling (Behera et al., 2018). The $E I_{30}$ and $\mathrm{R}$ factor values of the created maps were classified as shown in Table 2.

The $\mathrm{R}$ values were correlated with latitude, longitude and elevation, aiming for the best comprehension of erosivity spatial variability within Mato Grosso State. In order to argue about the peculiarities, critical situations and regionally isolated events, the $E I_{30}$ and $\mathrm{R}$ maps were presented with the identification of macro-regions of agro economic similarity (northwest, north, northeast, middle-north, west, south-center and southeast), as established by the Mato Grosso Institute of Agriculture Economics (IMEA, 2010).

Table 2. The categories for interpretation of the $\mathrm{R}$ and $E I_{30}$ index.

\begin{tabular}{|c|c|c|}
\hline \multirow{6}{*}{$\begin{array}{l}\text { R categories } \\
\text { according to Oliveira et al. (2013) }\end{array}$} & Erosivity Category & R $\left(\mathbf{M J ~ m m ~ h a - 1} h^{-1}\right.$ year $\left.^{-1}\right)$ \\
\hline & Low & $\mathrm{R} \leq 2452$ \\
\hline & Medium & $2452<\mathrm{R} \leq 4905$ \\
\hline & Medium-high & $4904<\mathrm{R} \leq 7357$ \\
\hline & High & $7357<\mathrm{R} \leq 9810$ \\
\hline & Very High & $\mathrm{R}>9810$ \\
\hline \multirow{6}{*}{$\begin{array}{c}\boldsymbol{E I}_{\mathbf{3 0}} \text { categories } \\
\text { according to Carvalho (2008) }\end{array}$} & Erosivity Category & $E I_{30}\left(\mathrm{MJ} \mathrm{mm} \mathrm{ha}{ }^{-1} h^{-1}\right.$ month $\left.^{-1}\right)$ \\
\hline & Very Low & $<250$ \\
\hline & Low & $250<\mathrm{R} \leq 500$ \\
\hline & Medium & $500<\mathrm{R} \leq 750$ \\
\hline & High & $750<\mathrm{R} \leq 1000$ \\
\hline & Very High & $\mathrm{R}>1000$ \\
\hline
\end{tabular}

\section{RESULTS AND DISCUSSION}

The distinctness between dry and wet/rainy season is reflected by the $E I_{30}$ values for the different months of the year (Figure 2). The period from October to April corresponds to 91\% of the annual erosivity. From May to September, the period with the lowest rainfall rates, the $E I_{30}$ values contributed to only $9 \%$ of the annual erosivity.

Table 3 provides the parameters of the semivariogram used in the spatial dependence analysis and the reliability of the spatial characterization of the $E I_{30}$ and $\mathrm{R}$ factor in Mato Grosso State. The SDD values indicated that the spatial dependence of the regionalized variables is strong $(<25 \%)$ for nine months of the year (Cambardella et al., 1994). The semivariograms of May, June and July were the only ones that did not present a strong spatial dependence category, showing SDD values of 32, 40 and 26\%, respectively, which are categorized as moderate spatial dependence (Cambardella et al., 1994).

The semivariogram for the $\mathrm{R}$ values showed $13 \%$ of the total semivariance was random and framed in the strong spatial dependence category (Cambardella et al., 1994). SDD values determined by Aquino et al. (2012), Viola et al. (2014), Silva et al. (2010b) and Mello et al. (2013) were classified as strong spatial dependence, and accounted for 12, 0, 7, 5 and $0 \%$ of the random variation, respectively. 


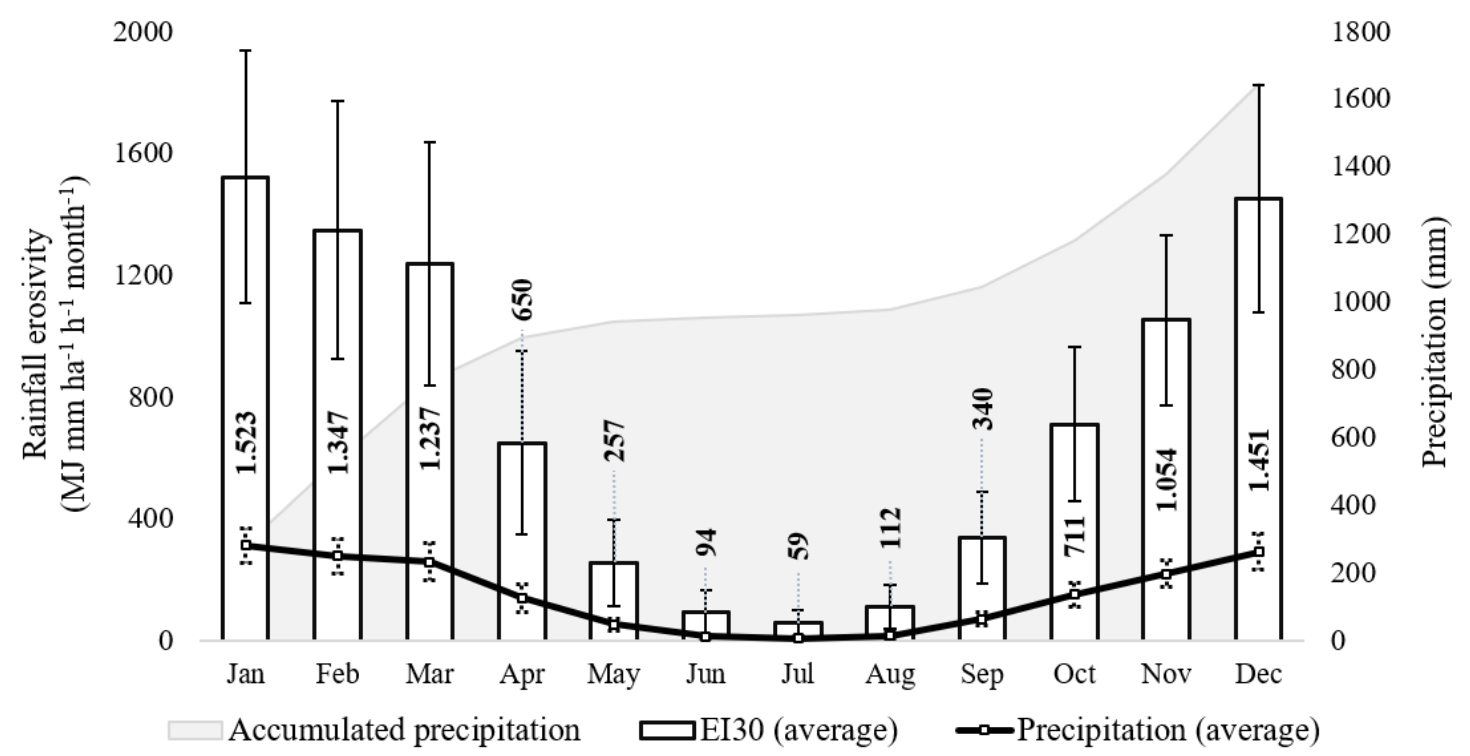

Figure 2. Average monthly and standard deviation of the $E I_{30}$ and the precipitation values of the 158 studied stations in Mato Grosso State.

In all semivariograms, the best parameters were obtained by using an exponential model. Such results endorse the available literature studies, which show that this model presents the best parameters when compared with other models, such as Gaussian and spherical (Mello et al., 2007; Montebeller et al., 2007; Silva et al., 2010b; Viola et al. 2014).

Table 3. Parameters of the semivariograms used to spatialize $E I_{30}$ and $\mathrm{R}$ values in Mato Grosso State.

\begin{tabular}{lcccccc}
\hline \multirow{2}{*}{ Period } & \multicolumn{6}{c}{ Parameters } \\
\cline { 2 - 7 } & $\boldsymbol{C}_{\mathbf{0}}$ & $\boldsymbol{C}_{\mathbf{0}}+\boldsymbol{C}_{\mathbf{1}}$ & $\mathbf{R}^{\mathbf{2}} \mathbf{s}$ & $\mathbf{R}^{\mathbf{2}} \mathbf{c v}$ & $\mathbf{S D D}(\boldsymbol{\%})$ & Range (km) \\
\hline January & 33200 & 277400 & 0.96 & 0.65 & 12 & 1798.2 \\
February & 49000 & 409000 & 0.95 & 0.60 & 12 & 3136.32 \\
March & 17000 & 345000 & 0.82 & 0.70 & 5 & 2669.76 \\
April & 5100 & 221200 & 0.77 & 0.72 & 3 & 2987.28 \\
May & 4759 & 14971 & 0.88 & 0.49 & 32 & 794.88 \\
June & 1225 & 3071 & 0.65 & 0.51 & 40 & 207.36 \\
July & 451 & 1735 & 0.95 & 0.53 & 26 & 719.28 \\
August & 1829 & 11339 & 0.85 & 0.52 & 16 & 2345.76 \\
September & 6009 & 49568 & 0.84 & 0.64 & 12 & 2796.12 \\
October & 16212 & 239850 & 0.77 & 0.66 & 7 & 5280.12 \\
November & 25565 & 209359 & 0.96 & 0.57 & 11 & 5200.2 \\
December & 39394 & 275310 & 0.87 & 0.61 & 14 & 3165.48 \\
\hline Annual & 1456791 & 10836743 & 0.82 & 0.66 & 13 & 2222.64 \\
\hline
\end{tabular}

$\boldsymbol{C}_{\mathbf{0}}$ : nugget effect; $\boldsymbol{C}_{\mathbf{0}}+\boldsymbol{C}_{\mathbf{1}}$ : sill; $\mathbf{R}^{2} \mathbf{s}$ : determination coefficient of semivariogram; $\mathbf{R}^{2} \mathbf{c v}$ : determination coefficient of cross-validation; and SDD: spatial degree dependence. All adjusted semivariograms are exponential.

Figure 3 shows the $E I_{30}$ maps for Mato Grosso, contrasting the seven macro-regions proposed by the IMEA (2010). Overall, when analyzing the discrepancy in the $E I_{30}$ values throughout the months of the year, variations can be seen in the erosivity bands towards northwest-southeast, which is when the rainy season starts, and towards southeast-northwest, which is the rainy-dry transition period (Figure 3). This variability pattern is attributed to the 
influence of the Continental Equatorial Mass (CEM), created from the high evapotranspiration of the Amazon forest, which passes over Mato Grosso and provides territory-wide rainfall events.

The CEM expansion starts in August, leaving the Amazon region towards the Mato Grosso State. This movement appears predominantly in the northwest-southeast direction until reaching São Paulo State. From January, the area of influence of this mass begins to fade in the southeast-northwest direction, finally concentrating only in the original region (Amazon region), where it stays and restricts its influence on the pluviometric pattern (Zavattini, 2009; Gan et al., 2009; Marcuzzo et al., 2012).

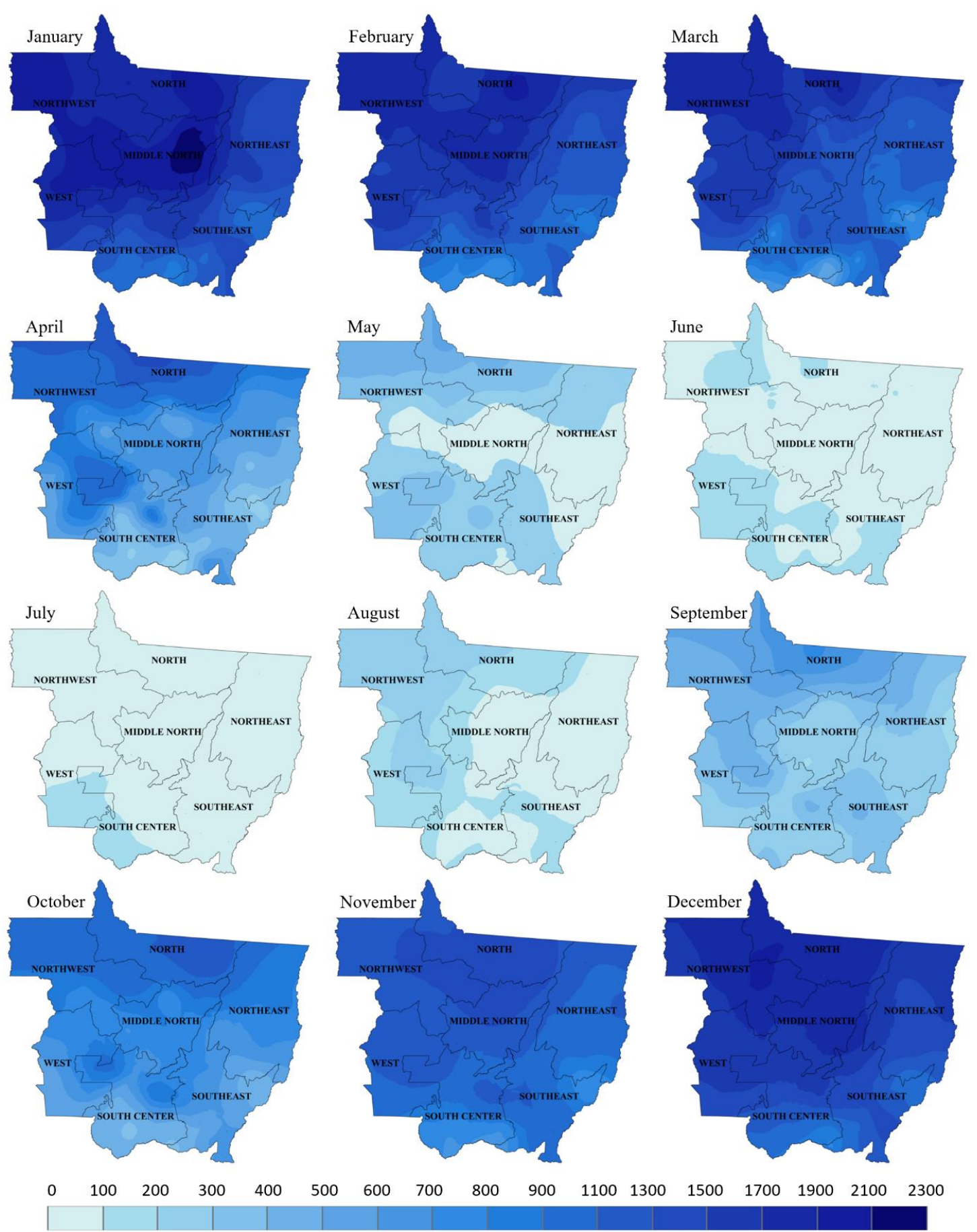

Figure 3. Monthly erosivity maps $\left(E I_{30}\right)$ for Mato Grosso State (MJ mm ha $\left.{ }^{-1} \mathrm{~h}^{-1} \mathrm{month}^{-1}\right)$.

\section{IPABH}


It is possible to note that Mato Grosso State presents different $E I_{30}$ patterns in three distinct periods during the year (Figure 3). The first one is in October and November, related to the beginning of the rainy season, in which the $E I_{30}$ values increase and range between the low and very high categories. The second period, from December to March, is associated with the most precipitation in Mato Grosso, in which the $E I_{30}$ values are predominantly high and very high. The third period, from April to September, corresponding to the driest season in Mato Grosso, when low $E I_{30}$ values occur mostly in the low and very low categories.

During the first and second $\mathrm{EI}_{30}$ periods, many agricultural activities occur in Mato Grosso, causing changes on the soil surface. These are considered the more critical periods, especially from October to February (responsible for 69\% of R), when activities such as tilling, sowing and harvesting are concentrated. In the third period, associated with low erosivity, the majority of the soils are covered by the crop canopy, characterizing the least critical phase. However, activities of soil preparation and invasive plant control during the drought season can cause soil loss, due to the first erosive rainfalls that occur in September (Morais et al., 1991).

As shown in this study, Tocantins (Viola et al., 2014) and Goiás (Almeida and Casaroli, 2016) states were also characterized as having high and very high $E I_{30}$ values between December and March (Period 2), and low and very low $E I_{30}$ values from April to September (Period 3). Such similarity is due to the uniformity of rainfall distribution that is proportionated by the proximity between these states. Such proximity makes the South Atlantic Convergence Zone (SACZ) and the CEM behave with similar intensity above the territory of Mato Grosso, Goiás and Tocantins States (Carvalho and Jones, 2009; Gan et al., 2009).

In the map of R shown in Figure 4, very high category values predominate in the northern region of Mato Grosso and lower $\mathrm{R}$ values in the southern region (the same was observed for the $E I_{30}$ values). However, even the lowest values of $\mathrm{R}$, found in the southern region, are classified as a medium-high category, according to Oliveira et al. (2013). Considering the entire Mato Grosso State, it includes only the three highest categories of the five proposed by this author.

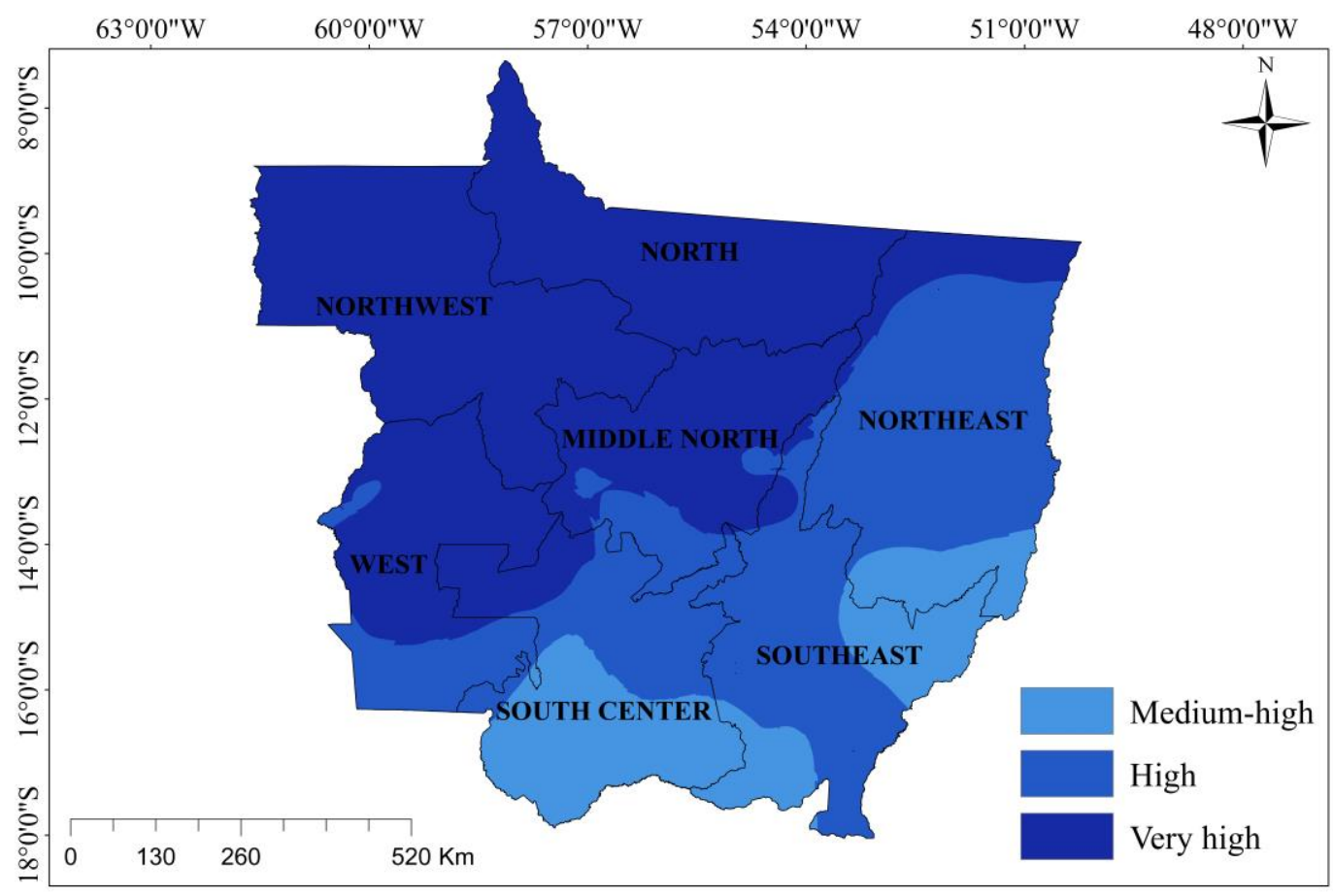

Figure 4. Map of the annual $\mathrm{R}$ for the Mato Grosso State classified according to Oliveira et al. (2013). 
Panagos et al. (2017) mapped world's erosivity and obtained values higher than $5200 \mathrm{MJ}$ $\mathrm{mm} \mathrm{ha} \mathrm{h}^{-1} \mathrm{~h}^{-1}$ year $^{-1}$ (medium-high class or upper) for Mato Grosso State territory, highlighted for regions with values upper than $7400 \mathrm{MJ} \mathrm{mm} \mathrm{ha}^{-1} \mathrm{~h}^{-1}$ year-1 (high or very high classes) at north and northwest. Oliveira et al. (2013) and Trindade et al. (2016) mapped the erosivity of Brazil and got values for Mato Grosso always higher than $6000 \mathrm{MJ} \mathrm{mm} \mathrm{ha}^{-1} \mathrm{~h}^{-1}$ year $^{-1}$ (mediumhigh class or upper), with remarkable increase of erosivity to the north and northeast of the state (between 10000 and $14000 \mathrm{MJ} \mathrm{mm} \mathrm{ha}^{-1} \mathrm{~h}^{-1}$ year ${ }^{-1}$ ), that categorizes such as a very high class. Despite the similar range of erosivity values between the present study and those presented by Oliveira et al. (2013), Trindade et al. (2016) and Panagos et al. (2017), there is a considerable difference in spatial variation of the data, perhaps due to the higher density of information used in this work. Such comparison evidences the importance of erosivity studies that contemplate smaller areas and use greater information density.

The mean $\mathrm{R}$ value observed for Mato Grosso was $8835 \mathrm{MJ} \mathrm{mm} \mathrm{ha} \mathrm{m}^{-1} \mathrm{~h}^{-1} \mathrm{year}^{-1}$, which is classified as high according to Oliveira et al. (2013). The high R values obtained for Mato Grosso are typical of tropical regions and corroborate with those obtained in Minas Gerais (Mello et al., 2007), Mato Grosso do Sul (Oliveira et al., 2012), Tocantins (Viola et al., 2014) and Paraná (Waltrick et al., 2015) Brazilian states.

The $\mathrm{R}$ values attained in tropical regions are typically higher than those in temperate regions. Examples can be observed in the studies done in Switzerland (Meusburger et al., 2012), Italy (Borrelli et al., 2016), Europe (Ballabio et al., 2017) and the global scale (Panagos et al., 2017). In fact, Panagos et al. (2017) mapped the $R$ for all the world and obtained an average value of $7104 \mathrm{MJ}$ and $3729.3 \mathrm{MJ} \mathrm{mm} \mathrm{ha}^{-1} \mathrm{~h}^{-1}$ year $^{-1}$ for the tropical and temperate climate regions, respectively. The high values in tropical regions result from the great amount of convective rainfall (high intensity and high kinetic energy values of the raindrops) when compared with the characteristics of temperate climates (Oliveira et al., 2013; Machado et al., 2014).

All macro-regions of Mato Grosso State have high R values (Figure 4), which highlight the fact that any agricultural activity developed there requires the adoption of conservation practices. However, the most critical values occur in the northwest, north, west and middlenorth macro-regions. The northwest and north macro-regions are dominated by areas with native forests and pastures, which are considered effective cover for soil protection (Da Cunha et al., 2017). Unlike the northwest and north macro-regions, the middle-north and west contain large areas of agricultural land and, thus, they are considered the most critical macro-regions. In the middle-north, specifically, in the municipality of Nova Mutum, Sorriso, Lucas do Rio Verde, Nova Ubiratã, Vera, Santa Carmem, Feliz Natal, Cláudia, Paranatinga and União do Sul, which are responsible for a great part of the grain production in Mato Grosso, the highest $E I_{30}$ values have been observed. These values occur in January and correspond to approximately $2300 \mathrm{MJ} \mathrm{mm} \mathrm{ha}^{-1} \mathrm{~h}^{-1}$ month $^{-1}$ (Figure 3).

The spatialization of $\mathrm{R}$ values in Mato Grosso State (Figure 4) shows the variation of values in the northwest-southeast direction, as similarly observed in the $E I_{30}$ maps (Figure 3). Such characteristic corroborates the results of Silva (2004) and Trindade et al. (2016) that spatialized the $\mathrm{R}$ in Brazil. This variation of values in the northwest-southeast direction occurs due to two factors: the influence of the CEM on the state precipitations (Zavattini, 2009; Gan et al., 2009; Marcuzzo et al., 2012) and the change of vegetation in the northwest-southeast direction, accompanied, in the same direction, by decreasing occurrence of convective rains.

Similarly to the Amazon region, in the northwest of Mato Grosso dense forests predominate, but towards northwest-southeast of Mato Grosso we find the Amazon-Cerrado ecotone and then the Cerrado biome, which is a relatively dry forest with less vegetation density. In the Amazon region, high rates of evapotranspiration and high temperatures occur, which frequently cause convective rainfall (Mello et al., 2013). Due to the decrease of rainforest

\section{IPABH}

Rev. Ambient. Água vol. 13 n. 6, e2276 - Taubaté 2018 
vegetation in the northwest-southeast direction, the frequency of rainfall also reduces and, consequently, the $\mathrm{R}$ values decrease.

The extension of the CEM and the decrease of the denser vegetation towards northwestsoutheast also explain the inverse and significant association between $\mathrm{R}$ and latitude (Figure 5a). The greater capacity of latitude to explain the variations of $R$ in Mato Grosso is justified by the large latitudinal variation, in comparison to longitudinal variation, between Mato Grosso and the Amazon region, considering its strong influence on the pluviometric pattern of this state.
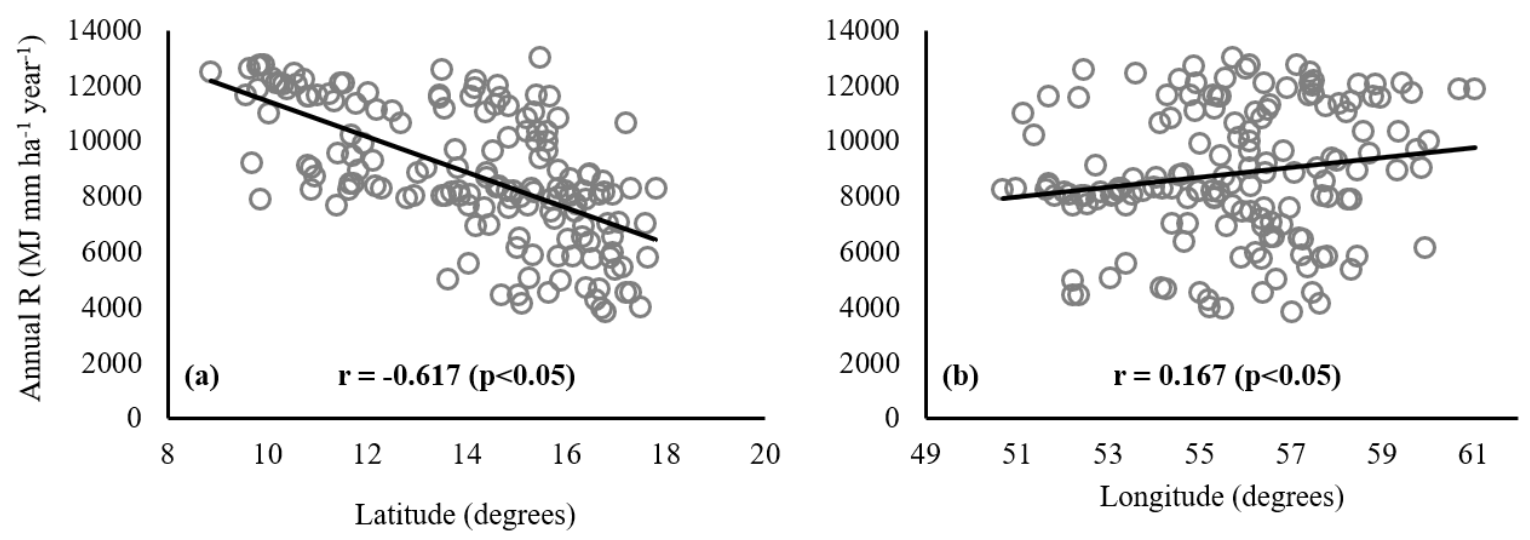

Figure 5. Correlation graphs between $R$ and latitude (a) and longitude (b).

Similar results regarding the variation of the $\mathrm{R}$ values compared to the geographic coordinate variations in the central-west region of Brazil were obtained by Mello et al. (2013). These authors also associated the correlation between $\mathrm{R}$ and latitude with the influence of Amazonian vegetation and its high rainfall rates. In Minas Gerais State, Mello et al. (2007) did not obtain relevant correlation coefficients between the geographic coordinates and the $\mathrm{R}$ values. Despite being also influenced by hot and humid air masses from the Amazon (CEM), the $\mathrm{R}$ value in Minas Gerais is more influenced by the mountains ranges, which effect orographic rainfalls, than by variations in latitude and longitude.

As shown in the Figures $6 a$ and $6 \mathrm{~b}$, the correlation between the $\mathrm{R}$ and elevation values is high and significant only up to $300 \mathrm{~m}$. The greater $\mathrm{R}$ values in high places come from the greater precipitation in these regions, which result from the higher values of accumulated kinetic energy. These results corroborate those obtained by Moreira et al. (2006), who noted reduced $R$ values with the decrease of elevation in São Paulo State.
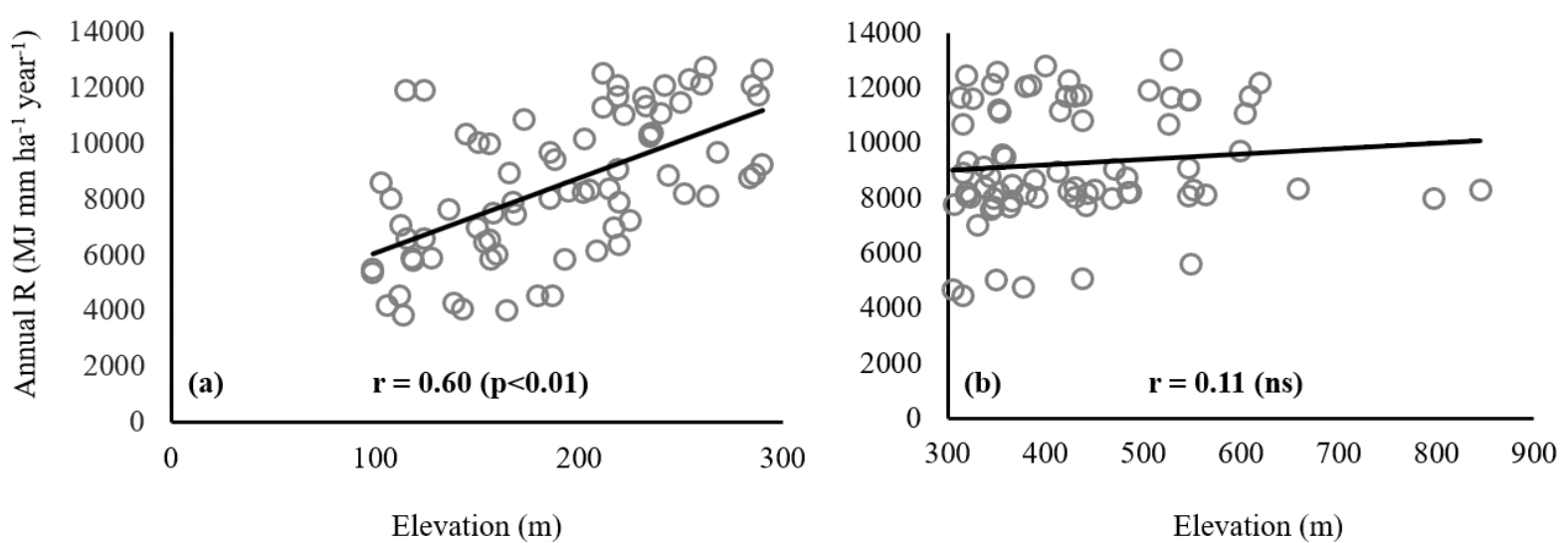

Figure 6. Correlation graph between $\mathrm{R}$ and elevation, from 0 to $300 \mathrm{~m}$ (a) and from 300 to $900 \mathrm{~m}$ (b). 


\section{CONCLUSIONS}

The mean $\mathrm{R}$ value for Mato Grosso is classified as high and equivalent to $8835 \mathrm{MJ} \mathrm{mm} \mathrm{ha}^{-1} \mathrm{~h}^{-1}$ year $^{-1}$.

Ninety-one percent $(91 \%)$ of the total annual of erosivity occurs from October to April in Mato Grosso State.

The period from October to February is considered the most critical in Mato Grosso State, due to the high values of erosivity (responsible for $69 \%$ of $\mathrm{R}$ ) together with the presence of exposed areas during planting and harvesting times.

In Mato Grosso, $\mathrm{R}$ values in the very high category predominate in the northern region and high and very high in the southern region, respectively.

In all macro-regions of Mato Grosso State, there are high $\mathrm{R}$ values. However, the most critical values (very high) are observed in the northwest, north, west and middle-north macroregions.

Besides rainfall, the latitude and elevation, up to $300 \mathrm{~m}$, were the characteristics that best correlated with the spatial variations of $\mathrm{R}$ in the Mato Grosso State.

\section{REFERENCES}

AGÊNCIA NACIONAL DE ÁGUAS - ANA (Brasil). Sistema nacional de informações sobre recursos hídricos. Brasília, 2002.

ALMEIDA, C. O. S. D. Erosividade das chuvas no estado de Mato Grosso. 2009. Dissertação (Mestrado em Ciências Agrárias) - Universidade de Brasília, Brasília, 2009.

ALMEIDA, C. O.; AMORIM R. S.; COUTO, E. G.; ELTZ, F. L.; BORGES L. E. Potencial erosivo da chuva de Cuiabá, MT: Distribuição e correlação com a precipitação pluviométrica. Revista Brasileira de Engenharia Agrícola e Ambiental, v. 15, p. 178184, 2011. http://dx.doi.org/10.1590/S1415-43662011000200011

ALMEIDA, C. O.; AMORIM, R. S.; ELTZ, F. L.; COUTO, E. G.; JORDANI, S. A. Erosividade da chuva em municípios do Mato Grosso: Distribuição sazonal e correlações com dados pluviométricos. Revista Brasileira de Engenharia Agrícola e Ambiental, v. 16, p. 142-152, 2012.

ALMEIDA, R. T. S.; CASAROLI, D. Erosividade média e o calendário agrícola da microrregião sudoeste do estado de Goiás. GeoFocus, Revista Internacional de Ciencia y Tecnología de la Información Geográfica, v. 17, p. 26-43, 2016.

AQUINO, R. F.; SILVA, M. L. N.; FREITAS, D. A. F. D.; CURI, N.; MELLO, C. R. D.; AVANZI, J. C. Spatial variability of the rainfall erosivity in southern region of Minas Gerais State, Brazil. Ciência e Agrotecnologia, v. 36, n. 5, p. 533-542, 2012. http://dx.doi.org/10.1590/S1413-70542012000500006

BALLABIO, C.; BORRELLI, P.; SPINONI, J.; MEUSBURGUER, K.; MICHAELIDES, S.; BEGUERÍA, S. et al. Mapping monthly rainfall erosivity in Europe. Science of the Total $\begin{array}{lllll}\text { Environment, } & \text { v. } & 579, & \text { p. } & 1298-1315,\end{array}$ https://doi.org/10.1016/j.scitotenv.2016.11.123

BEHERA, S. K.; MATHUR, R. K.; SHUKLA, A. K.; SURESH, K.; PRAKASH, C. Spatial variability of soil properties and delineation of soil management zones of oil palm plantations grown in a hot and humid tropical region of southern India. Catena, v. 165, p. 251-259, 2018. https://doi.org/10.1016/j.catena.2018.02.008 
BORRELLI, P.; DIODATO, N.; PANAGOS, P. Rainfall erosivity in Italy: a national scale spatio-temporal assessment. International Journal of Digital Earth, v. 9, n. 9, p. 835850, 2016. https://doi.org/10.1080/17538947.2016.1148203

CAMBARDELLA, C. A.; MOORMAN, T. B.; PARKIN, T. B.; KARLEN, D. L.; NOVAK, J. M.; TURCO, R. F. et al. Field-scale variability of soil properties in central Iowa soils. Soil science society of America journal, v. 58, n. 5, p. 1501-1511, 1994. http://dx.doi.org/10.2136/sssaj1994.03615995005800050033x

CARVALHO, N. O. Hidrossedimentologia prática. São Paulo: Interciência, 2008.

CARVALHO, L. M. V.; JONES, C. Zona de Convergência do Atlântico Sul. In: CAVAlCANTI, I. F. de A. et al. (Orgs.). Tempo e Clima no Brasil. São Paulo: Oficina de Textos, 2009.

DA CUNHA, E. R.; BACANI, V. M.; PANACHUKI, E. Modeling soil erosion using RUSLE and GIS in a watershed occupied by rural settlement in the Brazilian Cerrado. Natural Hazards, v. 85, n. 2, p. 851-868, 2017. https://doi.org/10.1007/s11069-016-2607-3

DI RAIMO, L. A. D. L.; TORRES, G. N.; ALMEIDA, C. O. S.; AMORIM, R. S. S.; COUTO, E. G.; NOBREGA, R. L. B. Rainfall seasonality and erosivity for two agro-industrial regions in Brazil. Scientia Agrária, v. 19, p. 44-56, 2018.

GAN, M.; RODRIGUES, L. R.; RAO, V. B. Monção na américa do sul. In: CAVALCANTI, I. F. de A. et al. (Orgs.). Tempo e Clima no Brasil. São Paulo: Oficina de Textos, 2009.

INSTITUTO MATO-GROSSENSE DE ECONOMIA AGROPECUÁRIA - IMEA, Mapa das $\begin{array}{llll}\text { macrorregiões do } & \text { IMEA. } & \text { Nov. }\end{array}$ http://www.imea.com.br/upload/publicacoes/arquivos/justificativamapa.pdf. Access: 12 Oct. 2016

MACHADO, D. O.; ALVES-SOBRINHO, T.; RIBEIRO, A. D. S.; IDE, C. N.; OLIVEIRA, P. T. S. Erosividade da chuva para o bioma Pantanal. Engenharia Sanitária e Ambiental, v. 19, n. 2, p. 195-201, 2014. http://dx.doi.org/10.1590/S1413-41522014000200010

MARCUZZO, F.; ROCHA, H. M.; MELO, D. Mapeamento da precipitação pluviométrica no bioma pantanal do Estado do Mato Grosso. Geoambiente On-line, v. 16, p. 01-19, 2011a.

MARCUZZO F.; ROCHA H. M.; MELO D. Mapeamento da precipitação pluviométrica no bioma cerrado do Estado do Mato Grosso. Boletim Goiano de Geografia, v. 31, n. 2, p. 83-97, $2011 b$.

MARCUZZO, F. F.; MELO, D. C.; COSTA, H. C. Sazonalidade e distribuição espaço-temporal das chuvas no bioma do Cerrado do Estado do Mato Grosso do Sul. Revista Brasileira de Recursos Hídricos, v. 17, n. 1, p. 77-86, 2012.

MEllo, C. R.; SÁ, M. A. C.; CURI, N.; MELlO, J. M.; VIOLA, M. R.; da SILVA, A. M. Erosividade mensal e anual da chuva no Estado de Minas Gerais. Pesquisa Agropecuária Brasileira, v. 42, n. 4, p. 537-545, 2007.

MELLO, C. D.; VIOLA, M. R.; BESKOW, S.; NORTON, L. D. Multivariate models for annual rainfall erosivity in Brazil. Geoderma, v. 202, p. 88-102, 2013. https://doi.org/10.1016/j.geoderma.2013.03.009 
MELLO, C. R.; VIOLA, M. R.; OWENS, P. R.; DE MELLO, J. M; BESKOW, S. Interpolation methods for improving the RUSLE R-factor mapping in Brazil. Journal of Soil and $\begin{array}{lllllll}\text { Water Conservation, } & \text { v. } 70, \quad \text { n. 3, p. 182-197, }\end{array}$ http://dx.doi.org/10.2489/jswc.70.3.182

MEUL, M.; VAN MEIRVENNE, M. Kriging soil texture under different types of nonstationarity. Geoderma, v. 112, p. 217-233, 2003. https://doi.org/10.1016/S00167061(02)00308-7

MEUSBURGER, K.; STEEL, A.; PANAGOS, P.; MONTANARELLA, L.; ALEWELL, C. Spatial and temporal variability of rainfall erosivity factor for Switzerland. Hydrology and Earth System Sciences, v. 16, p. 167-177, 2012. https://doi.org/10.5194/hess-16$167-2012$

MONTEBELLER, C. A.; CEDDIA, M. B.; CARVALHO, D. F. de; VIEIRA, S. R.; FRANCO, E. Variabilidade espacial do potencial erosivo das chuvas no Estado do Rio de Janeiro. Engenharia Agrícola, v. 27, n. 2, p. 426-435, 2007. https://doi.org/10.1590/S010069162007000300011.

MORAIS, L. D.; SILVA, V. D; NASCHENVENG, T. D. C.; HARDOIN, P. C.; ALMEIDA, J. D.; WEBER, O. D. S. et al. Índice EI30 e sua relação com o coeficiente de chuva do sudoeste do Mato Grosso. Revista brasileira de ciência do solo, v. 15, n. 3, p. 339-344, 1991.

MOREIRA, M. C.; CECÍLIO, R. A.; PINTO, F. D. A. D. C.; PRUSKI, F. F. Desenvolvimento e análise de uma rede neural artificial para estimativa da erosividade da chuva para o Estado de São Paulo. Revista Brasileira de Ciência do Solo, v. 30, n. 6, p. 1069-1076, 2006.

OLIVEIRA, P. T.; RODRIGUES, D. B.; SOBRINHO, T. A.; CARVALHO, D. F. D.; PANACHUKI, E. Spatial variability of the rainfall erosive potential in the state of Mato Grosso do Sul, Brazil. Engenharia Agrícola, v. 32, n. 1, p. 69-79, 2012. http://dx.doi.org/10.1590/S0100-69162012000100008

OLIVEIRA, P. T. S.; WENDLAND, E.; NEARING, M. A. Rainfall erosivity in Brazil: A review. Catena, v. 100, p. 139-147, 2013. https://doi.org/10.1016/j.catena.2012.08.006

PANAGOS, P.; BORRELLI, P.; MEUSBURGUER, K.; YU, B.; KLIK, A.; LIM, K. J. et al. Global rainfall erosivity assessment based on high-temporal resolution rainfall records. Scientific reports, v. 7, n. 1, p. 4175, 2017.

RENARD, K. G.; FREIMUND, J. R. Using monthly precipitation data to estimate the R-factor in the revised USLE. Journal of hydrology, v. 157, n. 1-4, p. 287-306, 1994. https://doi.org/10.1016/0022-1694(94)90110-4

SILVA, A. M. Rainfall erosivity map for Brazil. Catena, v. 57, n. 3, p. 251-259, 2004. https://doi.org/10.1016/j.catena.2003.11.006

SILVA, S.; de SOUZA, G. S.; de OLIVEIRA, R. B. Variabilidade espacial do potencial erosivo das chuvas para o estado do Espírito Santo, Brasil. Irriga, v. 15, n. 3, p. 312, 2010a. https://doi.org/10.15809/irriga.2010v15n3p312

SILVA, M.; NAVES SILVA, M. L.; CURI, N.; RODRIGUES DOS SANTOS, G. et al. Avaliação e espacialização da erosividade da chuva no vale do rio doce, região centroleste do Estado de Minas Gerais. Revista Brasileira de Ciência do Solo, v. 34, n. 4, 2010 b. 
TRINDADE, A. L. F.; de OLIVEIRA, P. T. S.; ANACHE, J. A. A.; WENDLAND, E. Variabilidade espacial da erosividade das chuvas no Brasil. Pesquisa Agropecuária Brasileira, v. 51, n. 12, p. 1918-1928, 2016.

VIOLA, M. R.; AVANZI, J. C.; de MELLO, C. R.; de OLIVEIRA LIMA, S.; ALVES, M. V. G. Distribuição e potencial erosivo das chuvas no Estado do Tocantins. Pesquisa Agropecuária Brasileira, v. 49, n. 2, p. 125-135, 2014.

WALTRICK, P. C.; de MELlO MACHADO, M. A.; DIECKOW, J.; de OLIVEIRA, D. Estimativa da erosividade de chuvas no estado do Paraná pelo método da pluviometria: atualização com dados de 1986 a 2008. Revista Brasileira de Ciência do Solo, v. 39, n. $1,2015$.

WISCHMEIER, W. H.; SMITH, D. D. Predicting rainfall erosion losses: a guide to conservation planning. Washington: United States Department of Agriculture, 1978. 58p. (Agriculture Handbook, 537).

ZAVATTINi J. A. As chuvas e as massas de ar no estado de Mato Grosso do Sul: estudo geográfico com vista à regionalização climática. São Paulo: Cultura acadêmica, 2009. 


Ambiente \& Água - An Interdisciplinary Journal of Applied Science
ISSN 1980-993X - doi:10.4136/1980-993X
www.ambi-agua.net
E-mail: ambi.agua@gmail.com

\title{
Silver nanoparticles impregnated with polyamide-66 to disinfect drinking water
}

\author{
ARTICLES doi:10.4136/ambi-agua.1947
}

Received: 19 Jun. 2016; Accepted: 12 Oct. 2018

\author{
Luciano André Deitos Koslowski ${ }^{1 *}$; André Lourenço Nogueira²; \\ Silvana Licodiedoff ${ }^{1}$; Adrieny Taliny Comper $^{3}$; Marilena Valadares Folgueras ${ }^{4}$

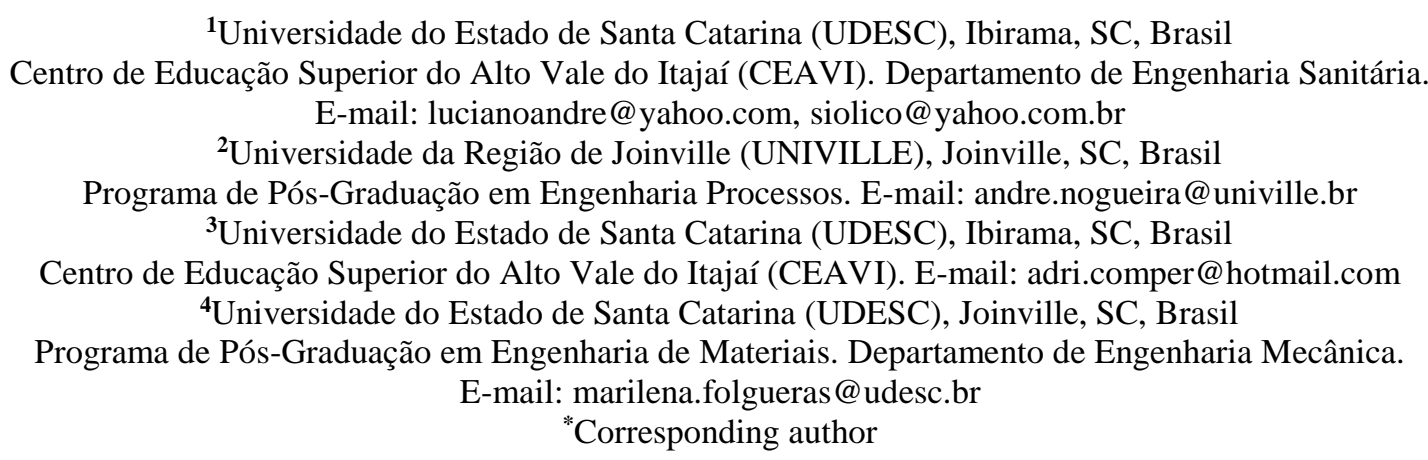

\begin{abstract}
The importance of the preservation of water resources has resulted in the application of technologies such as nanostructured materials, which are able to minimize the impact associated with water contamination. This work evaluated the application of polyamide-66 (PA) pellets functionalized with silver nanoparticles (AgNPs) at polymer mass percentages of $0.05,0.10$ and $0.50 \%$ to disinfect of drinking water. Studies were carried out in three stages. The first stage was the synthesis of the silver nanoparticles by using silver nitrate as a metal precursor and sodium borohydrate as a reduction agent. The colloidal dispersion was characterized by UVVis spectrophotometry and transmission electron microscopy (MET). Afterwards, the nanostructures were incorporated into a polyamide- 66 polymeric matrix. In the second stage, the silver ions leached from the polymer matrix in the water after a three-hour period were quantified in order to evaluate the limit established by Conama Resolution 357/2005, which imposes a concentration limit of $0.010 \mathrm{mg} \mathrm{L}^{-1}$. The best results were obtained with the application of $0.05 \%$ AgNPs in the polymeric matrix, yielding an average concentration of silver ions lixiviated of $0.008 \mathrm{mg} \mathrm{L}^{-1}$. The last step comprised the quantification of the antibacterial activity of the polymer matrix containing $0.05 \%$ of AgNPs against the microorganism E. coli using the Standard Test Method for Determining the Antimicrobial Agents Under Dynamic Contact Conditions. The samples containing 0.05\% of AgNPs exhibited an antibacterial reduction of $97.89 \%$ after $24 \mathrm{~h}$ of incubation under stirring at room temperature $\left(25^{\circ} \mathrm{C}\right)$.
\end{abstract}

Keywords: E. coli., polyamide-66, silver nanoparticles, water disinfection. 


\section{Uso de nanopartículas de prata impregnadas em poliamida-66 para desinfecção de água para consumo}

\section{RESUMO}

A importância da preservação dos recursos hídricos tem resultado na aplicação de tecnologias, tais como o uso de materiais nanoestruturados, para minimizar o impacto associado à contaminação da água. Neste trabalho, foi avaliada a aplicação de pellets de poliamida-66 (PA) funcionalizados com nanopartículas de prata (AgNPs), em percentuais de 0.05; $0.10 \mathrm{e}$ $0.50 \%$ em relação à massa de polímero, na desinfecção de água para consumo. O presente estudo teve como principal objetivo sintetizar as nanopartículas de prata, e avaliar a atividade antibacteriana destas nanoestruturas em relação à bactéria Gram negativa Escherichia coli quando incorporadas numa matriz de PA. A síntese das nanopartículas de prata foi realizada empregando o nitrato de prata como sal do metal precursor e o borohidreto de sódio como agente redutor. A dispersão coloidal foi caracterizada por espectrofotometria na região UV-Vis e microscopia eletrônica de transmissão. Posteriormente, foi realizada a quantificação de íons prata lixiviada da matriz polimérica para a água no período de 3 horas, de forma a avaliar comparativamente ao limite estabelecido pela Resolução do Conama 357/2005, que impõe um limite de concentração da prata de $0.010 \mathrm{mg} \mathrm{L}^{-1}$. O melhor resultado consistiu na aplicação de $0.05 \%$ de AgNPs na matriz polimérica, lixiviando uma quantidade equivalente a uma concentração média de íons prata de $0.008 \mathrm{mg} \mathrm{L}^{-1}$. A última etapa foi a utilização da matriz polimérica funcionalizada com as AgNPs em ensaios microbiológicos para mensurar a atividade antibacteriana do produto obtido contra o microrganismo E. coli. Os resultados ilustram que após $24 \mathrm{~h}$ de incubação, sob agitação e temperatura de $25^{\circ} \mathrm{C}$, as amostras com $0.05 \%$ de AgNPs apresentaram uma redução antibacteriana de 97,89\%.

Palavras-chave: desinfecção da água, E. coli., nanopartículas de prata, poliamida-66.

\section{INTRODUCTION}

Drinking water sources are becoming increasingly scarce as a result of prolonged droughts and water pollution (Vörösmarty et al., 2000). Nascimento and Araújo (2013) reported that freshwater quality has been compromised due to anthropogenic actions mainly related to the disposal of sewage, which may contain a range of microorganisms natural to the human intestinal microbiota, such as members of the Enterobacteriaceae family. Pollution and water contamination increase the need for measures to mitigate environmental impact so that the application and optimisation of technologies for the adequate treatment of water are not compromised (Araújo et al., 2016).

Nanotechnology has attracted significant interest from several research areas in relation to the application of nanomaterials. In the medical field, metallic nanoparticles and their oxides have been proven effective against microorganisms (Nogueira et al., 2014; Kim et al., 2016).

In recent years, several studies have been undertaken on the application of silver nanoparticles in water disinfection, aiming at improving conventional water treatments (Zhang and Oyanedel-Craver, 2013). Such studies have reported the antimicrobial activity of silver nanoparticles against bacteria such as Escherichia coli, Pseudomonas aeruginosa and Salmonella typhi (Alizadeh et al., 2014). The action mechanisms and toxicity have been attributed to the interaction of $\mathrm{Ag}^{+}$ions with sulphuric groups in the cell membrane of the microorganisms (Durán et al., 2016). Silver ions are of limited antimicrobial application due to their high toxicity and low stability. However, these drawbacks can be overcome by replacing $\mathrm{Ag}^{+}$ions with properly stabilized silver nanoparticles (Mohanty et al., 2012). 
Recent research indicates that silver nanoparticles act on the surface of the cell membrane and diffuse into the bacterium (Durán et al., 2016). There are some non-conclusive hypotheses about the mechanism of action of this nanostructure, including that silver might exhibit a synergistic action rather than a restrictive mode of action in relation to its antibacterial activity (Mohanty et al., 2012). Therefore, the objective of this study was to present a viable alternative for water disinfection using silver nanoparticles (AgNPs) incorporated in a polyamide-66 (PA) matrix as a bactericidal material.

\section{MATERIAL AND METHODS}

\subsection{Silver nanoparticles (AgNPs) synthesis}

In the literature, the synthesis of silver nanoparticles comprise different production methods, varying types and quantities of reactants, reaction time, stirring rate, heating, among other parameters. The preparation of these nanostructures relies on the use of aqueous solutions of silver salts - reducing and stabilizer agents - which are heated under stirring for a certain time (Polte et al., 2012). Variables such as the type and concentration of reactants (precursor salt and reducing agent) and stabilizers, $\mathrm{pH}$ and temperature have significant impact on particle size and morphology (Nogueira et al., 2014).

In this work, synthesis reactions of silver nanoparticles were conducted in a boron-silicate reactor with a 200-mL capacity, operating in a semi-continuous regime under controlled temperature and stirring. The silver nanoparticles were synthesized by initially adding $180 \mathrm{~mL}$ of deionized water to the reactor. Then, the precursor metal salt (silver nitrate $-\mathrm{AgNO}_{3}$, Cennabras, Brazil) was added to the water until a concentration in the reaction medium equal to $9.3 \mathrm{mmol} \mathrm{L}^{-1}$ was reached. The stabilizing agent employed to stabilize the colloidal dispersion (silver nanoparticles) was a hydrosoluble silicone wax containing amine functional groups (Quimisa, Brazil).

The concentration of this compound in the reaction medium was $0.84 \mathrm{~g} \mathrm{~L}^{-1}$. The operational temperature was set at $20{ }^{\circ} \mathrm{C}$ and a stirring rate of $600 \mathrm{rpm}$ was kept for $10 \mathrm{~min}$ to ensure complete solubilization. Then, $20 \mathrm{~mL}$ of a sodium borohydride solution (Nuclear, Brazil), with a concentration of $4.64 \mathrm{~g} \mathrm{~L}^{-1}$ and a temperature of $10^{\circ} \mathrm{C}$ was added at an approximate flow rate of $1.5 \mathrm{~mL} \mathrm{~min}{ }^{-1}$. Following the addition of the reducing agent, the system was kept under temperature and stirring control for additional $10 \mathrm{~min}$ to ensure completion of the reaction.

In the next step, silica powder (Syloid $244 \mathrm{FD}, 5 \mu \mathrm{m}$ average diameter, Grace Division) was added to the metallic silver colloidal dispersion at the ratio of $1.0 \mathrm{~g}$ of silica to $8.0 \mathrm{~mL}$ of colloidal dispersion. The resulting suspension was kept under stirring for 30 minutes. Afterwards, the system was left to rest to allow the sedimentation of the silica particles to functionalize the silver nanoparticles. The silica was separated from the supernatant using a separator funnel and the solid material was dried at $50^{\circ} \mathrm{C}$ for $48 \mathrm{~h}$.

The incorporation of the AgNP-containing powder into polyamide-66 was performed in the extruder illustrated in Figure 1a (Cristal Master Model GR 001) operating at $250^{\circ} \mathrm{C}$ at a dosing speed of $12.60 \mathrm{~min}^{-1}$. The polyamide (PA) filaments incorporated with AgNPs were processed in a granulator (SAGEC Model S650/2) (Figure 1b) for the production of functionalized pellets with approximate area of $1.0 \mathrm{~cm}^{2}$ and mass $0.25 \mathrm{~g}$. PA/AgNPs pellets were produced at concentrations of $0.05 \%, 0.10 \%$ and $0.50 \%$ in relation to the weight of the silica powder incorporated with AgNPs. 


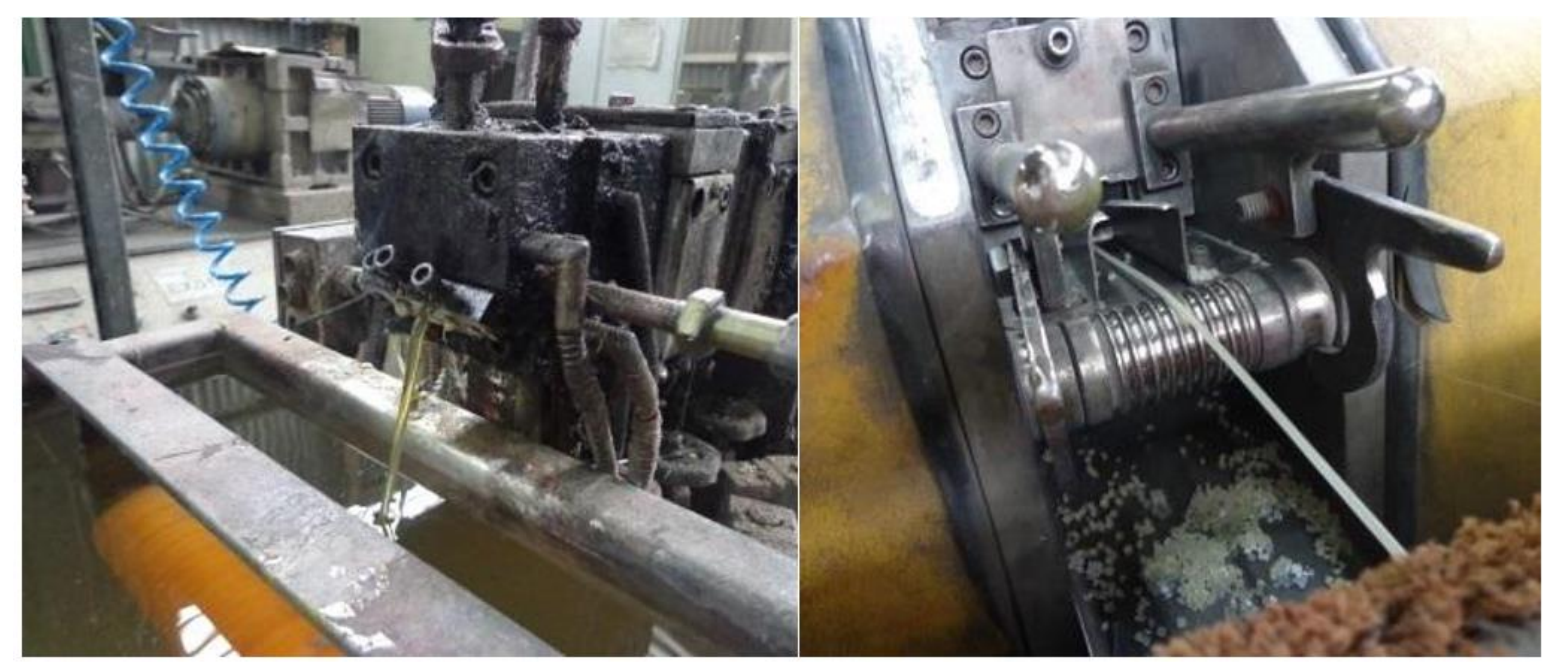

Figure 1. (a) Extruder used to obtain PA/AgNPs filaments; (b) Granulator used to obtain PA/AgNPs pellets.

\subsection{Characterization of nanoparticles}

MET analyses were performed to evaluate the mean size, size distribution and geometric shape of the synthesized nanoparticles. Ten drops of silver nanoparticles dispersed in water were dripped onto a 300-mesh grid covered with carbon film. After drying at room temperature, the grids were examined in a microscope (JEOL, JEM-2100) and the images were captured at a voltage of $200 \mathrm{kV}$.

UV-Vis spectrophotometry analyses were conducted to obtain information on the optical properties of the synthesized product by absorption spectra. Thus, $0.1 \mathrm{~mL}$ of the AgNPs colloidal dispersion were diluted in $7.5 \mathrm{~mL}$ of deionized water, and $3.0 \mathrm{~mL}$ of this solution were added into a glass cuvette with a $10 \mathrm{~mm}$ optical path to obtain the absorption spectra in a spectrophotometer (Schimadzu, model UVPC-V.3.9). The UV-Vis tests were performed in triplicate and the same solution was prepared three times to ensure reproducibility of the results.

\subsection{ICP-MS essays}

The ICP-MS technique (Optima 8300 Perkin-Elmer) was selected to quantify the concentration of silver ions leached from the PA/AgNPs pellets after $3 \mathrm{~h}$ of contact with water samples contaminated with $E$. coli. The silver quantification was undertaken with solutions used in microbiological tests in the presence of silver nanoparticles, according to the methodology recommended in the Standard Methods for the Examination of Water and Wastewater (22nd ed.), methods SMEWW-3120 B and SMEWW-3030 E. Samples containing $0.05 \%, 0.10 \%$ and $0.50 \%$ of silica powder incorporated with AgNPs were prepared for the determination of $\mathrm{Ag}^{+}$ions by addition of rhodium as internal standard at concentration $5 \mu \mathrm{g} \mathrm{L}^{-1}$ and $1 \%(\mathrm{v} / \mathrm{v}) \mathrm{HNO}_{3}$. The same methodology was used for the calibration and control solutions. The pneumatic nebulization was performed with argon gas (99.99\% purity) to avoid interference in the tests.

\subsection{Microbiological tests}

For the analysis of faecal coliforms, Gram-negative bacteria E. coli (CCT-8739) was selected as faecal origin bacteria because it is directly related to health problems associated with contaminated water consumption. Faecal coliform analysis of water potability was performed using the Multi-Tube Fermentation Technique (TFTM) as described by APHA (2012). Serial dilutions were prepared and the medium to be analysed was transferred to test tubes containing the appropriate culture medium and a gas-collecting tube (Durhan tube). Following incubation 
of the tubes, the samples that showed positive results for the presence of coliforms were submitted to three dilutions $\left(10^{-1}, 10^{-2}\right.$ and $\left.10^{-3}\right)$ and subdivided into three groups comprising three tubes with their own culture medium.

The presumptive test for coliforms was performed using Lauril Sulfate Triptose (LST) broth enriched with $50 \mathrm{mg} \mathrm{L}^{-1}$ of 4 -methylumbelliferyl- $\beta$-D-glucuronide (LST-MUG). The analyses were performed by pipetting $1.0 \mathrm{~mL}$ aliquots of different dilutions into a series of three tubes containing $9.0 \mathrm{~mL}$ of LST-MUG and provided with an inverted Durham tube, homogenized and incubated at $35^{\circ} \mathrm{C}$ for $48 \mathrm{~h}$. Gas production observed in the Durham tubes indicated the presence of coliforms.

Following the $24 \mathrm{~h}$ incubation at $37^{\circ} \mathrm{C}$ using the serial tube methodology, all the LSTMUG tubes that exhibited fluorescence were considered positive for E. coli when exposed to ultraviolet light $(6 \mathrm{~W})$ with a long wavelength $(366 \mathrm{~nm})$ in a dark room.

The E. coli solution was prepared using the strain cultured in TSB broth. Then, $200 \mu \mathrm{L}$ of such solution were dispensed into a tube containing $3.0 \mathrm{~mL}$ of a $0.85 \% \mathrm{NaCl}$ solution (mass percentage). Afterwards, the turbidity corresponding to 0.5 on the McFarland scale (109 bacteria $\mathrm{mL}^{-1}$ ) was determined. The solution obtained was subjected to antimicrobial susceptibility tests by the plate diffusion method (Müller Hinton Agar) and the polymer matrix containing the AgNPs were transferred into the plates and incubated for $24 \mathrm{~h}$ at $25^{\circ} \mathrm{C}$. The antimicrobial activity of the pellets impregnated with silver nanoparticles was assessed by the most probable number (MPN), according to the ASTM International ( 2001).

The tests were carried out using $2.0 \mathrm{~g}$ of PA/AgNPs pellets containing 0.05, 0.10 and $0.50 \%(\mathrm{~m} / \mathrm{m})$ of silica powder functionalized with the metal nanostructures. Three triplicate samples comprising $2.0 \mathrm{~g}$ of pellets without silver nanoparticles were used as control.

Subsequently, $1.0 \mathrm{~g}$ of inoculum was solubilized in $50 \mathrm{~mL}$ of deionized water at a concentration of 2.0-3.0 × $10^{5} \mathrm{CFU} \mathrm{mL}^{-1}$. The flasks were closed and incubated in a shaking oven with temperature controlled at $25^{\circ} \mathrm{C}$ for $24 \mathrm{~h}$. Several dilutions were prepared from $1.0 \mathrm{~mL}$ from each vial. All tests were performed in triplicate. The microbial reduction percentage was calculated by Equation 1 .

Reduction $\%\left(\frac{U F C}{m l}\right)=\frac{B-A}{B} \times 100$

where: $\mathrm{A}$ is the microbial count in the sample containing (AgNPs) $(\mathrm{CFU} / \mathrm{mL})$ and $\mathrm{B}$ is the microbial count in the sample with no antibacterial agent (control).

The samples were stirred at $40 \pm 2 \mathrm{~min}^{-1}$ for $20 \mathrm{~h}$ on a magnetic stirrer. Afterwards, the samples were vacuum-filtered and the liquid fraction was subjected to inductively coupled plasma atomic mass spectroscopy (ICP-MS) to quantify the silver leached from the PA/AgNPs pellets.

\subsection{Statistical analysis and $\boldsymbol{E}$. coli reduction kinetics}

The data were treated by analysis of variance (ANOVA) and Tukey's test at $5 \%$ of significance using Statistica for Windows (Version 7.0, Statsoft). The results allowed determining the reduction kinetics of $E$. coli under two different conditions: agitation and no agitation of the solution added with AgNPs. The reaction order was determined by the Pearson correlation coefficient, $\mathrm{R}^{2}$, which measures the degree of linear correlation between two quantitative variables, yielding values between 0 and 1 . 


\section{RESULTS AND DISCUSSION}

Figure 2 shows a transmission electron microscopy (TEM) image of the silver nanoparticles. The synthesized nanostructures exhibited an approximate spherical shape, with an average size between 20 and $30 \mathrm{~nm}$.

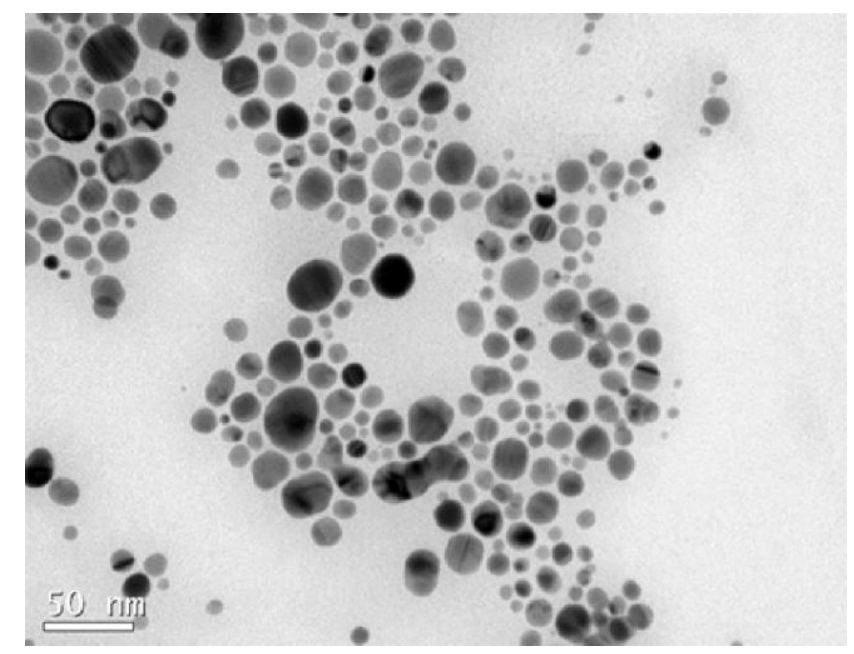

Figure 2. MET image $(\times 450,000$ times $)$.

The absorbance spectrum shown in Figure 3 shows a peak absorbance close to $400 \mathrm{~nm}$. Similar results were published in Nogueira et al. $(2014 ; 2016)$, who reported that silver nanoparticles with predominantly spherical shape presented a surface plasmon resonance that absorbs the radiation at wavelength around $400 \mathrm{~nm}$ in the UV-visible region.

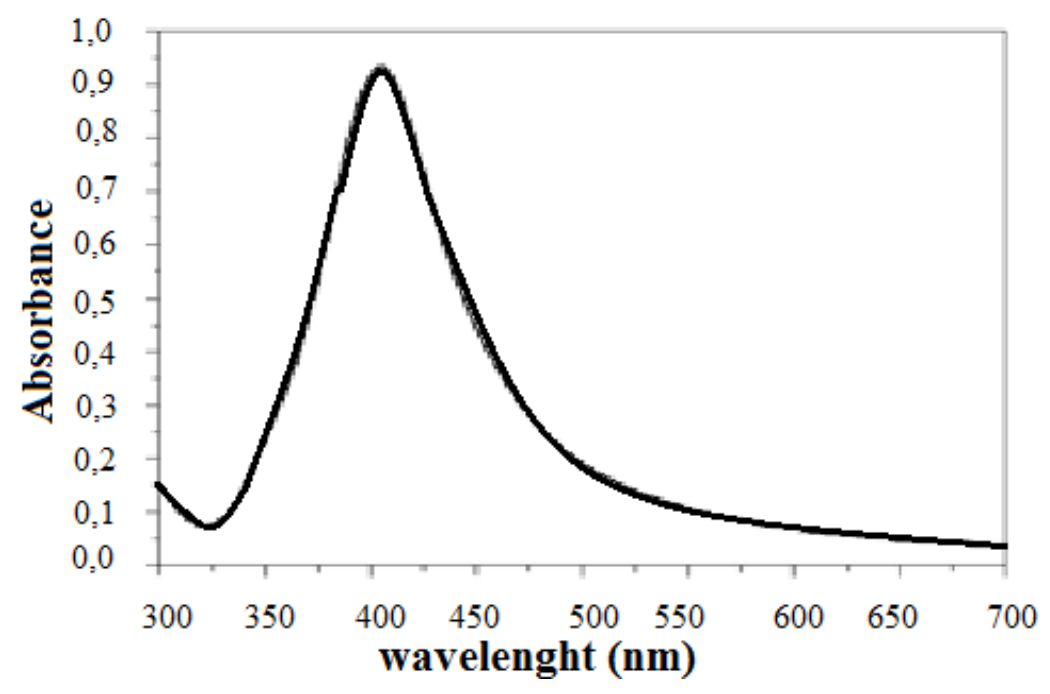

Figure 3. Absorption spectrum of synthesized silver nanoparticles.

The silica microparticles with adsorbed silver nanoparticles were also analysed by transmission electron microscopy. The images presented in Figure 4 show that the metallic nanostructures are well dispersed on the silica's surface. Figure 4a, a conventional image without contrast, shows the nanoparticles as dark spots. In Figure $4 \mathrm{~b}$, to which an optical contrast feature was applied, the bright dots indicate the presence of a metallic material adsorbed on the surface of the silica microparticles. This metallic material corresponds to the silver nanoparticles, which reflect part of the incident electron beam. 

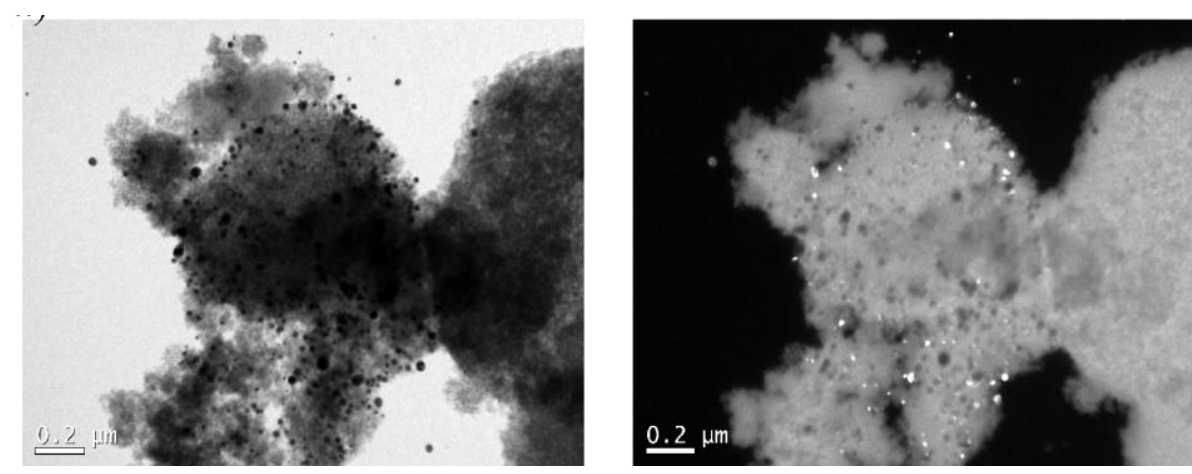

Figure 4. MET image of the silver nanoparticles adsorbed on the silica surface: a) without contrast; b) with contrast.

The following average values were obtained from the silver-leaching tests as a function of the amount of functionalized silica incorporated in the polyamide: $0.052 \mathrm{mg} \mathrm{L}^{-1}(0.50 \%)$, $0.020 \mathrm{mg} \mathrm{L}^{-1}(0.10 \%)$ and $0.008 \mathrm{mg} \mathrm{L}^{-1}(0.05 \%)$. The polyamide sample that complied with the maximum limit of leached silver as established in the Conama resolution 357/2005 (CONAMA, 2005) $\left(0.010 \mathrm{mg} \mathrm{L}^{-1}\right)$ was used in the microbiological tests. The tests were performed with pellets containing $0.05 \%$ by weight of silica powder functionalized with silver nanoparticles.

The antibacterial activity was determined in terms of mean faecal contamination $\left(\mathrm{CFU} \mathrm{m} \mathrm{L}{ }^{-1}\right)$. The tests were carried out in triplicate and the Tukey test was used to analyse the bactericidal effect of the pellets containing silver nanoparticles $(\mathrm{N})$ on the representative Gramnegative bacteria (E. coli) after exposure times of $1 \mathrm{~h}, 2 \mathrm{~h}$ and $3 \mathrm{~h}$. AgNP-free samples were used as control. The data summarized in Table 1 indicate that the averages followed by the same letter in the columns do not differ by the Tukey test $(\mathrm{Tt})$ at $5 \%$ significance level.

Table 1. Faecal coliform (E. coli) contamination (average \pm standard deviation) of different samples.

\begin{tabular}{cccccc}
\hline Sample PA/AgNps & CFU mL $^{-1}$ & Tt & Control & Tt & CFU mL \\
\hline NA251 & $1.67 \pm 2.08$ & d & BA251 & ef & $6.10 \pm 1.05$ \\
NA252 & $1.33 \pm 1.53$ & d & BA252 & ef & $19.07 \pm 7.22$ \\
NA253 & $1.00 \pm 1.73$ & ed & BA253 & c & $47.17 \pm 11.77$ \\
NSA251 & $28.50 \pm 1.31$ & ef & BSA251 & b & $61.60 \pm 1.49$ \\
NSA252 & $23.83 \pm 1.10$ & f & BSA252 & a & $90.27 \pm 4.91$ \\
NSA253 & $16.07 \pm 5.33$ & f & BSA253 & b & $70.00 \pm 2.00$ \\
\hline
\end{tabular}

Legend: $\mathrm{N}=$ silver nanoparticles; $\mathrm{B}=$ control (no nanoparticles); $\mathrm{A}=$ stirring; $\mathrm{SA}=$ no stirring; $\mathrm{Tt}=$ Tukey test (5\% significance level).

Table 1 shows the interaction between residence time and stirring. A significant microbial reduction to final concentrations of $1.33 \mathrm{CFU} \mathrm{mL}^{-1}$ (NA252) and $1.00 \mathrm{CFU} \mathrm{mL}^{-1}$ (NA253) were reached in the presence of silver nanoparticles for residence times of $2 \mathrm{~h}$ and $3 \mathrm{~h}$, respectively. In Table 1, averages followed by the same letter in the same columns do not differ by the Tukey test at a 5\% significance level. The control (BSA252) reached an average E. coli count of $90.27 \mathrm{CFU} \mathrm{mL} \mathrm{m}^{-1}$ in $2 \mathrm{~h}$. The reduction in the presence of silver nanoparticles (NA252) for the same residence time was $93.05 \%(\mathrm{p}<0.05)$. The antimicrobial activity is ascribed to the action of silver ions on the respiratory chain of bacteria, by decoupling the electron transfer in oxidative phosphorylation, thereby inhibiting the enzymes of the respiratory chain (Feng et al., 2000). Figure 5 shows the reduction kinetics of E. coli attributed to the antibacterial activity of silver nanoparticles.

Figure 5 shows the mean percentage of microbial reduction ascribed to the antibacterial activity of silver nanoparticles incorporated in polyamide-66. The lowest antibacterial reduction 
occurred for sample NSA251 (53.73\%), no stirring and $1 \mathrm{~h}$ contact time. The most significant reduction was observed for sample NA253 (97.89\%), corresponding to stirring and $3 \mathrm{~h}$ contact time.

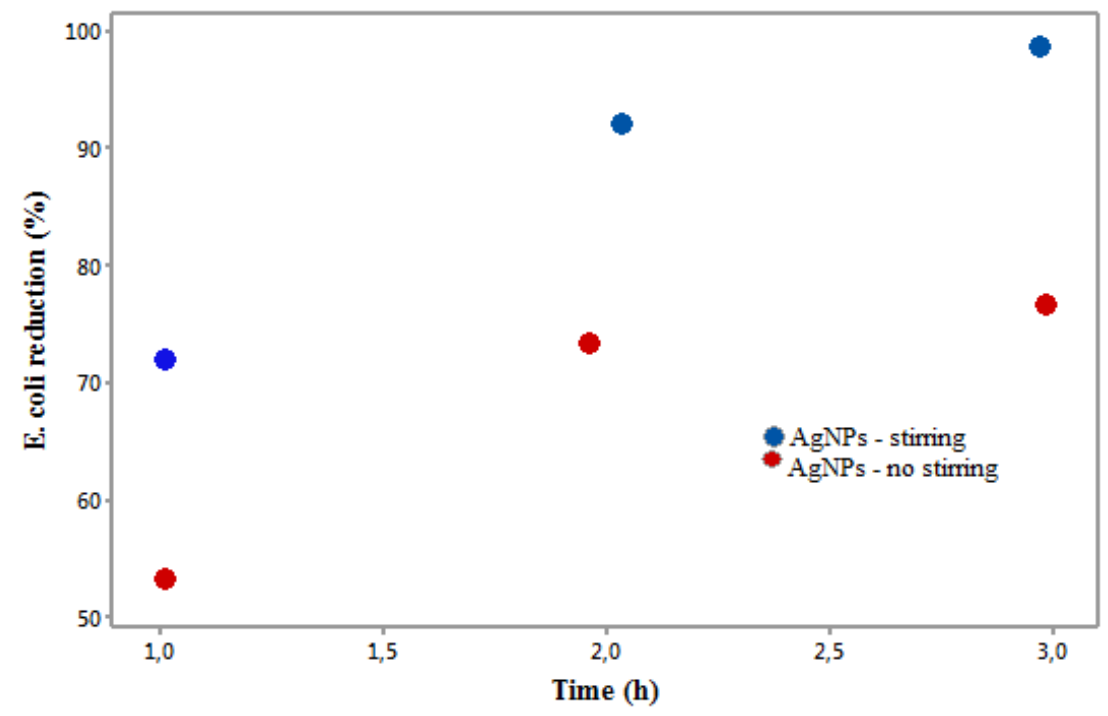

Figure 5. Reduction kinetics of E. coli.

The microbiological analysis revealed that both conditions (stirring and no stirring), result in a relevant bactericidal effect, as stated by Tan et al. (2015). Some authors confirm that AgNPs establish chemical bonds with sulphur and phospholipids present in the DNA, inhibiting various cellular processes in gram-negative bacteria (Franci et al., 2015; Li et al., 2011; Morones et al., 2005). The changes are associated with adverse effects resulting from the antibacterial activity of AgNPs in the cell membrane due to increased production of reactive oxygen species (ROS) (Franci et al., 2015).

The cellular stress mediated by reactive oxygen species has a detrimental and irreversible effect on the intracellular structure of bacteria (Morones et al., 2005; Choi and Hu, 2008). Xu et al. (2012) reported that some reactive oxygen species (ROS), including superoxide $\left(\cdot \mathrm{O}_{2}{ }^{-}\right)$, hydrogen peroxide $\left(\mathrm{H}_{2} \mathrm{O}_{2}\right)$ and hydroxyl radical $(\cdot \mathrm{OH})$, are generated during aerobic metabolism.

The chemical interaction between AgNPs and the cell membrane of bacteria can be related to the presence of sulphur in proteins, forming preferential sites with AgNPs (Zhang et al., 2013). Therefore, exposure to AgNPs promotes an increase in the rate of lipid peroxidation and oxidation of the protein due to lesser thiol groupings $(-\mathrm{SH})$ bounded to protein (Strużyński et al., 2014). The reduction of thiol levels and glutathione activity may induce AgNP-exposed organisms to ineffective antioxidant mechanisms against cellular stress mediated by reactive oxygen species (Becaro et al., 2015).

When stirring was used, the bacterial activity was reduced exponentially as $\mathrm{R}^{2}$ approached 1.0. It was possible to obtain a trend line with a very satisfactory correlation coefficient of 0.9973, according to Equation 2.

$y=0.1631 \mathrm{e}^{0.5574 \mathrm{x}}$

where: $\mathrm{t}$ is the residence time (h).

Equation 2 represents the exponential microbial reduction as a function of the initial concentration of the indicator bacterium, time and bacterial reduction rate. Equation 2 allows prediction of the bacterial reduction without the use of stirring in any residence time. 
The Pearson coefficient was 0.9349 for the tests without stirring. Equation 3 represents the exponential curve of the sample behaviour in these conditions.

$\mathrm{y}=0.1358 \mathrm{e}^{0.5295 \mathrm{x}}$

\section{CONCLUSIONS}

Functional nanoparticles supported in a polymeric matrix were proved an efficient bacterial inhibitor for water disinfection. The results concerning the leaching tests indicate that the concentration of $0.05 \%$ AgNPs in the polymer matrix met the maximum value allowed by the current legislation (Conama 357/2005), which is $0.010 \mathrm{mg} . \mathrm{L}^{-1}$. The most significant reduction (97.89\%) was observed for the sample with AgNPs, stirring and $3 \mathrm{~h}$ contact time. The antibacterial reduction related to stirring can be explained by the high surface area/volume ratio of the silver nanoparticles, which in theory yield a greater diffusive contact between the AgNPs and the bacteria, allowing a fast release of $\mathrm{Ag}^{+}$and consequent reduction of antibacterial activity. A longer diffusive contact time between silver nanoparticles and the studied bacteria results in structural alterations and deformations in the membrane walls and nucleic acids of the bacterial cells.

\section{REFERENCES}

ALIZADEH, H.; SALOUTI, M.; SHAPOURI, R. Bactericidal effect of silver nanoparticles on intramacrophage brucella abortus 544. Jundishapur Journal of Microbiology, v. 7, n. 3, 2014. https://dx.doi.org/10.5812\%2Fjjm.9039

AMERICAN PUBLIC HEALTH ASSOCIATION. Standard methods for the examination of water and wastewater. 22. ed. Washington, D.C., 2012. p. 9-70.

ARAÚJO, K. S.; ANTONELLI, R.; GAYDECZKA, B.; GRANATO, A. C.; MALPASS, G. R. P. Processos oxidativos avançados: uma revisão de fundamentos e aplicações no tratamento de águas residuais urbanas e efluentes industriais. Revista Ambiente \& Água, v. 11, n. 2, p. 387-401, 2016. http://dx.doi.org/10.4136/ambi-agua.1862

ASTM INTERNATIONAL. E 2149 Standard test method for determining the antimicrobial activity of immobilized antimicrobial agents under dynamic contact conditions. West Conshohocken, 2001.

BECARO, A. A.; PUTI, F. C.; CORREA, D. S.; PARIS, E. C.; MARCONCINI, J. M.; FERREIRA, M. D. Polyethylene films containing silver nanoparticles for applications in food packaging: characterization of physico-chemical and anti-microbial properties. Journal of nanoscience and nanotechnology, v. 15, n. 3, p. 2148-2156, 2015. https://doi.org/10.1166/jnn.2015.9721

CHOI, O.; HU, Z. Size dependent and reactive oxygen species related nanosilver toxicity to nitrifying bacteria. Environmental science \& technology, v. 42, n. 12, p. 4583-4588, 2008. http://dx.doi.org/10.1021/es703238h

CONSELHO NACIONAL DO MEIO AMBIENTE (Brasil). Resolução n ${ }^{\circ}$ 357/05. Estabelece a classificação das águas doces, salobras e salinas do Território Nacional. Diário Oficial [da] União, Brasília, n. 53, de 18 mar. 2005, p. 58-63.

DURÁN, N.; DURÁN, M.; DE JESUS, M. B.; SEABRA, A. B.; FÁVARO, W. J.; NAKAZATO, G. Silver nanoparticles: a new view on mechanistic aspects on antimicrobial activity. Nanomedicine: Nanotechnology, Biology and Medicine, v. 12, n. 3, p. 789-799, 2016. https://doi.org/10.1016/j.nano.2015.11.016 
FENG, Q. L.; WU, J.; CHEN, G. Q.; CUI, F. Z.; KIM, T. N.; KIM, J. O. A mechanistic study of the antibacterial effect of silver ions on Escherichia coli and Staphylococcus aureus. Journal of biomedical materials research, v. 52, n. 4, p. 662-668, 2000. https://doi.org/10.1002/1097-4636(20001215)52:4<662::AID-JBM10>3.0.CO;2-3

FRANCI, G.; FALANGA, A.; GALDIERO, S.; PALOMBA, L.; RAI, M.; MORELLI, G. et al. Silver nanoparticles as potential antibacterial agents. Molecules, v. 20, n. 5, p. 8856-8874, 2015. http://dx.doi.org/10.3390/molecules20058856

KIM, H.; KIM, Y., KIM, Y.; LEE, S. Removal of ZnO Nanoparticles in Aqueous Phase and Its Ecotoxicity Reduction. Clean Technology, v. 22, n. 2, p. 89-95, 2016. https://doi.org/10.7464/ksct.2016.22.2.089

LI, M.; ZHU, L.; LIN, D. Toxicity of ZnO nanoparticles to Escherichia coli: mechanism and the influence of medium components. Environmental Science \& Technology, v. 45, p. 1977-1983, 2011. http://dx.doi.org/1 0.1021/es102624t

MORONES, J. R.; ELECHIGUERRA, J. L.; CAMACHO, A.; HOLT, K.; KOURI, J. B.; RAMÍREZ, J. T. et al. The bactericidal effect of silver nanoparticles. Nanotechnology, v. 16, p. 2346-2353, 2005. https://doi.org/10.1088/0957-4484/16/10/059

MOHANTY, S.; MISHRA, S.; JENA, P.; JACOB, B.; SARKAR, B.; SONAWANE, A. An investigation on the antibacterial, cytotoxic, and antibiofilm efficacy of starch-stabilized silver nanoparticles. Nanomedicine: Nanotechnology, Biology and Medicine, v. 8, p. 916-924, 2012. https://doi.org/10.1016/j.nano.2011.11.007

NASCIMENTO, S. F. V.; ARAÚJO, F. F. M. Ocorrência de bactérias patogênicas oportunistas em um reservatório do semiárido do Rio Grande do Norte, Brasil. Revista de Ciências Ambientais-RCA, v. 7, p. 91-104, 2013. http://dx.doi.org/10.18316/1080

NOGUEIRA, A. L.; MACHADO, R. A.; de SOUZA, A. Z.; MARTINELLO, F.; FRANCO, C. V.; DUTRA, G. B. Synthesis and characterization of silver nanoparticles produced with a bifunctional stabilizing agent. Industrial \& Engineering Chemistry Research, v. 53, p. 3426-3434, 2014.http://dx.doi.org/10.1021/ie4030903

NOGUEIRA, A. L.; MACHADO, R. A.; de SOUZA, A. Z.; FRANCO, C. V.; DUTRA, G. B. Influence of process parameters and scalability of the semi-batch production of functionalized silver nanoparticles. The Canadian Journal of Chemical Engineering, v. 94, n. 8, p. 1472-1485, 2016. https://doi.org/10.1002/cjce.22530

POLTE, J.; TUAEV, X.; WUITHSCHICK, M.; FISCHER, A.; TGUENEMANN, A. F; RADEMANN, K. et al. Formation mechanism of colloidal silver nanoparticles: analogies and differences to the growth of gold nanoparticles. Acs Nano, v. 6, n. 7, p. 5791-5802, 2012. http://dx.doi.org/10.1021/nn301724z

STRUŻYŃSKI, W.; DĄBROWSKA-BOUTA, B.; GRYGOROWICZ, T.; ZIEMIŃSKA, E.; STRUŻYŃSKA, L. Markers of oxidative stress in hepatopancreas of crayfish (Orconectes limosus, raf) experimentally exposed to nanosilver. Environmental toxicology, v. 29, n. 11, p. 1283-1291, 2014. http://dx.doi.org/ 10.1002/tox.21859

TAN, Z. Q.; LIU, J. F.; GUO, X. R.; YIN, Y. G.; BYEON, S. K.; MOON, M. H. et al. Toward full spectrum speciation of silver nanoparticles and ionic silver by on-line coupling of hollow fiber flow field-flow fractionation and minicolumn concentration with multiple detectors. Analytical Chemistry, v. 87, n. 16, p. 8441-8447, 2015. http://dx.doi.org/10.1021/acs.analchem.5b01827 
VÖRÖSMARTY, C. J.; GREEN, P.; SALISBURY, J.; LAMMERS, R. B. Global water resources: vulnerability from climate change and population growth. Science, v. 289, p. 284-288, 2000. http://dx.doi.org/10.1126/science.289.5477.284

XU, H.; QU, F.; XU, H.; LAI, W.; WANG, Y. A.; AGUILAR, Z. P. et al. Role of reactive oxygen species in the antibacterial mechanism of silver nanoparticles on Escherichia coli O157: H7. Biometals, v. 25, n. 1, p. 45-53, 2012. https://doi.org/10.1007/s10534-0119482-X

ZHANG, H.; OYANEDEL-CRAVER, V. Comparison of the bacterial removal performance of silver nanoparticles and a polymer based quaternary amine functionalized silsesquioxane coated point-of-use ceramic water filters. Journal of Hazardous Material, v. 260, p. 272-277, 2013. http://dx.doi.org/10.1016/j.jhazmat.2013.05.025

ZHANG, W.; LI, Y.; NIU, J.; CHEN, Y. Photogeneration of reactive oxygen species on uncoated silver, gold, nickel, and silicon nanoparticles and their antibacterial effects. Langmuir, v. 29, n.15, p. 4647-4651, 2013. http://dx.doi.org/10.1021/la400500t 


\begin{tabular}{|} 
Ambiente \& Água - An Interdisciplinary Journal of Applied Science \\
ISSN 1980-993X - doi:10.4136/1980-993X \\
www.ambi-agua.net \\
E-mail: ambi.agua@gmail.com
\end{tabular}

\title{
Sensitivity analysis of the Soil and Water Assessment Tools (SWAT) model in streamflow modeling in a rural river basin
}

\author{
ARTICLES doi:10.4136/ambi-agua.2221 \\ Received: 10 Dec. 2017; Accepted: 12 Oct. 2018 \\ Luana Lavagnoli Moreira*; Dimaghi Schwamback; Daniel Rigo \\ Universidade Federal do Espirito Santo (UFES), Vitória, ES, Brasil \\ Departamento de Engenharia Ambiental. E-mail: lavagnoliluana@gmail.com, \\ dimaghis@gmail.com,rigo@npd.ufes.br \\ *Corresponding author
}

\begin{abstract}
The uncertainties present in hydrological models have made them difficult and often impossible to apply. This work evaluated the sensitivity of input parameters in the SWAT model used for the modeling of average monthly flow-discharge in the Jucu River Basin, located in the southeast portion of the state of Espírito Santo, Brazil. Sensitivity analysis was performed using the SWAT-CUP program, which uses the SUFI-2 algorithm. Four sensitivity analysis tests differing by the length of hydrological series, number of iteration and fluviometric station locations resulted in different sensitivity levels of input parameters used in the model. In this way, the present study emphasizes the need for a greater detailing of methodological processes used in the sensitivity analysis, so that different hierarchies of parameters can be obtained through the same tool.
\end{abstract}

Keywords: sensitive parameters, simulation, SWAT-CUP.

\section{Análise de sensibilidade do modelo Soil and Water Assessment Tools (SWAT) na modelagem de vazões em uma bacia hidrográfica rural}

\section{RESUMO}

As incertezas presentes em modelos hidrológicos têm dificultado e muitas vezes inviabilizado sua aplicação. Este trabalho tem como objetivo a avaliação da sensibilidade dos parâmetros de entrada no modelo SWAT para a modelagem de vazões médias mensais na bacia do rio Jucu, localizado na porção sudeste do estado do Espírito Santo (Brasil). A análise de sensibilidade foi realizada por meio do programa SWAT-CUP ao qual faz uso do algoritmo SUFI-2. Quatro testes que se diferenciavam pelo tamanho da série hidrológica, escolha da estação de monitoramento de vazões e número de variações dos valores dos parâmetros durante a análise de sensibilidade resultaram em diferentes níveis de sensibilidade para os parâmetros de entrada do modelo SWAT. Desta forma, o presente estudo enfatiza a necessidade de maior detalhamento dos processos metodológicos empregados na análise de sensibilidade, tendo em vista que diferentes hierarquias de parâmetros podem ser obtidas por meio da mesma ferramenta.

Palavras-chave: parâmetros sensíveis, simulação, SWAT-CUP. 


\section{INTRODUCTION}

Hydrological models are powerful tools to represent water-resource availability and behavior in drainage basins under many applications, such as climate change, flood, drought, runoff and nutrient movement (Abbaspour et al., 2015). They can assist in the planning and decision-making processes for environment protection and the guarantee of water availability for future uses (Da Silva et al., 2015; Fatichi et al., 2016).

The Soil and Water Assessment Tool (SWAT) is a physically based, continuous-time, mathematical-hydrological model (Arnold et al., 1998). It has been initially designed to estimate water quantity and quality under different conditions over time (past, present and future) in small- and large catchments with satisfactory accuracy (Francesconi et al., 2016; Lamba et al., 2016; Zhang et al., 2016; Golmohammadi et al., 2017).

The ability of a hydrological model to produce satisfactory predictions are necessarily correlated to adequate sensitivity analysis and model calibration (Song et al., 2015). Hydrological models, such as SWAT, incorporate several parameters (pedological, climatic, hydrological and others) obtained theoretically and through field data collection. Some of these contribute greatly to model outputs (sensitive parameters), while others have minor relevance (non-sensitive parameters) (Van Griensven et al., 2006).

The calibration process of the SWAT model using all of the input variables requires a great deal of effort, money and time, whereas the removal of sensitive variables decreases the accuracy of the results (Zadeh et al., 2017; Song et al., 2015). The inappropriate removal of parameters during the sensitivity process may lead to inconsistent model results (Sahu et al., 2016).

Sensitivity analyses can be classified into local, in which changes in parameters are made one-by-one, while all the others are kept constant, and global, which promotes a multilinear regression of the entire input space (Brouziyne et al., 2017; Song et al., 2015). There are many techniques that can be applied to sensitivity analyses: manual operations, screening methods, regression analyses, variance-based methods, meta-modeling methods, and others (Song et al. 2015).

Besides the increasing of SWAT publications, only a few of the techniques focus on sensitivity-analysis improvements (Brouziyne et al., 2017). Wu and Liu (2012) proposed an automated sensitivity analysis through R-package Flexible Modeling Environment (FME). Romagnoli et al. (2017) highlighted that data availability, such as flowstream and precipitation series length, may affect the sensitivity ranking. Kouchi et al. (2017) examined the sensibility of parameters under different algorithms and objective functions, obtaining a diverse range of sensitive parameters leading to different streamflow estimations.

Some other studies done in Brazil (Da Silva et al., 2015; Pontes et al., 2016; Brighenti et al., 2016) and internationally are also relevant (Sarrazin et al., 2016; Zhang et al., 2016; Tegegne et al., 2017) when searching for regional-sensitive parameters. However, none of these has paid much attention to how procedures (number of iterations) and data input (length of historical series and fluviometric station selection) may affect the sensitivity-analysis process.

Considering this deficiency, this paper conducted a global sensitivity analysis using the Sequential Uncertainty Fitting Version 2 (SUFI2) algorithm replicated under four different scenarios differing by input variables and number of iterations. Using this procedure, we investigated how methodologies can influence the rank of sensitive parameters on the SWAT model. 


\section{MATERIAL AND METHODS}

\subsection{Hydrological modeling}

The study relates to the Jucu River Basin, located in the southeast portion of the state of Espírito Santo, which has a catchment area of $2,183 \mathrm{~km}^{2}$ (Figure 1). This area was chosen because it is the main freshwater source for more than 1.9 million inhabitants (IBGE, 2018) of the metropolitan area of Vitória (state capital), making the accurate prediction of water availability over time crucial. Additionally, the basin has a database from previous monitoring (such as streamflow, soil use, and pedology), which are required for SWAT-modeling runs.

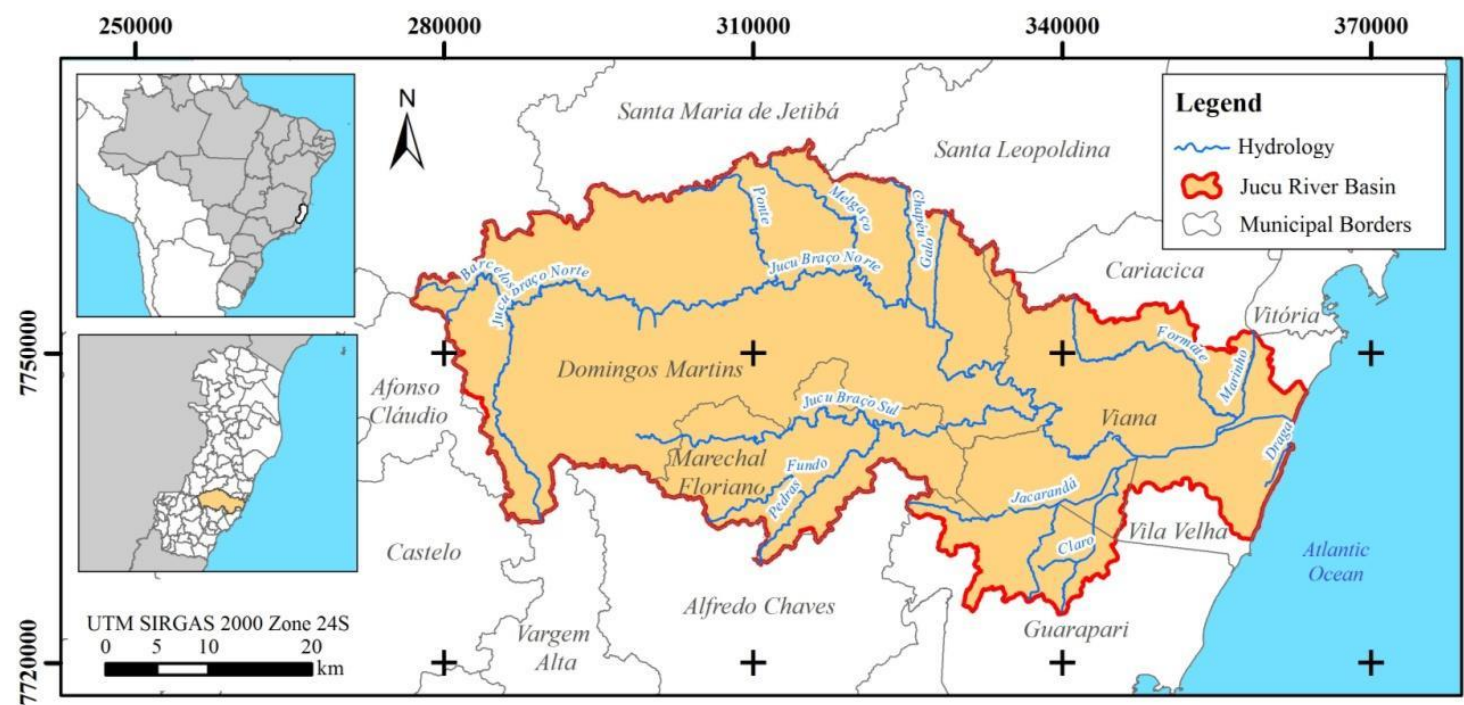

Figure 1. Location of the Jucu River Basin.

The first SWAT-modeling step involved the design of the hydrographic basin, sub-basins and drainage network by means of a digital elevation model (DEM) with a spatial resolution of 30 meters (Figure 2a) obtained by the Advanced Spaceborne Thermal Emission and Reflection Radiometer (ASTER) in 2011.

Then, physiographic data of pedology (Figure 2b), land use and occupation (Figure 2c) and classes of slopes were obtained. The soil information was acquired from a survey of soil from the state of Espírito Santo conducted in 1978 by the Brazilian Agricultural Research Corporation (EMBRAPA). The soils types found in the Jucu River Basin were:

- LVd2 - dystrophic red yellow ferralsol: A moderate clayey texture, strong corrugated relief;

- LVd3 - dystrophic red yellow ferralsol: A moderate clayey texture, and mountainous relief;

- LVd12 - dystrophic red yellow ferralsol: A moderate clayey textured, soft wavy relief;

- Cd1 - dystrophic haplic cambisol: A moderate clayey texture, and medium strong wavy mountainous relief;

- PV2 - alic acid red yellow acrisol: A moderate clayey relief texture;

- Amd2 - dystrophic arenosol: A moderate sandy flat relief;

- Ad1 - dystrophic fluvisol: A weak and moderate texture, medium plane relief;

- AR - eutrophic leptosol: A moderate texture and clayey, steep relief, mountainous and strong wavy. 
Land-use and occupation data were obtained from a survey carried out by the State Institute of Environment and Water Resources (IEMA, 2007). From the data described above, the hydrologic response units (HRU) were established.

After HRU definition, the data from climatic stations located in the study basin were inserted on the SWAT model. These data refer to solar radiation $\left(\mathrm{KJ} . \mathrm{m}^{2}\right)$, rainfall $(\mathrm{mm})$, maximum and minimum air temperatures $\left({ }^{\circ} \mathrm{C}\right)$, relative humidity $(\%)$ and wind speed $\left(\mathrm{m} . \mathrm{s}^{-1}\right)$. These data were obtained from the Capixaba Institute for Research, Technical Assistance and Rural Extension (INCAPER, 2016) and the National Water Agency (ANA, 2016).

The last stage of SWAT processing consisted of the simulation, where the warm-up period, simulation period, time-step of the monthly simulation, and output data (water production series of monthly average flows) were defined. Once the output data were determined, the sensitivity analysis of the parameters related to water production in the river basin was performed.

The sensitivity analysis used discharge data from two different fluviometric stations. The first, under code 57230000, was called "Fazenda Jucuruaba"; and the second, under code 57170000, was called "Córrego do Galo". Both are under the responsibility of the National Water Agency (ANA). The latter station covers a drainage area of $1,675.19 \mathrm{~km}^{2}$, while the former station covers $965.67 \mathrm{~km}^{2}$, as shown in Figure 2-d. The list of climatic stations, station operators, coordinates of the station, data type and respective length of historical records is shown in Table 1, arranged in turn geographically by means of Figure 2-d.

A

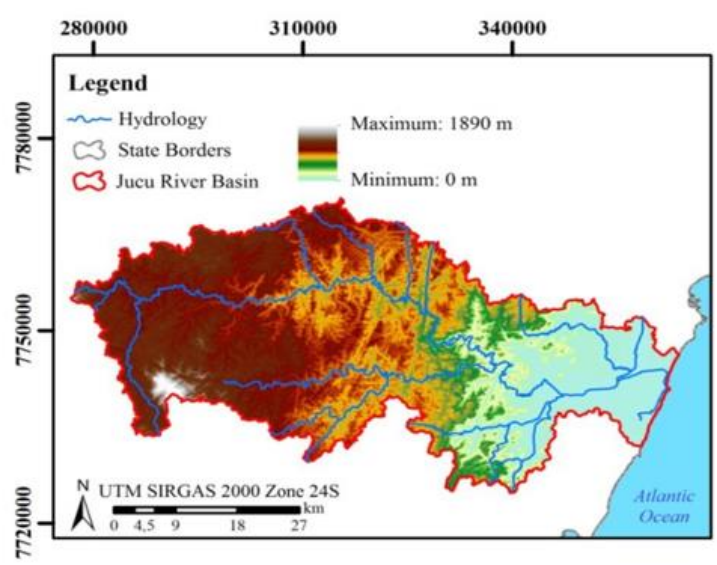

C

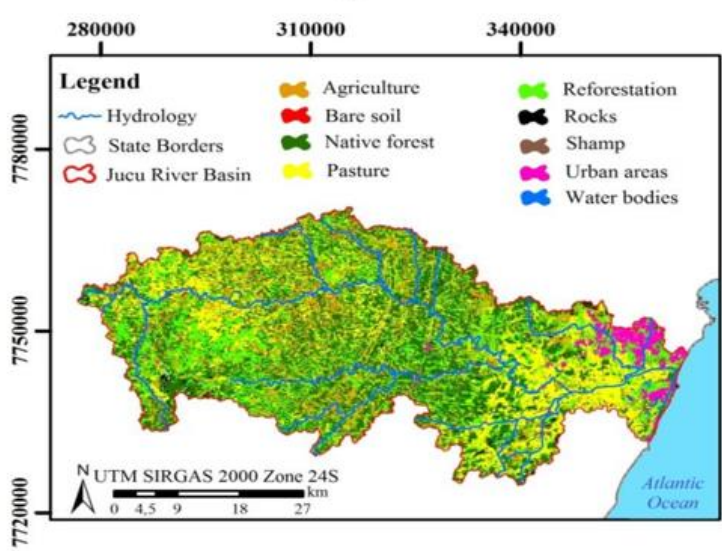

B

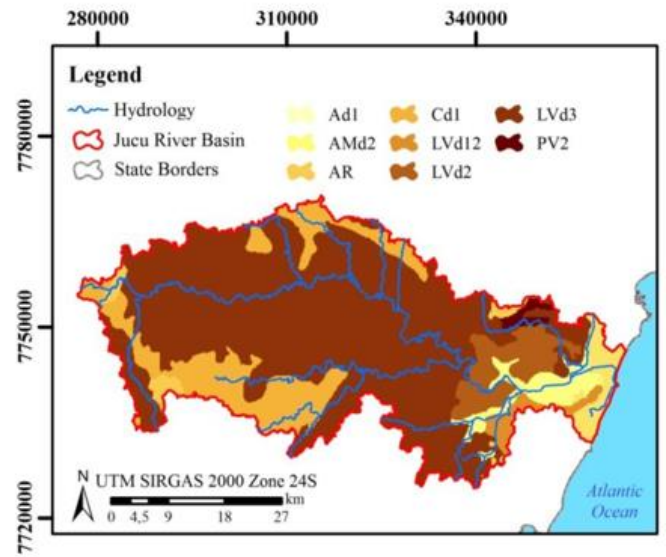

D

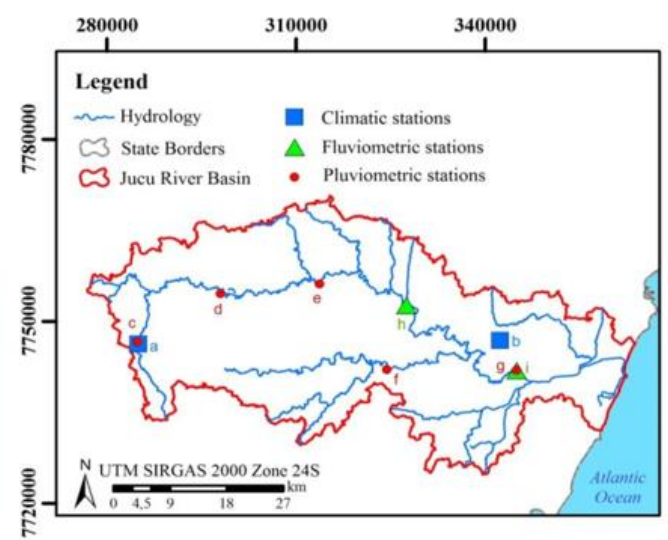

Figure 2. Map of topography (A), pedology (B), land use (C), location of climatic, fluviometric and pluviometric stations (D) in the Jucu River Basin. 
Table 1. Input data of the SWAT model.

\begin{tabular}{lcccccc}
\hline \multirow{2}{*}{ Type } & Symble & Station & \multirow{2}{*}{ Code } & Controller & \multicolumn{2}{c}{ Coordinates* } \\
\cline { 3 - 6 } Climatic & $\mathrm{a}$ & Domingos Martins & - & \multirow{2}{*}{ INCAPER } & 7745120.60 & 284999.72 \\
& $\mathrm{~b}$ & Viana & - & & 7746850.66 & 342404.53 \\
& $\mathrm{c}$ & Arace & 02041020 & & 7718808.69 & 281119.36 \\
\multirow{3}{*}{ Pluviometric } & $\mathrm{d}$ & Marechal Floriano & 02040012 & & 7716039.40 & 218592.79 \\
& $\mathrm{e}$ & Perobinha & 02040015 & ANA & 7735136.92 & 260035.13 \\
& $\mathrm{f}$ & Fazenda Jucuruaba & 02040001 & & 7709938.37 & 310756.88 \\
\multirow{2}{*}{ Fluviometric } & $\mathrm{g}$ & Marechal Floriano & 02040012 & & 7716039.40 & 218592.79 \\
& $\mathrm{~h}$ & Córrego do Galo & 57170000 & \multirow{2}{*}{ ANA } & 7752588.84 & 327516.21 \\
& $\mathrm{i}$ & Fazenda Jucuruaba & 57230000 & & 7741838.41 & 344989.90 \\
\hline
\end{tabular}

*UTM SIRGAS 2000 Zone 24S.

\subsection{Sensibility Analysis}

The sensitivity of the SWAT parameters was performed using the Sequential Uncertainty Fitting Version 2 (SUFI2) algorithm executed by the SWAT Calibration and Uncertainty Programs (SWAT-CUP) software. This process is carried out in conjunction with the calibration process, so it is necessary to include the flows estimated by the SWAT and the monitored flows. That is necessary because sensitivity is estimated according to the variations according to objective function that evaluates the model calibration's effectiveness.

The sensitivity of the parameters is computed by multiple regression systems represented in Equation 1, which returns the values of the parameters generated by the Latin hypercube sampling versus the objective function values (Abbaspour et al., 2007).

$$
g=\alpha+\sum_{i=1}^{m} \beta_{i} b_{i}
$$

where $g$ is the objective function value; $b$ is the parameter; $\alpha$ is the regression constant; $\beta$ corresponds to the technical coefficient attached to the variable $b$; and $\mathrm{m}$ is equal to the number of parameters.

The mean of the variations in the objective function estimates the sensitivity. It is computed by altering each parameter, one by one, while all other parameters remain the same. This is evaluated by the values of $\mathrm{t}$-stat and $\mathrm{p}$-value. The higher the absolute value of $\mathrm{t}$-stat and smaller the value of p-value, the more sensitive is the parameter (Abbaspour et al., 2007).

The $\mathrm{t}$-stat is the regression coefficient of a parameter divided by its standard error. If the coefficient value is greater than its standard error, the value of t-stat is greater than zero, so the parameter is sensitive (Abbaspour et al., 2015). To calculate the p-value, it is necessary to compare the value of t-stat with the values given on the t-Student distribution table. The $\mathrm{p}$-value for each parameter tests the null hypothesis that the regression coefficient is equal to zero.

A small value of $p$-value $(<0.05)$ indicates that we can reject the null hypothesis. This means that the parameter exerts influence on the dependent variable, thus it is sensitive. The value of 0.05 indicates that there is a $95 \%$ probability that a parameter change will affect the dependent variable (Abbaspour et al., 2009).

The parameters chosen for this analysis refer to those that can be adjusted and relate only to the water production in a river basin. The SWAT database presents a table of these parameters indicating their ranges of value, action plan (basin, sub-basin or HRU), form of variation of values (replace by a given value, add to the existing parameter value or relative when an existing parameter value is multiplied by), and the sensitivity-analysis group (water production, sediment yield or water quality).

\section{IPABH}

Rev. Ambient. Água vol. 13 n. 6, e2221 - Taubaté 2018 
Table 2 shows the parameters available for water production, their description, lower (LL) and upper (UL) limits for adjustments and the method of value variation. The parameter descriptions, physical properties, and lower/upper limits are detailed by Arnold et al. (2012) in Soil \& Water Assessment Tool Input/Output Documentation. The limits used here are adequate with field analyses, when compared with the indicated values given by Arnold et al. (2012).

Table 2. Parameters of the sensitivity analysis related to water production.

\begin{tabular}{|c|c|c|c|c|c|}
\hline Parameter & Description & Unit & LL & LU & $\begin{array}{l}\text { Method of } \\
\text { variation }\end{array}$ \\
\hline ALPHA_BF & Baseflow alpha factor & day & 0 & 1 & Replace \\
\hline BIOMIX & Biological mixing efficiency & $1-1$ & 0 & 1 & Replace \\
\hline BLAI & Maximum potential leaf area index & $\mathrm{m}^{2} \mathrm{~m}^{-2}$ & 0 & 1 & Replace \\
\hline CANMX & Maximum canopy storage & $\mathrm{mm}$ & 0 & 10 & Replace \\
\hline CH_K2 & $\begin{array}{l}\text { Effective hydraulic conductivity in the main } \\
\text { channel alluvium }\end{array}$ & $\mathrm{mm} \mathrm{h}^{-1}$ & 0 & 150 & Replace \\
\hline CH_N2 & Manning's "n" value for the main channel & $\mathrm{s} \mathrm{m}^{-3}$ & 0 & 1 & Replace \\
\hline $\mathrm{CN} 2$ & $\begin{array}{l}\text { Initial SCS runoff curve number for moisture } \\
\text { condition II }\end{array}$ & $1-1$ & $-25 \%$ & $25 \%$ & Relative \\
\hline EPCO & Plant uptake compensation factor & $1-1$ & 0 & 1 & Replace \\
\hline ESCO & Soil evaporation compensation factor & $1-1$ & 0 & 1 & Replace \\
\hline GW_DELAY & Groundwater delay time & day & -10 & 10 & Add \\
\hline GW_REVAP & Groundwater "revap" coefficient & $1-1$ & $-0,036$ & 0,036 & Add \\
\hline GWQMN & $\begin{array}{l}\text { Threshold depth of water in the shallow } \\
\text { aquifer required for return flow to occur }\end{array}$ & $\mathrm{mm}$ & -1000 & 1000 & Add \\
\hline REVAPMN & $\begin{array}{l}\text { Threshold depth of water in the shallow } \\
\text { aquifer for "revap" or percolation to the deep } \\
\text { aquifer to occur }\end{array}$ & $\mathrm{mm}$ & -100 & 100 & Add \\
\hline SOL_ALB & Moist soil albedo & $1-1$ & $-25 \%$ & $25 \%$ & Relative \\
\hline SOL_AWC & Available water capacity of the soil layer & $\mathrm{mm} \mathrm{mm}^{-1}$ & $-25 \%$ & $25 \%$ & Relative \\
\hline SOL_K & Saturated hydraulic conductivity & $\mathrm{mm} \mathrm{h}^{-1}$ & $-25 \%$ & $25 \%$ & Relative \\
\hline SOL_Z & Depth from soil surface to bottom of layer & $\mathrm{mm}$ & $-25 \%$ & $25 \%$ & Relative \\
\hline SURLAG & Surface runoff lag coefficient & day & $-25 \%$ & $25 \%$ & Relative \\
\hline TLAPS & Temperature lapse rate & ${ }^{\circ} \mathrm{C} \mathrm{km}^{-1}$ & 0 & 10 & Replace \\
\hline SLSUBBSN & Average slope length & $\mathrm{m}$ & 0 & 50 & Replace \\
\hline
\end{tabular}

Four sensitivity tests were performed to verify the influence of the amount of input data (length of historical records of flows and fluviometric station location) and the number of variations in the values of each parameter within the range present in Table 1 (iterations) during the analysis. The tests are listed below:

- 1st Test: long historical records (1987 to 2015) flow data from the Fazenda Jucuruaba fluviometric station with 300 iterations;

- 2nd Test: long historical records (1987 to 2015) flow data from the Córrego do Galo fluviometric station with 300 iterations;

- 3rd Test: same characteristics as the 2nd Test, but with 100 iterations;

- 4th Test: short historical records (2013 to 2015) flow data from the Córrego do Galo fluviometric station with 300 iterations.

The results obtained by the sensitivity analyses were evaluated by the t-stat and p-values. The first provides the sensitivity measure, where the higher its value the more sensitive the parameter is. The second determines the significance of the sensitivity, where a value close to zero indicates greater significance provided by SWAT-CUP. 


\section{RESULTS AND DISCUSSION}

The modeling results in SWAT divided the Jucu River Basin into 147 sub-basins, creating a total of 2,341 hydrological response units (HRU). The fluviometric station of Fazenda Jucuruaba was located in sub-basin Number 128 and Córrego do Galo in sub-basin Number 57.

The first sensitivity test generated the sensitivity hierarchy of the parameters presented in Figure 3-a according to p-value and t-stat values. The second test, based on the same characteristics as the first one, but with data from the Córrego do Galo fluviometric station, generated the results of Figure 3-b. The third test corresponds to the same characteristics of the second, but only 100 iterations were used (Figure 3-c). Finally, the fourth test was constructed with short historical records of 3 years (2013 to 2015), with flow data from the Córrego do Galo fluviometric station, using 300 iterations (Figure 3-d).

Van Griensven et al. (2006) suggest the classification of parameters regarding their sensitivity by means of the increasing hierarchical position of the parameters. Thus, the parameters can be categorized as very important (1st), important (2nd-6th), slightly important (7th-14th) and not important (15th-20th).

For each test, the parameters considered as very important and important according to Van Griensven et al. (2006) correspond to the first six parameters with the lowest values of $p$-value and higher values (in module) of t-stat. They are presented below in descending order of sensitivity for the four tests:

- 1st test - ALPHA_BF, SOL_Z, GW_DELAY, CN2, SOL_K, and ESCO;

- 2nd test - ALPHA_BF, SOL_Z, GW_DELAY, ESCO, CN2, and CH_K2;

- 3rd test - ALPHA_BF, SOL_Z, GW_DELAY, SOL_K, CH_K2, and CANMX;

- 4th test -SOL_Z, ALPHA_BF, GWQMN, GW_DELAY, CN2, and SOL_K.

In terms of sensitivity in predicting superficial flow rates, note that some parameters are important in some tests, while not in others. For example, the ESCO parameter is important in the 1st and 2nd tests, although in the 3rd test it is considered slightly important and not important in the 4th test. Thus, the ESCO parameter can be turned into one of the most- or leastsensitive parameters for the same region under study depending on the methodology used.

From the results (Figure 3), the least-sensitive parameters (the six with the major p-values in Figure 3) were categorized as "not important"; but in other tests, some were kept in the "not important" while others moved to the "slightly important" category. Even though that was expected, some parameters are generally less-sensitive, such as BLAI, REVAPMN, and CH_N2, while the most-sensitive are ALPHA_BF, SOL_Z, GW_DELAY, and CN2.

For each performance used on the input data, such as length of historical records, fluviometric station chosen or the number of iterations used during the analysis-sensitivity process, there is a different list and sequence of sensitivity parameters. Even Abbaspour et al. (2018), the main developer of the SWAT sensitivity analysis method, affirms that sensitivity analysis provides information about the most important process-drivers in the study region, according to local characteristics.

Therefore, the most sensitivity parameters should be analyzed for each study region, since the input data (land use, pedology, physical characteristics of the watershed and climatic data) are different. Besides, this paper indicates the use of different performances in analysis sensitivity in order to make the best choice of the most influential parameters on flow estimation. Each performance should be well-justified, such as the length of historical records, monitoring stations, number of iterations, minimum interval, maximum interval and method of variation of each during the sensitivity analysis. 
A
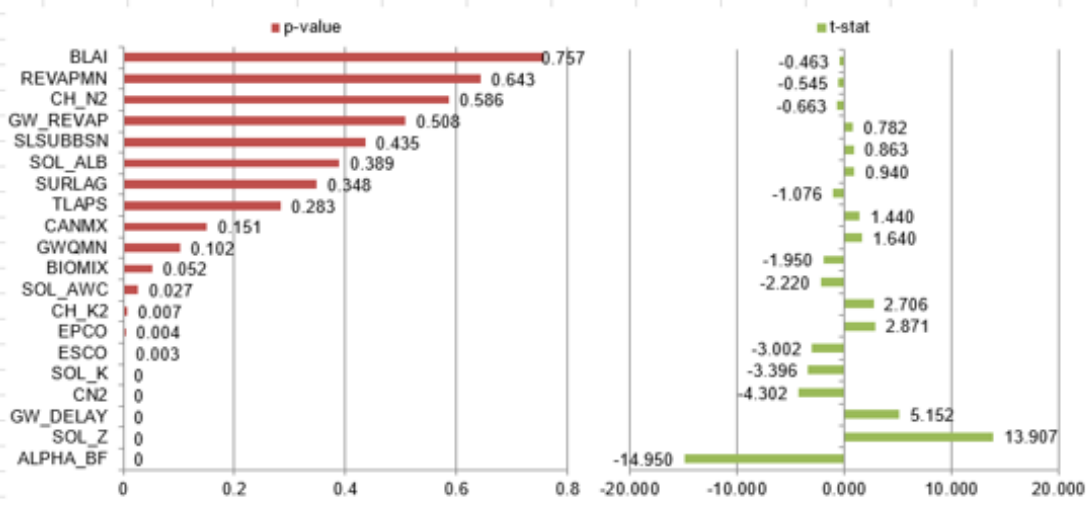

B
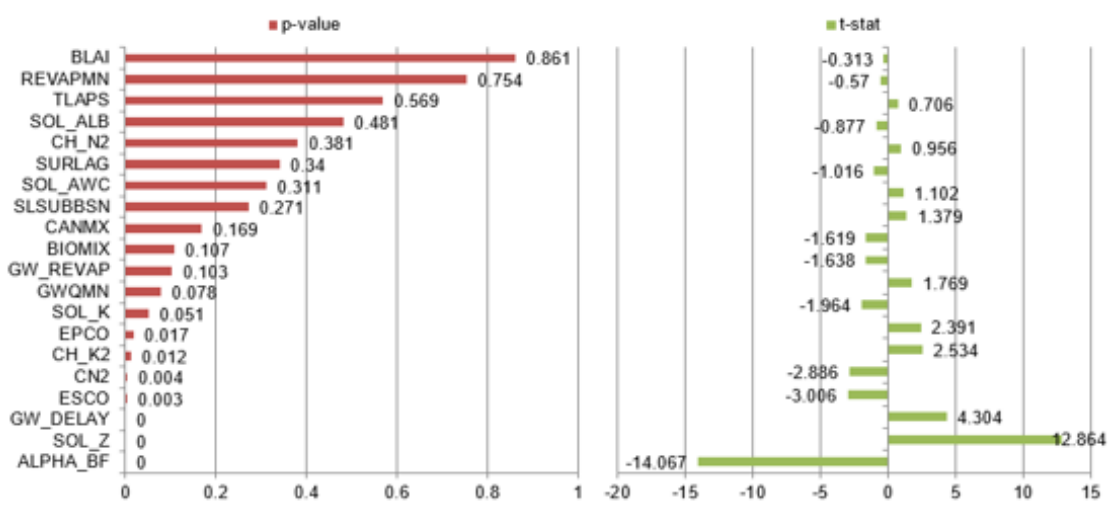

C
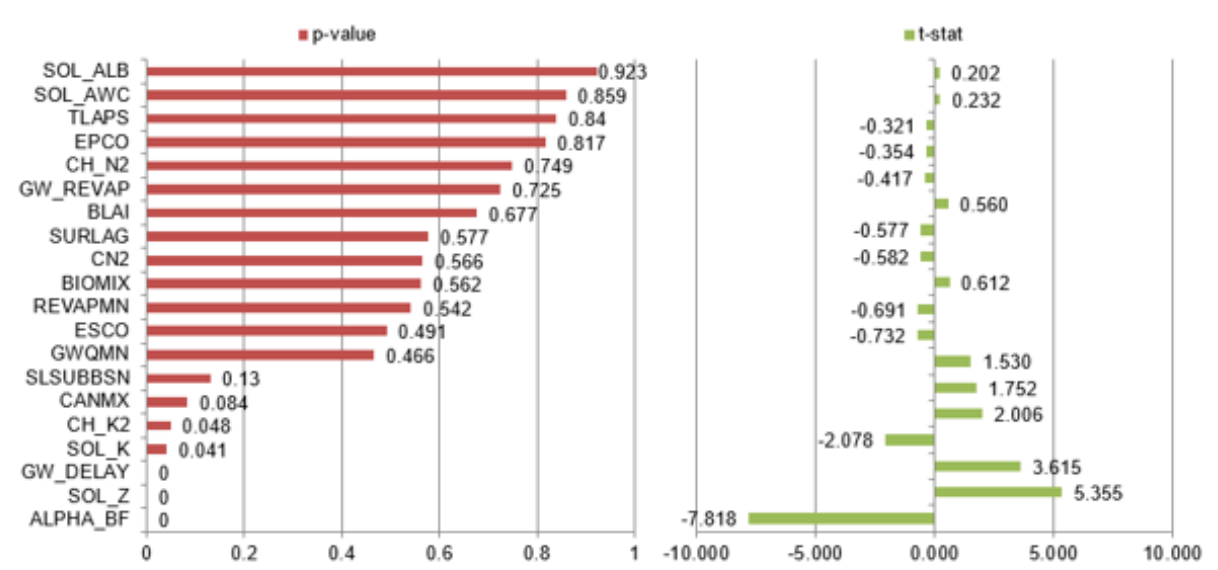

D
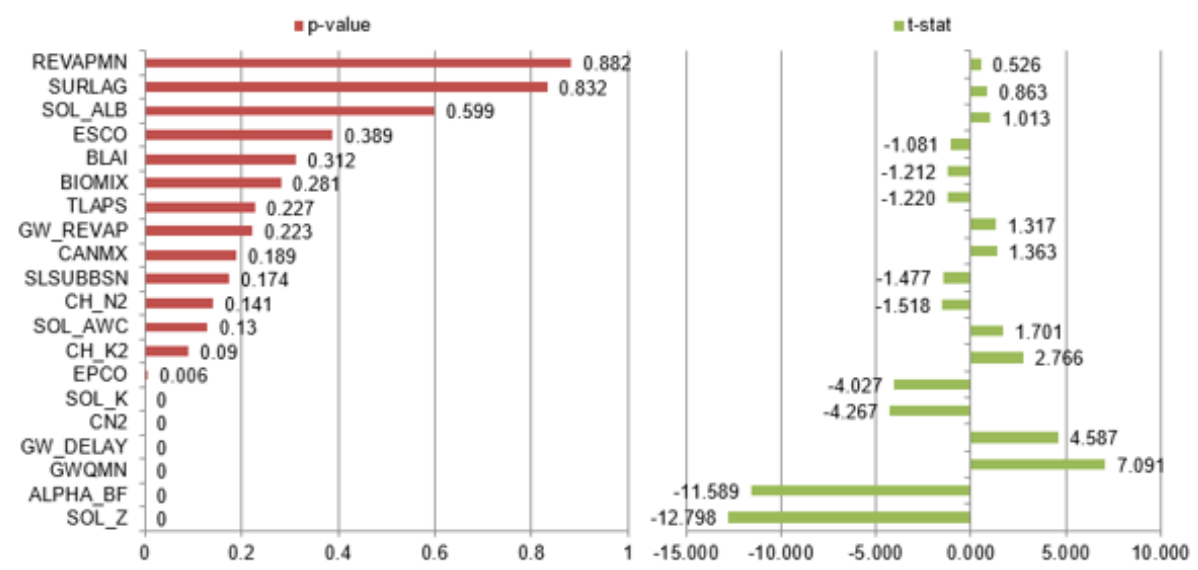

Figure 3. Sensitivity of flow parameters for the first (A), second (B), third (C) and fourth (D) tests. 
In this case study, we opted for the five common parameters obtained in the first and second alternatives, since the calibration tests used flow data from both fluviometric stations. The number of iterations considered appropriate corresponds to these alternatives because the SWAT-CUP developer recommends it. Lastly, the largest historical records available encompass a more-extensive series of flood and drought events.

In summary, the parameters considered the most sensitive for the study region are: basal recession constant (ALPHA_BF), depth from soil surface to bottom of layer (SOL_Z), recharge time of the shallow aquifer (GW_DELAY), evaporation compensation factor (ESCO) and the SCS runoff curve number for moisture condition II (CN2).

\section{CONCLUSIONS}

The study investigated how methodological procedures (changing input variables and the number of iterations) can influence the ranking of sensitive parameters on the SWAT model. The primary conclusions reached are summarized as:

- The sensitivity of the hydrologic parameters of the SWAT model not only depends on the physiographic and climatic variables of the study area, but also on the procedures used in the sensitivity analysis. The SWAT-CUP sensitivity analysis using the SUFI-2 algorithm obtained different parameter hierarchies. It emphasizes the relevance of a greater detailing of methodological processes used in the sensitivity analysis, considering that different hierarchies of parameters can be obtained through the same tool.

- Besides characteristics from the study area, all the procedures used to formulate the sensitivity analysis scenarios, such as variation in the number of iterations, fluviometric station location and length of historical records, affected significantly the results of sensitive parameters for estimating flow rate in the Jucu River Basin. Therefore, it is important that each study region that uses the SWAT model to predict superficial flow rates perform different procedures in sensitivity analysis to correctly determine the most sensitive parameters.

- Among the range of input variables of the model, pedological variables were the ones that presented the highest sensitivity for the Jucu River Basin.

We recommend the application of similar tests using other algorithms, rather than SUFI2, for parameter sensitivity analysis to estimate mean flows. In this way, it would be possible to investigate how those methodological procedures affect the results by the use of different sensitivity techniques.

\section{REFERENCES}

ABBASPOUR, K. C.; YANG, J.; MAXIMOV, I.; SIBER, R.; BOGNER, K.; MIELEITNER, J. et al. Modelling hydrology and water quality in the pre-alpine/alpine Thur watershed using SWAT. Journal of Hydrology, v. 333, n. 2-4, p. 413-430, 2007. http://dx.doi.org/10.1016/j.jhydrol.2006.09.014

ABBASPOUR, K. C.; ROUHOLAHNEJAD, E.; VAGHEFI, S.; SRINIVASAN, R.; YANG, H.; KLØVE, B. A continental-scale hydrology and water quality model for Europe: Calibration and uncertainty of a high-resolution large-scale SWAT model. Journal of Hydrology, v. 524, p. 733-752, 2015. https://dx.doi.org/10.1016/j.jhydrol.2015.03.027 
ABBASPOUR, K. C.; VAGHEFI, S. A.; SRINIVASAN, R. A Guideline for Successful Calibration and Uncertainty Analysis for Soil and Water Assessment: A Review of Papers from the 2016 International SWAT Conference. Water, v. 10, n. 6, p. 1-18, 2018. https://dx.doi.org/10.3390/w10010006

ABBASPOUR, K. C.; FARAMARZI, M.; GHASEMI, S. S.; YANG, H. Assessing the impact of climate change on water resources in Iran. Water Resources Research, v. 45, p. 1-16, 2009. http://dx.doi.org/10.1029/2008WR007615

AGÊNCIA NACIONAL DE ÁGUAS (Brasil). Portal Hidroweb. 2016. Available at: http://www.snirh.gov.br/hidroweb. Access in: June 2016.

ARNOLD, J. G.; KINIRY, J. R.; SRINIVASAN, R.; WILLIAMS, J. R.; HANEY, E. B.; NEITSCH, S. L. Input/Output Documentation. Version 2012. Atlanta: Texas Water Resources Institute, 2012.

ARNOLD, J. G.; SRINIVASAN, R.; MUTTIAH, R. S.; WILLIAMS, J. R. Large area hydrologic modeling and assessment - Part I: Model development. Journal of American Water Resource Association, v. 34, p. 73-89, 1998. https://dx.doi.org/10.1111/j.17521688.1998.tb05961.x

BRIGHENTI, T. M.; BONUMÁ, N. B.; CHAFFE, P. L. B. Hierarchical Calibration of SWAT model for a watershed in southern Brazil. Revista Brasileira de Recursos Hídricos, v. 21, n. 1, p. 53-64, 2016. http://dx.doi.org/10.21168/rbrh.v21n1.p53-64

BROUZIYNE, Y.; ABOUABDILLAH, A.; BOUABID, R.; OUESLATI, O. SWAT manual calibration and parameters sensitivity analysis in a semi-arid watershed in North-western Morocco. Arabian Journal Of Geosciences, v. 10, n. 19, p.1-13, 2017. http://dx.doi.org/10.1007/s12517-017-3220-9

DA SILVA, M.; DE AGUIAR NETTO, A.; DE JESUS NEVES, R.; DO VASCO, A.; ALMEIDA, C.; FACCIOLI, G. Sensitivity Analysis and Calibration of Hydrological Modeling of the Watershed Northeast Brazil. Journal of Environmental Protection, v. 6, p. 837-850, 2015. https://dx.doi.org/10.4236/jep.2015.68076

EMPRESA BRASILEIRA DE PESQUISA AGROPECUÁRIA (EMBRAPA). Levantamento de reconhecimento dos solos do estado do Espírito Santo. 1978. Available at: https://www.embrapa.br/busca-de-publicaNSEs/-/publicacao/335800/levantamento-dereconhecimento-dos-solos-do-estado-do-espirito-santo. Access in: August 2016.

FATICHI, S.; VIVONI, E. R.; OGDEN, F. L.; IVANOV, V. Y.; MIRUS, B.; GOCHIS, D. et al. An overview of current applications, challenges, and future trends in distributed process-based models in hydrology. Journal of Hydrology, v. 537, p. 45-60, 2016. https://dx.doi.org/10.1016/j.jhydrol.2016.03.026

FRANCESCONI, W.; SRINIVASAN， R.; PÉREZ-MIÑANA， E.; WILLCOCK， S.; QUINTERO, M. Using the Soil and Water Assessment Tool (SWAT) to model ecosystem services: A systematic review. Journal of Hydrology, v. 535, p. 625-636, 2016. https://dx.doi.org/10.1016/j.jhydrol.2016.01.034

GOLMOHAMMADI, G.; RUDRA, R.; DICKINSON, T.; GOEL, P.; VELIZ, M. Predicting the temporal variation of flow contributing areas using SWAT. Journal of Hydrology, v. 547, p. 375-386, 2017. https://dx.doi.org/10.1016/j.jhydrol.2017.02.008 
INSTITUTO BRASILEIRO DE GEOGRAFIA E ESTATÍSTICA (IBGE). Estimativa da população de 2017. Available at: https://www.ibge.gov.br/estatisticasnovoportal/sociais/populacao/9103-estimativas-de-populacao.html?=\&t=o-que-e.

Access in: June 2018.

INSTITUTO CAPIXABA DE PESQUISA, ASSISTÊNCIA TÉCNICA E EXTENSÃO RURAL (INCAPER). Meteorologia. 2016. Available at: https://meteorologia.incaper.es.gov.br. Access in: June 2016.

INSTITUTO ESTADUAL DE MEIO AMBIENTE E RECURSOS HÍDRICOS (IEMA). Geobases. 2007. Available from: https://geobases.es.gov.br. Access in: Jul. 2016.

KOUCHI, D. H.; ESMAILI, K.; FARIDHOSSEINI, A.; SANAEINEJAD, S. H.; KHALILI, D.; ABBASPOUR, K. C. Sensitivity of Calibrated Parameters and Water Resource Estimates on Different Objective Functions and Optimization Algorithms. Water, v. 9, n. 384, p. 1-16, 2017. https://dx.doi.org/10.3390/w9060384

LAMBA, J.; THOMPSON, A. M.; KARTHIKEYAN, K. G.; PANUSKA, J. C.; GOOD, L. W. Effect of best management practice implementation on sediment and phosphorus load reductions at subwatershed and watershed scale using SWAT model. International

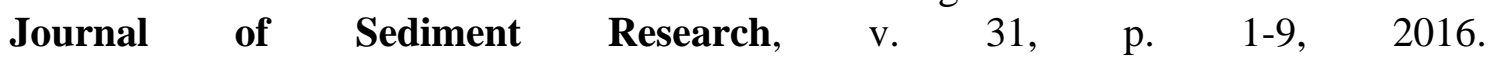
https://dx.doi.org/10.1016/j.ijsrc.2016.06.004

PONTES, L. M.; VIOLA, M. R.; SILVA, M. L. N.; BISPO, D. F. A.; CURI, N. Hydrological Modeling of Tributaries of Cantareira System, Southeast Brazil, with the Swat Model. Engenharia Agrícola, v. 36, n. 6, p. 1037-1049, 2016. http://dx.doi.org/10.1590/18094430-Eng.Agric.v36n6p1037-1049/2016

ROMAGNOLI, M.; PORTAPILA, M.; RIGALLI, A. Assessment of the SWAT model to simulate a watershed with limited available data in the Pampas region, Argentina. Science Of The Total Environment, v. 596-597, p. 437-450, 2017. http://dx.doi.org/10.1016/j.scitotenv.2017.01.041

SAHU, M.; LAHARI, S.; GOSAIN, A. K.; OHRI, A. Hydrological Modeling of Mahi Basin Using SWAT. Journal of Water Resource and Hydraulic Engineering, v. 5, p. 68-79, 2016. http://dx.doi.org/10.5963/JWRHE0503001

SARRAZIN, F.; PIANOSI, F.; WAGENER, T. Global Sensitivity Analysis of environmental models: Convergence and validation. Environmental Modelling \& Software, v. 79, p. 135-152, 2016. https://dx.doi.org/10.1016/j.envsoft.2016.02.005

SONG, X.; ZHANG, J.; ZHAN, C.; XUAN, Y.; YE, M.; XU, C. Global sensitivity analysis in hydrological modeling: Review of concepts, methods, theoretical framework, and applications. Journal of Hydrology, v. 523, p. 739-757, 2015. https://dx.doi.org/10.1016/j.jhydrol.2015.02.013

TEGEGNE, G.; PARK, D. K.; KIM, Y. Comparison of hydrological models for the assessment of water resources in a data-scarce region, the Upper Blue Nile River Basin. Journal Of Hydrology: Regional Studies, v. 14, p. 49-66, 2017. http://dx.doi.org/10.1016/j.ejrh.2017.10.002

VAN GRIENSVEN, A.; MEIXNER, T.; GRUNWALD, S.; BISHOP, T.; DILUZIO, M.; SRINIVASAN, R. A global sensitivity analysis tool for the parameters of multi-variable catchment models. Journal of Hydrology, v. 324, p. 10-23, 2006. https://dx.doi.org/10.1016/j.jhydrol.2005.09.008 
WU, Y.; LIU, S. Automating calibration, sensitivity and uncertainty analysis of complex models using the R package Flexible Modeling Environment (FME): SWAT as an example. Environmental Modelling \& Software, v. 31, p. 99-109, 2012. http://dx.doi.org/10.1016/j.envsoft.2011.11.013

ZHANG, D.; CHEN, X.; YAO, H.; JAMES, A. Moving SWAT model calibration and uncertainty analysis to an enterprise Hadoop-based cloud. Environmental Modelling \& Software, v. 84, p. 140-148, 2016. https://dx.doi.org/10.1016/j.envsoft.2016.06.024

ZADEH, F. K.; NOSSENT, J.; SARRAZIN, F.; PIANOSI, F.; GRIENSVEN, A. V.; WAGENER, T. et al. Comparison of variance-based and moment-independent global sensitivity analysis approaches by application to the SWAT model. Environmental $\begin{array}{lllllll}\text { Modelling \& Software, } & \text { v. 91, p. 210-222, }\end{array}$ https://dx.doi.org/10.1016/j.envsoft.2017.02.001 


\begin{tabular}{|c} 
Ambiente \& Água - An Interdisciplinary Journal of Applied Science \\
ISSN 1980-993X - doi:10.4136/1980-993X \\
www.ambi-agua.net \\
E-mail: ambi.agua@gmail.com
\end{tabular}

\title{
Analysis and modeling of water quality as a contribution to the preliminary framework proposal for the Una River (Pernambuco/Brazil)
}

\author{
ARTICLES doi:10.4136/ambi-agua.2251 \\ Received: 09 Mar. 2018; Accepted: 12 Oct. 2018
Simone Rosa da Silva1; Marcos Antonio Barbosa da Silva Junior ${ }^{2 *}$; Eduardo Elvino Sales de Lima ${ }^{3}$ \\ ${ }^{1}$ Universidade de Pernambuco (UPE), Recife, PE, Brasil \\ Departamento de Engenharia Civil. E-mail: simonerosa@poli.br \\ ${ }^{2}$ Universidade Federal de Pernambuco (UFPE), Recife, PE, Brasil \\ Departamento de Engenharia Civil. E-mail: marcos15barbosa@ hotmail.com \\ ${ }^{3}$ Agência Estadual de Meio Ambiente (CPRH), Recife, PE, Brasil \\ E-mail: eduardoelvino@hotmail.com \\ *Corresponding author
}

\begin{abstract}
The present paper presents a preliminary proposal for a framework for the Una River, located in the state of Pernambuco, divided into prevailing-use classes. This proposal integrates the results of an analysis of water quality parameters and a mathematical modeling performed along a section of the river. Data from six State Environmental Agency (CPRH) monitoring stations were used, which collected data for temperature, $\mathrm{pH}, \mathrm{DO}, \mathrm{BOD}$, phosphorus, thermotolerant coliforms, turbidity, and color between 2002 and 2014. The mathematical model used was QUAL-UFMG and the parameters evaluated were DO and BOD. The results showed that the DO and BOD parameters were within the limits established by CONAMA Resolution No. 357/2005 for Class 2, but other parameters such as phosphorus presented nonconformities. Based on this, the proposed framework for the Una River covered Classes 1 and 2. It is hoped that such a proposal will serve as a reference for the basin committee in order to discuss and deliberate on the multiple uses preponderant along the river, aiming to approve and implement the framework.
\end{abstract}

Keywords: framework, Una river, water quality.

\section{Análise e modelagem da qualidade da água como subsídio à proposta preliminar de enquadramento do rio Una (Pernambuco/Brasil)}

\section{RESUMO}

O presente trabalho apresenta uma proposta preliminar para o enquadramento do rio Una, localizado no estado de Pernambuco, em classes de usos preponderantes. Esta proposta integra os resultados da análise dos parâmetros da qualidade da água e da modelagem matemática realizada num trecho do rio. Foram utilizados os dados do monitoramento de seis estações da Agência Estadual de Meio Ambiente - CPRH, entre os anos de 2002 e 2014, e analisados os parâmetros de temperatura, $\mathrm{pH}, \mathrm{OD}, \mathrm{DBO}$, fósforo, coliforme termotolerantes, turbidez e cor. 
Na modelagem matemática, o modelo utilizado foi o QUAL-UFMG e os parâmetros avaliados foram o OD e DBO. Os resultados mostraram que os parâmetros de OD e DBO ficaram dentro dos limites estabelecidos pela Resolução CONAMA n ${ }^{\circ}$ 357/2005 para a Classe 2, porém outros parâmetros como o fósforo apresentaram desconformidades em seus índices. Com base nisso, o enquadramento preliminar proposto para o rio Una abrangeu as Classes 1 e 2. Espera-se que tal proposta sirva como referência ao comitê da bacia, para que sejam discutidos e deliberados os usos múltiplos preponderantes ao longo do rio, objetivando assim, a aprovação e implementação do enquadramento.

Palavras-chave: enquadramento, qualidade da água, rio Una.

\section{INTRODUCTION}

The term "framework" refers to the definition of quality goals to be achieved for water bodies within a river basin. In Brazil, the National Water Resources Policy (Federal Law no 9.433/1997) establishes that the framework for water bodies divided into prevailing use classes, as defined by CONAMA Resolution $n^{\circ} 357 / 2005$, should guarantee the necessary water quality standards for the most restrictive uses. In basins where the current condition of the water body quality is not appropriate for its intended uses, targets should be established to implement the respective frameworks, as recommended by CNRH Resolution $n^{\circ}$ 091/2008 (Brasil, 1997; CONAMA, 2005; CNRH, 2008).

In order to simulate water quality parameters in compliance with the proposed framework, simplified one-dimensional mathematical models are commonly used, which represent flow through the average velocity in the cross section, neglecting the vertical and transverse variations. With the advancement of computing, it is possible to perform spatially distributed modeling using geographic information systems (GIS), allowing the integration between point and diffuse pollution sources. These models can also be integrated into decision support systems for water-resource management in a watershed (Fan et al., 2012; Gomes and Simões, 2014; Silva et al., 2017).

The Una River basin does not have a framework prevailing use class. In the absence of this instrument, current legislation (CONAMA n ${ }^{\circ} 357 / 2005$ ) establishes that fresh water bodies are to be considered Class 2. According to the Pernambuco State Water Resources Policy (State Law $\mathrm{n}^{\circ}$ 12.984/2005, Article 55, XI and Article 47, VI), the proposed framework should be made by the Basin Agency, approved by the Basin Committee and later ratified by the State Council of Water Resources. In the absence of the Basin Agency, the above-mentioned State Law (Article 48, XIII) assigns responsibility for the elaboration of said proposal to the management and environmental body (Pernambuco, 2005).

With the goal of contributing as a theoretical subsidy for future framework proposals in the Una River basin, the present article presents a preliminary study for the classification of the main river into a prevailing-use class, based on the analysis of water quality parameters, mathematical modeling, and current water use.

\section{MATERIALS AND METHODS}

\subsection{Characterization of the study area}

The study area is the Una River basin that covers parts of the states of Pernambuco and Alagoas. With a total area of $6,740.31 \mathrm{~km}^{2}$, of which $6,262.78 \mathrm{~km}^{2}$ are in Pernambuco, the basin in question covers totally or partially 42 municipalities. The principal river, of the same name as the basin, has a length of $290 \mathrm{~km}$ with its source located in the municipality of Capoeiras, having intermittent flow until approximately the town of Altinho, where it becomes perennial (Figure 1). 


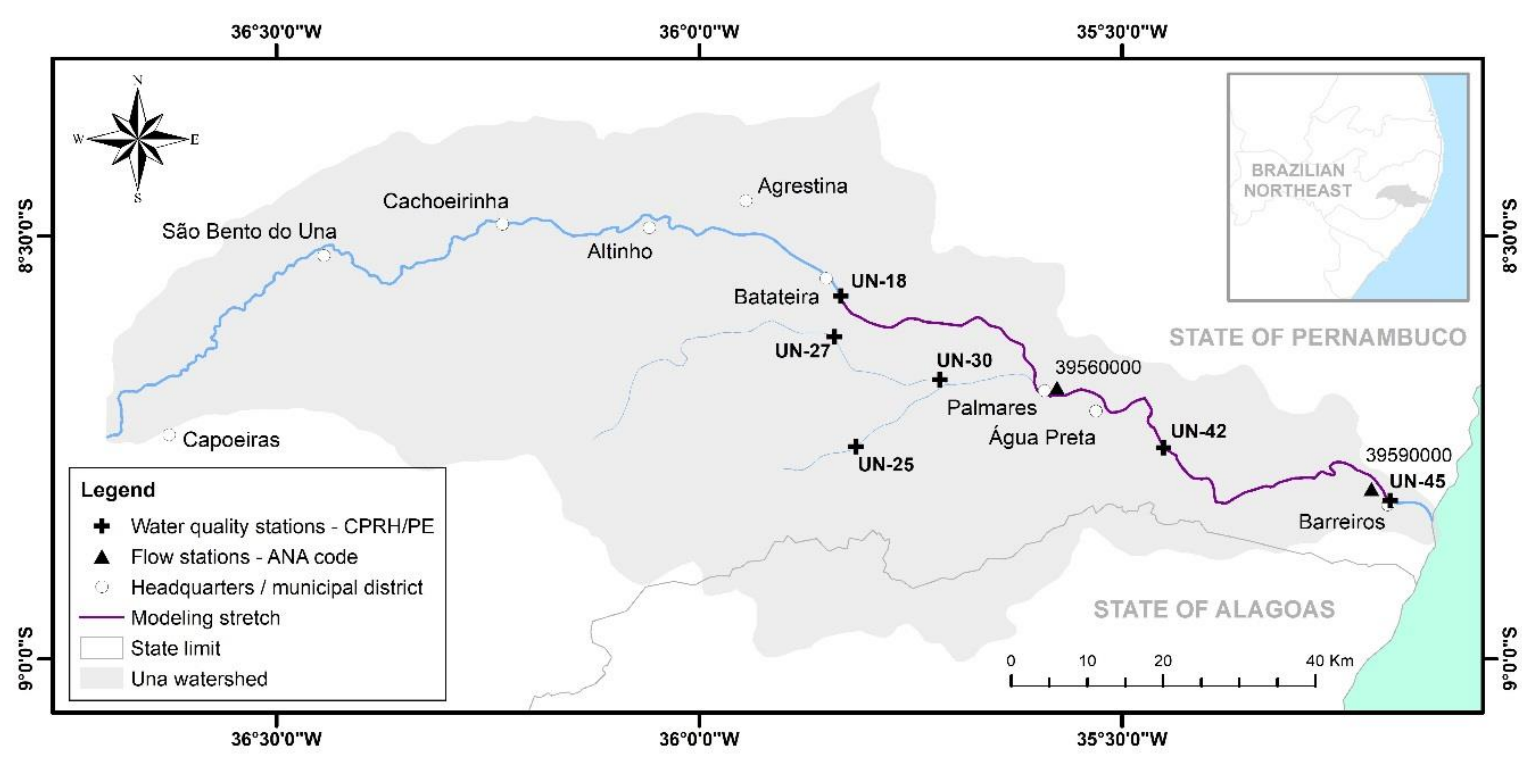

Figure 1. Map showing the location of the Una River hydrographic basin.

The most significant uses for the water in the basin are focused on public water supply and irrigation of short- and long-cycle crops. Due to the use and occupation of the soil (which houses urban areas, public slaughterhouses, industries, polyculture and sugar cane cultivation), the Una River became a receptacle for domestic, agroindustrial, and industrial effluents (the main source of pollution). According to Lima (2016), the release of industrial effluents decreased significantly with the deactivation of several sugar and alcohol sector plants in the basin. Only the Pumaty Plant, located in the municipality of Palmares, remains in operation. Despite this, sugarcane plantations continue across large parts of the basin, provoking an increase in nutrient concentration in the Una River, due to fertirrigation practices.

In this current situation, the water quality of the Una River is moderately compromised. The results of the monitoring carried out in December 2017 by the State Environmental Agency (CPRH) indicate that the river has regular water quality conditions (with acceptable levels of pollution) and is compatible with the limits of Class 3 (CPRH, 2018).

The Una River Basin Committee (COBH Una, in Portuguese) was created by CRH/PE Resolution $\mathrm{n}^{\mathrm{o}}$ 005/2002. It has 24 members for the 2015-2018 term, these being 12 representatives of the municipal, state, and federal governments, 8 representatives of water users in the basin, and 4 representatives of civil entities. Currently, the Una River basin has no master water plan nor any framework, as already mentioned. In general, the focus of the attention of $\mathrm{COBH}$ Una is controlling flooding, which has caused significant damages in several municipalities in the basin during 2010 and 2017.

\subsection{Water quality monitoring data}

Initially, data from all the monitoring stations operating in the basin were analyzed. The data were made available by the CPRH through its official website. The physicochemical and bacteriological analyses were carried out for six monitoring stations (three stations on the main river channel and three on its tributaries) between 2002 and 2010, with a bimonthly collection frequency for temperature, $\mathrm{pH}, \mathrm{DO}, \mathrm{BOD}$, color, turbidity, and phosphorus parameters and every four months for thermotolerant coliforms. After defining the parameters, the data were separated by year, station, and collection frequency, and further divided into dry (September to March) and rainy (April to August) seasons. In order to evaluate the empirical distribution of the data, boxplot charts were drawn in Excel to show the minimum, maximum, and median values. These results were then compared against the limits of the Class 2 standards. 


\subsection{Modeling the QUAL-UFMG water quality model}

The QUAL-UFMG model, developed by Von Sperling (2007) as an adaptation of the QUAL2E model, has been widely used by many Brazilian researchers to evaluate water quality, simulate scenarios, and predict water body behavior. It is a one-dimensional model, developed in a Microsoft Office Excel spreadsheet, suitable for rivers with relatively low permanent flows. It allows the modeling of river water quality through a simple and fast simulation of dissolved oxygen, biochemical oxygen demand, total nitrogen and its concentration, and coliform bacteria (Louzada Valory et al., 2016).

The choice of the above-mentioned model was based on the following criteria: ease of use, considering both the interface and the language; the utilization of basic parameters to qualitatively evaluate water resources ( $\mathrm{DO}, \mathrm{BOD}$, phosphorus, thermotolerant coliforms, temperature, $\mathrm{pH}$, color, and turbidity); availability of water quality monitoring data over a 10year period; and data on the flow of the water body to be modeled. In addition, this model had been previously used with other basins in Pernambuco, producing satisfactory results (Pinheiro et al., 2013; Araújo, 2013; Silva, 2015; Lima, 2016).

Although up to 15 organic components of water quality were simulated, two basic parameters were used to perform this study: dissolved oxygen (DO) and biochemical oxygen demand (BOD). To model DO and BOD in watercourses, Equation 1 is used to calculate the weighted average of the concentrations with the aggregated element flows. It is observed that the value of $\mathrm{C}_{0}$ is obtained through a weighted average of the flows, DO and BOD.

$$
C_{0}=\frac{Q_{r} \times C_{r}+Q_{r} \times C_{e}}{Q_{r}+Q_{e}}
$$

Where: $\mathrm{C}_{0}\left(\mathrm{DO}\right.$ or $\left.\mathrm{BOD}_{5}\right)$ : concentration of the mixture $\left(\mathrm{mg} \mathrm{L}^{-1}\right) ; \mathrm{C}_{\mathrm{r}}\left(\mathrm{DO}_{\mathrm{r}}\right.$ or $\left.\mathrm{BOD}_{\mathrm{r}}\right)$ : concentration in the river upstream from the mixing point $\left(\mathrm{mg} \mathrm{L}^{-1}\right) ; \mathrm{C}_{\mathrm{e}}\left(\mathrm{DO}_{\mathrm{e}}\right.$ or $\left.\mathrm{BOD}_{\mathrm{e}}\right)$ : concentration in the sewer upstream from the mixing point $\left(\mathrm{mg} \mathrm{L}^{-1}\right)$; and $\mathrm{Q}_{\mathrm{r}}$ and $\mathrm{Q}_{\mathrm{e}}$ : flows of the river and of the sewer $\left(\mathrm{m}^{3} \mathrm{~s}^{-1}\right)$.

The section to be modeled was defined based on the size of the series of historical flow and water quality data (DO and BOD) available at stations along the Una River. With this criterion, the data series from two ANA fluviometric stations (Palmares - code 39560000 and Barreiros - code 39590000) and three CPRH water quality stations (UN-18, UN-42, and UN45) were considered satisfactory, resulting in a modeled stretch $118 \mathrm{~km}$ long (Figure 1).

It is important to note that other relevant points were considered during the modeling, such as the inclusion of pollution sources from the sugar and alcohol sector (represented by the Pumaty Plant, the only one currently in operation) and the organic load resulting from the sewage of the municipalities of Palmares, Água Preta and Barreiros, as well as from their respective public slaughterhouses. The input data required and used by the QUAL-UFMG water quality mathematical model are presented below in a simplified manner:

- River flow $(Q r)$ and sewage flow (Qe): flow data were obtained from the Hydrological Information System (Hidroweb) of the National Water Agency (ANA) and stored with the software application Hidro 1.2, also made available by ANA. The sewage flow was estimated for the three municipalities mentioned above through the application of Equation 2, considering the 2010 population data (from IBGE), the per capita consumption of $250 \mathrm{~L} \mathrm{hab}^{-1} \mathrm{~d}^{-1}$, and using $80 \%$ as the coefficient of return. In addition, effluent outflows from public slaughterhouses were estimated for the high slaughter season, between October and December, based on the amount of cattle, pigs, and goats slaughtered per day. 
$Q_{e}=\left[\frac{\left(Q_{P C} \times P o p \times R\right)}{1000}\right] \div 8640$

Where: Qe: average domestic sewage flow $\left(\mathrm{m}^{3} \mathrm{~s}^{-1}\right)$; QPC: per capita water quota $\left(\mathrm{L} \mathrm{hab}^{-1} \mathrm{~d}^{-1}\right)$; Pop: population (hab); and R: coefficient of return.

- Dissolved oxygen in the river $\left(D O_{r}\right), B O D_{5,20}$ in the river $\left(B O D_{r}\right)$ and water temperature $(T)$ : these parameters were obtained from the average data of the six water quality monitoring stations between 2002 and 2010, for the dry period only.

- Dissolved oxygen in the sewage $\left(D O_{e}\right)$ and $B O D_{5,20}$ in the sewage $\left(B O D_{e}\right)$ : as most sewage from the municipalities as well as from public slaughterhouses is not treated, for the self-purification calculations, the $\mathrm{DO}_{\mathrm{e}}$ was considered to be $0 \mathrm{mg} \mathrm{L}^{-1}$. The $\mathrm{BOD}_{\mathrm{e}}$ was estimated by the division between the of $\mathrm{BOD}_{5}$ load $\left(\mathrm{kg} \mathrm{d}^{-1}\right)$ and the sewage flow $\left(\mathrm{m}^{3} \mathrm{~d}^{-1}\right)$.

- River velocity $(v)$, river depth $(H)$, and travel time $(t)$ : velocity and depth were inferred from the key curve at the selected fluviometric stations, using the cross section and the level series, both obtained from Hidroweb. The travel time was obtained by the ratio between the length of the river section and the velocity.

- DO saturation concentration (Cs): obtained as a function of river water temperature, ranging from $0^{\circ} \mathrm{C}=14.6 \mathrm{mg} \mathrm{L}^{-1}$ to $40^{\circ} \mathrm{C}=6.4 \mathrm{mg} \mathrm{L}^{-1}$ (Collischown and Tassi, 2010).

- Minimum permissible $D O\left(D O_{\min }\right)$ and maximum permissible BOD (BOD $\left.D_{\max }\right)$ : for $\mathrm{DO}_{\min }$ and $\mathrm{BOD}_{\max }$ in the river, the value of $5.0 \mathrm{mg} \mathrm{L}^{-1}$ was adopted, according to CONAMA Resolution $n^{\circ}$ 357/2005 (CONAMA, 2005) for Class 2.

- Coefficients of deoxygenation $\left(K_{1}\right)$, decomposition $\left(K_{d}\right)$. and reaeration $\left(K_{2}\right)$ : the $\mathrm{K}_{1}$ value depends on the temperature because it exerts considerable influence on microbial metabolism. The empirical relationship between temperature and the deoxygenation rate is given by Equation 3:

$K_{1_{T}}=K_{1_{20}} \times \theta^{(T-20)}$

Where: $K_{1}: \mathrm{K}_{1}$ at any temperature $\mathrm{T}\left(\mathrm{d}^{-1}\right) ; K_{1_{20}}: \mathrm{K}_{1}$ at temperature $\mathrm{T}=20^{\circ} \mathrm{C}\left(\mathrm{d}^{-1}\right)$; $\mathrm{T}$ : water temperature $\left({ }^{\circ} \mathrm{C}\right)$; and $\theta$ : temperature coefficient (dimensionless). The coefficients $\mathrm{K}_{\mathrm{d}}$ and $\mathrm{K}_{2}$ can also be defined by Equation 2 . For $\mathrm{K}_{1}$ and $\mathrm{K}_{\mathrm{d}}$, the value 1.047 is generally used for $\theta$, and for $\mathrm{K}_{2}, 1.024$. The coefficients $K_{1_{20}}, K_{d_{20}}$, and $K_{2_{20}}$ were extracted from Von Sperling (2007).

The calibration of the model was performed manually, varying the coefficients $\left(K_{1}, K_{d}\right.$, and $\mathrm{K}_{2}$ ) and obeying the value ranges (restrictions) found in the literature (Table 1), decreasing the sum of the squares of the errors until a satisfactory adjustment is obtained near 1 (Equation 4). This was based on the observed mean DO and BOD data from 2002 to 2010, taking the dry and rainy periods into consideration. The validation was done using the average values observed during the dry period between 2011 and 2014.

Table 1. Calibrated coefficients and reference values.

\begin{tabular}{llcccc}
\hline \multirow{2}{*}{ Coef. Description } & \multirow{2}{*}{ Unit } & Typical values* & \multicolumn{2}{c}{ Calibrated values** } \\
\cline { 4 - 6 } & & & & $1^{\text {st }}$ section & $2^{\text {nd }}$ section \\
\hline $\mathrm{K}_{1}$ & Deoxygenation coefficient & $\mathrm{d}^{-1}$ & 0.08 to 0.45 & 0.35 & 0.20 \\
$\mathrm{~K}_{\mathrm{d}}$ & BOD decomposition coefficient & $\mathrm{d}^{-1}$ & 0.10 to 3.00 & 1.72 & 0.60 \\
$\mathrm{~K}_{2}$ & Reaeration coefficient & $\mathrm{d}^{-1}$ & 0.00 to 10.00 & 7.00 & 6.00 \\
\hline
\end{tabular}

$*$ Von Sperling (2007). ** $1^{\text {st }}$ section: between UN-18 and UN-42; $2^{\text {nd }}$ section: between UN-42 and UN-45.

$R^{2}=1-\frac{\sum\left(Y_{O b s}-Y_{E s t}\right)^{2}}{\sum\left(Y_{O b s}-Y_{A v g O b s}\right)^{2}}$ 
Where: $\mathrm{R}^{2}$ : Nash-Sutcliffe coefficient; and $\mathrm{Y}_{\mathrm{Obs}}, \mathrm{Y}_{\text {Est }}$ and $\mathrm{Y}_{\text {AvgObs: }}$ observed, estimated, and average observed values.

\subsection{Preliminary framework proposal}

Due to the limited availability of water quality data, the framework was proposed for the Una River only, disregarding its tributaries and reservoirs.

With the results obtained from the water quality analysis and modeling, it was possible to establish a preliminary framework proposal for the main river channel related to the guidelines established in the current legislation, the uses identified in the basin, the water quality analysis data, and the simulation model of the Una River's behavior.

\section{RESULTS AND DISCUSSION}

\subsection{Analysis of water quality parameters}

The results of the analysis of the eight water quality parameters monitored at the six basin stations during the dry and rainy periods from 2002 to 2010 are discussed below and presented in Figure 2:

- Temperature: along the Una River, the water temperature ranged from $24^{\circ} \mathrm{C}$ to $33^{\circ} \mathrm{C}$, maintaining an average temperature of $28.1^{\circ} \mathrm{C}$. It is worth noting that CONAMA Resolution $n^{\circ} 357 / 2005$ (CONAMA, 2005) does not specify any temperature limits for the framework classes, but, for Amorim et al. (2017), high temperatures do decrease the solubility of gases, reducing the DO concentration.

- Potential Hydrogen $(p H)$ : despite the presence of industrial areas in the basin's municipalities, the $\mathrm{pH}$ values remained unchanged. The mean values found ranged from 6.0 to 9.0 at all monitoring stations, falling within the limit allowed by CONAMA Resolution $\mathrm{n}^{\mathrm{o}} 357 / 2005$ (CONAMA, 2005). Although its values were still found to conform to limits, it was observed that the $\mathrm{pH}$ at station $\mathrm{UN}-18$ varied little due to the low flow of the river along this section. Other UN-25, UN-30 and UN-42 stations presented lower mean $\mathrm{pH}$ values in the rainy season (UN-25: 7.00, UN-30: 6.30, UN42: 6.70) when compared to the dry period (UN-25: 7.10; UN-30: 6.85; UN-42: 6.95), corroborating with the results obtained by Piratoba et al. (2017). According to the author, this situation can be attributed both to natural factors (with increasing rainfall, the $\mathrm{pH}$ tends to rise, since dilution of dissolved compounds increases and there is a greater flow) for anthropogenic factors (through the launch of domestic and industrial sewage affecting the $\mathrm{pH})$.

- Dissolved Oxygen (DO): the highest variation in DO was found to be concentrated at stations UN-30 (dry season) and UN-25 (rainy season) with intervals of 0 to $6.80 \mathrm{mg} \mathrm{L}^{-1}$ and 1.80 to $9.10 \mathrm{mg} \mathrm{L}^{-1}$, respectively. These large fluctuations in DO concentration in Una River waters were also observed by Melo et al. (2018), identifying variations from 0.9 to $9.5 \mathrm{mg} \mathrm{L}^{-1}$. Because of these large fluctuations, the monitored DO values (for all seasons) were at some point outside of the limit recommended in CONAMA Resolution $n^{\circ} 357 / 2005$ (CONAMA, 2005) for Class 2, which is $\geq$ $5 \mathrm{mg} \mathrm{L}^{-1}$. This fact can be associated with the intense urban occupation along the banks of the river, which releases effluent from domestic sources, industry, and public slaughterhouses directly into the river. Another contributing factor is related to the presence of the Pumaty Plant, located upstream of the UN-42 station, which greatly influences water quality, especially during the dry season. Nevertheless, at stations UN$18, \mathrm{UN}-25, \mathrm{UN}-42$ and UN-45, the mean DO values were within the limit specified in the resolution across the entire study period. 
- Biochemical Oxygen Demand (BOD): at stations UN-18, UN-25 and UN-30, the BOD parameter was observed to be higher than the limit established by the current environmental legislation (Class $2 \leq 5 \mathrm{mg} \mathrm{L}^{-1} \mathrm{O}_{2}$ ) at sometimes. For example, during the dry season, a maximum of $25 \mathrm{mg} \mathrm{L}^{-1}$ was recorded, while during the rainy season, BOD values above $20 \mathrm{mg} \mathrm{L}^{-1}$ were found. The increase in the BOD values indicates an increase in the concentration of organic matter in the river, suggesting the increase of the potential for pollution. On the other hand, when the analysis is done using average values, they were found to be in compliance with the limit established for Class 2 . According to Cetesb (2006), waters with BOD of less than $4 \mathrm{mg} \mathrm{L}^{-1}$ are classified as clean waters, and waters with BOD values above $10 \mathrm{mg} \mathrm{L}^{-1}$, as polluted. From this criterion, also used by Amorim et al. (2017), and considering only the mean values monitored for BOD at all stations, the Una river waters were considered clean during the analyzed period.

- Color: federal environmental legislation indicates the natural true color level for a water body has a maximum limit of $75 \mathrm{mg} \mathrm{L}^{-1} \mathrm{Pt}$ for fresh water. After analyzing the data, it was found that during the dry period, only the UN-30 station had maximum values above the recommended limit. During the rainy season, the recommended maximum level was exceeded by stations UN-30, UN-42, and UN-45. In average terms, this parameter presented values that were within the limit established by legislation.

- Turbidity: the average turbidity levels were within the maximum limit established by CONAMA Resolution $n^{\circ}$ 357/2005 (CONAMA, 2005), $\leq 100$ UNT, considering both dry and rainy seasons. During the dry season, only station UN-18 presented values above that foreseen by legislation, with peaks of 250 UNT. It was found that the greatest variations in turbidity are related to the presence of suspended materials during the rainy season. It was verified that the higher variations of this parameter are related to the presence of suspended materials during the rainy season, since the surface runoff has a direct relation of influence with the turbidity, according to Costa Filho et al. (2017). In addition, domestic sewage and various industrial effluents can also cause water turbidities to rise.

- Phosphorus: the phosphorus concentrations ranged from 0.01 to $0.81 \mathrm{mg} \mathrm{L}^{-1}$ in the rainy season and from 0.02 to $1.48 \mathrm{mg} \mathrm{L}^{-1}$ in the dry season. At all monitoring stations, these values are above the limit established by CONAMA Resolution $n^{\circ}$ 357/2005 (CONAMA, 2005), when evaluated for Classes 1 and 2. This situation was also observed by Melo et al. (2018) when the water quality was evaluated in regions close to the four reservoirs (currently under construction) located in the perennial stretch of the Una river, from March/2014 to April/2015. These results demonstrate the high level of contribution of nutrients resulting from the fertirrigation practices of sugarcane, and from effluent release by municipalities, which may cause problems such as eutrophication and toxic algal blooms.

- Thermotolerant coliforms: the maximum values observed during the dry and rainy seasons are on the order of 10,000 NMP $100 \mathrm{ml}^{-1}$, while the average values are above 1,000 NMP $100 \mathrm{ml}^{-1}$ (limit established for Class 2). Only UN-27 presented, on average, values in accordance with the current environmental legislation, when both dry and rainy seasons were analyzed. This is because there is funding from COMPESA (Pernambuco Sanitation Company) that guarantees periodic monitoring to meet water quality standards in this area. The high levels of thermotolerant coliforms point towards fecal contamination from domestic effluents, released by the municipalities of Água Preta, Palmares and Barreiros. 
DRY SEASON

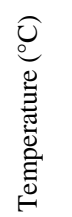

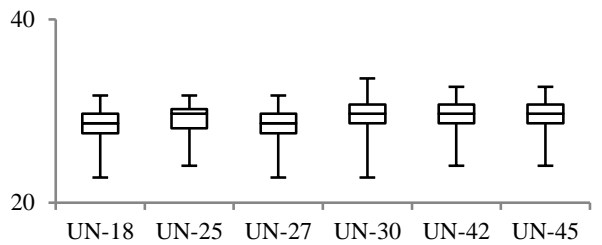

.

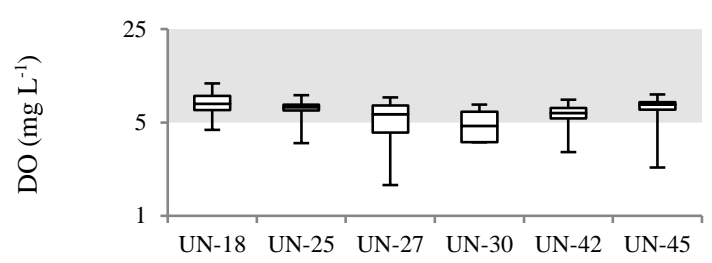

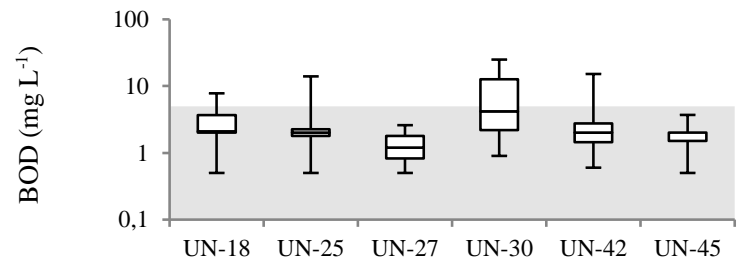

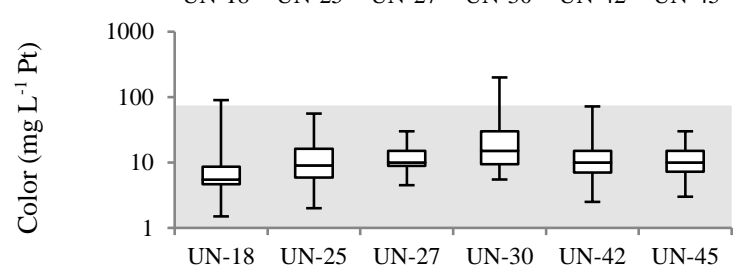

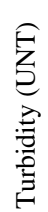

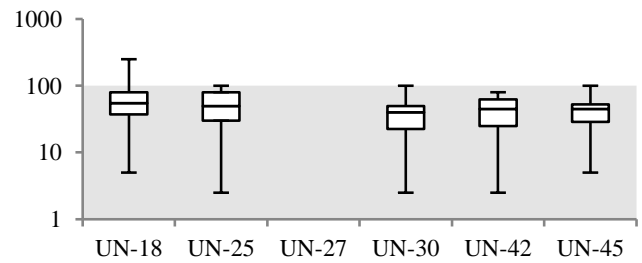

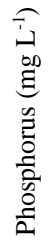

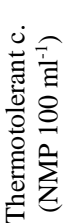
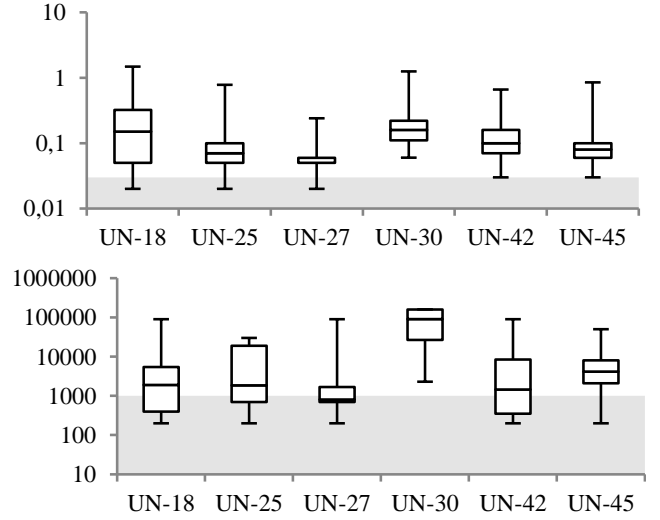

RAINY SEASON
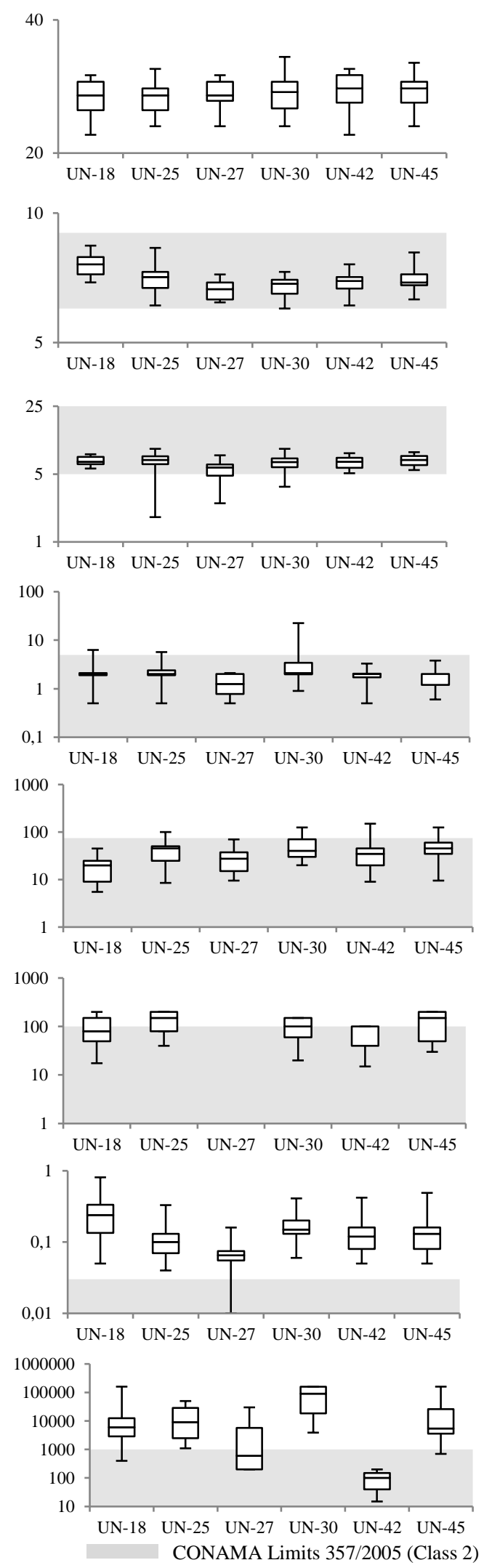

Figure 2. Graphical analysis of water quality parameters. 


\subsection{Simulation of DO and BOD parameters on a perennial section of the Una River}

The manual calibration of the QUAL-UFMG model resulted in a satisfactory adjustment between the estimated and observed DO and BOD values. The Nash-Sutcliffe coefficients $\left(\mathrm{R}^{2}\right)$ for both parameters were calculated at 0.998 and 0.999 , respectively. This means that the model was able to represent $99.8 \%$ and $99.9 \%$ of the variance in the experimental DO and BOD data. During the validation of the model, performed only for the dry season between the years 2011 and 2014, it was observed that the simulated parameters (DO and BOD) were representative when compared to the observed data $\left(R_{D O}^{2}=0.709\right.$ and $\left.R_{B O D}^{2}=0.779\right)$.

The results of the simulation showed that the Una River has a high dilution capacity, since the modeled section, even in the dry season, had a high flow rate. It was also observed that, during the period from 2002 to 2010, the simulations of both DO and BOD along the section modeled were within the CONAMA Resolution $n^{\circ} 357 / 2005$ (CONAMA, 2005) Class 2, 100\% and $99.5 \%$, respectively (Figure 3a). In the period from 2011 to 2014, the simulated DO and BOD parameters met the limits of the above-mentioned resolution for Class 2 for $100 \%$ of the modeled section (Figure 3b). This result does not invalidate the need to install sanitary sewage systems for the municipalities within the basin (with an efficiency greater than $90 \%$ ), since they do not have adequate systems to treat effluents and as population grows, increased organic load could lead to public health problems. Figure 3 shows the simulation of the DO and BOD parameters, based on the calibration and validation of the model.
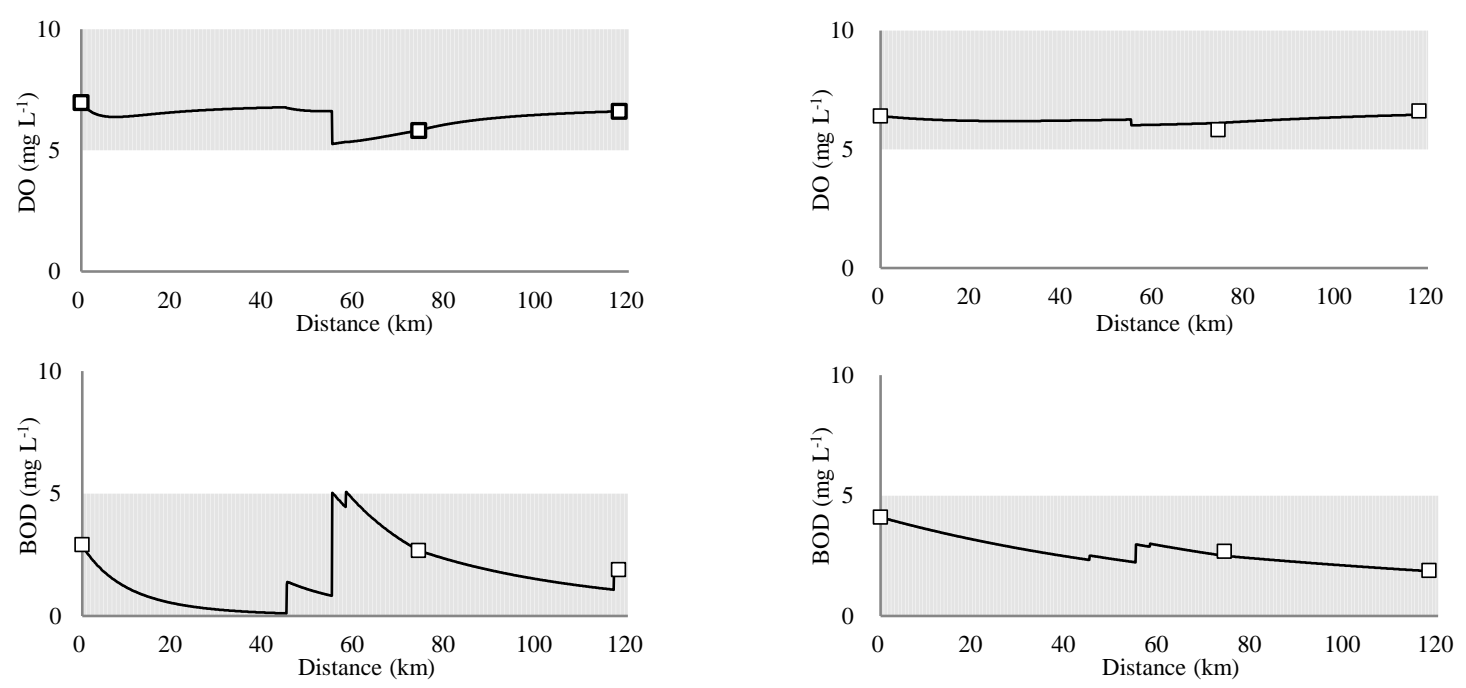

(a)

(b)

CONAMA 357/2005 Limits (Class 2) Observed values Estimated values

Figure 3. (a) Calibration of the DO and BOD parameters for the period from 2002 to 2010. (b) Validation of the DO and BOD parameters for the dry season from 2011 to 2014.

\subsection{Presentation of the preliminary framework proposal}

Based on the results obtained from the water quality analysis, mathematical modeling, and knowledge of current water use in the basin, Figure 4 represents the proposal established for the Una River framework. In this preliminary proposal, the proposed framework classes and the multiple predominant water use along four stretches of the river are identified, namely: 


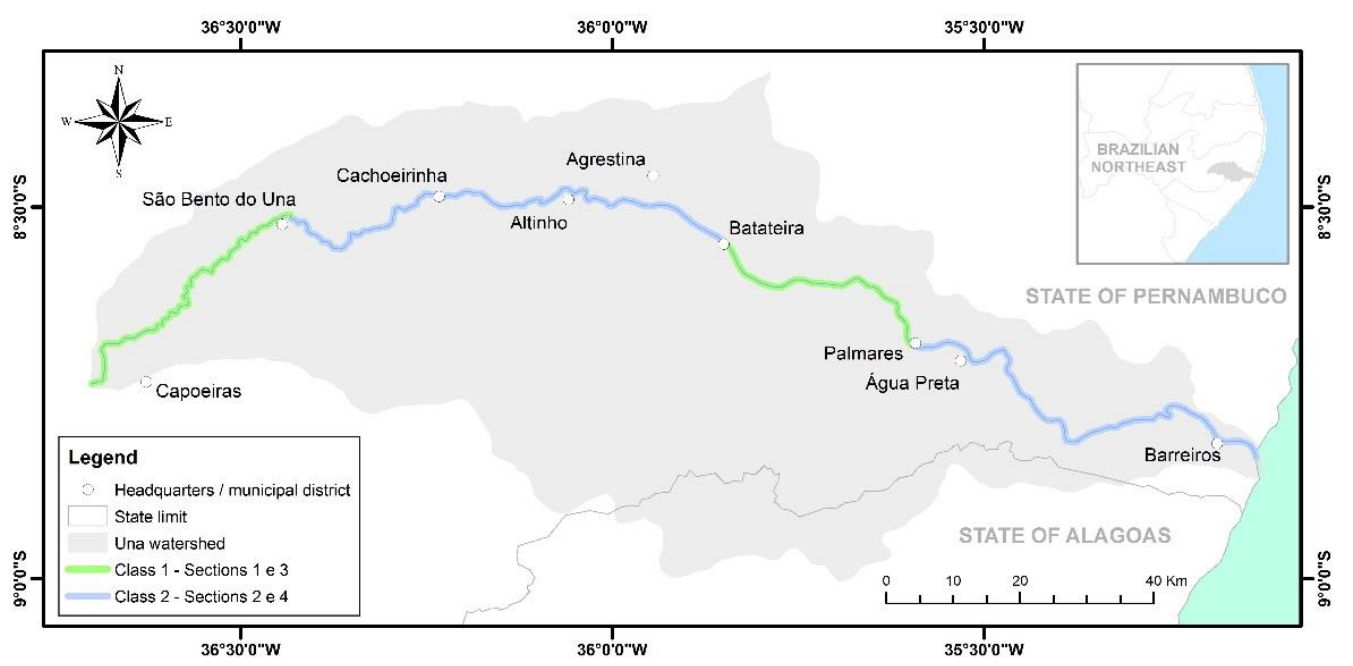

Figure 4. Identification of the sections framed by intended use class.

- Section 1 (Source until São Bento do Una): most of this section passes through rural areas, without the presence of industry or activities of great size. Thus, when water is present along this stretch, the local population will draw it from the river for human consumption, in addition to using it for domestic activities such as washing clothes, and recreation. Therefore, the current practices justify the proposed Class 1 framework. On the other hand, this section is also characterized by diffuse pollution, which compromises water quality to a lesser extent (presenting parameters consistent with Class 2), because it is intermittent during most of the year. The predominant uses are: human and animal water supply; irrigation of fruits and vegetables consumed raw that grow along the ground; and recreation.

- Section 2 (São Bento do Una until the vicinity of Batateiras): the analysis of the monitored water quality data suggested that this section be classified as Class 2, establishing the prevailing uses already being practiced along this section. A large volume of untreated domestic effluent from the municipalities upstream of the district of Batateiras was identified throughout this section. The prevailing uses are: human, animal and industrial water supply; and irrigation of sugarcane crops.

- Section 3 (Vicinity of Batateiras until Palmares): in this section, the Una River receives flow from other tributaries, which improves its capacity to self-purify the organic matter, even during the dry season, as shown by the results of the OD and BOD parameter modeling. Although such parameters are within the limits of Class 2, this section was classified as Class 1, demanding more severe standards of water quality, since the greater use of water in this section is destined to agriculture. In this case, the preponderant intended uses are: human and animal water supply; and irrigation of fruits and vegetables consumed raw that grow along the ground.

- Section 4 (Palmares until the mouth of the Una River): very little water is captured from this section for human supply, but a large amount is used for agriculture. Many municipalities in this region have small plots with sanitary sewage coverage, favoring a large load of domestic and industrial effluent (such as the Pumaty Plant operation), which are released directly into the river. Despite this, decreases in the BOD levels occur due to the increased flow from tributaries in this stretch, in addition to the significant increase in rainfall, resulting in a considerable capacity for self-purification. This situation, together with the water quality analysis and modeling, justifies the proposed Class 2 framework for this section. The predominant uses are: human, animal and industrial water supply; and irrigation of sugarcane. 


\section{CONCLUSIONS}

The water quality analyses showed that, in average terms, most of the parameters monitored during the dry and rainy seasons are within the limits established by CONAMA Resolution $n^{\circ} 357 / 2005$ (CONAMA, 2005), for Class 2. Only the parameters of phosphorus and thermotolerant coliforms are outside the standards recommended by the aforementioned legislation, a fact mainly associated with the release of domestic, industrial, and public slaughterhouse effluents from urban areas along the river shore.

In spite of this, the water quality modeling showed that the Una River has a high selfpurification capacity along its perennial stretch, even during the dry season, considered to be the most critical. This result is justified by the fact that the Una River basin is located in an area with high rainfall, characteristic of the southern part of the State of Pernambuco.

This hydraulic and hydrological condition of the basin made it possible to classify some stretches of the Una River as Class 1, establishing prevailing uses with more strict water quality standards, even when somewhat distant from the current practices. To this end, a framework implementation program should be established, whereby the intermediate progressive goals of water quality improvement can be defined. In the case of the Una River, it is extremely necessary to control the sources of water pollution, through adaptation to the release standards for industrial effluents and the implementation of sewage systems for the municipalities along the river.

With this proposal, the Una River will have a set of monitoring parameters that will serve as a reference for achieving and maintaining the required water quality, in order to ensure water quality compatible with its intended uses.

\section{REFERENCES}

AGÊNCIA ESTADUAL DE MEIO AMBIENTE E RECURSOS HÍDRICOS - CPRH (PE). Resultados do monitoramento das bacias. Available at: http://www.cprh.pe.gov.br. Access on: 17 Feb. 2018.

AMORIM, D. G.; CAVAlCANTE, P. R. S.; SOARES, L. S.; AMORIM, P. E. C. Enquadramento e avaliação do índice de qualidade da água dos igarapés Rabo de Porco e Precuá, localizados na área da Refinaria Premium I, município de Bacabeira (MA). Engenharia Sanitária e Ambiental, v. 22, n. 2, p. 251-259, 2017. http://dx.doi.org/10.1590/S1413-41522016131212

ARAUJO, A. F. Modelagem matemática da qualidade da água como suporte ao enquadramento de corpos de água: o caso do Rio Sirinhaém - PE. 2013. 94f. Dissertação (Mestrado em Tecnologia Ambiental) - Instituto de Tecnologia de Pernambuco, Recife, 2013.

BRASIL. Presidência da República. Casa Civil. Lei Federal nº 9.433, de 8 de janeiro de 1997. Institui a Política Nacional de Recursos Hídricos e cria o Sistema Nacional de Gerenciamento de Recursos Hídricos. Diário Oficial [da] União, Brasília, DF, 8 jan. 1997.

COLLISCHONN, W.; TASSI, R. Introduzindo a hidrologia. Porto Alegre: IPH/URGS, 2010. $151 \mathrm{p}$.

COMPANHIA AMBIENTAL DO ESTADO DE SÃO PAULO - CETESB. Qualidade das águas interiores no Estado de São Paulo. São Paulo, 2006. CETESB. Available in: https://cetesb.sp.gov.br/aguas-interiores/publicacoes-e-relatorios/. Access in: 04 jan. 2018 . 
CONSELHO NACIONAL DE RECURSOS HÍDRICOS (Brasil). Resolução nº 91, de 5 de novembro de 2008. Dispõe sobre procedimentos gerais para o enquadramento dos corpos de água superficiais e subterrâneos. Diário Oficial [da] União, Brasília, DF, 5 nov. 2008.

CONSELHO NACIONAL DO MEIO AMBIENTE (Brasil). Resolução n ${ }^{\circ}$ 357, de 17 de março de 2005. Dispõe sobre a classificação dos corpos de água e diretrizes ambientais para o seu enquadramento, bem como estabelece as condições e padrões de lançamento de efluentes, e dá outras providências. Diário Oficial [da] União, Brasília, DF, 17 mar. 2005 .

COSTA FILHO, E.; CRUZ, K. K. T.; GOMES, M. M. A. Estudo sobre a influência do escoamento superficial no parâmetro de turbidez na bacia hidrográfica do rio Pirapama, Pernambuco, Brasil. In: ENCONTRO INTERNACIONAL DAS ÁGUAS, 9., Recife, 2017. Trabalhos... Recife: Unicap, 2017.

FAN, C.; WANG, W.; LIU, K. F.; YANG, T. Sensitivity Analysis and Water Quality Modeling of a Tidal River Using a Modified Streeter-Phelps Equation with HEC-RAS-Calculated Hydraulic Characteristics. Environmental Modeling \& Assessment, v. 17, n. 1, p. 639651, 2012. https://doi.org/10.1007/s10666-012-9316-4

GOMES, F. C.; SIMÕES, S. J. C. Simulação de modelagem qualitativa para avaliação preliminar da qualidade da água na bacia do Ribeirão das Perdizes em Campos do Jordão/SP, como subsídio ao enquadramento. Revista Brasileira de Recursos Hídricos, v. 19, n. 3, p. 309-326, 2014.

LIMA, E. E. S. Modelagem matemática da qualidade da água como suporte ao enquadramento da bacia do rio Una - PE. 2016. 108f. Dissertação (Mestrado em Tecnologia Ambiental) - Instituto de Tecnologia de Pernambuco, Recife, 2016.

LOUZADA VALORY, J. P.; REIS, J. A. T.; MENDONÇA, A. S. F. Combining genetic algorithms with a water quality model to determine efficiencies of sewage treatment systems in watersheds. Journal of Environmental Engineering, v. 142, p. 04015080, 2016. https://doi.org/10.1061/(ASCE)EE.1943-7870.0001048

MELO, D. F. B. C.; RIBEIRO, M. H. G.; ALBUQUERQUE JUNIOR, E. C.; GONÇALVES, E. A. P. Avaliação da bacia do rio Una-Pernambuco: perspectiva da qualidade da água após a construção de 4 barragens para contenção de cheias. Revista Brasileira de $\begin{array}{lllllll}\text { Geografia } & \text { Física, } & \text { v. } 11, \quad \text { n. } & 2, & \text { p. }\end{array}$ https://doi.org/10.26848/rbgf.v11.2.p612-627

PERNAMBUCO. Lei Estadual n ${ }^{\circ}$ 12.984, de 30 de dezembro de 2005. Dispõe sobre a Política Estadual de Recursos Hídricos e o Sistema Integrado de Gerenciamento de Recursos Hídricos, e dá outras providências. Diário Oficial [do] Estado de Pernambuco, Recife 30 dez. 2005.

PINHEIRO, R. B.; MONTENEGRO, S. M. G. L.; SILVA, S. R.; MEDEIROS, Y. D. P.; AURELIANO, J. T. Outorga para Lançamento de Efluentes - Uma Metodologia de Apoio à Gestão de Recursos Hídricos. Revista Brasileira de Recursos Hídricos, v. 18, n. 4, p. 55-65, 2013.

PIRATOBA, A. R. A.; RIBEIRO, H. M. C.; MORALES, G. P.; GONÇALVES E GONÇALVES, W. Caracterização de parâmetros de qualidade da água na área portuária de Barcarena, PA, Brasil. Revista Ambiente \& Água, v. 12, n. 3, p. 435-456, 2017. https://doi.org/10.4136/ambi-agua.1910 
SILVA, M. C. A. A. Modelagem matemática da qualidade da água como suporte ao enquadramento da bacia do rio Goiana - PE. 2015. 109f. Dissertação (Mestrado em Tecnologia Ambiental) - Instituto de Tecnologia de Pernambuco, Recife, 2015.

SILVA, M. A. P. M.; FARIA, S. D.; MOURA, P. M. Modelagem da qualidade da água na bacia hidrográfica do Rio Piracicaba (MG). Engenharia Sanitária e Ambiental, v. 22, n. 1, p. 133-143, 2017.

VON SPERLING, M. Estudos e modelagem da qualidade da água de rios. Belo Horizonte: DESA/UFMG, 2007. 588 p. 


\begin{tabular}{|c} 
Ambiente \& Água - An Interdisciplinary Journal of Applied Science \\
ISSN 1980-993X - doi:10.4136/1980-993X \\
www.ambi-agua.net \\
E-mail: ambi.agua@gmail.com
\end{tabular}

\title{
Comparison of different slow-release nutrient composites produced to stimulate microorganisms
}

\author{
ARTICLES doi:10.4136/ambi-agua.2259
}

Received: 21 Mar. 2018; Accepted: 05 Oct. 2018

\author{
Everton Amazonas Reis*; Emelay Pereira Bispo; \\ Maria Helena Miguez Rocha Leão; Selma Gomes Ferreira Leite
}
Escola de Química da Universidade Federal do Rio de Janeiro (UFRJ-EQ), Rio de Janeiro, RJ, Brasil Departamento de Engenharia Química (DEQ). E-mail: evertonamazonas@yahoo.com.br, emelaybispo@poli.ufrj.br,mhrl@eq.ufrj.br, selma@eq.ufrj.br
*Corresponding author

\begin{abstract}
Concern for environmental quality has increased in society because industrial and technological development has released high levels of contaminants into the environment, such as hydrocarbons. A technique widely used for bioremediation is biostimulation, which may be enhanced by microencapsulation. This research formulated slow-release nitrogen and phosphorus compounds using different polymer (Alginate/Capsul@, carboxymethyl cellulose) matrices and compared them with the agricultural product Osmocote ${ }^{\circledR}$ and mineral medium Bushnell-Haas as hydrocarbonoclastics biostimulation agents in the environment for pollutant bioremediation. $\mathrm{N}$ (nitrogen) and $\mathrm{P}$ (phosphorus) were immobilized using lyophilization and ionic gelation techniques. Experiments were conducted using encapsulated material and evaluated for biomass production, glucose consumption as organic carbon source and $\mathrm{N}$ and $\mathrm{P}$ supply. The immobilized carboxymethyl cellulose compound showed the best results of glycosidic degradation (66.7\%) and microbial biostimulation (350 mg L-1 protein) compared to systems containing free nutrients $(11.3 \%$ and $150 \mathrm{mg} \mathrm{L}-1$ degradation glycosidic and microbial biostimulation, respectively). Thus, this compound is a potential slow release product for bioremediation processes.
\end{abstract}

Keywords: biotechnology, environmental, pollution.

\section{Comparação entre diferentes compósitos de liberação lenta de nutrientes para estimulação de microrganismos}

\section{RESUMO}

A preocupação com a qualidade ambiental aumentou na sociedade porque $o$ desenvolvimento industrial e tecnológico liberou altos níveis de contaminantes no meio ambiente, como os hidrocarbonetos. Uma técnica amplamente utilizada para a biorremediação é a bioestimulação, que pode ser reforçada por microencapsulação. $O$ objetivo desta pesquisa foi formular compostos de nitrogênio e fósforo de liberação lenta usando diferentes matrizes de polímeros (Alginato/Capsul®, Carboximetilcelulose) e compará-los com o produto agrícola Osmocote ${ }^{\circledR}$ e meio mineral Bushnell-Haas como agentes de bioestimulação hidrocarbonoclasticos no meio ambiente para biorremediação poluente. $\mathrm{N}$ (nitrogênio) e 
P(fósforo) foram imobilizados usando técnicas de liofilização e gelificação iónica. As experiências foram conduzidas usando material encapsulado e avaliadas para produção de biomassa, consumo de glicose como fonte de carbono orgânico e fornecimento de $\mathrm{N}$ e P. O compósito imobilizado composto por carboximetil celulose apresentou os melhores resultados de degradação glicosídica $(66,7 \%$ ) e bioestimulação microbiana (350 mg L-1 de proteína) em comparação com os sistemas contendo nutrientes livres $(11,3 \%$ e $150 \mathrm{mg} \mathrm{L}-1$ de degradação glicosídica e bioestimulação microbiana respectivamente). Assim, este composto é um potencial produto de liberação lenta para processos de biorremediação.

Palavras-chave: ambiental, biotecnologia, poluição.

\section{INTRODUCTION}

Concern for environmental quality has increased in society. The increase in industrial and technological development has led to highly contaminated soils, rivers, lakes, oceans, groundwater and sediments (Röling and Versevel, 2002). Because many contaminants have mainly originated from oil industries, high levels of carbon (originating from petroleum hydrocarbons) have been released to the environment.

According to the US Environmental Protection Agency (USEPA), one of the most widely reported processes in the literature for treating areas contaminated with high levels of available carbon is the bioremediation process. Bioremediation is a treatment process that uses naturally occurring microorganisms to degrade hazardous substances and transform them into less- or non-toxic substances (USEPA, 2004).

Bioremediation technologies can be classified as ex situ or in situ. Ex-situ technologies are treatments that remove contaminants to a location outside the contamination place, and in situ technologies involve treating the contaminants where they occur. In situ bioremediation techniques are advantageous because they can eliminate transportation costs with less intervention (Iwamoto and Nasu, 2001; Tyagi et al., 2011).

Different techniques can be used for in situ bioremediation, including natural attenuation, bioaugmentation and biostimulation. Natural attenuation is a reduction of toxicity, mobility or volume of the contaminant without human intervention and can occur by physical, chemical and biological processes. Bioaugmentation, however, involves stimulating the native populations that are reintroduced to the contamination site or the addition of wild strains or nonnative mixed cultures to the contaminated site, which can degrade the pollutant. Finally, biostimulation is a technique aimed at stimulating native microbiota in a given environment due to an adequate supply of nutrients and favorable environmental conditions. However, the main idea is to influence development of indigenous microorganisms at a contaminated site to reduce the contaminant through its use as a carbon source in microbial metabolism, which reduces pollutants over time (Azubuike et al., 2016; Iwamoto and Nasu, 2001; Tyagi et al., 2011). Currently, many studies have used biostimulation, because it causes less damage to the environment. However, the stimulus is not always immediate and may require some time before results appear. The quantity and type of added nutrients depend on the carbon, nitrogen and phosphorus ratio $(\mathrm{C}: \mathrm{N}: \mathrm{P})$ in the environment. This ratio should always be balanced to allow the microorganisms to grow adequately (Azubuike et al., 2016).

To provide such nutrients, cause less impact on the system and generate good nutritional relationships, many scientific investigations have used the microencapsulation technique for active materials in formulating slow-release fertilizers. Using this technique, the contents gradually release and meet the nutritional requirement of the involved organisms (Bansode et al., 2010; Reis et al., 2013; Favaro-Trindade et al., 2008).

Microencapsulation is a technology for packaging liquids, solids and gases in small, sealed 
capsules, which isolates and protects them from adverse environmental conditions, such as light, oxygen, moisture and interaction with other compounds. Capsules can release their contents at controlled rates under specific conditions. These packages are spherical with a nanometer size; however, they are strongly influenced by the originating material structure (Bastos et al., 2009; Suave et al., 2006).

One of the key steps in coating is selecting appropriate wall materials. Coating materials are film-forming materials selected from a wide variety of natural and synthetic polymers, depending on the coated material and the desired microcapsule characteristics (Bastos et al., 2009; Dubey et al., 2009). Ideally, the wall material must be an emulsifier, promote adequate content release when reconstituted into the product, have good film-forming ability, have a low viscosity with high levels of solids, and have high hygroscopicity. The following are among the most commonly used wall materials: carbohydrates (starch, maltodextrins, sucrose and cyclodextrins), cellulose (carboxymethyl cellulose and derivatives), gum (Arabic and agar), lipids (waxes, paraffin and fatty acids), and proteins (gluten, casein, gelatin and others) (Dubey et al., 2009; Suave et al., 2006).

Recently, studies have evaluated the use of slow-release fertilizer, as a form of bio stimulus, to provide the concentrations of nutrients necessary for the bioremediation process. However, the majority of products that have been applied are usually used for different agricultural cultivars and provide nutrients (Darmayati et al., 2017; Becker et al., 2016). There are few studies on this line of bioremediation and the use of polymers such as encapsulation matrix has been reported for application mainly in the area of food and drugs.

Given the above considerations, the aim of this research was to formulate nitrogen and phosphorus slow-release compounds using different polymers (alginate / Capsul®, carboxymethyl cellulose) matrices and compare them to the agricultural product Osmocote ${ }^{\circledR}$ and mineral medium Bushnell-Haas as biostimulation agents of hydrocarbonoclastics in the environment for pollutant bioremediation.

\section{MATERIAL AND METHODS}

\subsection{Preparing slow-release encapsulate}

In order to obtain the first encapsulation, monopotassium phosphate, dipotassium phosphate and ammonium nitrate (all at $1 \mathrm{~g} \mathrm{~L}-1$ and acquired from the Proquímios industry, Brazil) were weighed, dissolved in distilled water and mixed in a 3\% sodium alginate solution (w v-1) (from the Proquímios industry) and 4\% Capsul ${ }^{\circledR}$ (w v-1) (National Starch and Chemical Corporation USA). The final solution was transferred to a separator funnel and dripped into a $0.3 \mathrm{M}$ calcium chloride solution (Vetec company, Brazil), which is the ionic gelation technique shown in Figure 1, where spherical capsules were formed at the end of the production and dried in an oven at $60^{\circ} \mathrm{C}$ for $1 \mathrm{~h}$.

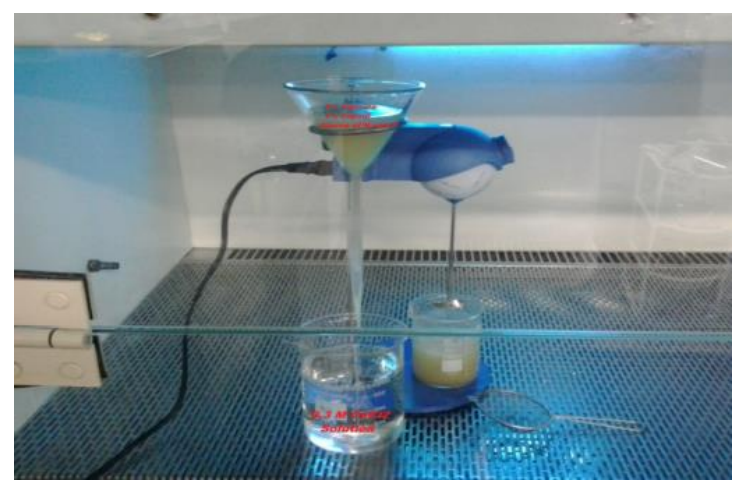

Figure 1. Alginate and Capsul® capsule production. 
To produce the second encapsulated carboxymethyl cellulose (CMC), monopotassium phosphate, dipotassium phosphate and ammonium nitrate (all at a concentration of $1 \mathrm{~g} \mathrm{~L}-1$ and from the Proquímios industry) were weighed, dissolved in distilled water and mixed in $1 \%$ carboxymethyl cellulose solution (Figure 2), which formed a solution that was freeze-dried in a countertop Enterprise I Terroni lyophilizer.
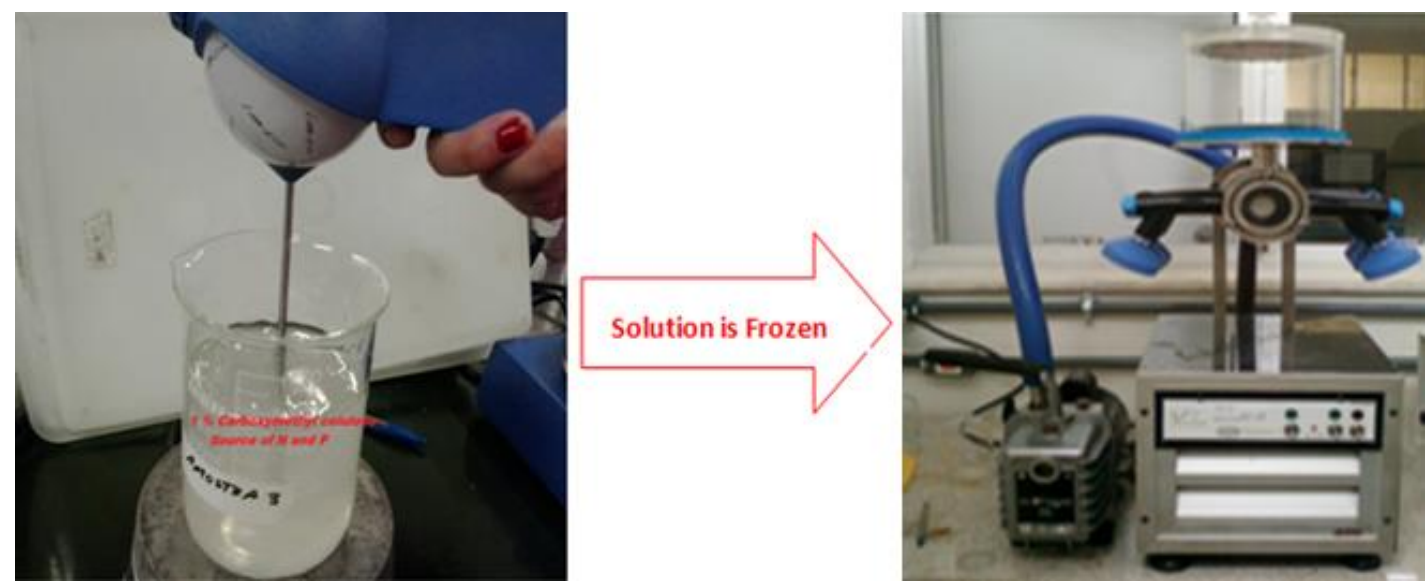

Figure 2. Schematic for producing immobilized carboxymethyl cellulose.

\subsection{Morphology analysis of encapsulates}

A morphological analysis of capsules was performed at the Ceramic Materials Laboratory of the Military Institute of Engineering in Rio de Janeiro. For this analysis, a JEOL® scanning electron microscope (SEM) Model JSM 5800W was used. The capsule sample was subjected to drying in an oven at $80^{\circ} \mathrm{C}$ for $24 \mathrm{~h}$. Then, the samples were placed on metallic cylindrical holders (stubs) measuring $10 \mathrm{~mm}$ in diameter and secured with double-sided adhesive tape. The sample in the stubs was then coated with gold and placed in the SEM. The acceleration voltage used was $20 \mathrm{kV}$, with the secondary electron image as detector.

\subsection{Biostimulation experiments}

All experiments were inoculated with Pseudomonas sp. obtained from a marine environment with a history of hydrocarbon contamination and purchased by the laboratory of Industrial Microbiology of UFRJ (Lima et al., 2007). After growing in a nutrient broth, the strain was maintained in a refrigerator and transferred to fresh nutrient broth every month. For each experiment, the pre-inoculum came from a stock grown in a new sterile nutrient broth, which was maintained at $30^{\circ} \mathrm{C}$ for $24 \mathrm{~h}$. The inoculum initially used was $5 \mathrm{ml}$ for each $100 \mathrm{ml}$ of experimental medium in the biostimulation system.

To understand the biostimulation process, experiments were performed using liquid systems composed of Bushnell-Haas (BH) (Hamdan and Fulmer., 2011; Reis et al., 2013) mineral medium and $2 \%$ glucose $(\mathrm{w} v-1)$. The mineral medium $(\mathrm{BH})$ was then modified based on Reis et al. (2013) in which the nitrogen and phosphorus sources were replaced by immobilized matrices carboxymethyl cellulose. The biostimulation was performed in $500 \mathrm{ml}$ glass jars with $200 \mathrm{ml}$ of mineral medium of modified composition in which $\mathrm{N}$ and $\mathrm{P}$ were replaced by the encapsulated versions at the same concentrations as the original medium. The experiments with the commercial product Osmocote ${ }^{\circledR}$ were also conducted for comparison with the produced matrices, besides experiments with Bushnell- Haas (Reis et al., 2013) medium which was used as a positive control containing free nutrients.

All experiments were carried out in triplicate for $96 \mathrm{~h}$, the samples were collected at intervals of $0,24,48$ and $96 \mathrm{~h}$; and the phosphorus, ammonia nitrogen and glucose concentrations were analyzed in all the proposed systems. 


\subsection{Analytical determinations}

The ammonia nitrogen, total phosphorus and glucose were analyzed using a colorimetric kit specific for each analysis (Doles ${ }^{\circledR}$, Brazil), and the protein concentration was determined using the Lowry method with BSA as the standard (Lowry et al., 1951).

\section{RESULTS}

\subsection{Production and morphological characterization of slow-release nutrient encapsulate}

The compound composed of 3\% (w v-1) sodium alginate and 4\% (w v-1) Capsul@, was diluted in distilled water and mixed with nutrients to form a solution source that was dripped in calcium chloride, which produced small whitish spheres that after drying had an average diameter of $0.2 \mathrm{~mm}$ (Figure 3).

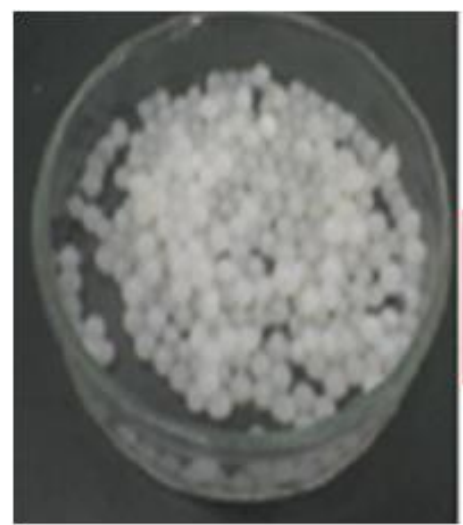

(a)

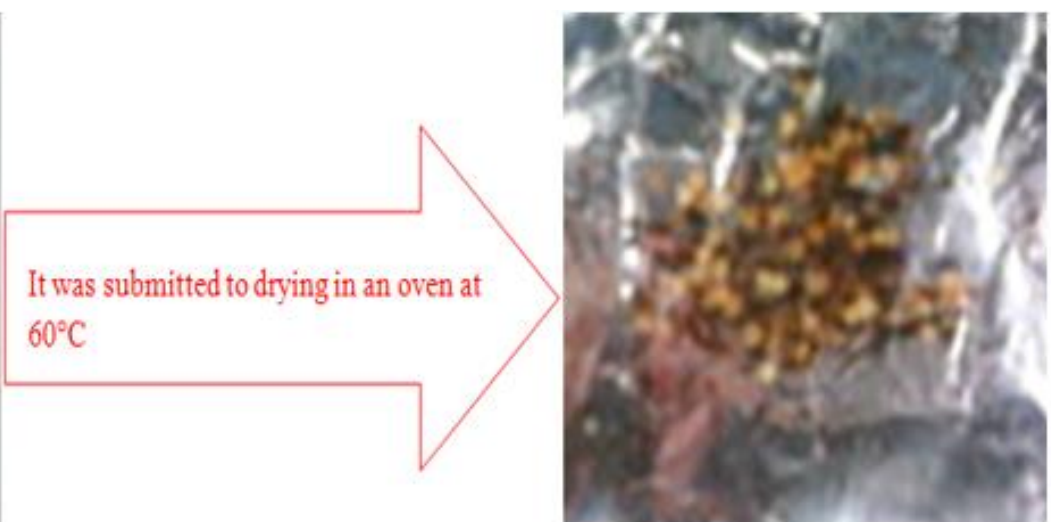

(b)

Figure 3. Illustration of the encapsulation of alginate / Capsul@ and nutrients $(\mathrm{N}$ and $\mathrm{P})$ obtained before (a) and after drying in an oven at $60^{\circ} \mathrm{C}(\mathrm{b})$.

The compound composed of $1 \%$ (w v-1) carboxymethyl cellulose was diluted in distilled water and mixed with nutrients, forming a solution that was freeze-dried, which produced a compact product subsequently subjected to manual grinding for better handling (Figure 4).

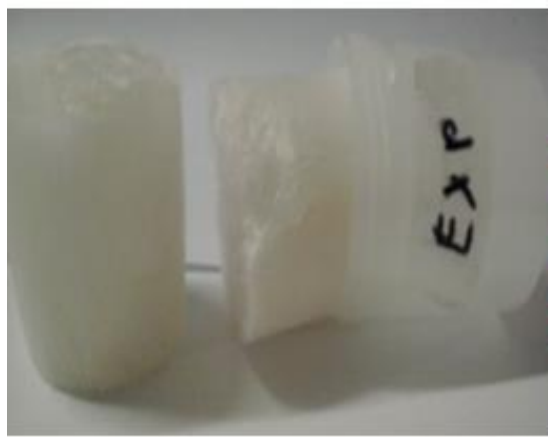

(a)

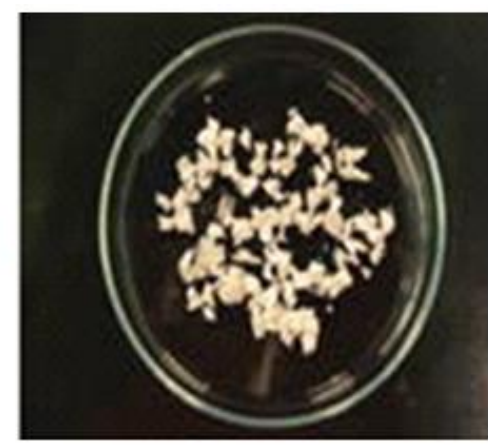

(b)

Figure 4. Illustration of the encapsulation of carboxymethyl cellulose and nutrients ( $\mathrm{N}$ and $\mathrm{P}$ ) obtained before (a) and after freeze-drying process (b).

The scanning electron microscopy provides information on the morphological characteristics of the encapsulates, such as the presence of cracks and pores, allowing rapid and direct analysis of the efficiency of the encapsulation process (Figures 5 and 6).

\section{IPABH}




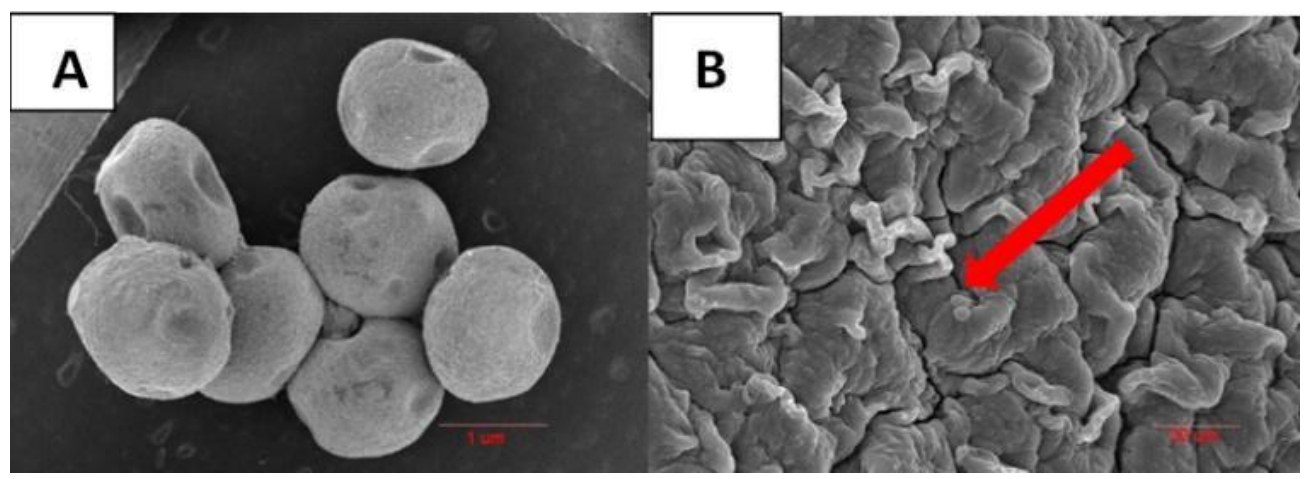

Figure 5. Encapsulate scanning electron microscopy of the polymers alginate/Capsul ${ }^{\circledR}$ with nutrients: a) An increase of $20 \mathrm{x}$ was observed, the scale bar is $1 \mu \mathrm{m}$; and b) An increase of $1000 \mathrm{x}$ was observed, the scale bar is $20 \mu \mathrm{m}$.

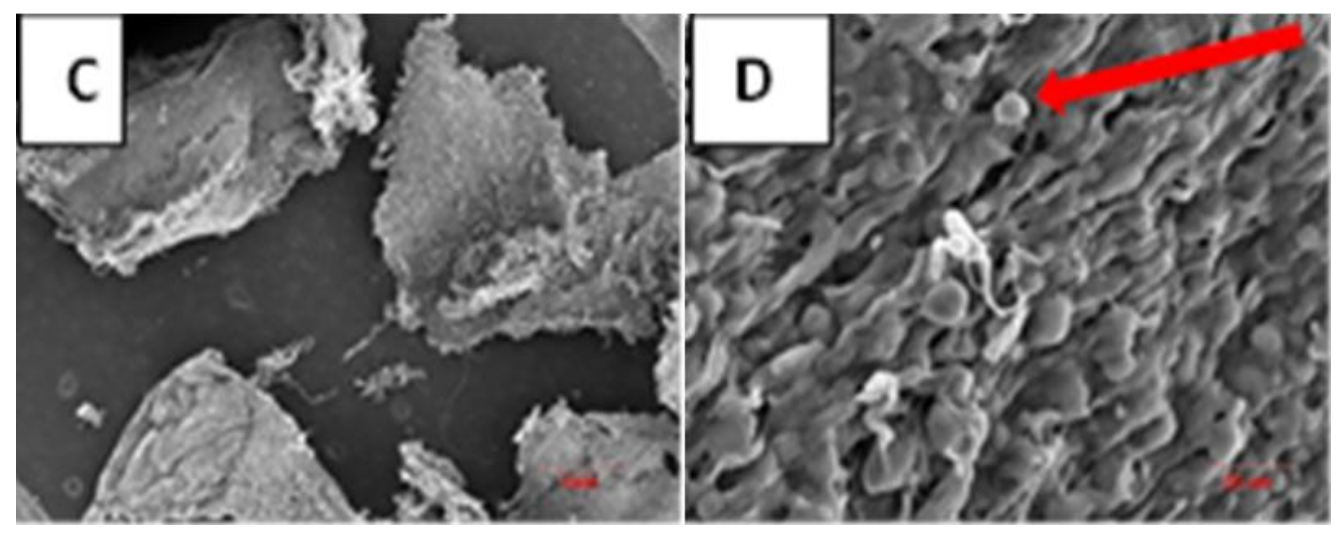

Figure 6. Encapsulate scanning electron microscopy of the polymer CMC with nutrients: c) An increase of $19 \mathrm{x}$ was observed, the scale bar is $1 \mu \mathrm{m}$; and, d) An increase of $1000 \mathrm{x}$ was observed, the scale bar is $20 \mu \mathrm{m}$.

Through the SEM images, it can be observed that both of the compounds formed Alginate / Capsul ${ }^{\circledR}$ as the carboxymethylcellulose presented in its polymeric walls granules scattered on the surface, as shown in Figures 5 and 6 (red arrows). According to Madene et al. (2006) and Matté and Rosa (2013), when this type of interaction between the encapsulated material (nutrients) and encapsulation material (polymers) occurs, the formed product is defined as microsphere.

In the images (Figures $5 \mathrm{~b}$ and $6 \mathrm{~d}$ ), it can be seen that, in both cases during the encapsulation process, there are cracks on the produced materials' walls.

\subsection{Assessing the biostimulation process}

In the biostimulation process (Figure 7), the microorganism was evaluated as a function of time and increased the profile of the nutrient concentrations, the carbon-source consumption and a protein concentrations (microbial growth).

The results of Figure $7 \mathrm{a}$ show that the initial $\mathrm{N}$ concentration in the matrix containing systems was lower, indicating a possible retention of that nutrient when compared to the $\mathrm{BH}$ medium. An increase of $\mathrm{N}$ in the first 24 hours still appeared, with higher a value obtained in alginate/Capsul@ system.

The free-nutrient system, Bushnell Haas (BH), in the same 24-hour period showed a visible consumption of nutrient by the decrease of its concentration. It is also observed that the $\mathrm{BH}$ and immobilized alginate/Capsul ${ }^{\circledR}$ systems exhibited nutrient stabilization after $48 \mathrm{~h}$ of the process. The Osmocote and Immobilized CMC systems showed a drop profile in nutritional concentrations during the same period. 

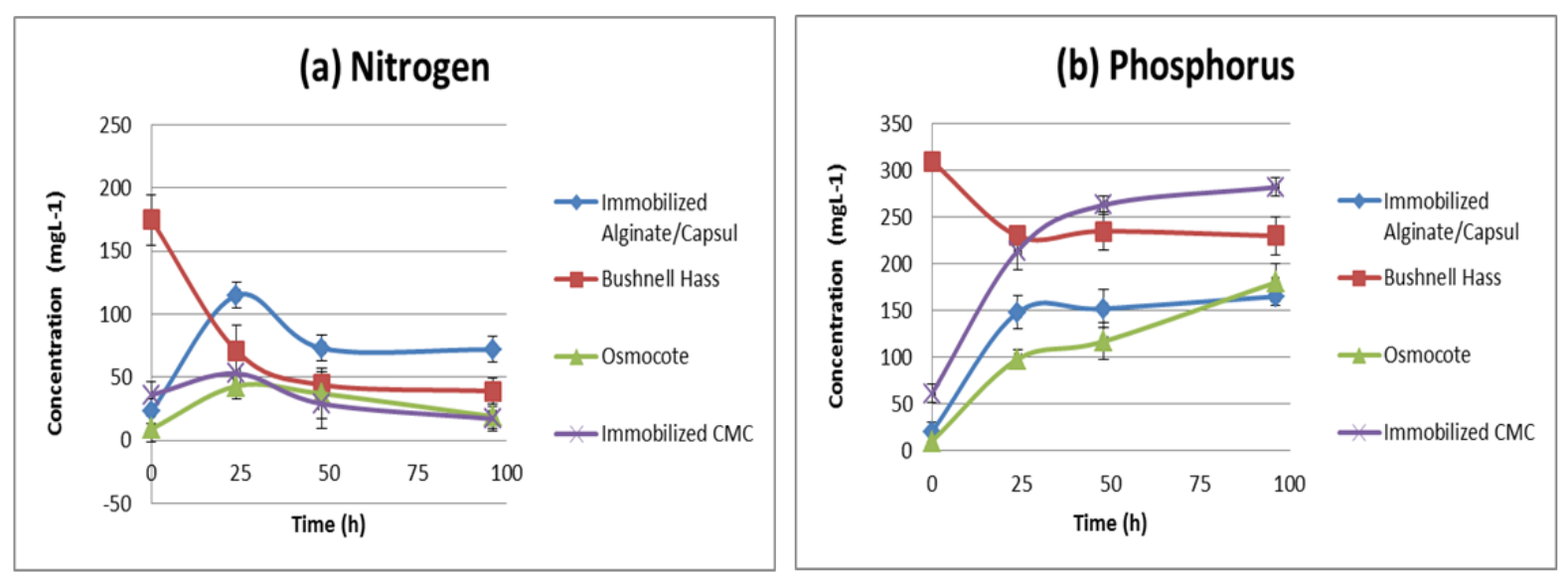

Figure 7. Variation of nutrient concentration over time in different systems: (a) nitrogen and (b) phosphorus.

The results of the nutrient phosphorus release presented in Figure $7 \mathrm{~b}$ show that the polymer immobilization systems controlled the nutrients' release, but it is possible to observe that these systems provided a considerable phosphorus concentration in the medium already in the first 24 hours. It is also observed that throughout the experiment the mentioned systems were able to gradually increase the phosphorus concentration. The BH system showed a drop of the concentrations in the $24 \mathrm{~h}$ of experiment and after that period the concentration profile remained stable until the end.

Microbial growth and carbon source consumption during the experiment in the different studied systems can be analyzed in Figures 8 (a) and (b).
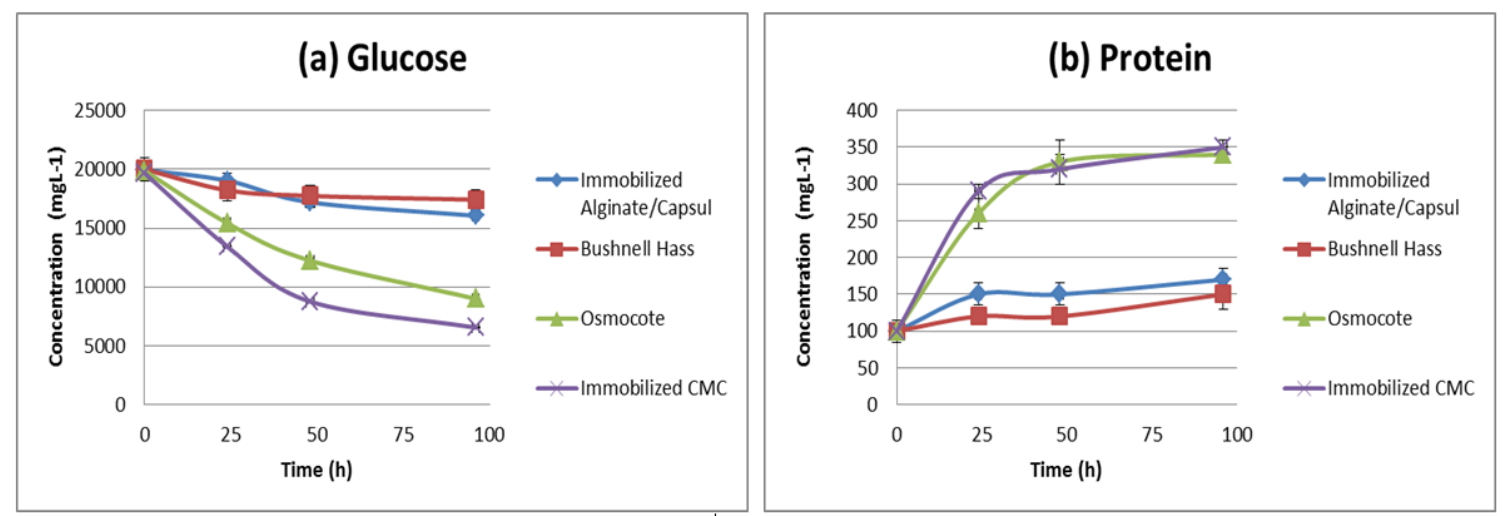

Figure 8. Variation of the carbon source consumption (a) and the estimated microorganism growth in different systems.

In Figure 8a it is possible to observe all the systems studied in the work presented a profile of the consumption of the carbon source throughout the experiment, with a concentration decrease in the medium. It is also verified that the system which provided the lowest concentration of carbon consumed was the experiment in the $\mathrm{BH}$ medium and the one that showed the highest decrease (higher consumption) in glucose concentration was the CMC immobilized system followed by the Osmocote system.

The results found in Figure $8 \mathrm{~b}$ show that both alginate/Capsul ${ }^{\circledR}$ immobilized nutrient and the free nutrient $(\mathrm{BH})$ systems provided a gradual profile in microbial growth. It is also possible to observe that both the CMC immobilized and the Osmocote system showed the highest values of protein concentration, unlike the other systems, whereas the system that exhibited a lower rate of protein concentration was the Bushnell Hass system.

The slow-release product developed in this study showed that, despite the experiment being conducted for 96 hours, there was no total release of nutrients (whose initial immobilized

\section{IPABH}

Rev. Ambient. Água vol. 13 n. 6, e2259 - Taubaté 2018 
concentration was equivalent to the Bushnell-Haas medium) and still has a residual concentration in the system (as seen in Figure 8) that would extend the time of biological activity. For an application in environmental systems, hence, not only the concentration of nutrients to be encapsulated but also the polymers could still be optimized, allowing a more adequate control of the release time thus prolonging the time of the process.

\section{DISCUSSION}

The polymer materials used for the production of slow release systems are good filmforming agents, so they were suitable to promote nutrient protection (Borrmann et al., 2011; Chan et al., 2009; Franchetti and Marconato, 2006), as shown in Figures 5 and 6.

Reis et al (2013) produced slow-release capsules for oil bioremediation using polymers based on alginate / NPK Capsul ${ }^{\circledR}$ to encapsulate and apply liquid systems with oil from a mineral medium. The authors observed degradation of $43.6 \%$ of total petroleum hydrocarbon.

In another study of oil spill bioremediation in ocean waters, Warr et al. (2013) produced a fertilizer nutrient clay base encapsulate using carboxymethylcellulose and simulated the application of this and obtained a reduction $98 \%$ of the concentration of total alkanes present in the oil in 1 month.

The data presented in Figures $7(\mathrm{a}, \mathrm{b})$ and $8(\mathrm{a}, \mathrm{b})$ show the efficiency of the polymer systems compared to the systems with free nutrients for stimulation of the environmental microorganisms.

The analyzes of the immobilized systems, alginate/Capsul ${ }^{\circledR}$, Osmocote ${ }^{\circledR}$ and CMC, show that there was a gradual release in the first $24 \mathrm{~h}$, seen in Figure $7(\mathrm{a}, \mathrm{b})$. This initial release provided a better rate of protein growth as observed in Figure 8b. This was possibly fundamental to provide a better $\mathrm{C}$ : $\mathrm{N}$ : $\mathrm{P}$ ratio, thus allowing the involved microorganisms maintain this more adequate relationship until the end of the experiment. This can be corroborated by the analyses of Figures $7(a, b)$ and 8 (b) of the Bushnell-Hass system, since this system provided all the nutrients in the first hours but did not exhibit the best protein growth rate (Figure 8b). Wolicka et al. (2009), applying aerobic microorganisms in bioremediation in situ of soil contaminated by petroleum products, also observed that proper C: N: P ratio was necessary to obtain good microorganism growth. According to Das and Chandran (2011), the surplus of free nutrients can inhibit the activity of the oil-degrading microorganisms and so, instead of remedying, will cause a negative impact on the environment.

In Figure $7 b$, low nutrient consumption by microorganisms was well seen in all systems with immobilized nutrients. Also the Bushnell-Hass system showed a drop in phosphorus concentrations in the first 24 hours, and after that period until the end of the experiment that concentration remained constant, indicating that the medium showed an excess of this nutritional source.

In Figure $8 \mathrm{~b}$ it was possible to observe that the best growth rates were in the immobilized CMC and Osmocote systems because they provided good stimulus to the involved microorganisms. This was likely due to the polymers' dissolution, since they dissolve in contact with the water and thus release their nutrients (Käistner, 1997; Mendonça et al., 2008).

In the literature some authors (Coulon et al., 2007; Yu et al., 2005) reported in their research the continuing need for nitrogen and phosphorus correction to stimulate degrading the microorganisms' hydrocarbons. Chaîneau et al. (2005) found in their studies a stimulatory effect of the oil-degrading microbial community for 150 days, as they increased the concentration of added nutrients. These studies support the need for the use of the encapsulated material as a source of slow release to the environment to be treated, allowing a reduction in the cost of bioremediation and increased effectiveness. 
The encapsulates produced from freeze-dried polymer matrixes of Carboxymethylcellulose and Osmocote provided good bacterial estimation when compared to other systems. The use of immobilized CMC presents a great potential in the release of nutrients with a better cost / benefit ratio, as it provided a good use of the nutrients and produced lower residual quantities in the system.

\section{CONCLUSION}

Polymer matrices containing nitrogen and phosphorus proved to be effective in releasing nutrients to promote microbial growth, and became a good solution for the treatment of environmental areas with lower eutrophication risk.

Compounds immobilized with $1 \%$ (w v-1) carboxymethylcellulose formed good structures for nutrient release, producing biostimulation comparable to the commercial Osmocote $\AA$ product.

\section{ACKNOWLEDGEMENTS}

The authors would like to thank Coordenação de Aperfeiçoamento de Pessoal de Nível Superior - Brasil (CAPES) - Finance Code 001, the CNPq (Conselho Nacional de Desenvolvimento Científico e Tecnológico) and Universidade Federal do Rio de Janeiro UFRJ / School of Chemistry / Department of Biochemical Engineering for financial support, which helped implement the present work.

\section{REFERENCES}

AZUBUIKE, C. C.; CHIKERE, C. B.; OKPOKWASILI, G. C. Bioremediation techniquesclassification based on site of application: principles, advantages, limitations and prospects. World Journal of Microbiology \& Biotechnology, v. 32, n. 11, p. 180, 2016. http://dx.doi.org/10.1007/s11274-016-2137-x

BANSODE, S. S.; BANARJEE, S. K.; GAIKWAD, D. D.; JADHAV, S. L.; THORAT, R. M. Microencapsulation: a review. International Journal of Pharmaceutical Sciences Review and Research, v. 1, n. 2, p. 38-43, 2010.

BASTOS, D. S.; ARAÚJO, K. G. L.; ROCHA-LEÃO, M. H. M. Ascorbic acid retaining using a new calcium alginate-Capsul based edible film. Journal of Microencapsulation, p. 2697-103, 2009. https://doi.org/10.1080/02652040802175805

BECKER, B. R.; DE SOUZA, E. S.; MARTINS, R. L.; BUENO, J. L. Bioremediation of oilcontaminated beach and restinga sediments using a slow-release fertilizer. CLEAN Air Soil Water, v. 44, n. 9, p. 1154-1162, 2016. http://dx.doi.org/10.1002/clen.201500023

BORRMANN, D.; LEITE, S. G. F.; ROCHA-LEÃO, M. H. M. Microencapsulation of passion fruit (Pathflora) juice in Capsul®. International Journal of Fruit Science, v. 11, p. 376385, 2011. https://doi.org/10.1080/15538362.2011.630299

CHAÎNEAU, C. H.; ROUGEUX, G.; YÉPRÉMIAN, C.; OUDOT, J. Effects of nutrient concentration on the biodegradation of crude oil associated microbial populations in the soil. Soil Biology and Biochemistry, v. 37, p. 1490-1497, 2005.

CHAN, E. S.; LEE, B. B.; RAVINDRA, P.; PONCELET, D. Prediction models for shape and size of calcium-alginate macrobeads produced through extrusion technique. Journal of

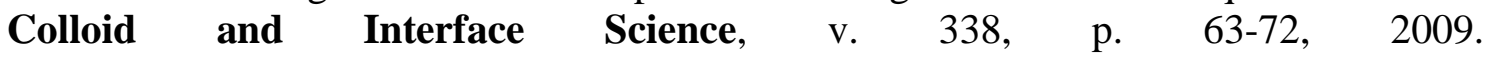
https://doi.org/10.1016/j.jcis.2009.05.027 
COULON, F.; MCKEW, B. A.; OSBORN, A. M.; MCGENITY, T. J.; TIMMIS, K. N. Effects of temperature and biostimulation on oil-degrading microbial communities in temperate estuarine waters. Environmental Microbiology, v. 9, p. 177-186, 2007. https://doi.org/10.1111/j.1462-2920.2006.01126.x

DARMAYATI, Y.; SANUSI, H. S.; PRARTONO, T.; SANTOSA, D. A.; NUCHSIN, R. Optimal bacterial density and fertilizer dosage for bioremediation of oil contaminated sandy beach: a case of cilacap, Indonesia. Biotropia, v. 24, n. 3, p. 182-191, 2017. http://dx.doi.org/10.11598/btb.2017.24.3.611

DAS, N.; CHANDRAN, P. Microbial degradation of petroleum hydrocarbon contaminants: an overview. Biotechnology Research International, v. 2011, p. 1-13, 2011. http://dx.doi.org/10.4061/2011/941810

DUBEY, R.; SHAMI, T. C.; RAO, K. U. B. Microencapsulation Technology and Applications. Defence Science Journal, v. 59, n. 1, p. 82-95, 2009.

FAVARO-TRINDADE, C. S. F.; PINHO, S. C.; ROCHA, G. A. Review: Microencapsulation of food ingredients. Brazilian Journal of Food Technology, v. 11, n. 2, p. 103-109, 2008 .

FRANCHETTI, S. M. M.; MARCONATO, J. C. Polímeros biodegradáveis - Uma solução parcial para diminuir a quantidade dos resíduos plásticos. Química Nova, v. 29, n. 4, p. 811-816, 2006.

HAMDAN, L. J.; FULMER, P. A. Effects of COREXIT® EC9500A on bacteria from a beach oiled by the Deepwater Horizon spill. Aquatic Microbial Ecology, v. 63, p. 101-109, 2011. https://dx.doi.org/10.3354/ame01482

IWAMOTO, T.; NASU, M. Current bioremediation practice and perspective. Journal of Bioscience and Bioengineering, v. 92, n. 1, p. 1-8, 2001. https://doi.org/10.1263/jbb.92.1

KÄISTNER, U.; HOFFMANN, H.; DÖNGES, R.; HILBIG, J. Structure and solution properties of sodium carboxymethyl cellulose. Colloids Surfaces A: Physicochemical and Engineering Aspects, v. 124, p. 307-328, 1997. https://dx.doi.org/10.1016/S09277757(96)03786-7

LIMA, C. J. B.; FRANÇA, F. P.; SERVULO, E. F. C.; RESENDE, M. M.; CARDOSO, V. L. Enhancement of rhamnolipid production in residual soybean oil by an isolated strain of Pseudomonas aeruginosa. Applied Biochemistry and Biotecnology, v. 137: p. 463-467, 2007. https://doi.org/10.1007/978-1-60327-181-3_39

LOWRY, O. H.; ROSEBROUGH, N. J.; FARR, A. L.; RANDALL, R. J. Protein measurement with the Folin phenol reagent. The Journal of Biological Chemistry, v. 193, n. 1, p. 265 $275,1951$.

MADENE, A.; JACQUOT, M.; SCHER, J.; DESOBRY, S. Flavour encapsulation and controlled release - a review. International Journal of Food Science \& Technology, v. 41, n. 1, p. 1-21, 2006. https://doi.org/10.1111/j.1365-2621.2005.00980.x

MATTÉ, M. G.; ROSA, S. A tecnologia da microencapsulação através das microesferas de quitosana. Revista Iberoamericana de Polímeros, v. 14, n. 5, p. 206-218, 2013.

MENDONÇA, V.; ABREU, N. A. A.; SOUZA, H. A.; TEIXEIRA, G. A.; HAFLE, O. M.; RAMOS, J. Diferentes Ambientes e Osmocote ${ }^{\circledR}$ na produção de mudas de tamarindeiro (Tamarindus indica). Ciência e Agrotecnologia, v. 32, n. 2, p. 391-397, 2008. https://doi.org/10.1590/S1413-70542008000200007 
REIS, E. A.; ROCHA-LEÃO, M. H. M.; LEITE, S. G. F. Slow-Release Nutrient Capsules for Microorganism Stimulation in Oil Remediation. Applied Biochemistry and Biotechnology, v. 169, p. 1241-1249, 2013. https://doi.org/10.1007/s12010-012-0022-0

RÖLING, W. F. M.; VERSEVEL, H. W. Natural attenuation: What does the subsurface have in store? Biodegradation, v. 13, p. 53-64, 2002. https://doi.org/10.1023/A:1016310519957

SUAVE, J.; DALL'AGNOL, E. C.; PEZZIN, A. P. T.; SILVA, D. A. K.; MEIER, M. M.; SOLDI, V. Microencapsulation: Innovation in different areas. Health and Environment Journal, v. 7, n. 2, p. 12-20, 2006.

TYAGI, M.; DA FONSECA, M. M. R.; DE CARVALHO, C. C. C. R. Bioaugmentation and biostimulation strategies to improve the effectiveness of bioremediation processes, Biodegradation, v. 22, p. 231-241, 2011. https://dx.doi.org/10.1007/s10532-010-9394-4

UNITED STATES. Environmental Protection Agency. Treatment Technologies for Site Cleanup: Annual Status Report (ASR). 11 ${ }^{\text {th }}$ ed. Washington, 2004.

WARR, L. N.; FRIESE, A.; SCHWARZ, F.; SCHAUER, F.; PORTIER, R. J.; BASIRICO, L. M. et al. Bioremediating Oil Spills in Nutrient Poor Ocean Water Using Fertilized Clay Mineral Flakes: Some Experimental Constraints. Biotechnology Research International, v. 2013, 2013. http://dx.doi.org/10.1155/2013/704806

WOLICKA, D.; SUSZEK, A.; BORKOWSKI, A.; BIELECKA, A. Application of aerobic microorganisms in bioremediation in situ of soil contaminated by petroleum products. $\begin{array}{llllll}\text { Bioresour Technology, } & \text { v. } 100, \quad \text { p. } & 3221-3227, & \end{array}$ https://doi.org/10.1016/j.biortech.2009.02.020

YU, K. S.; WONG, A. H.; YAU, K. W.; WONG, Y. S.; TAM, N. F. Natural attenuation, biostimulation and bioaugmentation on biodegradation of polycyclic aromatic hydrocarbons (PAHs) in mangrove sediments. Marine Pollution Bulletin, v. 51, n. 8-12, p. 1071-7, 2005. https://doi.org/10.1016/j.biortech.2009.02.020 


Ambiente \& Água - An Interdisciplinary Journal of Applied Science
ISSN 1980-993X - doi:10.4136/1980-993X
www.ambi-agua.net
E-mail: ambi.agua@gmail.com

\title{
Variabilidade espacial do estoque de carbono e atributos físicos do solo em terra preta arqueológica sob pastagem
}

\author{
ARTICLES doi:10.4136/ambi-agua.2002
}

Received: 11 Sep. 2016; Accepted: 10 Jul. 2018

\begin{abstract}
Marcelo Dayron Rodrigues Soares ${ }^{1}$; Milton César Costa Campos ${ }^{1 *}$; José Maurício da Cunha'; Zigomar Menezes de Souza ${ }^{2}$; Ivanildo Amorim de Oliveira ${ }^{3}$; Renato Eleotério de Aquino ${ }^{3}$; Bruno Campos Mantovanelli ${ }^{4}$, Ludimila Souza Oliveira ${ }^{1}$

\author{
${ }^{1}$ Universidade Federal do Amazonas (UFAM), Humaitá, AM, Brasil \\ Instituto de Educação, Agricultura e Ambiente (IEAA). E-mail: marcelo.dayron@gmail.com, \\ mcesarsolos@gmail.com,maujmc@gmail.com, ludimila.ufam@outlook.com \\ ${ }^{2}$ Universidade Estadual de Campinas (UNICAMP), Campinas, SP, Brasil \\ Faculdade de Engenharia Agrícola. E-mail: zigomams@agri.unicamp.br \\ ${ }^{3}$ Universidade Estadual Paulista "Júlio de Mesquita Filho" (UNESP), Jaboticabal, SP, Brasil \\ Programa de Pós-Graduação em Agronomia. E-mail: ivanildoufam@gmail.com, aquino.rea@gmail.com \\ ${ }^{4}$ Universidade Federal Rural de Pernambuco (UFRPE), Recife, PE, Brasil \\ Departamento de Agronomia (DEPA). E-mail: brunomantovanelli21@gmail.com \\ "Corresponding author
}

\section{RESUMO}

Algumas áreas de Terra Preta Arqueológica na Amazônia vêm sendo utilizadas com pastagem o que tem gerado grande preocupação quanto às alterações dos atributos físicos e o estado de agregação do solo. O objetivo deste estudo foi avaliar a variabilidade espacial e as possíveis modificações dos atributos físicos e agregados do solo em terra preta arqueológica sob pastagem. Uma grade de $80 \times 56 \mathrm{~m}$ foi usada e a amostragem realizada em 88 pontos em disposição de 8 x 8m. Nas camadas de $0-0,05,0,05-0,10$ e $0,10-0,20 \mathrm{~m}$ foram avaliados: a densidade do solo (Ds), carbono orgânico total (COT), estoque de carbono (Est C), diâmetro médio ponderado (DMP), macroporosidade (Macro), microporosidade (Micro) e volume total de poros (VTP). Pelo exame de semivariogramas constatou-se a ocorrência de dependência espacial. Mesmo a área de estudo sendo em pastagem observou-se que os valores de Ds, Macro e VTP, estiveram acima ou abaixo dos valores de referências que podem causar restrição ao crescimento radicular de plantas e à infiltração de água no solo. O DMP e Ds foram dependentes do COT, pois os valores de ambos aumentam ou diminuem de acordo com a camada. Com o aumento da camada do solo, houve o acréscimo do estoque de carbono.

Palavras-chave: estrutura do solo, geoestatística, manejo.

\section{Spatial variability of physical attributes and soil aggregates in archaeological dark dirt under pasture}

\begin{abstract}
Some areas of archaeological dark dirt in the Amazon have been used with pasture that has generated great concern regarding changes in soil physical attributes and its aggregation state. The objective of this study was to evaluate the spatial variability and possible modifications of soil physical and aggregate attributes in archaeological black dirt under pasture. A grid of $80 \mathrm{x}$
\end{abstract}


$56 \mathrm{~m}$ with 88 sampling points distributed in $8 \times 8 \mathrm{~m}$ were marked. Soil layers at 0-0.05, 0.050.10 , and $0.10-0.20 \mathrm{~m}$ were analyzed for: soil density (SD), total organic carbon (TOC), carbon stock (C stock), meanweight diameter (MWD), macroporosity (Macro), microporosity (Micro), and total porosity (TP). From semivariograms tests it was verified the occurrence of spatial dependence. Even with major pasture cover in the study area it was observed that the values of Ds, Macro, and VTP were above or below the reference values, which may cause restriction for root growth of plants and water infiltration in the soil. The DMP and Ds were COT-dependent because values of both increase or decrease depending on the soil layer. When higher the soil layer there was an increase in carbon stock.

Keywords: geostatistics, management, soil structure.

\section{INTRODUÇÃO}

A diversidade geológica existente na Amazônia, aliada ao relevo diferenciado e sob a influência de fortes temperaturas e precipitações, resultaram na formação das mais variadas classes de solo. Uma das principais características dos solos da Amazônia é sua baixa fertilidade, no entanto, os solos denominados de terras pretas arqueológicas (TPAs) ocorrentes nessa região têm se destacado por sua elevada fertilidade natural.

As terras pretas arqueológicas são solos com características de coloração escura, com presença de fragmentos cerâmicos e/ou líticos incorporados aos seus horizontes mais superficiais (Kämpf e Kern, 2005) e apresentam teor alto a muito alto de fósforo disponível (Campos et al., 2011). Esses solos ocorrem em manchas descontínuas por toda a Amazônia e tem como destinação principal o plantio de subsistência pelas populações locais. Devido ao pouco conhecimento do potencial agrícola, essas áreas vêm sendo convertidas de áreas de pastagens, principalmente na região sul do Amazonas, por sistemas extrativistas rudimentares que promovem modificações nos atributos físicos do solo.

Dentre os atributos físicos mais sensíveis a essas mudanças, destacam-se: a estabilidade de agregados, densidade do solo, a macroporosidade e teor de carbono orgânico. Tais atributos são indicadores utilizados para verificar as alterações no solo (Vasconcelos et al., 2010; Vieira et al., 2011). Dentre as diversas maneiras de verificar mudanças nos atributos do solo, a análise geoestatística é uma das mais eficazes (Alho et al., 2014). O comportamento dos atributos físicos pode ser monitorado pela distribuição espacial. Segundo Souza et al. (2004), os atributos físicos variam entre pontos relativamente próximos em área de mesma unidade taxonômica, muitas vezes de forma significativa.

Dado à necessidade de entender a variabilidade espacial dos atributos físicos e o carbono orgânico do solo, vários estudos já foram realizados enfatizando variações causadas pelo próprio uso e manejo em áreas de TPAs (Aquino et al., 2014b; Oliveira et al., 2013), porém o conhecimento ainda é escasso e não há informações que tratam a variabilidade espacial dessas áreas sob pastagem.

Dessa forma, o objetivo desse trabalho foi verificar a variabilidade espacial dos atributos físicos e o estado de agregação do solo em área de terra preta arqueológica sob pastagem na região de Manicoré, AM.

\section{MATERIAL E MÉTODOS}

A área de estudo está situada no sul do Estado do Amazonas, nas mediações da comunidade de Santo Antônio do Matupi, às margens da BR 230, Transamazônica, na região de Manicoré, AM. As coordenadas geográficas são $07^{\circ} 53^{\prime} 36,84^{\prime \prime}$ de latitude Sul e $61^{\circ} 23^{\prime} 54,49^{\prime \prime}$ de longitude Oeste e com altitude média de $83 \mathrm{~m}$. De acordo com a classificação de Köppen, o clima da 
região é do tipo tropical chuvoso, apresentando um período seco de pequena duração (Am), temperaturas variando entre 25 e $27^{\circ} \mathrm{C}$ e precipitação média varia entre de 2.500 e $2.750 \mathrm{~mm}$ ao ano (Brasil, 1978).

O material de origem é proveniente da Formação Içá, caracterizada com produto de sedimentação pleistocênica, coberta por depósitos eólicos. O relevo é constituído por platôs com superfícies planas, sendo a zona de borda marcada por colinas e cristas alinhadas e localmente escarpadas (CPRM, 2001). A pastagem foi implantada há sete anos sob pastejo extensivo com o cultivo de Brachiaria brizanta. A identificação dos horizontes, a descrição morfológica e coleta de amostras dos horizontes dos solos foram realizadas conforme Dos Santos et al. (2013) e o solo foi classificado como Argissolo Vermelho Amarelo Distrofico típico segundo critérios estabelecidos pelo SiBCS (EMBRAPA, 2013).

Estabeleceu-se uma malha amostral de $80 \times 56 \mathrm{~m}$ que continham 88 pontos de amostragem georreferenciados dispostos em malha de $8 \times 8 \mathrm{~m}$. Em cada ponto realizou-se a coleta de solo para as amostras deformadas e indeformadas nas camadas: 0-0,05; 0,05-0,010 e 0,10-0,20m (Figura 1).
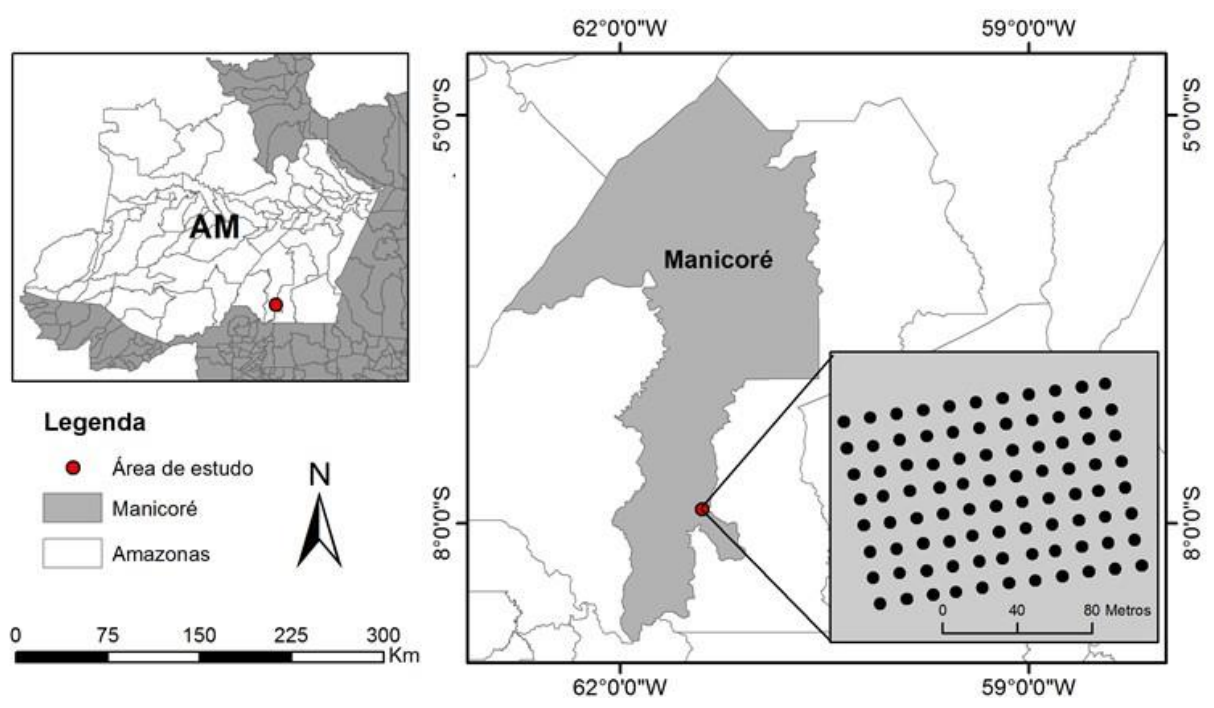

Figura 1. Mapa de localização da área de estudo e malha amostral.

O estado de agregação das amostras de solo foi avaliado pelo índice de diâmetro médio ponderado (DMP), por via úmida, conforme metodologia descrita por Kemper e Chepil (1965). As amostras de solos foram retiradas em forma de blocos, as quais foram secas ao ar e passadas em peneiras de $9,52 \mathrm{~mm}$ e $4,76 \mathrm{~mm}$. Em seguida, os agregados retidos na peneira de $4,76 \mathrm{~mm}$ foram empregados na análise da estabilidade de agregados via úmida, colocadas sobre um jogo de peneiras com tamisagem de $2,0 \mathrm{~mm} ; 1,0 \mathrm{~mm} ; 0,5 \mathrm{~mm} ; 0,25 \mathrm{~mm} ; 0,105 \mathrm{~mm}$; e $0,063 \mathrm{~mm}$ e submetendo-os a oscilações verticais. Transcorridos 15 minutos, as porções retidas em cada peneira foram transferidas para potes de alumínio com auxílio de jatos de água e secas em estuda a $105^{\circ} \mathrm{C}$ por um período de $24 \mathrm{~h}$ para posterior pesagem.

O carbono orgânico total (COT) foi determinado pelo método de Walkley-Black modificado por Yeomans e Bremner (1988). O estoque de carbono (Est C) foi determinado pela expressão proposta por Veldkamp (1994): Est $\mathrm{C}=(\mathrm{CO} \times \mathrm{Ds} \times \mathrm{e}) / 10$, em que Est $\mathrm{C}=$ estoque de carbono orgânico $\left(\mathrm{Mg} \mathrm{ha}^{-1}\right)$; COT = teor de carbono orgânico total $\left(\mathrm{g} \mathrm{kg}^{-1}\right)$; Ds = densidade do solo $\left(\mathrm{kg} \mathrm{dm}^{-3}\right)$; e = espessura da camada $(\mathrm{cm})$.

As amostras de solo indeformadas foram saturadas por meio da elevação gradual de uma lâmina de água até atingir cerca de $2 / 3$ da altura do anel. O volume total de poros (VTP) foi obtida pela diferença entre a massa do solo saturado e a massa do solo seco em estufa a $105^{\circ} \mathrm{C}$ durante $24 \mathrm{~h}$. A microporosidade (Micro) do solo foi determinada pelo método da mesa de

\section{IPABH}

Rev. Ambient. Água vol. 13 n. 6, e2002 - Taubaté 2018 
tensão a 6 kPa, conforme Embrapa (1997). Pela diferença entre a VTP e a Micro, obteve-se a macroporosidade (Macro). A densidade do solo (Ds) foi calculada pela relação entre a massa seca a $105^{\circ} \mathrm{C}$ durante $24 \mathrm{~h}$ da amostra de solo do cilindro volumétrico e o volume do mesmo.

Para caracterização da variabilidade espacial, foi utilizada a análise geoestatística. $\mathrm{O}$ semivariograma experimental foi estimado pela Equação 1.

$$
\hat{\gamma}(h)=\frac{1}{2 N(h)} \sum_{i=1}^{N(h)}\left[Z\left(x_{i}\right)-Z\left(x_{i}+h\right)\right]^{2}
$$

em que:

$\gamma(\mathrm{h})$ - semivariância estimada a partir dos dados experimentais;

$\mathrm{Z}$ - valores medidos nos pontos xi e xi $+\mathrm{h}$;

$\mathrm{N}(\mathrm{h})$ - número de pares de valores medidos separados por uma distância h;

Com os dados obtidos foram efetuadas a estatística descritiva dos dados e a hipótese de normalidade avaliada pelo teste de Kolmogorov-Smirnov por meio do software Minitab 14. Os semivariogramas foram ajustados ao melhor modelo matemático por meio da validação cruzada (VC) "cross-validation" e coeficiente de terminação $\left(\mathrm{R}^{2}\right)$ pelo software GS+. Para a confecção dos mapas espaciais utilizou-se o software Surfer versão 8.0.

O grau de variabilidade foi estimado pelo coeficiente de variação (CV) dos atributos, conforme sugerido por Warrick e Nielsen (1980) que consideram baixa variabilidade quando $\mathrm{CV}<12 \%$; média para o intervalo $12-60 \%$ e alta variabilidade quando CV $>60 \%$. A análise do grau de dependência espacial (GDE) foi realizada segundo Cambardella et al. (1994) que preconizam a proporção em porcentagem do efeito pepita $\left(\mathrm{C}_{0}\right)$ em relação ao patamar $\left(\mathrm{C}_{0}+\mathrm{C}_{1}\right)$ e apresentam: (a) dependência forte <25\%; (b) dependência moderada entre 25 e $75 \%$ e (c) dependência fraca $>75 \%$.

\section{RESULTADOS E DISCUSSÃO}

Os resultados da análise descritiva dos dados indicaram ajuste a uma distribuição normal (Tabela 1). Os índices de assimetria e curtose foram próximos de zero, com exceção do DMP e Micro na camada $0,05-0,10 \mathrm{~m}$. A média e a mediana para todos dos atributos foram próximos. De acordo com Campos et al. (2013), quando uma distribuição é simétrica, os valores da média e mediana são coincidentes. Em todos os casos, com exceção para o DMP, os atributos ajustaram-se à distribuição normal determinada por meio do teste de Kolmogorov-Smirnov.

Os valores médios de densidade do solo variaram entre 1,27 a $1,29 \mathrm{~kg} \mathrm{~m}^{-3}$, estes resultados estão de acordo com os obtidos por Dos Santos et al. (2013) em estudos com caracterização de TPA's no Sul do Amazonas. Segundo Steinbeiss et al. (2009), a baixa Ds está relaciona aos altos teores de carbono orgânico e a intensa atividade biológica. Mesmo sob pastagem, as menores Ds são típicos em áreas de TPA. De modo geral, esses resultados estão abaixo do valor crítico para Ds, conforme Blaiski et al. (2008), os quais afirmam que valores de Ds acima de $1,5 \mathrm{~kg} \mathrm{~m}^{-3}$ promovem significativas restrições ao desenvolvimento radicular das plantas.

Quanto a agregação do solo, observou-se que os agregados estáveis e de maior diâmetro (DMP) foram encontrados de forma contínua nas camadas de 0,0-0,05 e 0,05-0,10m. Os menores valores foram verificados na camada $0,10-0,20 \mathrm{~m}$. Em estudos realizados com variação espacial dos agregados em terra preta arqueológica, Rocha Silva et al. (2011) observaram que a variação do DMP por camada é reduzida à medida que aumenta a camada avaliada. Para Campos et al. (2012), como esses solos são de origem antrópica, a alta concentração de matéria orgânica derivada da queima parcial do carvão vegetal pode deixar este solo mais solto e, consequentemente, com a predominância de formação de microagregados. Rozane et al. (2010), 
avaliando os agregados em diversos manejos, verificaram os maiores valores de DMP na camada superficial de área de pastagem.

Tabela 1. Medidas descritivas dos dados do diâmetro médio ponderado (DMP), densidade do solo (Ds), carbono orgânico total (COT), macroporosidade (Macro), microporosidade (Micro), volume total de poros (VTP) em diferentes camadas.

\begin{tabular}{|c|c|c|c|c|c|c|c|}
\hline & DMP & Ds & Est C & COT & Macro & Micro & VTP \\
\hline & $(\mathrm{mm})$ & $\mathrm{kg} \mathrm{cm}^{-3}$ & Mg há ${ }^{-1}$ & $\mathrm{~g} \mathrm{~kg}^{-1}$ & & $\mathrm{~m} \mathrm{~m}^{-3}$ & \\
\hline & \multicolumn{7}{|c|}{$0,00-0,05 \mathrm{~m}$} \\
\hline Média & 3,14 & 1,29 & 88,92 & 137,06 & 0,11 & 0,24 & 0,39 \\
\hline Mediana & 3,16 & 1,30 & 89,05 & 136,93 & 0,12 & 0,23 & 0,38 \\
\hline $\mathrm{CV}^{1}$ & 3,14 & 9,13 & 8,75 & 4,06 & 23,47 & 11,74 & 8,81 \\
\hline Curtose & 0,71 & $-0,01$ & $-0,10$ & 1,49 & 0,55 & 2,98 & 1,52 \\
\hline Assimetria & 1,03 & 0,37 & $-0,33$ & $-0,72$ & 0,47 & 0,05 & 0,37 \\
\hline \multirow[t]{2}{*}{$\mathrm{d}^{2}$} & $0,03^{\mathrm{ns}}$ & $0,15^{*}$ & $0,15^{*}$ & $0,15^{*}$ & $0,08^{*}$ & $0,08^{*}$ & $0,09^{\prime \prime}$ \\
\hline & \multicolumn{7}{|c|}{$0,05-0,10 \mathrm{~m}$} \\
\hline Média & 3,12 & 1,27 & 86,16 & 135,28 & 0,18 & 0,24 & 0,42 \\
\hline Mediana & 3,19 & 1,29 & 86,75 & 135,56 & 0,17 & 0,23 & 0,40 \\
\hline $\mathrm{CV}^{1}$ & 5,52 & 8,05 & 7,22 & 1,68 & 21,43 & 11,08 & 9,09 \\
\hline Curtose & 7,74 & $-0,74$ & $-0,67$ & 0,41 & 1,07 & 4,78 & 0,59 \\
\hline Assimetria & $-2,49$ & 0,17 & $-0,15$ & $-0,68$ & 0,57 & 1,18 & 0,10 \\
\hline \multirow[t]{2}{*}{$\mathrm{d}^{2}$} & $0,01^{\mathrm{ns}}$ & $0,15^{*}$ & $0,15^{*}$ & $0,15^{*}$ & $0,15^{*}$ & $0,15^{*}$ & $0,15^{*}$ \\
\hline & \multicolumn{7}{|c|}{$0,10-0,20 \mathrm{~m}$} \\
\hline Média & 3,01 & 1,27 & 164,19 & 133,91 & 0,22 & 0,21 & 0,43 \\
\hline Mediana & 3,07 & 1,23 & 163,9 & 134,1 & 0,23 & 0,21 & 0,44 \\
\hline $\mathrm{CV}^{1}$ & 6,55 & 8,39 & 7,69 & 1,56 & 15,07 & 11,84 & 7,67 \\
\hline Curtose & 0,59 & 0,10 & 0,20 & 1,18 & 0,03 & 1,26 & $-0,16$ \\
\hline Assimetria & $-1,01$ & 0,22 & 0,16 & 0,50 & 0,07 & 0,69 & 0,17 \\
\hline $\mathrm{d}^{2}$ & $0,01^{\mathrm{ns}}$ & $0,15^{*}$ & $0,15^{*}$ & $0,15^{*}$ & $0,15^{*}$ & $0,09^{*}$ & $0,15^{*}$ \\
\hline
\end{tabular}

${ }^{1} \mathrm{CV}$ : coeficiente de variação; ${ }^{2} \mathrm{~d}$ : teste de normalidade Kolmogorov-Smirnov, *significativo a $5 \%$ de probabilidade.

Menores valores do estoque de carbono foram obtidos nas duas camadas superficiais, o que foi influenciado, principalmente, pelos maiores valores de densidade do solo. Provavelmente a maior densidade do solo na camada superficial é decorrente do pisoteio do gado. O maior valor do estoque de carbono foi encontrado na última camada. Em estudos com alguns atributos físicos em diversas áreas, entre elas, pastagem, Coutinho et al. (2017) afirmam que há influência do carbono orgânico do solo sobre a Ds, uma vez que onde foram obtidos os maiores valores de carbono orgânico foi onde se quantificou os menores valores de Ds e viceversa.

Os coeficientes de variação $(\mathrm{CV})$ indicaram homogeneidade dos dados $(\mathrm{CV}<12)$ segundo Warrick e Nielsen (1980). Como exceção, a macroporosidade teve valores de CV medianos $(23,47 \%, 21,4 \%$ e $15,07 \%$ respectivamente) em concordância com os resultados obtidos por Aquino et al. (2014b) em estudo com área de pastagem e Aquino et al. (2014a) em área com TPA.

Constatou-se que os valores médios da Micro permaneceram praticamente constantes nas duas primeiras camadas, com pequena diminuição na última camada. Já a Macro e a porosidade total mostraram comportamento inverso a Micro, com isso, o aumento da Ds pode reduzir a

\section{IPABH}

Rev. Ambient. Água vol. 13 n. 6, e2002 - Taubaté 2018 
macroporosidade e elevar a Micro. Para Santos et al. (2012), o crescimento das raízes pode ser prejudicado quando a macroporosidade do solo é reduzida a valor inferior a $0,15 \mathrm{~m}^{3} \mathrm{~m}^{-3}$. No entanto, os resultados ficaram acima do valor de referência.

Os parâmetros dos modelos ajustados aos semivariogramas para os diferentes atributos são apresentados na Tabela 2. Os valores da validação cruzada (VC) oscilaram entre 0,61 e 1,01. De acordo com Alho et al. (2014) quanto mais próximos de 1 a VC maior a confiabilidade e mais eficiente o modelo para representar o estudo. O coeficiente de determinação $\left(r^{2}\right)$ dos semivariogramas revelam ótimos ajustes, oscilando entre 0,52 e 0,97. Todavia, é válido considerar que os atributos tiveram os menores valores de $\mathrm{C}_{0}$ indicando uma maior representatividade da variabilidade espacial destes atributos na área de estudo.

A variação da razão de dependência (RD) foi de 3 a 50 indicando que os atributos apresentam um máximo de 50\% de aleatoriedade nos dados de amostragem. Todos os atributos apresentaram dependência espacial. Segundo Cambardella et al. (1994) a RD foi classificada como forte e moderada. Lima et al. (2010) afirmam que quanto maior a dependência espacial da variável melhor estrutura espacial e maior precisão podem ser obtidas na estimativa em locais não amostrados.

Tabela 2. Modelos e parâmetros estimados dos semivariogramas experimentais em área dos atributos do solo em diferentes camadas.

\begin{tabular}{|c|c|c|c|c|c|c|c|}
\hline \multirow[t]{2}{*}{ Parâmetros } & DMP & Ds & Est C & COT & Macro & Micro & VTP \\
\hline & \multicolumn{7}{|c|}{$0-0,05 \mathrm{~m}$} \\
\hline Modelo & Esf. & Esf. & Exp. & Exp. & Exp. & Exp. & Esf. \\
\hline $\mathrm{C}_{0}$ & 0,0035 & 0,0003 & 5,4000 & 6,4100 & 0,9100 & 0,9000 & 0,30 \\
\hline $\mathrm{C}_{0+} \mathrm{C}_{1}$ & 0,0073 & 0,0123 & 48.84 & 20,5900 & 8,5410 & 7,7080 & 8,11 \\
\hline${ }^{1} \mathrm{RD}$ & 49 & 3 & 11 & 31 & 11 & 12 & 11 \\
\hline $\mathrm{a}(\mathrm{m})$ & 53 & 14 & 17 & 28 & 19 & 15 & 13 \\
\hline$r^{2}$ & 0,85 & 0,92 & 0,94 & 0,80 & 0,88 & 0,52 & 0,70 \\
\hline \multirow[t]{2}{*}{${ }^{3} \mathrm{VC}$} & 0,89 & 0,82 & 0,78 & 0,83 & 0,70 & 0,76 & 0,96 \\
\hline & \multicolumn{7}{|c|}{$0,05-0,10 \mathrm{~m}$} \\
\hline Modelo & Esf. & Exp. & Exp. & Exp. & Exp. & Exp. & Exp. \\
\hline $\mathrm{C}_{0}$ & 0,0013 & 0,00127 & 4.10 & 0,4600 & 1,2400 & 1,2100 & 1,46 \\
\hline $\mathrm{C}_{0+} \mathrm{C}_{1}$ & 0,0275 & 0,0099 & 36.57 & 4,4690 & 11,7900 & 6,0080 & 12,07 \\
\hline${ }^{1} \mathrm{RD}$ & 5 & 13 & 11 & 10 & 11 & 20 & 12 \\
\hline $\mathrm{a}(\mathrm{m})$ & 21 & 24 & 15 & 17 & 19 & 34 & 17 \\
\hline$r^{2}$ & 0,90 & 0,97 & 0,91 & 0,74 & 0,90 & 0,61 & 0,84 \\
\hline \multirow[t]{2}{*}{${ }^{2} \mathrm{VC}$} & 0,69 & 0,88 & 0,72 & 0,82 & 0,67 & 1,01 & 0,65 \\
\hline & \multicolumn{7}{|c|}{$0,10-0,20 \mathrm{~m}$} \\
\hline Modelo & Exp. & Exp. & Esf. & Esf. & Exp. & Exp. & Exp. \\
\hline $\mathrm{C}_{0}$ & 0,0040 & 0,0011 & 5,70 & 2,251 & 1,0500 & 0,5200 & 5,7700 \\
\hline $\mathrm{C}_{0+} \mathrm{C}_{1}$ & 0,0354 & 0,0088 & 130,3 & 4,5030 & 9,5500 & 4,2670 & 11,550 \\
\hline${ }^{1} \mathrm{RD}$ & 11 & 12 & 4 & 50 & 11 & 12 & 50 \\
\hline $\mathrm{a}(\mathrm{m})$ & 17 & 21 & 14 & 43 & 19 & 19 & 53 \\
\hline$r^{2}$ & 0,69 & 0,85 & 0,75 & 0,91 & 0,88 & 0,94 & 0,94 \\
\hline${ }^{2} \mathrm{VC}$ & 0,99 & 0,98 & 0,95 & 0,81 & 0,61 & 0,80 & 0,72 \\
\hline
\end{tabular}

DMP: diâmetro médio ponderado; Ds: Densidade do solo; COT: carbono orgânico total; Esf.: Esférico; Exp.: Exponencial; $\mathrm{C}_{0}$ : efeito pepita; $\mathrm{C}_{0+} \mathrm{C}_{1}$ : patamar; ${ }^{1} \mathrm{RD}$ : razão de dependência espacial; $\mathrm{r}^{2}$ : coeficiente de determinação; ${ }^{2} \mathrm{VC}$ : validação cruzada. 
Os atributos DMP, Ds, Est C, COT, Macro, Micro e VTP apresentaram estruturas de dependência espacial conforme demonstrado pelos ajustes ao modelo esférico e exponencial. De maneira geral os atributos que mostraram maior e menor continuidade espacial foi o DMP e Ds na camada superficial. O DMP se ajustou ao modelo esférico com um raio de dependência espacial de 53m (alcance) e um RD de 49\% de aleatoriedade nos dados; para a Ds, o modelo foi o esférico com um raio de dependência espacial de $14 \mathrm{~m}$ e uma razão de aleatoriedade de $3 \%$.

Observando os mapas de krigagem para o COT e DMP (Figura 2) pode-se afirmar que há relação espacial, visto que as escalas de solo que apresentam os maiores valores do DMP nas camadas de 0-0,05 e 0,05-0,10m coincidem onde há predominância dos maiores valores do COT. O que enfatiza a importância do COT para a agregação do solo (Rozane et al., 2010). Em estudo realizado em diferentes manejos, Wendling et al. (2012) observou que o COT em área de pastagem apresentou maior teor de carbono quando comparado com outros manejos. Para Dos Santos et al. (2013) os elevados teores de COT são características de TPAs. É válido ressaltar que a agregação do solo pode ser alterada de forma direta pelo manejo e indireta por fatores bióticos e abióticos, sendo considerado como indicador físico da qualidade dos solos.

Observa-se que os menores valores de Est $C$ ocorreram nas camadas 0-0,05 e 0,05-0,10m, havendo um acréscimo na camada de 0,20-0,30m influenciado pelos maiores valores de Ds. Provavelmente os maiores valores de Ds na camada superficial são atribuídos ao pisoteio animal, uma vez que é notória a sua influência nas áreas periféricas, ou seja, nas bordas do mapa. Em estudos realizado por Alho et al. (2014), com agregados e estoque de carbono em campo natural e floresta, relataram que o conteúdo de COT foi determinante para os resultados de Est C.
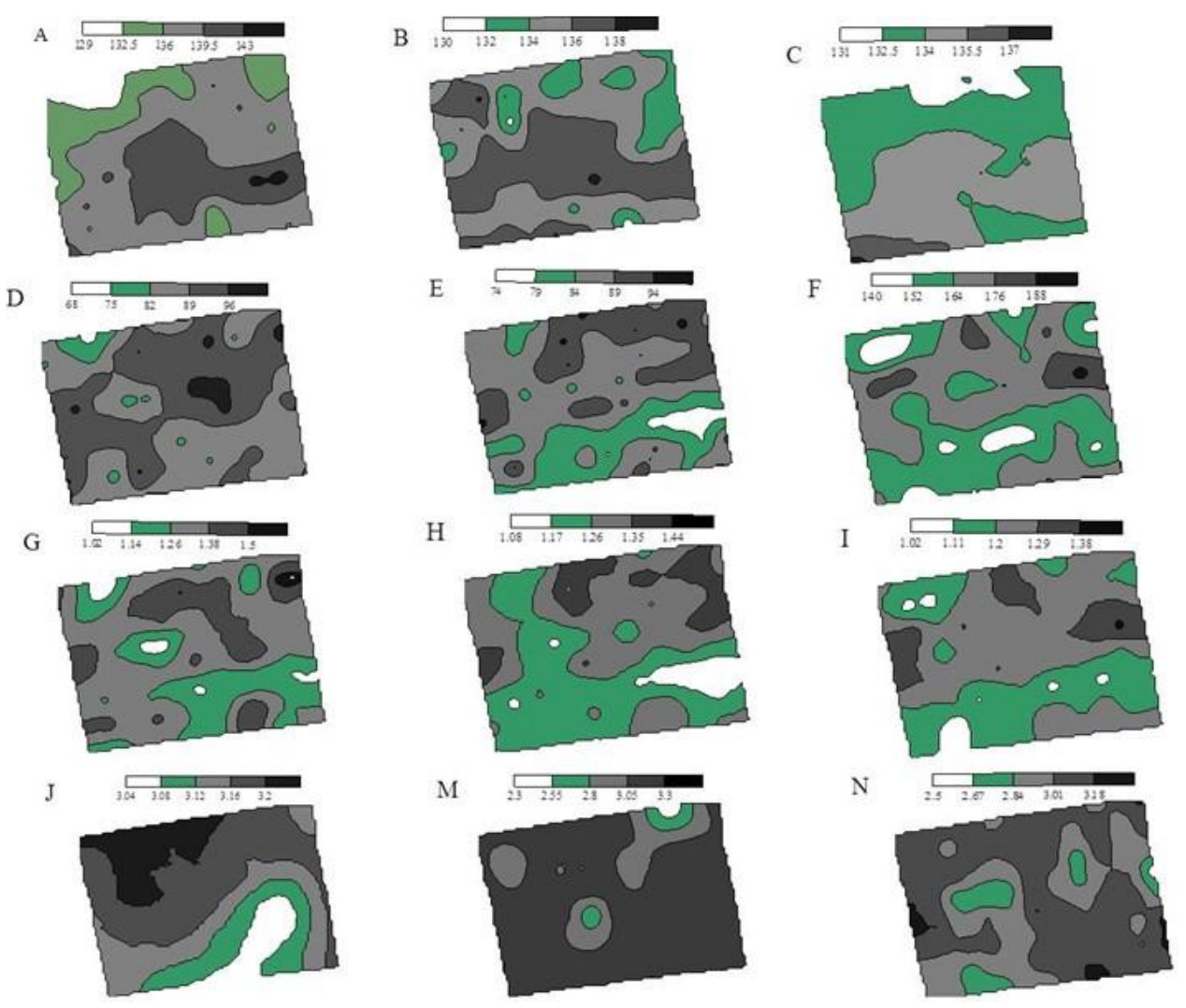

Figura 2. Mapas de distribuição espacial nas camadas 0-0,05, 0,05-0,10 e 0,10$0,20 \mathrm{~m}$, respectivamente para o carbono orgânico total (COT: A, B e C); estoque de carbono (Est C.: D, E e F); densidade do solo (Ds: G, H e I); diâmetro médio ponderado (DMP: J, M e N). 
O VTP apresentou correlação positiva com a Macro, o qual é verificado nos mapas destes atributos (Figura 3). A Macro é um atributo inteiramente ligado ao crescimento das plantas e seus valores ficaram acima de $0,10 \mathrm{~m}^{3} \mathrm{~m}^{-3}$. Segundo Kiehl (1979), valores abaixo de $0,10 \mathrm{~m}^{3} \mathrm{~m}^{-3}$ prejudicam o desenvolvimento das raízes, a infiltração de água e aeração do solo. Observa-se que os maiores valores da Micro se concentram na camada superficial $\left(0,32 \mathrm{~m}^{3} \mathrm{~m}^{-3}\right)$ indicando uma forte relação com a Ds (Figura 2). Já o VTP, apresentou seus valores quase contínuos nas primeiras camadas com acréscimo considerável na última camada (Figuras 4 e 5).

A

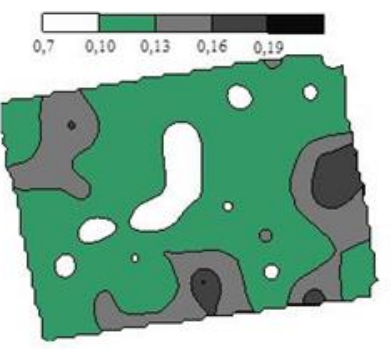

D

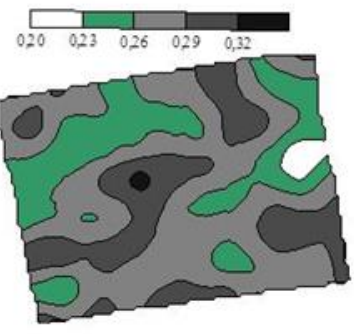

G

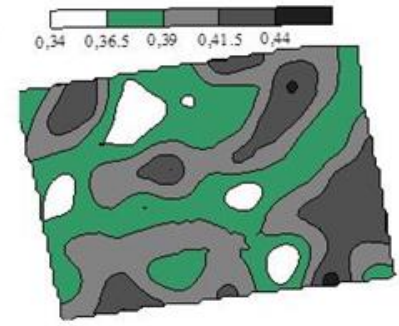

B

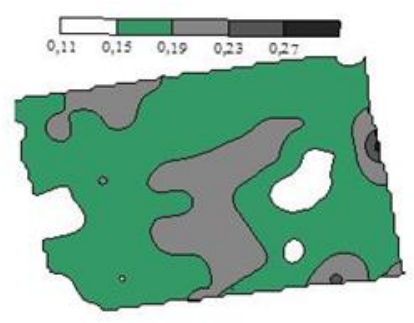

E

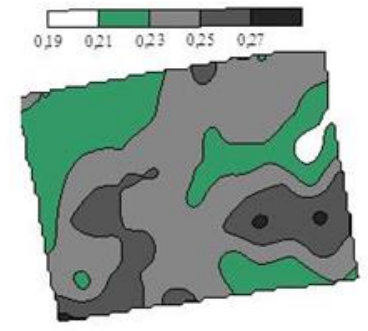

$\mathrm{H}$

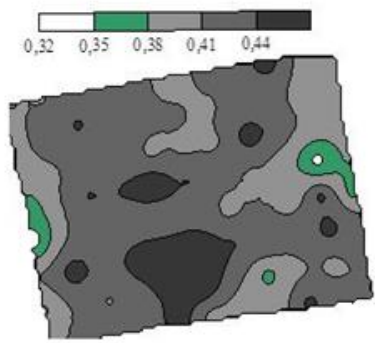

C

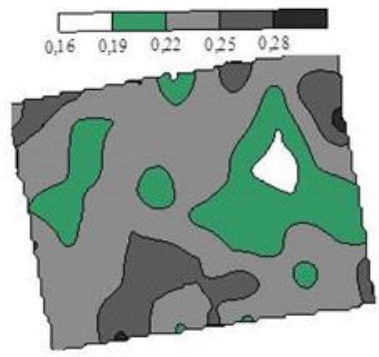

F

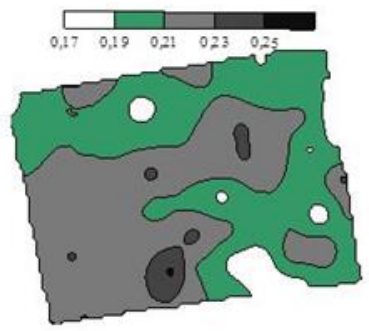

I

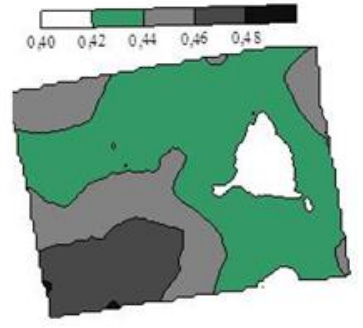

Figura 3. Mapas de distribuição espacial nas camadas $0-0,05,0,05-0,10$ e 0,10-0,20 m, respectivamente para a macroporosidade (Macro: A, B e C), microporosidade (Micro: D, E e F) e volume total de poros (VTP: G, H e I). 
A

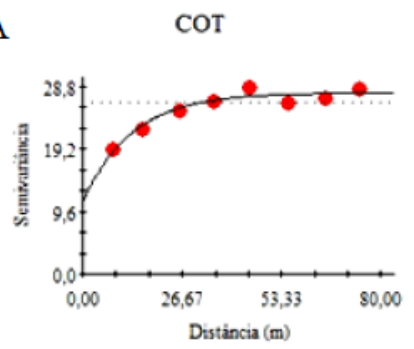

D

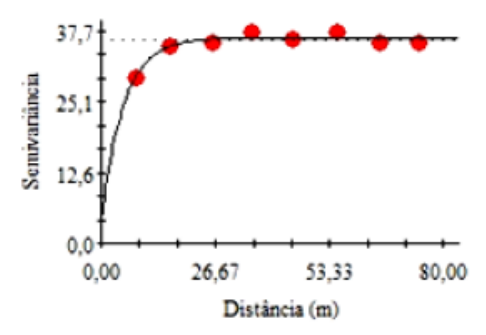

G

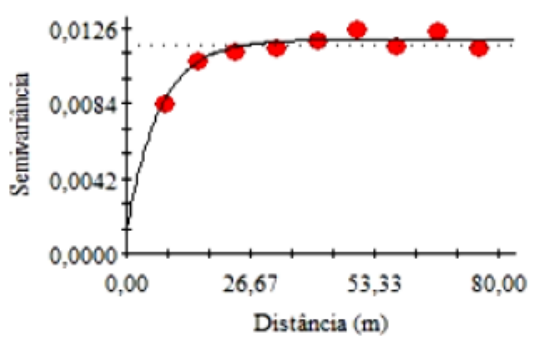

B

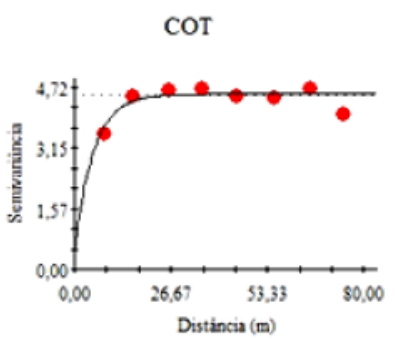

E

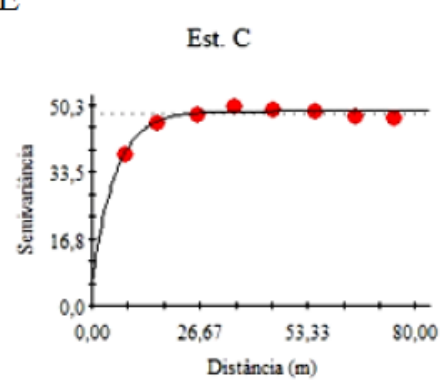

$\mathrm{H}$

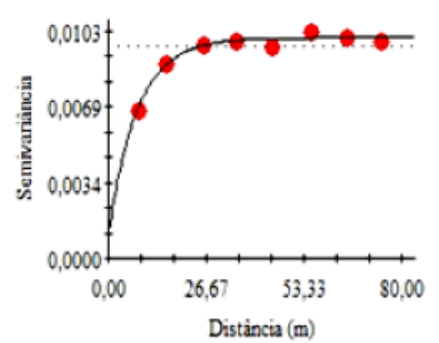

C COT

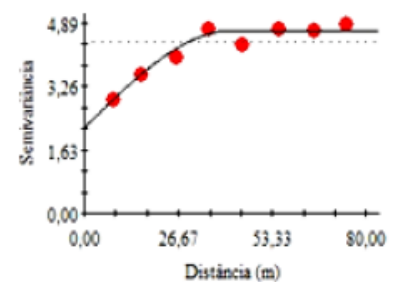

F

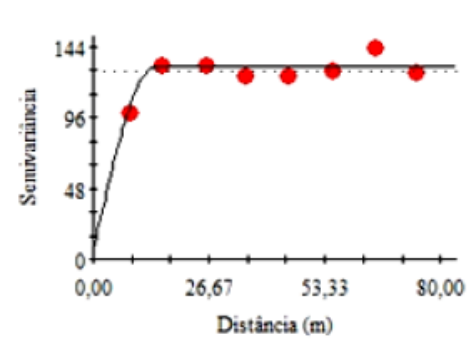

I

Ds

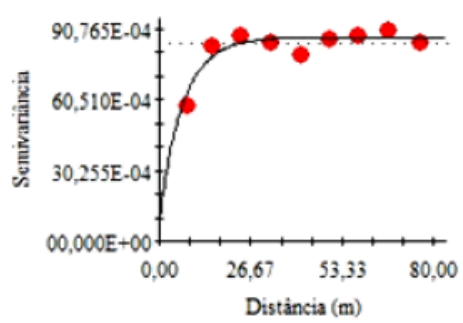

Figura 4. Semivariogramas experimentais nas camadas $0-0,05,0,05-0,10$ e $0,10-0,20 \mathrm{~m}$, respectivamente para o Carbono Orgânico Total (COT: A, B e C), Estoque de Carbono (Est. C: D, E e F) e densidade do solo (Ds: G, H e I).

\section{CONCLUSÕES}

De modo geral, mesmo estando inserida em área de pastagem, as variáveis Ds, Micro, Macro e VPT estiveram dentro dos valores de referências, os quais poderiam vir a restringir o desenvolvimento das plantas e a infiltração de água no solo.

O DMP e a Ds mostraram dependência de COT, pois os valores de ambos atributos aumentam ou diminuem de acordo com a camada.

Em camadas, os estoques de carbono estiveram mais relacionados à densidade do solo do que propriamente aos teores de carbono orgânico. 

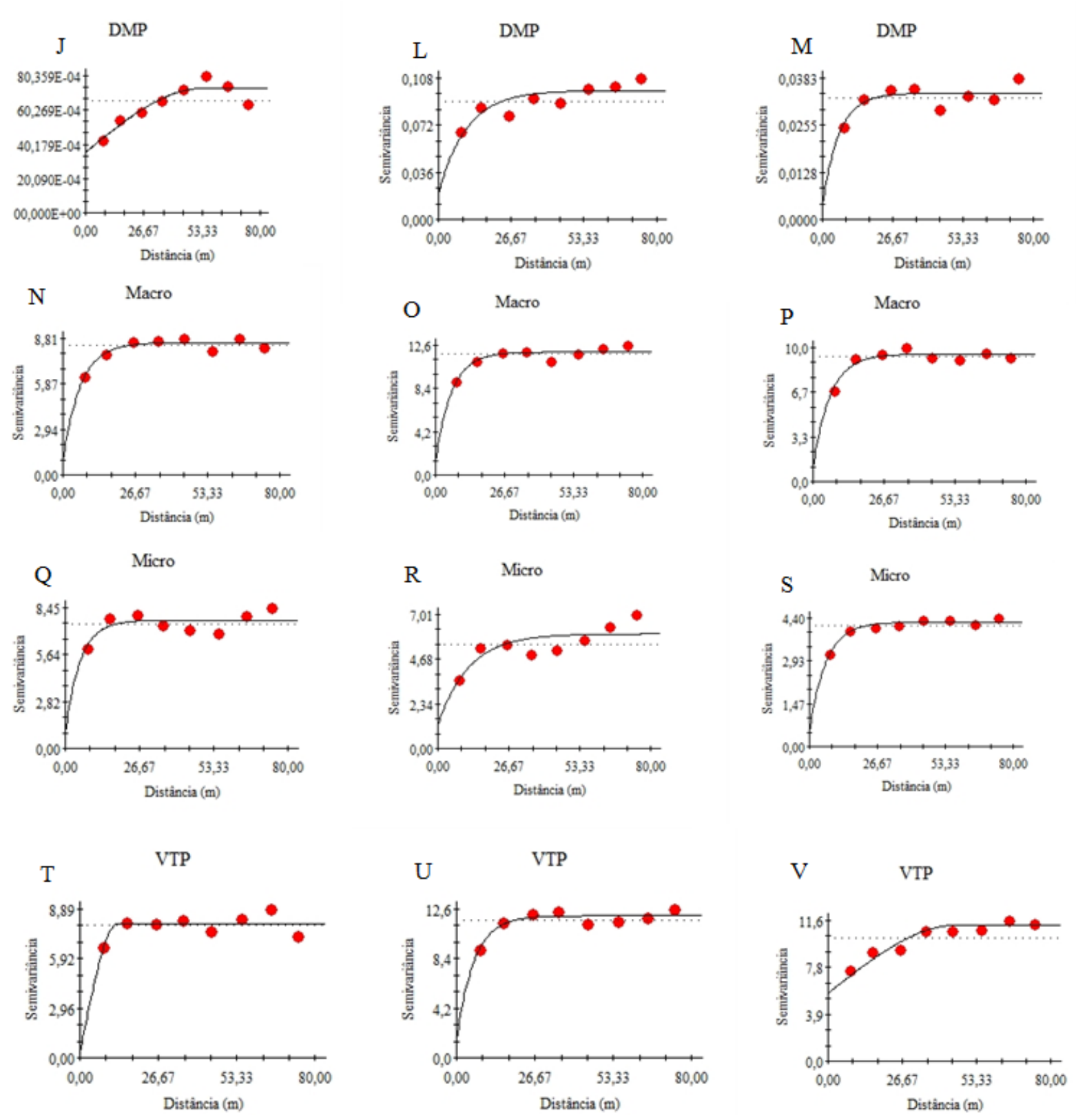

Figura 5. Semivariogramas experimentais nas camadas $0-0,05,0,05-0,10$ e $0,10-0,20 \mathrm{~m}$, respectivamente para o diâmetro médio ponderado (DMP: J, L e M), macroporosidade (Macro: N, O e P), microporosidade (Micro: G, H e I) e volume total de poros (VTP: T, U e V).

\section{REFERÊNCIAS}

ALHO, L. C.; CAMPOS, M. C. C.; SILVA, D. M. P.; MANTOVANELLI, B. C.; SOUZA, Z. M. Variabilidade espacial da estabilidade de agregados e estoque de carbono em Cambissolo e Argissolo. Pesquisa Agropecuária Tropical, v. 44, p. 246-254, 2014.

AQUINO, R. E.; CAMPOS, M. C. C.; MARQUES JÚNIOR, J.; OLIVEIRA, I. A.; MANTOVANELLI, B. C.; SOARES, M. D. R. Geoestatística na avaliação dos atributos físicos em latossolo sob floresta nativa e pastagem na Região de Manicoré, Amazonas.

Revista Brasileira Ciência do Solo, v. 38, p. 397-406, 2014b. http://dx.doi.org/10.1590/S0100-06832014000200004 
AQUINO, R. E.; CAMPOS, M. C. C.; OLIVEIRA, I. A. MARQUES JÚNIOR, J.; SILVA, D. M. P.; SILVA, D. A. Variabilidade espacial de atributos físicos de solos antropogênico e não antropogênico na região de Manicoré, Am. Bioscience Journal, v. 30, p. 988-997, 2014a. http://www.seer.ufu.br/index.php/biosciencejournal/article/view/21833

BRASIL. Ministério das Minas e Energia. Projeto Radambrasil, folha SB. 20, Purus. Rio de Janeiro, 1978. 561p.

BLAISKI, E.; TORMENA, C. A.; FIDALSKI, J.; GUIMARÃES, R. M. Quantificação de degradação física do solo por meio da curva de resistência do solo à penetração. Revista Brasileira Ciência do Solo, v. 32, p. 975-983, 2008. https://doi.org/10.1590/S010006832008000300007

CAMBARDELLA, C. A.; MOORMAN, T. B.; NOVAK, J.M.; PARKIN, T. B.; KARLEN, D. L.; TURCO, R. F.; KONOPKA, A. E. Field-scale variability of soil properties in central lowa soils. Soil Science of Society of America Journal, v. 58, p. 1501-1511, 1994. 10.2136/sssaj1994.03615995005800050033x

CAMPOS, M. C. C.; RIBEIRO, M. R.; SOUZA JÚNIOR, M. S.; RIBEIRO FILHO, M. R.; SOUZA, R. V. C. C.; ALMEIDA, M. C. Caracterização e classificação de terras pretas arqueológicas na Região do Médio Rio Madeira. Bragantia, v. 70, n. 3, p. 598-609, 2011.

CAMPOS, M. C. C. C.; SANTOS, L. A. C.; SIlvA, D. M. P.; MANTOVANELli, B. C.; SOARES, M. D. R. Caracterização física e química de terras pretas arqueológicas e de solos não antropogênicos na região de Manicoré, Amazonas. Revista Agro@mbiente On-line, v. 6, p. 102-109, 2012. http://dx.doi.org/10.18227/1982-8470ragro.v6i2.682

CAMPOS, M. C. C.; SOARES, M. D. R.; SANTOS, L. A. C.; OLIVEIRA, I. A.; AQUINO, E. A. Spatial variability of physical attributes in Alfissol under agroforestry, Humaitá region, Amazonas state, Brazil. Revista de Ciências Agrárias, v. 56, p. 149-159, 2013. http://dx.doi.org/10.4322/rca.2013.023

COUTINHO, F. S.; PEREIRA, M. G.; MENEZES, C. E. G.; GUARESCHI, R. F.; ASSUNÇÃO, S. A. Attributes of soil under agriculture, grazing and three succession stages of forest. Floresta e Ambiente, v. 24, p. 3-11, 2017. http://dx.doi.org/10.1590/2179-8087.091914

CENTRO DE PESQUISA DE RECURSOS MINERAIS - CPRM. Hidroclimatologia, geologia, recursos minerais, geomorfologia e unidades de paisagens. Manaus, 2001. 93p. (Relatório Técnico).

Dos SANTOS, L. A. C.; CAMPOS, M. C. C., AQUINO, R. E.; BERGAMIN, A. C.; SILVA, D. M. P.; MARQUES JUNIOR, J. et al. Caracterização de terras pretas arqueológicas no Sul do Estado do Amazonas. Revista Brasileira de Ciência do Solo, v. 37, p. 825-836, 2013. http://dx.doi.org/10.1590/S0100-06832013000400001

EMPRESA BRASILEIRA DE PESQUISA AGROPECUÁRIA - EMBRAPA. Manual de métodos de análise de solo. 2. ed. Rio de Janeiro: CNPS, 1997. 212p.

EMPRESA BRASILEIRA DE PESQUISA AGROPECUÁRIA - EMBRAPA. Centro Nacional de Pesquisa de Solos. Sistema Brasileiro de Classificação de Solos. Brasília, 353p. 2013. 
KÄMPF, N.; KERN, D. C. O solo como registro da ocupação humana pré-histórica na Amazônia. In: TORRADOVIDAL, P.; ALLEONI, L. R. F.; COOPER, M.; SILVA, A. P. (eds). Tópicos em ciência do solo. Viçosa: Sociedade Brasileira de Ciência do Solo, 2005. p. 277-320.

KEMPER, W. D.; CHEPIL, W. S. Size distribution of aggregates. In: BLACK, C. A. (eEd.). Methods of soil analysis. Madison: American Society of Agronomy, 1965. p.499-510.

KIEHL, E. J. Manual de edafologia: relações solo-planta. 1. ed. São Paulo: Agronômica Ceres, 1979. 264p.

LIMA, J. S. S.; SOUZA, G. S.; SILVA, S. A. Amostragem e variabilidade espacial de atributos químicos do solo em área de vegetação natural em regeneração. Revista Árvore, v. 34, p. 127-136, 2010. http://dx.doi.org/10.1590/S0100-67622010000100014

OLIVEIRA, I. A.; CAMPOS, M. C. C.; SOARES, M. D. R.; AQUINO, R. E.; MARQUES JÚNIOR, J.; NASCIMENTO, E. P. Variabilidade espacial de atributos físicos em um cambissolo háplico, sob diferentes usos na região sul do Amazonas. Revista Brasileira de Ciência do Solo, v. 37, p.1103-1112, 2013. http://dx.doi.org/10.1590/S010006832013000400027

ROCHA SILVA, F. W.; LIMA, H. N.; TEIXEIRA, W. G.; MOTTA, M. B.; SANTANA, R. M. Caracterização química e mineralogia de solos antrópicos (Terras Pretas de Índio) na Amazônia Central. Revista Brasileira de Ciência do Solo, v. 35, p. 673-681, 2011. https://doi.org/10.1590/S0100-06832011000300002

ROZANE, D. E.; CENTURION, J. F.; ROMUALDO, L. M.; TANIGUCHI, C. A. K.; TRABUCO, M.; ALVES, A. U. Estoque de carbono e estabilidade de agregados em um Latossolo Vermelho distrófico, sob diferentes manejos. Bioscience Journal, v. 26, p. 24$32,2010$.

SANTOS, D.; SOUZA, E. G.; NÓBREGA, L. H. P.; BAZZI, C. L.; GONÇALVES JÚNIOR, A. C. Variabilidade espacial de atributos físicos de um Latossolo vermelho após cultivo de soja. Revista Brasileira Engenharia Agrícola e Ambiental, v.16, p.843-848, 2012.

SOUZA, Z. M.; MARQUES JÚNIOR, J.; PEREIRA, G. T. Variabilidade espacial de atributos físicos do solo em diferentes formas do relevo sob cultivo de cana-de-açúcar. Revista Brasileira de Ciência do Solo, v. 28, p. 937-944, 2004.

STEINBEISS, S.; GLEIXNER, G.; ANTONIETTI, M. Effect of biochar amendment on soil carbon balance and soil microbial activity. Soil Biology and Biochemistry, v. 41, p.1301-1310, 2009. https://doi.org/10.1016/j.soilbio.2009.03.016

VASCONCELOS, R. F. B.; CANTALICE, J. R. B.; OLIVEIRA, V. S.; COSTA, Y. D. J.; CAVALCANTE, D. M. Estabilidade de agregados de um Latossolo Amarelo distrocoeso de tabuleiro costeiro sob diferentes aportes de resíduos orgânicos da cana-de-açúcar. Revista Brasileira de Ciência do Solo, v. 34, p. 309-316, 2010.

VELDKAMP, E. Organic carbon turnover in three tropical soils under pasture after deforestation. Soil Science Society American Journal, v. 58, p. 175-180, 1994. http://dx.doi.org/10.2136/sssaj1994.03615995005800010025x 
VIEIRA, S. R.; DECHEN, S. C. F.; SIQUEIRA, G. M.; DUFRAC, G. Variabilidade espacial de atributos físicos e químicos relacionados com o estado de agregação de dois Latossolos cultivados no sistema de semeadura direta. Bragantia, v. 70, p. 185-195, 2011.

WARRICK, A. W.; NIELSEN, D. R. Spatial variability of soil physical properties in the field. In: HILLEL, D. Applications of soil physics. New York: Academic Press, 1980. p. 319344.

WENDLING, B.; VINHA-FREITAS, I. C.; OLIVEIRA, R. C. de; BABATA, M. M.; BORGES, E. N. Densidade, agregação e porosidade do solo em áreas de conversão do cerrado em floresta de pinus, pastagem e plantio direto. Bioscence Journal, v. 28, p.256$265,2012$.

YEOMANS, J. C.; BREMNER, J. M. A rapid and precise method for routine determination of organic carbon in soil. Communication in Soil Science and Plant Analysis, v. 19, p. 1467-1476. 1988. https://doi.org/10.1080/00103628809368027 